\author{
UNIVERSIDADE DE SÃO PAULO \\ FACULDADE DE FILOSOFIA, LETRAS E CIÊNCIAS HUMANAS \\ DEPARTAMENTO DE HISTÓRIA
}

\title{
UMA CIVILIZAÇÃO DO ARROZ \\ Agricultura, comércio e subsistência no Vale do Ribeira (1800-1880)
}

\section{Agnaldo Valentin}

Orientador: Prof. Dr. José Flávio Motta

Tese apresentada ao Programa de Pósgraduação em História Econômica da Faculdade de Filosofia, Letras e Ciências Humanas da Universidade de São Paulo, para a obtenção do título de doutor.

SÃO PAULO 
Aos meus pais 


\section{Agradecimentos}

Nos agradecimentos de minha dissertação, dizia: “Dirijo-me inicialmente ao Prof. Dr. José Flávio Motta, orientador desta dissertação. Nosso convívio ao longo de praticamente de uma década, enriquecido pelas divergências e conflitos, propiciou a consolidação de uma forte amizade que, espero, possa ser cultivada por muito tempo". Passado mais um qüinqüênio, só me resta ofertar-lhe esta tese como um prêmio por esta etapa que pudemos concluir.

Aos membros da banca de qualificação, Prof. Dr. Iraci del Nero da Costa e Prof. Dr. Renato Leite Marcondes, pelas críticas e sugestões ofertadas ao projeto e aos resultados preliminares lá apresentados. Devo àquela manhã boa parte da ordenação deste trabalho.

À Prof.a. Dra. Maria Cristina Mineiro Scatamachia, diretora do Museu Histórico e Arqueológico de Iguape e ao Prof. Dr. Antonio Carlos Sant’Ana Diegues, diretor do Núcleo de Pesquisas de População de Áreas Úmidas da Universidade de São Paulo, pela solidariedade enquanto fotografava os inventários post-mortem depositados naquele Museu. Também ao Sr. Roberto Fortes pelas informações e pela atenção dispensada.

Aos funcionários do Arquivo do Estado de São Paulo, do Museu Histórico e Arqueológico de Iguape e do Fórum de Eldorado Paulista pela gentileza e presteza na consulta aos documentos. 


\title{
Resumo
}

Acompanhamos o evolver econômico das localidades de Iguape e Xiririca, no Vale do Ribeira, entre 1800 e 1880. Durante este período, a região especializou-se no cultivo do arroz, destinado principalmente para o Rio de Janeiro. Pudemos estabelecer ritmos distintos envolvendo a estrutura de produção e comercialização dos grãos, compondo um ciclo econômico completo. Também buscamos relacionar este movimento com o nível e a composição da riqueza dos ribeirenses. Dedicamos especial atenção aos bens de raiz, escravos e dívidas ativas, os três grupos com maior participação na composição da riqueza. Nossos resultados, além de evidenciarem a adoção do cultivo de arroz em todos os estratos econômicos, indicam mudanças significativas na hierarquia social à medida que o ciclo se desenrolava, especialmente entre proprietários de engenho de arroz e comerciantes.

\section{Palavras-chaves}

Vale do Ribeira; arroz; nível e composição da riqueza; posse de escravos

\begin{abstract}
This thesis looks at the economic evolution of the Iguape and Xiririca villages in the Vale of Ribeira region between 1800 and 1880. During this period, the region concentrated in the rice culture, notably to supply the Rio de Janeiro's market. In this study we identified different rhythms in the structures of production and marketing of this crop, defining a complete economic cycle. We also show that the evolution of the rice culture is correlated with the wealth levels of the local population. We looked particularly at assets, number of slaves, and credits, the main indicators of wealth in the region at that time. Our findings not only show that rice production evolved across all economic classes, but also suggests that changes in the local social hierarchy matched the economic cycle development, particularly in the case of rice mill owners and traders.
\end{abstract}

\section{Key words}

Vale do Ribeira; rice; level and wealth composition; slaveholding 


\section{Sumário}

INTRODUÇÃO _ 1

DELIMITAÇÃO DO ESPAÇO FÍSICO ___ 5

DA COLONIZAÇÃO DO VALE DO RIBEIRA NO SÉCULO XVI À DECADÊNCIA DO ARROZ__ 8

OS OBJETIVOS E AS FONTES DOCUMENTAIS ___ 16

1. PRODUÇÃO E COMÉRCIO NO VALE DO RIBEIRA NO SÉCULO XIX ___ 25

AS PRIMÍCIAS E A EXPANSÃO DO COMÉRCIO DE ARROZ NO PORTO DE IGUAPE - 1803 A $1830 \_25$

AS ATIVIDADES ECONÔMICAS NOS DOMICÍLIOS: UMA COMPARAÇÃO EM 1801 E $1836 \_36$

A MOVIMENTAÇÃO PORTUÁRIA ENTRE 1840 E 1880

OSCILAÇÕES E TENDÊNCIAS DA PRODUÇÃO E DO PREÇO DO ARROZ - 1840 A $1870 \_49$

OS REMETENTES E AS REMESSAS DE ARROZ - 1837 A 1865

A RIQUEZA MEDIDA ATRAVÉS DOS INVENTÁRIOS _ـ 65

2. A POSSE DOS BENS DE RAIZ _

UM RETRATO DA EXPANSÃO: O CADASTRO DE BENS RÚSTICOS DE 1818 _ 79

AS PROPRIEDADES RURAIS: RIQUEZA ACUMULADA E A MERCANTILIZAÇÃO DAS TERRAS _ 98

AS PROPRIEDADES URBANAS _ 119

3. ESTRUTURA DA POSSE DE ESCRAVOS NO VALE DO RIBEIRA _ _ 129

ESTRUTURA DE POSSE NAS LISTAS NOMINATIVAS (1801-1836)___ 129

A ESTRUTURA DE POSSE NOS INVENTÁRIOS RIBEIRENSES __ 191

OS ESCRAVOS AVALIADOS NOS INVENTÁRIOS RIBEIRENSES__ 218

4. A ELITE AGRÁRIA E COMERCIAL NO VALE DO RIBEIRA _ 229

COMERCIANTES E PROPRIETÁRIOS - UMA VISÃO GERAL _— 232

ESTRITOS PROPRIETÁRIOS DE ENGENHO DE ARROZ _—_ 260

AMPLIANDO O CAMPO DE ATIVIDADES ECONÔMICAS _ـ 269

COMERCIANTES E COMERCIANTES___ 287

DELINEANDO O ESPAÇO AGRÁRIO __ 296

5. CAPUARAS, RIBEIRINHOS, REMEDIADOS E EMPENHADOS___ 305

LIVRES, LIBERTOS E ESCRAVOS NA ECONOMIA RIBEIRENSE___ 305

A RIQUEZA NOS INVENTÁRIOS DE NÃO-ESCRAVISTAS ___ 327

CONSIDERAÇÕES FINAIS____ 345

APÊNDICE — 349

A POPULAÇÃO NO VALE DO RIBEIRA___ 349

OS INGÊNUOS NOS INVENTÁRIOS ___ 358

FONTES E BIBLIOGRAFIA —— — 359

FONTES PRIMÁRIAS MANUSCRITAS, IMPRESSAS E EM MEIO ELETRÔNICO___ 359

BIBLIOGRAFIA CITADA — 361

ANEXOS ___ 371

PROPRIETÁRIOS E ESCRAVOS DO VALE DO RIBEIRA _— 372

RELAÇÃO DOS INVENTÁRIOS CONSULTADOS ___ 390 


\section{INTRODUCÃO}

A definição do objeto de estudo desta tese - o evolver econômico e a composição da riqueza no Vale do Ribeira paulista - originou-se de um desdobramento de nossa dissertação de mestrado, cujo tema abrangia a demografia e a estrutura de posse de escravos na vila de Apiaí nos séculos XVIII e XIX. Lá nos deparamos com o intenso crescimento do cultivo de arroz na freguesia de Iporanga, então pertencente à vila de Apiaí, entre os anos de 1824 e 1835. Ao tentarmos compreender qual o significado daqueles números, muito pouco pudemos localizar na produção acadêmica da história econômica brasileira.

No entanto, muito soubemos da região através de outras literaturas. Contamos com uma produção bibliográfica, do campo geográfico, pelo Departamento de Geografia da Universidade de São Paulo nas décadas de 1940 e 1950. Os relatos acerca da história do Vale do Ribeira concentram-se em mãos de autores locais, como o inglês Ernesto Young, que se estabeleceu em Iguape em fins do século XIX e publicou vários artigos na Revista do Instituto Histórico e Geográfico de São Paulo; Antonio Paulino de Almeida, natural de Cananéia e que, durante anos, ocupou o cargo de arquivista-chefe do Arquivo do Estado de São Paulo e Roberto Fortes, autor contemporâneo cuja filiação intelectual remonta à tradição memorialística presente nos dois primeiros autores. Como se pode supor, ainda que abundantes em conteúdo informativo, estas produções não sistematizam e avaliam os fatos aos moldes dos trabalhos científicos, abrangendo uma infinidade de assuntos cuja conexão e profundidade nem sempre satisfazem as necessidades de um recorte específico. Especialmente no campo da história econômica, as informações são ralas: há uma certa unanimidade, para o Vale do Ribeira, na delimitação dos dois grandes períodos de maior dinamismo - a exploração do ouro de aluvião e a cultura do arroz - porém sem outros desdobramentos, tanto no sentido de exploração da documentação pertinente como em sua inserção histórica.

Outros autores consultados que necessitaram realçar o evolver econômico da região, utilizam informações relativamente genéricas. Tome-se, a exemplo, o artigo produzido por Roberto Braga, do qual transcrevemos abaixo alguns trechos:

A economia da região só tomou algum impulso no século seguinte [século XVII - AV], quando teve seu primeiro empreendimento econômico em escala comercial: a mineração. Foi o chamado "ciclo do ouro" do Vale do Ribeira, que começou com a descoberta do metal na retroterra de Iguape, na zona do médio Ribeira. Aí foram encontradas as primeiras jazidas auríferas do Brasil, que fizeram com que a região apresentasse um relativo desenvolvimento, concentrado, no entanto, na vila de Iguape que, por sua posição estratégica, tornou-se a porta de escoamento do metal, tendo sediado, inclusive, a primeira casa de fundição de ouro do país, a "Casa Real de Fundição", construída em 1635 (BRAGA, 1999, p. 2-3). 
O ciclo do arroz, que teve seu auge aproximadamente entre 1836 e 1874, foi, sem dúvida, o período de maior prosperidade da região. Em 1836, a região concentrava 100 dos 109 engenhos de beneficiamento de arroz instalados na província e em 1852 já eram 107 os engenhos instalados na região. Outra medida do crescimento econômico da região era a quantidade de escravos que, em 1836 , representavam $28,9 \%$ da população total, um índice superior à média da Província, que era de $26,6 \%$ de população escrava (BRAGA, 1999, p. 4).

O crescimento econômico trazido pela rizicultura limitou-se, no entanto, à zona da Baixada do Ribeira, ainda assim concentrando-se nos dois núcleos principais, Iguape e Cananéia, onde a produção do arroz era controlada pelos proprietários dos engenhos de beneficiamento $\mathrm{e}$, principalmente, pelos comerciantes de Iguape. Os pequenos povoados e vilarejos ribeirinhos da retroterra pouco se beneficiaram dessa riqueza. A zona do Alto Ribeira não chegou a ser alcançada pela rizicultura (à exceção de Iporanga, onde se plantava algum arroz), mantendo-se no mesmo processo de estagnação. Essa fase de relativa prosperidade da baixada do Ribeira não durou muito. A partir da segunda metade do século XIX, a rizicultura começou a entrar em decadência, levando de roldão toda a economia regional (BRAGA, 1999, p. 5).

Em linhas gerais, nossos resultados confirmam as afirmações de Braga quanto à primazia dos proprietários de engenho de arroz e dos comerciantes, aos sinais de decadência na segunda metade do século XIX e ao padrão de distribuição da riqueza. No entanto, não temos respostas para outras indagações: por que o domínio dos comerciantes sobre os proprietários de engenho? Qual foi a real dimensão desta prosperidade econômica? Ademais, as causas da aludida crise na rizicultura não se encontram explicitadas de forma convincente. Entre os iguapenses - e parte da comunidade acadêmica - há uma explicação que se assenta na abertura, entre os anos de 1828 e 1856, de um canal de comunicação entre um dos meandros do rio Ribeira e a costa marítima, próximo ao núcleo urbano de Iguape, conforme indica a figura abaixo. 


\section{Assoreamento do porto de Iguape}

A

Situação antes da construção do Valo Grande

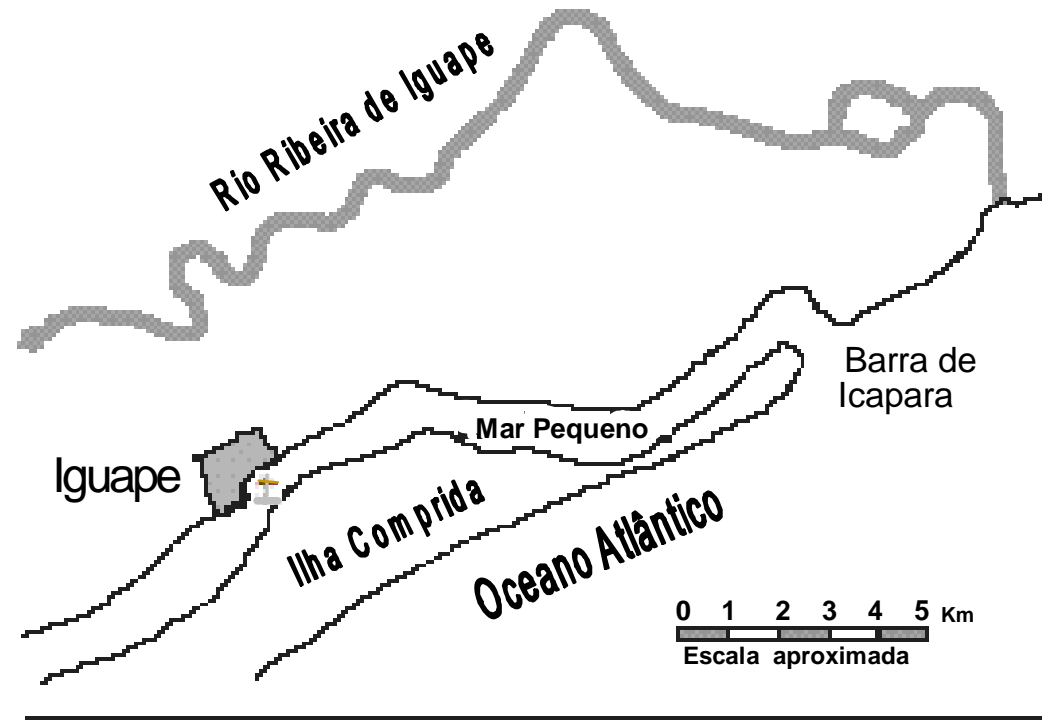

B

Situação em 1903

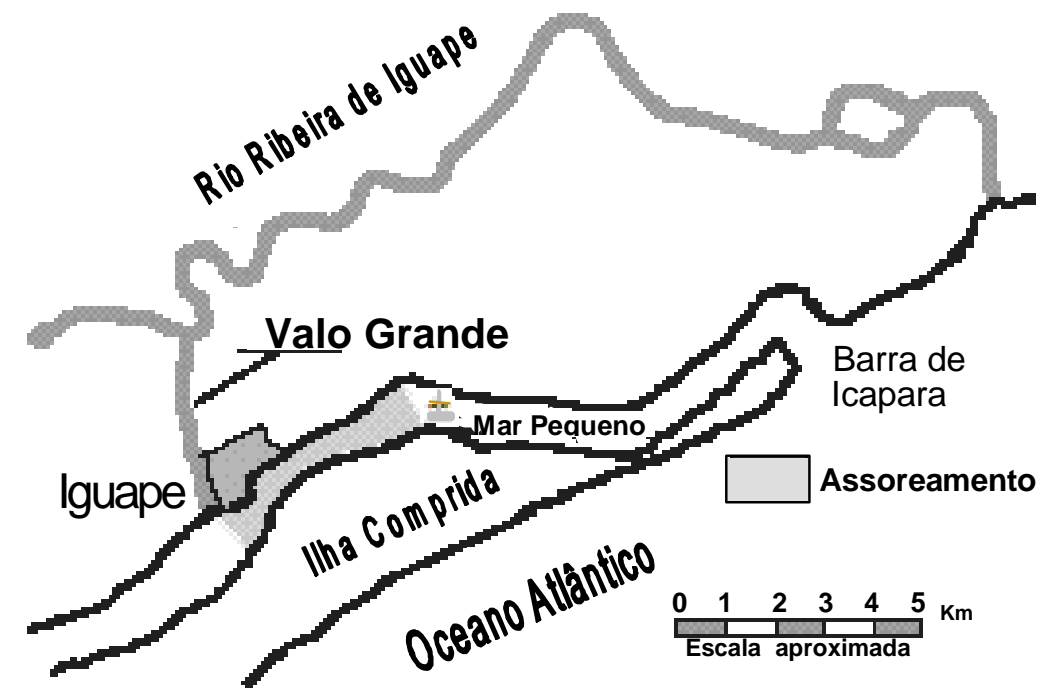

Fonte: BRAGA, 1999, p. 13.

Originalmente este canal deveria possuir 10 braças (ou 22 metros) de largura e objetivava facilitar o transporte da produção agrícola oriunda do Vale até o porto. No entanto, suas margens sofreram rápido assoreamento, acumulando sedimentos na desembocadura de tal forma que, no início do século XX, impediriam o atraque de navios de grande porte no Porto Grande, às margens do Mar Pequeno, principal escoadouro do arroz colhido na região. 
A preocupação dos iguapenses com o canal já aparece em 1861, quando a Câmara Municipal recebeu um relatório elaborado pelo francês Frederico Krecherly, alertando sobre os prejuízos ao porto de Iguape. De posse do documento, os camaristas encaminharam-no ao governo provincial:

A Câmara Municipal da cidade de Iguape tem a honra de fazer chegar ao conhecimento de $V$.E. a representação inclusa que em uma de suas sessões lhe dirigiu o súdito francês Luiz Krecherly, fazendeiro estabelecido neste município a fim de que V.E. a tome na devida consideração para providenciar como parecer o caso. Em sua representação o dito fez ver a esta Câmara que o canal desta cidade que comunica o mar com a Ribeira, obra em que se tem gasto grande soma e bastante tempo, na persuasão de ser de muita utilidade ao desenvolvimento material desta localidade, em vez desta esperada vantagem está se revestindo de males que já tem afetado aos moradores do porto desta cidade para aonde acudindo as areias conduzidas do canal pela correnteza das águas têm prejudicado por entulhos que se tem dado e que continua, a ponto de recuar-se que em breve ficará de todo inavegável. Esta Câmara, reconhecendo a importância do objeto e não se achando habilitada para apreciá-la como cumpre, por falta de pessoas profissionais que examinado a vala e ancoradouro, emitisse com acerto seu parecer sobre seu estado atual e sobre o receio que se prevê, e ao mesmo tempo aconselhasse o remédio devido para acautelar o mal, entendeu que devia submeter ao conhecimento de VE para providenciar como melhor servir. Lembra a V.E. que seria conveniente enviar ao lugar uma comissão de engenheiros para se proceder com mais acerto. ${ }^{1}$

O desastre ambiental efetivamente causado pela construção do canal, contudo, compõe outra inconsistência. Pelo menos até 1880, limite superior de nossa investigação, não percebemos nenhuma alteração significativa no número de embarcações que transportavam o arroz até o porto do Rio de Janeiro, principal destino dos grãos colhidos. Ademais, a capacidade das embarcações raramente superava 200 toneladas e a carga máxima de sacos embarcados manteve-se em torno de 1.000 a 1.500 por navio (ou 60 a 90 toneladas), sugerindo que o assoreamento, mesmo manifestando seus efeitos imediatamente após a conclusão do canal, como sugere a correspondência acima, não impedia a entrada de mercadorias e a saída do principal produto agrícola da região.

Diante do exposto, torna-se ocioso afirmar a necessidade de melhores investigações acerca do tema, como se percebe nas próprias palavras de Roberto Braga:

Em resumo, o declínio da economia escravista do Vale do Ribeira, assim como a do Vale do Paraíba e a Nordestina, não se deveu a um "imperialismo" das regiões cafeeiras, mas a uma conjugação de fatores histórico-geográficos que devem ser analisados dentro de um processo muito mais amplo que foi a crise do complexo rural escravista, no bojo do processo capitalista de modernização das relações de produção no Brasil (BRAGA, 1999, p. 20).

No mesmo ano, Plácido Cali alinhava suas considerações acerca da decadência econômica do Vale:

A nível nacional, a formação da economia cafeeira produziu uma grande oferta de

\footnotetext{
${ }^{1}$ Arquivo Público do Estado de São Paulo (AESP), Ofícios diversos de Iguape, ordem n. ${ }^{\circ} 1.044$.
} 
câmbio e criou facilidades para a importação de arroz. Já em nível regional, destacamos dois fatores. O primeiro se refere a problemas de substituição da mão-de-obra escrava pela assalariada, a partir da abolição da escravidão. A escassez de mão-de-obra pode ter colaborado para o abandono dessa agricultura na região, já que a maioria das fazendas se localizava em pontos isolados e distantes de qualquer núcleo urbano ou até de povoados menores. O segundo fator liga-se à abertura de um desvio das águas do Ribeira para o Mar Pequeno, feito com o objetivo de encurtar a distância até o porto de Iguape (CALI, 1999, p. 148).

Se no plano nacional a influência da cafeicultura parece dividir a opinião dos dois autores em tela, Cali reafirma as mesmas causas regionais destacadas por Roberto Braga. Especificamente sobre o problema da mão-de-obra, os registros censitários e os inventários consultados evidenciam a redução expressiva da população escrava ao longo de toda a segunda metade do Oitocentos, porém a quantidade de arroz exportada manteve-se relativamente constante durante todo o período.

Nesse sentido, apresentamos aqui uma breve descrição espacial e histórica da região investigada, bem como do desenvolvimento da cultura do arroz no Brasil.

\section{Delimitação do espaço físico}

A definição dos limites geográficos da área em estudo apresenta-se dificultosa caso o critério de recorte utilize elementos antropomórficos ou naturais. Isso decorre da extensão das áreas em que se cultivava arroz, pois ultrapassavam os limites fitogeográficos e unidades geomorfológicas. A referência fundamental aqui utilizada é a pesquisa de doutorado de Pasquale Petrone. O seu critério para a delimitação da área foi uma linha em torno da cota 100 metros de altitude, estabelecendo um semicírculo com cerca de $6.800 \mathrm{~km}^{2}$ que determina, ao oeste, as serras divisórias entre os estados de São Paulo e Paraná; ao norte, as escarpas baixas da Serra de Paranapiacaba e, ao leste, as Serras de Itatins e Bananal; no entanto, parte expressiva do Vale ainda estaria excluída da área de estudo. Petrone supera essa limitação adotando uma faixa limítrofe variável que possibilita a interligação entre a baixada do Ribeira e áreas contíguas, excetuando os vales dos rios São Lourenço e Juquiá, a nordeste, e no próprio Vale do Ribeira a montante da Serra do Batatal, o caminho em direção a Iporanga (cf . PETRONE, 1966, p. 20-21). ${ }^{2}$

A origem do vale é assim descrita por Petrone:

Segundo o que parece mais provável, ainda no pleistoceno a maior parte da área em consideração constituía como que um gigantesco golfão com linha de costa emoldurada pela vizinhança de Paranapiacaba e com suas águas pontilhadas, aqui e ali, por ilhas

\footnotetext{
${ }^{2}$ Ainda sobre a delimitação proposta por Petrone, ressaltamos a exclusão do município de Miracatu, antiga Prainha, única região que identificamos nos inventários consultados o cultivo de café. A presente pesquisa não descartará as informações sobre seus moradores.
} 
maiores e menores, todas montanhosas. Com o tempo o referido golfão foi sendo entulhado graças ao trabalho do mar, com a formação de restingas, e ao trabalho das águas continentais - e do próprio mar - colmatando as zonas lagunares que se formavam. As ilhas, soldadas ao continente pelas restingas e cordões litorâneos, inicialmente originando tômbolos, logo tornaram-se morros "ilhados" na baixada em formação. Ao mesmo tempo definiu-se, na zona sedimentar que se formava, o curso do Ribeira de Iguape, por cuja calha encontrou vazão boa parte das aluviões que contribuíram para o progressivo entulhamento da baixada. Daí a presença, na área em questão, de uma das mais amplas zonas litorâneas brasileiras de sedimentação (PETRONE, 1966, p. 26-27).

São duas as grandes áreas sedimentares: a primeira corresponde a uma faixa de 10 $\mathrm{km}$ que acompanha a linha da costa e a segunda se encontra ao longo do rio Ribeira de Iguape, desde o canal do Valo Grande até a barra do rio Batatal, para além de Eldorado (antiga Xiririca), bem como às margens dos afluentes Juquiá e Jacupiranga. Segundo Petrone, “(...) essas áreas correspondem a várzeas e zonas alagadiças, abrangendo também trechos terraceados, especialmente nas porções a montante da barra do Jacupiranga no Ribeira” (PETRONE, 1966, p. 28). Esta faixa - que constitui o locus do cultivo do arroz - deriva da sinuosidade da bacia fluvial, alimentada por um regime de chuvas relativamente intenso (1.500 a 2.000 milímetros por ano), que busca por um caminho possível sobre um solo impermeável, dando origem às várzeas, banhados e brejos de grande extensão, não apenas na faixa litorânea, mas também no interior do vale. Para Petrone o rio é o elemento fundamental da possibilidade humana na região:

No conjunto a hidrografia regional é um dos elementos mais significativos para a vida do homem. Graças à sua riqueza e ao fato de raramente não se apresentar com rios de perfis longitudinais regulares, tipicamente de planície, tem sido aproveitada pela navegação, tendo sido o meio de penetração e de fixação dos povoadores. Via de comunicação, elemento justificador de determinadas culturas, fonte de pesca, ou elemento perturbador como decorrência da cheias, os rios contribuem para definir grande parte das características das paisagens regionais (PETRONE, 1966, p. 31).

Temperaturas médias anuais que oscilam entre os $18^{\circ} \mathrm{C}$ nos meses frios e $25^{\circ} \mathrm{C}$ nas épocas mais quentes, umidade relativa do ar nunca abaixo de $70 \%$ e maior incidência pluviométrica nos meses mais quentes, com invernos secos, caracterizam o clima da região como quente e úmido. Desse conjunto conclui Petrone:

As condições climáticas da baixada não só são grandemente responsáveis pelas características de boa parte das atividades agrícolas como, e principalmente, devem ser responsabilizadas pelas dificuldades em definir um calendário agrícola para a região. A inexistência de um ritmo sazonário bem marcado, assim como as irregularidades e desvios que se verificam, anualmente, no regime térmico e especialmente no pluviométrico, em grande parte explicam a inexistência, especialmente para as lavouras temporárias, de calendários bem definidos e, para as grandes lavouras permanentes, problemas inesperados, tais com a ausência prolongada de chuvas ou a presença de períodos excepcionalmente úmidos (PETRONE, 1966, p. 34-35).

Segundo Petrone, os solos da baixada do Ribeira não são considerados muito férteis por sua fragilidade, pouca profundidade e predominância de materiais silicosos. Há manchas 
de massapés e salmourões concentradas na região sublitorânea, ao longo das cidades de Registro, Jacupiranga e Eldorado. Sobre aqueles solos que constituem o substrato das áreas inundáveis, “(...) incluem-se entre os que na região oferecem melhores possibilidades, o que em parte se vê comprovado pela permanência de certas culturas sedentárias, a exemplo o arroz, apesar das técnicas rudimentares empregadas” (PETRONE, 1966, p. 37). ${ }^{3}$

Nice Lecocq Müller assim descreve as referidas técnicas empregadas pela população ribeirinha:

O caboclo "capuava" tem uma cultura semelhante, tecnicamente, à que é praticada nas regiões novas: como sua cultura é extensiva, mudando-se de ano para ano de lugar, ele tem que estar sempre empregando a derrubada e queimada da mata ou capoeiras e trabalhando em terreno relativamente entulhado por troncos carbonizados e tocos de árvores. Em conseqüência, não poderia deixar de ter uma agricultura presa à enxada (...) $\mathrm{O}$ arroz, embora fixo em sua ocupação, é produzido seguindo métodos muito primitivos. O plantio é feito pelo sistema do "chuço", que aliás também é feito nas culturas de manutenção, e que foi tão bem descrito por Carlos Borges Schmidt: "Preso à cinta trazia o roceiro uma minúscula sacola, com capacidade de litro... onde estavam as sementes... Na mão um pau roliço, com coisa de cinco e meio a seis palmos de comprido e tão grosso como um cabo de enxadão dos mais pesados, a extremidade inferior terminando ponteaguda. Caminhava um passo espichado. Dava uma batida no chão fofo, recémqueimado e encharcado pela chuva que há pouco caíra. Jogava no buraco assim feito dois ou três grãos... cobria e socava a cova com o próprio pau". Na fase de crescimento das plantas ele pouco faz, deixando que as ervas invadam as culturas e, quando chega a colheita, terá que se haver com o mato já crescido para conseguir se apossar das vagens de feijão, das espigas de milho, ou para arrancar a "rama" afim de colher a mandioca. Por esse motivo e também devido a possíveis chuvas pesadas ou enchentes que lhe derrubem o arrozal, a colheita do arroz é feita a canivete, cortando as espigas uma a uma; se a foice fosse empregada, tudo se perderia entre o mato e o lodo. Quando chegar a época de nova preparação do solo, o mato, até então vigoroso, terá de ser cortado e queimado: prática que é portanto comum ao capuava e ao ribeirinho (MÜLLER, 1948, p. 59-61).

\footnotetext{
${ }^{3}$ Acrescenta o autor: "A não ser no caso dos solos das áreas inundáveis, praticamente conservados pelas cheias, periódicas ou não, todos os demais, com poucas exceções, não suportam atividades agrícolas muito intensas. Normalmente, destruído o revestimento vegetal natural, especialmente no caso da floresta pluvial, os solos se refazem com demasiada lentidão. Embora em muitos casos, em especial nos solos das colinas e terraços antigos, as primeiras colheitas possam surpreender pela abundância, após alguns anos, às vezes apenas 3 ou 4, os solos se esgotam, os rendimentos deixam de ser compensadores e, em conseqüência, devem ser abandonados, dando lugar a capoeiras ralas. Nas áreas de sedimentação marinha, o problema é mais grave, dada a maior fragilidade dos solos. Nos casos dos depósitos marinhos antigos a presença de uma dura camada de areia consolidada, a poucos centímetros de profundidade, torna seu aproveitamento difícil"' (PETRONE, 1966, p. 38). Para uma caracterização geomorfológica mais recente da baixada do Ribeira, ver FRANCHI, 1999, p. 46-53.
} 
Tal descrição parece válida para todo o Oitocentos, independente da posse ou não de escravos. $^{4}$ A principal distinção refere-se ao processamento do arroz colhido. Ao tempo dos autores aqui citados, apresentavam-se os engenhos movidos a vapor, aos moldes dos engenhos centrais de cana já descritos pela historiografia, convivendo com os engenhos d’água. Durante o período enfocado nesta pesquisa, a energia hidráulica movia as unidades processadoras de arroz, dispersas ao longo de todo o Vale. ${ }^{5}$

Assim descrita a região, a seção seguinte sumaria seu processo de ocupação da região e a inserção do arroz na economia colonial.

\section{Da colonização do Vale do Ribeira no século XVI à decadência do arroz}

Ao aportar, em 12 de agosto de 1531, na barra de Cananéia, a expedição de Martim Afonso de Souza foi recepcionada por um grupo de europeus, provavelmente degredados e abandonados em expedições anteriores. Entre eles, fazia-se presente Cosme Fernandes, conhecido como "bacharel”. Esses informes, do diário de viagem redigido pelo irmão de Martim Afonso, Pero Lopes de Souza, constam em todos os textos consultados sobre a história da região. Segundo Ernesto Young, Cosme Fernandes, apesar de se encontrar com a esquadra portuguesa na barra ao sul da Ilha Comprida, habitava a região próxima a um morro na barra de Capara, ao norte da ilha, conhecida como “outeiro do bacharel” (cf. YOUNG, 1903, p. 225). ${ }^{6}$ Nesta região, por volta de 1577 , os habitantes teriam erigido a primeira capela. Conta ainda Young que, entre 1620 e 1625, liderados por Francisco Álvares Marinho, seus

\footnotetext{
${ }^{4}$ Corsino Medeiros dos Santos assim o descreve: “O plantio era feito normalmente por duas pessoas. Naturalmente poderia haver vários pares de pessoas ocupadas na tarefa, conforme a extensão do campo cultivado e a rapidez com que desejasse concluir a semeadura. Uma delas ia à frente com uma enxada na mão, abrindo covas em círculo ou em linha, mas distando uma da outra mais ou menos um palmo ou palmo e meio. A outra pessoa vinha atrás atirando nas covas uma quantidade de sementes que variava entre 5 a 10 grãos por cova e em seguida as cobria com uma porção de terra, com o pé. Isto para impedir que as aves comessem as sementes e para facilitar a germinação (...) Havia também o plantio em terrenos alagados, embora com menos freqüencia. Para tanto, o arroz era deixado durante 24 horas na água, a fim de que ao se proceder a semeadura, a semente fosse imediatamente ao fundo, evitando ser comida por aves" (SANTOS, 1979, p. 7-8). Para o autor, "as técnicas de cultivo do arroz no Brasil permaneceram primitivas e empíricas por quase duzentos anos, porquanto o estímulo da demanda era muito fraco para promover a modernização. De um lado o arroz enfrentava a forte concorrência da mandioca, do milho e do feijão nos hábitos alimentares do brasileiro, $e$ de outro, o surto cafeeiro criou condições para a importação de arroz barato. Somente no começo do século atual [século XX - AV] é que iniciou a expansão e modernização da cultura de arroz” (SANTOS, 1979, p. 8).

${ }^{5} \mathrm{Na}$ documentação consultada, a primeira referência a um engenho a vapor data de 1867.

${ }^{6}$ Acerca do famigerado "bacharel”, há interpretações diversas entre os autores consultados. Edmundo Krone, por exemplo, identifica-o como Francisco Chaves, o bacharel de Cananéia (cf. KRONE, 1938, p. 542). Antonio Paulino de Almeida aceita a versão de que se tratavam de pessoas distintas e que Chaves seria genro de Cosme Fernandes, o verdadeiro bacharel (cf. ALMEIDA, 1955, p. 31).
} 
moradores abandonaram o antigo local e se estabeleceram na área correspondente ao atual núcleo urbano de Iguape (cf. YOUNG, 1897, p. 86-87). ${ }^{7}$

Acredita Young que a nova capela, dedicada a Nossa Senhora das Neves, data de 1637 e foi demolida em 1858, quando as imagens foram transferidas para a nova matriz, sob a invocação do Senhor Bom Jesus (cf. YOUNG, 1903, p. 320). Próximo a essa região, em meados desse século, Paranaguá vivia o auge da extração aurífera. Paulino de Almeida publicou dados obtidos por Young referentes às entradas registradas na oficina de fundição de Iguape entre os anos de 1668 e 1677. Os informes diários são esparsos, mas permitem uma avaliação grosseira da produção de ouro na região. Assim, por exemplo, no dia 21 de fevereiro de 1668, seis mineradores teriam comparecido à casa de fundição para quintarem o ouro, totalizando 245 oitavas, sendo o padre Francisco Pereira da Silva o responsável por 200 oitavas do valor indicado. O único registro disponível para o ano de 1670 refere-se ao dia 6 de outubro, quando 190 oitavas foram arrecadadas de 13 mineradores, sendo um certo Manoel da Costa o principal contribuinte com 82,5 oitavas. O último dado obtido pelo historiador iguapense data de 27 de dezembro de 1677, quando sete mineradores depositaram 420 oitavas (cf. ALMEIDA, 1955, p.39-43). ${ }^{8}$

A busca e exploração do ouro de aluvião nos cursos d’água que compõem a bacia do Ribeira exerceram papel fundamental na ocupação interior do vale, atingindo não apenas seus limites com o paredão da Serra de Paranapiacaba (Eldorado e Iporanga), como também regiões serra acima (Apiaí e Paranapanema). Ao que tudo indica, as descobertas do ouro das Gerais e Cuiabá estimularam o êxodo de parte desses mineradores, não obstante a permanência de núcleos isolados em Xiririca e Apiaí (Cf. ALMEIDA, 1955, p. 45-46 e VALENTIN, 2001, em especial capítulos 2 a 4).

Em que pese o caráter efêmero das atividades mineratórias, as povoações da orla marítima provavelmente obtiveram ganhos não desprezíveis, pois se constituíam em rotas

\footnotetext{
${ }^{7}$ Em outra obra, afirma o autor: "Assim parece natural que o povo, não podendo edificar suas casas em lugar cômodo, em virtude de ser o local acanhado e ainda distante da única travessia fácil entre o Mar Pequeno e o rio Ribeira, então preferido para os estabelecimentos agrícolas, lembrasse de mudar a vila para esta planície, onde encontraria espaço para seu aumento futuro, materiais para suas construções e proximidade dos sítios que iam se formando" (YOUNG, 1903, p. 238-239).

${ }^{8}$ Sérgio Buarque de Holanda ressalta o alento que significou os descobertos da região: "É ali, entre Iguape e Paranaguá, e um pouco nas aluviões auríferas das vizinhanças de São Paulo, principalmente para as bandas de Parnaíba e Voturuna, que se vai desenvolver nessa fase a maior colheita de ouro (....) A atração do ouro foi causa, segundo velhas notícias, da fixação de grande número de moradores de São Paulo no lugar das novas minas. Não só as margens do Cubatão e dos contrafortes que circundam a baía de Paranaguá foram esquadrinhadas por essa gente; também no alto da serra, as jazidas do Atuba e do Barigui serão logo procuradas" (HOLANDA, 1960, p. 255). Sobre a fase aurífera da Capitania, ver ainda MAFFEI \& NOGUEIRA (1966).
} 
obrigatórias tanto do abastecimento de toda a hinterlândia como do escoamento do ouro. Ao início do Setecentos, despontava outra atividade econômica: a construção de embarcações. Data de 1711 o primeiro registro transcrito de construção de uma nau nas cercanias de Cananéia, ${ }^{9}$ tendo nesta vila seu auge entre 1761 e o primeiro terço do século seguinte. Pari passu, a mesma fonte refere, em vários anos, a abundância da produção de farinha de mandioca e sua comercialização com as praças de Santos e Rio de Janeiro. Estas duas atividades também se desenvolveram na vizinha Iguape, como indica a lista nominativa de 1801 e os inventários consultados.

Portanto, ao início do governo do Morgado de Mateus, distinguem-se alguns núcleos populacionais: a vila de Iguape e seu entorno, na faixa litorânea; a área de Xiririca, ainda vinculada à extração do ouro e uma pequena massa populacional dispersa entre os dois limites, resultado da expansão acima descrita, referida na documentação como "Ribeira acima”.

Uma estimativa das atividades econômicas da vila de Iguape e sua freguesia de Xiririca em meados da segunda metade do século XVIII provém dos rendimentos da Câmara Municipal no triênio 1762-1764. Exceto as vilas de São Paulo (21,2\%), Paranaguá (14,3\%) e Santos (9,9\%), todas as demais localidades arrecadaram valores abaixo dos Rs. 200\$000. No cômputo geral, Iguape ocupava a $13^{\mathrm{a}}$ posição entre 19 vilas, somando Rs. 107\$023, o que representava 3,4\% do total do triênio. ${ }^{10}$ Esta posição sugere um quadro não muito animador entre os comerciantes iguapenses, uma vez que parte dos rendimentos da Câmara derivava dos impostos sobre bens adquiridos em outras regiões e comercializados no Vale.

É nesse momento que temos os primeiros registros do cultivo do arroz na Colônia como produto mercantil. O arroz, segundo Henrique Carneiro, constitui um dos chamados alimentos modernos:

\footnotetext{
9 “Este foi o ano em que chegaram os construtores para a dita nau, sendo vindo do Rio de Janeiro. Seu estaleiro foi o mesmo profetizado lugar, o qual ainda hoje se apelida - estaleiro da Nau. Juntaram-se jornaleiros para o serviço e trabalho dela. Trabalhou-se na sua construção um ano. Havia pagamento na semana, com dinheiro e fazendas. Não houve naquele ajuntamento infelicidade mais sentida do que morrerem afogados o contra-mestre do aparelho e o piloto, que passavam de passagem da terra firme para a sua banda, na condução de seus mastaréus. Esta, julgo, foi a primeira obra naval aqui fabricada. Acabou-se a nau. Repicaram-se os sinos. Celebrou-se missa. Lançou-se ao mar com felicidade e com ela se navegou até Lisboa, onde naquela corte por sua naturalidade teve o nome de "Nau Cananéa"” (ALMEIDA, 1948, p. 11). O trecho transcreve anotações do livro "Memórias memoráveis" da Câmara de Cananéia.

10 Todas as porcentagens referem-se ao total arrecadado. Arrecadações menores que Iguape: Curitiba, Pindamonhangaba, Jacareí, Cananéia, Itanhaém e São Vicente; acima de Iguape, além das três já citadas, encontravam-se Guaratinguetá, Itu, Sorocaba, Mogi, Taubaté, São Sebastião, Ubatuba, Parnaíba e Jundiaí (cf. D.I., v. 19, p. 90). Segundo Roberto Fortes, "na segunda metade do século XVIII, a maior fonte de recursos da Câmara - talvez a única - eram os novos impostos cobrados sobre a aguardente e o sal comercializados na Vila, principalmente sobre os primeiros" (FORTES, 2000, p. 164).
} 
Os alimentos modernos são aqueles que se difundiram pelo mundo por meio da intensificação do comércio e do intercâmbio provocada pelas navegações transoceânicas da "primeira globalização" do século XVI, entre os quais o açúcar constituiu talvez o produto mais importante, mas também os álcoois destilados, as especiarias, as bebidas quentes, além de diversos produtos regionais que a época moderna universalizou (batata, tomate, milho, arroz, trigo etc.) (CARNEIRO, 2005, p. 75).

Nos explica Corcino Medeiros dos Santos que na Colônia, a introdução do arroz europeu de origem asiática só ocorreu por volta de 1745:

Tudo indica tratar-se do arroz vermelho, da terra ou de Veneza, como era chamado, que foi trazido pelos ilhéus dos Açores. Mas sua cultura se desenvolveu apenas até 1766, a partir de quando foi sendo substituído pelo arroz branco da Carolina. Entretanto, esta substituição não foi simples; mas era de maior interesse comercial e, por isso, necessária. Para promovê-la foi preciso que, em 1772, um bando do governador do Maranhão cominasse as penas de multa, cadeia, calcota e surra aos que continuassem na cultura do arroz vermelho da terra em vez do branco da Carolina, único permitido (SANTOS, 1979, p. 7).

No Rio de Janeiro, o primeiro grande engenho de arroz no Rio de Janeiro provavelmente data de 1756, construído por Antonio Marques Guimarães em seu sítio “Andaray Pequeno”, no Engenho Velho. Guimarães possuía o exclusivo para o processamento dos grãos, conforme nos explica Dauril Alden, porém a má condução dos negócios impediu a prosperidade dos negócios sob seu comando. Em 1759, Manoel Luis Vieira, em sociedade com comerciante radicado em Lisboa, Domingos Lopes Loureiro, adquiriu o engenho por 56 mil cruzados. ${ }^{11}$ Segundo Alden, Vieira trabalhara como caixeiro na casa comercial de Couto Pereira e, antes da aquisição, manteve-se como seu corresponde em Lisboa durante três anos.

Com o engenho reformado e o privilégio do exclusivo, em 1760 comprou 35.255 alqueires de arroz em casca de 417 fornecedores e, no ano seguinte, 48.425 alqueires de 684 pessoas. ${ }^{12} \mathrm{O}$ funcionamento do engenho foi abruptamente interrompido em 1762 por uma ordem de prisão que manteve Vieira distante dos negócios por mais de 6 anos. Em 1766 Vieira conseguiu renovar o alvará que lhe garantia a manutenção do exclusivo, porém só conseguiu reabrir o engenho em 1768, comprando 60 mil arrobas de arroz em casca e 100 mil no ano seguinte. Em 1770 um outro viés, desta vez na Europa, travaria seus negócios: credores ingleses de seu sócio lisboeta obtiveram o embargo das remessas de grãos realizadas naquele ano. Incentivado pelo Marques do Lavradio, Vieira ainda tentou reerguer a empresa,

\footnotetext{
${ }^{11}$ Este engenho, movido a água, possuía 3 rodas mestras e 24 rodas secundárias que acionavam 2 pedras para a retirada da primeira casca e 28 pilões para a eliminação da segunda. Contava com 2 administradores, 5 feitores e 42 escravos, além de 80 bois carreteiros que moviam 6 carretas e um saveiro que transportava o arroz ensacado até o porto fluminense (cf. SANTOS, 1979, p. 12).

${ }^{12}$ Segundo a proporção observada no Vale do Ribeira, cada alqueire de arroz pilado derivava de 2 a 2,5 alqueires de arroz em casca. Assim, 48 mil alqueires de arroz em casca produziriam cerca de 20 mil alqueires de arroz pilado ou 10 mil sacos. Aproximadamente 90 anos depois, os maiores engenhos do Vale do Ribeira produziam cerca de 2 mil sacos ou um quinto do engenho de "Andaray Pequeno".
} 
buscando auxílio entre os comerciantes fluminenses e pleiteando um empréstimo junto à Coroa. Até 1779 seu pedido não fora julgado e, dois anos antes, Vieira vendeu parte de suas terras no Rio de Janeiro, provavelmente indicando o abandono das atividades (cf. ALDEN, 1959, p. 529-536).

Dentre as dificuldades enfrentadas por Manoel Luis Vieira para a obtenção de créditos, ele incluiu a expansão dos engenhos de arroz no Maranhão. Segundo Corcino Medeiros dos Santos, em 1770 a Companhia Geral do Maranhão e Grão Pará possuía três engenhos de arroz no Maranhão; no entanto, ao mesmo tempo em que investia em engenhos centrais, os administradores da Companhia estimulavam a construção de pequenas unidades (cf. SANTOS, 1979, p. 14).

Praticamente toda a produção destinava-se ao mercado externo. Entre 1772 e 1807, do porto do Rio de Janeiro saíram cerca de 158 mil sacos de arroz correspondendo a médias decenais iguais a 3.197 na década de 1770, 5.671 na década de 1780 e 4.300 nas duas posteriores. Em 1777, as exportações de açúcar refinado renderam Rs. 114:155\$650; as de arroz, pouco mais de 3 contos de réis (Rs. 3:669\$760). Já em 1796, esses valores atingiam Rs. 571:844\$700 e Rs. 23:257\$500, respectivamente (cf. LOBO, 1978, p. 59-63). Guardadas as proporções, enquanto a renda obtida através do açúcar quintuplicou, aquela percebida com as exportações de arroz cresceu cerca de 6 vezes.

Ainda no mesmo período (entre 1796 e 1811), o arroz se mantinha como produto de exportação em alguns portos: sétimo lugar no Rio de Janeiro, segundo lugar no Maranhão, terceiro lugar no Pará, sexto lugar em Santos. No conjunto dos produtos, o arroz ocupava a quinta posição, correspondendo a 4\% do valor total exportado no período e tendo Portugal como principal destino. A quantidade total de arroz exportada variou de pouco mais de 427 mil arrobas em 1796 a cerca de 780 mil em 1806. Nesse último ano, por exemplo, Maranhão e Pará respondiam por mais de seis décimos (62\%) do total, seguidos pelo Rio de Janeiro (29\%) e nenhuma exportação através do porto de Santos (Cf. ARRUDA, 1980, p. 392 a 398). ${ }^{13}$ Em relação ao Rio de Janeiro, os dados de Larissa Brown mostram essa “febre” em algumas freguesias cariocas, especialmente Itaguaí, que na década de 1810 exportou, em média, cerca de 13.000 alqueires anuais. Sua percepção corrobora a idéia expressa acima: “(...) rice was among the most important exports of Itaguaí during the early nineteenth century. By the

\footnotetext{
${ }^{13}$ Em sacos, estas quantidades correspondem a 170 mil sacos em 1796 e 312 mil sacos em 1806. Em 1798, segundo dados compilados por Corcino Medeiros dos Santos, as exportações somavam 559.424 arrobas, 56\% proveniente do Maranhão, 31\% do Rio de Janeiro, 11\% do Pará e apenas 2\% do porto de Santos (cf. SANTOS, 1979, p. 18).
} 
eighteen-teens, however, rice shipments were in decline while coffee was in the ascendant" (BROWN, 1986, p. 324).

Para Celso Furtado, o crescimento das exportações de arroz guarda associação com um momento favorável no mercado internacional.

Tão importante quanto a ajuda financeira, entretanto, foi a modificação no mercado mundial de produtos tropicais, provocada pela guerra da independência nos EUA e logo em seguida pela revolução industrial inglesa. Os dirigentes da companhia [Geral do Maranhão e Grão Pará - AV] perceberam desde o início que o algodão era o produto tropical cuja procura estava crescendo com mais intensidade e que o arroz produzido nas colônias inglesas e principalmente consumido no sul da Europa não sofria restrição de nenhum pacto colonial (FURTADO, 1989, p. 91). ${ }^{14}$

Os dados coligidos por Larissa Brown sobre o arroz remetido do Vale do Ribeira para o Rio de Janeiro indicam que, em 1799, Iguape e Cananéia respondiam por 40\% do total (ou 7.318 dos 18.045 alqueires); em 1813, 33\% e, em 1821, 69\% ou 18.885 dos 31.099 alqueires importados (cf BROWN, 1986, p. 417). Outro informe que também indica a expansão do comércio nessa fase diz respeito ao fluxo de navios: em 1797, Brown afirma que apenas seis embarcações vindas de Iguape e Cananéia entraram no porto do Rio de Janeiro, número que se manteve razoavelmente constante até 1813, com o registro de 15 navios, valor médio observado até 1822 (cf. BROWN, 1986, p. 410). ${ }^{15}$ Segundo as tábuas de comércio elaboradas por John Luccock entre 1813 e 1817, as partidas de Iguape em direção ao Rio de Janeiro representaram 22\% em 1815, 23\% em 1816 e 18\% em 1817 do total de embarcações oriundas dos portos da Capitania paulista (Cf. LUCCOCK, 1951, p. 403). ${ }^{16}$

Entre as décadas de 1820 e 1850 não conseguimos localizar dados sobre as exportações de arroz. Em 1857, o relatório do Ministério da Fazenda forneceu as remessas de arroz para o mercado externo segundo os portos de origem para os exercícios de 1851/52 a

\footnotetext{
${ }^{14}$ Aparentemente os efeitos da independência americana não foram tão prolongados: em relação à década de 1770 , a produção norte-americana nos anos de 1780 recuou $40 \%$, porém recuperando o mesmo patamar na década seguinte, não obstante os drásticos efeitos da independência das colônias inglesas nas áreas produtoras de arroz: "During the Revolutionary War the great rice plantations of both Loyalists and Americans fell into disrepair and their slaves escaped, approximately 7.000 fleeing to the British lines, where they grant freedom. Others fled into the back country to find refuge with de Creek Indians and into Florida with the Seminoles. After the war, the rice coast was slowly rehabilitated and the plantations of this area once again became thriving units" (SMITH, 1985, p. 29; sobre os dados de produção, ver p. 214-215).

${ }^{15}$ Não obstante a manutenção do bloqueio sofrido pelas localidades litorâneas: "A região [Litoral - AV] sofreu o impacto das medidas adotadas por Bernardo José de Lorena. Este, no sentido de estimular a Capitania e evitar que os produtos fossem exportados pelo Litoral Norte para o Rio de Janeiro e, ademais, visando concentrar todo o comércio marítimo de São Paulo no porto de Santos, proibiu, em 1789, o comércio realizado fora desse porto. Isso teve um impacto negativo nas atividades econômicas desenvolvidas no litoral norte da Capitania (...) O efetivo impacto dessas medidas, na época violentamente criticadas pelos habitantes da região, deve ter causado efeitos negativos sobre as atividades econômicas das localidades envolvidas, mas incapaz de conter o forte dinamismo no período como um todo" (LUNA, 1998, p. 109).

${ }^{16}$ Os portos considerados pelo autor são: Santos, São Sebastião, Cananéia, Paranaguá, Iguape, Bertioga e Guaratuba. Luccock registrou 106 embarcações em 1815, 57 em 1816 e 87 em 1817.
} 
1855/56. Pelo porto do Rio de Janeiro - principal destino do arroz embarcado em Iguape - a quantidade total exportada nos cinco exercícios, 124.548 alqueires, gerou uma renda equivalente a Rs. 437:459\$803 ou Rs. 3\$511 por alqueire. Entre 1851 e 1855, a quantidade total de arroz que saiu do Vale do Ribeira igualou-se a 487.434 alqueires, gerando uma renda total de Rs. 1:214:942\$027, a um preço médio de Rs. $2 \$ 493$, o que representava $71 \%$ do preço médio de exportação. No extremo, se o litoral sul paulista fosse o único fornecedor do grão para a praça carioca, ainda assim praticamente três quartos do arroz teriam outro destino que não o mercado externo. ${ }^{17}$ É possível afirmar, portanto, que a partir da década de 1850 o arroz do Vale do Ribeira atendia essencialmente a demanda interna pelo cereal.

Vozes dissonantes manifestaram-se em vários momentos contra a manutenção do cultivo do arroz na região. Em 1845, José Inocêncio Alves Alvim, diretor da Mesa de Rendas de Iguape, exprimia sua indignação:

É verdadeiramente digno de lástima o estado presente da máxima parte (por não dizer da totalidade, o que talvez seria mais exato) dos lavradores tanto deste município [Iguape - AV] como os de Xiririca! Possuindo-lhes boas situações e em geral terra excelente para todo o gênero de cultura com especialidade para a de cana, do café, do algodão, do fumo etc. não tem sabido aproveitá-las, cultivando unicamente arroz e deixando por mão tudo o mais a ponto de comprarem muitas vezes a farinha para sustento da família; pelo que a maior parte deles vivem empenhados e sem esperança de melhor futuro! (ALVIM, 1845, p. 9).

Ao passar pela região, cerca de uma década depois, Carlos Rath, animado com o cultivo de café na região do rio Juquiá, afirmava:

\begin{abstract}
É de esperar que aqueles agricultores depois que observaram praticamente a maneira de beneficiar e cultivar o café e que se convenceram das vantagens resultantes deste ramo, venham por fim aplicar-se a ele abandonando a cultura do arroz. O algodão, fumo e mamona produz de modo admirável; qualquer destas plantas cultivadas em porte grande, daria maior interesse que a cultura do arroz, entretanto apenas os lavradores plantam meia dúzia de pés de cada um deles para remédios caseiros. Em muitas partes, em volta inteiras da Ribeira, de Juquiá e de outros rios, estão as margens cobertas de palmas Christi ou mamoneiras que nascem espontaneamente e que no tempo próprio estão carregadíssimas de frutos. Custará certamente acreditar-se, porém é verdade: tudo se perde, porque ninguém se importa de aproveitar tão grande proveito da natureza; entretanto, o azeite de mamona que se consome no país é importado do rio de Janeiro. ${ }^{18}$
\end{abstract}

\footnotetext{
${ }^{17}$ Cf. Balanço da Receita e Despesa do Império, 1857, Quadro 66. Ainda segundo o relatório, no mesmo período, pelo porto do Maranhão saíram 312.167 arrobas (ou aproximadamente 62 mil alqueires) a um preço médio anual de Rs. $1 \$ 536$ por arroba; pelo porto do Pará, 162.485 alqueires a Rs. $2 \$ 513$ por alqueire/ano. Sebastião Ferreira Soares, em “Notas estatísticas...”, publicado originalmente em 1860, afirma que a exportação de arroz para a Europa pelas províncias do Pará e Maranhão na década de 1850 não ultrapassava os 50.000 alqueires anuais ou 25.000 sacos. No início da década de 1860, os dados compulsados por Eulalia Maria Lobo corroboram a percepção de que o arroz recebido no porto carioca destinava-se ao consumo local, pois não constava mais da lista dos 10 produtos mais importantes da pauta de exportações (cf. LOBO, 1978, p. 273).

${ }^{18}$ AESP, Ofícios diversos de Iguape, ordem n. ${ }^{\circ} 1.043 a$.
} 
No início da década de 1870, entretanto, o engenheiro J. Coutinho revelava uma percepção das condições ambientais mais próxima daquela que hoje conhecemos do Vale do Ribeira:

O principal gênero cultivado nas margens da Ribeira é o arroz para o qual se presta perfeitamente o clima e o terreno. Por diversas vezes têm-se tentado a cultura do café, porém sem resultado vantajoso, o mesmo acontecendo com a do algodão, por causa da umidade atmosférica. Nos terrenos banhados pelo São Lourenço, afluente do Juquiá, prosperam, entretanto, muito bem estas duas plantas, segundo fui informado. A cana desenvolve-se satisfatoriamente mas o caldo contém pequena porção de matéria sacarina, exigindo por isso o cozimento grande quantidade de combustível, principalmente na parte inferior do vale, onde a terra é muito úmida. ${ }^{19}$

Para Coutinho, a alternativa agrícola para a região passava pelo cultivo de plantas de clima úmido, como o cacau e a seringueira:

Abertas as estradas de Xiririca a Paranapanema, e de Iporanga a Faxina, aclimado o cacaueiro e Sinphonia elastica, e posta em prática a exploração de ferro de Jacupiranga, chumbo e prata de Iporanga e Apiahy, bismuto e antimônio da região que se estende à Assunguy, então não terá Iguape que invejar a sorte dos distritos cafezistas, sendo nesta época o mais rico e industrioso. ${ }^{20}$

É possível dimensionar o entusiasmo de J. Coutinho utilizando seus próprios cálculos sobre a renda per capita em Iguape comparada com a região campineira. Lá, segundo o engenheiro, a renda por habitante atingia Rs. 9\$506; em Iguape, Rs. \$534, isto é, 17 vezes menos do que a obtida com a agricultura agro-exportadora do Oeste paulista.

Contudo, os arrozais mantiveram-se como a principal prática agrícola dos ribeirenses. No início da década de 1880, não obstante “(...) a ausência de uma política capaz de orientar a produção e os mecanismos de distribuição para o consumo do conjunto de populações urbanas” (LINHARES, 1979, p. 218), o estímulo à importação de arroz estrangeiro produziu uma considerável redução no preço registrado no Rio de Janeiro, de Rs. $14 \$ 000 / 12 \$ 000$ para Rs. $8 \$ 000 / 6 \$ 000$ por saco, reduzindo ainda mais os ganhos obtidos pelos ribeirenses (cf. LINHARES, 1979, p. 176). Esta prática, segundo Paul Mandell, manteve-se até 1896, quando o governo brasileiro duplicou a tarifa de importação de 30 para 60 réis por quilo. Esta taxa foi novamente duplicada em 1903 e reajustada em 33\% em 1906; ainda incidia uma sobretaxa de 50\%, resultando em 215 réis por quilo, praticamente 50\% do preço no atacado. Os dados sintetizados pelo autor evidenciam uma queda substancial na quantidade importada no primeiro decênio do século XX, de 100 mil toneladas em 1902 para pouco menos de 11 mil em 1909. Os efeitos desta política induziram o desenvolvimento do cultivo do arroz em outras regiões brasileiras, como o Rio Grande do Sul, Goiás, Mato Grosso e a

\footnotetext{
${ }^{19}$ AESP, Ofícios diversos de Iguape, ordem n. ${ }^{\circ} 1.047$.

${ }^{20}$ AESP, Ofícios diversos de Iguape, ordem n. ${ }^{\circ} 1.047$.
} 
retomada da lavoura no Maranhão. Em São Paulo, a região de Ribeirão Preto passou a produzir arroz em larga escala, atingindo depois o triângulo mineiro (cf. MANDELL, 1972, p. 175-178).

O Vale do Ribeira, com inserção tardia na produção mercantil do arroz, ${ }^{21}$ já não mais fazia parte destes centros mais dinâmicos. Reduzidas as possibilidades de escoamento dos grãos através do porto de Iguape e pouco beneficiado pelo ramal ferroviário da Estrada de Ferro Sorocabana, que chegou até Juquiá tardiamente no ano de 1912, o cultivo de arroz manteve-se, por falta de opção, até fins da década de 1960, porém com valores insignificantes: 130 mil sacos em 1950 e 147 mil em 1969 (cf. FORTES, v. I, 2000, p. 95). ${ }^{22}$

\section{Os objetivos e as fontes documentais}

Da "febre do arroz" no século XVIII, aqui entendida como o aumento da produção direcionado para a exportação, aparentemente os ribeirenses puderam se aproveitar apenas de sua fase final. Como sugere Larissa Brown, enquanto as demais regiões produtoras do centrosul passaram a investir no cultivo do café, as plantações de arroz ocupavam cada vez mais espaço ao longo do rio Ribeira e seus afluentes, atingindo valores máximos na década de 1850. Destarte, a perda do estatuto de produto de exportação para o atendimento da demanda interna afetou sobremaneira a economia regional, assentada na manutenção da lavoura arrozeira como o principal produto com valor mercantil.

Nesse sentido, nossa investigação busca articular estas mudanças no mercado de arroz com a acumulação da riqueza dos ribeirenses entre os anos de 1800 e 1880, distinguindo-a nos diversos estratos populacionais e relacionando as variações observadas na composição dessa riqueza com a dinâmica gerada pela disseminação, auge e estagnação das atividades vinculadas ao cultivo e comercialização do arroz.

Ao posicionarmos nossa pesquisa dentro da historiografia econômica, carreamos um conjunto de preocupações metodológicas. Posto ser inegável que “(...) a excessiva ênfase dada ao econômico acabou por criar um monstro invertebrado, pouco atraente e, sobretudo, distante da complexidade inerente à história dos homens” (FRAGOSO \& FLORENTINO,

\footnotetext{
${ }^{21}$ Não conseguimos determinar com exatidão o início dessa produção em larga escala no Vale do Ribeira. A lista nominativa de 1798, que não utilizamos em nosso estudo populacional, indica a saída de 10 mil alqueires de arroz (ou 5 mil sacos) através do porto de Iguape. As mudanças na estrutura de posse de escravos manifestam os efeitos iniciais da rizicultura nas duas décadas derradeiras do século XVIII, isto é, cerca de 30 anos após o início desse cultivo em outras regiões da colônia. No Capítulo 1 apresentamos o fluxo de arroz exportado pelo porto de Iguape ao longo do século XIX.

${ }^{22}$ Como comparação, o autor destaca que a exportação de manjuba, em 1967, somou Cr\$ 31.035.787,00 e, a de arroz, Cr\$5.947.500,00.
} 
1997, p. 3), compreendemos a necessidade de não se perder a importância do fato econômico, buscando delimitar a história das relações sociais de produção, circulação e consumo das mercadorias, assim como o universo mental e simbólico dos produtores e consumidores (cf. ARRUDA, 1998, p. 175-191).

Da mesma forma, lembra Hebe Castro que “(...) os métodos quantitativos, se trouxeram as grandes massas para a história, ao trabalharem com dados agregados, tenderam a retirar-lhes a face humana” (CASTRO, 1997, p. 50). Diante dessa adversidade, recortes alternativos propiciam a geração de estudos históricos diferenciados: "Novos métodos de leitura e tratamento de fontes demográficas ou cartorárias, em níveis de agregação menores que os praticados nas décadas anteriores, e sua combinação com fontes qualitativas também vêm produzindo expressivos resultados” (CASTRO, 1997, p. 52). ${ }^{23}$

Buscamos, durante a execução deste trabalho, enfocar dois planos: um essencialmente quantitativo, relativo ao próprio desenvolvimento da produção agrícola na região em apreço e ao perfil da riqueza retida nos aludidos estratos populacionais. O outro busca identificar as estratégias e possibilidades de expansão e controle desta riqueza no espaço das relações sociais de produção.

Definir a acumulação de riqueza como objetivo central da pesquisa implica a adoção de uma definição: de qual riqueza está se falando? Tal questionamento nos remete às fontes primárias consultadas. Os inventários post-mortem constituem um tipo documental amplamente utilizado por pesquisadores na reconstituição de um recorte possível da composição de bens possuídos, pois “(...) dispomos de informações precisas sobre a situação do defunto, de seu cônjuge e dos herdeiros; quando a morte atingiu uma pessoa casada, é possível, na maioria dos casos, reconstituir a fortuna dos casais; finalmente, a composição dos bens é bastante detalhada” (DAUMARD, 1985, p. 215). ${ }^{24}$ Isso não significa, entretanto, que um conjunto de cuidados não devam ser tomados durante a consolidação das informações: por exemplo, sempre é possível a ocorrência de variabilidade na composição dos bens arrolados, omissões (ou inclusões indevidas) por conta de doações em vida, ausência de objetos não valorados, ajustes meramente contábeis nas partilhas que não correspondam às respectivas cotas recebidas pelos herdeiros.

\footnotetext{
${ }^{23}$ A autora refere-se aos trabalhos atribuídos aos historiadores vinculados à micro-história (cf. VAINFAS, 2002. Ver também o prefácio de Jacques Revel para o livro A herança imaterial, de Giovanni Levi, 2000).

${ }^{24}$ Entre as inúmeras pesquisas desenvolvidas com base nesta fonte documental, destacamos MELLO (1985), SCHWARTZ (1999), FRAGOSO (1998), SAMPAIO (1994), OLIVEIRA (1997), MARCONDES (1998), MARQUES (2000), TEIXEIRA (2001), NOGUERÓL (2003), LOPES (2005), REIS (2005) e GARAVAZO (2006).
} 
Também ao pesquisador não é possível desconsiderar que um desses documentos, tomado isoladamente, indique apenas uma fotografia do momento da vida material do inventariado. Por outro lado, "a análise de um conjunto de inventários, entretanto, permite captar o(s) movimento(s). Pode-se, por exemplo, agregar inventários em grupos específicos e perceber trajetórias de vidas que se assemelham, estabelecendo-se padrões de conduta ou de produção" (FARIA, 1998, p. 227).

Tais considerações não eximem os resultados obtidos de problemas analíticos. Como ressalta João Fragoso, apreender como a riqueza se distribui entre os grupos sociais é fundamental na medida em que se reconhece essa riqueza como causa de uma forte desigualdade socioeconômica. Para tanto, não basta analisar o conjunto de informes segundo estratos quantitativos contínuos. Nessa medida, a possibilidade de incorporação de classes sócio-profissionais permite maior aproximação à idéia de partição dessa riqueza entre classes sociais (cf. FRAGOSO, 1998, p. 46-47). Ademais, é preciso sempre ter em mente que essa documentação não diz respeito ao universo populacional da área estudada, mas a determinados grupos sociais que possuíam riqueza e que foram submetidas à avaliação por conta da necessidade legal da partilha dos bens.

Nossa empreitada em tentar identificar o posicionamento sócio-profissional dos inventariados mostrou-se relativamente satisfatória, sob a qual classificamos tanto os inventários como os informes das listas nominativas. ${ }^{25}$ Esta classificação assenta-se na principal ocupação exercida pelo inventariado ou chefe de domicílio e, no caso das listas nominativas, utilizamos o próprio informe anotado pelo recenseador. Para os inventários, buscamos inicialmente sua localização nas próprias listas nominativas e também em outros documentos, como as relações de proprietários de engenho, os manifestos de carga que acompanhavam as remessas de arroz e o rol de comerciantes que recolhiam a taxa sobre casas de negócios abertas em Iguape e Xiririca. Como último recurso, recorremos aos próprios bens avaliados, como os tipos de cultivados avaliados, a posse de arroz, de mercadorias etc. ${ }^{26}$

\footnotetext{
${ }^{25}$ Utilizamos a matriz sugerida por COSTA \& NOZOE, 1987.

${ }^{26}$ Nossa experiência com este tipo documental parece bem distinta da vivida por Luiz Paulo Ferreira Nogueról, para quem "A identificação de comerciantes e produtores, por meio dos inventários, não é tarefa difícil. De fato, usando os termos que usualmente se empregam atualmente, é possivel indicar quais pessoas eram donas de lojas e quais eram donas de escravos e terras. A partir daí, estabelecemos identidades. Verificamos, porém, que era raro um comerciante não possuir terras e escravos. De igual maneira, os produtores possuíam dívidas ativas referentes às mercadorias que haviam produzido e tinham vendido" (NOGUERÓL, 2003, p. 44). Em nossa amostra, estas situações citadas por Nogueról não permitiam decidir qual era, de fato, a principal área de atuação de alguns inventariados. De qualquer forma, o próprio autor relativiza o problema: “(...) uma separação em compartimentos estanques das duas categorias sociais ainda que logicamente possível, não o é em termos reais, o que não nos surpreende: é que a separação entre capital mercantil e capital produtivo serve antes à apreensão de uma certa dinâmica social do que à sua fiel descrição" (NOGUERÓL, 2003, p.44).
} 
Acreditamos que esta classificação, que guarda um inegável fator apriorístico, revela-se fundamental para a consolidação do conhecimento econômico do passado brasileiro, muito dele construído através da análise comparativa. Não obstante, propomos nesta tese uma forma alternativa para agregar inventários, baseado no peso relativo de cada grupo de bens avaliados na composição da riqueza. Outrossim, se a primeira estabelece um diálogo para fora, a segunda volta-se para dentro, para a hierarquia interna à sociedade ribeirense. Detalhamos em seguida alguns procedimentos adotados no tratamento dos 678 inventários post-mortem que compõem nossa amostra. ${ }^{27}$

Das avaliações contidas nos inventários, agregamos os resultados em seis grupos. Os bens de raiz incluem sítios, chácaras, terrenos, casas, construções diversas e cultivados. Preservamos a distinção entre os bens rurais e urbanos, o que nos permitiu identificar estratégias distintas na acumulação de riqueza entre os ribeirenses. O item escravos corresponde ao total de cativos avaliados no processo. Adiantamos que as informações sobre os cativos nos inventários mostram-se bem mais pobres do que as obtidas nas listas nominativas: além do nome e idade, as demais informações (origem, cor, condição conjugal, ocupação) aparecem em poucos casos. Ademais, optamos pela exclusão dos filhos de escravas nascidos após a promulgação da Lei do Ventre Livre. No Apêndice desta tese apresentamos uma avaliação desta decisão.

Sob a denominação móveis agregamos um conjunto diversificado de bens: todos os bens pessoais do inventariado (roupas, móveis, utensílios domésticos, jóias em prata e ouro) e todas as ferramentas (de agricultura e de atividades específicas, embarcações, carros, objetos de ferro e cobre, couros para secagem de arroz, componentes do tráfico de farinha - forno, roda e prensa -, instrumentos de medida etc.). A categoria dinheiro representa todos os valores monetários em ouro, prata e cobre, além de valores declarados em mãos de terceiros. Optamos por incluir aqui os únicos três casos com posse de ações, não apenas pela insignificante freqüência como também pelo pequeno valor que estas representavam. Nossa decisão por assim compor os dois últimos grupos decorreu do baixo valor que tais categorias

\footnotetext{
${ }^{27}$ Nossa amostra corresponde a cerca de 75\% dos inventários listados no Museu de História e Arqueologia de Iguape (doravante MHAI) e $85 \%$ dos processos pertencentes ao Fórum de Eldorado Paulista (FEP). Não conseguimos determinar sua representatividade no conjunto dos processos abertos durante o século XIX pois, conforme afirma Alves Alvim, "Não existe nem no Arquivo da Câmara nem nos cartórios nem nos livros da Matiz documento algum que mencione o nome do fundador da vila e com certeza o ano da sua fundação; todos os documentos antigos foram consumidos por dous incêndios: um no Cartório Judicial Público de Notas, onde se guardavam os livros da Comarca e outro na casa do vigário Antonio Cordeiro de Oliveira, onde se achavam os livros da Matriz” (ALVIM, 1845, p. 15v.). O autor não refere os anos, porém acreditamos que o do Cartório Judicial tenha ocorrido nas primeiras décadas do século XIX, a julgar pela baixa freqüência de inventários entre os anos de 1800 a 1840.
} 
representavam na riqueza total: a soma de todos os bens pertencentes ao grupo móveis atinge $5,8 \%$ da riqueza e o dinheiro, $2,6 \%$.

As dívidas ativas conglomeram todos os haveres declarados pelo inventariante ou seu representante legal. Estes aparecem com denominações distintas nos inventários: simplesmente dívidas ativas, conta de livro, créditos, vales. Em muitos processos encontramos apenas o valor total das mesmas; nos casos que pudemos localizar o rol de devedores, compilamos os informes e em praticamente todos eles os valores totais não se igualaram. Neste caso, aceitamos os nossos resultados totalizadores. Adotamos os mesmos procedimentos para as dívidas passivas e, para ambos, buscamos assinalar a ligação parental do credor ou devedor em relação ao inventariado.

Trabalhamos com duas medidas de riqueza: a riqueza bruta corresponde à soma dos grupos: bens de raiz, escravos, móveis, dinheiro e dívidas ativas; e a riqueza liquida, o resultado da subtração das dívidas passivas ao primeiro valor. Estas não guardam associação com as medidas de monte-mor ou monte-menor: no caso da primeira, desprezamos as informações sobre ajustes relativos a dotes e doações realizadas pelo inventariado por não podermos determinar com exatidão o tempo transcorrido entre a doação e a morte. Também não consideramos alterações de valores feitas após a primeira avaliação, exceto a exclusão de bens que comprovadamente não compunham o patrimônio do inventariado. Ainda não consideramos as despesas realizadas para pagamento do funeral e das custas do inventário, basicamente por entendermos que tais descontos produziriam distorções desproporcionais em relação à quantidade de bens avaliados. Como se perceberá ao longo trabalho, no Vale do Ribeira fazia-se como prática comum o expediente da arrematação dos bens em praça pública, geralmente por solicitação do inventariante ou atendendo exigências dos credores. Como resultado, poderiam acarretar acréscimos ou diminuições nos valores atribuídos, dependendo da “demanda” pelo bem leiloado. Utilizamos estas informações para ilustrar algumas situações, porém tais variações também não foram levadas em consideração em nossos cálculos de riqueza.

Em certa medida, os problemas sobre a abrangência dos inventários são solucionados pelo uso das listas nominativas, pois estas cobrem o conjunto da população e, em virtude de sua freqüência, permitem um acompanhamento longitudinal com maior minúcia. Não obstante, arrolamos outras limitações ao uso dessa fonte documental. Os Capitães-mores das vilas paulistas, responsáveis pela confecção das listas, não raramente cometiam deslizes dos mais variados tipos em sua elaboração: duplicidade de registros, eliminação de fogos, inferência de dados tanto a respeito do número total e das idades das pessoas como das 
atividades econômicas afetas aos domicílios, ou ainda praticavam simples “atualizações” de listas anteriores, às vezes mediante consulta dos registros eclesiásticos de batismos e mortes, porém não raras vezes com o acréscimo da unidade às idades. Ademais, o período coberto pelos referidos arrolamentos corresponde, grosso modo, ao último terço do Setecentos e à primeira trintena do século XIX.

Por se tratar de uma fonte serial, o levantamento de seu conjunto fornece dados sobre a consistência dos informes lá constantes, tanto em relação ao padrão demográfico como ao conjunto de informes econômicos concernentes aos fogos. Nesse último aspecto, cabe ressaltar que, além dos registros fogo a fogo, utilizamos os quadros sobre as exportações e importações realizadas durante o ano e, no caso específico de Iguape, há informes sobre a movimentação portuária, explorados no Capítulo 1. Tal conjunto não apenas enriquece o manancial de informações sobre a localidade como também favorece o exercício da crítica sobre os dados, seja em seu agregado ou em aspectos específicos relacionados à produção das mercadorias arroladas ou a determinados segmentos populacionais. ${ }^{28}$ A conjugação dos informes nas listas nominativas com os censos populacionais de 1854 e 1874 propiciaram o dimensionamento da população livre e escrava no Vale do Ribeira em quase todo o período em estudo. Apresentamos no Apêndice este evolver populacional.

Ademais, é inegável que o conjunto de estudos produzidos a partir desse tipo de fonte documental estabeleceu uma sólida metodologia, evidenciando aspectos relativos à composição dos fogos, relações familiares, vínculos econômicos e padrões de riqueza, ${ }^{29}$ destacando-se neste último caso a estrutura de posse de escravos. ${ }^{30}$

Estes dois corpos documentais constituem a espinha dorsal deste trabalho. Buscamos estabelecer um diálogo entre ambos ao longo de sua execução, com a sempre presente observação das limitações acima expostas e lembrando que os nomes das pessoas - variávelchave para o intercâmbio entre tais fontes - embutem a possibilidade de outros erros:

\footnotetext{
${ }^{28}$ Cabe referenciar a existência de outros estudos que buscaram problematizar os informes constantes nas listas nominativas, como os encetados por FERNÁNDEZ, 1989; NOZOE, \& COSTA, 1991; NOZOE \& COSTA, 1992; NADALIN, 1994 e BACELLAR, 1994.

${ }^{29}$ Destacamos, entre outros, os seguintes autores: MARCÍLIO, 2000; MESQUITA, 1975; COSTA, 1992; MOTTA, 1999; MARCONDES, 1998; GUTIERREZ GALLARDO, 1986; RANGEL, 1990; LUNA, 1992 e 1998.

${ }^{30}$ Neste caso, a vinculação do cativo é estabelecida com seu proprietário, conforme pioneiro estudo encetado por Francisco Vidal Luna (cf. LUNA, 1981) e reiterado, por exemplo, em COSTA, \& NOZOE, 1989; MARCONDES, 1998 e MOTTA, 1999. O estabelecimento das faixas de tamanho dos plantéis deve compreender, simultaneamente, dois critérios: a visão da dinâmica da localidade e a análise comparativa com outras regiões escravistas, segundo preconizado por Costa \& Nozoe: "Os pontos de corte para a determinação do tamanho de cada faixa, assim como o número das mesmas, foram definidos em função de análise preliminar na qual tentamos identificar os grupos que apresentavam características demográficas e econômicas não muito díspares" (COSTA \& NOZOE, 1989, p. 327, nota n. ${ }^{\circ}$ 4).
} 
variações na forma de redação ao longo do tempo, a recorrência de homônimos no Brasil dos séculos XVIII e XIX, a constatação de que os sobrenomes dos cônjuges e filhos não obedecem ao padrão hodierno etc.

Ainda destacamos os documentos que forneceram informes valiosos à elaboração do evolver da economia ribeirense ao longo do período. A série publicada pelo Arquivo do Estado de São Paulo, denominada Documentos Interessantes para a História e Costumes de São Paulo, compreende as correspondências entre o governo da Capitania (e depois Província) com autoridades portuguesas e locais; a contrapartida dessa documentação encontra-se nos manuscritos avulsos classificados na mesma instituição como Ofícios diversos, de autoria dos iguapenses que ocuparam cargos públicos na Câmara, nos juizados e nas delegacias. Esse conjunto traz o transcorrer do cotidiano administrativo da vila: relatórios sobre ocorrências, atas de eleições, listas de voluntários dos Corpos de Milícias, episódios envolvendo a apropriação das terras nacionais, constituindo assim um rico acervo de nomes, locais e datas. ${ }^{31}$ Nesse conjunto ainda incluímos os relatórios mensais da Mesa de Rendas de Iguape, que forneceram informações detalhadas sobre quantidades e preços das mercadorias importadas e exportadas através daquela escala, assim como a relação das embarcações que registraram passagem ${ }^{32}$ e os livros relativos ao pagamento de sisa sobre transações de compra e venda de propriedades rurais e urbanas e o pagamento de impostos sobre estabelecimentos comerciais.

Para todas as fontes que indicam valores monetários, destacamos a necessidade de tratamento de ajuste frente à desvalorização da moeda nacional, principalmente ao longo da segunda metade do século XIX. Dessa forma, convertemos os valores monetários em libras

\footnotetext{
${ }^{31}$ Uma aplicação dessas fontes para a reconstituição da história econômica de uma localidade paulista pode ser encontrada em VALENTIN, 2001, principalmente capítulos 2 a 4.

${ }^{32}$ Em seu clássico trabalho sobre o plantio de cana e produção de açúcar em São Paulo, Maria Thereza Schorer Petrone utiliza-se dos dados constantes em fontes de mesma natureza: os mapas de exportação do porto de Santos e as listas da barreira de Cubatão. Apesar da constatação "A ausência de exatidão nos dados estatísticos, tanto nos que se referem ao número de engenhos, quanto sobre produção e exportação se fez sentir ao longo de todo nosso trabalho", destaca a autora: "Usamos os dados, mesmo percebendo que apresentavam incoerências, para balizar a evolução da produção açucareira em São Paulo. Sempre sentimos, porém, não somente a falta de dados estatísticos para compreender a evolução da economia canavieira, como também a sua inexatidão" (PETRONE, 1968, p. 140). Na década de 1980, como desdobramento de comunicação publicada por José Jobson de Andrade Arruda (ARRUDA, 1979, p. 1033-1060), duas dissertações de mestrado por ele orientadas revisitaram essas fontes: Hernani Maia Costa recupera a organicidade do conjunto documental das barreiras paulistas, inserindo-as no contexto tributário da Província (cf. COSTA, 1984 e 2001). Já Francisco Alves da Silva retoma a barreira de Cubatão e analisa a circulação dos produtos agrícolas lá apontados, enfocando não apenas o açúcar e o café, mas também os cultivos considerados pelo autor como sendo de subsistência: farinha, feijão, milho, arroz, toucinho, chá, batatas, além de carnes, couros e animais em pé (cf. SILVA, 1985).
} 
inglesas. ${ }^{33}$ Esse procedimento é o mesmo adotado, entre outros, por Renato Marcondes, não obstante o conhecimento de que "esta decisão implica a aceitação de uma possibilidade de subestimação da inflação, especialmente após 1850” (MARCONDES, 1998, p. 309-310). A alternativa, isto é, a manutenção dos valores em moeda corrente, dificulta a comparação de riquezas avaliadas em momentos distintos. No entanto, objetivando a comparação com dados de autores que assim não procederam, utilizamos também os valores nominais de bens e riquezas.

A presente tese organiza-se em 5 capítulos. No primeiro, tratamos do quadro econômico mais amplo da região entre 1800 e 1880. Ali enfocaremos os dados obtidos acerca da produção e comercialização do grão, assim como um panorama da riqueza avaliada através dos inventários coletados. Os dois seguintes tratarão dos dois principais ativos presentes nos inventários: os bens de raiz (Capítulo 2) e os escravos (Capítulo 3). Nossa análise sobre os bens de raiz parte do Inventário de Bens Rústicos de 1818 e avança utilizando os informes constantes nos próprios inventários e nos registros de pagamento de sisa sobre bens de raiz. Nosso principal interesse recaiu sobre as propriedades rurais, porém também apresentamos alguns dados relativos aos bens urbanos, principalmente em Iguape.

O Capítulo 3, ainda que não consideremos o central deste trabalho, configura-se no mais extenso - e também mais árido ao leitor. A primeira parte trata da estrutura de posse de escravos em Iguape e Xiririca através de listas nominativas das três primeiras décadas do século XIX. Em seguida, cotejamos estes resultados com os obtidos através dos inventários abertos entre 1800 e 1841. Posteriormente, apresentamos a estrutura de posse atinente aos demais anos e encerramos o capítulo com algumas considerações acerca do preço atribuído aos escravos nos processos consultados.

Nos dois capítulos finais utilizamos quase que exclusivamente os resultados obtidos de nossa amostra de inventários. O Capítulo 4 confronta os representantes da elite ribeirense, a saber, proprietários de engenho de arroz e comerciantes. Inicialmente comparamos o padrão da riqueza acumulada. Em seguida, apresentamos alguns casos que pudemos acompanhar através das fontes consultadas, desenhando as trajetórias econômicas desses representantes.

E por fim, dedicamos o Capítulo 5 aos demais estratos da estrutura produtiva da região. Buscamos demonstrar a abrangência da cultura do arroz e seus impactos em todas as

\footnotetext{
${ }^{33}$ Optamos por utilizar a série “Curso de câmbio sobre Londres, de 1808 a 1906” (IBGE, 1986). Para uma revisão das séries disponíveis, ver NOZOE et. alli, 2004.
} 
camadas da sociedade ribeirense. Em seguida, dedicamos atenção aos não-proprietários de cativos do ponto de vista de uma classificação interna ao próprio grupo. 


\section{PRODUCC̃̃O E COMÉRCIO NO VALE DO RIBEIRA NO SÉCULO XIX}

Neste capítulo pretendemos fornecer ao leitor um painel das atividades econômicas desenvolvidas no Vale do Ribeira entre 1800 e 1880. Alguns dos temas apresentados trazem uma visão definitiva do assunto; outros serão retomados em capítulos posteriores. Incluem-se no primeiro grupo o movimento comercial entre 1803 e 1830, a movimentação portuária entre 1840 e 1880 e a produção e comercialização de arroz entre 1840 e 1870 . As partes que tratam da produção nos domicílios do Vale do Ribeira e da riqueza acumulada nos inventários visam tão-somente compor um quadro mais amplo; tanto as fontes como os resultados merecerão tratamento mais qualificado nos capítulos procedentes.

\section{As primícias e a expansão do comércio de arroz no porto de Iguape - 1803 a 1830}

As listas nominativas concernentes à vila de Iguape fornecem a partir de 1803 - de forma bastante irregular - as entradas e saídas de embarcações, bem como a quantidade e valor das cargas transportadas. Naquele ano registraram-se 15 saídas do porto de Iguape. Exceto quatro navios novos em lastro, cinco deles dirigiram-se para o porto de Santos com carga variada, ${ }^{34}$ totalizando pouco menos de 9 contos de réis (Rs. 8:806\$360). As quatro partidas destinadas ao Rio de Janeiro, compostas principalmente por madeiras e arroz pilado, corresponderam a Rs. 1:960\$800. ${ }^{35}$ As entradas de embarcações com carga somavam nove registros, carregando fazendas secas provenientes do Rio de Janeiro (5 navios), carne seca, toucinho, sal e algodão de Santos e Santa Catarina (4 navios), totalizando Rs. 16:960\$017, além de Rs. 2:100\$000 em aguardente, toucinho, farinha de trigo e congonha importados de Paranaguá, Apiaí e Paranapanema, estes dois últimos por terra. ${ }^{36}$

\footnotetext{
${ }^{34}$ Arroz, madeiras, farinha, milho, feijão, goma etc.

35 Uma das saídas (para Cananéia) não continha a carga e outra, carregada de madeira, não constava a identificação do destino.

${ }^{36}$ Este é o único ano que encontramos informação sobre o comércio por via terrestre. Não descartamos a possibilidade do tráfego comercial por via terrestre, porém acreditamos que seu volume represente parcela inexpressiva da quantidade total, a julgar pela recorrência de reclamações acerca da qualidade dos caminhos, com a que reproduzimos, redigida pelo diretor da Mesa de Rendas de Iguape, em 1856: "O comércio interno com a povoação de serra acima é quase nenhum, apenas um ou outro lavrador chega a esta cidade para vender os gêneros de sua lavoura, a saber, toucinho, cevadas e algum gado; pouco, estes gêneros são aqui consumidos e sempre reputados por altos preços e mal chegam para o consumo da população da cidade e destes há falta contínua, falta esta devida a não existirem estradas a comunicar esta com aquelas povoações, pois que as picadas que existem (...) não animam aos tropeiros a arriscarem seus gêneros e animais; são essas picadas: uma que segue desta cidade à vila de Xiririca e dali à Freguesia de Paranapanema e outros pontos vizinhos; outra que de Santo Antonio de Juquiá vai a Itapetininga e seu arredores e uma outra chamada do Travessão, no rio Ipiranga, que também comunica para Paranapanema e Itapetininga"(AESP, Ofícios diversos de Iguape, ordem n. ${ }^{\circ}$ 1.043a). Destarte, tomamos a quantidade de arroz exportada pelo porto de Iguape como indicador da quantidade de arroz cultivado na região.
} 
Em verdade, o ano acima considerado insere-se no período que vigorava, em território paulista, a proibição de envio de navios diretamente ao porto do Rio de Janeiro. Esse ato, original do Capitão-general Bernardo José de Lorena (1788-1797), foi parcialmente revisto em 1798 por Antonio Manoel de Mello Castro e Mendonça, retomado por Antonio José de Franca e Horta em 1803 e só revogado com a chegada da família real ao Rio de Janeiro (cf. PETRONE, 1968, p. 141-151). A anotação de partidas para o porto do Rio de Janeiro na lista desse ano obrigou o Capitão-mor de Iguape, José Antonio Peniche, a comparecer diante do Capitão-general paulista para prestar explicações sobre a infração ocorrida (cf. DI, v. 55, p. 172-173 e 250-251).

Seis anos mais tarde a movimentação portuária em Iguape já refletia o impacto da presença da Corte portuguesa no Brasil: das 12 saídas, a maioria se dirigia ao Rio de Janeiro (7 navios) e Santos perdia a primazia do comércio iguapense, com 5 embarcações. As primeiras transportavam principalmente arroz, ao passo que as demais carregaram um leque mais amplo de mercadorias: taboados, café, farinha e milho. Maior distinção notamos nos valores negociados, pois se através de Santos as vendas geraram o montante de Rs. 4:319\$125, aquelas realizadas com o porto carioca renderam praticamente o triplo (Rs. 13:786 \$015). Tal situação também se fez evidente nas importações realizadas: dos 9 navios registrados, 6 procediam do Rio de Janeiro, com carga equivalente a Rs. 6:773\$846 versus Rs. 5:338\$792 dos 3 navios oriundos de Santos.

As tabelas seguintes sintetizam os resultados das exportações obtidos entre os anos de 1809 e 1825, segundo porto de destino e valor em libras. Do conjunto de embarcações que partiram de Iguape, todas transportavam alguma quantidade de arroz. O porto do Rio de Janeiro predominava na quantidade de embarcações e de arroz despachada. O cômputo geral indicado nas duas tabelas oculta, entretanto, oscilações significativas entre os anos considerados. ${ }^{37}$ Conforme assinalado, o ano de 1809 ainda refletia as decisões tomadas pela Coroa portuguesa no sentido de liberar a atracação de navios paulistas nas docas cariocas. A partir de 1812, quando mais de oito décimos das embarcações e do arroz destinavam-se à sede do governo luso, consolidava-se essa nova forma de comercialização.

\footnotetext{
${ }^{37}$ Para todos os testes de médias adotamos nível de significância igual a 5\%.
} 
Tabela 1.1

Distribuição das embarcações segundo destino e valor em libras

(Porto de Iguape, 1809 a 1825)

\begin{tabular}{|c|c|c|c|c|c|c|c|c|c|c|c|c|c|c|c|c|}
\hline \multirow{2}{*}{ Anos } & \multicolumn{4}{|c|}{ Rio de Janeiro } & \multicolumn{4}{|c|}{ Santos } & \multicolumn{4}{|c|}{ outros destinos } & \multicolumn{4}{|c|}{ total } \\
\hline & $\mathbf{N}$ & $\%$ & valor $(£)$ & $\%$ & $\mathbf{N}$ & $\%$ & valor $(£)$ & $\%$ & $\mathbf{N}$ & $\%$ & valor $(£)$ & $\%$ & $\mathbf{N}$ & $\%$ & valor $(£)$ & $\%$ \\
\hline 1809 & 8 & 61,5 & 4.122 & 76,1 & 5 & 38,5 & 1.296 & 23,9 & - & - & - & - & 13 & 7,0 & 5.418 & 6,5 \\
\hline 1811 & 15 & 75,0 & 8.592 & 71,9 & 4 & 20,0 & 2.654 & 22,2 & 1 & 5,0 & 698 & 5,8 & 20 & 10,8 & 11.944 & 14,4 \\
\hline 1812 & 15 & 88,2 & 10.498 & 88,7 & 2 & 11,8 & 1.336 & 11,3 & - & - & - & - & 17 & 9,2 & 11.834 & 14,2 \\
\hline 1815 & 23 & 85,2 & 9.540 & 94,5 & 3 & 11,1 & 516 & 5,1 & 1 & 3,7 & 39 & 0,4 & 27 & 14,6 & 10.095 & 12,1 \\
\hline 1816 & 13 & 56,5 & 4.310 & 74,9 & 9 & 39,1 & 1.420 & 24,7 & 1 & 4,3 & 27 & 0,5 & 23 & 12,4 & 5.758 & 6,9 \\
\hline 1817 & 17 & 70,8 & 12.623 & 82,8 & 4 & 16,7 & 931 & 6,1 & 3 & 12,5 & 1.683 & 11,0 & 24 & 13,0 & 15.237 & 18,3 \\
\hline 1822 & 23 & 85,2 & 10.792 & 92,8 & 3 & 11,1 & 496 & 4,3 & 1 & 3,7 & 346 & 3,0 & 27 & 14,6 & 11.634 & 14,0 \\
\hline 1825 & 29 & 82,9 & 10.644 & 94,3 & 4 & 11,4 & 128 & 1,1 & 2 & 5,7 & 511 & 4,5 & 35 & 18,9 & 11.283 & 13,6 \\
\hline total & 143 & 77,3 & 71.121 & 85,5 & 34 & 18,4 & 8.777 & 10,5 & 8 & 4,3 & 3.304 & 4,0 & 185 & 100,0 & 83.203 & 100,0 \\
\hline
\end{tabular}

Obs.: outros destinos = Montevidéu, Paranaguá, Rio Grande e Buenos Aires.

Tabela 1.2

Distribuição das embarcações com arroz segundo destino, quantidade e valor em libras

(Porto de Iguape, 1809 a 1825)

\begin{tabular}{|c|c|c|c|c|c|c|c|c|c|c|c|c|c|}
\hline \multirow{2}{*}{ Anos } & \multirow{2}{*}{ saídas } & \multicolumn{4}{|c|}{ Rio de Janeiro } & \multicolumn{4}{|c|}{ Santos } & \multicolumn{4}{|c|}{ total } \\
\hline & & alqueires & $\%$ & valor $(£)$ & $\%$ & alqueires & $\%$ & valor $(£)$ & $\%$ & alqueires & $\%$ & valor $(E)$ & $\%$ \\
\hline 1809 & 13 & 12.770 & 77,7 & 4.030 & 77,8 & 3.655 & 22,3 & 1.147 & 22,2 & 16.425 & 6,4 & 5.177 & 6,6 \\
\hline 1811 & 20 & 21.057 & 76,9 & 8.454 & 76,4 & 6.336 & 23,1 & 2.605 & 23,6 & 27.393 & 10,6 & 11.059 & 14,0 \\
\hline 1812 & 17 & 23.229 & 88,6 & 10.471 & 88,7 & 3.000 & 11,4 & 1.332 & 11,3 & 26.229 & 10,1 & 11.803 & 14,9 \\
\hline 1815 & 27 & 39.097 & 95,0 & 9.517 & 94,9 & 2.061 & 5,0 & 507 & 5,1 & 41.158 & 15,9 & 10.023 & 12,7 \\
\hline 1816 & 22 & 18.735 & 77,5 & 4.205 & 77,7 & 5.431 & 22,5 & 1.208 & 22,3 & 24.166 & 9,3 & 5.413 & 6,9 \\
\hline 1817 & 24 & 29.709 & 93,2 & 12.612 & 93,1 & 2.169 & 6,8 & 930 & 6,9 & 31.878 & 12,3 & 13.542 & 17,1 \\
\hline 1822 & 27 & 43.493 & 95,5 & 10.772 & 95,7 & 2.046 & 4,5 & 485 & 4,3 & 45.539 & 17,6 & 11.258 & 14,3 \\
\hline 1825 & 35 & 45.311 & 99,0 & 10.611 & 98,9 & 456 & 1,0 & 113 & 1,1 & 45.767 & 17,7 & 10.724 & 13,6 \\
\hline total & 185 & 233.401 & 90,3 & 70.672 & 89,5 & 25.154 & 9,7 & 8.327 & 10,5 & 258.555 & 100,0 & 78.999 & 100,0 \\
\hline
\end{tabular}

Obs.: outros destinos com 3,3\% somam 3,3\% do total de alqueires e 3,7\% do valor em libras, não inclusos na tabela.

Esta tendência, também observada nos dois anos da década de 1820, modificou-se parcialmente entre os anos de 1816 e 1817. Não se trata apenas, conforme indicam as tabelas, de uma redução na quantidade de arroz exportada (que caiu de 41.308 alqueires em 1815 para 24.166 alqueires em 1816 e 35.940 alqueires em 1817, neste último incluindo os outros destinos), mas também na renda, que foi, entre 1815 e 1816, de $£ 10.060$ para $£ 5.413$ (ou de Rs. 32:735\$520 para Rs. 22:299\$500). Analisando apenas a quantidade de grãos exportados, 
poder-se-ia imaginar condições adversas ao cultivo dos grãos redundando em más safras. No entanto, o preço médio do alqueire de arroz conhecia, desde 1809, sucessivos aumentos, passando de Rs. $1 \$ 050$ para Rs. $1 \$ 459$ em 1812. Durante todo o ano de 1815 , o preço se manteve em torno de Rs. 800 por alqueire; em 1816, apenas em dezembro houve uma alta, alcançando a média de Rs. 822 para, no ano seguinte, atingir Rs. $1 \$ 564{ }^{38}$

Roberto Simonsen identifica dois fenômenos distintos atuando neste momento na economia: uma forte aceleração das emissões realizadas pelo neófito Banco do Brasil a partir de 1814 e uma mudança na paridade da taxa de câmbio, que passou de 73,25 dinheiros por mil-réis em 1815 para 58,25 em 1816, decorrente do final das guerras napoleônicas e conseqüente estabilidade da moeda britânica. Ademais, entre 1809 e 1819, a balança comercial entre Brasil e Portugal manteve-se positiva, à exceção dos anos de 1816 e 1817, como uma espécie de efeito retardado das políticas agrícolas do período pombalino (cf. SIMONSEN, 1962, p. 404 e segs.). Mircea Buescu não tem a mesma percepção do período: não obstante os esforços de Pombal, o autor identifica uma etapa recessiva no último quartel do século XVIII, apenas parcialmente recuperada nas duas primeiras décadas do Oitocentos.

Especificamente em relação aos preços, nota Buescu que “(...) tal como aconteceu em épocas anteriores e como vai verificar-se em épocas subseqüentes, a variação dos preços apresenta-se de forma bastante incoerente, denotando a inconsistência do mercado" (BUESCU, 1973, p. 124). Para o período aqui considerado, a taxa de variação dos preços calculada por Buescu atingiu 34,5\% entre 1807 e 1819, resultado de três observações (1807, 1813 e 1819). ${ }^{39}$ Sem descartar a importância das emissões realizadas pelo Banco do Brasil, a pressão altista dos produtos de exportação entre 1808 e 1822 e a alteração cambial a partir de 1814, Buescu considera que a elevação dos preços no período decorreu principalmente da “(...) incapacidade de expansão da produção de consumo local, marginalizada pelo mercantilismo e colonialismo" (BUESCU, 1973, p. 130).

Mais recentemente, os dados coletados por João Fragoso acerca dos preços registrados no porto do Rio de Janeiro para o charque, farinha de mandioca, trigo e aguardente guardam, em certa medida, o mesmo movimento observado para o arroz exportado em Iguape: o trigo e a aguardente sofreram uma redução dos preços entre 1814 e 1815, enquanto o charque e a farinha mantiveram-se constantes. O dado contrastante pertence ao açúcar, que

\footnotetext{
${ }^{38}$ As outras três mercadorias exportadas através do porto iguapense não apresentaram a mesma oscilação: o alqueire da farinha de mandioca passou de Rs. 480 em 1815 para Rs. 533 em 1816 e Rs. 720 em 1817; a arroba do café também subiu, nos três anos, de Rs. 861 para Rs. 1 \$085 e Rs. 1\$280. No entanto, as quantidades exportadas desses produtos não garantem a consistência das oscilações.

${ }^{39}$ Cf. BUESCU, 1973, p. 125. Entre 1809 e 1817, o preço do arroz em Iguape variou 190\%.
} 
entre 1812 e 1816 passou de Rs. $1 \$ 011$ para Rs. 2\$304, caindo depois, em 1822, para Rs. $1 \$ 407$ (cf. FRAGOSO, 1998, p. 279). A indisponibilidade dos preços do arroz de Iguape no porto do Rio de Janeiro no período analisado ou, diversamente, das outras mercadorias em seus portos de origem não permite avançar nas considerações sobre tais oscilações. ${ }^{40}$

Tais considerações não eliminam a possibilidade de o preço do arroz acompanhar o preço dos produtos transacionáveis com o exterior ou oscilar conforme o valor das mercadorias destinadas ao consumo interno. A historiografia brasileira clássica ocupou-se em investigar a vocação agroexportadora manifesta desde o período colonial, considerando a produção de alimentos para o comércio interno como um fenômeno residual. Caio Prado Jr., ${ }^{41}$ por exemplo, assume a condição de auto-suficiência da grande unidade agrícola exportadora e reconhece a existência de duas formas básicas de produção de alimentos: uma tipicamente voltada para o autoconsumo, essencialmente rural e vinculada à lavoura de exportação e outra, desenvolvida nas fraldas das áreas urbanas, com algum grau de especialização e predomínio de pequenas propriedades. A oferta desses bens de consumo dependia, em última análise, dos preços dos exportáveis:

O papel secundário a que o sistema econômico do país, absorvido pela grande lavoura, vota à agricultura de subsistência (...) cria um problema que é dos mais sérios que a população colonial teve de enfrentar. Refiro-me ao abastecimento dos núcleos de povoamento mais denso, onde a insuficiência alimentar se tornou quase sempre a regra (...) Isso ocorre sobretudo nos momentos de alta de preços dos produtos de grande lavoura, quando as atividades e atenções se voltam inteiramente para ela e as culturas alimentares são desleixadas e abandonadas (PRADO JÚNIOR, 1989, p. 163).

Por seu turno, são conhecidas as análises de Celso Furtado sobre as crises dos sistemas voltados para o mercado externo e a expansão da economia de subsistência, com análises detalhadas para o setor açucareiro do Nordeste e mineratório em Minas Gerais (cf. FURTADO, 19891, p. 119-122). Apesar de o autor tratar secundariamente tal tema, suas considerações guardam certa relação com a perspectiva pradiana, especialmente nos liames com o setor exportador.

\footnotetext{
${ }^{40}$ Verificamos ao longo das oito décadas outros momentos semelhantes ao descrito. Ao tentar elucidá-las, esbarramos na ausência de séries históricas consistentes dos preços dos produtos comercializados, de tal forma que não mais abordaremos estas oscilações.

${ }^{41}$ É importante ressaltar que o autor reconhece o duplo papel exercido pelo arroz: "Quanto ao arroz, embora se consuma largamente no país, o grande volume de sua produção se explica sobretudo pela exportação que dele se faz. Podemos mesmo distinguir, na rizicultura colonial, um setor de grande lavoura, como no Maranhão, $e$ também em menor escala, no Pará e no Rio de Janeiro, onde o estímulo é claramente o de comércio exterior; e outro, de proporções muito mais reduzidas, disseminado por várias regiões, e que tem o mesmo caráter das demais culturas exclusivamente de subsistência, como as de mandioca e do milho" (PRADO JÚNIOR, 1989, p. 158). O autor provavelmente se refere ao período que engloba as últimas décadas do século XVIII e os primeiros anos do Oitocentos.
} 
Em verdade, o arroz cultivado no Vale do Ribeira não pode ser caracterizado, pelo menos no período entre o final do século XVIII e início do XIX, como sendo exclusivamente de consumo interno ou tão-somente um produto agrícola exportável. No entanto, fica evidente que os ganhos auferidos por este comércio alterou os padrões de consumo dos ribeirenses, conforme assinalam os dados da tabela seguinte.

Tabela 1.3

Distribuição das embarcações atracadas segundo origem e valor em libras

(Porto de Iguape, 1809 a 1825)

\begin{tabular}{c|rc|rc|rc|rc|rr|rr}
\hline \multirow{2}{*}{ Anos } & \multicolumn{4}{|c|}{ Rio de Janeiro } & \multicolumn{5}{|c|}{ Santos } & \multicolumn{4}{c}{ total } \\
\cline { 2 - 12 } & $\mathbf{N}$ & $\mathbf{\%}$ & valor (£) & $\mathbf{\%}$ & $\mathbf{N}$ & $\mathbf{\%}$ & valor (£) & $\mathbf{\%}$ & $\mathbf{N}$ & $\mathbf{\%}$ & valor (£) & \% \\
\hline 1809 & 6 & 66,7 & 2.032 & 55,9 & 3 & 33,3 & 1.602 & 44,1 & 9 & 6,4 & 3.634 & 4,2 \\
1811 & 12 & 75,0 & 8.332 & 68,1 & 4 & 25,0 & 3.896 & 31,9 & 16 & 11,4 & 12.228 & 14,2 \\
1812 & 11 & 84,6 & 9.990 & 79,6 & 2 & 15,4 & 2.553 & 20,4 & 13 & 9,3 & 12.543 & 14,6 \\
1815 & 12 & 63,2 & 7.787 & 68,9 & 7 & 36,8 & 3.521 & 31,1 & 19 & 13,6 & 11.308 & 13,1 \\
1816 & 10 & 62,5 & 6.141 & 83,0 & 6 & 37,5 & 1.258 & 17,0 & 16 & 11,4 & 7.400 & 8,6 \\
1817 & 16 & 76,2 & 12.937 & 82,7 & 5 & 23,8 & 2.710 & 17,3 & 21 & 15,0 & 15.647 & 18,2 \\
1822 & 18 & 75,0 & 9.998 & 86,0 & 6 & 25,0 & 1.625 & 14,0 & 24 & 17,1 & 11.623 & 13,5 \\
1825 & 13 & 59,1 & 10.166 & 87,1 & 9 & 40,9 & 1.512 & 12,9 & 22 & 15,7 & 11.678 & 13,6 \\
\hline total & 98 & 70,0 & 67.384 & 78,3 & 42 & 30,0 & 18.678 & 21,7 & 140 & 100,0 & 86.062 & 100,0 \\
\hline
\end{tabular}

Obs.: outras origens $=$ Cananéia e Paranaguá, com 2,8\% das entradas e 0,6\% do valor, não inclusos no total.

A expansão observada entre 1809 e 1825 tem relação com a capacidade produtiva: enquanto as exportações somaram $£$ 83.203, os gastos com importações totalizavam $£ 86.619$ (incluindo as outras origens), resultando em um saldo negativo de 3,9\%. Em outras palavras, enquanto a renda obtida através das exportações cresceu a uma taxa geométrica de 4,7\% ao ano, os dispêndios com produtos vindos principalmente dos portos do Rio de Janeiro e Santos aumentavam a uma taxa de 7,8\% ao ano. ${ }^{42}$ Em relação aos informes sobre os portos de origem desses navios, vale destacar, retomando a Tabela 1.1, a discrepância entre as saídas e entradas: no período, as saídas para o Rio de Janeiro (143 casos) e Santos (34 registros) não mantêm proporção com as 98 entradas provindas do porto carioca e as 42 oriundas do porto santista, além de o valor registrado não guardar proporcionalidade com o número de entradas. Possivelmente muitos dos navios que faziam o transporte do arroz retornavam em lastro para o canal do Mar Pequeno e apenas no ano de 1817 o número de entradas igualou-se ao de

\footnotetext{
${ }^{42}$ Em mil-réis, as exportações aumentaram 6,8\% ao ano e as importações, 10,0\%.
} 
saídas. Ainda no campo das exceções, em 1816 - período de quebra da quantidade exportada e também do acentuado declínio do preço do arroz - a participação de embarcações vindas do Rio de Janeiro perdeu a condição de predomínio relativa aos demais portos.

O déficit acumulado no saldo comercial iguapense, entretanto, atingiria valores mais expressivos em fins da década de 1820. Em 1828 as exportações somavam $£ 10.053$ contra $£$ 13.576 gastas em importações. Em 1829, £ 21.979 somavam as despesas com mercadorias nacionais e estrangeiras ante a uma receita de $£ 9.445$ e, em 1830, apenas $£ 8.137$ versus $£$ 13.748. Considerando todos os anos com informações disponíveis, o saldo negativo monta a $£$ 25.154 ou 22,7\% de toda a produção escoada pelo canal do Mar Pequeno. Ampliando o intervalo (1809 a 1830), os ganhos anuais com as exportações cresceram a 1,9\% versus 6,5\% em gastos com importações.

Esse déficit acumulado pode, em princípio, vincular-se ao preço do alqueire de arroz: sua cotação em moeda nacional valorizou 52\% no período; porém, quando convertido em libras, o preço em 1830 valia apenas 46\% daquele praticado em 1809. Nesse sentido, os saldos negativos só não foram maiores, pois, como indica a Tabela 1.1, a expansão da quantidade de arroz exportado manteve vigoroso crescimento: seu valor praticamente triplica entre 1809 e 1830, representando uma taxa anual de 5,3\%. Mesmo essa cifra não cobriria o aumento de mais de $1.700 \%$, em moeda nacional (ou 400\% em moeda inglesa), com gastos em bens vindos de outros portos. Como mencionado anteriormente, trata-se de um período em que a taxa de conversão sofreu uma apreciação considerável, especialmente após 1815, quando o valor médio passou de 73,25 dinheiros por mil-réis para 22,1825 em 1830.

Ainda em relação ao montante de gastos segmentado por grandes produtos, o Rio de Janeiro exercia o monopólio no fornecimento de escravos recebidos por mar, aguardente e praticamente dominava o mercado de sal (95\%) e fazendas secas (83\%). Ao porto de Santos coube a oferta de $28 \%$ dos molhados e $66 \%$ dos panos de algodão. Excluindo o ano de 1825, cujas indicações não precisavam gastos por produtos, as fazendas secas representaram 51\% das compras realizadas pelos comerciantes do Vale do Ribeira, seguidas por molhados e escravos, ambos com $17 \%$ do total. Essa totalização guarda oscilações fortes em diferentes anos. Por exemplo, em 1815 e 1816, a participação dos gastos com escravos representou, respectivamente, $4 \%$ e $7 \%$ - os menores valores observados para o período -, ao passo que as fazendas secas atingiram $74 \%$ e $67 \%{ }^{43}$

\footnotetext{
${ }^{43}$ Em 1812, o dispêndio com escravos representou $£ 4.330$ contra $£ 512$ em 1815 e $£ 538$ em 1816; já o gasto com fazendas secas passou de $£ 6.264$ em 1812 para $£ 8.342$ em 1815 e $£ 4.980$ em 1816.
} 
Entre os anos de 1809 e 1825 a fonte consultada permitiu discriminar os comerciantes responsáveis pelas cargas que desembarcavam no porto de Iguape. Os 489 registros compreendiam 101 consignatários distintos. Mais de quatro décimos (42\%) apareciam como responsáveis por uma única consignação; outros $31 \%$ com até 4 consignações, restando $28 \%$ com 5 ou mais consignações. A Tabela 1.4 discrimina aqueles com 10 ou mais registros.

Tabela 1.4

Comerciantes consignatários de mercadorias

(Porto de Iguape, 1809 a 1822)

\begin{tabular}{|c|c|c|c|c|c|}
\hline Comerciante & consignações & $\%$ & valor total $(£)$ & $\%$ & valor médio $(\xi)$ \\
\hline José Antonio Peniche & 31 & 6,3 & 6.294 & 8,4 & 203,0 \\
\hline Francisco Manoel de Alvarenga & 27 & 5,5 & 3.860 & 5,2 & 143,0 \\
\hline Baldoino Francisco da Costa & 24 & 4,9 & 3.015 & 4,0 & 125,6 \\
\hline Vitorino José Franco & 22 & 4,5 & 3.005 & 4,0 & 136,6 \\
\hline Antonio José Peniche & 21 & 4,3 & 5.645 & 7,6 & 268,8 \\
\hline Manoel Rodrigues do Rosario & 21 & 4,3 & 2.072 & 2,8 & 98,7 \\
\hline Bento Pupo de Gouveia & 18 & 3,7 & 2.384 & 3,2 & 132,5 \\
\hline Manoel Alves da Costa & 17 & 3,5 & 1.302 & 1,7 & 76,6 \\
\hline Bartolomeu da Costa de Almeida Cruz & 16 & 3,3 & 1.188 & 1,6 & 74,2 \\
\hline Antonio Moreira Ramos & 14 & 2,9 & 3.397 & 4,6 & 242,7 \\
\hline Antonio Borges Diniz & 14 & 2,9 & 1.563 & 2,1 & 111,7 \\
\hline Francisco Carneiro da Silva Braga & 12 & 2,5 & 3.976 & 5,3 & 331,4 \\
\hline José Antonio dos Anjos & 12 & 2,5 & 1.683 & 2,3 & 140,2 \\
\hline José Gonçalves Maia & 12 & 2,5 & 1.502 & 2,0 & 125,2 \\
\hline Candido Pupo da Rocha & 11 & 2,2 & 1.683 & 2,3 & 153,0 \\
\hline João José de Carvalho Simões & 11 & 2,2 & 1.622 & 2,2 & 147,4 \\
\hline José Francisco Carneiro da Silva Braga & 11 & 2,2 & 1.513 & 2,0 & 137,5 \\
\hline Antonio José Rodrigues & 10 & 2,0 & 3.011 & 4,0 & 301,1 \\
\hline menos de 10 consignações & 185 & 37,8 & 25.861 & 34,7 & 139,8 \\
\hline total & 489 & 100,0 & 74.575 & 100,0 & 257,4 \\
\hline
\end{tabular}

Os consignatários com menos de 10 recebimentos, que respondiam por 38\% dos despachos e 35\% do valor comercializado, concentravam suas compras em fazendas secas (56\% do gasto em libras), molhados (16\%) e escravos (12\%). A documentação consultada não permitiu determinar a quantidade de mercadorias transacionadas. A maioria dessas transações envolvia pequenos montantes: 39\% dos registros não superavam 50 libras. Das $£ 1.817$ gastas 
nesta faixa, fazendas secas (27\%) e molhados (41\%) correspondiam às mercadorias mais compradas, além de 16\% compondo mercadorias diversas. No outro extremo, apenas 24 registros superavam as 300 libras, envolvendo $£ 12.042$ gastas em fazendas secas (59\%), molhados (14\%), escravos (19\%) e diversos (8\%). Do conjunto de nomes, alguns se tornariam importantes negociantes no Vale do Ribeira a partir da década de 1830, como Bernardo Antonio Neves, Francisco de Souza Castro, José Jacinto de Toledo, Manoel Antonio Ramos, Miguel Antonio Jorge e Rafael Gomes Carneiro. ${ }^{44}$

No grupo com mais de 10 consignações, o Capitão-mor José Antonio Peniche e seu filho Antonio José Peniche respondiam por 16\% das despesas realizadas no período, atuando no ramo de fazendas secas (39\% do total gasto) e escravos (47\%).

Caso distinto compõe Bartolomeu da Costa de Almeida Cruz, que na Tabela 1.4 ocupa o último lugar no montante dispensado em compras ( $£$ 1.188). O perfil de suas compras parecia atender demandas internas à atividade de rizicultor: além de escravos (11\% em duas compras), Almeida Cruz encomendou grande quantidade de panos de algodão (42\% em 6 consignações); já os gastos com fazendas secas e molhados somavam menos de $5 \%$ dos recursos empenhados. Ademais, Almeida Cruz fazia-se presente no mercado iguapense através de seu cunhado José Gonçalves Maia. Maia pertencia ao grupo com mais de 10 consignações, conforme mostra a Tabela 1.4. As $£$ 1.502, gastas principalmente com fazendas secas (95\%) o equiparava com Francisco Manoel de Alvarenga (95\% entre fazendas secas e molhados), Vitorino José Franco (82\%), Baldoino Francisco da Costa (97\%), Antonio José Rodrigues (88\%), Bento Pupo de Gouveia (86\%), Manoel Rodrigues do Rosário (84\%), Manoel Rodrigues da Costa (90\%), José Francisco Carneiro da Silva Braga (82\%) e João José de Carvalho Simões (83\%), que mantinham o abastecimento no Vale do Ribeira durante as duas primeiras décadas do Oitocentos.

Outros como Candido Pupo da Rocha, Antonio Borges Diniz, José Antonio dos Anjos, Antonio Moreira Ramos e Francisco Carneiro da Silva Braga, possuíam um padrão de dispêndio mais diversificado, posto que também atuavam no mercado de escravos com parcelas que variaram de 13 a 50\% do montante. Os dados compulsados informam 43 registros de compras de escravos, porém oito deles não informam a quantidade. No sentido de tentar precisar melhor o fluxo de cativos, tomamos o preço médio por escravo no mesmo ano e estimamos a quantidade provável de escravos associados a estes oito casos, todos apresentados na Tabela 1.5 .

\footnotetext{
${ }^{44}$ A trajetória e acumulação destes e outros comerciantes será pormenorizada no Capítulo 4.
} 
Tabela 1.5

Distribuição dos consignadores de escravos segundo número de escravos recebidos e valor em libras (Porto de Iguape, 1809 a 1822)

\begin{tabular}{|c|c|c|c|c|}
\hline Consignador & escravos & $\%$ & valor $(£)$ & $\%$ \\
\hline José Antonio Peniche & 117 & 28,1 & 3.684 & 28,6 \\
\hline Antonio José Peniche & 55 & 13,2 & 1.879 & 14,6 \\
\hline Antonio Moreira Ramos & 63 & 15,1 & 1.758 & 13,6 \\
\hline José Antonio da Silva & 38 & 9,1 & 993 & 7,7 \\
\hline Francisco Carneiro da Silva Braga & 28 & 6,7 & 778 & 6,0 \\
\hline Florido José de Moraes & 20 & 4,8 & 775 & 6,0 \\
\hline Antonio José Pedro & 14 & 3,4 & 547 & 4,2 \\
\hline Antonio Borges Diniz & 14 & 3,4 & 443 & 3,4 \\
\hline José Antonio dos Anjos & 16 & 3,8 & 417 & 3,2 \\
\hline Rafael Gomes Carneiro & 9 & 2,2 & 333 & 2,6 \\
\hline Vitorino José Franco & 5 & 1,2 & 172 & 1,3 \\
\hline Candido Pupo da Rocha & 5 & 1,2 & 157 & 1,2 \\
\hline José Francisco Carneiro da Silva Braga & 4 & 1,0 & 139 & 1,1 \\
\hline Bartolomeu da Costa de Almeida Cruz & 5 & 1,2 & 131 & 1,0 \\
\hline Bento Pupo de Gouveia & 4 & 1,0 & 129 & 1,0 \\
\hline João José de Correia & 4 & 1,0 & 125 & 1,0 \\
\hline Manoel Alves da Costa & 3 & 0,7 & 102 & 0,8 \\
\hline Antonio Lopes Rodrigues & 3 & 0,7 & 93 & 0,7 \\
\hline João José Tavares & 2 & 0,5 & 67 & 0,5 \\
\hline Pedro Gonçalves da Rocha & 2 & 0,5 & 61 & 0,5 \\
\hline José Furtado & 2 & 0,5 & 61 & 0,5 \\
\hline Manoel Lopes Mendonça da Silva & 4 & 1,0 & 52 & 0,4 \\
\hline total & 417 & 100,0 & 12.885 & 100,0 \\
\hline
\end{tabular}

A considerar a amostra acima, os Peniche (pai e filho) dominavam o fornecimento de cativos no Vale do Ribeira no início do século XIX que, de resto, era controlado por alguns poucos comerciantes: os seis primeiros respondiam por 77\% dos 417 escravos recebidos no porto de Iguape. As anotações não indicavam sexo ou origem desses escravos, mas os montantes gastos permitiram elaborar a Tabela 1.6, que indica o fluxo e preço dos cativos comparados com a praça do Rio de Janeiro, majoritária no fornecimento dos escravos para Iguape. $^{45}$

\footnotetext{
${ }^{45}$ Em apenas um registro verificamos outra origem (Santos) que não o Rio de Janeiro.
} 
Tabela 1.6

Distribuição do fluxo anual de escravos

(Porto de Iguape e Rio de Janeiro, 1809 a 1825)

\begin{tabular}{c|ccc|cc}
\hline Anos & escravos & valor $(£)$ & preço médio (£) & fluxo RJ $^{\mathbf{a}}$ & preço médio RJ (£) $^{\mathbf{b}}$ \\
\hline 1809 & 21 & 539 & 25,6 & 13.171 & 31,8 \\
1811 & 64 & 2.148 & 37,8 & 22.520 & 31,8 \\
1812 & 147 & 4.329 & 29,4 & 18.270 & 31,8 \\
1815 & 18 & 512 & 28,4 & 13.330 & 25,8 \\
1816 & 17 & 538 & 31,6 & 18.140 & 25,8 \\
1817 & 57 & 2.049 & 35,9 & 17.670 & 25,8 \\
1822 & 95 & 2.500 & 26,3 & 23.280 & 30,0 \\
1828 & 62 & 3.049 & 49,2 & 45.390 & - \\
1829 & 157 & 5.509 & 35,1 & 47.280 & - \\
1830 & 17 & 727 & 42,8 & 30.620 & 33,6 \\
\hline
\end{tabular}

a entrada de africanos, cf. FLORENTINO, 1997, p. 51.

${ }^{\mathrm{b}}$ homens e mulheres africanos, preços retirados de inventários cariocas, cf. FLORENTINO, 1997, p. 220.

Deve-se notar que, não obstante a diferença entre o fluxo de escravos africanos no porto fluminense e a entrada de cativos em Iguape, as flutuações observadas guardam um grau de associação significativo. ${ }^{46}$ Conforme destaca Manolo Florentino, “A tendência ao crescimento do volume de entradas indica o crescimento do volume de negócios e da própria economia escravista alimentada de braços africanos através do porto do Rio" (FLORENTINO, 1997, p. 45). Nesse sentido, os escravistas iguapenses comportavam-se de forma assemelhada aos seus pares cariocas e mineiros graças aos ganhos resultantes da comercialização do arroz e aos déficits acumulados. A rede de fornecimento de escravos que atendia o Vale do Ribeira também receptava parte do arroz escoado pelo porto de Iguape, além de suprir outras regiões paulistas. Segundo Roberto Guedes Ferreira, um certo “Antonio Tertuliano dos Santos [que] vendeu 192 escravos novos (africanos) entre 1828 e 1830, despachados a partir da Corte do Rio de Janeiro, 139 (72,4\%) dos quais enviados para a capitania de São Paulo” (FERREIRA, 2005, p. 31), fornecia escravos e vendia açúcar proveniente da vila de Itu. Este comerciante aparecia como credor nos inventários de Agostinho Lourenço da Silva Doria (1836), Escolástica Correa, esposa de João Antonio Carriço (1844), Francisco de Castro Guimarães (1841), Gertrudes Maria, esposa de Francisco

\footnotetext{
46 Tomando como hipótese a defasagem de um ano entre a oferta carioca e o desembarque em Iguape, a correlação de Pearson atinge 0,72 entre 1809 e 1828.
} 
Florêncio de Souza (1842), todos de Iguape, e Gregório Nunes de Gusmão (1843), comerciante de Xiririca.

À guisa de conclusão preliminar, evidenciamos nestas três primeiras décadas a concentração das atividades comerciais em alguns poucos negociantes estabelecidos no Vale do Ribeira, o que não impedia a ação de dezenas de outros pequenos mercantes e mascates, com acessibilidade diferenciada à praça mercantil do Rio de Janeiro, entreposto fornecedor das mercadorias e principal destino da produção agrícola da região.

\section{As atividades econômicas nos domicílios: uma comparação em 1801 e 1836}

Apresentamos aqui uma síntese das atividades econômicas descritas nas listas nominativas de 1801 e 1836, os dois únicos anos com indicações pormenorizadas sobre as atividades e quantidade da produção agrícola na vila de Iguape.

A tabela seguinte delineia, para o ano de 1801, os domicílios em Iguape e Xiririca segundo as atividades econômicas e a presença ou não de escravos.

Tabela 1.7

Distribuição dos fogos segundo atividades econômicas e presença de escravos

(Iguape e Xiririca, 1801)

\begin{tabular}{|c|c|c|c|c|c|c|c|c|c|c|c|c|}
\hline \multirow{3}{*}{ Atividades econômicas } & \multicolumn{6}{|c|}{ Iguape } & \multicolumn{6}{|c|}{ Xiririca } \\
\hline & \multicolumn{4}{|c|}{ presença de escravos } & \multirow{2}{*}{ total } & \multirow{2}{*}{$\%$} & \multicolumn{4}{|c|}{ presença de escravos } & \multirow{2}{*}{ total } & \multirow{2}{*}{$\%$} \\
\hline & $\operatorname{sim}$ & $\%$ & não & $\%$ & & & $\operatorname{sim}$ & $\%$ & não & $\%$ & & \\
\hline agricultura e manufatura rural & 84 & 13,7 & 308 & 50,1 & 392 & 63,7 & 41 & 28,9 & 62 & 43,7 & 103 & 72,5 \\
\hline mineração & - & - & - & - & - & - & 1 & 0,7 & 1 & 0,7 & 2 & 1,4 \\
\hline atividades do mar & 5 & 0,8 & 28 & 4,6 & 33 & 5,4 & - & - & - & - & - & - \\
\hline artesanato & 35 & 5,7 & 47 & 7,6 & 82 & 13,3 & 7 & 4,9 & 17 & 12,0 & 24 & 16,9 \\
\hline igreja & 2 & 0,3 & - & - & 2 & 0,3 & 1 & 0,7 & - & - & 1 & 0,7 \\
\hline corpo militar & - & - & 2 & 0,3 & 2 & 0,3 & - & 0,0 & - & - & - & - \\
\hline rentistas & 8 & 1,3 & 1 & 0,2 & 9 & 1,5 & 1 & 0,7 & - & - & 1 & 0,7 \\
\hline comerciantes & 26 & 4,2 & 6 & 1,0 & 32 & 5,2 & 2 & 1,4 & - & - & 2 & 1,4 \\
\hline transportes & - & - & - & - & - & - & - & - & 5 & 3,5 & 5 & 3,5 \\
\hline jornaleiros & 2 & 0,3 & 50 & 8,1 & 52 & 8,5 & - & - & 1 & 0,7 & 1 & 0,7 \\
\hline atividades não classificadas & 1 & 0,2 & 10 & 1,6 & 11 & 1,8 & 1 & 0,7 & 2 & 1,4 & 3 & 2,1 \\
\hline total & 163 & 26,5 & 452 & 73,5 & 615 & 100,0 & 54 & 38,0 & 88 & 62,0 & 142 & 100,0 \\
\hline
\end{tabular}

As atividades de agricultura e manufatura rural concentravam a maioria dos domicílios tanto em Iguape como em Xiririca, representando mais de 60\% dos casos. Enquanto na freguesia de Xiririca apenas esta categoria e a dos artesãos apresentavam valores significativos, registramos em Iguape uma maior diversidade de atividades econômicas 
envolvendo, além dos artesãos, jornaleiros, as atividades marítimas e os comerciantes, todas com valores totais acima de 5\% das unidades domiciliares.

A freqüência relativa de fogos escravistas em Xiririca (38\%) superava o valor observado em Iguape (26\%), porém com distribuição assemelhada entre as atividades econômicas. Agricultores e artesãos representavam as duas classes com maior participação entre as unidades escravistas nas duas localidades - com maior peso na freguesia, atingindo 48 dos 54 casos. Em Iguape tal parcela representava 73\% dos fogos escravistas, cabendo aos comerciantes 16\%. Entre os não-escravistas, vale a mesma observação acerca da diversidade de atividades econômicas dos iguapenses vis-à-vis os moradores de Xiririca.

Tabela 1.8

Distribuição dos fogos da atividade econômica agricultura e manufatura rural segundo presença de escravos

(Iguape e Xiririca, 1801)

\begin{tabular}{|c|c|c|c|c|c|c|c|c|c|c|c|c|}
\hline \multirow{3}{*}{ Ocupações } & \multicolumn{6}{|c|}{ Iguape } & \multicolumn{6}{|c|}{ Xiririca } \\
\hline & \multicolumn{4}{|c|}{ presença de escravos } & \multirow{2}{*}{ total } & \multirow{2}{*}{$\%$} & \multicolumn{4}{|c|}{ presença de escravos } & \multirow{2}{*}{ total } & \multirow{2}{*}{$\%$} \\
\hline & $\operatorname{sim}$ & $\%$ & não & $\%$ & & & $\operatorname{sim}$ & $\%$ & não & $\%$ & & \\
\hline cafeicultores & - & - & - & - & - & - & 1 & 1,0 & - & - & 1 & 1,0 \\
\hline carvoeiros & 1 & 0,3 & 3 & 0,8 & 4 & 1,0 & - & - & - & - & - & - \\
\hline criadores de bovinos & - & - & - & - & - & - & 1 & 1,0 & 1 & 1,0 & 2 & 1,9 \\
\hline cultivo de arroz e mandioca ${ }^{a}$ & 5 & 1,3 & 15 & 3,8 & 20 & 5,1 & - & - & - & - & - & - \\
\hline cultivo de arroz e mandioca ${ }^{\mathrm{b}}$ & - & - & - & - & - & - & 7 & 6,8 & 5 & 4,9 & 12 & 11,7 \\
\hline cultivo de arroz ${ }^{\mathrm{a}}$ & 32 & 8,2 & 61 & 15,6 & 93 & 23,7 & 1 & 1,0 & 7 & 6,8 & 8 & 7,8 \\
\hline cultivo de arroz ${ }^{c}$ & 1 & 0,3 & 1 & 0,3 & 2 & 0,5 & 10 & 9,7 & 16 & 15,5 & 26 & 25,2 \\
\hline cultivo de mandioca $^{\mathrm{a}}$ & 14 & 3,6 & 56 & 14,3 & 70 & 17,9 & 2 & 1,9 & 1 & 1,0 & 3 & 2,9 \\
\hline cultivo de mandioca $^{\mathrm{d}}$ & 1 & 0,3 & - & - & 1 & 0,3 & 3 & 2,9 & 3 & 2,9 & 6 & 5,8 \\
\hline cultivo de tabaco $^{\mathrm{a}}$ & - & - & - & - & - & - & 1 & 1,0 & 2 & 1,9 & 3 & 2,9 \\
\hline cultivo de tabaco $^{\mathrm{b}}$ & - & - & - & - & - & - & 2 & 1,9 & 6 & 5,8 & 8 & 7,8 \\
\hline cultivos não especificados & 17 & 4,3 & 112 & 28,6 & 129 & 32,9 & 3 & 2,9 & 11 & 10,7 & 14 & 13,6 \\
\hline engenho de aguardente & - & - & - & - & - & - & 2 & 1,9 & 1 & 1,0 & 3 & 2,9 \\
\hline engenho de arroz & 5 & 1,3 & - & - & 5 & 1,3 & 3 & 2,9 & - & - & 3 & 2,9 \\
\hline madeireiros e lenhadores & 8 & 2,0 & 60 & 15,3 & 68 & 17,3 & 3 & 2,9 & 5 & 4,9 & 8 & 7,8 \\
\hline moradores novos & - & - & - & - & - & - & 2 & 1,9 & 3 & 2,9 & 5 & 4,9 \\
\hline pescadores de água doce & - & - & - & - & - & - & - & - & 1 & 1,0 & 1 & 1,0 \\
\hline total & 84 & 21,4 & 308 & 78,6 & 392 & 100,0 & 41 & 39,8 & 62 & 60,2 & 103 & 100,0 \\
\hline \multicolumn{13}{|l|}{${ }^{a}$ cultivo exclusivo } \\
\hline \multicolumn{13}{|l|}{${ }^{\mathrm{b}}$ com outros cultivares } \\
\hline c com outros cultivares excet & 110 & & & & & & & & & & & \\
\hline${ }^{\mathrm{d}}$ com outros cultivares exce & & & & & & & & & & & & \\
\hline
\end{tabular}

As diferenças percebidas associam-se não apenas à diferença populacional entre a vila e a freguesia, mas principalmente aos distintos processos históricos que englobam a 
gênese e formação das localidades. Ganhamos maior clareza nessa distinção ao analisar os dados da Tabela 1.8, que apresenta as ocupações dos agricultores do Vale do Ribeira em 1801, ainda segundo a presença ou não de escravos.

Como destaque inicial, ressaltamos a elevada freqüência de domicílios agrupados na categoria de cultivos não especificados, especialmente no caso de Iguape. A indicação de cinco novos moradores na freguesia de Xiririca e a ausência de casos na vila, assim como a elevada ausência de informações sobre os cultivos na vila podem indicar distintos graus de zelo na confecção da lista nominativa ora utilizada. Mesmo assim, chama atenção no caso de Xiririca a baixa freqüência de algumas ocupações, como a de criadores e pescadores de água doce, inexistentes em Iguape.

$\mathrm{Na}$ freguesia o cultivo de arroz, exclusivamente ou combinado com outras culturas, fazia-se presente em $48 \%$ dos fogos contra $31 \%$ em Iguape. ${ }^{47}$ Nesta, a mandioca rivalizava com a gramínea, atingindo 23\% das unidades e 20\% dos casos em Xiririca. O tabaco completa a lista de cultivos com maior freqüência, aparentemente praticado apenas pelos habitantes de Xiririca. Como indicam as notas da tabela anterior, os demais cultivos aparecem praticamente todos em Xiririca e correspondiam a pequenas quantidades de feijão e milho. Em Iguape, os resultados sugerem práticas quase monocultoras: há o cultivo exclusivo de arroz, o de mandioca e o combinado, com praticamente nenhuma referência a outras plantações.

Os engenhos de aguardente, então disseminados por toda a Capitania, aparecem apenas em três domicílios, todos pertencentes à freguesia. Mesmo os engenhos de pilar arroz, fundamentais para o processamento das espigas colhidas, constavam em apenas 8 fogos, todos escravistas.

Os fogos iguapenses com cultivo de arroz e mão-de-obra cativa totalizavam 38 casos contra 20 que plantavam mandioca; destes, cinco praticavam as duas modalidades. Em Xiririca, a participação dos escravistas rizicultores (21 casos) superava as 12 unidades com cativos e cultivo de mandioca (e sete casos com ambos os cultivares) e os três com cultivo de tabaco. Já entre os não-proprietários, enquanto em Iguape prevalecia o equilíbrio entre os cultivos de arroz (77 fogos) e mandioca (71 fogos), com apenas 15 unidades mistas, em Xiririca os 28 fogos rizicultores superavam os 12 com plantação de mandioca, sendo cinco os que cultivavam as duas variedades. Em outras palavras, a exigência de força de trabalho escrava não se configurava como fator limitante à expansão da rizicultura, porém fica nítido -

\footnotetext{
${ }^{47}$ Incluindo os proprietários de engenho de arroz.
} 
principalmente em Iguape - que o momento privilegiado pela lista nominativa registra uma certa dicotomia entre as antigas práticas agrícolas e o recente cultivo da gramínea.

Ainda destacamos a presença de madeireiros e lenhadores, que na vila de Iguape representavam 17\% dos fogos em 1801. Essa ocupação parece intimamente relacionada com os resultados da Tabela 1.9, que distribui as ocupações dos artesãos segundo a posse de escravos.

\section{Tabela 1.9}

Distribuição dos fogos da atividade econômica artesanato segundo presença de escravos

(Iguape e Xiririca, 1801)

\begin{tabular}{|c|c|c|c|c|c|c|c|c|c|c|c|c|}
\hline \multirow{3}{*}{ Ocupações } & \multicolumn{6}{|c|}{ Iguape } & \multicolumn{6}{|c|}{ Xiririca } \\
\hline & \multicolumn{4}{|c|}{ presença de escravos } & \multirow{2}{*}{ total } & \multirow{2}{*}{$\%$} & \multicolumn{4}{|c|}{ presença de escravos } & \multirow{2}{*}{ total } & \multirow{2}{*}{$\%$} \\
\hline & $\operatorname{sim}$ & $\%$ & não & $\%$ & & & $\operatorname{sim}$ & $\%$ & não & $\%$ & & \\
\hline alfaiates & 2 & 2,4 & 6 & 7,3 & 8 & 9,8 & 1 & 4,2 & - & - & 1 & 4,2 \\
\hline calafates & 1 & 1,2 & 4 & 4,9 & 5 & 6,1 & - & - & - & - & - & - \\
\hline canoeiros & 6 & 7,3 & - & - & 6 & 7,3 & 3 & 12,5 & 10 & 41,7 & 13 & 54,2 \\
\hline carpinteiros & 16 & 19,5 & 21 & 25,6 & 37 & 45,1 & - & - & 2 & 8,3 & 2 & 8,3 \\
\hline costureiras & 2 & 2,4 & 3 & 3,7 & 5 & 6,1 & - & - & 2 & 8,3 & 2 & 8,3 \\
\hline esteieiros & - & - & 3 & 3,7 & 3 & 3,7 & - & - & - & - & - & - \\
\hline ferreiros & 3 & 3,7 & 1 & 1,2 & 4 & 4,9 & - & - & 1 & 4,2 & 1 & 4,2 \\
\hline oleiros e telheiros & 3 & 3,7 & 2 & 2,4 & 5 & 6,1 & 3 & 12,5 & 2 & 8,3 & 5 & 20,8 \\
\hline padeiros & 1 & 1,2 & - & - & 1 & 1,2 & - & - & - & - & - & - \\
\hline paneleiros e gameleiros & - & - & 1 & 1,2 & 1 & 1,2 & - & - & - & - & - & - \\
\hline pintores & 1 & 1,2 & - & - & 1 & 1,2 & - & - & - & - & - & - \\
\hline sapateiros & - & - & 5 & 6,1 & 5 & 6,1 & - & - & - & - & - & - \\
\hline serralheiros & - & - & 1 & 1,2 & 1 & 1,2 & & - & - & - & - & - \\
\hline total & 35 & 42,7 & 47 & 57,3 & 82 & 100,0 & 7 & 29,2 & 17 & 70,8 & 24 & 23,3 \\
\hline
\end{tabular}

A madeira fornecida por lenhadores e madeireiros constituía a matéria-prima de canoeiros e carpinteiros, que em ambas as localidades representavam mais da metade dos fogos registrados. Os resultados da tabela, entretanto, sugerem diferenças importantes entre a vila e a freguesia. Sobre os canoeiros, todos os de Iguape detinham escravos, fato comum a apenas três casos de Xiririca. Os primeiros provavelmente manufaturavam embarcações de maior porte, mantendo a tradição registrada desde meados da centúria anterior; os demais possivelmente se envolviam com o fabrico de canoas de pequeno porte, apropriadas para uso na rede fluvial do rio Ribeira. A mesma observação vale para os carpinteiros: em Iguape verificamos a distinção entre “carpinteiro de obra branca” e "carpinteiro da ribeira”, expressões que designavam especialistas na construção e reparos de embarcações marítimas juntamente com os cinco calafates indicados na tabela acima, além de pelo menos nove escravos que especializados nesta atividade. 
Passadas três décadas e retomando os resultados indicados na seção anterior sobre a expressiva expansão na quantidade de arroz exportada pelo porto de Iguape, a Tabela 1.10 apresenta as atividades econômicas em Iguape e Xiririca em 1836.

Tabela 1.10

Distribuição dos fogos segundo atividades econômicas e presença de escravos

(Iguape e Xiririca, 1836)

\begin{tabular}{|c|c|c|c|c|c|c|c|c|c|c|c|c|}
\hline \multirow{3}{*}{ Atividades econômicas } & \multicolumn{6}{|c|}{ Iguape } & \multicolumn{6}{|c|}{ Xiririca } \\
\hline & \multicolumn{4}{|c|}{ presença de escravos } & \multirow{2}{*}{ total } & \multirow{2}{*}{$\%$} & \multicolumn{4}{|c|}{ presença de escravos } & \multirow{2}{*}{ total } & \multirow{2}{*}{$\%$} \\
\hline & $\operatorname{sim}$ & $\%$ & não & $\%$ & & & $\operatorname{sim}$ & $\%$ & não & $\%$ & & \\
\hline agricultura e manufatura rural & 200 & 19,1 & 599 & 57,3 & 799 & 76,5 & 94 & 31,0 & 175 & 57,8 & 269 & 88,8 \\
\hline atividades do mar & 4 & 0,4 & 41 & 3,9 & 45 & 4,3 & - & - & - & - & - & - \\
\hline artesanato & 14 & 1,3 & 30 & 2,9 & 44 & 4,2 & 2 & 0,7 & 13 & 4,3 & 15 & 5,0 \\
\hline igreja & 2 & 0,2 & 1 & 0,1 & 3 & 0,3 & 1 & 0,3 & - & - & 1 & 0,3 \\
\hline magistratura e empregos civis & 2 & 0,2 & 2 & 0,2 & 4 & 0,4 & 1 & 0,3 & - & - & 1 & 0,3 \\
\hline profissões liberais & 3 & 0,3 & 1 & 0,1 & 4 & 0,4 & - & - & 1 & 0,3 & 1 & 0,3 \\
\hline rentistas & - & - & 1 & 0,1 & 1 & 0,1 & - & - & - & - & - & - \\
\hline comerciantes & 59 & 5,6 & 25 & 2,4 & 84 & 8,0 & 3 & 1,0 & 9 & 3,0 & 12 & 4,0 \\
\hline transportes & - & - & - & - & - & - & - & - & 1 & 0,3 & 1 & 0,3 \\
\hline jornaleiros & - & - & - & - & - & - & - & - & 2 & 0,7 & 2 & 0,7 \\
\hline atividades não classificadas & 16 & 1,5 & 45 & 4,3 & 61 & 5,8 & - & - & 1 & 0,3 & 1 & 0,3 \\
\hline total & 300 & 28,7 & 745 & 71,3 & 1.045 & 100,0 & 101 & 33,3 & 202 & 66,7 & 303 & 100,0 \\
\hline
\end{tabular}

As atividades agrícolas representavam mais de três quartos dos fogos iguapenses e quase nove décimos dos domicílios de Xiririca. Em relação aos informes de 1801, o aumento foi de 104\% e 161\%, respectivamente. Porém, o comércio apresentou proporção mais elevada, passando de 32 para 84 casos em Iguape e de 2 para 12 casas comerciais em Xiririca. Além de jornaleiros e rentistas, que a lista de 1836 praticamente não registrou a presença, a atividade econômica com maior redução na participação relativa foi o artesanato. Nesse caso, observamos uma redução do número absoluto de fogos: na vila, de 82 para 44 casos e na freguesia, de 24 para 15 unidades. Apesar de os carpinteiros ainda representarem a maior ocupação da atividade, a causa principal da aludida redução associa-se com o declínio da manufatura de embarcações e a adesão de parcela dos antigos artesãos às atividades agrícolas.

Dessa forma, o rol de atividades apresentadas na tabela acima, ao indicar uma menor diversidade dos empreendimentos econômicos dos habitantes do Vale do Ribeira, sugere a acomodação ao cultivo do arroz e aos seus ganhos, a despeito dos sucessivos déficits no saldo comercial ao longo da década de 1820. Tal opção independeu da presença de escravos, atingindo dois terços dos fogos escravistas de Iguape e praticamente a totalidade dos casos de Xiririca. Nesse sentido, os comerciantes constituem a outra atividade econômica digna de nota a concentrar posses escravistas, especialmente em Iguape. 
A Tabela 1.11, que apresenta as ocupações dos fogos ligados às atividades agrícolas, evidencia essa tendência.

Tabela 1.11

Distribuição dos fogos da atividade econômica agricultura e manufatura rural segundo presença de escravos

(Iguape e Xiririca, 1836)

\begin{tabular}{|c|c|c|c|c|c|c|c|c|c|c|c|c|}
\hline \multirow{3}{*}{ Ocupações } & \multicolumn{6}{|c|}{ Iguape } & \multicolumn{6}{|c|}{ Xiririca } \\
\hline & \multicolumn{4}{|c|}{ presença de escravos } & \multirow{2}{*}{ total } & \multirow{2}{*}{$\%$} & \multicolumn{4}{|c|}{ presença de escravos } & \multirow{2}{*}{ total } & \multirow{2}{*}{$\%$} \\
\hline & $\operatorname{sim}$ & $\%$ & não & $\%$ & & & $\operatorname{sim}$ & $\%$ & não & $\%$ & & \\
\hline cultivo de arroz e mandioca $^{\mathrm{a}}$ & 16 & 2,0 & 93 & 11,6 & 109 & 13,6 & - & - & - & - & - & - \\
\hline cultivo de arroz e mandioca ${ }^{\mathrm{b}}$ & 14 & 1,8 & 31 & 3,9 & 45 & 5,6 & - & - & - & - & - & - \\
\hline cultivo de arroz ${ }^{\mathrm{a}}$ & 93 & 11,6 & 350 & 43,8 & 443 & 55,4 & 58 & 21,6 & 152 & 56,5 & 210 & 78,1 \\
\hline cultivo de arroz ${ }^{c}$ & - & - & 6 & 0,8 & 6 & 0,8 & - & - & - & - & - & - \\
\hline cultivo de mandioca ${ }^{a}$ & 3 & 0,4 & 36 & 4,5 & 39 & 4,9 & - & - & - & - & - & - \\
\hline cultivo de mandioca $^{\mathrm{d}}$ & - & - & 1 & 0,1 & 1 & 0,1 & - & - & - & - & - & - \\
\hline cultivos não especificados & 44 & 5,5 & 76 & 9,5 & 120 & 15,0 & - & - & 1 & 0,4 & 1 & 0,4 \\
\hline engenho de aguardente & 5 & 0,6 & 3 & 0,4 & 8 & 1,0 & 2 & 0,7 & 2 & 0,7 & 4 & 1,5 \\
\hline engenho de arroz & 22 & 2,8 & 3 & 0,4 & 25 & 3,1 & 33 & 12,3 & 13 & 4,8 & 46 & 17,1 \\
\hline engenho de arroz e aguardente & 2 & 0,3 & - & - & 2 & 0,3 & 1 & 0,4 & - & - & 1 & 0,4 \\
\hline madeireiros e lenhadores & 1 & 0,1 & - & - & 1 & 0,1 & - & - & 6 & 2,2 & 6 & 2,2 \\
\hline pescadores de água doce & - & - & - & - & - & - & - & - & 1 & 0,4 & 1 & 0,4 \\
\hline total & 200 & 25,0 & 599 & 75,0 & 799 & 100,0 & 94 & 34,9 & 175 & 65,1 & 269 & 100,0 \\
\hline
\end{tabular}

a cultivo exclusivo

${ }^{\mathrm{b}}$ com outros cultivares

${ }^{\mathrm{c}}$ com outros cultivares exceto mandioca

${ }^{\mathrm{d}}$ com outros cultivares exceto arroz

Os domicílios com alguma presença de arroz representavam 95\% dos 269 fogos de Xiririca e 79\% dos 799 iguapenses. ${ }^{48}$ Com relação à distribuição de 1801, além da expansão da rizicultura, merece destaque o desaparecimento do tabaco e da mandioca da freguesia; esta se manteve em Iguape em cerca de um quinto dos domicílios, porém a parcela daqueles com cultivo exclusivo caiu de $18 \%$ para 5\%.Tais resultados, porém, não traduzem o abandono desse cultivar: ao longo de todo o século XIX os instrumentos de processamento da mandioca para a obtenção de farinha mantiveram-se presentes entre as ferramentas avaliadas nos inventários consultados.

Outra maneira de aquilatar a importância do cultivo do arroz reside na posse de engenhos de arroz, que saltou de 8 casos em 1801 para 71 unidades em 1836. A maioria dos engenhos pertencia a escravistas, porém os 16 casos associados a não-proprietários sugere a convivência de unidades com diferentes capacidades de processamento do arroz,

\footnotetext{
${ }^{48}$ Incluso os engenhos de arroz.
} 
principalmente em Xiririca. O aumento no número de engenhos de aguardente constitui o contraponto ao domínio da rizicultura, passando de 3 para 15 as instalações registradas pelas listas nominativas.

O quadro acima descrito fornece algumas pistas sobre o desenvolvimento da cultura da gramínea no Vale do Ribeira. Pelo grau de envolvimento dos escravistas, tem-se a impressão de que o cultivo de arroz destinado à comercialização resultou de iniciativa de agricultores escravistas. A associação entre força de trabalho cativa e posse de engenhos de arroz estabelecia uma das condições necessárias para a diferenciação dentro da estrutura econômica do Vale do Ribeira. Nesse sentido, as palavras de Sérgio Buarque de Holanda elucidam o evolver da produção de arroz:

(...) de simples produto caseiro que tinha sido durante dois séculos, o arroz se tornara verdadeiramente um artigo comercial de certa importância. Deve-se tal fato, segundo todas as probabilidades, à introdução na Capitania de engenhos de água mais aperfeiçoados do que o monjolo, fato ocorrido em data incerta, mas que deve situar-se seguramente nos três últimos decênios do século XVIII [principalmente em Santos - AV]. Como tantas vezes tem acontecido no curso da história econômica, o progresso técnico na elaboração do produto precedeu, na realidade, a criação de um artigo de permuta e de uma fonte de riqueza (HOLANDA, 1947, p. 58).

\section{A movimentação portuária entre 1840 e 1880}

Não localizamos nenhum informe sobre a movimentação portuária de Iguape entre os anos de 1825 e 1842. Com a instalação da Mesa de Rendas, possivelmente em fins da década de 1830, relatórios sistemáticos sobre as entradas e saídas de navios passaram a ser produzidos, especialmente após 1842. Aqueles conservados no Arquivo do Estado de São Paulo permitiram a recuperação de uma série correspondente aos anos de 1842 a 1869. Distintamente dos sumários anexos aos Maços de População, encontramos apenas dados sobre datas de entrada e saída dos navios, origem e destino, além do nome, tipo de embarcação, proprietário e/ou mestre, sem menção à carga transportada. Até 1853, patachos, 
brigues e iates monopolizavam o transporte das cargas; ${ }^{49}$ a partir de então, o porto de Iguape passou a receber os vapores que cobriam a rota entre o Rio de Janeiro e os portos do Sul. ${ }^{50} \mathrm{~A}$ licença pertencia ao carioca José Rodrigues Ferreira, que também aparece sob a denominação de “Companhia Intermediária”, atuando de 1855 até 1865. A partir de 1867 a concessionária passou a se denominar "Linha Intermediária” sob direção de Mendes, Filho \& Lemos. Entre 1855 e 1869, estes vapores transportaram 21\% do arroz remetido e 22\% das saídas para o Rio de Janeiro ou 36\% no cômputo total. A Tabela 1.12 apresenta o movimento de saída recuperado a partir desses registros.

Entre 1842 e 1869 o número total de saídas, 977, correspondia à média anual de 38 embarcações. Não obstante, ao longo da série destacamos variações importantes. Por exemplo, entre 1842 e 1850 concentravam-se 24\% das partidas (36 partidas por ano), na década seguinte 31\% (40 partidas por ano) e, durante 1861 a 1869, 45\% (49 partidas por ano). ${ }^{51}$

\footnotetext{
${ }^{49}$ A tipologia das embarcações arroladas nos documentos consultados assemelha-se à encontrada por Larissa Brown, que assim refere: "In the eighteenth century ship classification was uncertain, as modifications were to existing ship types to improve them for war and commerce. Because the modest vessels of the late colonial coasting trade in Latin America have not attracted the same attention from naval historians as is lavished on men of war and the trans-oceanic vessels, detailed information is sparse about the lanchas, sumacas, and bergantins which the bulk of Brasilian coastal commerce. These launches, smacks and brigantines made up the vast majority of the coastal fleet. Large decked and masted canoes (canoas de voga) were also commonplace for short trips between neighboring ports and within bays, Among the rarer vessel types in the coastal trade were small sloops or ketches (chalupas), yachts (iates), and ocean-going vessels such as corvettes (curvetas), schooners (escunas), pinks (penques) and galleys (galeras). The small and medium-range trades were served primarily by launches and smacks, while brigantines as well as smacks were employed in the longer coastal voyages, particularly in the trade with Rio Grande do Sul" (BROWN, 1986, p. 197-8). Todos os navios eram movidos por energia eólica. Patacho: "Antigo navio a vela, de mastreação constituída de gurupés e dois mastros: o de vante, mastro de brigue, e o de ré, mastro de lúgar, com velas de entremastros"; brigue: "Antigo navio à vela, de mastreação constituída de gurupés e dois mastros de brigue, o de ré envergando também vela latina quadrangular e com velas de entremastros"; brigue-escuna: "Antigo navio à vela, de mastreação constituída de gurupés e dois mastros: o de vante, mastro de brigue; o de ré, mastro de escuna"; iate: "Navio à vela, de mastreação constituída de gurupés e dois mastros, em geral inteiriços, com velas latinas quadrangulares e gafetopes"; bergantim: "Antiga embarcação à vela e remo, esguia e veloz, com um ou dois mastros de galé e oito a 10 bancos para os remadores, usada no Oriente pelos portugueses". Definições obtidas no Dicionário Aurélio Eletrônico, versão 3.0, novembro de 1999.

${ }^{50}$ Entre 1847 e 1849 um único vapor denominado “Voador”, cujo proprietário era Manoel José de Araujo Costa, realizou 4 embarques de arroz, conforme constam nos manifestos de carga.

${ }^{51}$ As médias calculadas têm como denominador 6,5 anos para o período entre 1842-1850, 7,5 anos para o intervalo seguinte e 9 anos para a última faixa, conforme observações indicadas nas Tabelas 1.12 e 1.13.
} 
Tabela 1.12

Movimento de saída de navios segundo destino

(Porto de Iguape, 1842-1869)

\begin{tabular}{|c|c|c|c|c|c|c|}
\hline \multirow{2}{*}{ Anos } & \multicolumn{3}{|c|}{ Rio de Janeiro } & \multicolumn{3}{|c|}{ demais localidades } \\
\hline & total & vapores & tonelagem & total & vapores & tonelagem \\
\hline $1842^{b}$ & 18 & - & 1.627 & 7 & - & 238 \\
\hline 1843 & 19 & - & 1.984 & 2 & - & 45 \\
\hline 1844 & 26 & - & 2.746 & 9 & - & 254 \\
\hline 1845 & 36 & - & 3.934 & 7 & - & 128 \\
\hline $1846^{\mathrm{a}}$ & 11 & - & 1.273 & 4 & - & 80 \\
\hline $1848^{\mathrm{b}}$ & 15 & 1 & $1.548(1.620)$ & 1 & - & 23 \\
\hline 1849 & 34 & 2 & 3.811 (3.899) & 2 & - & 20 \\
\hline 1850 & 39 & - & 4.862 & 2 & - & 53 \\
\hline $1851^{b}$ & 9 & - & 1.071 & 2 & - & 121 \\
\hline 1852 & 25 & - & 2.865 & 4 & - & 131 \\
\hline $1853^{\mathrm{a}}$ & 16 & - & 1.763 & 4 & - & 89 \\
\hline $1855^{\mathrm{b}}$ & 21 & 2 & $2.096(3.215)$ & 2 & - & 49 \\
\hline 1856 & 42 & 11 & $2.664(5.184)$ & 14 & 8 & 318 (2.813) \\
\hline 1857 & 26 & 15 & $1.156(5.721)$ & 17 & 20 & $46(4.071)$ \\
\hline 1858 & 27 & 6 & $2.064(3.194)$ & 11 & 11 & $61(1.330)$ \\
\hline 1859 & 27 & 5 & $2.168(2.756)$ & 20 & 16 & 315 (2.264) \\
\hline $1860^{\mathrm{C}}$ & 22 & - & 2.365 & 12 & 9 & $114(1.370)$ \\
\hline $1861^{\mathrm{C}}$ & 20 & - & 2.305 & 4 & - & 152 \\
\hline 1862 & 29 & 18 & $1.586(3.176)$ & 13 & 16 & 86 (1.506) \\
\hline 1863 & 23 & 15 & 1.507 (2.509) & - & 8 & - (596) \\
\hline 1864 & 30 & 18 & 1.998 (3.728) & 14 & 15 & 87 (1.619) \\
\hline $1865^{c}$ & 36 & 4 & 2.989 (3.215) & 11 & 1 & 349 (465) \\
\hline $1866^{\mathrm{c}}$ & 46 & - & $4.224(4.224)$ & 16 & 2 & $482(482)$ \\
\hline 1867 & 38 & 3 & 3.661 (5.141) & 19 & 4 & 592 (2.391) \\
\hline 1868 & 49 & 3 & $4.826(5.783)$ & 20 & 14 & $189(4.831)$ \\
\hline 1869 & 48 & 6 & 4.227 (6.087) & 23 & 18 & 133 (6.271) \\
\hline total & 732 & 109 & $67.220(85.458)$ & 245 & 142 & 4.155 (31.392) \\
\hline
\end{tabular}

Obs.: tonelagem = soma declarada da capacidade das embarcações sem e (com) vapores.

1847 e 1854: anos não encontrados.

a: apenas primeiro semestre.

b: apenas segundo semestre.

c: os vapores não foram registrados ou foram parcialmente.

Se comparados com o ano de 1825 (35 saídas), a média para a década de 1840 não indica diferença significativa. A principal distinção ocorreu com a implantação da linha de paquetes a vapor: se desconsiderados, as médias relativas aos três períodos igualam-se, respectivamente a 35, 26 e 33. Da mesma forma, a carga máxima anual, em média (exceto os vapores) 3.010 toneladas, também apresentou variações ao longo das quase três décadas 
consideradas. No intervalo entre 1842 e 1850, esse valor correspondia a 3.183 toneladas por ano. Na década seguinte, 2.560 toneladas por ano e, no último período, 3.258. Em complementação, a tonelagem média por partida, que no cômputo geral igualou-se a 93 toneladas por embarcação, atingiu, nas faixas consideradas, a 98, 90 e 91 toneladas por navio, respectivamente. Novamente, a inclusão dos vapores altera os valores: a carga máxima anual passou para 4.987 toneladas (120 toneladas por embarcação) e, nos três períodos, 3.211, 5.246 e 6.054 toneladas, com médias por embarcação igualando-se a 98, 132 e 123 toneladas, respectivamente.

As saídas para o Rio de Janeiro representaram 70\%, seguidas por Paranaguá (11\%) e Santos (8\%). Sem os vapores, as participações correspondiam, respectivamente a 77\%, 2\% e 11\%. Nesse subconjunto, considerando a tonelagem das embarcações, ao Rio de Janeiro destinava-se $88 \%$ da carga, evidenciando assim a manutenção da primazia daquela praça no escoamento do arroz.

O que revelam os números - uma expansão da capacidade de transporte de cargas a partir da década de 1850 em relação ao período anterior - oculta uma perda da lucratividade na cadeia produtiva do arroz. Em 1854, oito embarcações a vela que atuavam na rota IguapeRio de Janeiro pertenciam a negociantes locais, ${ }^{52}$ permitindo o embolso dos fretes. Carlos Rath, estranhando o fato de que as embarcações, para atracarem no ancoradouro de Iguape, entravam pela distante barra de Cananéia, ao sul de Iguape e não pela de Capara, ao norte, fez o seguinte diagnóstico:

O verdadeiro motivo porque aquele canal é de propósito desacreditado, é por causa de alguns ambiciosos e caprichosos negociantes, ou antes donos das embarcações que não desejam que entrem outras embarcações, especialmente vapores para lhes não ir tirar a safra de arroz. Este pacto prova pouco bom senso comum que têm tais especuladores às custas de seus compatriotas. Com pouca despesa se acaba com este obstáculo, se se trabalha por alertar a navegação e comércio do interior do distrito de Iguape que veria a ser importantíssimo. Por estes motivos é a única saída a barra de Cananéia, não obstante levarem as embarcações 2 e mais dias até barra fora ou a subir até Iguape. ${ }^{53}$

Em relatório destinado ao governo da Província em 1871, o engenheiro J. Silva Coutinho informava que o frete do saco de arroz entre Iguape e o Rio de Janeiro cobrado

\footnotetext{
52 Brigue-escuna "Triunfo da Monarquia”, de 131 toneladas (Antonio Borges Diniz); bergantim "Comércio Brasileiro" de 99 toneladas (Filadelpho de Souza Castro), patacho "Aurora” de 98 toneladas (Antonio Borges Diniz), patacho "Conceição Feliz” de 115 toneladas (Manoel José Gomes da Silva, morador em Cananéia); brigue "Iguapense" de 135 toneladas (Filadelpho de Souza Castro), brigue-escuna "Josefina" de 129 toneladas (Joaquim Caetano da Silva Araujo), brigue-escuna "União” de 86 toneladas (João Mancio da Silva Franco) e o patacho "Safarascada” (João Mancio da Silva Franco), cf. AESP, Ofícios diversos de Iguape, ordem n. ${ }^{\circ}$ 1.043a.

${ }^{53}$ AESP, Ofícios diversos de Iguape, ordem n. ${ }^{\circ} 1.043 a$.
} 
pelos vapores da Mendes, Filho \& Lemos regulava a Rs. $1 \$ 600$, não muito acima dos preços cobrados pelos demais barcos movidos a vela. ${ }^{54}$

Tabela 1.13

Proprietários e tempo médio de permanência das embarcações movidas a vela (Porto de Iguape, 1842 a 1869)

\begin{tabular}{|c|c|c|c|c|}
\hline Períodos & proprietários & saídas & $\%$ & permanência (dias) \\
\hline \multirow{13}{*}{ 1842-1850 } & Antonio Borges Diniz & 34 & 22,2 & 22,9 \\
\hline & Filadelpho de Souza Castro & 29 & 19,0 & 30,4 \\
\hline & José Xavier de Almeida Cruz & 15 & 9,8 & 25,2 \\
\hline & Manoel Martins Ribeiro & 14 & 9,2 & 23,6 \\
\hline & José Bonifácio de Andrada & 13 & 8,5 & 22,1 \\
\hline & Antonio José Peniche & 12 & 7,8 & 26,6 \\
\hline & Manoel José Gomes da Silva & 12 & 7,8 & 24,8 \\
\hline & Manoel Pereira dos Santos & 8 & 5,2 & 25,8 \\
\hline & José Jacinto de Toledo & 6 & 3,9 & 52,6 \\
\hline & Luis Alvares da Silva & 5 & 3,3 & 62,0 \\
\hline & José Tiburcio e Antonio Vaz Ferreira & 3 & 2,0 & 16,0 \\
\hline & João Mancio da Silva Franco & 2 & 1,3 & 20,5 \\
\hline & total & 153 & 100,0 & 27,4 \\
\hline \multirow{11}{*}{$1851-1860$} & João Mancio da Silva Franco & 57 & 33,3 & 41,7 \\
\hline & Antonio Borges Diniz & 44 & 25,7 & 43,1 \\
\hline & Manoel José Gomes da Silva & 16 & 9,4 & 38,9 \\
\hline & Antonio Vaz Ferreira & 14 & 8,2 & 37,7 \\
\hline & Filadelpho de Souza Castro & 14 & 8,2 & 62,9 \\
\hline & Francisco da Silva Mendes & 8 & 4,7 & 29,0 \\
\hline & José Alves da Costa Pacca & 6 & 3,5 & 27,8 \\
\hline & Antonio dos Anjos Silva & 4 & 2,3 & 20,3 \\
\hline & Antonio José Peniche & 4 & 2,3 & 32,0 \\
\hline & Manoel Martins Ribeiro & 4 & 2,3 & 69,5 \\
\hline & total & 171 & 100,0 & 42,0 \\
\hline \multirow{10}{*}{ 1861-1869 } & Antonio dos Anjos Silva & 52 & 24,9 & 16,9 \\
\hline & João José da Costa & 28 & 13,4 & 12,1 \\
\hline & Antonio Joaquim Flores & 24 & 11,5 & 11,3 \\
\hline & Francisco da Silva Mendes & 24 & 11,5 & 33,5 \\
\hline & Urcezino da Silva & 23 & 11,0 & 20,4 \\
\hline & João Mancio da Silva Franco & 18 & 8,6 & 27,8 \\
\hline & João Otavio Santos & 18 & 8,6 & 14,3 \\
\hline & Joaquim José da Costa & 17 & 8,1 & 34,8 \\
\hline & Manoel José Gomes da Silva & 5 & 2,4 & 42,0 \\
\hline & total & 209 & 100,0 & 20,7 \\
\hline
\end{tabular}

Considerando o volume médio de 50 mil sacas, o negócio envolveu, em 1871, cerca de 80 contos de réis, o que representava algo em torno de 18\% da receita total das exportações. Ao transportarem um quinto do arroz colhido no vale, os proprietários dos

\footnotetext{
${ }^{54}$ AESP, Ofícios diversos de Iguape, ordem n. ${ }^{\circ} 1.047$.
} 
paquetes retiravam dos negociantes iguapenses parcela significativa dos ganhos da cadeia de processamento e comercialização do grão. Uma medida indireta da dimensão desta perda se dá pelo tempo médio de permanência das embarcações iguapenses no canal do Mar Pequeno, conforme indica a Tabela $1.13 .^{55}$

O tempo médio de permanência no segundo período, 42 dias, representa praticamente o dobro do observado nos demais intervalos. Na década de 1850 as linhas regulares de paquetes a vapor passaram a transportar cargas de arroz, conforme destacado anteriormente. Uma análise mais detalhada dos proprietários com maior tempo de permanência naquela década mostra que são justamente aqueles com maior número de saídas e que também compareceram na década anterior com significativa participação no transporte do arroz. Esse período parece marcar a transição para um outro padrão de posse das embarcações movidas a vela: de 113 toneladas, capacidade média dos navios entre 1842 e 1850, passou-se para 102 toneladas entre 1851 e 1860 e para 89 toneladas entre 1861 e 1869, ou seja, uma redução de $21 \%$, valor relativo assemelhado às perdas de cargas para os paquetes a vapor.

A Tabela 1.14 apresenta os registros de entradas entre 1842 e 1869. A comparação inicial com os resultados anteriores indica a menor participação de navios oriundos de outras localidades vis-à-vis as embarcações remetidas do porto carioca, independente da inclusão dos vapores. As entradas totalizaram 1.017 registros ou 39,1 entradas por ano. As relativas ao primeiro período correspondiam a 23\% (36 entradas por ano); no intervalo seguinte, 32\% (43 entradas por ano) e, entre 1861 e 1869, 45\% (51 entradas por ano).

Qualquer análise mais detalhada do significado das capacidades de transporte desses navios se vê impossibilitada pela ausência de informes sobre as cargas que estes traziam. Assim como nos primeiros anos do Oitocentos, muitos deles deveriam retornar vazios, principalmente após o início das linhas a vapor. Por serem sediadas no Rio de Janeiro, provavelmente estas Companhias teriam a preferência dos comerciantes cariocas no envio das mercadorias demandadas pelos seus pares do Vale do Ribeira. De outro lado, muitos dos proprietários de embarcações listados na Tabela 1.13 também possuíam casas de negócios e/ou abasteciam os negociantes da terra, gerando não apenas mais um ponto de atrito como também outra perda de rendimento através dos fretes dessas mercadorias.

\footnotetext{
${ }^{55}$ A amostra representa 603 registros de 22 embarcações e 21 proprietários. A Tabela 1.13 exclui 70 casos cujas datas de entrada e/ou saída não continham informações completas.
} 
Tabela 1.14

Movimento de entrada de navios segundo a origem, porto de Iguape

(1842-1869)

\begin{tabular}{|c|c|c|c|c|c|c|}
\hline \multirow{2}{*}{ Anos } & \multicolumn{3}{|c|}{ Rio de Janeiro } & \multicolumn{3}{|c|}{ demais localidades } \\
\hline & total & vapores & tonelagem & total & vapores & tonelagem \\
\hline $1842^{\mathrm{b}}$ & 17 & - & 1.523 & 5 & - & 56 \\
\hline 1843 & 25 & - & 2.612 & 3 & - & 57 \\
\hline 1844 & 26 & - & 2.704 & 11 & - & 306 \\
\hline 1845 & 35 & - & 3.732 & 7 & - & 327 \\
\hline $1846^{\mathrm{a}}$ & 8 & - & 1.005 & 6 & - & 218 \\
\hline $1848^{\mathrm{b}}$ & 13 & 1 & 1.261 & 3 & - & 230 \\
\hline 1849 & 29 & - & 3.463 & 4 & 2 & 263 \\
\hline 1850 & 38 & - & 4.559 & 3 & - & 359 \\
\hline $1851^{\mathrm{b}}$ & 11 & - & 1.246 & 2 & - & 170 \\
\hline 1852 & 24 & - & 2.794 & 6 & - & 352 \\
\hline $1853^{\mathrm{a}}$ & 12 & - & 1.364 & 5 & - & 123 \\
\hline $1855^{\mathrm{b}}$ & 25 & 2 & 2.413 & 3 & - & 76 \\
\hline 1856 & 47 & 11 & 3.302 & 14 & 8 & 194 \\
\hline 1857 & 32 & 20 & 1.763 & 18 & 15 & 80 \\
\hline 1858 & 33 & 7 & 2.667 & 11 & 10 & 61 \\
\hline 1859 & 35 & 15 & 2.004 & 9 & 6 & 162 \\
\hline 1860 & 31 & 7 & 2.561 & 5 & 2 & 114 \\
\hline 1861 & 23 & - & 2.636 & 4 & - & 152 \\
\hline 1862 & 36 & 21 & 2.019 & 11 & 13 & 86 \\
\hline 1863 & 27 & 20 & 1.725 & 5 & 6 & - \\
\hline 1864 & 30 & 17 & 1.983 & 13 & 15 & 87 \\
\hline 1865 & 35 & 4 & 2.879 & 11 & 1 & 349 \\
\hline 1866 & 50 & 2 & 4.657 & 15 & - & 430 \\
\hline 1867 & 43 & 4 & 4.461 & 19 & 3 & 638 \\
\hline 1868 & 50 & 4 & 4.347 & 19 & 13 & 189 \\
\hline 1869 & 45 & 7 & 3.906 & 23 & 18 & 133 \\
\hline total & 780 & 142 & 69.586 & 23 & 112 & 5.212 \\
\hline
\end{tabular}

Do total de embarcações, as entradas oriundas do Rio de Janeiro representaram 75\%, seguidas por Paranaguá (10\%) e Santos (9\%). Desconsiderando os vapores, as participações correspondiam, respectivamente, a 81\%, 4\% e 11\%. O rol de produtos importados por Iguape neste período ultrapassa 160 itens (exceto escravos), porém merecem destaque pelo montante envolvido os panos de algodão, carne seca, farinha de trigo, fazendas secas, fumo, miudezas, sal e vinhos, todos oriundos do porto carioca. Exceto pelos queijos e toucinho, o porto de Santos não oferecia nenhum produto com destaque comercial, porém complementava a oferta 
carioca com quantidades de açúcar, café, farinha de milho, feijão e fumo. Estes gastos serão detalhados em seguida, onde trataremos do fluxo de produtos transportados pelas embarcações aqui analisadas.

\section{Oscilações e tendências da produção e do preço do arroz - 1840 a 1870}

Nas duas primeiras décadas do Oitocentos, a principal característica da produção e comercialização do arroz residia no substantivo aumento da quantidade exportada apesar da desproporcional elevação de seu preço nominal e, por conta da apreciação da taxa de conversão, da redução substancial do seu valor em libras que, em última análise, afetava o consumo de bens importados. Como principal resultado dessa expansão forçada, percebiam os ribeirenses um forte crescimento da renda nominal gerada a partir das exportações e a contrapartida - o aumento nos gastos de bens e escravos importados do Rio de Janeiro, cujos preços vinculavam-se às oscilações da moeda britânica - produziu, no final da década de 1820, elevados déficits na balança comercial.

\section{Gráfico 1.1}

\section{Oscilações do preço do arroz}

(Porto de Iguape, 1839 a 1870)

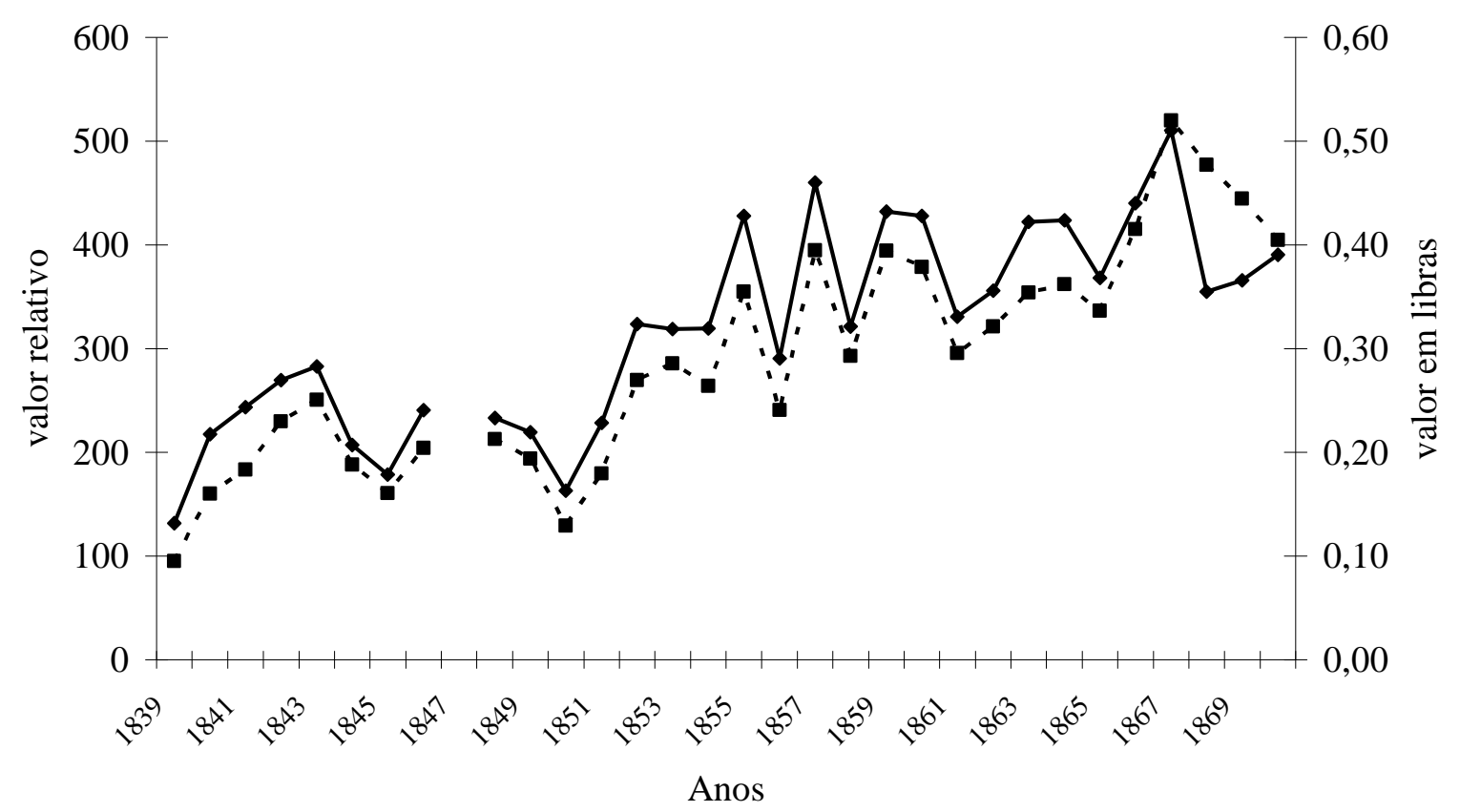

- - variação do preço em mil-réis $(1809=100) \rightarrow$ preço em libras

O Gráfico 1.1 parte do final desse período e expande as observações até 1870, considerando as oscilações relativas do preço do arroz em moeda nacional e o seu valor em libras. Diferentemente do início do século XIX, as oscilações do preço do arroz entre as 
décadas de 1840 e 1870 seguem atreladas às variações da taxa de conversão. A série começa com dois ciclos completos na década de 1840 e, a partir de 1850, acentua-se uma tendência com oscilações - de elevação do preço que se manteve até meados da década de 1860.

Como resultado imediato, recoloca-se a importância da taxa de conversão no mecanismo de formação de preços em uma economia que, a partir da década de 1840, tornarse-ia dependente das exportações do café. A relação de causalidade neste caso suscitou divergências entre diversos autores. Celso Furtado propôs que as oscilações cambiais principalmente a partir da segunda metade do século XIX - visavam manter a renda monetária do setor exportador nacional em face dos choques de demanda externa. Os efeitos desse mecanismo ajustariam os sucessivos desequilíbrios da balança de pagamentos ao inibirem a demanda interna de produtos importados. Segundo Furtado, a natureza de tal modo de ajuste decorria da condição de economia brasileira:

Na economia dependente, exportadora de produtos primários, a crise se apresentava
como um cataclismo, imposto de fora para dentro. As contorções que realizava essa
economia, para defender-se da pressão esmagadora que vinha do exterior, não
guardavam semelhança com as ações e reações que se processavam na economia
industrializada nos períodos de depressão e recuperação que sucediam à crise. Se a
baixa dos preços de exportação se transformasse, como seria de esperar dentro da
lógica do sistema, em redução dos lucros dos empresários, é evidente que, conforme
fosse o grau dessas perdas, muitos deles teriam de interromper a produção de café ou
as compras desse produto aos pequenos produtores locais (...) Qualquer que fosse a
redução no preço internacional do café, sempre era vantajoso, do ponto de vista do
conjunto da coletividade, manter o nível das exportações. Defendia-se assim o nível de
emprego dentro do país e limitavam-se os efeitos secundários da crise (FURTADO,
1989, p. 166-67).

Essa forma de entendimento, que o próprio autor consagrou como "socialização das perdas”, não tem unanimidade entre os intérpretes da história econômica brasileira. Parte das críticas decorre das conseqüências empíricas do modelo. Como corolário, as oscilações cambiais resultariam num movimento dos preços de magnitude distinta das flutuações, pois estes não se ajustariam na fase pró-cíclica, tornando o fenômeno inflacionário perene. Se há verdade na relação causal entre a queda da cotação internacional do café e a desvalorização da taxa de câmbio, também é correto o contrário, isto é, cotações em alta guardam correlação com valorização cambial. No entanto, os saldos da balança comercial mantinham-se negativos. Diante de tais evidências, Mircea Buescu, ao analisar o período pós-independência até a metade do século XIX, comenta:

Pode-se admitir que, dada a importância das importações na pauta de consumo, a taxa cambial influenciava o nível geral de preços, mas também que a taxa cambial equiparava o nível de preços internos como os estrangeiros. De fato, verificava-se uma forte coincidência entre o sentido da variação dos preços, tal como foi calculada no que precede [o índice construído pelo autor - AV] e o da taxa de câmbio. A ordem de grandeza é diferente e em vários casos a flutuação do câmbio é maior - o que sugere 
que esta constituía, tanto causa inflacionária, como desinflacionaria (BUESCU, 1973, p. 153).

Os valores indicados no Gráfico 1.1 tendem a concordar com a interpretação sugerida por Buescu, porém tal constatação deve ser encarada com ressalvas, uma vez que se trata de um único gênero e uma única região produtora. De qualquer forma, o preço do arroz no mercado nacional apresenta um certo alinhamento, como sugere o Gráfico 1.2, que compara os preços mensais do saco de arroz em Iguape e no porto do Rio Grande entre 1848 e 1857. É possível identificar oscilações semelhantes tanto na redução do preço entre 1848 e 1851, como nas flutuações entre 1852 e 1855 e no ciclo completo nos dois últimos anos. ${ }^{56}$

\section{Gráfico 1.2}

Preços nominais do arroz

(Iguape e Rio Grande, 1848 a 1857)

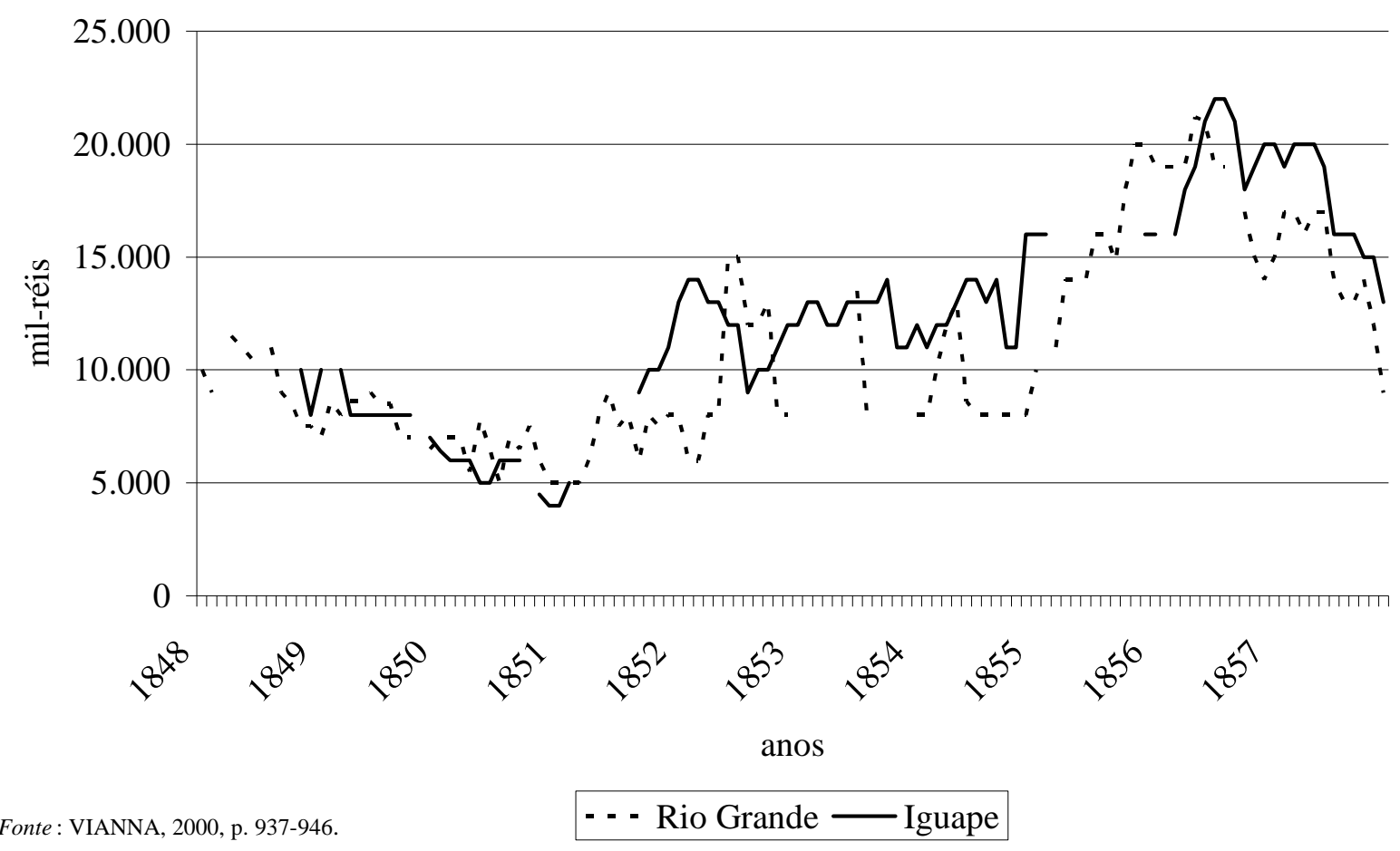

Provavelmente a percepção dos ribeirenses acerca dos ganhos obtidos com o arroz relacionava-se com as variações em moeda corrente, como mostra o gráfico anterior, e também no valor relativo do arroz confrontado com outros produtos nacionais, como indicam as análises seguintes.

\footnotetext{
${ }^{56}$ O mesmo tipo de comparação utilizando os preços anuais do Rio de Janeiro não evidenciou resultados semelhantes. Agradeço à Prof. ${ }^{a}$ Maria Eulália L. Lobo por graciosamente ceder a referida série. Afonso de Alencastro Graça Filho obteve uma extensa série de preços de produtos de produção local e importados em São João del Rei. Para o arroz, considerado pelo autor como um cultivo de produção e consumo local, os períodos de alta correspondem aos anos de 1848-49 e 1853-58, coincidindo apenas parcialmente com os resultados expostos no Gráfico 1.2 (cf. GRAÇA FILHO, 2002, p. 158).
} 
O movimento conjunto do preço do arroz e da taxa de câmbio contrapõe-se ao relativo descolamento de seu preço se comparado com os demais produtos nacionais descarregados no porto de Iguape. ${ }^{57}$ Apesar das oscilações, o preço do arroz conseguiu, até 1857, manter uma relativa paridade com os bens da “cesta básica”: enquanto aquele aumentou 72\%, o índice geral cresceu 95\%. Daí em diante, há um descolamento de tal forma que, exceto entre 1867 e 1869, os bens nacionais importados tornam-se, em média, 70\% mais caros do que a cotação média do grão no porto de Iguape. Nesse sentido, a aludida sinalização mostra-se ambígua: se no mercado para consumo de bens importados os preços do arroz favoreciam a posição dos ribeirenses, a capacidade de compra de bens de consumo nacionais sofreu uma sensível redução entre os anos de 1860 e 1870.

\section{Gráfico 1.3}

Preço nominal do arroz e taxa de câmbio

(Porto de Iguape, 1839 a 1870)

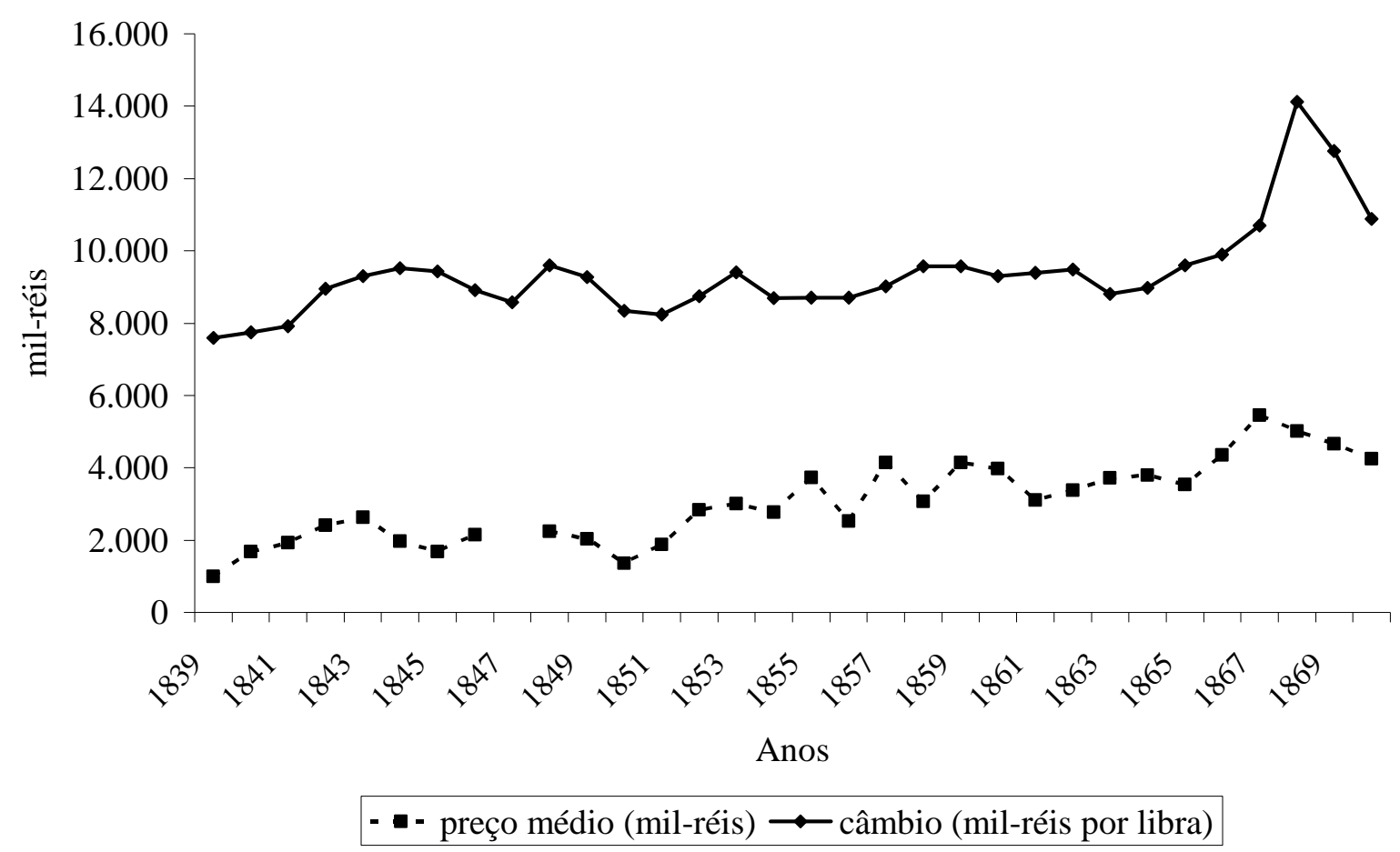

\footnotetext{
${ }^{57}$ O índice de preços pondera valores e quantidades compradas de carne seca, açúcar, café, aguardente e fumo. Temos clareza que alguns destes também se destinavam ao mercado externo, de tal sorte que nosso índice não pode ser considerado um legítimo indicador dos preços nacionais.
} 
Gráfico 1.4

Índice de preços nacionais e arroz

(Porto de Iguape, 1842 a 1870)

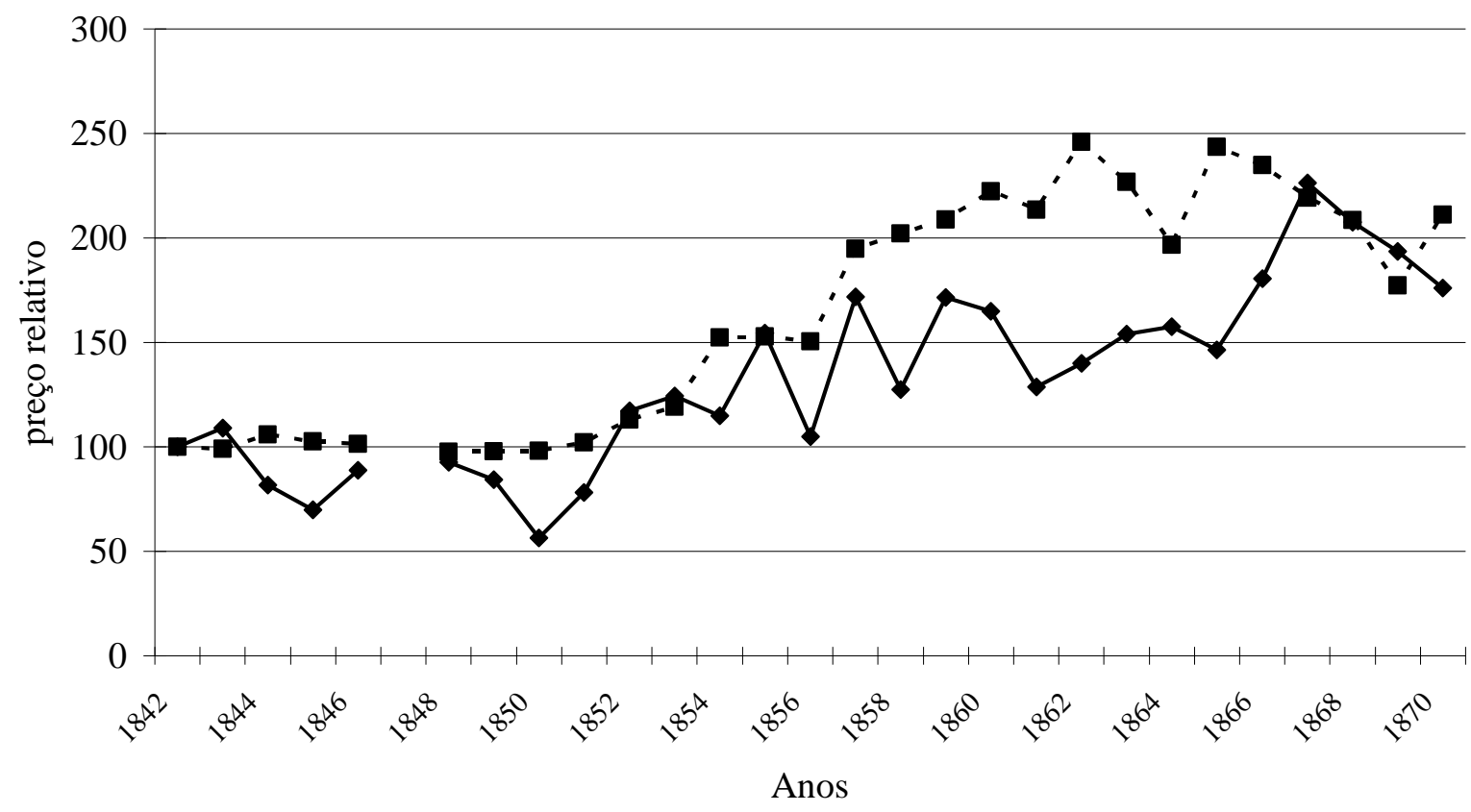

- •- índice de preços (1842=100) $\rightarrow$ preço arroz (1842=100)

Gráfico 1.5

Receitas e despesas totais

(Porto de Iguape, 1840 a 1870)

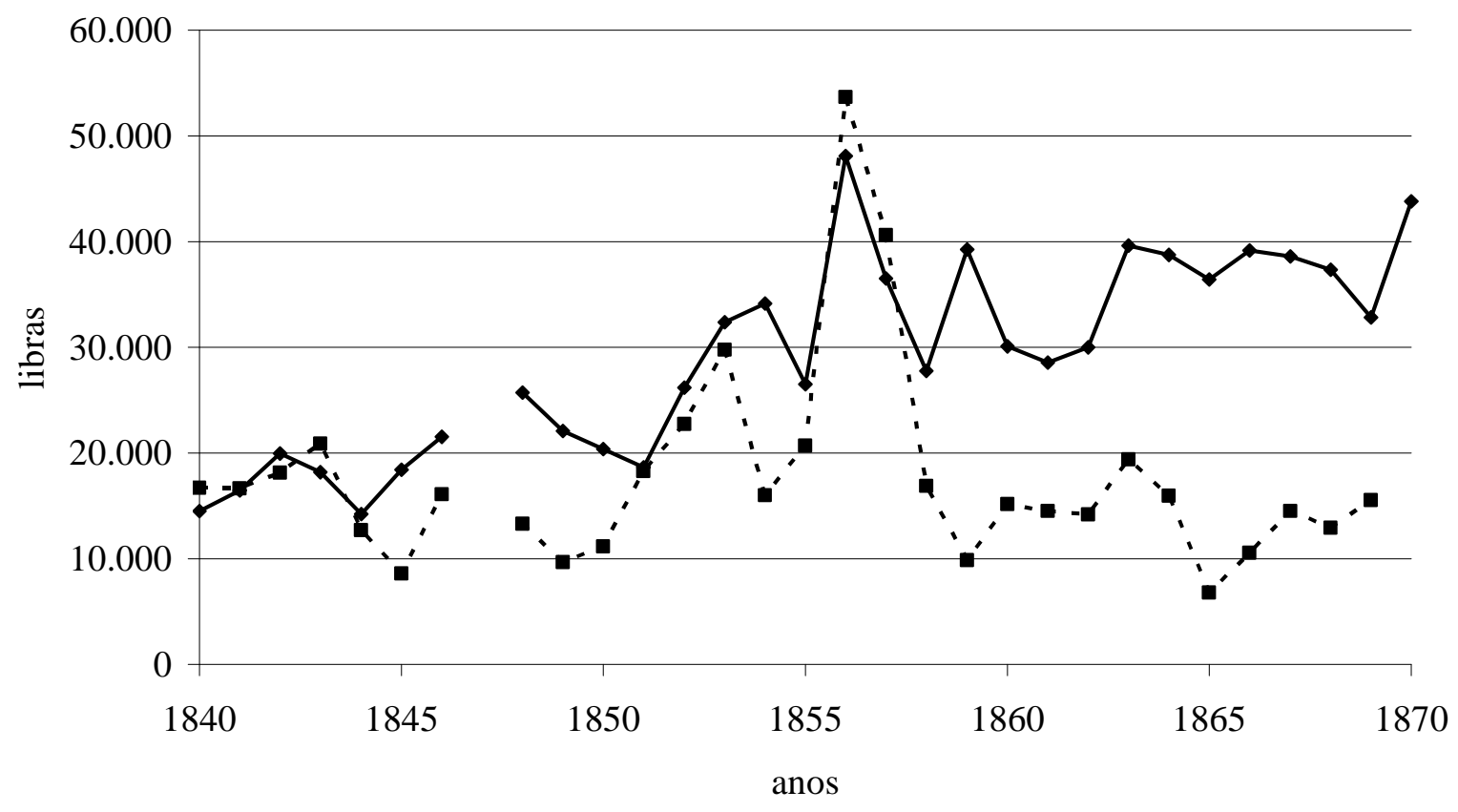

$\rightarrow$ exportações - - - importações 
Este resultado também pode ser visualizado no Gráfico 1.5, que apresenta as receitas e gastos anuais, já convertidos em libras, para o período em tela. Alertamos que os valores de despesa, distintamente dos dados analisados anteriormente, não mais incluem os gastos realizados com escravos. No entanto, não parece que tal ausência possa mudar as tendências merecedoras de destaque. A primeira delas retoma o quadro observado em fins da década de 1820: a manutenção de um elevado padrão de gastos, no qual a inclusão do dispêndio com cativos apenas melhor evidenciaria a permanência dos déficits. Esse período vai até 1844 e reaparece entre 1850 e 1856. Porém esses movimentos, ao contrário do observado no início do século XIX, guardam uma associação com as receitas obtidas pelas exportações. Após 1857, o montante gasto com importações retoma a faixa da década de 1840, apesar da manutenção das receitas entre 30 e 40 mil libras anuais.

Pelo lado das receitas, o arroz correspondia a 94\% do total. Outros cinco produtos com maior valor acumulado - canjica, algodão, milho, couros de boi e café - representavam apenas 3\% das receitas totais, restando a 96 outros itens menos de 3\% do valor acumulado no período. Da pauta de importações, manteve-se a divisão original entre produtos nacionais e importados, que representaram, respectivamente, 27\% e 73\% no período. Estes percentuais oscilaram muito: em 1856, por exemplo, as importações estrangeiras perfaziam 93\%; entre os anos de 1860 e 1864, as nacionais ultrapassavam a marca de quatro décimos, atingindo 58\% em 1862.

Desses valores depreende-se que a redução acima citada ocorreu primordialmente entre os gêneros importados: entre 1841 e 1857, o valor médio gasto com bens importados atingiu $£ 16.521$ e, no período seguinte, $£$ 9.000; para os bens nacionais, esses valores igualaram-se, respectivamente, a $£ 4.478$ e $£$ 5.616. Durante meados da década de 1850, notamos uma mudança no padrão da economia do Vale do Ribeira: de um quadro deficitário, passa-se ao acúmulo de sucessivos valores positivos na balança comercial, não por expansão de produção ou por variações no preço da gramínea, mas por uma contenção de gastos, especialmente de bens estrangeiros. Portanto, ainda que o preço do arroz ocupasse uma posição favorável em relação à taxa de câmbio, a crescente importância da demanda por produtos nacionais e a sua valorização, conforme indica o Gráfico 1.4, possivelmente contaminaram a cadeia produtiva, em especial no que afeta à quantidade de grãos exportados, segundo os resultados expressos no Gráfico 1.6. 


\section{Gráfico 1.6}

Preço do arroz e quantidade exportada

(Porto de Iguape, 1839 a 1870)

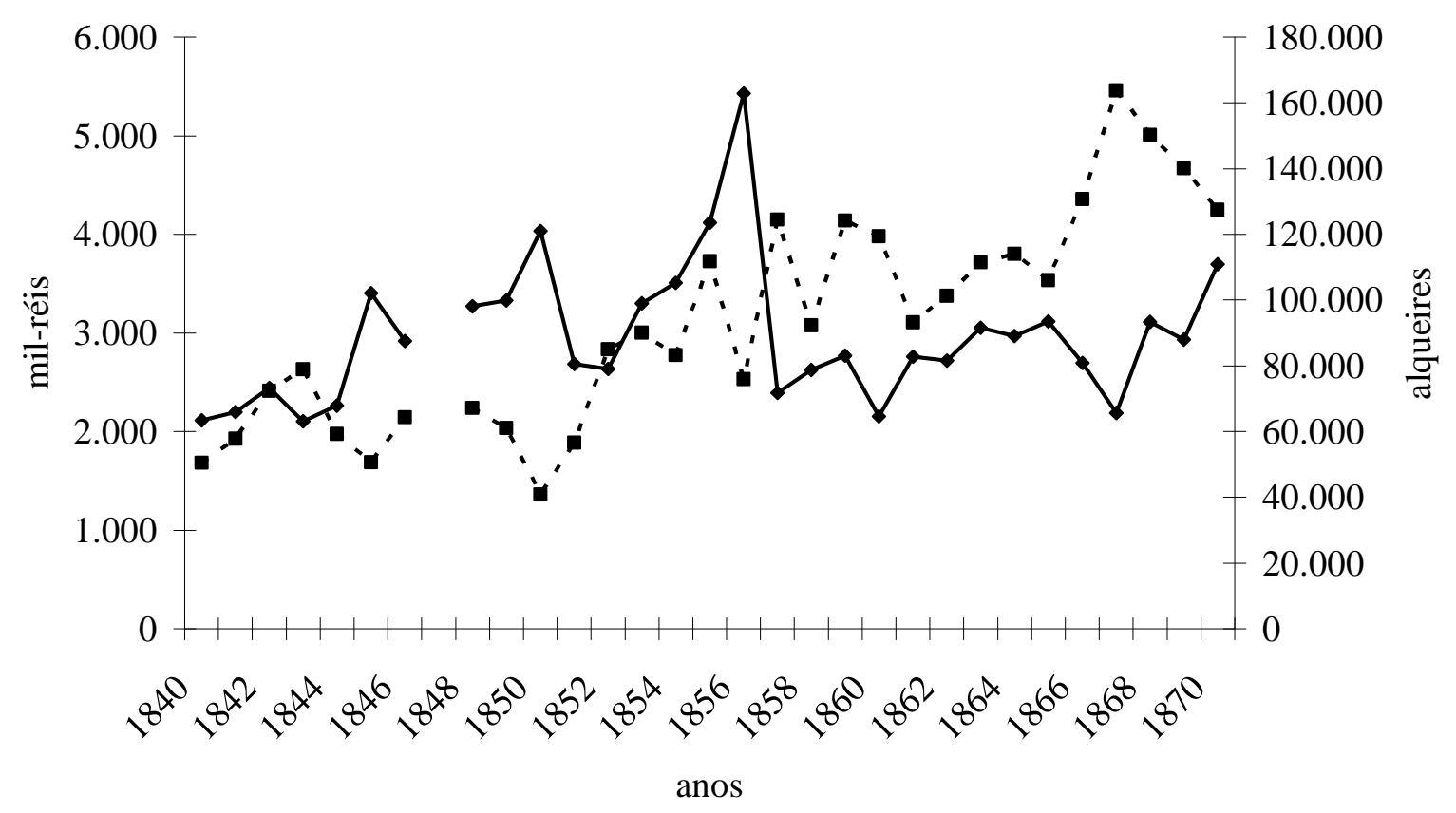

- - - preço do arroz $\longrightarrow$ exportação

A quantidade média de arroz remetido, que no período de 1839 a 1857 atingiu cerca de 90 mil alqueires por ano, reduziu-se a 79,5 mil alqueires no intervalo entre 1858 e 1870 . Os valores médios ocultam as oscilações anuais que, segundo os relatos coevos, resultavam das freqüentes inundações ${ }^{58}$ e da presença constante de competidores biológicos como roedores, aves e insetos. ${ }^{59}$ Seja por conta dos impedimentos naturais, pela perda de competitividade do preço do arroz em face dos outros produtos nacionais, pela redução da

\footnotetext{
${ }^{58}$ Um dos fatores que possivelmente contribuiu para a quebra da quantidade exportada a partir de 1857 foi a grande enchente ocorrida em 1858. O rol de moradores com prejuízos ultrapassava 400 casos e o valor estimado superava 58 contos de réis ou $£ 6.300$ (AESP, Ofícios diversos, ordem n. ${ }^{\circ} 1.043 a$ ).

${ }^{59}$ Pelo menos esta é a percepção registrada por Carlos Rath em 1885: A cultura de arroz além de não produzir grandes lucros é sujeita a muitas eventualidades, uma só das quais realizando-se é bastante para fazer perder todas as despesas e trabalhos de plantação; tais são às vezes as extraordinárias enchentes da ribeira e de outros rios caudalosos em uns anos. As chuvas excessivas nos tempos das derrubadas, queimadas ou colheitas, os milhões de ratos que, aparecendo repentinamente, tudo destroem, os pássaros, periquitos, guaraúnas, pombas, pixoxós que aparecem em quantidade extraordinária, as lagartas que chamam, Coruquerés são outras pragas que a perseguem. Admiro como estes pássaros, especialmente os Pixoxós que comem, até de noite, destroem e arrasam, ajudados pelos Coruquerés e ratos, arrozais inúmeros de uma noite para o dia. Acresce que esta cultura, no Distrito de Iguape, onde é feita somente nos terrenos charcosos, é sobremaneira prejudicial e fatal à saúde dos trabalhadores, especialmente dos escravos. (AESP, Ofícios diversos de Iguape, ordem n. ${ }^{\circ} 1.043 a$ ).
} 
produtividade por exaustão dos solos e baixa qualidade das sementes, ${ }^{60}$ ou ainda pela redução da mão-de-obra escrava durante a segunda metade do século XIX, o Gráfico1.6 sugere que o período após a década de 1850 não mais apresentava o dinamismo observado na primeira metade do Oitocentos.

Ainda que os dados coletados para as décadas de 1870 e 1880 não possuam a mesma qualidade daqueles já apresentados, podemos afirmar com relativa segurança que a quantidade exportada manteve-se no mesmo patamar registrado na década de 1860 e com preços nominais assemelhados aos praticados na segunda metade daquele decênio. Como corolário das mudanças descritas nos últimos parágrafos, analisamos em seguida os ribeirenses envolvidos com a comercialização dos grãos colhidos no período.

\section{Os remetentes e as remessas de arroz - 1837 a 1865}

A fonte utilizada para a presente análise - os manifestos de carga que acompanham as embarcações enviadas de Iguape aos portos de destino - permitiu reconstituir a série desde 1837 até $1880 .{ }^{61}$ Verificamos que, em consonância com o Gráfico 1.6, o decênio entre 1847 e 1856 concentrou $43 \%$ dos sacos remetidos, contra 28\% entre os anos de 1837 a 1846 e 27\% entre 1857 e 1861. Vale dizer, a quantidade remetida de arroz manteve-se em crescimento desde 1837 até 1856, quebrou no qüinqüênio 1857-1861 e esboçou uma ligeira recuperação no período final.

No entanto, ao longo do tempo a escrituração dos manifestos modificou-se: até 1866 os mapas arrolavam a carga segundo cada remetente de arroz; após esta data os documentos apenas indicavam a carga total enviada por embarcação. É fato que tal característica também se fez presente no período anterior, porém com participação crescente: entre 1842 e 1846, 777 sacos não puderam ter seus remetentes identificados; entre 1847 e 1851, 82 sacos; entre 1852 e 1856, o número salta para 6.943 sacos. Nos dois qüinqüênios seguintes os valores são representativos, 54.694 e 172.908 sacos, considerando o número de sacos com identificação dos remetentes: 64.139 e 22.548, respectivamente.

\footnotetext{
${ }^{60}$ Tal hipótese é sugerida no relatório de Coutinho: “Como acontece com a cana, e acontece com todas as plantas, degenerou-se o arroz em Iguape em conseqüencia de ter se empregado sempre a mesma semente e não lavrar-se a terra. Antigamente um alqueire de plantas dava 200 a 300 de semente, e hoje apenas 150 no máximo, regulando o termo médio de 80 a 120. Também o grão tornou-se muito menor, e tanto que em outro tempo obtinha-se de 4 alqueires em casca dois de arroz pilado e agora são precisos 4,5 a 5 alqueires. Esta diferença explica bem o atraso dos lavradores da Ribeira, que atribuem a causas mui diversas o discernimento de suas rendas" (AESP, Ofícios diversos de Iguape, ordem n. ${ }^{\circ}$ 1.047).

${ }^{61}$ Esta resulta da conjugação de documentos do Arquivo do Estado de São Paulo e do Museu Histórico e Arqueológico de Iguape. Agradeço o Sr. Roberto Fortes por gentilmente permitir a consulta a esta documentação.
} 
Tabela 1.15

Remessas, remetentes e sacos de arroz enviados segundo faixas de remessa

(Porto de Iguape, 1837-1865)

\begin{tabular}{|c|c|c|c|c|c|c|}
\hline Períodos & faixas & remessas & remetentes & sacos & sacos/remessa & sacos/remetente \\
\hline \multirow{6}{*}{$1837-1841$} & até 20 & 497 & 204 & 12.894 & 25,9 & 63,2 \\
\hline & 21 a 50 & 676 & 52 & 21.423 & 31,7 & 412,0 \\
\hline & 51 a 100 & 490 & 38 & 13.707 & 28,0 & 360,7 \\
\hline & 101 a 200 & 647 & 23 & 27.937 & 43,2 & $1.214,7$ \\
\hline & 201 ou mais & 574 & 14 & 41.484 & 72,3 & $2.961,1$ \\
\hline & total & 2.884 & 331 & 117.445 & 40,7 & 354,8 \\
\hline \multirow{6}{*}{$1842-1846$} & até 20 & 540 & 210 & 16.952 & 31,4 & 80,7 \\
\hline & 21 a 50 & 725 & 69 & 20.446 & 28,2 & 296,3 \\
\hline & 51 a 100 & 960 & 52 & 29.481 & 30,7 & 566,9 \\
\hline & 101 a 200 & 1.095 & 27 & 43.177 & 39,4 & $1.599,1$ \\
\hline & 201 ou mais & 1.040 & 14 & 82.077 & 78,9 & $5.862,6$ \\
\hline & total & 4.360 & 372 & 192.133 & 44,1 & 516,5 \\
\hline \multirow{6}{*}{ 1847-1851 } & até 20 & 485 & 195 & 15.221 & 31,4 & 78,1 \\
\hline & 21 a 50 & 667 & 70 & 19.687 & 29,5 & 281,2 \\
\hline & 51 a 100 & 1.167 & 58 & 36.740 & 31,5 & 633,4 \\
\hline & 101 a 200 & 1.087 & 29 & 47.864 & 44,0 & $1.650,5$ \\
\hline & 201 ou mais & 1.276 & 14 & 117.222 & 91,9 & $8.373,0$ \\
\hline & total & 4.682 & 366 & 236.734 & 50,6 & 646,8 \\
\hline \multirow{6}{*}{$1852-1856$} & até 20 & 777 & 284 & 23.333 & 30,0 & 82,2 \\
\hline & 21 a 50 & 816 & 68 & 25.917 & 31,8 & 381,1 \\
\hline & 51 a 100 & 1.476 & 55 & 48.285 & 32,7 & 877,9 \\
\hline & 101 a 200 & 1.020 & 24 & 50.298 & 49,3 & $2.095,8$ \\
\hline & 201 ou mais & 865 & 11 & 83.186 & 96,2 & $7.562,4$ \\
\hline & total & 4.954 & 442 & 231.019 & 46,6 & 522,7 \\
\hline \multirow{6}{*}{$1857-1861$} & até 20 & 341 & 169 & 11.450 & 33,6 & 67,8 \\
\hline & 21 a 50 & 216 & 49 & 6.715 & 31,1 & 137,0 \\
\hline & 51 a 100 & 259 & 38 & 9.794 & 37,8 & 257,7 \\
\hline & 101 a 200 & 218 & 24 & 15.390 & 70,6 & 641,3 \\
\hline & 201 ou mais & 198 & 11 & 20.790 & 105,0 & $1.890,0$ \\
\hline & total & 1.232 & 291 & 64.139 & 52,1 & 220,4 \\
\hline \multirow{6}{*}{$1862-1865$} & até 20 & 77 & 50 & 2.802 & 36,4 & 56,0 \\
\hline & 21 a 50 & 32 & 19 & 1.170 & 36,6 & 61,6 \\
\hline & 51 a 100 & 46 & 19 & 6.484 & 141,0 & 341,3 \\
\hline & 101 a 200 & 43 & 14 & 4.416 & 102,7 & 315,4 \\
\hline & 201 ou mais & 60 & 10 & 7.676 & 127,9 & 767,6 \\
\hline & total & 258 & 112 & 22.548 & 87,4 & 201,3 \\
\hline \multirow{6}{*}{ total } & até 20 & 2.717 & 822 & 82.652 & 30,4 & 100,5 \\
\hline & 21 a 50 & 3.132 & 95 & 95.358 & 30,4 & $1.003,8$ \\
\hline & 51 a 100 & 4.398 & 61 & 144.491 & 32,9 & $2.368,7$ \\
\hline & 101 a 200 & 4.110 & 29 & 189.082 & 46,0 & $6.520,1$ \\
\hline & 201 ou mais & 4.013 & 14 & 352.435 & 87,8 & $25.173,9$ \\
\hline & total & 18.370 & 1.021 & 864.018 & 47,0 & 846,2 \\
\hline
\end{tabular}

Destarte, os resultados aqui apresentados necessitam cuidados quanto à sua interpretação, em especial aqueles relativos à segunda metade do século XIX., uma vez que centralizamos nossas análises nos remetentes de arroz. Feitas estas observações, a Tabela 1.15 apresenta a quantidade de remessas e remetentes em períodos qüinqüenais e organizados por faixas de remessa. 
Os manifestos de carga possibilitaram a identificação de 1.021 pessoas ou grupos, porém a grande maioria se caracteriza como remetentes eventuais, compreendendo 917 (ou 90\%) com 50 remessas ou menos durante os 28 anos abarcados na Tabela 1.15. Respondiam no conjunto por $32 \%$ das remessas e $21 \%$ dos sacos. Dentro desse grupo merece destaque 510 casos (50\%) com apenas uma remessa identificada e valor médio igual a 32 sacos por remessa. Esse tipo de análise pode conter alguns vieses e um deles diz respeito à saída de grandes remetentes logo nos primeiros anos considerados ou à emergência de novos negociantes ou agricultores, cujo tempo coberto pela fonte não permitiu sua identificação, ou ainda associações entre agricultores e/ou comerciantes de curtíssima duração. Esses casos provavelmente superestimam as médias calculadas, como indica o valor mediano, 24 sacos, observado tanto para os remetentes com apenas um registro como para o conjunto com até 20 remessas.

As faixas intermediárias - 51 a 200 remessas - congregam 90 remetentes (8\%) e 8.508 remessas (46\%), envolvendo 333.573 sacos (37\%) ou 39 sacos por remessa. Não se tratava de um grupo homogêneo, como indica o valor médio de sacos por remessa na Tabela 1.15; o agrupamento de 101 a 200 remessas configura-se como uma fatia de transição entre um grande bloco de pequenos remetentes (eventuais ou não) e o grupo com mais de 200 remessas. Entre os 26 casos que compunham essa faixa, há nomes já citados nas seções anteriores, como Antonio José Peniche, Filadelpho de Souza Castro, Francisco Carneiro da Silva Braga, José Gonçalves Maia e outros tantos. ${ }^{62}$ Muitos deles não aparecem o tempo todo, por morte ou mudança. ${ }^{63}$ Por fim, o grupo de remetentes com mais de 200 envios de arroz compunha-se por 14 pessoas ou pouco mais de $1 \%$ do total e realizaram $22 \%$ das remessas e $41 \%$ dos sacos de arroz. Mais adiante analisaremos o perfil desses agentes. Por ora, parece interessante observar as variações ocorridas entre as diferentes faixas de remessa ao longo do tempo.

No qüindênio 1842-1856, a participação dos remetentes com até 50 remessas oscilou entre $24 \%$ e $32 \%$, e entre $15 \%$ e $21 \%$ dos sacos embarcados, com as maiores marcas registradas no último terço (1852-1856) - fase de boas safras, conforme indica o Gráfico

\footnotetext{
${ }^{62}$ Um caso relevante pertencente a este grupo é Roso Lucas Lagoa, que durante anos exerceu a função de agente comercial das empresas de navegação a vapor. Em vários manifestos de carga desses navios ele aparece como o único remetente, possivelmente suprimindo os demais nomes. É possível, entretanto, que parte dessa quantidade seja de propriedade de Lagoa, pois antes de assumir o cargo, exercia atividades comerciais em Xiririca.

63 Nesse sentido, uma outra análise poderia ordenar os remetentes segundo grupos familiares, o que provavelmente produziria resultados distintos. Por exemplo, os primos Antonio José Peniche e Antonio Francisco de Ataide Peniche, ambos pertencentes à faixa analisada, somam 357 remessas, não considerando as alianças familiares estabelecidas através dos casamentos.
} 
1.6. ${ }^{64}$ Nesse mesmo período o grupamento intermediário (51 a 200 remessas) elevou sua participação de $47 \%$ para $50 \%$ das remessas e de $38 \%$ para $43 \%$ dos sacos. Os maiores remetentes também aumentaram a participação nos dois terços iniciais do intervalo analisado, porém entre 1847-1851 e 1852-1856 a participação relativa nas remessas caiu de 27\% para $17 \%$ e os sacos, de $49 \%$ para 36\%. Parte dessa oscilação se deve à ausência, por falecimento, de três das 14 pessoas que, desde 1837, compunham o reduzido segmento. Essas ausências e o aumento das participações nas demais faixas sugerem que nenhum dos 11 restantes açambarcou o arroz por eles remetido.

Na década posterior à quebra do volume exportado, em que pese a parcial cobertura da fonte utilizada, associamos aos pequenos remetentes cerca de $44 \%$ das remessas feitas; ao grupo intermediário, 35\%, restando em torno de $20 \%$ aos grandes remetentes. A quantidade de sacos envolvida oscilou com maior intensidade: no período 1857-1861 os pequenos enviaram $28 \%$ do total e os médios, $40 \%$. No qüinqüênio seguinte, as participações alçaram 18\% e 48\%, respectivamente. Já sugerimos que o final da década de 1850 marcava uma mudança na conformação econômica do setor agrário do Vale do Ribeira vinculado à produção e comércio de arroz. As oscilações aqui percebidas - reafirmando a precariedade da fonte concernente a tal fase - também indicam novas acomodações, acrescentando outros fatores à aludida alteração.

Em primeiro lugar notamos, como indica a Tabela 1.16, que das 14 pessoas que compunham o grupo dos grandes remetentes, todas já constavam nos manifestos desde 1837. Isso significa que ao longo de três décadas não emergiu nenhum outro negociante de arroz avultado. Poder-se-ia objetar acerca do número mínimo de remessas desse pequeno grupo, porém vale pensar que tal valor equivale a sete remessas anuais considerando todo o período ou, tomando os resultados da Tabela 1.12, ter alguma remessa em cerca de $30 \%$ dos navios que zarparam com destino ao Rio de Janeiro. Isto sugere que os 14 negociantes conseguiam manter o domínio da comercialização da gramínea sem grandes esforços e sem a ameaça de concorrentes. Mesmo a não substituição daqueles que desapareceram dos mapas parece reforçar a idéia de que a condição para pertencer a esta pequena elite não estava ao alcance dos demais remetentes.

\footnotetext{
${ }^{64}$ A quantidade média de alqueires exportada nos intervalos, segundo a fonte utilizada para a construção do referido gráfico: 1839-41, 60.704; 1842-46, 78.802; 1847-51, 99.883; 1852-56, 113.955; 1857-61, 76.217; 186266, 87.319.
} 
Tabela 1.16

Remetentes com mais de 200 remessas

(Mesa de rendas de Iguape, 1837 a 1865)

\begin{tabular}{l|ccccc}
\hline \multicolumn{1}{c|}{ Nomes } & remessas & início & final & sacos & sacos/remessa \\
\hline Luis Alvares da Silva & 426 & $06 / 07 / 1837$ & $13 / 10 / 1864$ & 29.966 & 70,3 \\
João Mancio da Silva Franco & 407 & $06 / 07 / 1837$ & $25 / 08 / 1864$ & 42.510 & 104,4 \\
José Bonifácio de Andrade e Silva & 350 & $01 / 08 / 1837$ & $29 / 05 / 1861$ & 16.172 & 46,1 \\
Miguel Antonio Jorge & 349 & $01 / 08 / 1837$ & $21 / 03 / 1865$ & 78.644 & 225,3 \\
José Xavier de Almeida Cruz & 280 & $12 / 06 / 1837$ & $05 / 03 / 1862$ & 28.296 & 101,0 \\
José Alves da Costa Pacca & 278 & $01 / 08 / 1837$ & $21 / 03 / 1865$ & 11.302 & 40,7 \\
José Jacinto de Toledo & 277 & $06 / 07 / 1837$ & $03 / 05 / 1854$ & 35.212 & 127,1 \\
José Ferreira de Aguiar e Silva & 260 & $21 / 08 / 1837$ & $25 / 02 / 1865$ & 21.073 & 81,0 \\
Francisco Manoel dos Passos & 259 & $12 / 10 / 1837$ & $27 / 06 / 1864$ & 10.091 & 39,0 \\
Rafael Descio & 268 & $12 / 06 / 1837$ & $25 / 08 / 1864$ & 19.081 & 80,1 \\
José Joaquim Cardoso & 234 & $13 / 07 / 1837$ & $25 / 09 / 1856$ & 15.262 & 65,2 \\
Manoel Ferreira da Silva & 233 & $13 / 07 / 1837$ & $11 / 01 / 1855$ & 19.732 & 84,7 \\
João Antonio de França & 218 & $31 / 05 / 1838$ & $12 / 03 / 1862$ & 15.851 & 72,7 \\
Antonio de Magalhães Mesquita & 204 & $13 / 07 / 1837$ & $21 / 03 / 1864$ & 9.243 & 45,3 \\
\hline
\end{tabular}

Acresça-se ainda que, não obstante o poder desse grupo, os pequenos remetentes detinham um certo grau de liberdade para executarem suas operações mercantis, conforme indicam os valores relativos descritos nos parágrafos anteriores. Isso não significa menosprezar a freqüência e importância das redes mercantis locais, descritas para diferentes localidades e conjunturas econômicas dos séculos XVIII e XIX e também presentes no Vale 
do Ribeira. ${ }^{65} \mathrm{O}$ que se tem em mente é a interferência de fatores peculiares à região, conforme indicam os gráficos seguintes.

Gráfico 1.7

Distribuição mensal de sacos remetidos segundo faixas de remessa

(Porto de Iguape, 1837 a 1860)

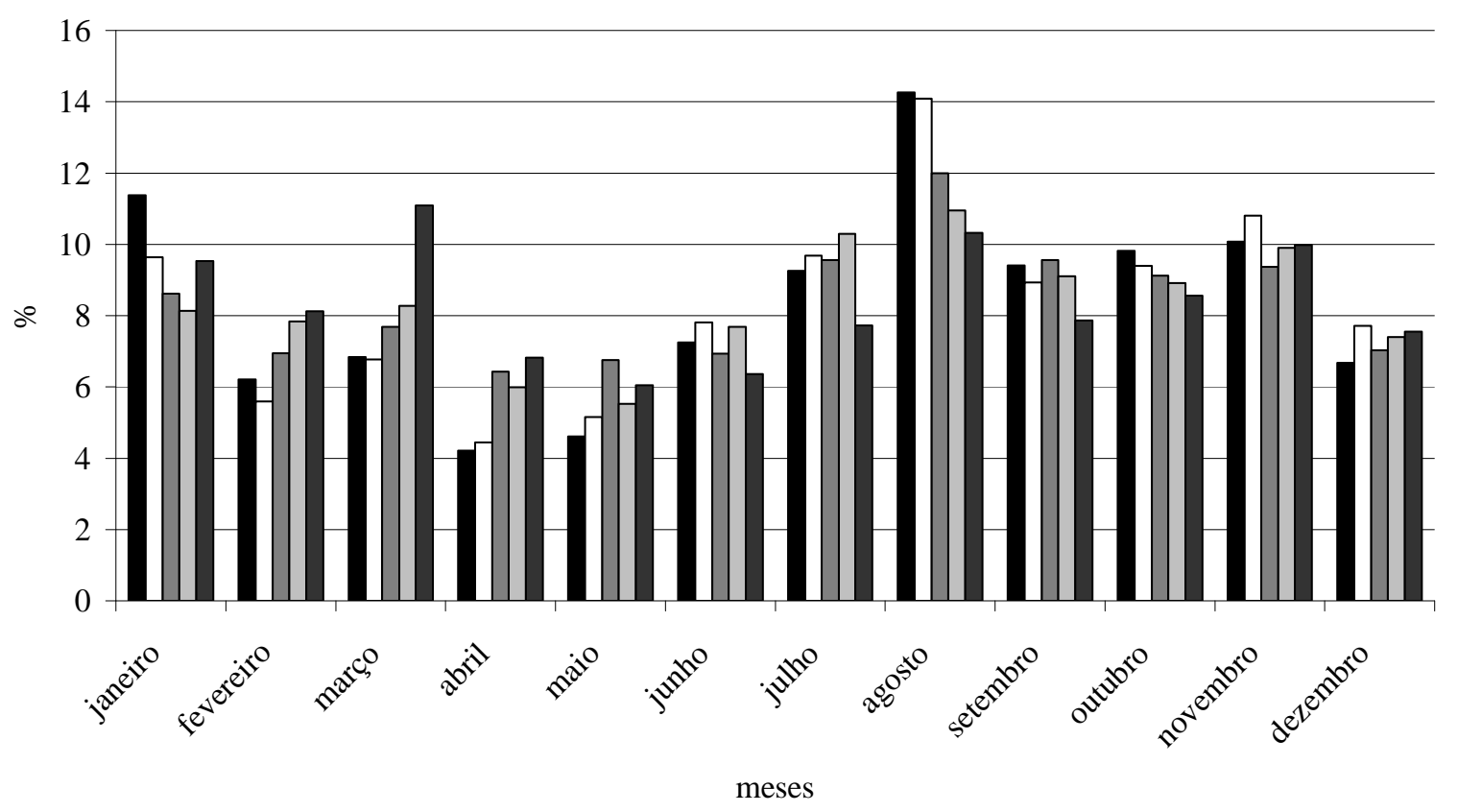

até $20 \square 21$ a $50 \square 51$ a $100 \square 101$ a $200 \square 201$ ou mais

65 Em 1845, o vereador, deputado provincial e diretor da Mesa de Rendas de Iguape, José Inocêncio Alves Alvim, assim descrevia este mecanismo em Iguape: “Os antigos viviam mui parcamente, poucas despesas faziam no trajar e passadio. O país, ainda todo novo fornecia-lhes caça em abundância quase sem trabalho; os rios e alagoas estavam coalhados de peixe; tinham à porta de casa quase todo o necessário e indispensável para a vida porque também não se descuidavam de plantar mandioca e algodão. Assim, vivendo eles com a mais estrita economia, não existindo então a lei que permite a convenção de juros ,puderam pagar seus primeiros empenhos aos negociantes e depois, com o pouco que lhes foi rendendo a cultura do arroz, puderam fazer casa e deixar alguma coisa a seus descendentes (continua [observação do autor - AV]). Nos presentes tempos tudo tem mudado. Com o aumento da população e sua disseminação pelos rios ao interior a caça tem desaparecido, o peixe já não abunda nos rios e alagoas; o luxo tem introduzido até pelos sertões necessidades que os antigos desconheciam, tanto respeito ao trajar como ao passadio; assim os lavradores presentemente são obrigados por suas circunstâncias a comprar para si e para suas famílias fazendas de custo, bem como a pagar por altos preços a carne de porco e o toucinho que lhes vem das vilas de Serra Acima e a carne seca do Rio Grande e outros comestíveis indispensáveis; por isso quando mesmo tenham a fortuna de ter uma boa safra de arroz, todo seu produto se lhes vai em despesas e se não podem adiantar; e se por desgraça falha a safra, a necessidade os obriga a contraírem dívidas com os negociantes da vila pagando prêmios de 1, 1 e meio, 2, 2 e meio por cento ao mês, conforme o maior ou menor grau de cobiça e dureza de coração daqueles que então ditam a lei aos necessitados; e ei-los, os pobres lavradores caídos em um abismo de que jamais se podem levantar, ficam por toda a sua vida cativos dos negociantes; porque a cultura do arroz mal lhes dá para viverem e pagam exorbitantes prêmios e ainda bem se a podem pagar; porque aliás aí vem a acumulação delas ao capital e os conseqüentes prêmios de prêmios seguindo-se como se tem visto a ruína total das casas e a miséria das famílias. Tal é, sem exageração, o desgraçado estado e deplorável sorte de quase todos os lavradores de Iguape e Xiririca, sendo bem poucos os que vivem desempenhados em melhores circunstâncias". (ALVIM, 1845, p.1011) Este e outros trechos do relatório foram transcritos por Carlos Rath em 1855. 


\section{Gráfico 1.8}

Distribuição mensal do número de remessas segundo faixas de remessa

(Porto de Iguape, 1837 a 1860)

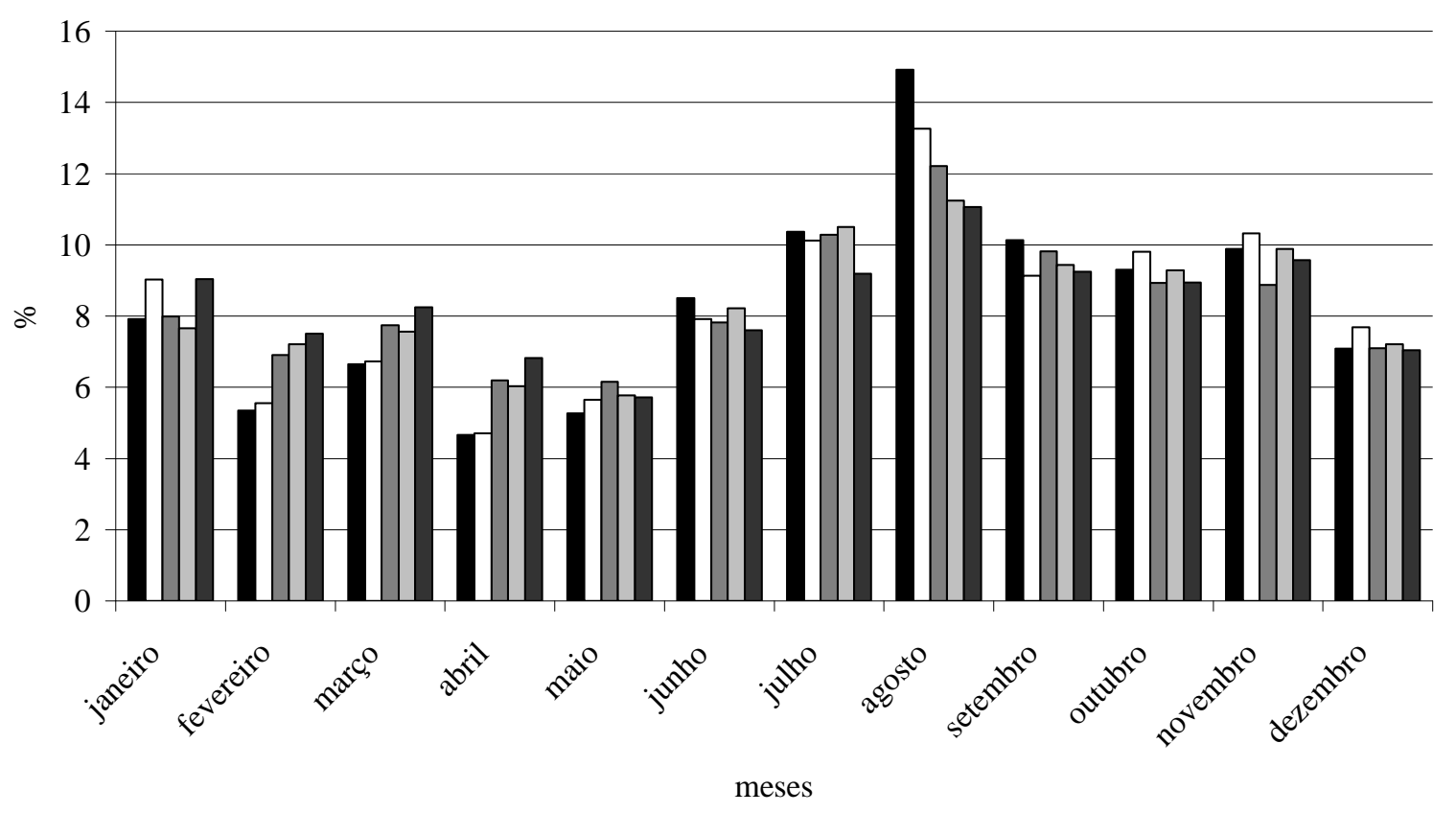

até $20 \square 21$ a $50 \square 51$ a $100 \square 101$ a $200 \square 201$ ou mais

Segundo Ernesto Young, o calendário das atividades agrícolas para cultivo do arroz começava nos meses de julho a setembro, com a coivara e roçada das terras e a semeadura nos meses de outubro, novembro e dezembro, e excepcionalmente em janeiro no caso de terrenos alagadiços. Nos meses de janeiro e fevereiro costumavam ocorrer as capinações, e ainda em fevereiro já se colhia algum arroz. Nos meses de março e abril, principalmente, e maio, secundariamente, as atividades eram de colheita (cf. YOUNG, 1899, p. 112-116). A safra, de acordo com os Gráficos 1.7 e 1.8, ganhava os navios a partir de junho, mas é no mês de agosto que as remessas ocorriam com maior intensidade. Nessa época, conforme indica a correspondência abaixo, datada aos 6 de junho de 1865 e endereçada ao presidente da Província, a cidade devia receber um número significativo de representantes comerciais de outras praças:

A Câmara Municipal da Cidade de Iguape cumprindo-lhe como órgão deste Município, procurar os meios de fazer prosperar a localidade onde se acham adistritos os seus mais vitais interesses vem respeitosamente à presença de Vossa Excelência expor o seguinte: acontecendo, Exmo. Sr., que nos meses de junho, julho e agosto, tempo este da safra do arroz, que é o ramo principal da nossa lavoura, acodem a este município por especulação muitos negociantes e mascates de municípios estranhos que aqui estabelecem e finda a safra se retiram, causando assim graves prejuízos ao comércio e indústria; atendendo às constantes reclamações dos negociantes, artistas e operários desta praça e município que, assaz prejudicados por tais especuladores, altamente reclamam uma pronta providência em prol de seus interesses, esta Câmara já por patriotismo e já porque reconhece a necessidade de uma medida enérgica que possa 
senão destruir, ao menos modificar de qualquer forma esses obstáculos que se antepõem ao favorável incremento do comércio e indústria deste município, resolveu para esse fim em Sessão Extraordinária de hoje formular um artigo de Postura, que junto remete à Vossa Excelência, pedindo-Ihe respeitosamente que se digne sancionar até que reúna a Assembléia. ${ }^{66}$

Esse documento não apenas confirma o calendário descrito por Young ou os dados dos dois últimos gráficos, mas agrega uma outra categoria de remetentes, os "negociantes e mascastes” de municípios estranhos, que possivelmente contribuíam para o elevado número de pequenos remetentes. Ademais, entre os meses de julho e agosto ocorria (e ainda ocorre) a principal festa da cidade, dedicada ao Senhor Bom Jesus. O fluxo de fiéis dos vários rincões do Vale do Ribeira possivelmente carreava modestas quantias de arroz, cujo embarque deveria ocorrer nos meses de julho e agosto.

Estes informes ajudam a compreender a elevada participação relativa dos pequenos remetentes nestes dois meses, tanto em relação aos sacos remetidos como ao número de remessas. Nos meses seguintes o fluxo da safra continuava, porém com menor intensidade e sem distinções significativas entre as faixas de remessa. O mês de janeiro aparece como atípico, pois há uma desproporção entre as remessas (entre 8 e 9\%) e os sacos (entre 8 e 11\%). Nos meses de fevereiro e março observamos o mesmo fenômeno, porém apenas nas faixas de remessa mais elevadas. Tomando como referência o calendário agrícola de Young, poderíamos supor que a maior intensidade de remessas por parte dos médios e grandes remetentes decorresse do adiantamento das safras próprias.

Acerca dos maiores remetentes, retornemos à Tabela 1.16. De imediato, vale notar que nenhum nome arrolado pertencia ao grupo dos grandes comerciantes descritos na primeira seção deste capítulo, ainda que lá se tenha mencionado alguns deles como pequenos: José Jacinto de Toledo, Miguel Antonio Jorge e outros. Pelo menos três deles representavam a segunda geração familiar a capitanear as atividades comerciais no Vale do Ribeira: José Xavier de Almeida Cruz, filho de Bartolomeu Xavier de Almeida Cruz, João Mâncio da Silva Franco, filho de Vitorino José Franco, comerciante iguapense do início do século XIX, e João Antonio de França, cuja família há muito se encontrava estabelecida em Xiririca; os dois primeiros possuíam seus pais listados na Tabela 1.4 como consignatários de mercadorias desembarcadas no porto de Iguape nas primeiras décadas do século XIX. Destaque-se também

\footnotetext{
${ }^{66}$ AESP, Ofícios diversos de Iguape, ordem n. ${ }^{0}$ 1.045. Eis o teor da postura: "A Câmara Municipal da Cidade de Iguape propõe os seguintes artigos de Postura: Artigo Primeiro: Toda a pessoa de Município estranho que vier vender gêneros de qualquer espécie neste Município pagará o imposto de Rs. $150 \$ 000$ por um ano e no caso de querer firmar sua residência pagará somente no ano seguinte o mesmo imposto que pagam os estabelecimentos no lugar. Artigo Segundo: Os contraventores do artigo antecedente serão multados em Rs. 200\$000”, que foi vetada pelo governo Provincial.
} 
o caso do italiano Rafael Descio, residente em Iporanga, limite do Vale com a Serra do Mar e provavelmente um dos poucos remetentes de arroz colhido naqueles confins.

Observando a ordenação segundo número de remessas, Luis Álvares da Silva e João Mâncio da Silva Franco são os únicos que superaram a marca de 400 registros. O primeiro, que possuía o título de comendador (assim como José Jacinto de Toledo), natural de Cananéia, aparece na lista de 1836, então com 31 anos, morador na vila de Iguape e detinha 2 escravos. Na lista de matrícula de 1874, esse número igualava-se a 37. Trata-se, segundo Roberto Fortes, de um caso assemelhado ao do Capitão-mor Peniche, pois mantinha a casa comercial e unidades produtoras de arroz, com atuação forte na política local. ${ }^{67}$ O segundo, além da ligação parental ao comércio, foi cunhado de José Jacinto de Toledo por duas vezes. Sua trajetória parece emblemática do quadro de estagnação aqui esboçado após a década de 1850: comerciante, proprietário de embarcações e herdeiro de duas partes da herança de Toledo, João Mâncio parece obter cabedal suficiente para, juntamente com Luis de Matos Pereira e Castro, o Barão do Flamengo, assumirem, em 1889, o controle do Banco Comercial do Rio de Janeiro e, dessa forma, drenar parcela da riqueza acumulada para a Corte carioca, onde fixou moradia em fins da década de $1870 .^{68}$

Se alguém merece o título de “rei do arroz", não se trata de nenhum iguapense, mas sim do português Miguel Antonio Jorge, residente em Xiririca. Apesar da quarta posição em número de remessas, a quantidade de sacos remetidos, 78.644, traduz uma média de sacos por remessa (225) que supera em quase duas vezes o segundo maior valor, de José Jacinto de Toledo (127). Em 1828, Jorge fazia parte da lista de moradores da Segunda Companhia de Ordenanças de Xiririca, então com 24 anos e proprietário de dois escravos; em 1836 sua posse totalizava 13 cativos. A julgar pelos registros anotados nos livros de sisa de Xiririca, este negociante destinou parte considerável de seus ganhos à compra de terras: entre 1849 e 1879, Miguel Antonio realizou 100 compras registradas (ou 12\% de todas as negociações do período), envolvendo a quantia de quase 38 contos de réis (ou $14 \%$ do valor total constante nos livros). ${ }^{69}$

Estes e outros casos serão retomados no Capítulo 4 desta tese, quando confrontaremos a riqueza e trajetória de proprietários de engenho e comerciantes.

\footnotetext{
${ }^{67}$ FORTES, Roberto. Vultos Iguapenses, ed. preliminar em meio eletrônico, cortesia do autor.

${ }^{68}$ LAEMMERT, 1889, p. 1.210 e FORTES, Roberto. Vultos Iguapenses, ed. preliminar em meio eletrônico, cortesia do autor.

${ }^{69}$ AESP, Sisa, ordens n. ${ }^{\circ} 8.600$ a 8.603.
} 


\section{A riqueza medida através dos inventários}

Esta última parte busca delinear o perfil da riqueza acumulada no Vale do Ribeira ao longo do século XIX através dos 678 inventários abertos entre 1800 e 1880. Apresentamos os resultados em três intervalos: o primeiro, que vai de 1800 a 1840, correspondeu à fase de gênese e expansão da rizicultura, com 109 inventários; o segundo, de 1841 a 1860, grosso modo, foi o período com as maiores quantidades exportadas do grão (262 casos) e o último (1861 a 1880, 307 inventários), que se caracterizou pela estabilidade econômica e pela redução acentuada da força de trabalho escrava. A Tabela 1.17 distribui os percentuais de casos e riqueza acumulada, em libras, segundo faixas de riqueza bruta.

Tabela 1.17

Distribuição relativa da quantidade e riqueza acumulada nos inventários segundo faixas de riqueza bruta (Iguape e Xiririca, 1800 a 1880)

\begin{tabular}{|c|c|c|c|c|c|c|c|c|}
\hline \multirow{3}{*}{$\begin{array}{c}\text { Faixas de riqueza } \\
\text { bruta }(£)\end{array}$} & \multicolumn{6}{|c|}{ intervalos } & \multirow{2}{*}{\multicolumn{2}{|c|}{ total }} \\
\hline & \multicolumn{2}{|c|}{$1800-1840$} & \multicolumn{2}{|c|}{$1841-1860$} & \multicolumn{2}{|c|}{ 1861-1880 } & & \\
\hline & $\mathbf{N}$ & riqueza & $\mathbf{N}$ & riqueza & $\mathbf{N}$ & riqueza & $\mathbf{N}$ & riqueza \\
\hline até 500 & 73,5 & 22,3 & 72,2 & 21,9 & 64,8 & 14,9 & 69,0 & 18,4 \\
\hline 501 a 1.000 & 12,8 & 16,0 & 14,5 & 17,2 & 17,3 & 17,7 & 15,5 & 17,3 \\
\hline 1.001 a 2.000 & 7,3 & 17,3 & 7,6 & 19,0 & 12,4 & 23,2 & 9,7 & 20,9 \\
\hline acima de 2.000 & 6,4 & 44,4 & 5,7 & 41,9 & 5,5 & 44,2 & 5,8 & 43,4 \\
\hline total & 16,0 & 13,9 & 38,6 & 35,0 & 45,4 & 51,1 & 100,0 & 100,0 \\
\hline
\end{tabular}

Obs.: a linha totalizadora soma $100 \%$, para $\mathrm{N}$ e riqueza, nos três subperíodos.

Não obstante a maior abrangência do primeiro subperíodo, nele pudemos identificar apenas $16 \%$ dos inventários e 14\% da riqueza bruta avaliada. No intervalo seguinte, 1841 a 1860, a parcela da riqueza acumulada se aproxima do porcentual de inventários, fato observado nas duas últimas décadas, que concentravam metade de toda a riqueza bruta e $45 \%$ dos inventários.

Esta desequilibrada distribuição se reflete nos resultados da coluna totalizadora: na faixa dos inventários com riqueza até 500 libras encontramos 69\% dos casos, com participação mais acentuada nos dois primeiros subperíodos. No conjunto, a eles pertenciam pouco mais de $18 \%$ da riqueza bruta, novamente com valores relativos maiores nos dois primeiros intervalos. No outro extremo, cerca de 6\% dos inventários continham bens cuja avaliação superava 2.000 libras, correspondendo a $43 \%$ da riqueza bruta total. No primeiro subperíodo estes processos possuíam maior peso tanto na quantidade como na riqueza.

Nas faixas intermediárias, registramos parcelas crescentes tanto na quantidade de inventários como na riqueza possuída, porém com intensidades diferentes na riqueza. No 
grupo entre 501 a 1.000 libras, a participação passou de 16\% para 18\% e, na faixa seguinte, de $17 \%$ para $23 \%$.

Tabela 1.18

Distribuição relativa de inventários e riqueza

(Várias localidades, anos selecionados)

\begin{tabular}{|c|c|c|c|c|c|c|c|}
\hline \multirow{2}{*}{ Localidades } & \multirow{2}{*}{ período } & \multirow{2}{*}{$\begin{array}{c}\text { total de } \\
\text { inventários }\end{array}$} & \multicolumn{2}{|c|}{ até $£ 500$} & \multicolumn{2}{|c|}{$£ 2.000$ ou mais } & \multirow{2}{*}{$\begin{array}{l}\text { \% de não- } \\
\text { escravistas }\end{array}$} \\
\hline & & & inventários & riqueza & inventários & riqueza & \\
\hline \multirow{3}{*}{ Rio de Janeiro $^{\text {a }}$} & 1820 & 62 & 50,4 & 3,3 & 24,6 & 90,7 & - \\
\hline & 1840 & 73 & 46,7 & 3,6 & 26,0 & 85,5 & - \\
\hline & 1860 & 131 & 35,9 & 1,5 & 39,6 & 92,8 & - \\
\hline Lorena $^{\mathrm{b}}$ & $1830-1879$ & 186 & 50,0 & 2,1 & 16,7 & 89,5 & 16,7 \\
\hline Mariana $^{c}$ & $1850-1888$ & 319 & 55,2 & 10,3 & 7,9 & 63,5 & 28,8 \\
\hline \multirow{2}{*}{ Araxá $^{\text {d }}$} & $1816-1848$ & 118 & 66,9 & 15,9 & 8,5 & 56,3 & 16,9 \\
\hline & $1856-1888$ & 212 & 57,1 & 11,1 & 13,2 & 60,6 & 29,2 \\
\hline $\operatorname{Mogim}_{\text {Mirim }}{ }^{\mathrm{e}}$ & 1831-1880 & 593 & 57,2 & 8,1 & 12,6 & 69,6 & 29,8 \\
\hline Ribeirão Preto ${ }^{\mathrm{f}}$ & $1849-1879$ & 119 & 60,5 & 7,1 & 15,1 & 77,2 & 46,2 \\
\hline \multirow{4}{*}{ Vale do Ribeira } & $1800-1840$ & 109 & 73,5 & 22,3 & 6,4 & 44,4 & 17,4 \\
\hline & $1841-1860$ & 262 & 72,2 & 21,9 & 5,7 & 41,9 & 34,4 \\
\hline & $1861-1880$ & 307 & 64,8 & 14,9 & 5,5 & 44,2 & 36,5 \\
\hline & $1800-1880$ & 678 & 69,0 & 18,4 & 5,8 & 43,4 & 32,6 \\
\hline
\end{tabular}

FRAGOSO, 1998, p. 311.

${ }^{\circ}$ MARCONDES, 1998, p. 168-169.

'TEIXEIRA, 2001, p. 28

${ }^{u}$ REIS, 2005, p. 217-218.

'SOARES, 2003, p. 116.

${ }^{1}$ LOPES, 2005, p. 59 e 72.

De maneira geral, detectamos que uma leve tendência de maior desigualdade no último subperíodo, conforme indica também o índice de Gini: de valores praticamente iguais nos dois primeiros intervalos $(0,671$ e 0,670$)$, o indicador alcança 0,687 no último período. ${ }^{70}$

\footnotetext{
${ }^{70}$ Para o período todo, 0,679. Francisco Vidal Luna assim descreve esse indicador: "O índice de Gini corresponde a um coeficiente estatístico, largamente utilizado para medir a concentração de riqueza. Constitui, na verdade, a relação entre áreas de um quadrado, construído de forma a representar, num dos eixos (o horizonte), a população segmentada em percentis e no outro (o vertical), a riqueza ou renda (também dividida em percentis) da comunidade estudada. Caso os detentores da renda (ou riqueza) e esta se distribuíssem de maneira absolutamente igualitária, a cada ponto do eixo horizontal corresponderia outro na diagonal do quadrado. Como geralmente isso não ocorre, quando se plotam esses valores no quadrado, obtém-se uma curva, chamada de 'Lorenz'. Dividindo a área entre a curva de Lorenz e a diagonal pela área triangular sob a diagonal, determina-se o índice de Gini. Dessa forma, quanto mais regularmente se distribui a renda ou riqueza, mais próximo de zero estará o valor do índice (zero no limite); correlativamente, quanto mais concentrada estiver a riqueza ou renda, maior será o valor do aludido índice que, no máximo, iguala-se à unidade" (LUNA, 1981, p.121, nota n. ${ }^{\circ}$ 4).
} 
A Tabela 1.18 compara a distribuição da riqueza no Vale do Ribeira com algumas outras localidades brasileiras ao longo do século XIX.

Outros estudos utilizando a mesma fonte documental revelaram distribuições assemelhadas, porém com distintas intensidades. A capital do Império e Lorena guardam em comum as maiores parcelas de riqueza concentradas no grupo com mais de 2.000 libras, não obstante o contingente expressivo de inventários classificados entre aqueles com avaliações que não superavam as 500 libras. No caso de Lorena, Renato Marcondes fornece o índice de Gini igual a 0,748 , valor bem superior ao observado no Vale do Ribeira nos três subperíodos (cf. MARCONDES, 1998, p. 168-169). Em outras regiões agrárias, porém distanciadas das atividades agroexportadoras, notamos maior parcela da riqueza presente nas menores faixas de riqueza, como nas localidades mineiras de Mariana e Araxá. ${ }^{71}$ Os inventários da região paulista de Mogi Mirim abertos entre 1831 e 1880 revelam uma distribuição de riqueza parecida com a observada em Mariana. Segundo Leonel de Oliveira Soares, o período assinalado marca a transição de uma economia essencialmente abastecedora para outra voltada para o mercado externo com rápido desenvolvimento da lavoura cafeeira. Nos primórdios de Ribeirão Preto, então essencialmente pecuarista (1849 a 1879), 61\% dos inventários pertenciam à menor faixa de riqueza e acumulavam 7\% dos bens inventariados, ao passo que $15 \%$ dos casos com mais de 2.000 libras detinham $79 \%$ da riqueza.

Dos resultados acima expostos, verificamos que o padrão de distribuição da riqueza no Vale do Ribeira tende a se alinhar com as localidades agrícolas com produção destinada ao consumo interno. Não obstante a diversidade econômica e os distintos padrões de acumulação de riqueza, nenhuma delas concentrava tantos inventários na menor faixa de riqueza, assim como parcela tão reduzida da riqueza inventariada na maior das faixas. Essa distribuição, que possivelmente indica a maior pobreza dos ribeirenses, relaciona-se com o perfil das pessoas inventariadas. $^{72}$ No conjunto, 33\% dos processos não possuíam escravos entre os bens avaliados, com participação crescente ao longo do tempo, como assinala a Tabela 1.18.

\footnotetext{
${ }^{71}$ A amostra analisada pela Déborah Reis em Araxá apresentou índices de Gini bastante variáveis, oscilando entre 0,552 no período $1826-1829$ a 0,743 em 1846-1848 e entre 0,581 a 0,719 no intervalo entre 1856-1858 a 1886-1888 (cf. REIS, 2005, p. 68).

${ }^{72}$ Uma possível influência nas variações dos valores médios das riquezas apontadas nos inventários poderia relacionar-se à condição conjugal do inventariado. Em casos onde o inventariante fosse o cônjuge, muito provavelmente o principal fator a intervir na quantidade de riqueza acumulada decorria de eventuais adiantamentos por conta de dotes ou doações realizadas em momentos pretéritos ao inventário. Já em se tratando de inventariados viúvos, possivelmente uma partilha anterior já teria ocorrido por conta do falecimento do cônjuge. Para os casos em que tal situação pôde ser identificada, realizamos um teste de médias para a riqueza bruta. Em nenhum subperíodo, tanto para escravistas como para não-escravistas, as diferenças evidenciaram relevância estatística, não obstante os valores médios superiores nos processos que tinham como inventariante o cônjuge.
} 
Exceto em Ribeirão Preto, nenhuma das localidades contempladas possuía parcela tão elevada de não-escravistas a compor as amostras estudadas.

Buscando melhor esclarecer o perfil dos não-proprietários ribeirenses, apresentamos na Tabela 1.19 os valores da riqueza bruta e líquida segundo a presença de cativos entre os bens avaliados.

Tabela 1.19

Indicadores de riqueza inventariada segundo posse de escravos

(Iguape e Xiririca, 1800 a 1880)

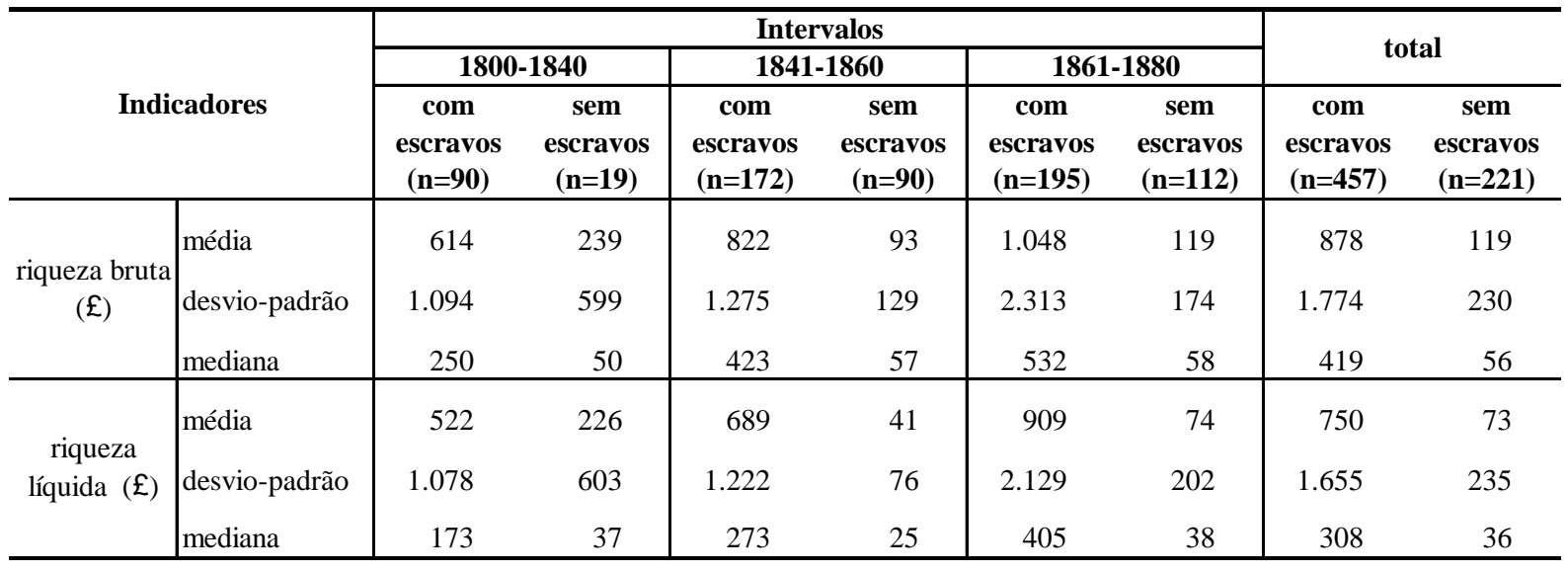

Apesar dos crescentes valores médios da riqueza bruta dos proprietários de escravos, não é possível afirmar que eles sejam estatisticamente diferentes. A principal causa decorre da elevada dispersão, também sempre crescente, evidenciando a presença de proprietários em distintos estratos de riqueza. Esta heterogeneidade igualmente pode ser inferida através da diferença entre os valores médios e medianos, estes últimos com crescimento significativo ao longo do tempo. Dessa forma, podemos afirmar que a conjunção de fatores locais gerados pela expansão e consolidação da cultura do arroz, e a conjuntura nacional, marcada pela expressiva valorização dos cativos, principalmente na segunda metade do século XIX, afetaram de forma diferenciada os escravistas do Vale do Ribeira, favorecendo principalmente o grupo de escravistas com menores posses. ${ }^{73}$

Entre os não-escravistas, a riqueza bruta média também não apresentou diferenças estatísticas significativas, porém o movimento se distingue do observado para os proprietários, com redução entre o primeiro e o segundo intervalo e manutenção no período

\footnotetext{
73 Provavelmente o melhor desempenho da riqueza mediana decorra da própria valorização do cativo, que será tema no capítulo sobre a estrutura da posse de escravos.
} 
subseqüente. ${ }^{74}$ Os valores relativamente iguais das medianas sugerem que parte dessa população não se assenhoreou da riqueza gerada pelas práticas agrícolas e comerciais descritas nas anteriormente.

Sobre a riqueza líquida, vale ressaltar que nem todos os inventários tiveram seu montante reduzido por dívidas passivas. Dessa forma, os menores valores médios e medianos - mais acentuados entre os não-proprietários e principalmente no segundo subperíodo - não correspondem à condição geral dos inventariados de Iguape e Xiririca. Entre os escravistas, as mesmas observações sobre os valores médios e medianos feitas para a riqueza bruta valem para a riqueza líquida. Como reflexo da ressalva acima, notamos o aumento da dispersão em torno dos resultados médios. A redução mais acentuada da riqueza líquida media e mediana entre os não-escravistas indica o maior grau de comprometimento do patrimônio com as dívidas passivas.

Apresentamos na Tabela 1.20 os índices de Gini calculados para a riqueza bruta e líquida ${ }^{75}$ para os dois segmentos aqui destacados.

Tabela 1.20

Índices de Gini para a riqueza bruta e riqueza líquida

(Iguape e Xiririca, 1800-1880)

\begin{tabular}{l|cc|cc}
\hline \multirow{2}{*}{ Subperíodos } & \multicolumn{2}{|c|}{ riqueza bruta } & \multicolumn{2}{c}{ riqueza líquida } \\
\cline { 2 - 5 } & com escravos & sem escravos & com escravos & sem escravos \\
\hline $1800-1840$ & 0,648 & 0,745 & 0,737 & 0,784 \\
$1841-1860$ & 0,584 & 0,568 & 0,667 & 0,797 \\
$1861-1880$ & 0,601 & 0,571 & 0,649 & 0,833 \\
\hline total & 0,610 & 0,606 & 0,677 & 0,833 \\
\hline
\end{tabular}

Em relação aos índices de riqueza bruta, ainda que os valores para escravistas e nãoproprietários calculados para o período completo guardem proximidade, a cada subperíodo notamos graus distintos de concentração. Para ambos os grupos, nossa amostra proporcionou valores relativamente elevados no primeiro subperíodo em relação aos demais. Esta maior desigualdade da riqueza parece retratar um momento de transição na economia ribeirense, congregando patrimônios acumulados dentro e fora do surto de desenvolvimento promovido pela rizicultura. Esta característica aparece minimizada no segundo intervalo, vale dizer, a

\footnotetext{
${ }^{74}$ O elevado valor médio no primeiro subperíodo deve-se ao inventário de Manoel Rodrigues do Rosário, aberto aos 17 de agosto de 1840 (MHAI, caixa n. ${ }^{\circ}$ 1). Nas listas nominativas, pelo menos desde 1815 este comerciante pardo sempre possuiu um ou dois escravos, porém no seu inventário não há cativo algum avaliado. As dívidas ativas somavam $£ 2.530$, resultado de 212 registros de créditos, representando 96\% de sua riqueza bruta.

${ }^{75}$ Para a riqueza líquida, que envolve a presença de valores negativos, o cálculo do índice de Gini segue o modelo proposto por CHEN et. alli. (1982, p. 473-76).
} 
maior parte dos inventários abertos entre 1841 e 1860 continha riqueza derivada da nova conformação produtiva da região, o que provavelmente contribuiu para reduzir as distâncias entre os patrimônios. Na última vintena, o indicador evidencia um pequeno aumento na concentração entre os proprietários, aqui entendido como um reflexo da decadência da escravidão e associado a capacidades específicas na manutenção da posse escrava e na diversificação da riqueza bruta.

A maior concentração da riqueza líquida, medida através do índice de Gini, denuncia que poucos conseguiam se manter indenes à rede de endividamento. De nossa amostra, cerca de 36\% dos casos não declararam dívidas passivas nos inventários. Entre os que possuíam débitos, o valor médio para o período igualou-se a $£ 157$, crescente ao longo do tempo e com diferença significativa entre escravistas ( $£$ 197) e não-escravistas ( $£ 72$ ). O maior impacto pode ser percebido na realocação dentro das faixas de riqueza, como mostra a Tabela 1.21.

Além da maior quantidade relativa de inventários reposicionados ao longo dos subperíodos (25\% no primeiro subperíodo e 33\% nos demais), a mudança progressivamente atinge faixas de riqueza bruta mais elevadas a cada subperíodo, acompanhando o crescimento da riqueza média da maioria escravista. ${ }^{76}$

\footnotetext{
76 Dos 425 inventários distribuídos na Tabela 1.21, 296 possuíam escravos contra 139 não-escravistas. O comprometimento da riqueza bruta com as dívidas passivas nos primeiros atingia $21 \%$ contra $60 \%$ para os demais. No conjunto da amostra, a porcentagem de dívidas passivas representava $16 \%$ da riqueza bruta.
} 
Tabela 1.21

Distribuição relativa dos inventários com dívidas passivas segundo faixas de riqueza bruta e líquida (Iguape e Xiririca, 1800-1880)

\begin{tabular}{|c|c|c|c|c|c|c|c|}
\hline \multirow{2}{*}{ Subperíodos } & \multirow{2}{*}{$\begin{array}{c}\text { faixas de } \\
\text { riqueza líquida }\end{array}$} & \multicolumn{5}{|c|}{ faixas de riqueza bruta } & \multirow{2}{*}{ total } \\
\hline & & 0 a 100 & 101 a 500 & 501 a 1.000 & 1.001 a 2.000 & acima de 2.000 & \\
\hline \multirow{7}{*}{$1800-1840$} & negativa & 4,7 & 7,8 & - & - & - & 12,5 \\
\hline & 0 a 100 & 21,9 & 9,4 & - & - & - & 31,3 \\
\hline & 101 a 500 & - & 29,7 & 6,3 & 1,6 & - & 37,5 \\
\hline & 501 a 1.000 & - & - & 6,3 & - & - & 6,3 \\
\hline & 1.001 a 2.000 & - & - & - & 6,3 & - & 6,3 \\
\hline & acima de 2.000 & - & - & - & - & 6,3 & 6,3 \\
\hline & total & 26,6 & 46,9 & 12,5 & 7,8 & 6,3 & 100,0 \\
\hline \multirow{7}{*}{$1841-1860$} & negativa & 11,1 & 7,8 & 0,6 & 0,6 & - & 20,0 \\
\hline & 0 a 100 & 16,7 & 10,0 & 1,1 & - & - & 27,8 \\
\hline & 101 a 500 & - & 28,3 & 6,7 & - & - & 35,0 \\
\hline & 501 a 1.000 & - & - & 6,7 & 1,1 & - & 7,8 \\
\hline & 1.001 a 2.000 & - & - & - & 4,4 & 0,6 & 5,0 \\
\hline & acima de 2.000 & - & - & - & - & 4,4 & 4,4 \\
\hline & total & 27,8 & 46,1 & 15,0 & 6,1 & 5,0 & 100,0 \\
\hline \multirow{7}{*}{$1861-1880$} & negativa & 6,8 & 3,7 & 1,0 & 0,5 & - & 12,0 \\
\hline & 0 a 100 & 20,9 & 7,3 & 0,5 & - & - & 28,8 \\
\hline & 101 a 500 & - & 20,9 & 6,8 & 0,5 & - & 28,3 \\
\hline & 501 a 1.000 & - & - & 11,0 & 5,2 & - & 16,2 \\
\hline & 1.001 a 2.000 & - & - & - & 7,3 & 1,0 & 8,4 \\
\hline & acima de 2.000 & - & - & - & - & 6,3 & 6,3 \\
\hline & total & 27,7 & 31,9 & 19,4 & 13,6 & 7,3 & 100,0 \\
\hline
\end{tabular}

Tendo em vista o limitado aumento da riqueza inventariada através de seus valores brutos e líquidos, os resultados acerca da composição da riqueza bruta, apresentados no Gráfico 1.9, mostram oscilações na composição da riqueza bruta ao longo do tempo. Neste gráfico optamos por apresentar apenas os três grupos com maior importância relativa. ${ }^{77}$

${ }^{77}$ Os móveis representavam 6\% da riqueza bruta em Iguape e 5\% em Xiririca; os valores monetários, 3\% e 2\%, aí inclusos os únicos quatro casos com posse de ações da Companhia Ribeirense de Navegação a Vapor, única modalidade de ativo desse tipo, inclusive títulos de dívida pública. 
Gráfico 1.9

Distribuição relativa da riqueza bruta segundo grupos de bens

(Iguape e Xiririca, 1800 a 1880)

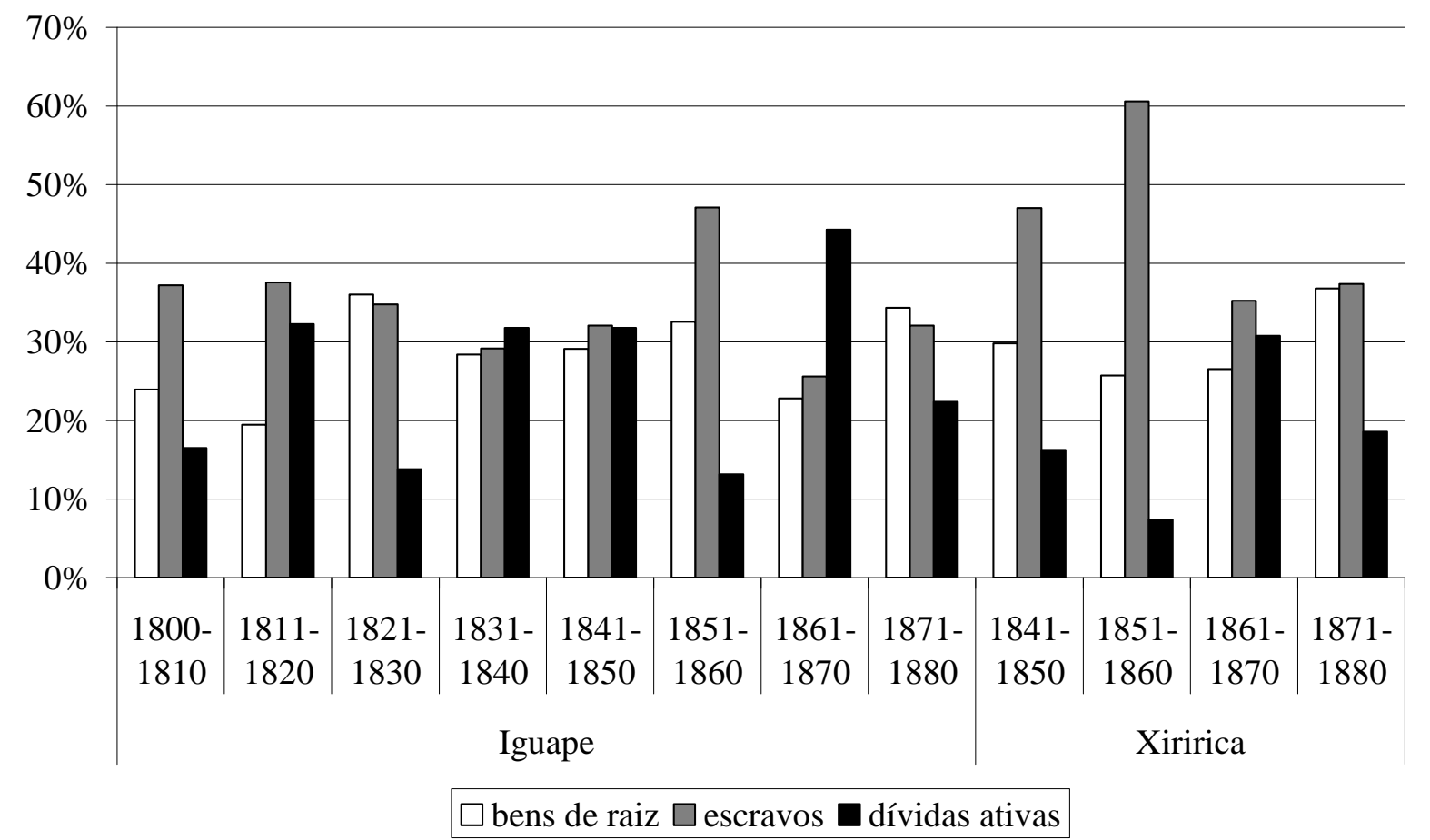

Em Iguape, notamos que pelo menos até a década de 1860, os escravos ocupavam posição de destaque entre os bens avaliados, ora alternando posição com os bens de raiz, ora com as dívidas ativas. Sua abrupta redução de importância na década de 1860 relaciona-se com eventos de distinta natureza. O primeiro, como detalharemos no capítulo sobre estrutura de posse, diz respeito ao decrescente número médio de escravos por inventário. O outro se relaciona com as mudanças no valor atribuído aos cativos: nas primeiras quatro décadas, manteve-se ao redor de $£ 27$, atingindo na década de 1840 e 1850, $£ 39$ e $£ 63$, respectivamente. Nos anos de 1860 , o preço médio recuou para $£ 57$, recuperando-se no último decênio, £ 67. A mesma conjugação de efeitos pode ser observada em Xiririca

Os bens de raiz, que possuíam participação em torno de $30 \%$ da riqueza nas décadas de 1820 a 1860, também apresentaram menor peso na década de 1860 e recuperação posterior. Da mesma forma que para os escravos, os valores médios das propriedades rurais sofreram oscilações. Trataremos deste tema no capítulo seguinte.

A participação das dívidas ativas atinge, em Iguape, marcas expressivas nas décadas de 1810, 1830 e 1840. O especial destaque na década de 1860 decorre, em parte, do comportamento dos outros dois grupos de bens, mas também pelo seu valor absoluto, cerca de 40 mil libras. Neste capítulo evidenciamos a importância do segmento comercial nas 
atividades econômicas desta localidade e a expressiva participação deste grupo apenas reafirma a importância da rede de crédito desenvolvida ao longo do período estudado.

De qualquer forma, esta distribuição da riqueza bruta não se revela fundamentalmente distinta das localidades que, na Tabela 1.18, apresentam um padrão de concentração semelhante ao do Vale do Ribeira. Por exemplo, em Araxá, na primeira metade do século XIX, bens de raiz e escravos respondiam igualmente por dois terços da riqueza, complementadas por $20 \%$ em dívidas ativas. Na segunda metade, os escravos compunham o maior ativo dos araxaenses, com 36\% contra 32\% em bens de raiz e $16 \%$ de dívidas ativas. ${ }^{78}$ Em Mogi Mirim, bens de raiz mantiveram participação constante ao redor de $30 \%$ entre os anos de 1831 a 1870 e atingindo 50\% da riqueza na década seguinte. Já os cativos apresentaram participações em torno de $40 \%$ até 1860, reduzindo a cerca de 33\% e 23\% nas duas décadas posteriores. As dívidas ativas aparecem com porcentual crescente, porém não ultrapassando a marca de 20\% (cf. SOARES, 2003, p. 150, 203-204). Em Mariana, os escravos respondiam por 39\% da riqueza nos inventários de escravistas abertos entre 1850 e 1888, também com parcelas decrescentes. Os bens de raiz (terras e benfeitorias na classificação da autora) ocupavam a segunda posição, com cerca de $25 \%$, seguidos pelas dívidas ativas, com $20 \%{ }^{79}$

A tabela seguinte apresenta alguns indicadores da riqueza bruta segundo atividades econômicas dos inventariados. Nota-se que a riqueza média dos comerciantes superava a dos demais grupos, porém com variações ao longo do tempo.

\footnotetext{
${ }^{78}$ Destaque ainda para as criações, com cerca de $10 \%$ na primeira metade e $12 \%$ na segunda. Na década de 1870 , os escravos representavam um terço da riqueza, porém nos anos 80 esta parcela reduziu-se a 12\% (Cf. REIS, 2005, p. 78-80).

${ }^{79}$ A participação de escravos decaiu de 51\% na década de 1850 para 32\% nos anos de 1870 (cf. TEIXEIRA, 2001, p. 30).
} 
Tabela 1.22

Indicadores de riqueza bruta segundo atividades econômicas

(Iguape e Xiririca, 1800-1880)

\begin{tabular}{|c|c|c|c|c|c|c|c|c|c|c|c|c|c|}
\hline & \multirow[b]{2}{*}{ atividades econômicas } & \multicolumn{3}{|c|}{$1800-1840$} & \multicolumn{3}{|c|}{$1841-1860$} & \multicolumn{3}{|c|}{$1861-1880$} & \multicolumn{3}{|c|}{ total } \\
\hline & & $\mathbf{N}$ & média & $\begin{array}{l}\text { desvio- } \\
\text { padrão }\end{array}$ & $\mathbf{N}$ & média & $\begin{array}{l}\text { desvio- } \\
\text { padrão }\end{array}$ & $\mathbf{N}$ & média & $\begin{array}{l}\text { desvio- } \\
\text { padrão }\end{array}$ & $\mathbf{N}$ & média & $\begin{array}{l}\text { desvio- } \\
\text { padrão }\end{array}$ \\
\hline \multirow{10}{*}{ 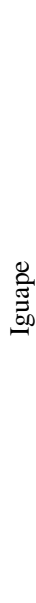 } & agricultura e manufatura rural & 63 & 597 & 1.228 & 139 & 575 & 1.195 & 128 & 441 & 589 & 330 & 527 & 1.011 \\
\hline & atiidades do mar & 4 & 84 & 25 & 11 & 251 & 188 & 6 & 263 & 246 & 21 & 223 & 194 \\
\hline & artesanato & 11 & 232 & 307 & 9 & 114 & 150 & 3 & 363 & 264 & 23 & 203 & 254 \\
\hline & igreja & 1 & 205 & - & 1 & 920 & - & - & - & - & 2 & 563 & 506 \\
\hline & magistratura e empregos civis & 1 & 543 & - & 1 & 852 & - & - & - & - & 2 & 697 & 218 \\
\hline & profissões liberais & - & $\because$ & - & 3 & 431 & 309 & 4 & 879 & 147 & 7 & 687 & 316 \\
\hline & rentistas & - & - & - & 6 & 1.040 & 1.270 & 1 & 41 & - & 7 & 897 & 1.219 \\
\hline & comércio & 23 & 770 & 862 & 34 & 960 & 1.460 & 24 & 2.945 & 5.673 & 81 & 1.494 & 3.352 \\
\hline & atividades não identificadas & 6 & 133 & 98 & 27 & 154 & 168 & 32 & 327 & 693 & 65 & 237 & 503 \\
\hline & total & 109 & 548 & 1.033 & 231 & 562 & 1.125 & 198 & 726 & 2.179 & 538 & 620 & 1.583 \\
\hline \multirow{5}{*}{ 茪 } & agricultura e manufatura rural & & - & - & 24 & 689 & 862 & 79 & 526 & 633 & 103 & 564 & 692 \\
\hline & artesanato & - & - & - & 3 & 354 & 289 & 6 & 89 & 80 & 9 & 177 & 206 \\
\hline & comércio & - & - & - & 2 & 955 & 1.128 & 15 & 1.913 & 2.746 & 17 & 1.800 & 2.603 \\
\hline & atividades não identificadas & - & - & - & 2 & 274 & 360 & 9 & 353 & 536 & 11 & 338 & 494 \\
\hline & total & - & - & - & 31 & 647 & 805 & 109 & 678 & 1.243 & 140 & 671 & 1.158 \\
\hline
\end{tabular}

Se compararmos as freqüências acima com a Tabela 1.10, que traz a distribuição dos fogos presentes em 1836 segundo as atividades econômicas, notamos que a amostra dos inventários subestima a participação de agricultores (62\% contra 77\% em Iguape e $74 \%$ contra $89 \%$ em Xiririca) em favor dos comerciantes (15\% versus $8 \%$ em Iguape e 12\% contra $4 \%$ em Xiririca), porém representa bem as categorias com menor expressão, como artesãos e atividades do mar, com cerca de $4 \%$ dos casos tanto nas listas como nos inventários. Este viés nos alerta sobre o cuidado necessário ao interpretar os resultados da composição da riqueza.

Aceito o alerta, passemos aos números. Em Iguape, a rigor, não é possível identificar mudanças importantes na riqueza média dos agricultores no intervalo considerado, distintamente dos comerciantes, que apresentaram variação de riqueza significativa, especialmente no último subperíodo. No entanto, chamamos a atenção para a maior dispersão em torno do valor médio dos agricultores nos dois primeiros subperíodos. Esta heterogeneidade reflete um conjunto muito diverso de proprietários de engenho, plantadores de arroz e outros agricultores com níveis de riqueza significativamente distintos e intimamente associados à quantidade de escravos avaliados, como ficará mais claro no 
Capítulo 3. Devidamente separados, buscamos no Capítulo 4 comparar a riqueza e trajetória de representantes dos proprietários de engenho e do segmento comercial no sentido de evidenciar como tais atividades se apropriaram da riqueza gerada pelas atividades agrícolas da região.

O resultado desse evolver, se sopesado com outras localidades, mostra-se claramente amesquinhado. Por exemplo, se comparado com o valor médio dos inventários de Mogi Mirim na década de 1830, £ 758, não podemos afirmar que se trata de um nível de riqueza substancialmente distinto daquele assinalado no primeiro subperíodo da Tabela 1.22, $£ 548$. Porém, se tomarmos o valor médio em 1870, £ 2.500, notamos claramente a diferença entre a capacidade de acumulação dos ribeirenses, permanentemente atrelados ao cultivo do arroz e dos moradores daquela localidade, que substituíam suas plantações de cana por café (cf. SOARES, 2003, p. 120). Na localidade mineira de Araxá, voltada para a agropecuária de subsistência, os inventários abertos entre 1836 e 1839 tinham como riqueza média £ 1.592 e, na década seguinte, $£$ 745. Novamente nas décadas de 1860 e 1870, os valores oscilam ( $£$ 1.104 e $£$ 695), porém também superam ou se equiparam com as médias gerais assinaladas na Tabela 1.22 (cf. REIS, 2005, p. 215).

Não obstante a dinâmica registrada nas primeiras décadas do século XIX, esta não se mostrou suficiente para consolidar no Vale do Ribeira um padrão de riqueza que, no mínimo, fosse comparável com outras regiões brasileiras inseridas nas redes de abastecimento desenhadas para sustentar os maiores centros urbanos do Império. No entanto, o grau de especialização no cultivo e comercialização dos grãos propiciou a formação de nichos que se mantiveram rentáveis mesmo em uma conjuntura desfavorável. Do conjunto de resultados até momento, notamos a presença de pelo menos duas gerações distintas no topo destas atividades, uma delas representada pelos comerciantes indicados nas Tabelas 1.4 e 1.5 e outra pelos remetentes de arroz da Tabela 1.16.

Ademais, os arranjos observados nas listas nominativas de 1801 e 1836 evidenciam que a prática rizicultora não se restringiu a um determinado segmento produtivo, atingindo praticamente todos os rincões do Vale com ocupação humana. Os traços desta ocupação, claramente dependente das águas do Ribeira e seus afluentes, delimita o interesse de iguapenses e xiririquenses por determinados tipos de propriedades rurais, como veremos no próximo capítulo. 


\section{A POSSE DOS BENS DE RAIZ}

Os estudos de propriedades rurais e urbanas através dos inventários realizam-se de forma bastante deficiente. Tal dificuldade se dá não pela natureza da fonte, mas pela precariedade com que os proprietários de terras e o corpo burocrático que produzia os documentos oficiais, atuais fontes primárias de pesquisa, tratavam os problemas dos limites e medidas de tais posses. Como relata Sheila Faria, os inventários setecentistas da região carioca de Campos já apresentavam estes traços, pois “Enquanto o tamanho da testada (frente) de um terreno era sempre fixado, os lados e os fundos recebiam na quase totalidade das descrições, indicações muito genéricas e pouco definidas” (FARIA, 1998, p. 364). ${ }^{80}$ No caso específico do Vale do Ribeira, a importância da testada vincula-se ao fato desta confrontar-se com algum corpo d’água, fonte natural da fertilidade do solo para a manutenção do cultivo do arroz e local de atraque das canoas para o transporte de pessoas e mercadorias, assim bem como o aproveitamento das margens para a construção das moradias rurais. Ao longo dos 80 anos investigados não verificamos nenhuma tendência de mudança na descrição das propriedades rurais, o que pode ser tomado como um sinal de que tal fator não representava elemento limitador na expansão das atividades agrárias na região, pois a precisa delimitação da propriedade constituir-se-ia em um forte instrumento de proteção da mesma.

Uma investigação mais aprofundada sobre a importância das propriedades rurais sem a informação do tamanho destas não pode ser fecunda. Não obstante, boa parte das análises aqui desenvolvidas toma o valor monetário como variável substituta da área, sob todos os riscos que tal procedimento possa acarretar. A pouca importância expressa às medidas dos lotes ao longo do século XIX se constitui no motivo subjacente a tal procedimento, associado ao fato já mencionado de que terras não representaram, pelo menos no Vale do Ribeira ao longo do Oitocentos, um fator limitante ao desenvolvimento das práticas agrícolas. ${ }^{81}$ Além disso, consideramos que a propriedade rural possui valor pelo que ela produz, abdicando

\footnotetext{
${ }^{80}$ Muito antes, Zélia Cardoso de Mello também verificou a ausência de medidas nos inventários paulistanos selecionados para a segunda metade do século XIX (cf. MELLO, 1990, p. 72), bem como Warren Dean em sua investigação sobre Rio Claro entre 1820 e 1920 (cf. DEAN, 1977, p. 19-37). Em estudos mais recentes este problema se mantém como obstáculo para a compreensão da dinâmica na ocupação e valorização das terras agrícolas, como mostram as pesquisas conduzidas por Déborah Reis para a localidade mineira de Araxá ao longo de todo o século XIX (cf. REIS, 2005, principalmente capítulo 3) e Juliana Garavazo para a localidade paulista de Batatais na segunda metade do Oitocentos (cf. GARAVAZO, 2006, capítulo 2).

${ }^{81} \mathrm{Tal}$ assertiva vale mesmo considerando os limites geográficos peculiares à região e os sinais inequívocos de estagnação expressos a partir de meados da década de 1850. Obviamente não operam no Vale do Ribeira, na segunda metade do século XIX, os mesmos fatores conhecidos nas regiões cafeeiras de valorização das terras e expansão da fronteira agrícola, na medida em que o arroz perdia o atrativo econômico, como já foi demonstrado anteriormente.
} 
totalmente de qualquer idéia de acumulação como reserva de valor ou de perspectiva futura de ganhos marginais. A estratégia utilizada centra-se nas variações dos valores médios e medianos das propriedades rurais descritas nos inventários e relacionadas nos registros de pagamento de sisa sobre transações de bens de raiz. A comparação propicia não apenas avaliar a consistência dos valores atribuídos nas avaliações como também o sentido quantitativo das oscilações.

Ao longo deste capítulo, o leitor perceberá que o uso da terra no Vale do Ribeira não permite classificá-lo dentro do conceito clássico de plantation, muito menos afirmar que se tratava de uma agricultura camponesa no sentido proposto por Ciro Flamarion Cardoso. As peculiaridades da empresa rizicultora, a saber, a mercantilização independente do uso de força de trabalho cativa, o estrito aproveitamento das áreas ribeirinhas, a relação ambígua entre proprietários de engenhos de arroz e comerciantes e o próprio evolver da economia ribeirense conformam um ambiente onde as práticas agrícolas se imiscuem, porém de forma a reproduzir a mesma estrutura fundiária. Pasquale Petrone, já na década de 1960, reafirmava esta condição: "Mesmo em propriedades de extensão relativamente grande dominam as explorações de pequenas dimensões” (PETRONE, 1961, p. 51). Devido à permanência dos sistemas de cultura na região, as observações empreendidas pelo autor são extremamente úteis para ilustrar a ocupação das terras no Vale do Ribeira.

Inicialmente Petrone propõe três grandes sistemas: a agricultura itinerante, a agricultura intensiva de caráter primitivo e a agricultura comercial. O primeiro sistema é subdividido em três formas: a roça dos “capuaras”, a roça dos praianos e o sistema de rotação nas áreas de colonização, sendo que os dois primeiros guardam relação com a ancestral ocupação humana na região. Para Petrone, a roça dos “capuaras”, praticada nos interstícios das áreas não fluviais, caracteriza-se pelo pouco tempo de uso da terra, geralmente 2 a 3 anos, uso do fogo para abertura das clareiras, áreas cultivadas pequenas e associação desordenada de culturas, predominando o milho, arroz, cana e banana. Destaca ainda o autor:

(...) a compreensão da presença do "capuara" não pode ser dissociada da compreensão do fenômeno do "posseiro" que, como em muitas outras áreas do país, teve na Baixada, e em grande parte ainda tem, um papel relevante. Na esmagadora maioria dos casos o "capuara" é um "posseiro", ou é um morador que vive em terras pra onde foram, como "posseiros", ascendentes seus (...) Pelo menos, são comuns aqueles que vivem em terras onde se instalaram seus antepassados, sem que, entretanto, possam apresentar qualquer título. Como é natural, o "posseiro" foi e em parte ainda é uma ponta de lança do povoamento, é um devassador de zonas não ocupadas e sob esse aspecto é quem, sem o saber, contribui para criar as primeiras condições de organização econômica do território onde se instala. Vivendo em zonas apartadas, é natural que tenha organizado sua economia na base de uma agricultura de subsistência ou de manutenção (PETRONE, 1961, p. 54-55). 
A segunda forma de agricultura itinerante são as roças dos praianos, distinta dos “capuaras” tanto pelas condições naturais - solos arenosos e mais pobres, coberturas vegetais distintas - como pelos cultivos praticados, com predomínio da mandioca, complementada pela pesca. Além disso, acrescenta Petrone que

Enquanto o "capuara" praticamente não tem preocupação especial na escolha da área a cultivar, bastando que haja revestimento florestal e que a topografia seja relativamente favorável, ou que haja capoeira desenvolvida, o praiano enfrenta problemas graves para a localização de suas modestas "roças" (PETRONE, 1961, p. 56-57),

preferindo as restingas para as lavouras de mandioca e os banhados para o cultivo do arroz. $^{82}$

O terceiro tipo que ainda guarda relação com as práticas agrícolas do século XIX é o que Petrone denomina agricultura intensiva de caráter primitivo, ainda praticado na segunda metade do século XX ao longo do rio Ribeira à jusante da barra do rio Jacupiranga e com predomínio do cultivo do arroz, de caráter comercial e sedentário, associado com pequenas roças de subsistência:

A lavoura do arroz está ligada ao rio, pois localiza-se nas áreas de vargedos inundáveis. Aproveita, justamente, das possibilidades que oferecem solos freqüentemente submetidos a cheias. Trata-se de lavoura primitiva, embora deva ser considerada intensiva pelo seu caráter sedentário associado à atenção, que requer, de uma numerosa mão-de-obra. $O$ fato do cultivo ser feito diretamente no terreno, sem replante, o renovar-se anualmente a plantação precedendo-a com a queimada, sem preocupação com manter limpo o campo de cultivo; a pequena atenção que se dá à própria "limpa" do arrozal, permitindo-se que as ervas daninhas se desenvolvam a vontade; a ausência de técnicas no sentido de aproveitar racionalmente as águas da cheias, assim como a colheita, feita, normalmente a canivete, são todos elementos que caracterizam o primitivismo da cultura, e contribuem para distinguí-la dos arrozais das áreas de lavoura intensiva do tipo chinês, por exemplo (PETRONE, 1961, p. 59) ${ }^{83}$

Sem mencionar o breve de artigo de Pasquale Petrone, Plácido Cali propõe um padrão de assentamento bastante assemelhado, utilizando-se dos resultados por ele obtidos nas investigações arqueológicas na região de Juréia-Itatins: o caiçara, o ribeirinho capuara e o fazendeiro (cf. CALI, 1999, p. 129-142). O primeiro deles é assim caracterizado:

Construíam casas de pau-a-pique e faziam roça de subsistência, onde predominava o cultivo da mandioca. Cultivavam também arroz, feijão, milho e outros produtos. No sítio Saltinho havia uma área de pasto para criação de modesto gado. A pesca era fundamental e os peixes abundantes tanto na praia quanto nos rios que deságuam na costa, como o Una do Prelado, o rio Verde, o Grajaúna e outros. A caça era complementar a sua dieta e em quantidade, até algumas décadas atrás. É provável que algum excedente de sua produção fosse comercializado para a aquisição de remédios, vestuário, sal, etc (CALI, 1999, p. 129).

\footnotetext{
${ }^{82}$ A terceira forma, a pequena propriedade policultora, praticada por imigrantes europeus e seus descendentes, não será melhor descrita por se tratar de um sistema ainda ausente no século XIX.

${ }^{83}$ As demais formas, classificadas pelo autor como "agricultura comercial”, envolvem o cultivo do chá, banana e outras frutas, práticas instaladas no século XX.
} 
No segundo tipo, no interior da serra da Juréia, se

(...) as condições de solo não eram tão adequadas ao cultivo da mandioca quanto na costa e a pesca menos farta, compensava-se com o cultivo do arroz nas várzeas dos ribeirinhos e a maior quantidade de caça e coleta de vegetais, como o palmito (CALI, 1999, p. 130)

O terceiro padrão, denominado pelo autor como fazendeiro, compunha-se por unidades voltadas à produção de arroz para exportação, assentada no uso de força de trabalho cativa.

Vários fatores condicionavam a escolha do local para a instalação de uma fazenda. Além do tamanho das terras disponível, deveria estar localizada próxima a um rio navegável para o escoamento da produção e ter fontes d'água potável. Aliás, água em abundância era fundamental, principalmente para mover os engenhos (...) Normalmente utilizavam construções com vários cômodos, podendo ou não abrigar sob o mesmo teto dependências de depósito e beneficiamento. Não há nenhum estudo específico sobre tal distribuição espacial na região, nem mesmo sobre as senzalas que abrigavam os escravos (...) Muitas fazendas de arroz, possuindo engenhos em sua propriedade, evitavam o serviço dos engenhos do Mar Pequeno (...) Mas a construção de um engenho representava um investimento que nem todos podiam arcar (CALI, 1999, p. 140-141).

Estas descrições provavelmente dão conta da maioria das formas de cultivo existentes ao longo do século XIX no Vale do Ribeira acrescendo-se que, em propriedades com quantidade significativa de cativos, as roças de subsistência deveriam ocupar maior espaço. Como se perceberá ao longo deste capítulo, a presença de escravos em propriedades rurais não guardava relação com nenhuma forma de cultura diferenciada, mas apenas em maior volume de cultivo, como já foi referido no primeiro capítulo deste trabalho.

A apresentação dos resultados obtidos segue em três partes: a primeira fundamentase em documentos mantidos no Arquivo do Estado de São Paulo, tanto nas caixas que armazenam os ofícios diversos produzidos pela Câmara de Iguape como no conjunto denominado "Tombamento de 1818”, que inclui o cadastro ou inventário de bens rústicos, realizado na Capitania paulista. A segunda parte descreve os bens rurais registrados nos inventários de Iguape e Xiririca segundo os recortes temporais propostos no capítulo anterior e também por algumas variáveis que permitiram a agregação destas propriedades, estrutura que se repete na última parte, dedicada aos bens de raiz urbanos. Nas duas últimas, confrontamos os resultados com o fluxo de bens transacionados, extraídos dos livros que registraram o pagamento da sisa sobre bens de raiz, também do acervo do Arquivo do Estado de São Paulo.

\section{Um retrato da expansão: o cadastro de bens rústicos de 1818}

O cadastro de bens rústicos de 1818, segundo Alice Canabrava, foi produzido em observação ao Aviso Régio de 21 de outubro de 1817. Para a autora, as informações deveriam 
subsidiar a política de desenvolvimento agrícola do governo regencial de D. João, que visava a

(...) introduzir na Colônia novas plantas cultivadas de valor comercial; a outorga de sesmarias a estrangeiros; a colonização oficial por meio do imigrante estrangeiro e da tentativa de implantar a pequena propriedade; o fomento a determinadas áreas do território para estimular o povoamento e colmatar os vazios da ocupação pelo colono; o estabelecimento de centros de melhoria das raças cavalares; o esforço para sedentarizar tribos indígenas implicadas na ruptura de linhas vitais de comunicação e povoamento (CANABRAVA, 1972, p. 79-80).

O documento arrola o nome do proprietário, as dimensões da posse, a forma de obtenção, uma observação genérica sobre o uso das terras e a quantidade de escravos utilizada. No caso do Vale do Ribeira, a relação aparentemente seguiu os cursos dos rios no sentido da foz em direção à cabeceira, permitindo vislumbrar ainda uma dimensão espacial dos limites da fronteira agrícola na região.

O recenseamento é composto 707 propriedades rurais, porém em muitos casos um único proprietário possuía mais de uma posse. Excetuando os prováveis casos de homonímia, verificamos a presença de 628 pessoas: 573 pertencentes à classe unitária de posse, outros 43 com 2 propriedades, 8 com 3 registros, 1 com 4 unidades, 1 com 5 e apenas dois casos extremos, um com 7 e outro com 8 propriedades. ${ }^{84}$ Dos 707 casos iniciais, apenas seis não forneciam a medida de testada do terreno, porém em 95 registros não há informação sobre a profundidade, o que permitiu o cálculo da área em 612 posses ou pouco mais de $86 \% .{ }^{85}$ No cômputo geral, verificamos um relativo equilíbrio entre propriedades obtidas por compra (29\%), herança (29\%) e posse (34\%), mas a distribuição espacial revela diferenças importantes. O documento consultado apresenta 34 diferentes regiões de Iguape, porém o detalhamento não se mostrou tão minucioso na freguesia de Xiririca, com apenas três regiões,

\footnotetext{
${ }^{84}$ Alice Canabrava, que não refere qual o procedimento utilizado, anotou 81 casos de proprietários em Iguape e Xiririca com mais de uma posse contra os 55 aqui considerados, refletindo a postura mais conservadora aqui adotada acerca dos homônimos. Nossos resultados provêm do confronto entre os proprietários constantes nos inventários e os moradores arrolados na lista nominativa de 1815. Estes valores provavelmente são os principais responsáveis pela diferença entre o número total de proprietários apresentado pela autora, 420 proprietários em Iguape e 84 em Xiririca, contra 532 e 80 adotados neste trabalho (cf. CANABRAVA, 1972, p. 105 e 122-123). ${ }^{85}$ Aliás, da freguesia provinha a maior parcela de propriedades com medidas incompletas: dos 161 registros, a área total pôde ser calculada em 80 casos. A falta de informações sobre o tamanho das propriedades rurais em Xiririca também ocorre nos inventários, como será visto nas seções seguintes. A ausência de medidas das propriedades rurais na Capitania paulista já chamava a atenção de Maria Thereza Petrone ao analisar as fazendas canavieiras do Oeste paulista (cf. PETRONE, 1968, p. 59-78). Revisitando os engenhos do Oeste paulista, Carlos Bacellar observa que mesmo o cadastro de propriedades de 1818 deve ser considerado com reservas em função das imprecisões de mensuração (cf. BACELLAR, 1997, p. 153). Ainda especificamente sobre o registro de 1818, assinala Alice Canabrava que das 9.435 propriedades rurais arroladas nas 40 localidades paulistas, 8.576 possibilitaram o cálculo da área total, representando 91\% do total, porcentagem maior do que a observada para o Vale do Ribeira (cf. CANABRAVA, 1972, p. 81). Segundo a autora, o litoral sul, que incluía Iguape, Xiririca e Cananéia, possuía 555 proprietários e 668 propriedades; os proprietários representavam 6,5\% e a área total, 4,6\% da Capitania, incluso apenas aqueles com área definida (cf. CANABRAVA, 1972, p. 82).
} 
sendo uma delas anotada simplesmente “Xiririca”. Seguindo as características geográficas e hidrológicas de região, assim como as limitações da documentação, optou-se pela conformação de nove grandes áreas, sendo oito relativas ao território iguapense e apenas uma associada à freguesia de Xiririca, conforme mostram a Figura 2.1 e a Tabela 2.1, que também agrega informações sobre forma de obtenção das propriedades rurais.

A distribuição por regiões evidencia áreas onde predominavam propriedades obtidas por compra ou herança, como a Juréia e a faixa litorânea de Iguape, o que indica a condição de antigüidade da ocupação daqueles territórios, como também pode ser inferido pela quantidade de propriedades presentes nos dois locais. Outras, como a região do Ribeira, mesclavam de modo assemelhado propriedades obtidas por compra, herança e posse, além de possuir a maior quantidade de sesmarias, ao lado da região do rio de Una. Nesta, assim como nas áreas em torno dos rios Jacupiranga, Peroupava e Juquiá, predominava o acesso através da posse, indicando claramente o sentido da expansão agrícola, resultado da disseminação da cultura do arroz. De certa forma, o mesmo resultado se insinua em Xiririca, porém de forma oculta uma vez que o nível de detalhamento espacial não permite diferenciar as áreas de ocupação mais antigas, possivelmente responsáveis pelos 105 casos de propriedades obtidas por compra e herança. 
Tabela 2.1

Regiões do Vale do Ribeira segundo denominação original e forma de obtenção das propriedades

(Iguape e Xiririca, 1818)

\begin{tabular}{|c|c|c|c|c|c|c|c|}
\hline Região & denominação original & compra & herança & posse & sesmaria & outros* & propriedades \\
\hline \multirow{6}{*}{ Juréia } & Costeira do mar e praia da Juréia & 4 & 9 & 3 & - & - & 16 \\
\hline & Porto do Prelado & 1 & - & - & - & 2 & 3 \\
\hline & praia da Juréia & 1 & 12 & - & - & - & 13 \\
\hline & Suamirim & 4 & 8 & - & - & - & 12 \\
\hline & Barra da Ribeira & 6 & 11 & - & - & 1 & 18 \\
\hline & total & 16 & 40 & 3 & $\mathbf{0}$ & 3 & 62 \\
\hline \multirow{14}{*}{ Faixa litorânea } & Prainha & 5 & 5 & - & - & 1 & 11 \\
\hline & Bopiranga & 4 & 4 & - & - & - & 8 \\
\hline & Capara & 7 & 7 & - & - & 2 & 16 \\
\hline & Geiva & 1 & - & - & - & - & 1 \\
\hline & Iquatinga & - & - & - & - & 1 & 1 \\
\hline & Enseada & 2 & 10 & - & - & 4 & 16 \\
\hline & Itaguá & - & 1 & - & - & - & 1 \\
\hline & Rocio & 1 & 4 & - & - & 6 & 11 \\
\hline & Sorocaba & 4 & 2 & - & - & - & 6 \\
\hline & Costeira da terra firme & 22 & 15 & - & - & - & 37 \\
\hline & rio de Subauma & 3 & 8 & - & - & - & 11 \\
\hline & rio de Subaumussu & 2 & - & - & - & - & 2 \\
\hline & Ilha do Mar - Vila Nova & 24 & 24 & - & - & 5 & 53 \\
\hline & total & 75 & 80 & $\mathbf{0}$ & $\mathbf{0}$ & 19 & 174 \\
\hline \multirow{6}{*}{ Una } & rio de Una & 4 & 2 & 6 & 3 & 4 & 19 \\
\hline & rio de Tingussu & - & - & 5 & 1 & 1 & 7 \\
\hline & rio de Itimirim & - & - & 5 & - & - & 5 \\
\hline & rio de Setanduva & - & 1 & 9 & 2 & - & 12 \\
\hline & rio Pequeno & 2 & - & 19 & 3 & - & 24 \\
\hline & total & 6 & 3 & 44 & 9 & 5 & 67 \\
\hline \multirow{4}{*}{ Jacupiranga } & rio de Jacupiranga & - & 1 & 36 & - & - & 37 \\
\hline & rio de Pariqueramirim & - & 1 & 1 & - & - & 2 \\
\hline & rio de Pariquerassu & 1 & - & 1 & - & - & 2 \\
\hline & total & 1 & 2 & 38 & $\mathbf{0}$ & $\mathbf{0}$ & 41 \\
\hline \multirow{3}{*}{ Peroupava } & rio de Peroupava & 2 & - & 18 & 3 & 1 & 24 \\
\hline & Capivari & - & 1 & - & 1 & 1 & 3 \\
\hline & total & 2 & 1 & 18 & 4 & 2 & 27 \\
\hline \multirow{5}{*}{ Ribeira } & rio da Ribeira & 9 & 8 & - & 2 & 1 & 21 \\
\hline & outro lado da Ribeira & 3 & 5 & 8 & 2 & - & 18 \\
\hline & Ribeira acima & 21 & 18 & 52 & 7 & 2 & 100 \\
\hline & lagoa de Bragatuba & 7 & 6 & 1 & - & 1 & 15 \\
\hline & total & 40 & 37 & 61 & 11 & 4 & 154 \\
\hline \multirow{3}{*}{ Juquiá } & rio de Juquiá & - & - & 15 & - & - & 15 \\
\hline & São Lourenço & 4 & - & 2 & - & - & 6 \\
\hline & total & 4 & $\mathbf{0}$ & 17 & $\mathbf{0}$ & $\mathbf{0}$ & 21 \\
\hline \multirow{4}{*}{ Xiririca } & Xiririca & 57 & 42 & 47 & - & - & 146 \\
\hline & Xiririca - rio de Taquari & 2 & - & 6 & - & - & 8 \\
\hline & Xiririca - rio de Xiririca & 4 & - & 3 & - & - & 7 \\
\hline & total & 63 & 42 & 56 & $\mathbf{0}$ & $\mathbf{0}$ & 161 \\
\hline & total geral & 207 & 205 & 238 & 24 & 33 & 707 \\
\hline
\end{tabular}


Figura 2.1

As regiões agrícolas do Vale do Ribeira no século XIX

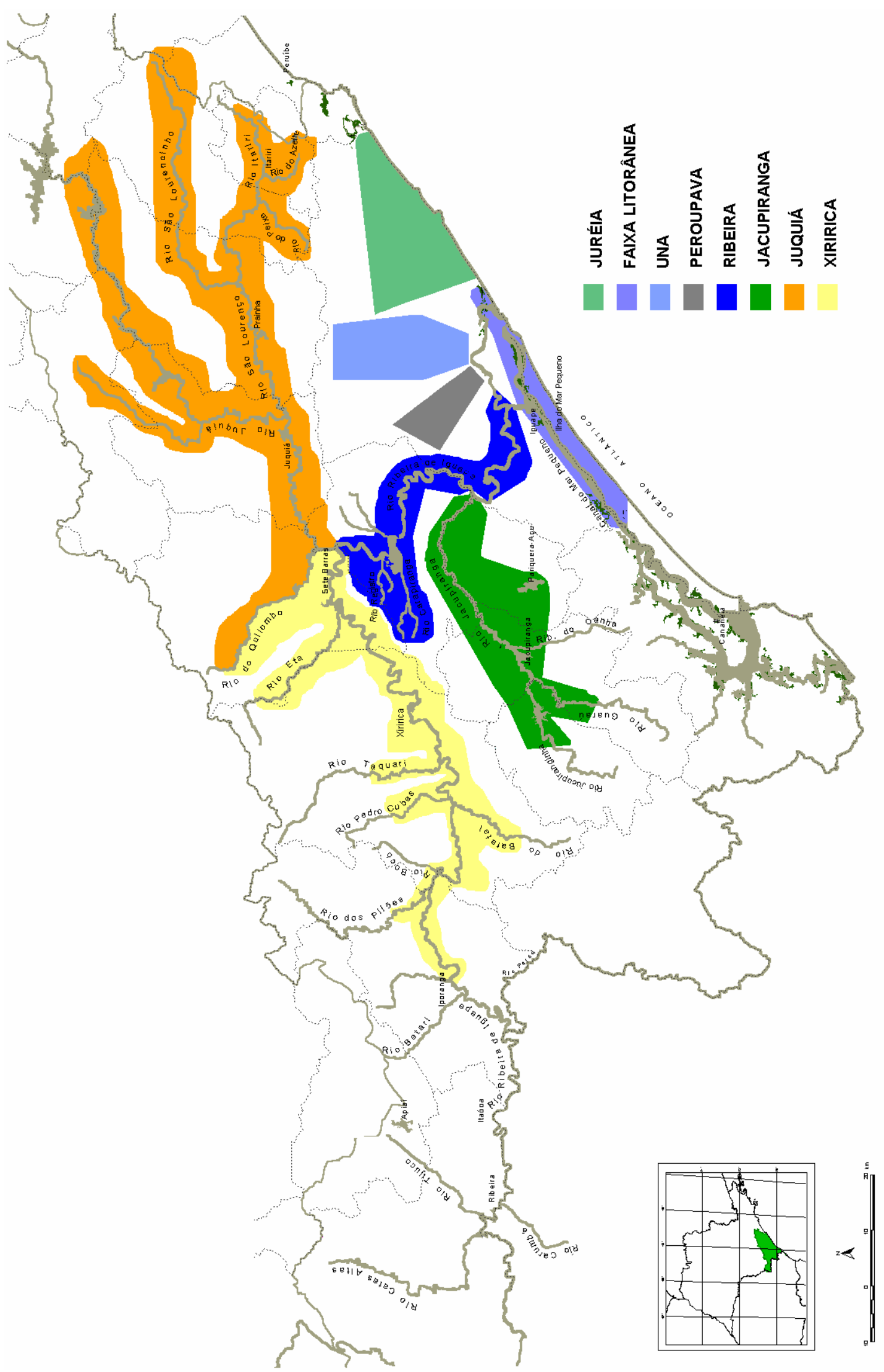


A repartição segundo o sexo dos proprietários indica o predomínio masculino, com 88\% dos casos. É interessante notar que, entre as mulheres, mais de quatro décimos (43\%) detinham a posse por herança e um terço (33\%) obteve as terras por compras, realizadas por elas mesmas ou pelo cônjuge. A posse agregava a maior parcela masculina (36\%), seguida por compras e herança (29\% e 27\%). Outra forma de perceber estas diferenças relaciona-se com a distribuição por sexo segundo regiões: na Juréia e Faixa litorânea, mulheres possuíam uma em cada cinco propriedades, ao passo que nas demais áreas essa participação atingia valores entre 5 e 12\%, chegando ao extremo de nenhuma mulher detentora de propriedades rurais no rio de Peroupava.

A área média (173 alqueires) e mediana (12 alqueires) revelam grande disparidade de propriedades no Vale do Ribeira em fins da década de 1820. Ressaltamos inicialmente a diferença significativa entre Xiririca e Iguape, que possuíam valores medianos iguais a 1,5 e 16,5 alqueires, respectivamente. A elevada freqüência de casos com medidas incompletas na freguesia pode ser a responsável pela diferença apontada, porém o estreitamento natural das áreas às margens do Ribeira na região de Xiririca possivelmente seja o principal fator dos baixos valores lá observados. ${ }^{86}$

No território iguapense, as propriedades no rio Juquiá apresentavam a maior média (11.681 alqueires), porém com mediana igual a 2 alqueires. A disparidade deve-se às terras de um certo João José Ribeiro, localizadas no rio São Lourencinho, que adquiriu da Real Fazenda uma área de 198.198 alqueires, contando com a presença de apenas cinco escravos. Este proprietário não foi localizado entre os habitantes da região em nenhuma das listas nominativas consultadas. Sabemos que, em 1786, João de Carvalho Gago, José de Carvalho Gago e Jeremias dos Santos obtiveram uma carta de sesmaria na região do rio São Lourencinho, com 3 léguas em quadra para cada um, o que representava 235.224 alqueires. ${ }^{87}$ Em 1811, José Placidino de Oliveira obteve outra carta dando posse a 2 léguas de testada e 3 de profundidade no rio São Lourenço e, no mesmo ano, José Joaquim Rodrigues e João Joaquim Rodrigues obtiveram, no rio Itariri, uma gleba de 6 léguas de testada por 3 de

\footnotetext{
${ }^{86}$ Nesse sentido, a recorrente referência ao "sertão" como limitador da extensão das propriedades inclui as escarpas das serras localizadas nas margens dos rios, absolutamente inúteis para o cultivo do arroz, porém fonte natural de energia potencial para a movimentação dos engenhos e interessantes para utilização como áreas de pastagem, como sugere a maior freqüência de animais entre os inventários da localidade: dos 532 inventários iguapenses, 170 possuíam algum valor em animais contra 83 dos 146 casos de Xiririca, além daquela possuir valor médio de semoventes menor do que esta, Rs. $134 \$ 768$ versus Rs. $190 \$ 103$.

${ }^{87}$ Os dados sobre as sesmarias foram gentilmente cedidos pelo Prof. Dr. Nelson Hideiki Nozoe, a quem agradeço.
} 
profundidade. Provavelmente a propriedade de João José Ribeiro deve se relacionar a uma das três cartas, porém não localizamos algum documento que comprovasse tal associação.

Os rios Ribeira e Una abrangiam áreas totais semelhantes (21.147 e 20.239 alqueires), porém com médias e medianas bem distintas. Os 150 registros da primeira possuíam, em média, 141 alqueires ao passo que na segunda as 66 propriedades tinham área média igual a 307 alqueires, além de medianas bem distintas: 20 e 54 alqueires, respectivamente. A mescla de tipos de acesso à propriedade na região do rio Ribeira, como foi visto na Tabela 2.1, deve compor a raiz das diferenças entre as duas regiões. Vale dizer, as propriedades mais próximas do litoral provavelmente constituíam um conjunto de terras exploradas há mais tempo e por isso sujeitas a partições e reduções da área, enquanto a ocupação daquelas mais distantes resultou da expansão da cultura do arroz, predominando a posse como forma de acesso, justificando a maior área.

Aparentemente esta expansão em direção ao interior explica os resultados observados no rio de Una e seus afluentes e, em menor grau, na região do rio Jacupiranga. O rio de Peroupava também parece se enquadrar neste modelo, porém como caso distinto: os 27 casos produziram uma média igual 448 alqueires, a segunda maior de Iguape, porém o valor mediano, 4 alqueires, só superava o observado no rio Juquiá. ${ }^{88}$ Possuíam terras no Peroupava proprietários de engenho como Bartolomeu da Costa Almeida Cruz, João Manoel Junqueira, José Antonio Peniche e Raimundo Pinto de Almeida, intercalados com pequenos proprietários, praticamente todos não-escravistas. Segundo a Figura 2.1, trata-se de uma pequena área e, portanto, com menor chance de apresentar a mesma variedade de proprietários que as demais regiões. Por fim, nas terras mais próximas do litoral predominavam as pequenas propriedades: na Juréia, a área média não passava de 77 alqueires, com mediana igual a 25 alqueires e na Faixa litorânea os valores atingiam, respectivamente, 32 e 9,5 alqueires.

Em comparação com os dados da Capitania, os resultados mostram uma forte influência da propriedade de João José Ribeiro, conforme mostra a Tabela 2.2. As duas colunas do Vale do Ribeira apresentam a distribuição com e sem a presença desta posse.

\footnotetext{
${ }^{88}$ Ressalte-se que os rios de Una, Peroupava e Ribeira concentravam 30 das 33 propriedades obtidas por sesmaria.
} 
Tabela 2.2

Distribuição relativa dos proprietários, da área possuída e valor da área média (em alqueires) segundo faixas de posse

(Capitania de São Paulo e Vale do Ribeira, 1818)

\begin{tabular}{|c|c|c|c|c|c|c|c|c|c|c|}
\hline \multirow{2}{*}{$\begin{array}{c}\text { Faixas de } \\
\text { posse } \\
\text { (alqueires) }\end{array}$} & \multicolumn{3}{|c|}{ Capitania $^{a}$} & \multicolumn{3}{|c|}{ Vale do Ribeira } & \multicolumn{4}{|c|}{ Vale do Ribeira $^{b}$} \\
\hline & $\begin{array}{c}\text { proprietários } \\
\%\end{array}$ & $\begin{array}{c}\text { área } \\
\%\end{array}$ & área média & $\begin{array}{c}\text { proprietários } \\
\%\end{array}$ & $\begin{array}{c}\text { área } \\
\%\end{array}$ & área média & $\begin{array}{c}\text { proprietários } \\
\%\end{array}$ & área & $\%$ & $\begin{array}{l}\text { área } \\
\text { média }\end{array}$ \\
\hline até 30 & 57,3 & 3,1 & 10,2 & 60,6 & 0,7 & 6,3 & 60,8 & 2,7 & & 6,3 \\
\hline 31 a 70 & 14,9 & 3,8 & 48,2 & 15,7 & 1,4 & 50,1 & 15,7 & 5,5 & & 50,1 \\
\hline 71 a 310 & 19,0 & 14,7 & 143,1 & 15,1 & 3,9 & 143,2 & 15,1 & 15,1 & & 143,2 \\
\hline 311 a 630 & 4,7 & 10,7 & 427,2 & 4,3 & 3,1 & 395,3 & 4,3 & 11,8 & & 395,3 \\
\hline acima de 630 & 4,1 & 67,7 & $3.052,9$ & 4,3 & 90,9 & $11.604,8$ & 4,1 & 64,9 & & $2.275,1$ \\
\hline total & 100,0 & 100,0 & 185,8 & 100,0 & 100,0 & 546,6 & 100,0 & 100,0 & & 143,2 \\
\hline
\end{tabular}

(a) CANABRAVA, 1972, p. 112-123

(b) exceto João José Ribeiro.

Tomando a última coluna do Vale do Ribeira, ainda que notemos pequenas diferenças na menor e maior faixa de posse na comparação com os dados da Capitania, não é possível distinguir dessemelhanças profundas, como bem retrata o índice de Gini: 0,86 tanto no Vale do Ribeira como na Capitania. Se considerada a propriedade de João José Ribeiro, o indicador de concentração atinge 0,96, valor muito superior a qualquer uma das regiões estudadas por Alice Canabrava. Verificamos maior impacto na distribuição da superfície, como mostra a primeira coluna do Vale do Ribeira: 91\% das áreas com medidas definidas pertenceriam à maior faixa de posse, restando $9 \%$ a todas as demais propriedades. ${ }^{89}$

Independente da presença de Ribeiro, a distribuição de terras no Vale mostra-se mais concentrada do a que a de cativos: 0,504, se considerado apenas os escravistas ou 0,816, inclusos todos os não-proprietários. ${ }^{90}$ Os distintos valores nos dois casos merecem destaque: contra os 707 proprietários de terras, o número total de fogos na lista nominativa de 1815 atingia 1.051 casos, resultando em um terço de chefes de domicílio que não constavam no arrolamento dos bens rústicos. Ademais, faziam parte como escravistas naquele ano 314 pessoas versus 210 proprietários de terras que também detinham cativos. Essas diferenças, além de refletirem o menor dispêndio necessário para a obtenção de terras se comparado com a compra de escravos, indicam que o acesso à terra na fase expansionista ocorria de maneira diferencial, favorecendo uma pequena parcela dos ribeirenses. ${ }^{91}$

\footnotetext{
89 A área de Juquiá merecerá maior detalhamento, mas adiante-se que esta só ganhará alguma importância agrícola a partir da década de 1840 .

${ }^{90}$ Valores referentes a 1815.

91 Tais resultados também foram observados em Bananal, onde “(...) verificamos a existência de uma estreita correlação entre a posse daqueles dois ativos [terras e escravos - AV]. Assim, quase dois terços (65\%) dos proprietários de terra produtores eventuais de café eram também senhores de escravos; para os cafeicultores de 1829, essa proporção atingia os quatro quintos (78,1\%)" (NOZOE \& MOTTA, 1999, p. 70). Para um quadro geral da associação entre terras e escravos, ver CANABRAVA, 2005, p. 203-225.
} 
Entre 1780 e 1821 foram concedidos 33 títulos de sesmaria dos quais 17 forneciam a área, totalizando 559.741 alqueires. Além das sesmarias na região do Juquiá, entre os outorgados localizamos vários grandes proprietários em 1818: Bento Pupo de Gouveia obteve uma carta com 0,5 légua de testada em 1783, Bartolomeu da Costa Almeida Cruz possuía carta de 0,5 légua em quadra obtida em 1803, mesma área obteve João Manoel Junqueira em 1804, Antonio Borges Diniz e José Antonio Peniche obtiveram em 1805, cada um, lotes de 0,5 légua de testada por 1 légua de profundidade. Ainda que bem menores do que as concedidas no Juquiá, a obtenção destas sesmarias contribuiu para a composição de grandes propriedades numa mescla que incorporava a compra, a posse e a doação ou herança de terras como formas de acesso.

A presença de escravos atingia 235 propriedades ou 33\% do total. Destas, 31\% estavam em Xiririca e correspondiam a $46 \%$ das posses; em Iguape as regiões da Ribeira, rio de Una e Faixa litorânea congregavam 56\% das propriedades com cativos, representando apenas em Una a maioria dos casos, com 54\% (na Ribeira as posses escravistas valiam 37\% e na Faixa litorânea, 22\%). Em relação à quantidade de escravos, Xiririca concentrava 22\% e, das regiões iguapenses, a Ribeira possuía 36\%, seguida pelo Rio de Una com 19\%. A Ribeira ainda detinha o segundo maior número médio de cativos por propriedade entre os escravistas, 7,5, perdendo apenas para os dez casos registrados no rio de Peroupava (7,7 cativos por propriedade); a média nas posses com escravos no rio de Una atingia 6,4 escravos e em Xiririca, $3,7 .^{92}$

Talvez uma forma mais adequada de se perceber a importância da distribuição espacial da força de trabalho cativa seja através do número médio de escravos no total das propriedades em cada região. Assim, áreas de fronteira ou em processo de ocupação, como Jacupiranga e Juquiá apresentavam o menor valor médio (0,4 escravos por propriedade), bem distinto do observado no rio de Una $(3,4)$ e Peroupava $(2,8)$, onde também predominava a posse como principal forma de acesso. A Ribeira, que mesclava antigas propriedades com novas áreas agrícolas, possuía um valor médio semelhante ao de Peroupava (2,7), enquanto as regiões de ocupação mais antiga detinham médias bem menores: Faixa litorânea $(0,6)$ e Juréia $(0,9)$.

Em relação às três modalidades mais freqüentes de acesso à propriedade, não verificamos diferença significativa no valor médio dos escravos, porém as obtidas por compra reuniam $34 \%$ da massa cativa contra $25 \%$ nas obtidas por herança e nas incorporadas por

\footnotetext{
${ }^{92}$ A média geral igualou-se a 5,1 escravos por propriedade.
} 
posse. ${ }^{93}$ Não há uma correlação clara entre área possuída e número de escravos: por exemplo, Bartolomeu da Costa Almeida Cruz possuía 8 posses que somavam 1.184 alqueires e 49 escravos; João Manoel Junqueira possuía 3 propriedades com 4.406 alqueires e 35 escravos; José Antonio Peniche detinha 7 posses com 7.035 alqueires e 60 escravos e Antonio Borges Diniz, com 5 posses e 1.276 alqueires, 40 escravos, todos em Iguape. Note-se que todos também constam entre os agraciados com cartas de sesmaria. No agregado, e especialmente entre os pequenos proprietários, o sentido aparece mais visível: dos 98 escravistas com até 4 cativos, 63 possuíam terras com até 30 alqueires e apenas em 6 casos a área ultrapassava 310 alqueires; $;^{94}$ entre aqueles com 10 ou mais escravos, apenas 6 dos 28 proprietários possuíam terras na primeira faixa de posse, enquanto 15 detinham áreas que ultrapassavam 310 alqueires.

Em síntese, o cadastro de bens rústicos retrata um estágio de plena expansão da rizicultura no Vale do Ribeira, com frentes que acompanhavam o leito dos rios, ocupando as baixadas inundáveis, com ou sem mão-de-obra escrava em convívio com áreas mais próximas ao litoral, com povoamento remoto e provavelmente com menor inserção da dinâmica emprestada pela gramínea na região. As áreas privilegiadas com presença de cativos correspondiam àquelas justamente mais próximas do núcleo urbano e também do porto através do qual o arroz seguia para o Rio de Janeiro e que também concentravam a maior quantidade de sesmarias. Outras áreas de fronteira, especialmente a dos rios Jacupiranga e Juquiá, mais distantes do litoral, possuíam colonizadores com perfil distinto, a maior parte desprovida de escravos. Neste caso vale ressaltar que a primeira ainda manteria a vocação econômica das outras áreas fluviais; já a segunda se distinguirá pela maior diversidade agrícola.

Parece correto atribuir parte desse efeito expansivo previamente à implantação da cultura do arroz, quando os novos escravistas instalados na região litorânea procuravam os melhores locais para a extração de madeiras com vistas à construção de embarcações. Desde o século XVIII o Vale do Ribeira era visto pelas autoridades portuguesas como um fornecedor estratégico de madeiras para a confecção de embarcações. E também desde então a extração das madeiras provocava atritos entre os artesãos e ocupantes das terras, como mostra a

\footnotetext{
93 Considerando-se exclusivamente a posse escrava, os iguapenses representavam 65\% dos proprietários e possuíam 78\% dos escravos, com média igual a 6,9 escravos por proprietário; em Xiririca a média manteve-se em 3,6 escravos por proprietário.

${ }^{94}$ Distribuição assemelhada aos não-escravistas: 65\% detinham áreas até 30 alqueires e apenas 3\% possuíam terras com mais de 310 alqueires.
} 
correspondência enviada pelo governo da Capitania, em 1800, endereçada ao Capitão-mor José Antonio Peniche:

Sendo presente a S. Exa. que os feitores e donos das embarcações que se estão construindo no distrito dessa vila, abusando da faculdade que se Ihes concedeu para o corte das madeiras e a pretexto de as pagarem pela sua justa avaliação têm cometido algumas desordens e violências, quais são: entrar pelos sítios e propriedades dos particulares, devassando-lhes, cortando e conduzindo delas os paus reais e de lei que mais the agradam, cujos paus na conformidade das ordens de S.A.R. e condição expressa das sesmarias eles têm até aqui guardado e conservado como são obrigados, sendo este absoluto procedimento manifestamente fundado na conveniência de lhes ficarem as ditas madeiras mais próximas à beira-mar e ser-lhes menos dispendiosas a condução delas para junto dos seus estaleiros: portanto é o mesmo Snr. servido ordenar a Vmce. que logo que esta lhe for apresentada mande notificar aos referidos construtores para que imediatamente se abstenham destes e semelhantes procedimentos, aliás advertindo-os mais que na forma até aqui praticada, devem cortar a madeira que lhes for necessária nos matos incultos que são do patrimônio de S.A.R. excetuando porém o rio Juquiá, Jacupiranga e Pariquerassu e que desde agora há o mesmo Snr. por defensor e vedados a todas as pessoas, proibindo da maneira mais positiva o entrar nele ninguém na diligência de semelhantes cortes, o que encarrega a Vmce. de fiscalizar e vigiar com a maior atenção e cautela. E para que a construção das embarcações do comércio se não desanime por este princípio, antes prospere, Vmce. facilitará aos mestres e diretores delas aqueles lugares que the parecerem mais adequados e convenientes para os seus cortes, declarando-lhe a qualidade de madeira que devem cortar e prendendo logo a ordem do mesmo Snr. todos os que excederem o corte por constar que eles desta faculdade abusam, cortando madeiras demais para venderem-na aos particulares, no que S. Exa. espera e confia do seu zelo e honra, se haja Vmce. com toda a inteireza e justiça. ${ }^{95}$

A leitura do documento revela a anterioridade do problema de invasão de terras, neste caso capitaneada pelos carpinteiros que buscavam pelas melhores madeiras para a construção de embarcações. Não se pode depreender qual a importância dos sertões dos rios Juquiá, Jacupiranga e Pariquerassu a tal ponto que se proibisse terminantemente a exploração da madeira naquelas regiões, mas talvez existisse a intenção de mantê-las como estoque estratégico. Canela, peroba, araribá, urucuana, maçaranduba, ipeúva, uvatinga, caxeta, jacarandá e cedro constavam em uma relação das árvores existentes ao longo dos rios, enviada pelo mesmo oficial em 1824 ao governo provincial; nessa correspondência explicava Peniche que as madeiras se achavam a uma distância de dois a três dias de viagem da vila de Iguape e ainda advertia:

Não há número certo de pessoas empregadas neste serviço [extração de madeiras $\mathrm{AV}]$, que sendo atualmente os habitantes lavradores, se ocupam em tirar alguma madeira, serrar algum taboado nas estações vagas de sua lavoura, e quando provisão para o seu mister ou de algum particular que nisso os ocupa. Quanto à despesa que nela se faz não se pode calcular porquanto a qualidade das madeiras é grande ou grosseira, dela só poderia servir de regra por ser certo que as melhores e maiores provisão por ser mais longe e conseqüentemente em grandes embarcações e trabalhosa condução de balsas ou de canoas, as mais pequenas, finas tem qualidade menos desejada. ${ }^{96}$

\footnotetext{
${ }^{95}$ AESP, D.I., v. 87, p. 187.

${ }^{96}$ AESP, Ofícios diversos de Iguape, ordem n. ${ }^{0} 1.038$.
} 
Se no passado as madeiras de melhor qualidade existiram em áreas mais acessíveis, foram dizimadas tanto pela construção naval como pela abertura de áreas plantáveis. Quatro anos mais tarde, o funcionário do governo provincial paulista Paulo Freire de Andrade detectava o mesmo problema:

(...) 1. que as sesmarias ainda não confirmadas estão nulas por não se acharem nas circunstâncias que a lei determina e que tais títulos são nocivos em poder daqueles, que não têm meios para em tanto terreno trabalharem, servindo somente a quem foram concedidas para negociarem com a venda do terreno que elas compreendem deixando, no entanto, terreno que outros desejam sem agricultura; 2 . que quase ninguém tem o seu terreno marcado em frente e fundo, podendo por isso tomar o espaço que bem quiser para muitas vezes o ter inculto e o deixar em mato virgem aos seus descendentes; além desse dano, outro é de ser esta falta de demarcação origem de contínuos litígios por causa dos limites; 3 . o negócio que continuamente se está fazendo com as terras do Estado, queira V.E. observar o artigo cultivador, já vendendo a uns, aos outros já em público leilão, sem que se executem as leis e as reiteradas ordens do governo da Província a este respeito; 4. o contínuo e indecente corte de madeiras nas matas Nacionais com grande prejuízo do Estado (...) Vila de Iguape, 15 de março de 1828. Paulo Freire de Andrade. ${ }^{97}$

É certo que a preocupação maior de Freire Andrade relacionava-se com a legitimidade da posse da terra. A inexistência de uma legislação a partir de 1821, com a suspensão da concessão de sesmarias só chegaria ao fim em 1854, com a regulamentação da Lei de Terras. $^{98}$ Os problemas apontados pelo funcionário provincial (a legalidade das sesmarias, a demarcação dos lotes, a apropriação de terras devolutas para transações e a destruição da vegetação primária) eram recorrentes. As provas aceitas como testemunho da posse, aberturas de roças e edificações de benfeitorias, promoviam um desordenado processo de ocupação, muitas vezes resultando em conflitos entre posseiros e senhores de terras. De fato, o vácuo legal criou problemas jurídicos para os juizes de Iguape, como revelam os dois fragmentos seguintes, datados nas décadas de 1830 e 1840.

“(...) Cumpre-me também fazer chegar ao conhecimento de V.E. que se faz imprescindível obstar o grande destroço das madeiras de lei em terras particulares, pois que para plantação do gênero arroz, único ramo de exportação desta vila, que tanto a tem feito florescer é de necessidade que os lavradores anualmente derrubem grandes extensões de mata virgem; nas queimas as fazem secar e com poucos anos se deterioram; decrescendo mais que nesta vila há muitos anos introduzia-se o abuso e é que um qualquer indivíduo e os mais deles sem forças para plantações sobem pelos rios arriba e ainda acham bom local para sítio com terras Nacionais continuam a derrubar uma porção de matos e fazerem uma pequena casa (vulgarmente chamada de rancho de barra no chão) e vivendo ali por alguns poucos de anos ou meses, passam a vender por uma exorbitante quantia não só o local do rancho mas ainda logradouros para uma e outra parte e tendo assim feito torna a subir mais arriba e obra pela mesma maneira. Em suma Exmo. Sr. tem acontecido um só homem ter vendido dois ou três sítios com logradouros de 500, 600 e mais braças de matos virgens do que se suscitam questões neste juízo e poucos fazem reconciliação; estes homens que por esta forma entram nas terras Nacionais são os que mais derrotam os matos, já com serrarias, já com vigas sem

\footnotetext{
${ }^{97}$ AESP, Ofícios diversos de Iguape, ordem n. ${ }^{\circ} 1.038$.

98 Sobre este período, ver MOTTA, 1998, capítulo IV.
} 
se reservarem madeiras quando as encontram a jeito; em semelhantes casos queira V.E. esclarecer-me se cada um indivíduo que precisa de terras para se asitiar pode entrar nelas sem concessão de uma autoridade que em virtude da lei esteja habilitado para Ihes conceder, marcando seus limites dentro dos quais possa trabalhar sem interrupção de pessoa alguma a se praticarem o que até aqui se tenham praticado. Iguape, 19 de janeiro de 1835. José Ribeiro Satiro, juiz de paz. ${ }^{99}$

A preocupação do juiz Satiro permite dicotomizar as práticas de ocupação das novas terras entre aqueles que a fazem por decorrência natural da expansão agrícola e o mecanismo especulatório de ocupação, venda e nova ocupação, condenável segundo a perspectiva do missivista. Ademais, tratava-se de terras Nacionais, isto é, terras devolutas. A movimentação dessas pessoas pela região possivelmente deveria incomodar parte da elite ribeirense, principalmente os comerciantes que, entre as formas de ganho, captavam a produção dos pequenos agricultores em troca de crédito através do consumo de mercadorias. É interessante notar a forma como Satiro se refere ao arroz, "que tanto a tem feito florescer”. Na década seguinte, a opinião do juiz José Bonifácio de Andrada seria distinta:

Confiado na sábia e reta administração de V.E. que tanto tem empenhado para o engrandecimento desta nossa Província; vou portanto representar a V.E. um meio qualquer para evitar tantas questões de terras que se suscitam nesta vila. Existem muitos lavradores posseiros de lugares aonde há anos vivem a plantar, outros com títulos dados pelos antigos capitães generais, mas não tomaram posse porque veio ordem de se não dar até que se fizesse Leis; nisto ficou que tem dado motivo muitas demandas e até desordens porque outros interesses ou por se arranjarem ou por espírito de intriga vão se estabelecer nas terras Nacionais já empossadas; ambos os vizinhos para tomarem terreno deitam roçadas abaixo entrando muitas vezes pela posse do que ali existia, do que tem resultado muitas intrigas e desordens a ponto de um roçar, outro plantar e tornar outro a colher a planta. Citam para o Juiz de Paz para se conciliarem, porém o que comete o esbulho não comparece para assim principiar a demanda, qual sempre resulta mal contra o mais pobre, que não tendo meios de intentar tais demandas que hoje em custas tanto se gasta, e afinal o mais poderoso sempre vence, sem nenhum deles terem títulos das terras; ora tais casos eu nada posso fazer porque não os posso obrigar a comparecer para se conciliarem e desta sorte gastam o tempo sem poderem trabalhar do que resulta prejuízo não só a eles, como ao engrandecimento da lavoura. Há poucos dias compareceram 11 lavradores pobres que existiam sitiados há anos em umas terras dadas pelo general João Carlos, mas não tomaram posse por ser vedado e citando esses ao intruso que os perturbava apossando-se com uma grande roçada nas terras que ocupavam aqueles pobres; o tal intruso sendo citado não quis comparecer em Juízo e continuou com mais gente a perturbar aqueles miseráveis. À vista do que imploro a V.E. haja de mandar alguma providência a tal respeito, porque assim fará mais um relevante serviço à Província, além das muitas provas que a sua sábia administração tem provido. Eu faço esta representação sem motivo algum de interesse, se não a bem da tranqüilidade e interesse dos povos, porque não sou lavrador, sim negociante e por isso não tenho questões algumas de terras; o meu fito é melhorar a sorte dos pobres e desta sorte engrandecer a nossa agricultura tão aniquilada. Espero que V.E. atenderá esta minha súplica e com a maior obediência e respeito cumprirei qualquer determinação que por VE me seja ordenada. DGVE, Iguape, 29 de maio de 1845. Ilmo. e Exmo. Sr. Conselheiro Manoel da Fonseca Lima e Silva, Digníssimo Presidente da Província de São Paulo. José Bonifácio de Andrada e Silva, Juiz de Paz. ${ }^{100}$

\footnotetext{
${ }^{99}$ AESP, Ofícios diversos de Iguape, ordem n. ${ }^{\circ} 1.039$.
}

${ }^{100}$ AESP, Ofícios diversos de Iguape, ordem n. ${ }^{\circ} 1.041$. 
Em verdade, nenhum dos dois ocupantes possuía o direito à terra, porém novamente a figura do invasor se reveste de transgressor, ao passo que aqueles já estabelecidos, os “11 lavradores pobres”, não obstante terem obtido as terras por doação ou por carta de sesmaria através do general João Carlos. O argumento de imparcialidade apresentado pelo juiz parece bastante estranho, pois, como já sugerido acima, o produto da lida agrícola representava a principal moeda de troca entre agricultores e comerciantes e, como visto no Capítulo 1, José Bonifácio constava da lista dos 10 maiores remetentes de arroz do Vale do Ribeira. Ademais, conforme ressaltado anteriormente, o otimismo expresso por Satiro já não aparece na fala de José Bonifácio, para quem a agricultura na região estava “aniquilada”. A partir da década de 1840 há uma freqüência significativa de opiniões contrárias à lavoura quase monocultora do arroz, porém não como o caso de Andrada e Silva, que apesar de não possuir engenho de arroz e poucas terras cultiváveis, sua riqueza acumulada derivava essencialmente da comercialização do grão e do fornecimento de crédito de pequena monta.

As disputas e os envolvidos com posse de terra aparecem em alguns poucos casos na documentação preservada no Arquivo do Estado de São Paulo. Uma delas constante de uma correspondência do Capitão-mor ao governo da Província, datada aos 12 de janeiro de 1824, revela uma das práticas no trato da posse de terras. Estas pertenciam a João Nunes Pereira e outros herdeiros, localizadas no rio de Setanduva, afluente do rio de Una. Ao que tudo indica, estes praticaram uma venda a Manoel Alves Carneiro, que não conseguindo obter a posse, recorreu ao governo provincial. No parecer do Capitão-mor a transação se realizou sob pressão do comprador, que utilizou artifícios intrigantes para concretizar a venda. O Capitãomor aproveitou a comunicação para destratar o grupo político ao qual Carneiro vinculava-se, o que torna sua versão sobre os fatos também comprometida, conforme pode ser lido abaixo:

Apresentando-me o respeitável despacho de V.E. proferido no requerimento e documentos juntos de João Nunes Pereira e mais herdeiros e sendo verdade pura todo expendido por ele em dito requerimento e documentos extraídos dos títulos das terras de Setanduva, de que se acha de posse ele e mais herdeiros por seus antepassados e de que se acham agora inquietados pelo suplicante Manoel Alves Carneiro por uma compra injusta e por ele mesmo seduzida para inquietar ao suplicante e mais herdeiros, por meio de pleitos e de intrigas debaixo do abrigo de seus parentes únicos revoltosos e inquietadores desses moradores assustados deles para se tornar flagelo desta vila, por isso que conheço como todos sabem a sua má intenção na dita dependência, o faço seguir à respeitável presença de V.E. em cumprimento do dito despacho. Sendo-me permitido dizer por esta ocasião que não podendo o meritíssimo desembargador e ouvidor convencê-lo a acomodação procurada pelo suplicante e conhecendo a razão deste me rogou para que chamasse ao suplicante e o reduzisse a que assim fiz, porém sem efeito algum porque vindo à minha presença o referido Manoel Alves a nada anuiu antes me respondeu absoluto, insubordinado e sem respeito algum. Ele tem seguido a doutrina de seus parentes Junqueiras e Vieiras únicos revoltosos e intrigantes, incultando-se caixeiro de um banido negócio deste último, dado largos passos na prática da intriga, fazendo-se habilitado em demandas que procura como esta para roubar as 
terras alheias a poder de intrigas, abandonando a companhia de seu pai e o honesto exercício da lavoura para viver ocioso, como vive, e se tornar flagelo de seus patrícios, prometendo para o futuro grande vantagem inquietadora por sua má conduta e insubordinação. O suplicante é pobre, é idoso, porém muito do bem, honrado e de boa qualidade, sendo este o único incômodo de perder suas terras se V.E. não o amparar por efeito da razão que tem. (...) Iguape, 12 de janeiro de 1824. José Antonio Peniche, Capitão-mor. ${ }^{101}$

Destacamos a importância atribuída ao quinhão de terra na região, pois no cadastro de 1818 o rio de Setanduva contava com apenas 12 propriedades, sendo três quartos obtidas por posse e praticamente todos possuíam escravos, sugerindo a vinculação da ocupação com o avançar da fronteira agrícola rizicultora. Nesse contexto, a mercantilização da terra exercida por Manoel Alves Carneiro revela-se motor do desengano de João Nunes Pereira e do apoio prestado pelo Capitão-mor de Iguape. ${ }^{102}$ Esclarecendo: Carneiro e Pereira realizam um negócio; o segundo, ao se perceber sem a terra e com um valor monetário que possivelmente o impedia de realizar uma aquisição equivalente, tenta desfazer a venda. Não obtendo sucesso, recorre ao poder instituído tentando reaver a propriedade vendida, que também não consegue dissuadir o comprador. Segundo a visão do Capitão-mor, Carneiro associava-se a um grupo de famílias que recorrentemente praticavam atos “revoltosos e intrigantes” e a sua prática de compra de terras só se fazia “a poder de intrigas”. Na leitura de Peniche, o vendedor, pobre, idoso, mas honrado e de boa qualidade, fora vítima do ardiloso comprador e a ele cabia a defesa do mais fraco contra o mais forte, por quem obviamente não nutria muita simpatia.

Não sabemos se João Nunes conseguiu ou não reaver as terras, porém há outros casos de resistência aos mecanismos de concentração das terras por parte da elite ribeirense, como a disputa entre a viúva Francisca Galdina e o comerciante Francisco Carneiro da Silva Braga. O parecer produzido pela comissão nomeada pela Câmara iguapense alegou incapacidade para dirimir a questão. Segundo consta, Galdina vivia nas terras há mais de 30 anos as quais teriam sido ocupadas por seus ascendentes há mais de 80 anos. O comerciante argumentava que obteve as terras por doação de seu sogro, Antonio Borges Diniz, que por sua vez as comprara de um certo Pedro Martins. Galdina e Braga teriam recorrido em instâncias superiores obtendo ganho de causa. A comissão não consegue discernir qual o direito válido, porém critica o juiz de direito iguapense que conduziu o processo:

(...) Não se pode deixar de notar parcialidade no juiz, bem que seja reconhecido por homem de bem, por não fazer dar execução às sentenças da suplicante, pois que pagando o suplicado as custas daquelas em que ela tinha sido vencedora com esse

\footnotetext{
${ }^{101}$ AESP, Ofícios diversos de Iguape, ordem n. ${ }^{\circ} 1.038$.

102 A interpretação dos documentos aqui analisados é tributária da leitura das pesquisas realizadas por Márcia Menendes Motta (cf. MOTTA, 1998)
} 
dinheiro pagava bem as custas em que fora por último condenada, sem que fosse preciso por-se-lhe os bens em praça para serem arrematados como foram; sendo assaz doloroso ver uma pobre desvalida despojada dos únicos bens que possuía, casa e roças, donde tirava sua triste subsistência. É ainda mais denotar-se a infundada e ilegal suspeita do mesmo juiz, quando a suplicante lhe requeria pela execução das sobreditas sentenças a seu favor e a prontidão com que logo depois mandou-lhe por os bens em praça e arrematar despachando contra ela. Reflete finalmente a comissão que a opinião pública desta vila é toda a favor da suplicante, apesar de ser uma viúva pobre, já idosa e sem abrigo e se acaso se lhe negar probidade, será por se não poder tratar com decência, visto que a fortuna a não mimoseou com seus favores. A comissão protesta que se não deixou levar pelo preceito da consideração de uma parte e nem de outra, atendeu a compaixão que naturalmente inspira uma infeliz a quem só uma coragem não vulgar faz ainda contender, consultou unicamente sua consciência e é esta que lhe serve de norte para expor francamente seu modo de pensar sem recear jamais a nota de parcialidade. É este o parecer da comissão. Paço da Câmara 18 de janeiro de $1832 .{ }^{103}$

Para além da declaração de incompetência da comissão, notamos que Francisca Galdina conseguiu mobilizar a seu favor a simpatia pública em sua qualificação de "viúva pobre, já idosa e sem abrigo”, condição que provavelmente influenciou politicamente a decisão da comissão, não obstante o relato do juiz Francisco da Silva Rego, que argumenta sobre a correção do procedimento adotado no caso:

Os fatos de que se queixa Francisca Galdina sendo alheios de verdade são argüidos por mero capricho e por intriga apoiados pela má insolvência de algumas pessoas por que tendo a questão sobre que trata variando os termos judiciais; nada mais se tem praticado do que o cumprimento e execução da lei a instância das partes como mostrarei no breve resumo desta minha resposta. Pedro Martins e sua mulher, possuidor de meia légua de terras no Rio de Una por título de sesmaria do Conde de Nasário herdada por inventário de seu falecido sogro o Cap. Januário Antunes, fazendo medir e demarcar as ditas terras compreendeu na dita meia légua os lugares Humbeva e Valongo; o que conhecendo justo a suplicante Francisca Galdina e querendo possuir legitimamente o dito lugar Valongo empenhou com o cap. Antonio Borges Diniz para que comprasse para depois Ihe transferir, querendo quando ela pudesse pagar. Tratando o dito cap. Antonio Borges o preço com o dito Pedro Martins obteve dele a compra da porção de terra que compreende desde a Humbeva até o Valongo por preço de Rs. $32 \$ 000$ de que the passou pública escritura em 27 de dezembro de 1809, o que tudo consta de autos processados por efeito de esta mesma questão. Este comprador consentiu morar a dita Francisca Galdina no lugar Valongo até que ela mesma se retirou para a barra da Ribeira, em razão de intrigas com o cap. Gregório Gonçalves da Rocha, contravizinho do lugar, pela sua má conduta e de seus sequazes; e como ficasse desocupada a terra o mesmo Borges Diniz assim comprador e possuidor aforou o dito lugar Valongo a José de Andrade e Silva que nele morou onze anos sem contradição alguma pelo dito aforamento em cujo período o referido Borges Diniz fez doação dele a seu genro cap. Francisco Carneiro da Silva Braga hoje possuidor. ${ }^{104}$

O conflito residia na primordial dúvida acerca da legitimidade da posse das terras.

Para Galdina, havia um direito legitimado pela posse ancestral e perdido provavelmente quando o capitão Januário Antunes obteve o título de sesmaria na mesma região, obrigando-a a se retirar. Se verdadeira, a articulação da viúva com o capitão Antonio Borges Diniz para reaver as terras através de uma compra indireta junto aos herdeiros do capitão Januário revela

\footnotetext{
${ }^{103}$ AESP, Ofícios diversos de Iguape, ordem n. ${ }^{\circ} 1.039$.

${ }^{104}$ AESP, Ofícios diversos de Iguape, ordem n. ${ }^{\circ} 1.039$.
} 
seu esforço em tentar se enquadrar no mesmo modelo praticado por Alves Carneiro no caso anterior; ao longo do processo, um dos argumentos utilizado por Galdina para desqualificar Silva Braga alegava que este teria pressionado Pedro Martins a passar um título de venda do terreno, fato negado pelo juiz. Segundo consta no cadastro de 1818, Pedro Martins manteve uma parte da sesmaria em seu poder, medindo 1.000 braças de testada por 0,5 légua de profundidade, avizinhando-se rio acima com Antonio Borges Diniz, Francisco Carneiro da Silva Braga e novamente Antonio Borges Diniz sugerindo que, da possível compra inicial, apenas uma parcela das terras seria destinada para Francisca Galdina. ${ }^{105}$

Algum tempo após sua saída das terras, Francisca Galdina tentou novamente instalarse na região, o que gerou uma ação de força nova por parte de Francisco Carneiro da Silva Braga, já em 1823. Daí em diante, a disputa passa para a esfera jurídica, marcada por tumultos, conflitos e articulações judiciais. De pronto, Galdina não respondeu às intimações e solicitou um embargo para a ouvidoria da Comarca, obtendo ganho de causa. É o próprio juiz Silva Rego que narra as trapalhadas burocráticas que se sucederam:

Tudo quanto fica dito consta dos autos de força nova a que me reporto, sendo necessário mostrar que a justificação foi ilegalmente processada por um escrivão que o juiz da justificação arvorou para escrever, ao mesmo tempo que o atual escrivão estava inquirindo perante o outro juiz as testemunhas de tutor na causa de força que corria entre estas partes tudo em dia 9 de dezembro de 1823 mostrando-se por isso que a dita Francisca Galdina tem grande patronato e que aquela sua justificação além de nula pela falta de citação é ilegal (...) É falssíssima a imputação da suplicante quando diz que em 1825 (...) o cap. Francisco Carneiro da Silva Braga com Pedro Martins fez com que este Ihe passasse título de venda de um terreno, quando pelo contrário a venda foi feita ao cap. Antonio Borges Diniz em 1809 com fica demonstrado e este doado a seu genro, ele tem defendido seu direito como doado-possuidor e não como comprador em cujo sentido tem uso da defesa do direito de propriedade que lhe pertence, obtendo a provisão de SMI datada de 31 de agosto de 1827 para o juiz ordinário desta vila proceder na medição, demarcação e tombo das terras em questão, o teve lugar perante o juiz que então era José Inocêncio Alves Alvim, o qual procedendo em todos os termos, autos, inquirições e mais diligências recomendadas na dita provisão julgou afinal a dita medição demarcação e tombo em dia 10 de novembro do mesmo ano (....). ${ }^{106}$

O trâmite jurídico da ação de Galdina, pelo grau de articulação, possivelmente contou com o apoio de membros da própria elite iguapense, o que não deve surpreender: exceto Pedro Martins, todos os demais envolvidos constam como imigrantes nas listas nominativas: o açoriano Antonio Borges Diniz, o português Francisco Carneiro da Silva Braga e o paulista de Taubaté Gregório Gonçalves da Rocha. No entanto, esta ajuda não foi

\footnotetext{
${ }^{105}$ Gregório Gonçalves da Rocha, citado pelo juiz como contravizinho de Galdina, possuía um lote de 400 braças de testada por 0,5 légua de profundidade na divisa rio abaixo com Pedro Martins. Antonio Borges Diniz também já possuía uma sesmaria na região, aparentemente adjunta à antiga sesmaria do capitão Januário.

${ }^{106}$ AESP, Ofícios diversos de Iguape, ordem n. ${ }^{\circ} 1.039$.
} 
suficiente para evitar o ato final de demarcação das terras, gerando a arrematação dos bens para pagamento das custas:

(...) Tendo esta sentença feita o seu devido trânsito e julgado sem que a suplicante Francisca Galdina dela apelasse ou embargasse não só ficou legalmente decidida a medição de demarcação e tombo das terras do Valongo a favor do possuidor-doado Carneiro da Silva Braga, seus títulos reconhecidos por verídicos e legítimos, como com o direito de haver da dita suplicante decaída e condenada às custas que se tinham feito o que requereu por meio da execução da sentença que a suplicante deixou correr a revelia dando lugar a que se perseguiu-se penhora em seus bens para o dito pagamento e como ela seja destituída de bens móveis e de raízes requereu o executante se penhorasse um pequeno rancho coberto de palha, uma roça de arroz e outra de mandioca que sendo postas em praça arrematou o cap. Antonio Borges Diniz por Rs. $31 \$ 658$ de que se deu posse judicial e ficou com o direito de dispor e de fazer o que bem Ihe parecesse como coisas suas arrematadas em praça pública, constando tudo quanto fica dito nos próprios autos de faço menção dos quais me reporto. ${ }^{107}$

A descrição e o valor dos bens arrematados revelam o grau de pobreza da viúva Galdina, da mesma forma que centenas de outros iguapenses. O trecho informa um dado inesperado, pois se tanto o rancho como as roças estavam em terras de Silva Braga, esperarse-ia que este fizesse a arrematação e não o sogro. Estaria Silva Braga impedido de arrematar os bens? Provavelmente não, pois entre os inventários consultados, vários são os casos onde o credor também é o arrematante dos bens, isto é, o envolvimento no processo possivelmente não impedia a participação na disputa pelo arremate. A participação direta de Borges Diniz sugere que a alegada doação poderia ser tão-somente uma figura jurídica para pressionar a saída de Galdina das terras. A ausência de legislação sobre o domínio da terra transparece no trecho abaixo, onde o juiz reconhece que um dos documentos anexados também não conseguia decidir a quem pertenceria a terra:

Todo o expendido pela suplicante Francisca Galdina em contrário é falta de verdade, é doloso, é argüido por malevolência caprichosa, pois que nem consta dos autos que ela fosse a primeira povoadora do lugar em questão nem tivesse a ela o direito de colono como inculca. As sentenças e acordãos constantes do documento n. 2 que ajunta bem se vê que não decidem o direito de domínio e posse e nem a favor de Francisca Galdina, nem do cap. Francisco Carneiro da Silva Braga por isso que este em reverência de ditas sentenças alcançou a provisão de SMI para fazer legalmente medir e demarcar e tombar as terras em questão e por meio de causa ordinária de embargos se decidiu a favor dele, todas as dúvidas e oposições suscitadas pela suplicante reconhecida deste então por intrusa. $^{108}$

Sem as terras e os cultivados, Francisca Galdina apelou para a comoção pública, que certamente resultou em ganhos, como bem demonstrou o depoimento da comissão da Câmara iguapense:

A suplicante Francisca Galdina tendo apresentado as sentenças que refere no seu documento n.3 ao Dr. ouvidor desta comarca, este mandou intimar ao cap. Francisco

\footnotetext{
${ }^{107}$ AESP, Ofícios diversos de Iguape, ordem n. ${ }^{\circ} 1.039$.

${ }^{108}$ AESP, Ofícios diversos de Iguape, ordem n. ${ }^{\circ} 1.039$.
} 
Carneiro da Silva Braga e deixando passar mais de um ano me apresentou para the mandar dar cumprimento (...) visto ter passado o semestre da lei sem se falar nela este meu despacho motivou vergonhosas queixas públicas da suplicante por portas, ruas, tabernas, contudo ela mesma mostra pelo seu documento n.4 lhe haver deferido novamente e se ela quisesse prosseguir na execução seria deferida com justiça porém como não quis prosseguir antes pediu que se entregasse suas sentenças assim se praticou como refere a conformação do escrivão no verso do dito documento n.4, pois o juiz não deve tomar a si a advocacia de ninguém nem se fazer parte por pessoa alguma e sim ordenar assistência das partes, que quando ignoram devem aconselhar-se a que parece querer a suplicante que se pratique pelo contrário com ela. A execução de seus bens foi anteriormente feita e depois de arrematados é que ela apareceu com as sentenças; por isso e por não requerer seu direito não houve a compensação que diz pretendia e quanto a dizer que este juiz a procurava para a capturar e que por isso se retirou de seu sítio para lugar muito remoto enquanto se procedeu à medição demarcação e tombo das terras em questão e se procedeu na execução de seus bens arrematados é ilusão falssíssima: é que na ocasião da medição ela esteve presente e veio com seus embargos como fica dito e na ocasião da execução foi para tudo citada, pois este (...) de mentiras e aleivosias com que a suplicante se tem coberto desde o seu princípio não pode produzir direito onde não há; pode sim por em dúvida a tribunais, a autoridades e magistrados que não conhecem de perto as cabalas e tramas dos impostores. É isso que se manda sempre em casos tais ouvir as partes acusadas. Tudo o mais expendido pela suplicante é um remate encadeado de aleivosias de que se valeu para compor o seu venenoso ramo que já ficou respondido na exposição que tenho feito a qual requeiro aos IImos. senhores da Câmara hajam de concluir originalmente nestes papeis para ir a presença de Exmo. Sr. presidente da Província como todos os documentos que vão juntos para a boa inteligência. É quanto me oferece responder por agora a este respeito à V.S. Vila de Iguape, 13 de janeiro de 1832. Francisco da Silva Rego. ${ }^{109}$

As afirmações finais de Francisco da Silva Rego parecem atribuir poderes absolutamente desproporcionais para quem possuía apenas um rancho e dois roçados, o que não apenas reitera a hipótese que Galdina contava com a ajuda de outras pessoas mais afeitas aos meandros da justiça imperial como mostra o esforço retórico em justificar a posição isenta e legal tanto dos juizes que o precederam e também de Francisco Carneiro da Silva Braga. No contexto da disputa política na vila, Diniz e Silva Braga faziam parte do grupo que obteve importante vitória, em 1825, sobre a demarcação do local de construção do canal que promoveria a ligação entre o rio Ribeira e o Mar Pequeno, contra um plano alternativo apresentado por José Inocêncio Alves Alvim e José Antonio dos Anjos, sendo que o primeiro ocupava a vaga de juiz ordinário quando foi ordenada a demarcação das terras. ${ }^{110}$

Seja qual tenha sido o resultado do processo, na lista nominativa de 1828 verificamos que Francisca Galdina, viúva, parda, 44 anos, encontrava-se instalada com outros cinco agregados - que na verdade deveriam compor um núcleo secundário formado pela filha, o genro e três netos - no Rio de Una. Esta ordenação no fogo parece se coadunar com o espírito de Galdina, pois seria esperado que o genro ocupasse o posto de cabeça do domicílio, cabendo à sogra a posição de agregada. Em 1836, nem Francisca nem seus agregados constam na lista

\footnotetext{
${ }^{109}$ AESP, Ofícios diversos de Iguape, ordem n. ${ }^{\circ} 1.039$.

${ }^{110}$ AESP, Ofícios diversos de Iguape, ordem n. ${ }^{\circ} 1.039$.
} 
nominativa. O processo de expulsão das áreas mais nobres da região em direção ao interior provavelmente nunca deixou de ocorrer, porém com maior intensidade na primeira metade do século XIX, que engloba as fases de expansão e apogeu da rizicultura.

\section{As propriedades rurais: riqueza acumulada e a mercantilização das terras}

Como já ressaltamos na introdução deste capítulo, os autores que se utilizaram dos inventários para o estudo dos bens rurais costumam referir de forma desoladora os resultados obtidos da análise dos bens de raiz descritos e avaliados nos processos. Em geral, predominam descrições com parcas informações sobre a produção, a ausência das medidas e da descrição das benfeitorias das propriedades, o que impossibilita associar o preço atribuído ao imóvel com qualquer outra variável.

Os excertos observados nos conjuntos gerados pelos ribeirenses não diferem de outras localidades brasileiras quanto à exatidão e exuberância na reprodução das propriedades rurais e urbanas pertencentes aos inventariados. Isto não se deve por sua freqüência, pois apenas 8\% da amostra não possuía bens desse tipo arrolados entre os pertences; porém, segmentados entre propriedades rurais e urbanas, os índices de ausências atingiam 22\% e 39\%, respectivamente, evidenciando o predomínio rural no conjunto dos inventários. Ademais, em 56\% dos casos o inventariado possuía um ou outro tipo de bem de raiz; entre os que detinham os dois tipos, 22\% pertenciam ao valor mínimo de duas posses e $66 \%$ possuíam até quatro propriedades combinadas entre si. $\mathrm{O}$ arranjo mais comum envolvia uma propriedade urbana associada a várias rurais, atingindo 3 em cada 5 inventários com os dois tipos de bens. No conjunto de todos os proprietários de bens de raiz, apenas 7\% possuíam 10 ou mais propriedades e o caso extremo ocorreu com o comerciante José Bonifácio de Andrada, falecido em 1863, que possuía 40 bens de raiz, sendo 8 rurais e 32 urbanos, representando cerca de $10 \%$ de sua riqueza bruta. ${ }^{111}$

As duas localidades possuíam um padrão de propriedade bastante distinto, como pode ser observado através do Gráfico 2.1, que distribui os inventários segundo a presença de bens rurais e urbanos, assim como o valor total obtido nas avaliações dos respectivos bens, em libras.

${ }^{111}$ MHAI, caixa n. ${ }^{\circ} 170$. 


\section{Gráfico 2.1}

Distribuição relativa dos inventários segundo presença de bens de raiz e valor acumulado (Iguape e Xiririca, 1800-1880)

Iguape

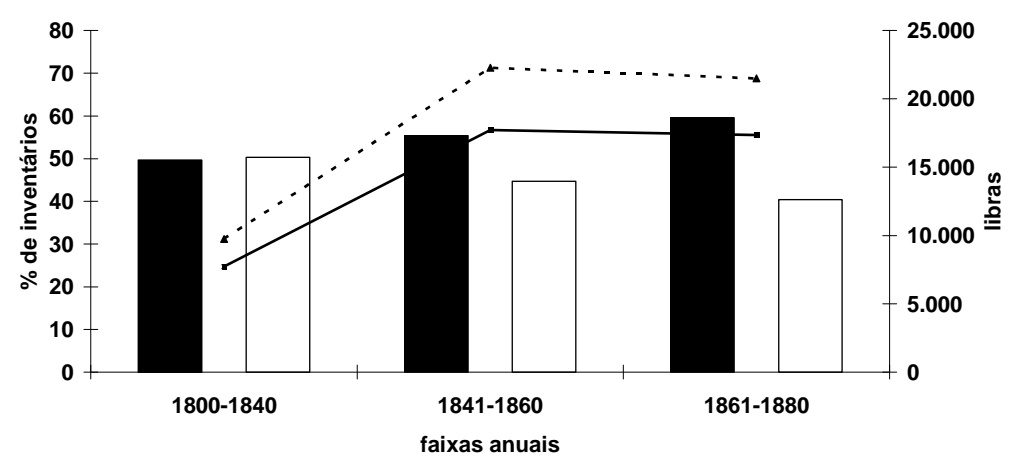

bens rurais $\square$ bens urbanos $-\wedge$ - bens rurais (libras) $\rightarrow$ bens urbanos (libras)

Xiririca

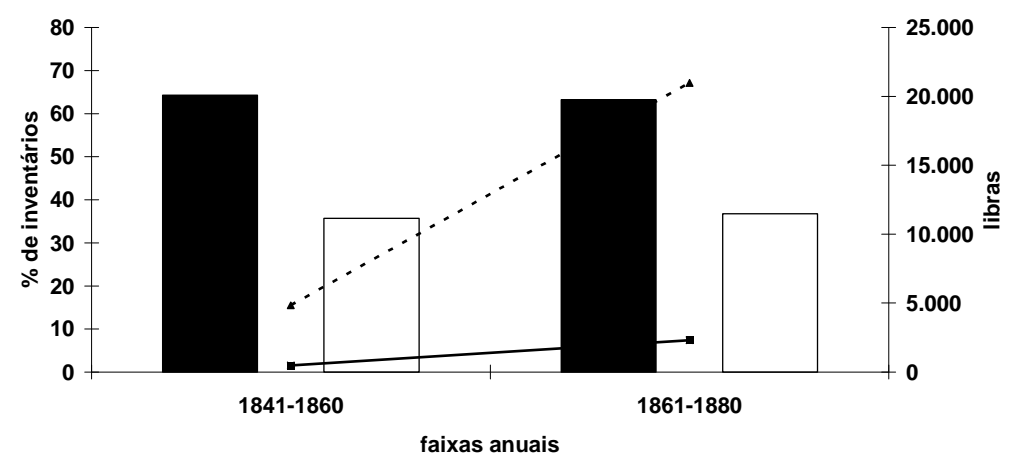

bens rurais $\square$ bens urbanos $\quad-\cdots$ bens rurais (libras) $\rightarrow$ bens urbanos (libras)

Os distintos perfis históricos das duas localidades mostram-se de maneira clara. Não obstante o predomínio dos bens de raiz rurais, em Iguape a antiguidade de sua ocupação, direcionada do litoral para o interior, e a primeva formação de um núcleo urbano impõem-se em todos os subperíodos através do relativo equilíbrio entre inventários com bens rurais e urbanos, bem como nos valores acumulados em cada um dos dois tipos. Disposição distinta registramos em Xiririca, onde o número de inventários com bens rurais sempre superou aquele com propriedades urbanas, assim como o valor dos mesmos. Notamos ainda o baixo valor acumulado ao longo dos subperíodos, revelando a incipiência de seu aglomerado urbano. No terceiro subperíodo, os 98 inventários com bens rurais de Xiririca acumulavam praticamente o mesmo valor dos 171 casos na mesma condição em Iguape, marca distintiva que se apresentará nas análises ulteriores.

Como tentativa de aferir os preços definidos pelos avaliadores, as tabelas seguintes comparam, em libras, alguns indicadores estatísticos obtidos nos inventários e nas transações 
de compra e venda através dos registros de sisa dos bens de raiz. ${ }^{112}$ As Tabelas 2.3 e 2.4 apresentam os bens de raiz rurais de Iguape e Xiririca.

Tabela 2.3

Indicadores estatísticos dos preços (em libras) das propriedades rurais

(Iguape, anos selecionados)

\begin{tabular}{l|rrrrc|rcccc}
\hline \multirow{2}{*}{$\begin{array}{c}\text { Faixas } \\
\text { anuais }\end{array}$} & \multicolumn{5}{|c|}{ sisa } & \multicolumn{4}{c}{ propriedades nos inventários } \\
\cline { 2 - 11 } & \multicolumn{1}{|c}{$\mathbf{N}$} & \% & média & desvio-padrão & mediana & \multicolumn{1}{c}{$\mathbf{N}$} & \% & média & desvio-padrão & mediana \\
\hline $1834-1839$ & 94 & 8,7 & 14,8 & 22,2 & 7,3 & 55 & 10,6 & 42,4 & 111,6 & 10,8 \\
$1845-1852$ & 219 & 20,3 & 17,2 & 28,5 & 7,0 & 129 & 24,9 & 57,2 & 170,3 & 16,8 \\
$1854-1856$ & 141 & 13,0 & 21,9 & 33,2 & 9,2 & 60 & 11,6 & 97,1 & 142,9 & 34,5 \\
$1860-1863$ & 171 & 15,8 & 28,6 & 50,4 & 10,8 & 61 & 11,8 & 95,4 & 156,0 & 32,3 \\
$1866-1873$ & 397 & 36,7 & 25,5 & 49,7 & 10,6 & 181 & 34,9 & 39,4 & 61,4 & 20,8 \\
$1876-1877$ & 59 & 5,5 & 44,9 & 136,2 & 10,2 & 32 & 6,2 & 73,1 & 101,1 & 29,0 \\
\hline total & 1.081 & 100,0 & 24,0 & 51,9 & 10,2 & 518 & 100,0 & 59,5 & 127,1 & 20,9 \\
\hline
\end{tabular}

Tabela 2.4

Indicadores estatísticos dos preços (em libras) das propriedades rurais

(Xiririca, anos selecionados)

\begin{tabular}{|c|c|c|c|c|c|c|c|c|c|c|}
\hline \multirow{2}{*}{$\begin{array}{l}\text { Faixas } \\
\text { anuais }\end{array}$} & \multicolumn{5}{|c|}{ sisa } & \multicolumn{5}{|c|}{ propriedades nos inventários } \\
\hline & $\mathbf{N}$ & $\%$ & média & desvio-padrão & mediana & $\mathbf{N}$ & $\%$ & média & desvio-padrão & mediana \\
\hline 1834-1839 & 85 & 7,9 & 30,7 & 50,4 & 7,6 & 67 & 12,9 & 47,5 & 59,7 & 17,5 \\
\hline 1845-1852 & 123 & 11,4 & 26,3 & 47,2 & 12,0 & 172 & 33,2 & 49,2 & 78,9 & 24,8 \\
\hline 1854-1856 & 29 & 2,7 & 56,4 & 77,9 & 23,0 & 48 & 9,3 & 72,8 & 75,6 & 46,0 \\
\hline 1860-1863 & 87 & 8,0 & 40,5 & 52,9 & 17,7 & 41 & 7,9 & 87,9 & 110,9 & 34,1 \\
\hline 1866-1873 & 148 & 13,7 & 47,8 & 83,2 & 21,3 & 132 & 25,5 & 50,1 & 61,5 & 30,0 \\
\hline $1876-1877$ & 35 & 3,2 & 119,9 & 224,1 & 30,7 & 31 & 6,0 & 45,1 & 46,1 & 21,1 \\
\hline total & 507 & 46,9 & 44,0 & 87,6 & 16,8 & 491 & 94,8 & 54,5 & 75,3 & 28,3 \\
\hline
\end{tabular}

Em ambas as localidades, os valores médios e medianos das propriedades dos inventários superavam os registrados no pagamento da sisa, assim como a maior dispersão em torno do valor médio dos primeiros sugere maior diversidade de propriedades nos inventários do que naquelas transacionadas pelos ribeirenses. Tais resultados não devem surpreender, dada a natureza da fonte utilizada: muito provavelmente os valores declarados para registro da transação deveriam ser inferiores aos realmente praticados, objetivando o menor recolhimento de impostos. O principal resultado está associado ao movimento geral dos preços: as elevações e reduções dos valores médios e medianos ocorrem de maneira simultânea nos dois conjuntos, embora com intensidades distintas. Grosso modo, até meados da década de 1860 há uma tendência de elevação dos preços, seguida por um recuo em fins dos anos 60 e início da década seguinte, quando os preços retomam a tendência altista. No período em que se observa o recuo, a taxa de câmbio passou de 25 dinheiros por mil-réis em 1865 para 18,1825

\footnotetext{
${ }^{112}$ Como os períodos abrangidos pelos registros de sisa diferem entre as duas localidades, as tabelas apresentam os resultados desagregados.
} 
em 1869, depreciando os valores em libras. Porém, mesmo nos valores nominais é possível verificar uma certa inflexão na curva ascensional dos preços ao final da década de 1860, sugerindo que não se trata apenas de um fenômeno cambial. No entanto, a precariedade das informações pode comprometer as especulações acima descritas; poder-se-ia supor que durante fases mais instáveis da economia imperial, ${ }^{113}$ os ribeirenses tendessem a manter uma posição conservadora.

Merece destaque também a diferença entre as duas localidades. Se nos registros de sisa os valores anotados em Xiririca mostravam-se ligeiramente superiores aos de Iguape, os indicadores obtidos a partir dos inventários revelam que as posses rurais dos xiririquenses possuíam avaliação bem mais elevada, além de apresentarem menor dispersão. Esse maior e mais igualitário padrão das propriedades rurais de Xiririca possivelmente se vinculam às características das duas amostras. Conforme foi ressaltado no capítulo anterior, em Iguape registramos maior proporção de processos com riquezas brutas diminutas, mormente nãoproprietários de escravos que também possuíam um único bem de raiz de pequeno valor. Uma massa significativa de pequenos valores tende a reduzir o valor médio, porém é na mediana que se observa o maior efeito, como bem evidenciado nas duas tabelas acima. ${ }^{114}$

É certo que na maioria dos processos não constava qualquer qualificação sobre as propriedades rurais, porém em alguns casos a presença de benfeitorias ou cultivados permitiu estabelecer uma classificação das propriedades rurais. Nossa distinção inicial privilegia seu tratamento mais genérico: “sítio", “terras”, “sorte de terras” e "morada de casas” predominavam entre os casos detectados e reproduzidos na tabela abaixo.

Tabela 2.5

Indicadores estatísticos do valor (em libras) das propriedades rurais inventariadas

(Iguape e Xiririca, 1800-1880)

\begin{tabular}{|c|c|c|c|c|c|c|c|c|c|c|}
\hline \multirow{2}{*}{ Tipos de bens } & \multicolumn{5}{|c|}{ Iguape } & \multicolumn{5}{|c|}{ Xiririca } \\
\hline & $\mathbf{N}$ & $\%$ & média & desvio-padrão & mediana & $\mathbf{N}$ & $\%$ & média & desvio-padrão & mediana \\
\hline morada de casas & 52 & 5,8 & 32,8 & 90,8 & 10,6 & 20 & 7,1 & 28,9 & 73,3 & 6,9 \\
\hline sitio & 227 & 25,3 & 110,4 & 179,2 & 46,7 & 128 & 45,7 & 122,2 & 134,8 & 72,6 \\
\hline sorte de terras & 74 & 8,3 & 29,3 & 49,0 & 16,2 & 9 & 3,2 & 17,2 & 11,2 & 16,7 \\
\hline terras & 503 & 56,1 & 36,0 & 98,8 & 14,7 & 110 & 39,3 & 47,6 & 71,4 & 31,3 \\
\hline outros & 40 & 4,5 & 79,9 & 152,5 & 13,5 & 13 & 4,6 & 261,3 & 499,2 & 40,9 \\
\hline total & 896 & 100,0 & 56,0 & 127,9 & 20,5 & 280 & 100,0 & 89,3 & 156,0 & 42,1 \\
\hline
\end{tabular}

\footnotetext{
113 O intervalo destacado corresponde à Guerra do Paraguai e como veremos adiante, o valor atribuído aos escravos nessa quadra também apresentou oscilações.

${ }^{114}$ A relativa proximidade dos valores contabilizados no pagamento da sisa entre as duas localidades poderia sugerir que a diferença observada nos inventários decorra essencialmente de critérios distintos de avaliação das propriedades rurais, guardando pouca ou nenhuma relação com diferenças substantivas na qualidade destes bens.
} 
Tanto os sítios como as terras possuíam maior valor em Xiririca, refletindo as características da amostra aqui selecionada. As propriedades denominadas como "sítios" apresentavam maiores valores médios e medianos tanto em Iguape como em Xiririca, apesar desta novamente apresentar menor variabilidade em torno da média, sugerindo menor diversidade de propriedades sob esta rubrica, além de valor mediano mais elevado. Aparentemente, a designação "sitio" cabia a propriedades mais complexas, incluindo cultivados, edificações e benfeitorias, sendo estes dois últimos os diferenciais em relação às “terras”. Sobre a presença das "moradas de casas” no ambiente rural, é possível conjeturar que estivessem associadas a uma porção de terras, porém os baixos preços indicados na tabela não corroboram tal hipótese. A existência deste arranjo pode também sugerir a presença de obstáculos para a obtenção de terras para a prática agrícola. A baixa freqüência nos inventários pode traduzir uma situação bem mais comum no contingente populacional não representado pelos inventários. Dessa forma, a fixação dessa parcela dar-se-ia exclusivamente pela posse da moradia, utilizando-se de terras alheias para o cultivo.

Faz-se necessário algum comentário acerca do termo "sorte de terras”, de baixa ocorrência em Xiririca, porém com certa importância em Iguape. Se tomados exclusivamente os valores médios, poder-se-ia supor uma relação de hierarquia entre estas e as posses designadas por “terras", detentoras de maior valor. Os valores medianos bastante assemelhados, todavia, não permitem a manutenção de tal distinção. Usualmente esta expressão aparecia empregada quando o inventariante não fornecia nenhuma dimensão linear da propriedade. Em Iguape, 51\% dos inventários que possuíam bens de raiz descreviam propriedades nomeadas como "terras", totalizando 425 posses (ou 84\% das 503 registradas na Tabela 2.5) que traziam a medida de testada, em braças até 1872 e em metros depois desta data. ${ }^{115}$ A relevância desta medida aparece quando se constata que para 52\% dos registros, o preço atribuído à propriedade correspondia a um “valor cheio” proporcional ao número de braças que formavam a testada. A evolução dessa proporcionalidade pode ser verificada no gráfico seguinte.

\footnotetext{
${ }^{115} \mathrm{O}$ número de casos nesta condição em Xiririca representava apenas $6 \%$ do total de propriedades avaliadas, justificando assim sua ausência nas tabelas e nos resultados que se seguem. Para a manutenção da homogeneidade, optou-se pela conversão dos valores em metros para braças na relação: 1 braça $=2,2$ metros.
} 
Gráfico 2.2

Preço das terras com testada declarada

(Iguape, 1800-1880)

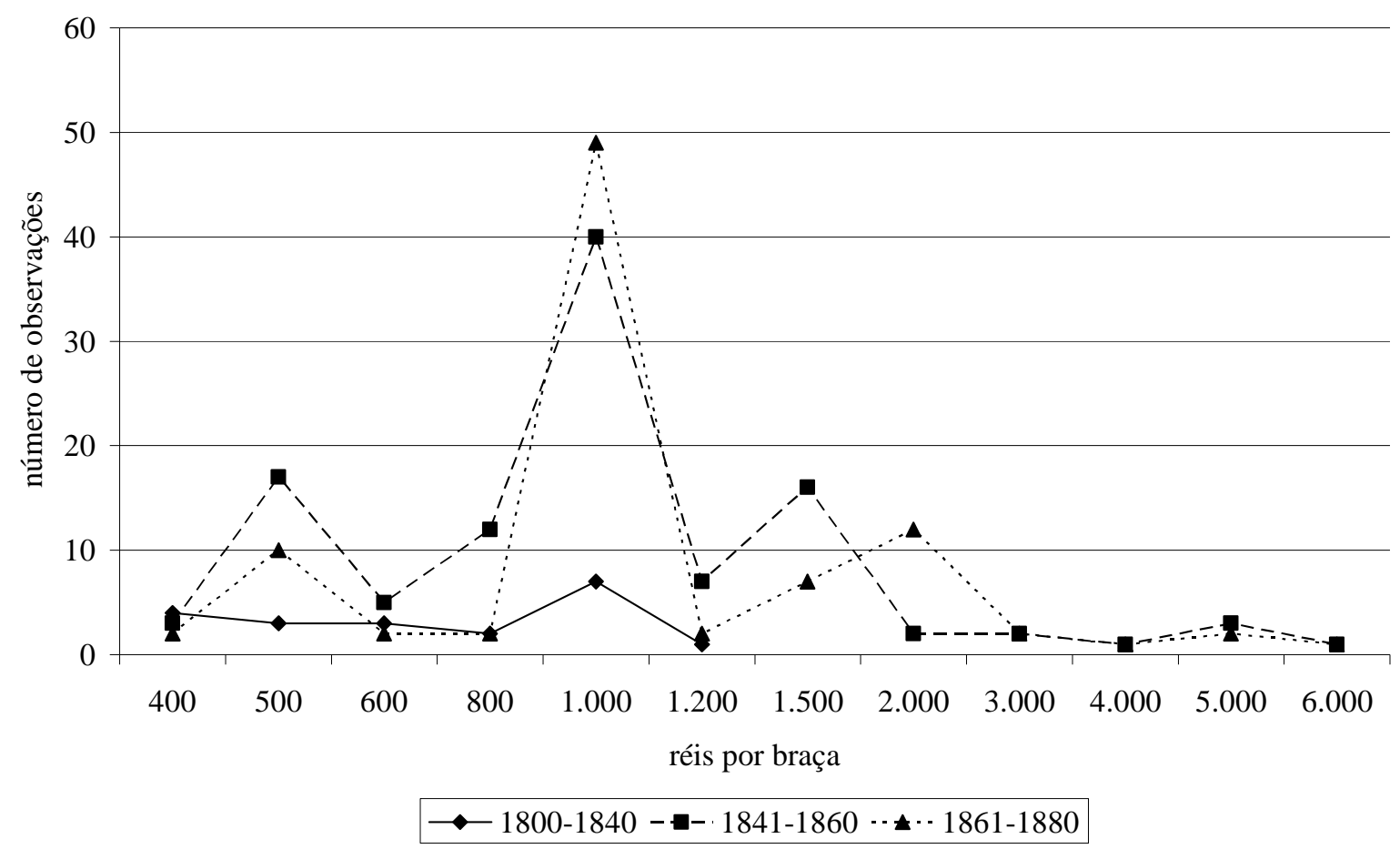

Entre os anos de 1800 e 1840, o valor máximo observado atingiu Rs. 1\$200, bem inferior aos Rs. 6\$000 registrados nos dois intervalos seguintes. No entanto, o registro com maior freqüência, Rs. 1\$000, também correspondia à moda nos demais subperíodos. Apesar de a distribuição sugerir a manutenção do preço, é preciso ressaltar que este conjunto congrega posses em diferentes regiões de Iguape e com distintos padrões de ocupação. Como ilustração, tomemos apenas as terras com Rs. 1\$000 a braça: dos oito registros relativos ao período entre 1800 e 1840, quatro possuíam algum tipo de benfeitoria e em dois praticava-se cultivo agrícola; dos 41 casos pertencentes ao subperíodo seguinte, apenas um possuía descrição de benfeitoria, enquanto em outros nove constavam a presença de cultivados, não possuindo os demais nenhuma qualificação especial por parte dos avaliadores, proporção assemelhada nos 49 registros assinalados entre 1861 e 1880. Assim, ainda que o número de ocorrências no primeiro intervalo não permita generalizações, notamos uma tendência de valorização entre a primeira fase e as demais assinaladas na figura acima. Subentende-se ainda que para os avaliadores - e supostamente para os proprietários em geral - a medida de profundidade não representava uma dimensão que pudesse alterar o valor da propriedade. Considerando-se que boa parte destas terras fazia testada para algum rio, limitando-se a faina 
agrícola à área inundável, não se deve estranhar que esta fosse a principal referência para a avaliação do imóvel.

Se aceita a testada como uma variável importante para a determinação do valor das terras, uma das tendências observadas diz respeito à redução do tamanho das propriedades ao longo do tempo: entre 1800 e 1840, 43\% delas possuíam mais de 250 braças de testada, ao passo que nos períodos seguintes, a participação se estabilizou em torno de 24\%; correlatamente, a freqüência de propriedades com até 100 braças passou de $16 \%$ para 35\%. ${ }^{116}$ O preço médio para aquelas com mais de 500 braças caiu de $£ 170$ no primeiro intervalo para $£ 116$ no último subperíodo, passando por $£ 96$ entre 1841 e 1860. A tabela seguinte apresenta a distribuição destas propriedades rurais totalizadas por inventário.

Tabela 2.6

Inventários com propriedades rurais medidas em braças segundo faixas de testada

(Iguape, 1800-1880)

\begin{tabular}{l|cc|cc|cc}
\hline Faixas de testada (braças) & inventários & $\mathbf{\%}$ & total de braças & $\mathbf{\%}$ & total em libras & $\mathbf{\%}$ \\
\hline até 100 & 60 & 24,2 & 3.662 & 3,6 & 635 & 4,1 \\
101 a 500 & 130 & 52,4 & 36.063 & 35,9 & 6.296 & 40,4 \\
501 a 1.000 & 43 & 17,3 & 30.036 & 29,9 & 3.428 & 22,0 \\
acima de 1.000 & 15 & 6,0 & 30.779 & 30,6 & 5.222 & 33,5 \\
\hline total & 248 & 100,0 & 100.540 & 100,0 & 15.581 & 100,0 \\
\hline
\end{tabular}

A distribuição entre faixas de testada revela um resultado semelhante ao observado para o conjunto da riqueza bruta dos inventários descrito no Capítulo 1: enquanto cerca de três quartos das propriedades não ultrapassavam as 500 braças, o valor em libras associado a elas representava 45\%. No outro extremo, apenas 15 inventariados possuíam propriedades cuja soma ultrapassava as 1.000 braças, porém representando $31 \%$ do total de braças e $34 \%$ do valor contabilizado. O índice de Gini para a medida de testada $(0,531)$, se confrontado com obtido para o valor monetário $(0,653)$ reafirma o desequilíbrio entre a posse e o valor atribuído, possivelmente associado a outros fatores, como a presença ou não de benfeitorias e cultivados, além da própria distribuição espacial das propriedades.

O recorte que qualifica os bens rurais de acordo com a presença de algum tipo de benfeitoria ou condição privilegiada é apresentado na Tabela 2.7 segundo três grupos descritivos, além daqueles que não possuíam informação: a existência de algum tipo de

\footnotetext{
${ }^{116}$ Em valores absolutos, o número total de propriedades com mais de 250 braças nos três subperíodos somava: 32, 37 e 52, respectivamente.
} 
benfeitoria como moradias, engenhos, senzalas, ${ }^{117}$ paióis etc.; os que assinalavam a presença de cultivos, especificados ou não e a descrição de alguma ocorrência natural que pudesse distinguir a posse, como a presença de água para movimentar engenhos, área para pasto etc. Cada ocorrência equivale a um inventário porém, em muitos casos, a existência de mais de um bem de raiz rural possibilitou a inclusão de um mesmo inventário em mais de um tipo descritivo, como ocorreu em 165 casos em Iguape e em 57 dos recolhidos em Xiririca.

Tabela 2.7

Indicadores estatísticos do valor (em libras) das propriedades rurais segundo características descritivas (Iguape e Xiririca, 1800-1880)

\begin{tabular}{|c|c|c|c|c|c|c|c|c|c|c|}
\hline \multirow{2}{*}{$\begin{array}{c}\text { Tipo de } \\
\text { descrição }\end{array}$} & \multicolumn{5}{|c|}{ Iguape } & \multicolumn{5}{|c|}{ Xiririca } \\
\hline & ocorrências & $\%$ & média & desvio-padrão & mediana & ocorrências & $\%$ & média & desvio-padrão & mediana \\
\hline benfeitorias & 164 & 27,6 & 164,3 & 265,5 & 79,3 & 83 & 43,0 & 163,7 & 172,4 & 99,7 \\
\hline cultivados & 110 & 18,5 & 47,0 & 114,8 & 22,4 & 16 & 8,3 & 76,6 & 64,7 & 62,3 \\
\hline dotes naturais & 31 & 5,2 & 50,1 & 43,4 & 33,0 & 6 & 3,1 & 116,4 & 70,6 & 108,8 \\
\hline sem informação & 290 & 48,7 & 57,0 & 116,3 & 22,4 & 88 & 45,6 & 107,1 & 236,4 & 45,8 \\
\hline total & 595 & 100,0 & 141,0 & 143,8 & 27,0 & 193 & 100,0 & 129,3 & 129,2 & 61,6 \\
\hline
\end{tabular}

As propriedades sem qualquer anotação predominavam em ambas as localidades. A proximidade dos valores médios e medianos aos registrados para as posses com cultivados, não obstante, permite aventar que se tratavam de grupos congêneres, ao menos entre os iguapenses. No outro extremo, os bens rurais com benfeitorias incorporadas detinham os maiores valores médios e medianos, apresentando também elevado desvio-padrão, que denota assimetrias significativas no valor conferido a estas melhorias, reflexo do vulto desses melhoramentos. A distinta participação relativa do grupamento nas duas localidades - mais acentuada em Xiririca - parece guardar relação com os diferentes perfis dos inventariados.

\footnotetext{
${ }^{117}$ Assim como notou Sheila Faria na região de Campos no século XVIII, entre os inventários aqui consultados há um silêncio acerca da presença de senzalas entre as benfeitorias: em Iguape, apenas dois inventários mencionavam a existência de senzala e rancho de escravos e, em Xiririca, tão-somente outros três casos. A autora aventa três hipóteses para tentar explicar esta baixa freqüência: o pequeno valor destas construções, a de que a moradia, sendo construída pelos próprios escravos, seria de posse dos cativos e a terceira, que angaria a simpatia da autora: “(...) o local onde dormiam os escravos se localizasse dentro das casas de morada do proprietário, sendo, mais uma vez, a designação plural 'casas de morada' que definia não só o complexo de moradia e beneficiamento como também um lugar onde dormiam pessoas diferenciadas” (FARIA, 1998, p. 368). A própria autora destaca que, com o passar do tempo, as senzalas ganham maior freqüência nos inventários consultados: "A separação do local de moradia dos escravos demonstrou claramente que a sociedade se tornou mais hierarquizada. Mesmo os mais pobres que, no século XVIII, jamais pensariam em possuir senzalas, num outro momento construíram casas para seus poucos escravos. Estou frisando uma tendência geral. É óbvio que, também no século XIX, havia os que permaneceram coabitando com seus escravos, principalmente nos locais onde a pobreza diferenciou muito pouco os grupos sociais ou mesmo, nos de fronteira agrícola em expansão" (FARIA, 1998, p. 372-3). No caso do Vale do Ribeira, parece mais provável uma explicação envolvendo a composição da primeira e terceira hipóteses acima delineadas. Em um processo-crime, relatado no Capítulo 5, é possível entender que os escravos utilizavam o paiol - outra benfeitoria pouco citada - como local de repouso. As observações da autora acerca da hierarquização social não parecem fazer sentido no caso dos ribeirenses e talvez se trate de um aspecto cultural que não possa ser captado nas fontes consultadas.
} 
A trajetória dos preços ao longo do tempo também revela discrepância: em Iguape, o preço médio das propriedades com benfeitorias atingiu maior valor entre os anos de $1841 \mathrm{a}$ 1860 ( $£ 189$ contra $£ 144$ nos demais períodos) ao passo que a mediana se manteve em trajetória ascendente durante todo o período estudado. Já em Xiririca o comportamento foi inverso, com maior preço mediano na vintena intermediária e preços médios crescentes, atingindo $£ 169$ no último subperíodo. Também com sentido oposto apresentou-se o desviopadrão, com valores mais homogêneos em Iguape e mais dispersos em Xiririca ao longo de todo o período.

Estas distinções coadunam-se com o traço predominantemente monocultor presente em Iguape vis-à-vis a maior diversidade de ocupações econômicas encetadas pelos agricultores de Xiririca. No caso de Iguape, os valores mais expressivos coincidem com o auge das exportações de arroz e que, visivelmente, perdem valor conjuntamente com os resultados mais estabilizados da produção rizicultora. Já em Xiririca, a convivência do cultivo do arroz com o processamento da cana mantiveram o valor das propriedades agrícolas, mesmo na conjuntura mais desfavorável da comercialização do principal produto agrícola ribeirense. Tais resultados podem ser apreciados nas tabelas seguintes, que apresentam os valores médios das posses rurais por inventariado segundo ocupação para os agricultores e atividades econômicas para os demais proprietários. Os valores monetários correspondem à soma de todos os bens rurais presentes nos processos.

Os agricultores formam um conjunto bastante heterogêneo: os proprietários de engenhos de arroz, correspondente a cerca de um quinto dos casos em ambas as localidades, detinham uma riqueza média bastante elevada se comparado com o valor médio total, porém os poucos agricultores que processavam a cana para a obtenção de açúcar ou aguardente também possuíam riqueza média expressiva. Apesar da importância econômica do arroz, estes proprietários, não obstante o reduzido número de casos, apresentavam propriedades rurais mais bem avaliadas, tanto isoladamente como associadas com engenhos de arroz. 


\section{Tabela 2.8}

Indicadores estatísticos do valor (em libras) dos bens de raiz rurais inventariados segundo atividades econômicas

(Iguape, 1800-1880)

\begin{tabular}{|c|c|c|c|c|c|}
\hline Atividades econômicas & $\mathbf{N}$ & $\%$ & média & desvio-padrão & mediana \\
\hline agricultura e manufatura rural & 302 & 73,8 & 144,3 & 270,8 & 55,8 \\
\hline produção de açúcar & 3 & 0,7 & 318,0 & 274,6 & 302,3 \\
\hline produção de aguardente & 5 & 1,2 & 261,5 & 425,4 & 66,4 \\
\hline beneficiamento de outros produtos mediante engenho & 86 & 21,0 & 326,9 & 386,8 & 201,9 \\
\hline engenho de arroz & 78 & 19,0 & 325,9 & 397,6 & 194,1 \\
\hline engenho de arroz e aguardente & 8 & 2,0 & 334,4 & 281,2 & 277,9 \\
\hline cultivo de cana & 2 & 0,5 & 138,1 & 36,2 & 138,1 \\
\hline cultivo de café & 3 & 0,7 & 661,3 & $1.036,8$ & 87,4 \\
\hline outros cultivos & 102 & 24,9 & 68,6 & 77,6 & 40,9 \\
\hline plantadores de arroz com outros cultivares & 77 & 18,8 & 72,6 & 76,7 & 43,0 \\
\hline plantadores de arroz e mandioca exclusivamente & 7 & 1,7 & 130,7 & 120,1 & 84,1 \\
\hline plantadores de arroz e cana & 4 & 1,0 & 48,8 & 49,6 & 34,9 \\
\hline plantadores de mandioca exclusivamente & 14 & 3,4 & 20,5 & 20,2 & 10,7 \\
\hline cultivos não especificados & 93 & 22,7 & 38,0 & 44,8 & 22,4 \\
\hline pecuária & 8 & 2,0 & 52,6 & 33,2 & 40,3 \\
\hline atividades do mar & 15 & 3,7 & 22,9 & 20,3 & 18,4 \\
\hline artesanato & 17 & 4,2 & 46,3 & 78,0 & 23,4 \\
\hline igreja & 1 & 0,2 & 168,4 & - & 168,4 \\
\hline profissões liberais & 4 & 1,0 & 71,3 & 61,2 & 61,0 \\
\hline rentistas & 1 & 0,2 & 11,2 & - & 11,2 \\
\hline comércio & 36 & 8,8 & 91,0 & 105,4 & 34,3 \\
\hline atividades não identificadas & 33 & 8,1 & 52,1 & 107,8 & 24,8 \\
\hline total & 409 & 100,0 & 122,7 & 240,3 & 45,4 \\
\hline
\end{tabular}

Relativamente, as práticas canavieiras possuíam maior importância em Xiririca, representados por $20 \%$ dos inventários contra pouco menos de $4 \%$ em Iguape, incluindo os casos com apenas o cultivo de cana. Possivelmente este maior valor atribuído decorra do equipamento necessário para a moagem e destilação da cana, compondo um patrimônio maior do que as mãos e pilões dos engenhos de arroz. 
Tabela 2.9

Indicadores estatísticos do valor (em libras) dos bens de raiz rurais inventariados segundo atividades econômicas

(Xiririca, 1841-1880)

\begin{tabular}{|c|c|c|c|c|c|}
\hline Atividades econômicas & $\mathbf{N}$ & $\%$ & média & desvio-padrão & mediana \\
\hline agricultura e manufatura rural & 105 & 81,4 & 188,8 & 259,3 & 110,9 \\
\hline produção de açúcar & 3 & 2,3 & 246,5 & 221,1 & 260,4 \\
\hline produção de aguardente & 7 & 5,4 & 389,7 & 681,8 & 173,2 \\
\hline beneficiamento de outros produtos mediante engenho & 29 & 22,5 & 284,3 & 276,2 & 209,3 \\
\hline engenho de arroz & 22 & 17,1 & 239,5 & 274,2 & 158,3 \\
\hline engenho de arroz e aguardente & 7 & 5,4 & 425,0 & 249,8 & 355,5 \\
\hline cultivo de cana & 10 & 7,8 & 148,7 & 122,7 & 92,1 \\
\hline cultivo de café & 1 & 0,8 & 110,9 & - & 110,9 \\
\hline outros cultivos & 28 & 21,7 & 162,9 & 168,3 & 116,1 \\
\hline plantadores de arroz com outros cultivares & 23 & 17,8 & 147,9 & 181,1 & 78,6 \\
\hline plantadores de arroz e mandioca exclusivamente & 1 & 0,8 & 189,0 & - & 189,0 \\
\hline plantadores de arroz e cana & 4 & 3,1 & 242,5 & 62,7 & 228,8 \\
\hline plantadores de mandioca exclusivamente & - & - & - & - & - \\
\hline cultivos não especificados & 25 & 19,4 & 63,4 & 43,2 & 58,9 \\
\hline pecuária & 2 & 1,6 & 183,0 & 184,4 & 183,0 \\
\hline artesanato & 6 & 4,7 & 41,1 & 31,0 & 37,2 \\
\hline comércio & 12 & 9,3 & 376,3 & 336,3 & 309,4 \\
\hline atividades não identificadas & 6 & 4,7 & 59,0 & 61,1 & 36,7 \\
\hline total & 129 & 100,0 & 193,3 & 263,9 & 99,7 \\
\hline
\end{tabular}

Entre os agricultores que não possuíam engenho, a plantação de arroz parece fortemente associada ao maior valor médio das terras, especialmente se comparados com aqueles com informação inexistente sobre os cultivares, ainda que entre estes seja razoável aceitar a presença de rizicultores. No subgrupo dos “outros cultivos”, todos os valores médios e medianos de Xiririca superavam os de Iguape, se bem que em alguns casos o número reduzido de observações não permita maiores generalizações. No entanto, é notória a condição inferior daqueles que, em Iguape, apenas cultivavam mandioca, igualando-os aos poucos proprietários de bens rurais cuja principal atividade econômica vinculava-se ao mar.

Destaque-se ainda os distintos valores observados entre os comerciantes de Iguape e Xiririca, tendo os últimos valores médios e medianos bem superiores aos primeiros. Tais distinções sugerem maior ênfase no binômio comércio-agricultura entre os xiririquenses, ao mesmo tempo em que possibilita vislumbrar um grau maior de especialização dos negociantes iguapenses, conforme será abordado no capítulo 4. Por ora, basta afirmar que o comprometimento com propriedades rurais representava cerca de $17 \%$ da riqueza bruta dos 12 comerciantes de Xiririca contra 5\% nos 34 casos iguapenses. Quanto às demais atividades, 
notamos a persistência de baixos valores médios e medianos, indicando possivelmente a condição secundária da faina agrícola entre estes proprietários. A quase ausência total desses casos em Xiririca apenas reafirma o perfil pouco diferenciado das atividades econômicas o que, neste caso, se traduz na auto-suficiência das unidades produtivas nas demandas por madeira e ferro, conforme sugere a elevada freqüência de ferramentas de carpintaria e tendas de ferreiro presentes nos inventários dos agricultores xiririquenses.

Ainda entre os agricultores, chama a atenção a baixa freqüência de cafeicultores, porém o valor médio observado em Iguape diverge significativamente de todos os demais segmentos apresentados na tabela. Tal resultado decorre da presença de Manoel Tavares Coimbra Cambiva, cafeicultor instalado no distrito de Juquiá. Pela sua condição de relativo isolamento, características climáticas e ocupação tardia, a região merece um destaque especial. Como descrito anteriormente, contava a área com poucos proprietários em 1818 e lá constava a maior propriedade, pertencente a João José Ribeiro. Em 1836, o quarteirão que englobava a região, denominado Prainha (hoje a cidade de Miracatu), apresentava 22 domicílios e 90 pessoas, todos não-escravistas, e pelo menos metade cultivava mandioca e arroz. No ano anterior, um ataque indígena mobilizou as forças milicianas da região, conforme se vê no trecho abaixo:

A Câmara Municipal desta vila participa a VE que andando à caça nos sertões do Rio de Itariri, braço do Rio do Juquiá, três homens ali moradores foram atraiçoadamente maltratados com flechas que surgiam de cima dos barrancos de um ribeirão por onde eles vinham carregados com as caças que tinham morto e por serem os ditos barrancos bastantemente altos e fechados de silvados não puderam conhecer se quem thes ofendia eram bugres ou fugidos aquilombados, mas o certo é que eles, apesar de feridos gravemente, dispararam um tiro de espingarda com o que conseguiram se recuarem as flechas até que alcançando a canoa se embarcaram para o povoado daquele rio, onde alguns deles chegaram com as flechas entranhadas no corpo por ser preciso cortar a carne para as flechas as tirar fora, acontecendo isto no dia 3 do corrente mês. $O$ juiz de paz daquele distrito se recorreu ao tenente-coronel da Guarda Nacional pedindo força armada para mandar explorar aquele sertão e a esta Câmara foi requisitada por este a pólvora e munição para o mesmo efeito, o que prontamente lhes foi fornecido e por isso teve ocasião de oficiar a aquele juiz de paz recomendando que sua exploração que mandava fazer averiguasse se os malfeitores eram bugres, fizesse todo o esforço possível por catequizar e domesticar e os remetesse para esta vila evitando toda a ofensa possível contra eles e que se fossem fugidos aquilombados o fizesse rigorosamente render e prender. (...) Iguape, 11 de fevereiro de $1835 .{ }^{118}$

Ainda em 1836, a região de Juquiá, mais próxima de Iguape, já mostrava sinais de ocupação mais intensa, contando com 111 fogos, a maioria (78\%) não-escravista e com 681

\footnotetext{
118 No mesmo ano o juiz ordinário de Iguape enviava ao governo provincial uma relação dos “indígenas reduzidos a estado de amizade” na freguesia de Juquiá, composta por 35 pessoas organizadas em seis famílias (AESP, Ofícios diversos de Iguape, ordem n. ${ }^{\circ}$ 1.039).
} 
pessoas entre livres (78\%) e cativos (22\%). Os cinco engenhos de aguardente superavam os quatro de arroz e a maior parte dos agricultores plantava arroz, mandioca e outros cultivos.

A área em apreço ganhou nova dinâmica a partir da década de 1840, com a chegada de imigrantes como Cambiva. O caso de Manoel Tavares Coimbra Cambiva é um dos raros que evidenciam o deslocamento de escravistas bem sucedidos de outras regiões para o Vale do Ribeira. Falecido em São João da Boa Vista no mês de fevereiro de 1854, seu inventário foi aberto em maio de 1855, tendo como inventariante a viúva Luciana Maria de Jesus. Tanto a riqueza bruta ( $£$ 7.028) como a líquida ( $£$ 6.799) posicionam Cambiva como a sexta maior fortuna entre os 678 inventários consultados. Em São João da Boa Vista, Cambiva possuía duas partes de terras e um sítio, alguns cavalos, dois escravos e praticamente todas as dívidas ativas, que somavam $£ 2.177$ em apenas 15 créditos. Além disso, a inventariante declarou possuir Rs. 1:600\$000 ( $£$ 184) em dinheiro, possivelmente resultado da liquidação de bens e negócios em São João. Os bens de raiz somavam $£$ 1.858, 68\% no Vale do Ribeira, incluindo um sítio no rio Bananal com 7.000 pés de café e divisas com Luis Krecherly, um sítio no rio São Lourenço divisa com Pedro Laragnoit e Salvador Luis Pereira, um outro sítio em Itariri divisa com Luis Beranger e Pedro José Paz. Além do café, Cambiva criava em suas propriedades no Vale suínos e gado vacum, somando 100 porcos, 53 tourinhos e 72 reses. Também possuía 44 escravos que perfaziam $£ 2.372{ }^{119}$

O núcleo agricultor ao longo dos rios São Lourenço, Juquiá e afluentes constituía a única região onde o café e a cana predominavam sobre o arroz. Segundo relato de José Inocêncio Alves Alvim

O café produz admiravelmente em vários distritos, especialmente no Juquiá, São Lourenço, Bananal e Itariri. Há pouco mais de 3 anos dois franceses da vila de Ubatuba, Mr. Robillard Fo. e Mr. Beranger, excitados pela fama da bondade das terras dos ditos rios, vieram examiná-las. Grande foi sua admiração ao verem o viço dos pés de café e sua produção e muito maior quando viram no meio do mato frondosas árvores ali abandonadas por mais de 20 anos carregados de frutos! Voltaram para Ubatuba e alguns meses depois vieram de novo com 20 e tantos escravos e deram começo a uma fazenda de café no Itariri, pagando por bom preço as terras. Essa fazenda tem hoje para mais de 30.000 pés de café e, segundo é em forma geral, com estado mais lisonjeiro possível. Veio depois um outro francês, Mr. Krecherly, e deu começo a outra fazenda (nota: esta fazenda já exporta muito café) no rio Bananal que também vai prosperando (nota: um outro francês, Mr. Laragnoit deu começo em 1848 a outra fazenda no rio de São Lourenço a qual se acha em estado próspero e já exporta bastante café). Há esperanças de que os habitantes daquelas excelentes terras depois que observarem praticamente a maneira de cultivar e beneficiar o café naquelas duas fazendas e se convencerem das vantagens resultantes de tal cultura, venham por fim a aplicar-se também nela, abandonando a do arroz. O algodão, o fumo e a mamona produzem de modo admirável que qualquer destas plantas cultivadas em ponto grande daria interesse muito maior do que a cultura do arroz; entretanto apenas os lavradores plantam meia

${ }^{119}$ MHAI, caixa n. ${ }^{\circ} 33$. 
dúzia de pés de cada uma delas apenas para remédios caseiros. Em muitas partes em voltas inteiras da Ribeira, do Juquiá e tantos rios, estão as margens cobertas de palmas cristu, as mamoeiras, que nascem espontaneamente e que no tempo próprio estão carregadíssimas de frutas e (custará certamente a acreditar, mas é verdade) tudo se perde porque ninguém se importa de aproveitar tão grande presente da natureza, entretanto o azeite de mamona que se consome no país é importado do Rio de Janeiro!!! (ALVIM, 1845, p. 12-13).

Segundo Roberto Braga, a reduzida produção de café no Vale do Ribeira deve-se ao fato de que, exceto em pequenas áreas, suas terras não se revelavam adequadas para o cultivo do café, conforme demonstra um zoneamento agrícola produzido em 1977 pela Secretaria de Agricultura paulista (cf. BRAGA, 1999, p. 19). A região aqui focalizada consta como "apta com restrições”, o que talvez tenha impedido o desenvolvimento de um núcleo cafeicultor mais robusto na região. De qualquer forma, Carlos Rath ao passar pela região, dez anos mais tarde, reproduz os comentários de Alvim e acrescenta:

As terras deste rio [Juquiá - AV] assim como as do Itariri são as melhores de todo o município, especialmente para a cultura do milho, feijão, cana e café. Mrs. Kerchely e Irmão (franceses) têm neste último (Bananal) uma fazenda de café e o capitão Tavares tem uma de criação de gados e de plantação de mantimentos em uma escala como ali ainda não há. É notável que os gados que se vê na Ribeira são em geral uma cruzada da China e do país que se dão muito bem com este clima, conservando-se limpos e lisos no couro e gordos, não têm bernes ou outros sinais ou inchações pelas mordidas dos insetos ou imundícies, enquanto os outros gados na serra acima têm de sofrer muito, ali principalmente pelas butucas. ${ }^{120}$

A ocupação tardia e as condições climáticas provavelmente serviram de estímulo para imigrantes que procuravam terras baratas e relativamente próximas ao litoral. Além de Cambíva, alguns agricultores franceses também organizaram fazendas na região, conforme constam dos relatos de Rath e Alves Alvim. Maria Luisa Marcílio, em 1973, já chamava a atenção para a presença de franceses moradores na vila paulista de Ubatuba entre 1820 e 1830, apresentando um rol onde, entre outros, encontram-se Carlos José Robillard, presente em 1822, 36 anos, casado, originário da Ilha de São Domingos e, na lista de 1824, Guilherme Barranger, idade desconhecida, solteiro, natural da França (cf. MARCÍLIO, 1973, p. 213). ${ }^{121}$ O primeiro provavelmente é pai de Robbilard Filho citado por Alves Alvim, cujo inventário não consta na lista consultada no Museu Histórico e Arqueológico de Iguape.

O outro é pai de Luis Beranger, cuja morte gerou dois processos volumosos. Beranger e Robillard atuavam conjuntamente, como se deduz da venda que ambos realizaram

\footnotetext{
${ }^{120}$ AESP, Ofícios diversos de Iguape, ordem n. ${ }^{\circ} 1.043$.

${ }^{121}$ Sobre a presença desses franceses, especula a autora três hipóteses: um dos grandes proprietários de terras de Ubatuba, morador no Rio de Janeiro, possivelmente teria acolhido e indicado a região para os demais compatriotas; a fuga de famílias francesas da Ilha de São Domingos após a independência da Ilha em 1804; um período de retração econômica da região de Nantes, origem de alguns dos franceses localizados por Marcílio, causado pelo fim do tráfico e a perda da Ilha de São Domingos, estimulando a emigração de famílias com algum cabedal, permitindo sua instalação como pequenos proprietários de escravos (cf. MARCÍLIO, 1973, p. 212).
} 
a Elias Pupo Ferreira em 1845, de umas terras localizadas no rio Itariri por Rs. 50\$000. Além disso, Beranger vendeu, em março de 1856, terras no rio Juquiá a Pedro José Paz por Rs. 200\$000. Segundo consta em uma certidão, Beranger teria cerca de 40 anos quando se matou, aos 26 de novembro de 1856. Possuía uma irmã de nome Juliana em Ubatuba e outros na França. Em outra certidão, consta que Beranger era filho de Guilherme Beranger, nascido em Savinay (ou Sacinay), no Loire, habitante no Brasil há vinte anos mais ou menos. Zeferino José do Prado foi nomeado como tutor dos órfãos em maio de 1857, sendo imediatamente contestado por Frederico Luis Krecherly, que alegava ser Beranger cidadão francês assim como seus filhos, cabendo assim à jurisdição das leis francesas o destino dos bens deixados pelo falecido.

Essa contenda durou cerca de quatro anos. O inventário, aberto aos 3 dias de março de 1860, descreve os bens presentes em sua única propriedade, um sítio no rio São Lourenço, no lugar denominado "Furadinho", com 12.000 pés de café, engenho de cana com dois alambiques, despolpador e ventilador para o café, avaliada em $£ 1.150$. Constam 46 animais entre gado vacum e bestas, dois fornos de cobre, 170 arrobas de café colhido, cinco pipas de aguardente, ferramentas diversas de agricultura, madeiras, caldeiras, sacos de algodão e 25 escravos, sendo 14 africanos e um crioulo entre os adultos e 10 cativos com menos de 15 anos, todos crioulos, somando $£$ 2.033. Além de uma dívida à inventariante, cerca de 4 contos de réis, Beranger devia a Antonio Feliciano Pupo e Joaquim da Silva Leite, de tal sorte que da riqueza bruta, $£$ 3.357, restou líquido $£ 2.830$, bens destinados à arrematação para a composição do pecúlio para os órfãos. ${ }^{122}$

Sobre os demais franceses, diz Paulo de Castro Laragnoit que Pedro Laragnoit chegou ao Brasil em 1835, instalando-se inicialmente como joalheiro na cidade de São Paulo, onde permaneceu até o começo da década de 1840. Em 1847 adquire de Domingos Pereira de Oliveira um sítio no rio São Lourenço, que mais tarde será conhecido como "Fazenda Prainha”, dedicando-se à criação de gado e cultivo de cana, arroz e café (cf. CASTRO, 1984, p. 2-26). Ainda segundo este autor, em 1841 instalaram-se na região os franceses Luis Beranger e Frederico Luis Krecherly (cf. CASTRO, 1984, p. 34). Junto com o irmão, Krecherly montou a fazenda Bananal, como

(...) uma fazenda de cana de açúcar e uma modelar fábrica de aguardente. O engenho para moagem de cana e os demais equipamentos para a fabricação de aguardente foram montados no sopé da Serra do Engenho, pela qual se despenha o belíssimo ribeirão do mesmo nome, que por meio de roda de água movimentava a fábrica. Havia ali um sistema de três alambiques conjugados, através dos quais a aguardente passava,

\footnotetext{
${ }^{122}$ MHAI, caixa n. ${ }^{\circ} 114$.
} 
chegando ao último alambique completamente fria (CASTRO, 1984, p. 37).

Relata Castro que, apesar do grande número de escravos e da expressiva produção, Krecherly não conseguiu honrar um crédito tomado ao comerciante iguapense José Bonifácio de Andrada e Silva. Arruinado, Krecherly retornou à França abandonando a fazenda, que em hasta pública foi arrematada pelo credor. ${ }^{123} \mathrm{O}$ autor também afirma que o francês alforriou todos os escravos antes de partir; porém, no Capítulo 5, descrevemos o caso de um cativo, outrora de Krecherly, que pertencia ao condomínio administrativo da fazenda. Segundo Castro, Laragnoit faleceu em 1883, não compondo a amostra aqui analisada. Sua riqueza bruta atingia pouco mais de 5,5 contos de réis. Entretanto, as dívidas passivas, que superavam a soma dos bens, conduziu as posses para arrematação pública (cf. CASTRO, 1984, p. 72). O principal credor de Laragnoit, Diogo Martins Ribeiro, fora sócio do seu filho, Pedro Laragnoit Júnior - falecido em 1877 - na casa comercial Ribeiro \& Laragnoit Jr., na Prainha, distrito de Juquiá. Pedro Laragnoit aparece três vezes como comprador de terras nos registros de sisa, a primeira datada em 1848, um cultivado no rio São Lourenço, no valor de Rs. 50\$000; em 1850, no mesmo rio, adquire de Maria do Belém um sítio por um conto de réis e, em 1867, compra de Demetrio Garcia um outro sítio na paragem denominada “Capuava” por Rs. $500 \$ 000$.

Pelo exposto, as atividades agrícolas empreendidas nesta região guardam muito mais semelhança com as práticas verificadas em Xiririca do que em Iguape e, neste caso, os padrões de relevo e clima sintetizam esta similaridade. Nos inventários, notamos um fluxo apreciável de xiririquenses para esta região, expandindo a lista de fatores a delinear a similaridade produtiva entre as duas paragens.

Como indica a Tabela 2.10, a região de Juquiá, entre as décadas de 1830 e 1860, ocupava a segunda posição entre as áreas com maior número de compras e vendas de terras, perdendo apenas para a Faixa litorânea; no subperíodo seguinte, há um equilíbrio entre as duas já citadas e as terras pertencentes às regiões de Jacupiranga e Ribeira. Ainda neste intervalo, apesar do menor valor médio, o preço mediano das transações se equiparava ao da Ribeira, que registrou o maior valor médio. Apesar da freqüência de transações, os franceses não constavam entre os principais compradores de terras nos registros de sisa. Luis de Barros Carneiro aparece com 13 negócios e £ 218, seguido por José Antonio Gomes Sobrinho, com 5

\footnotetext{
123 Consta nos registros de pagamento de sisa que Krecherly adquiriu, em 1855, um sítio com terras e benfeitorias no rio Bananal, área de Juquiá, de José Bonifácio de Andrada por Rs. 960\$000, possivelmente a origem da dívida relacionada ao crédito.
} 
registros e $£ 48$ e, com 4 compras, Joaquim Pedroso de Oliveira ( $£$ 57), Manoel Alves Carneiro (£ 263) e Manoel Francisco Martins de Castro (£ 93). ${ }^{124}$

Tabela 2.10

Indicadores estatísticos das transações de propriedades rurais

(Iguape, 1834-1877)

\begin{tabular}{|c|c|c|c|c|c|c|c|c|c|c|c|c|}
\hline \multirow[b]{2}{*}{ Regiões } & \multicolumn{6}{|c|}{ 1834-1860* } & \multicolumn{6}{|c|}{$1861-1877^{* *}$} \\
\hline & $\mathbf{N}$ & $\%$ & $\begin{array}{c}\text { transações } \\
\text { por ano }\end{array}$ & média & $\begin{array}{l}\text { desvio- } \\
\text { padrão }\end{array}$ & mediana & $\mathbf{N}$ & $\%$ & $\begin{array}{c}\text { transações } \\
\text { por ano }\end{array}$ & média & $\begin{array}{l}\text { desvio- } \\
\text { padrão }\end{array}$ & mediana \\
\hline Juréia & 29 & 7,7 & 1,8 & 20,3 & 32,7 & 10,8 & 49 & 9,4 & 3,8 & 17,4 & 38,5 & 6,2 \\
\hline Faixa litorânea & 87 & 23,1 & 5,4 & 13,4 & 19,4 & 4,5 & 96 & 18,4 & 7,4 & 9,6 & 10,8 & 5,2 \\
\hline Una & 45 & 12,0 & 2,8 & 26,4 & 47,2 & 8,5 & 50 & 9,6 & 3,8 & 33,5 & 55,4 & 14,2 \\
\hline Peroupava & 23 & 6,1 & 1,4 & 15,8 & 19,4 & 10,4 & 33 & 6,3 & 2,5 & 18,5 & 31,0 & 10,5 \\
\hline Ribeira & 48 & 12,8 & 3,0 & 27,4 & 30,4 & 16,1 & 98 & 18,8 & 7,5 & 49,3 & 114,9 & 15,0 \\
\hline Jacupiranga & 67 & 17,8 & 4,2 & 15,6 & 23,4 & 6,0 & 99 & 19,0 & 7,6 & 35,4 & 68,4 & 14,2 \\
\hline Juquiá & 77 & 20,5 & 4,8 & 14,9 & 28,0 & 7,5 & 97 & 18,6 & 7,5 & 28,6 & 55,3 & 14,9 \\
\hline total & 376 & 100,0 & 23,5 & 18,1 & 29,2 & 7,4 & 522 & 100,0 & 40,2 & 29,1 & 67,7 & 10,7 \\
\hline
\end{tabular}

*1834 a 1837, 1839, 1845, 1846, 1848 a 1852,1854 a 1856 e 1860

** 1861 a 1863,1866 a 1873,1876 e 1877

As regiões que concentravam a maior parte dos registros correspondem às regiões de expansão da fronteira agrícola Jacupiranga, Juquiá e o próprio Ribeira; ao mesmo tempo, a freqüência total de transações na Faixa litorânea, que identificamos como uma área de ocupação mais remota, congregava cerca de um quinto dos registros.

Ainda que a comparação na quantidade total de transações entre os dois subperíodos possa conter um viés decorrente dos intervalos anuais com disponibilidade de dados, o número médio evidencia um crescimento em quase todas as regiões, destacando-se as áreas da Juréia e Ribeira. O cadastro de 1818 indicava que na primeira predominava uma ocupação antiga, sendo a compra e a herança as formas usuais de legitimação da propriedade; já a segunda mesclava estas formas com a ocupação mais recente, como evidenciam as várias propriedades obtidas por posse, certamente refletindo a expansão da fronteira agrícola. Na região do Ribeira, nos dois subperíodos retratados na Tabela 2.10, registramos os maiores preços médios e medianos de Iguape. Já na Juréia, o aumento no número de transações entre os dois períodos não guarda relação o valor médio que oscilou negativamente, em comunidade à Faixa litorânea. ${ }^{125} \mathrm{O}$ fator diferencial parece residir na capacidade de expansão, bastante limitada na orla marítima e mais flexível na Juréia. No entanto, tais movimentos parecem residuais se comparados com a dinâmica percebida nas áreas do Ribeira, Jacupiranga

\footnotetext{
${ }^{124}$ Os registros organizados na tabela correspondem a $84 \%$ do total de casos, sendo excluídos todos os casos que não continham informações sobre a localização bem como aqueles que não puderam ser enquadrados nas grandes regiões aqui consideradas.

${ }^{125}$ Com relação ao elevado número de transações observado nesta região, ressalte-se que a área em apreço englobava terras próximas ao núcleo urbano de Iguape e na Ilha do Mar Pequeno, responsáveis por mais de quatro décimos das terras negociadas.
} 
e Juquiá, assim ordenadas segundo a antigüidade das ondas de ocupação. O elevado desviopadrão, principalmente no segundo intervalo, sugere uma larga amplitude de propriedades transacionadas, englobando desde pequenas sortes de terra até sítios com benfeitorias.

Nesse sentido, uma das características que parece distinguir o mercado de terras na fase madura da rizicultura em relação ao retrato esboçado pelo cadastro de terras de 1818 é a crescente tendência de regionalização. Em 1818, os proprietários com maior número de propriedades rurais possuíam-nas em distintas regiões do Vale do Ribeira.

O rol de compradores constantes nos registros de sisa revela a recorrência de casos semelhantes ao de Luis de Barros Carneiro, que concentrou suas compras na região do Juquiá. O segundo maior comprador de terras, Joaquim de Moraes Freitas Coutinho, com 12 transações, realizou-as todas em Jacupiranga; José Ferreira de Aguiar e Silva e depois, com sua morte, a firma comercial Viúva Ferreira Aguiar \& Filhos, realizaram 17 aquisições. Enquanto o primeiro ainda mantinha a prática de realizar compras pulverizadas em várias regiões, a firma concentrou-se na região de Jacupiranga, com cinco das sete compras com local identificado.

José Jacinto de Toledo, beneficiário do enriquecimento gerado ainda na primeira fase da rizicultura ribeirense, possuía um comportamento assemelhado ao de Aguiar e Silva, adquirindo 10 lotes de terras em diferentes regiões, assim como o comerciante e proprietário de engenho de arroz Luis Álvares da Silva. Outros, como Antonio Franco de Oliveira Canto e José Apolinário de Azevedo, ambos com 7 aquisições, concentravam os investimentos na Ribeira e Jacupiranga, respectivamente. ${ }^{126}$ Da convivência entre os dois tipos de estratégias emerge a percepção de maior complexidade das relações econômicas segundo uma nova distribuição espacial, fortalecida pela consolidação de aglomerados humanos distantes do litoral e que se tornavam relativamente independentes, não obstante a manutenção do arroz como forma predominante de prática agrícola e o porto de Iguape como único caminho para a entrada e saída de mercadorias.

As áreas no entorno dos rios Peroupava e Una mantiveram uma posição intermediária entre os dois grupos analisados acima, não apenas porque o número de transações por ano não apresentou o mesmo gradiente como também os valores médios e medianos das terras não variaram na mesma intensidade, principalmente na área de

\footnotetext{
${ }^{126}$ Quanto menor a frequiência de transações, mais concentradas em uma região específica: dos 35 compradores com quatro e cinco registros, 20 adquiriram terras sempre na mesma região. Apesar da ênfase nos casos dos compradores com mais de uma transação, estes representavam $24 \%$ dos casos no geral e, entre aqueles com localização estabelecida, tais valores oscilaram de 10\% na Juréia a 20\% em Jacupiranga e na Faixa litorânea.
} 
Peroupava. Aparentemente, tais regiões, restritas espacialmente, perderam rapidamente a característica de fronteira que apresentavam em 1818 e deixaram de ocupar o interesse dos agricultores iguapenses.

Não conseguimos delinear algum traço de especulação no mercado de terras observando o perfil dos vendedores. É fato que o comerciante João Mâncio da Silva Franco possuía a maior marca, com 10 vendas, porém entre os compradores ele realizou cinco aquisições e, aparentemente, nenhuma das aquisições corresponde a uma das vendas. Pelo menos até 1850, quando abriu inventário da primeira esposa, João Mâncio não possuía nenhuma propriedade rural entre os bens de raiz, mas apenas urbanas. A mesma dificuldade em associar compra e venda ocorre com as terras negociadas com Antonio José Peniche, que realizou oito vendas, terminando por aí os casos mais expressivos. O número de vendedores com mais de uma ocorrência representava 15\%, a grande maioria com duas transações, sugerindo que terras não representavam um ativo que possuísse caráter especulativo. Decerto, os valores das transações e sua freqüência revelam um perfil que parece mais associado à dinâmica populacional do que aos estímulos econômicos, pouco favoráveis principalmente nos anos posteriores à década de 1860 .

Estes traços gerais emergem de forma mais evidente quando se analisam os negócios realizados em Xiririca, conforme mostra a Tabela 2.11, que esquadrinha a região tomando como referência o núcleo urbano e a posição do afluente (lado direito ou esquerdo) em relação ao rio Ribeira.

Tabela 2.11

Indicadores estatísticos das transações de propriedades rurais

(Xiririca, 1847-1880)

\begin{tabular}{|c|c|c|c|c|c|c|c|c|c|c|c|c|}
\hline \multirow{2}{*}{ Regiões } & \multicolumn{6}{|c|}{ 1847-1860* } & \multicolumn{6}{|c|}{$1862-1880$} \\
\hline & $\mathbf{N}$ & $\%$ & $\begin{array}{c}\text { transações } \\
\text { por ano }\end{array}$ & média & $\begin{array}{l}\text { desvio- } \\
\text { padrão }\end{array}$ & mediana & $\mathbf{N}$ & $\%$ & $\begin{array}{c}\text { transações } \\
\text { por ano }\end{array}$ & média & $\begin{array}{l}\text { desvio- } \\
\text { padrão }\end{array}$ & mediana \\
\hline rio abaixo - direita & 23 & 19,2 & 2,3 & 47,5 & 44,5 & 35,0 & 41 & 12,8 & 2,2 & 39,4 & 54,6 & 17,9 \\
\hline rio abaixo - esquerda & 23 & 19,2 & 2,3 & 40,6 & 31,6 & 41,8 & 73 & 22,8 & 3,8 & 26,5 & 23,3 & 19,7 \\
\hline rio acima - direita & 32 & 26,7 & 3,2 & 27,4 & 25,7 & 16,9 & 77 & 24,1 & 4,1 & 50,8 & 71,6 & 32,4 \\
\hline rio acima - esquerda & 30 & 25,0 & 3,0 & 20,6 & 22,2 & 12,7 & 78 & 24,4 & 4,1 & 28,7 & 32,7 & 21,3 \\
\hline Ribeira & 12 & 10,0 & 1,2 & 34,5 & 18,1 & 30,1 & 51 & 15,9 & 2,7 & 47,7 & 52,9 & 39,2 \\
\hline total & 120 & 100,0 & 12,0 & 32,8 & 31,2 & 23,0 & 320 & 100,0 & 16,8 & 37,9 & 50,2 & 23,1 \\
\hline
\end{tabular}

Os valores totais mostram uma variação positiva tanto no número médio de transações por ano entre como no preço médio das transações, porém com valores medianos estáveis. No primeiro intervalo, as regiões rio acima concentram mais de 50\% das transações, 
porém com valores médios e medianos bem inferiores aos praticados nas áreas rio abaixo, provavelmente traduzindo o avanço da ocupação agrícola nas áreas mais distantes tanto do núcleo urbano de Xiririca como do porto de Iguape. Entre os anos de 1862 a 1880, o número de transações médias rio acima manteve valores mais elevados, especialmente no lado direito, onde os indicadores praticamente dobraram seu valor. Notamos também um aumento na freqüência de transações na margem esquerda rio abaixo e ao longo das margens do Ribeira; nesta o valor médio acompanhou o aumento no número de transações, o mesmo não ocorrendo naquela.

Comparando a linha totalizadora com a observada em Iguape, notamos que o número médio de transações correspondia à metade das compras lá registradas. Os valores médios e medianos mostraram-se superiores nos dois intervalos, porém com menor desvio-padrão. Dessa forma, além do maior valor médio, a menor disparidade entre os preços registrados sugere maior homogeneidade nas propriedades rurais negociadas pelos xiririquenses. Os preços médios nas áreas mais dinâmicas de Xiririca se equiparam aos encontrados nas áreas nobres de Iguape, como ao longo do rio Ribeira.

Destacamos ainda a baixa freqüência de transações rio abaixo pelo lado direito. Nesta região o comerciante português Miguel Antonio Jorge possuía a propriedade denominada “Caiacanga”. Segundo o agrimensor Henrique Ernesto Bauer, plantava-se café, algodão, cana, arroz e mandioca. Cerca de um quarto da área total da fazenda constituía-se por áreas baixas e alagadiças, próprias para o cultivo de arroz e cana. O agrimensor afirma que Jorge utilizava o arado para as plantações de cana em uma área de $20 \mathrm{~km}^{2}$, que correspondia a 3\% da propriedade; ocupavam a maior parte da propriedade capoeiras (67\%) e matas virgens (30\%). A principal fonte de energia derivava de um complexo sistema de armazenamento de água em açudes, fornecendo cerca de 30 cavalos mecânicos (cerca de 22.000 watts) para a movimentação de dois engenhos de arroz e um de cana, além de uma pequena serralheria. Além de instalada à margem direita do Ribeira, cerca de $10 \mathrm{~km}$ abaixo do núcleo urbano, pela fazenda passava a picada entre Xiririca e Sete Barras, que por sua vez permitia acessar as paragens serra acima. ${ }^{127}$

A construção dos referidos açudes não foi tranqüila, como pode se depreender do relato feito pelo vereador iguapense Manoel Homem Pamplona, designado para atender um reclamo dos moradores do rio Capinzal em 1860:

O vereador Manoel Homem Pamplona, fiscal e secretário da Câmara Municipal desta

${ }^{127}$ Cf. KRUG, 1938, p. 578-582. 
cidade, encarregado pela mesma Câmara de irem em comissão ao ribeirão do Capinzal, braço do rio de Jacupiranga, deste município para o fim de examinarem se a água encanada no fim do referido ribeirão pelo cidadão Miguel Antonio Jorge do distrito da vila de Xiririca priva ou não o trânsito de canoas pelos moradores dali e mesmo para examinarem o estado atual em que se acha tal encanamento a fim de dar uma exata informação, vem informar pelo modo seguinte: que Miguel Antonio Jorge com o fim de tirar águas para meter em seus tanques, colocou um açude em um pequeno córrego que deságua no ribeirão do Capinzal, represando assim esta água em um tanque de onde fez um talho para por ele conduzi-la a sua fazenda, apanhando este valo uma porção de vertentes de morros, que todas elas acodem ao ribeirão do Capinzal; que o córrego encanado e tirado do seu curso não faria muita falta, porém as vertentes dos morros que caem no valo e igualmente com ele, alguma falta podem fazer em tempo de seca; um pouco distante existe um ribeirão de bastante água que nasce de uma cachoeira e que também deságua no Capinzal, cujo ribeirão pretende Miguel Antonio Jorge fazer virar para o tanque, feito para cujo fim já fez junto da dita cachoeira quarenta braças de valo, mais ou menos, vindo por esta forma a tirar um dos maiores braços do ribeirão do Capinzal, que deste modo ficaria intransitável; e que vendo os moradores do ribeirão estas funções recearam ficar sem navegação, motivo porque foram ao açude e abriram fazendo secar o tanque; depois do que não houve continuação do serviço algum por quanto acha-se presentemente aberto o açude e o serviço dos valos parados. Acrescenta mais a comissão que os moradores do ribeirão do Capinzal unanimente dizem que quantas vezes Miguel Antonio Jorge encanar a água, quantas irão abrir por conta da falta que ela faz. É esse o parecer da comissão e achando ser o mais exato submeter à consideração da Câmara. Iguape, 15 de julho de $1860 .{ }^{128}$

Miguel Antonio Jorge também aparece como principal comprador de terras de Xiririca, com 88 transações entre 1849 e 1879, somando cerca de $£ 3.000$ ou 14\% do montante envolvido nas vendas de terras e mesma parcela das transações. Na margem direita abaixo da vila - região da fazenda “Caiacanga” - Jorge realizou apenas três aquisições, ao passo que no lado oposto adquiriu terras 15 vezes; a maior parcela das compras concentravase rio acima na margem esquerda, com 21 compras e outras 16 na margem direita. ${ }^{129} \mathrm{O}$ segundo maior comprador, Bernardo José Cabral, realizou 13 transações envolvendo $£ 453$. Outras 85 pessoas fizeram mais de uma compra representando, no total, $23 \%$ dos compradores e 54\% dos negócios.

As intenções de Miguel Antonio Jorge não são claras. Proprietário da terra e fornecedor de crédito, boa parte do arroz por ele remetido provavelmente provinha da fazenda “Caiacanga”, onde em 1852 possuía os engenhos de arroz e contava com 61 escravos, a maior posse dentre as poucas registradas na lista de proprietários de engenho redigida pela Câmara Municipal de Xiririca. ${ }^{130}$ Ao ampliar a extensão de seus domínios, Miguel Antonio Jorge poderia se apropriar da produção agrícola dos antigos proprietários, reafirmando sua posição de maior exportador de arroz do Vale, como mostramos no capítulo anterior. Os valores médios de suas compras, entretanto, pouco se diferenciavam do conjunto das transações

\footnotetext{
${ }^{128}$ AESP, Ofícios diversos de Iguape, ordem n. ${ }^{\circ} 1.044$.

${ }^{129}$ Outras nove nas ilhas do Ribeira, cinco sem informação e 18 em regiões não localizadas, além de uma única em Iguape.

${ }^{130}$ AESP, Ofícios diversos de Xiririca, ordem n. ${ }^{\circ} 1.339$.
} 
realizadas em Xiririca, sugerindo que não se tratavam de negociações onde o vendedor se sujeitasse à venda por um valor aquém daquele que seria o esperado, sem bem que nada podemos afirmar sobre a qualidade e condições de uso destas terras. Seu caso representa uma excepcionalidade na região: nenhum dos demais comerciantes ou grandes proprietários de engenho apresentou um fluxo ou estoque de bens rurais tão expressivo.

Observamos ao longo das páginas anteriores que o movimento das avaliações e das transações envolvendo propriedades rurais acompanhou o desempenho da economia ribeirense. Em Iguape, a valoração dos bens de raiz atingiu o grau máximo no período coincidente com o auge das exportações de arroz. Durante os anos seguintes, o arrefecimento do dinamismo agrícola se reflete na baixa incorporação de novas unidades produtivas e equipamentos para o processamento dos grãos, traduzidos aqui em menores valores médios e medianos. Notamos estes efeitos na maior dispersão dos valores registrados nas transações a partir da década de 1860. Não obstante a percepção geral de crescimento do valor atribuído nas avaliações e registrado através do pagamento de sisa, tais oscilações não parecem associadas a uma valorização decorrente da disputa por melhores terras. Em Xiririca, ressaltamos que os bens de raiz avaliados apresentaram maior valor médio do que os observados em Iguape. Ainda que o viés de nossa amostra possa responder por parte desta diferença, os valores obtidos nos registros de sisa reafirmam esta superioridade, que atribuímos à possibilidade do desenvolvimento de culturas diversificadas na região em apreço.

\section{As propriedades urbanas}

As casas e terrenos urbanos avaliados nos inventários não possuem o mesmo papel na estrutura produtiva da região, porém o fluxo e o estoque destas propriedades podem indicar tendências das expectativas e possibilidades na alocação da riqueza, principalmente entre os iguapenses. Já destacamos que uma das diferenças importantes em relação às duas localidades aqui estudadas respeita ao tamanho e importância do núcleo urbano de Iguape. O limite temporal inferior proposto nesta pesquisa encontra a vila de Iguape consolidada, incorporando artesãos, comerciantes, corpo burocrático, eclesiástico e proprietários de terras que mantinham domicílio à margem do canal que separa o continente da então conhecida Ilha do Mar Pequeno, hoje Ilha Comprida.

Em 1836, o quarteirão correspondente ao núcleo urbano iguapense compunha-se por 136 fogos, o que representava $17 \%$ dos casos verificados naquela lista nominativa. Comerciantes de todos os tipos chefiavam $42 \%$ das unidades, seguidos por agricultores e 
artesãos, com respectivamente $16 \%$ e $14 \%$, ainda destacando-se a elevada presença de casos cuja atividade não foi possível determinar (17\%). Não verificamos diferenças na idade média de homens e mulheres chefes de domicílio e mais da metade dos fogos chefiados por mulheres eram-no por mulheres solteiras ou viúvas, ambas com filhos, ao passo que os chefiados por homens predominavam famílias completas com filhos, com parcela importante de homens solteiros e sem filhos. Quanto à origem, predominavam pessoas do próprio Vale do Ribeira, porém com diferenças importantes: enquanto mulheres pertencentes a este grupo somavam $84 \%$, o valor correlato aos homens atingia $54 \%$, sendo $23 \%$ europeus e outros $17 \%$ de outras regiões paulistas. As mulheres chefiavam dois terços dos fogos pertencentes ao grupamento agrícola e 84\% das atividades não classificadas; nas demais atividades os homens mantinham predomínio quase absoluto. Roberto Fortes relata que a vila de Iguape possuía 273 casas em 1828, e o Porto da Ribeira 42 construções em 1833 (cf. FORTES, v. II, 2000, p. 170).

Em 1845, José Inocêncio Alves Alvim assim descrevia a vila de Iguape:

Tem ela 11 ruas, a saber: rua do Funil, rua Grande, rua Franca, Detrás do Funil, rua da Glória, rua do Rosário, rua do Campo, rua das Dores, Direita, do Comércio e Nova da Fonte. Tem 2 largos denominados da Matriz e do Ipiranga. Está dividida em 7 quarteirões e contém 343 casas, todas construídas de pedra e cal, entre as quais se notam 23 casas nobres. Há também um edifício público municipal; é uma casa de sobrado de 33 palmos de frente construída sobre terreno municipal pelo finado sargentomor Bento Pupo de Gouveia para quartel de duas companhias de milícias de que ele era comandante. Serve hoje de casa da Câmara e cadeia e também de quartel do Batalhão de Guardas Nacionais. Há dois templos, a Matriz e a Igreja da Senhora do Rosário dos pretos e mulatos. (...) Há na vila 42 lojas de fazendas e 48 armazéns de molhados, 8 tendas de alfaiates, 7 de sapateiros, uma de ferreiro, 4 de carpinteiros, 2 de marceneiros, duas farmácias, sempre desortidas, 4 cartórios - do Judicial e Notas, do Juízo de Órfãos, do Juízo de Paz e do Juízo Eclesiástico. Estão em andamento 3 obras públicas a saber: a da Nova Matriz, obra gigantesca, começada há 60 anos e cujas paredes ainda não estão em ponto de receber madeiras; a da nova cadeia e casa da Câmara, ainda pouco adiantada, o canal de comunicação entre a Ribeira e o Mar Pequeno, o qual já há anos que dá trânsito a canoas carregadas em ocasiões de marés de lua (ALVIM, 1845, p. 1719).

Cerca de dez anos depois, Carlos Rath apresentava suas impressões sobre o mesmo núcleo urbano:

A cidade tem diferentes praças espaçosas, porém é de lamentar, que nem as ruas antigas, nem as novamente alinhadas sejam esquadrinhadas, de sorte que as casas, assim antigas como modernas, aliás grandes e espaçosas, não têm ângulos retos, e o mesmo acontece com a nova matriz que ainda não está concluída, todos têm ângulos agudos e desaprumados, porém a construção é geralmente de pedra e cal e muito sólida. A vista da cidade do lado do mar, apresenta um aspecto muito desagradável; todas as casas deste lado, fazendo fundo para o mar, apresentam uma imensidade de muros, cercas de madeira e quintais que lhe tiram a vista. A nova Matriz segundo meu entender, é um montão de pedras, sem planos próprios e formosura para uma semelhante obra, e cheia de desproporções, digo, desproporcionada, as somas que nela se gasta e ainda se há de gastar, por isso que duas partes são concluídas, restando uma terça parte para fazer. Ela é dividida em três partes e em nenhuma parte cabe o povo 
que costuma freqüentar a festa. Se fossem em lugar dos paredões grossíssimos que se acham no meio e que repartem a igreja em três partes estreitas e compridas - existiam arcos altos, abertos com pilares adequados da obra, ficava tudo um templo só e assim mesmo repartidos no fundo para os três altares. Assim recebesse a capela mais luz no meio, e o templo cabesse o povo para todas as festas. Acho eu, lá também se adora um Deus. A antiga capela de N. S. das Neves guarda ainda a veneralíssima imagem do Senhor "Ecce homo". Acha-se principiada a nova capela de N.S.do Rosário, assim como a nova cadeia, casa da Câmara municipal e sala dos fundos, para estas duas últimas têm servido as casas do N.S. do Bom Jesus, e para cadeia uma pequena casa, que é o quartel aos lados do qual tem duas prisões, com grades de madeira. ${ }^{131}$

As características desprezadas por Rath - ruas desalinhadas, construções fora de esquadro, ausência de prumos - são recorrentes nas formações urbanas coloniais e assim permaneceram como registros de uma época. ${ }^{132}$ As obras públicas citadas pelos dois autores, iniciadas ainda no fastígio da rizicultura, agonizaram por anos com a perda de dinamismo após 1860: em 1871, segundo o engenheiro J. Coutinho, tanto o prédio da nova cadeia como a casa da Câmara ainda não estavam prontas; ${ }^{133}$ relata ainda Roberto Fortes que as obras na nova matriz começaram em fins do século XVIII e a inauguração, com as obras ainda inconclusas, ocorreu em 1856. Apenas em 1873 a primeira das duas torres receberia o sino (cf. FORTES, 2000, v. I, p. 233-241). Em outras palavras, a lentidão das construções públicas serve como termômetro da falta de novos impulsos que pudessem manter o dinamismo econômico observado na primeira metade do século XIX, em descompasso com a mudança na paisagem da vila, que vivenciava a ereção das principais edificações que ainda hoje compõem o núcleo histórico da cidade.

As residências descritas nos inventários apresentavam dois padrões: as paredes francesas, uma espécie de construção de taipa, e as construções de pedra e cal. Em alguns casos registramos a mescla das as duas técnicas, principalmente nas edificações assobradadas, com paredes mais sólidas no pavimento inferior e taipa no superior. Complementava a descrição a medida da fachada, em palmos até 1872 e em metros nos anos seguintes, o número de portas e janelas, os proprietários limítrofes e a rua na qual se localizava o bem de raiz.

O rol de propriedades urbanas inventariadas ultrapassava os limites do núcleo acima descrito, pois continha também bens nas freguesias de Jacupiranga e Juquiá, além das cidades vizinhas de Xiririca e Cananéia. Os 843 registros distribuem-se igualmente entre as vintenas de 1841 a 1860 e 1861 a 1880, com 40\% e 41\%, restando 19\% para o subperíodo inicial.

\footnotetext{
${ }^{131}$ AESP, Ofícios diversos de Iguape, ordem n. ${ }^{\circ} 1.043$.

132 Como modelo de desenvolvimento urbano colonial, Carlos Lemos bem descreve tais características para a cidade de São Paulo (LEMOS, 2004, capítulo 4.).

${ }^{133}$ AESP, Ofícios diversos de Iguape, ordem n. ${ }^{\circ} 1.047$.
} 
Estas propriedades constavam em 339 processos, em distribuição temporal indicada na Tabela 2.12, que também apresenta os valores médios e medianos das propriedades, em libras.

Tabela 2.12

Indicadores de preço (libras) das propriedades urbanas

(Iguape, 1800-1880)

\begin{tabular}{|c|c|c|c|c|c|c|}
\hline \multirow{2}{*}{\multicolumn{2}{|c|}{ Faixas anuais }} & \multicolumn{5}{|c|}{ Tipos de propriedade } \\
\hline & & \multirow{2}{*}{$\begin{array}{c}\begin{array}{c}\text { moradas de } \\
\text { casas }\end{array} \\
121\end{array}$} & \multirow{2}{*}{$\begin{array}{c}\begin{array}{c}\text { terrenos urbanos } \\
\text { limpos }\end{array} \\
24\end{array}$} & \multirow{2}{*}{$\begin{array}{c}\begin{array}{c}\text { terrenos urbanos com } \\
\text { alguma construção }\end{array} \\
15\end{array}$} & \multirow{2}{*}{$\frac{\text { outros** }^{* *}}{2}$} & \multirow{2}{*}{$\begin{array}{r}\text { total } \\
162\end{array}$} \\
\hline \multirow{4}{*}{$\begin{array}{c}1800-1840 \\
(80)^{*}\end{array}$} & propriedades & & & & & \\
\hline & média & 56,8 & 10,6 & 13,6 & 34,0 & 45,7 \\
\hline & desvio-padrão & 62,1 & 17,0 & 25,6 & 39,0 & 57,9 \\
\hline & mediana & 35,0 & 4,3 & 5,8 & 34,0 & 29,2 \\
\hline \multirow{4}{*}{$\begin{array}{c}1841-1860 \\
(143)^{*}\end{array}$} & propriedades & 209 & 98 & 23 & 8 & 338 \\
\hline & média & 75,3 & 6,8 & 46,4 & 14,7 & 52,0 \\
\hline & desvio-padrão & 85,9 & 10,8 & 55,0 & 20,5 & 75,9 \\
\hline & mediana & 47,9 & 3,6 & 31,8 & 4,4 & 28,3 \\
\hline \multirow{4}{*}{$\begin{array}{c}1861-1880 \\
(116)^{*}\end{array}$} & propriedades & 210 & 97 & 27 & 8 & 342 \\
\hline & média & 73,8 & 7,3 & 29,0 & 26,9 & 50,3 \\
\hline & desvio-padrão & 83,1 & 11,5 & 39,0 & 36,7 & 73,0 \\
\hline & mediana & 46,0 & 3,1 & 15,7 & 10,4 & 25,3 \\
\hline
\end{tabular}

* número de inventários

** terras, chácaras, construções sem identificação.

Em montante, as moradas de casas sempre representaram cerca de nove décimos do total em cada subperíodo, não obstante a presença significativa de outros tipos de propriedades, como mostra a tabela, porém com pequeno valor agregado. Apesar da diferença entre os valores médios das moradas de casas no primeiro subperíodo em relação aos demais, não é possível afirmar que estas sejam significativas, o mesmo valendo para os valores medianos. Persiste nos três intervalos elevada dispersão em torno da média, evidenciando a coexistência das paredes de meia-água com os sobrados de 5 portas. Notamos ainda um aumento no número de terrenos limpos em relação ao total de inventários em cada intervalo, provavelmente reflexo da expansão do núcleo urbano em direção ao Porto da Ribeira. Conforme relata Roberto Fortes, o caminho foi idealizado em fins da década de 1830. Ainda informa o autor que nessa quadra a Câmara expediu centenas de Cartas de Data concedendo terrenos urbanos a quem se comprometesse a construir casas das moradas (cf. FORTES, 2000, v. II, p. 170-171).

Acerca da qualidade de informação dos preços registrados nos inventários, procedemos à mesma comparação realizada anteriormente entre os valores, em libras, obtidos 
nos inventários e nos registros de pagamento de sisa por compra e venda dos imóveis urbanos, discriminados segundo os dois tipos de propriedades mais freqüentes, conforme apresenta a Tabela 2.13.

Tabela 2.13

Indicadores de preço (libras) das propriedades urbanas nos registros de sisa e inventários

(Iguape, anos selecionados)

\begin{tabular}{|c|c|c|c|c|c|c|c|c|c|}
\hline \multirow{2}{*}{$\begin{array}{c}\text { Tipo de } \\
\text { propriedade }\end{array}$} & \multirow{2}{*}{ faixas anuais } & \multicolumn{4}{|c|}{ sisa } & \multicolumn{4}{|c|}{ inventários } \\
\hline & & $\mathbf{N}$ & média & desvio-padrão & mediana & $\mathbf{N}$ & média & desvio-padrão & mediana \\
\hline \multirow{7}{*}{$\begin{array}{c}\text { moradas de } \\
\text { casas }\end{array}$} & 1834-1839 & 49 & 49,5 & 59,4 & 18,8 & 39 & 72,6 & 81,7 & 40,6 \\
\hline & 1845-1852 & 68 & 42,6 & 57,6 & 22,4 & 101 & 74,2 & 91,0 & 47,9 \\
\hline & $1854-1856$ & 18 & 78,1 & 88,6 & 57,4 & 32 & 98,2 & 79,2 & 77,5 \\
\hline & $1860-1863$ & 65 & 49,3 & 55,3 & 32,3 & 25 & 124,0 & 124,8 & 86,0 \\
\hline & $1866-1873$ & 133 & 50,4 & 85,8 & 26,0 & 83 & 71,2 & 67,4 & 47,0 \\
\hline & $1876-1877$ & 31 & 132,8 & 235,3 & 31,7 & 17 & 72,7 & 45,3 & 63,4 \\
\hline & total & 364 & 57,0 & 99,1 & 24,8 & 297 & 79,9 & 84,8 & 52,5 \\
\hline \multirow{7}{*}{ terrenos } & 1834-1839 & 34 & 4,9 & 10,1 & 2,2 & 25 & 10,9 & 16,7 & 4,1 \\
\hline & $1845-1852$ & 55 & 6,2 & 13,0 & 2,2 & 66 & 14,5 & 35,7 & 4,0 \\
\hline & $1854-1856$ & 9 & 6,2 & 5,2 & 3,7 & 14 & 24,8 & 29,7 & 13,1 \\
\hline & $1860-1863$ & 21 & 7,4 & 13,4 & 4,2 & 14 & 31,7 & 50,9 & 18,8 \\
\hline & $1866-1873$ & 15 & 25,1 & 52,5 & 4,0 & 44 & 10,4 & 12,5 & 4,4 \\
\hline & $1876-1877$ & 2 & 4,6 & 4,3 & 4,6 & 13 & 11,2 & 13,2 & 6,3 \\
\hline & total & 136 & 8,1 & 21,1 & 2,9 & 176 & 14,9 & 29,3 & 4,8 \\
\hline
\end{tabular}

Novamente, os valores médios e medianos das propriedades avaliadas nos inventários superam os praticados nas transações entre os iguapenses. Porém, diferentemente do observado para os bens rurais, não verificamos um movimento conjunto dos preços. Para aqueles bens, registramos uma tendência altista até meados da década de 1860 e que seria retomada no decênio seguinte. Tal comportamento pode ser visto no preço das propriedades presentes nos inventários, porém apresentam padrão diverso nos registros de sisa, especificamente na maior valoração no início da década de 1860 e na retomada ao longo da década posterior, esta última expressa através dos valores medianos. É certo que parte dessas diferenças decorram do próprio perfil dos inventariados: conforme evidenciamos anteriormente, além da maior presença de propriedades rurais, os arranjos mais freqüentes envolviam a posse de um único bem urbano e diversas posses de terras. Como decorrência, esperaríamos um perfil mais conservador na manutenção do imóvel urbano, mesmo em um contexto de expansão do núcleo urbano.

Talvez seja ociosa a recordação de que a posse de bens urbanos não se correlaciona unicamente com o atendimento de necessidades básicas. Ao longo dos séculos XVIII e XIX, a suntuosidade e grandeza destas propriedades traduziam o grau de poder e influência de seus proprietários. Dessa forma o elevado valor médio dos bens inventariados, se comparados com 
os negociados no cotidiano ganha novos contornos, pois traduz o relativo poder das maiores riquezas locais. Nesse sentido, a tabela seguinte distribui os indicadores de preços dos bens urbanos segundo atividades econômicas e ocupações, especificamente para o setor agrícola. Optamos pela redução do número de categorias em função da quantidade de bens apresentados, agrupando todos aqueles que não pertenciam aos setores agrícola e comercial dentro do grupo “demais atividades”.

Tabela 2.14

Indicadores de posse e preço (libras) das moradas de casas

(Iguape, 1800-1880)

\begin{tabular}{|c|c|c|c|c|c|c|c|c|}
\hline $\begin{array}{l}\text { Atividades } \\
\text { econômicas }\end{array}$ & faixas anuais & inventários & propriedades & $\begin{array}{l}\text { posse } \\
\text { média }\end{array}$ & $\begin{array}{l}\text { valor } \\
\text { médio }\end{array}$ & $\begin{array}{l}\text { desvio- } \\
\text { padrão }\end{array}$ & $\begin{array}{c}\text { valor } \\
\text { mediano }\end{array}$ & valor acumulado \\
\hline \multirow{4}{*}{$\begin{array}{l}\text { agricultura e } \\
\text { manufatura } \\
\text { rural }\end{array}$} & $1800-1840$ & 43 & 77 & 1,8 & 96,5 & 162,0 & 51,7 & 4.149 \\
\hline & $1841-1860$ & 73 & 110 & 1,5 & 109,4 & 207,9 & 57,4 & 7.985 \\
\hline & $1861-1880$ & 59 & 82 & 1,4 & 63,5 & 63,2 & 39,0 & 3.746 \\
\hline & total & 175 & 269 & 1,5 & 90,7 & 161,1 & 49,9 & 15.881 \\
\hline \multirow{4}{*}{$\begin{array}{l}\text { engenhos de } \\
\text { arroz }\end{array}$} & $1800-1840$ & 17 & 44 & 2,6 & 150,3 & 227,1 & 55,1 & 2.556 \\
\hline & $1841-1860$ & 23 & 44 & 1,9 & 207,0 & 340,8 & 94,7 & 4.761 \\
\hline & $1861-1880$ & 21 & 32 & 1,5 & 103,7 & 81,3 & 87,4 & 2.177 \\
\hline & total & 61 & 120 & 2,0 & 155,6 & 246,0 & 88,6 & 9.493 \\
\hline \multirow{4}{*}{$\begin{array}{c}\text { demais } \\
\text { atividades } \\
\text { agrícolas }\end{array}$} & $1800-1840$ & 26 & 33 & 1,3 & 61,3 & 88,4 & 37,6 & 1.593 \\
\hline & $1841-1860$ & 50 & 66 & 1,3 & 64,5 & 69,5 & 38,5 & 3.225 \\
\hline & $1861-1880$ & 38 & 50 & 1,3 & 41,3 & 35,6 & 26,8 & 1.569 \\
\hline & total & 114 & 149 & 1,3 & 56,0 & 66,0 & 32,5 & 6.387 \\
\hline \multirow{4}{*}{ comércio } & $1800-1840$ & 15 & 27 & 1,8 & 137,1 & 99,4 & 125,0 & 2.056 \\
\hline & $1841-1860$ & 22 & 51 & 2,3 & 188,2 & 171,2 & 147,0 & 4.141 \\
\hline & $1861-1880$ & 18 & 92 & 5,1 & 506,4 & 443,4 & 371,7 & 9.115 \\
\hline & total & 55 & 170 & 3,1 & 278,4 & 319,4 & 167,9 & 15.312 \\
\hline \multirow{4}{*}{$\begin{array}{c}\text { demais } \\
\text { atividades }\end{array}$} & $1800-1840$ & 16 & 17 & 1,1 & 41,4 & 51,9 & 25,6 & 663 \\
\hline & $1841-1860$ & 36 & 48 & 1,3 & 100,5 & 130,8 & 70,8 & 3.616 \\
\hline & $1861-1880$ & 27 & 36 & 1,3 & 97,9 & 113,8 & 52,1 & 2.643 \\
\hline & total & 79 & 101 & 1,3 & 87,6 & 114,3 & 47,9 & 6.923 \\
\hline \multirow{4}{*}{ total } & $1800-1840$ & 74 & 121 & 1,6 & 92,8 & 136,1 & 45,6 & 6.868 \\
\hline & $1841-1860$ & 131 & 209 & 1,6 & 120,2 & 185,0 & 72,8 & 15.743 \\
\hline & $1861-1880$ & 104 & 210 & 2,0 & 149,1 & 255,3 & 58,0 & 15.505 \\
\hline & total & 309 & 540 & 1,7 & 123,4 & 202,7 & 57,4 & 38.116 \\
\hline
\end{tabular}

Em valores absolutos, os agricultores detinham a maior quantidade de casas, somando praticamente metade dos 540 registros encontrados nos inventários. Dentre eles, os proprietários de engenhos de arroz, apesar de representarem 35\% dos inventários, possuíam 
45\% dos imóveis, porém com participação decrescente, conforme indica a posse média nos três subperíodos. Distintamente, comerciantes apresentaram a posse média crescente, de tal forma que, no total, os 55 inventários (18\% do total de casos) continham 31\% dos imóveis, cabendo às demais atividades cerca de 19\% das propriedades, com posse média assemelhada aos demais agricultores, isto é, a maioria dos casos continha apenas uma morada de casas.

Com relação aos valores, a tendência de crescimento dos preços médios ao longo dos subperíodos, observada no cômputo geral, não se reproduz nos estratos. Exceto para os imóveis pertencentes aos comerciantes, com preços médios crescentes, todos apresentam uma elevação entre os dois primeiros subperíodos e redução deste para o terceiro intervalo, movimento também reproduzido nos valores medianos. Possivelmente poder-se-ia alegar que os segmentos com menor número médio de propriedades também teriam o fator agravante do fracionamento desses bens, resultado de sucessivas partilhas do mesmo bem ao longo das gerações. À luz do evolver econômico descrito no capítulo precedente, tudo leva a crer que, além dos fatores relacionados ao processo sucessório, os proprietários vinculados ao setor agrícola - especialmente aqueles que auferiam ganhos através do beneficiamento do arroz atingiram elevado grau de opulência no subperíodo intermediário, marcado pelas boas safras e volumes expressivos de exportação; com a perda de dinamismo do setor, apenas conseguiam manter a posse das residências urbanas tendo o tempo como fator de deterioração destas propriedades.

A dessemelhança dos comerciantes não reside apenas no número médio de posses ou nos crescentes valores médios e medianos, que no terceiro subperíodo se distanciam totalmente dos demais segmentos econômicos. A maior dispersão em torno da média, como indica o desvio-padrão, sugere que os elevados valores médios resultam de alguns poucos imóveis com elevado valor e um conjunto de pequenas propriedades. No Capítulo 5 abordaremos este perfil com maior atenção, porém destacamos que dos 15 proprietários com dez ou mais propriedades urbanas, 12 possuíam casas de comércio, um era proprietário de engenho, outro agricultor e um advogado. Oito desses inventários pertencem ao último subperíodo e os demais ao intervalo entre 1841 e 1860, exceto os dois casos vinculados à atividade agrícola: o proprietário de engenho de arroz, Bento Pupo de Gouveia, datado de 1833 e o de Joaquina Maria de Jesus, esposa do agricultor Joaquim Pio Pupo, de 1836, aliás, filho de Bento Pupo de Gouveia. 
Uma outra forma de analisar a importância dos bens urbanos consiste na sua distribuição espacial pelas ruas da cidade. Para tanto, selecionamos 11 dos logradouros com maior número de ocorrências, que se encontram representados na Figura 2.2. ${ }^{134}$

Figura 2.2

Distribuição e localização das propriedades urbanas

(Iguape, 1800 a 1880)

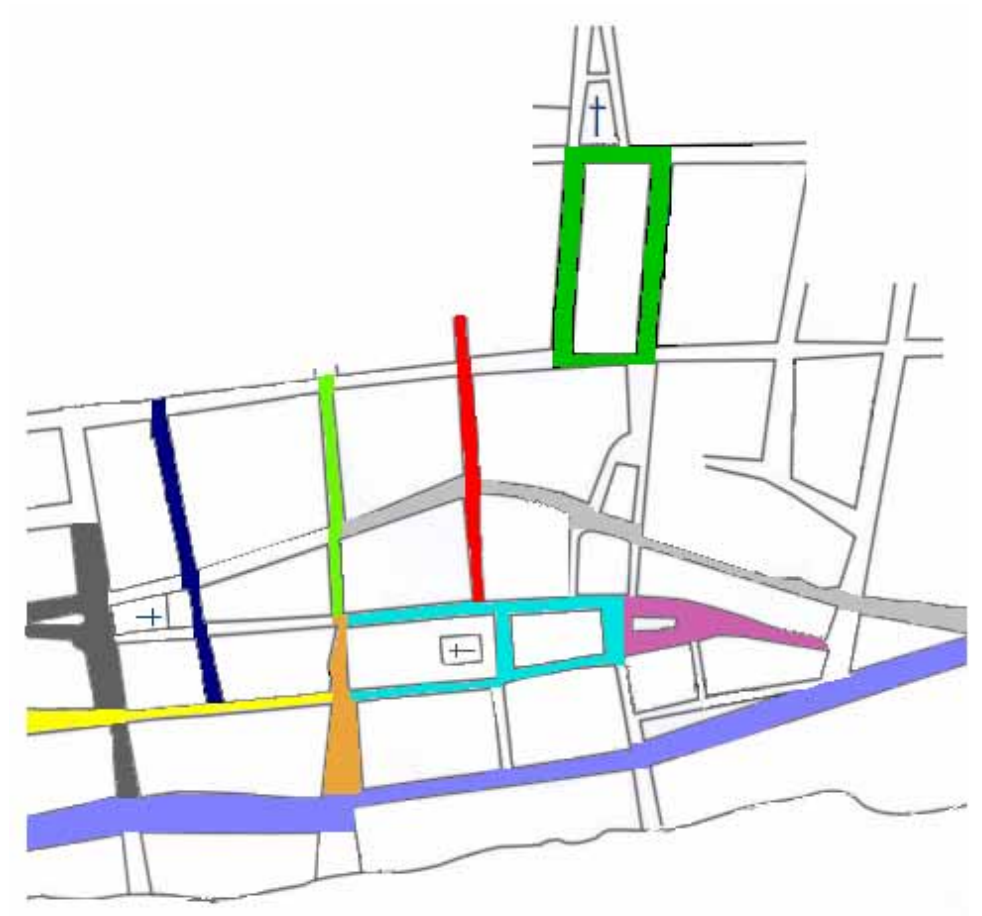

\begin{tabular}{|l|rc|rc|rc|}
\hline \multirow{2}{*}{ Localização } & \multicolumn{2}{|c|}{$\mathbf{1 8 0 0 - 1 8 4 0}$} & \multicolumn{2}{|c|}{$\mathbf{1 8 4 1 - 1 8 6 0}$} & \multicolumn{2}{|c|}{$\mathbf{1 8 6 1 - 1 8 8 0}$} \\
\cline { 2 - 7 } & casas & terrenos & casas & terrenos & casas & terrenos \\
\hline Largo de São Francisco & 4 & 2 & 4 & 8 & 5 & 7 \\
Rua da Glória & 15 & 1 & 29 & 3 & 22 & 2 \\
Rua do Funil & 8 & - & 11 & 3 & 26 & 4 \\
Rua do Mar & 18 & 6 & 29 & 2 & 5 & 5 \\
Largo da Matriz & 1 & - & 4 & - & 15 & - \\
Travessa das Dores & - & 4 & 4 & 3 & 7 & 4 \\
Rua da Palma & - & - & 17 & 1 & 21 & 3 \\
Rua das Dores & 1 & - & 1 & 11 & 9 & 9 \\
Rua Direita & 5 & 2 & 27 & 21 & 22 & 20 \\
Rua do Campo & 13 & 3 & 13 & 6 & 3 & 1 \\
Rosário & 1 & 4 & 9 & 5 & 18 & 15 \\
\hline
\end{tabular}

Do diagrama acima, notamos que a Rua Direita, Rua da Glória e Rua do Mar predominavam, com 45\% das ocorrências, porém em momentos distintos ao longo das oito décadas consideradas. Entre 1800 e 1840, as casas concentravam-se principalmente nas ruas do Mar, Glória e do Campo, ao passo que os terrenos encontravam-se espalhados em vários

${ }^{134}$ A reconstituição dos antigos logradouros baseia-se nos informes apresentados por Roberto Fortes (cf. FORTES, v. II, 2000, p. 169-190) e a representação das ruas abrange parte do atual Centro Histórico da cidade de Iguape. 
logradouros. As edificações na Rua do Mar possuíam maior valor médio ( $£$ 80), porém o maior valor mediano ( $£$ 52) pertencia à Rua do Campo. No subperíodo seguinte ainda predominavam as ruas da Glória e do Campo, porém a Rua Direita emergia como terceiro local com maior quantidade de casas inventariadas, além de possuir valor médio superior ( $£$ 102 contra $£ 68$ e $£ 52$, respectivamente).

Entre os terrenos, a Rua Direita concentrava um terço dos casos observados; esta rua manteria a posição de liderança no intervalo final, acompanhada de perto pelo complexo do Rosário, porém com diferença significativa no valor médio dos terrenos: no intervalo entre 1841 e 1860, os terrenos da Rua Direita valiam, em média, $£ 21$ contra apenas $£ 4$ no subperíodo seguinte. Mesmo o valor mediano reduzir-se-ia à metade, de $£ 4$ para $£ 2 .{ }^{135}$ Como comparação, os terrenos no Rosário valiam $£ 25$, em média e era de $£ 11$ o valor mediano. Entre as casas, as ruas da Glória e Direita ainda possuíam quantidade importante desse tipo de bem, mas a Rua do Funil detinha o maior número de residências, todos com valores médios em torno de $£$ 70. Ademais, a conclusão das obras da nova igreja deu novo impulso às construções no Largo da Matriz, com 15 residências inventariadas entre 1861 e 1880 e com preço médio de $£ 113$, bem acima do valor geral do período ( $£$ 73) e só menor do que os verificados no Largo de São Francisco, cujo número de imóveis presentes nos inventários manteve-se relativamente baixo (13 no total), mas com os maiores valores médios e medianos nos dois últimos subperíodos. Os comerciantes constituíam os principais proprietários destes imóveis de mais alto valor, aparentemente construídos no auge da economia ribeirense, entre as décadas de 1840 e 1860 . Porém, alguns proprietários de engenhos também possuíam casas nestas duas paragens, todavia avaliadas por menores preços.

Em síntese, o principal resultado a ser retido relaciona o dinamismo econômico da região com uma mudança no arranjo urbano, envolvendo não apenas a expansão da área ocupada como também a incorporação de um novo padrão imobiliário, ressaltando as diferenças de apropriação da riqueza entre os dois principais segmentos beneficiários da cultura do arroz. Uma outra indicação destas alterações pode ser verificada através do pagamento das sisas: no intervalo entre 1841 e 1860, as 100 transações envolvendo casas valeram, em média, $£ 47$ contra $£ 63$ nos 215 registros pertencentes ao intervalo seguinte. ${ }^{136}$

\footnotetext{
${ }^{135}$ Esta mudança parece associada a dois fatores: a redução da testada dos lotes e a maior distância do terrenos em relação às demais ruas indicadas na Figura 2.2.

${ }^{136} \mathrm{O}$ valor mediano passou de $£ 22$ para $£ 28$. Os terrenos passaram, em média, de $£ 6$ para $£ 14$ e o valor mediano dobrou de $£ 2$ para $£ 4$.
} 
Entre 1841 e 1860, 82 das 165 compras foram feitas por pessoas que realizaram um único negócio e, no outro extremo, oito compradores concluíram quatro compras ou mais, representando pouco mais de um quinto dos negócios envolvendo casas e terrenos. ${ }^{137}$ Entre os vendedores, 113 apareceram uma única vez e dois casos destacam-se por realizarem seis vendas: Joaquim Manoel Junqueira e José Antonio dos Santos Prado, ambos falecidos. Apenas o inventário do segundo consta entre os arrolados nesta investigação; Prado faleceu em 1845 e entre os bens avaliados constavam oito bens de raiz, todos urbanos: três moradas de casas e cinco terrenos. As vendas foram registradas entre 1848 e 1851 e referem-se a cinco das oito propriedades inventariadas, sendo três delas arrematadas em praça pública. As propriedades foram avaliadas em Rs. 1:780\$000 e vendidas por Rs. 880\$000, isto é, uma redução de praticamente 50\%. A principal diferença residia na morada de casas na Rua da Fonte, avaliada por Rs. 1:400\$000 e vendida por Rs. 532\$000, adquirida por Filadelfo de Souza Castro, que também adquiriu do mesmo falecido outros dois lotes de terrenos na Rua da Palma, justamente os três bens encaminhados para arrematação. ${ }^{138}$

O subperíodo seguinte guarda semelhança em relação ao perfil geral de compradores e vendedores: 53\% das 252 compras foram realizadas por pessoas que executaram um único negócio e novamente os comerciantes se destacavam entre aqueles com mais de uma compra. ${ }^{139}$ Entre os vendedores, os que compareceram uma única vez correspondiam a três quartos das vendas; outros 20 realizaram mais de uma venda e João Mâncio da Silva Franco, que também constava entre os principais compradores, realizou sozinho 10 destas transações. ${ }^{140}$ Um outro vendedor, Joaquim de Souza Castro, teve todas as seis transações registradas nos dias 13 e 15 de abril de 1863, assim como quatro das cinco vendas realizadas por João Francisco Mendes, em 24 e 25 de novembro de 1862.

Conforme veremos ao longo dos demais capítulos, esta maior importância assumida pelos comerciantes dentro do espaço urbano de Iguape possui rebatimento na economia regional, especialmente a partir da segunda metade do século XIX. Ao enfocarmos o perfil dos bens de raiz pertencentes aos ribeirenses, delimitamos o perfil de uma parte importante de sua riqueza acumulada. A outra parcela - os escravos - será abordada no capítulo seguinte.

\footnotetext{
137 O número máximo, seis transações, corresponde aos negócios feitos pelos comerciantes Antonio José Gonçalves e Filadelfo de Souza Castro. Com cinco transações, encontramos João Mâncio da Silva Franco, José Bonifácio de Andrada, José Carlos de Toledo, José Ferreira de Aguiar e Silva e Manoel Joaquim Martins, todos negociantes, e uma certa Claudina Julia, que não pudemos identificar.

${ }^{138}$ MHAI, caixa n. ${ }^{\circ}$ 202. A arrematação foi solicitada pela viúva para a liquidação das dívidas passivas do inventário.

${ }^{139}$ Os principais nomes foram José Ferreira da Silva, com 10 compras, João Mâncio da Silva Franco, com 9 e Francisco de Souza Silveira Gatto, com 7 aquisições.

${ }^{140}$ Não foi possível estabelecer uma associação entre os imóveis comprados e vendidos por Silva Franco.
} 


\section{ESTRUTURA DA POSSE DE ESCRAVOS NO VALE DO RIBEIRA}

O contingente escravo no Vale do Ribeira conheceu um expressivo crescimento entre fins do século XVIII e o primeiro terço da centúria seguinte. Conforme apresentamos no Apêndice deste trabalho, em Iguape a população cativa passou de 612 pessoas em 1789 para 2.035 em 1836 e em Xiririca, no mesmo período, de 265 para 523. Assinalamos também que a fase mais intensiva desse crescimento ocorreu entre 1801 e 1828. Segundo os dados do censo de 1854, Iguape possuía 4.720 escravos e Xiririca, 871. Daí até 1874, este contingente apresentou uma redução substancial, principalmente em Iguape, atingindo 1.575 pessoas; em Xiririca, o número de cativos somava 829 pessoas. Acompanhando os resultados expostos nos capítulos anteriores, as variações acima descritas guardam estreita relação com o próprio evolver econômico regional marcado pela forte expansão da rizicultura nas primeiras décadas do Oitocentos e a estagnação após os anos de 1850.

Apresentamos o perfil da estrutura da posse desses cativos em dois blocos. O primeiro privilegia o intervalo coberto pelas listas nominativas, privilegiando os anos de 1801, 1815, 1828 e 1836. Na segunda parte do capítulo, exploramos os dados obtidos nos inventários post-mortem, seguindo a divisão cronológica já adotada nos antecessores.

\section{Estrutura de posse nas listas nominativas (1801-1836)}

Nossa investigação privilegia a estrutura da posse de escravos em Iguape e Xiririca no primeiro terço do século XIX de forma desagregada para a vila e a freguesia e cotejada com outras localidades paulistas. Para tanto, utilizamos os dados fornecidos por Francisco Vidal Luna, José Flávio Motta, Renato Leite Marcondes e Ramón Vicente Garcia Fernández.

O trabalho de Luna é o mais amplo de todos, posto que abrange 25 localidades paulistas em três momentos distintos (1777, 1804 e 1828), lapso de tempo que percorre desde o chamado “renascimento agrícola” até a franca especialização de algumas regiões em cultivos voltados para a exportação. ${ }^{141}$

Do conjunto das conclusões apresentadas pelo autor, obtemos um quadro bastante diversificado da economia paulista. Luna ressalta a importância do Oeste Paulista, região que se consolidou economicamente através do processamento de cana e que apresentava a maior

\footnotetext{
${ }^{141} \mathrm{O}$ autor distribuiu as localidades em regiões, que em 1829 abrangiam o Vale do Paraíba (Areias, Cunha, Guaratinguetá, Jacareí, Lorena, Pindamonhangaba e São Luis do Paraitinga), Região da Capital (Atibaia, Cotia, Guarulhos, Mogi da Cruzes e São Paulo), o Oeste Paulista (Campinas, Itapeva, Itu, Jundiaí, Mogi Mirim e Porto Feliz), o Caminho do Sul (Curitiba, Itapetininga e Sorocaba) e o Litoral (Cananéia, Iguape, Santos e São Sebastião) (cf. LUNA, 1998, p. 163).
} 
concentração de escravos no período estudado. O Vale do Paraíba também possuía atividade açucareira importante, porém o café já demonstrava força, principalmente na vila de Areias. Em outras grandes áreas da Capitania ocorria ainda a produção de aguardente, pecuária e cultivos de arroz, feijão, milho e mandioca.

Parcela expressiva da população, livre e escrava, continuava dedicada e esses produtos, que representariam não só fonte de alimentos para essas populações, como também a principal alternativa de renda (LUNA, 1998, p. 160).

A presença de escravos nos domicílios estudados atingia cerca de $20 \%$ a $25 \%$ dos casos, tanto nas regiões de produção de açúcar e café como nas demais áreas. Desse conjunto, predominavam os pequenos escravistas, principalmente os que detinham posses unitárias. Destarte, os valores médios de posse oscilavam de 3 a 5 cativos em regiões de subsistência até 9 no Vale do Paraíba e 15 no Oeste Paulista (cf. LUNA, 1998, p. 160).

Das localidades paulistas especificamente selecionadas, apenas em Bananal predominava a agricultura de subsistência no início do século XIX. Desligada do cultivo da cana, José Flávio Motta verificou que, durante as três primeiras décadas da centúria, o amaino da rubiácea apresentou significativa expansão. Em 1829, 52\% dos fogos e 76\% da população total cultivavam o café, atingindo seu apogeu entre as décadas de 1850 e 1870 (cf. MOTTA, 1999, p. 47 e seguintes). Em Lorena, também localizada no Vale do Paraíba, predominava, em fins do século XVIII, o cultivo de cana e, ao longo do período coberto pelas listas nominativas, esta cultura manteve significativa importância, não obstante a crescente relevância do café como lavoura alternativa (cf. MARCONDES, 1998, p. 35-49).

Os povoamentos do Litoral Norte paulista - tão ancestrais quanto a vila de Iguape ganharam importância com a descoberta de metais preciosos nas Minas Gerais, tornando-se uma das rotas de saída das riquezas em direção à Metrópole portuguesa. No bojo dos incentivos implementados após a restauração administrativa da Capitania paulista, além de se tornar um porto importante para o escoamento de produtos oriundos das terras planaltinas, na própria faixa litorânea prosperou o cultivo da cana. No entanto, as restrições comerciais impostas ao comércio marítimo em fins do século XVIII promoveram a desarticulação tanto das rotas comerciais como das práticas agrícolas. Em Ubatuba, a partir da década de 1820, constatou Ramon Fernández o expressivo aumento do cultivo do café, propiciando a retomada do dinamismo verificado no limiar da centúria anterior (cf. FERNÁNDEZ, 1992, p. 50-68).

Uma análise pormenorizada da estrutura de posse de escravos no Vale do Ribeira deve levar em consideração a existência de proprietários e cativos em períodos prévios, associados a outras formas econômicas que não a rizicultura. No caso de Iguape, destacamos 
a importância dos artesões construtores de embarcações, estabelecidos na faixa litorânea. A freguesia de Xiririca, exaurida a pequena extração aurífera praticada na segunda metade do século XVIII, adquiriu um perfil essencialmente agrário e mais variado do que o observado em Iguape que, antes dos arrozais, possuía uma produção agrícola essencialmente assentada no cultivo de mandioca. Dessa forma, a dinâmica imposta pelo novo cultivo fez-se assentada sobre esta estrutura, que possuía como principais traços a predominância dos pequenos plantéis e a distribuição pouco concentrada dessas posses, conforme indicam os resultados sintetizados na Tabela 3.1

Tabela 3.1

Indicadores da posse de escravos no século XVIII

(Iguape e Xiririca, anos selecionados)

\begin{tabular}{lcccccccc}
\hline Localidade & ano & proprietários & escravos & média & mediana & moda & índice de Gini & razão de sexo \\
\hline Iguape & 1765 & 82 & 391 & 4,7 & 3 & 1 & 0,408 & - \\
Iguape & 1778 & 84 & 387 & 4,6 & 4 & 1 & 0,404 & 88,7 \\
Iguape & 1789 & 140 & 610 & 4,4 & 3 & 1 & 0,440 & 103,0 \\
Xiririca & 1765 & 33 & 161 & 4,9 & 3 & 1 & 0,434 & - \\
Xiririca & 1777 & 39 & 208 & 5,3 & 2 & 1 & 0,585 & 128,1 \\
Xiririca & 1789 & 36 & 263 & 7,3 & 4 & 1 & 0,587 & 130,7 \\
\hline
\end{tabular}

Em Iguape, entre 1765 e 1778, não notamos variações importantes tanto no número de proprietários como no de escravos, apresentando ainda no último ano uma razão de sexo que indicava a preponderância das mulheres entre os cativos. Tais sinais traduzem não apenas uma relativa estabilidade, mas também a impossibilidade ou desinteresse por parte dos iguapenses na aquisição de escravos. Já a lista de 1789 evidencia mudanças, traduzidas por uma forte expansão tanto na quantidade de escravistas como de cativos, não obstante a manutenção dos indicadores de posse. A ampliação do número de proprietários e escravos possivelmente guarda relação com a instalação dos estaleiros na região. Apesar de o primeiro registro transcrito de construção de uma nau nas cercanias de Cananéia datar de $1711,{ }^{142}$ o auge desta atividade ocorreu entre 1761 e o primeiro terço do século seguinte. Nas palavras de Almeida,

\footnotetext{
142 "Este foi o ano em que chegaram os construtores para a dita nau, sendo vindo do Rio de Janeiro. Seu estaleiro foi o mesmo profetizado lugar, o qual ainda hoje se apelida - estaleiro da Nau. Juntaram-se jornaleiros para o serviço e trabalho dela. Trabalhou-se na sua construção um ano. Havia pagamento na semana, com dinheiro e fazendas. Não houve naquele ajuntamento infelicidade mais sentida do que morrerem afogados o contra-mestre do aparelho e o piloto, que passavam de passagem da terra firme para a sua banda, na condução de seus mastaréus. Esta, julgo, foi a primeira obra naval aqui fabricada. Acabou-se a nau. Repicaram-se os sinos. Celebrou-se missa. Lançou-se ao mar com felicidade e com ela se navegou até Lisboa, onde naquela corte por sua naturalidade teve o nome de 'Nau Cananéa”' (ALMEIDA, 1948, p. 11). O trecho transcreve anotações do livro "Memórias memoráveis" da Câmara de Cananéia. Antes de Almeida, Benedito Calixto já havia feito referência a este documento (cf. CALIXTO, 1915, p. 656)
} 
A decadência da vila começou do princípio do século XIX em diante, tendo sido a última embarcação lançada ao mar, o veleiro 'Conceição Feliz' de que fora construtor José Gomes da Silva. Esse fato ocorreu em 1834 (ALMEIDA, 1948, p. 18, nota n. ${ }^{\circ} 1$ ).

Benedito Calixto apresenta a reprodução de um mapa realizado em fins do século XVIII que indicava a existência de 6 estaleiros em Cananéia e outros 6 em Iguape: ${ }^{143}$

(...) um à margem direita do rio Subauma; outro ao lado esquerdo da vila de Iguape, outro à margem esquerda da Ribeira em frente à lagoa ou furado do Pasto; outro na foz do rio Peroupava, e dois ainda nas margens do rio Una da Aldeia, sendo o primeiro à margem esquerda, na embocadura, e o segundo à margem direita, além da barra do rio das Areias (CALIXTO, 1915, p. 657) ${ }^{144}$

Relembramos aqui a importância relativa desses artesãos em 1801: além de madeireiros e lenhadores que correspondiam a 11\% dos fogos iguapenses, a inclusão de calafates, canoeiros e carpinteiros elevava a participação a praticamente 19\% das unidades e mais de $16 \%$ dos cativos. Provavelmente a parcela vinculada a estas atividades em 1789 deveria sobrepujar estas marcas e, adiantamos que parte dos artesãos presentes na lista de 1801 migrou para as atividades rizicultoras.

Uma inspeção nas listas de 1789 e 1801 constatou a presença de 62 escravistas comuns nos dois anos: ${ }^{145} 27$ aumentaram suas posses, 12 mantiveram o mesmo plantel e 23 conheceram redução no número de escravos possuídos, de tal forma que o número total de escravos envolvidos nos dois anos pouco se modificou: 317 em 1789 e 312 em 1801. Alguns dos escravistas com maior projeção no primeiro terço do Oitocentos já viviam na região em 1789, como José Antonio Peniche, ${ }^{146}$ que em 1789 possuía 8 escravos e, em 1801, 21 ou Bento Pupo de Gouveia, cuja posse passou de 1 para 14 escravos e ainda Lourenço Lopes

\footnotetext{
${ }^{143}$ Nas transcrições do autor das memórias da Câmara de Cananéia, cita-se o ano de 1761 como o do início das construções navais e “(...) diz ele que Alexandre de Souza Guimarães, natural da Europa e mais tarde capitãomor de Cananéia, foi o primeiro construtor naval, tendo feito uma sumaca da qual foi dono o sargento-mor Francisco Gayo da Camara, natural da Ilha de São Miguel. Neste estaleiro aprenderam o ofício muitos indivíduos que viviam até então na miséria; e deles saíram mais de 200 navios, quer durante a administração do fundador, quer sob a gerência de seu genro e sucessor, o sargento-mor Joaquim José da Costa" (CALIXTO, 1915, p. 685).

${ }^{144}$ Ainda relata Calixto que mantinha seu estaleiro em funcionamento na segunda metade do século XIX Antonio dos Anjos, instalado no rio Una da Aldeia, tendo ali fabricado o patacho "Dois Irmãos", que conduzia para o Rio de Janeiro o arroz colhido no Vale. Segundo os registros de movimentação portuária, o patacho "Dois Irmãos”, entre 1857 e 1869, pertencia ao próprio fabricante Antonio dos Anjos Silva. Em 1868, José Francisco de Paula e Silva comprou dois terços do patacho "Dois Irmãos" a Francisco da Silva Rocha e Antonio Joaquim Vieira Pau d'Alho por Rs. 666\$666 cada parte. No inventário de Henrique Pinto da Costa, aberto em 1873, constava a posse de metade do patacho "Dois Irmãos", avaliado em Rs. 2:000\$000.

${ }^{145}$ Utilizamos apenas o nome do escravista como referência, excluindo dessa forma casos de transferência da posse para cônjuges e/ou herdeiros.

${ }^{146}$ É possível que José Antonio Peniche tenha relações de parentesco com João Jorge Peniche, Capitão-mor da vila de Cananéia em 1776, ambos originários da localidade portuguesa de Peniche, no distrito de Leiria, região marítima de construção de embarcações. Da mesma forma que João Jorge, José Antonio Peniche também alcançou o cargo de Capitão-mor em Iguape, permanecendo nele até seu falecimento, provavelmente em 1831.
} 
Trigo, um dos primeiros proprietários de engenho de arroz, que expandiu seu plantel de 8 para 12 escravos.

Em Xiririca notamos que, apesar da relativa constância no número de proprietários, a quantidade de escravos manteve-se em crescimento desde 1765, como bem mostram os ascendentes valores médios. Ademais, como sugere a elevação no índice de Gini entre 1765 e 1777 e a sua manutenção em 1789, esta incorporação de cativos ocorreu de forma diferenciada entre os escravistas, possibilitando maior acúmulo por parte de alguns deles. Tais resultados provavelmente decorreram dos ganhos obtidos pela lida aurífera na região. Dentre os poucos inventários preservados desse período no Museu Histórico e Arqueológico de Iguape, dois deles mencionam o arraial de Ivaporunduva, localizada na freguesia e principal local de onde se extraía o ouro. Nos dois casos percebemos o enriquecimento e a expansão da posse escrava. $^{147}$

Um dos mineradores, Joaquim Machado de Moraes, faleceu no Rio de Janeiro em 1794 e seu inventário foi aberto pela viúva Arcângela de Almeida e Silva em março do mesmo ano. Entre os bens avaliados, destacam-se os dois bens de raiz (uma morada de casas na freguesia de Xiririca, avaliada em Rs. $12 \$ 800$ e uma lavra em Ivaporunduva, com preço de Rs. 71\$680), 24 escravos a Rs. 1:245\$000, ferramentas e móveis, resultando tudo em Rs. 1:709\$200. Quando computadas as dívidas passivas de Moraes (Rs. 2:120\$367) a partilha resultou em prejuízo aos credores. ${ }^{148}$ Desde 1765, Joaquim Machado de Moraes, então com 40 anos, habitava o bairro de Ivaporunduva, possuindo naquela época 14 escravos. Na lista de 1776, encontramos Joaquim Machado com 48 anos e proprietário de 24 escravos. Em 1789, aos 61 anos, morava na freguesia de Xiririca e era casado com Arcângela da Silva, 39 anos, com quem possuía 8 filhos e 31 escravos, o segundo maior plantel naquele ano. ${ }^{149}$ Entre 1789 e 1794 ocorreu uma sensível redução no número de escravos e, após a morte de Joaquim, muitos deles provavelmente foram vendidos para o pagamento das dívidas. Em 1801, o

\footnotetext{
${ }^{147}$ Tal assertiva baseia-se, além das observações anteriores, nos dados oferecidos por Antonio Paulino de Almeida acerca da presença, em Xiririca, no ano de 1766, de 21 mineradores proprietários de escravos, que detinham a posse de 269 cativos (cf. ALMEIDA, 1955, p. 46-47).

${ }^{148}$ MHAI, caixa n. ${ }^{\circ} 195$.

${ }^{149}$ A maior propriedade pertencia a João Dias Baptista, também de Xiririca, com 34 escravos. Outro plantel com 31 escravos, também de Xiririca, pertencia a João Manoel de Siqueira, casado com Joana Maria da Costa. Segundo reza a tradição oral, a atual comunidade negra naquela paragem vincula-se a Joana Maria: "Segundo relatos dos moradores e registros no Livro de Tombo, as terras de Ivaporunduva foram doadas por Joana Maria aos escravos que a serviram, contemplando-os também com a liberdade ao morrer". Ainda consta que "Joana Maria, mineira de origem, chegou ao arraial casada com o português André de Souza. Por falecimento do primeiro marido casou-se com o também português João Marinho e, pela segunda vez viúva, casou-se com o mineiro João Manuel de Siqueira Lima" (ANDRADE et. alli., 2000, p. 67). Em 1801, Joana Maria, 91 anos, viúva, parda, natural de Mariana, constava como moradora em Ivaporunduva com 2 escravos e 18 agregados, todos pretos.
} 
domicílio xiririquense chefiado pela viúva Arcângela da Silva, 47 anos, natural de Cananéia, compunha-se por 6 filhos e 7 escravos, porém nenhum deles constava entre os avaliados no inventário. Segundo a anotação do recenseador, aquele fogo se dedicava ao cultivo de arroz.

Um outro inventário mais antigo, o de Joaquim Morato do Canto, também mencionava o arraial de Ivaporunduva. No processo, aberto em 1770 pela viúva Rosa de Toledo Piza, afirma-se que lá se encontravam 4 dos 10 escravos avaliados, além de várias ferramentas, porém não constava a presença de lavras ou terras entre os bens de raiz. O monte-mor somou Rs. 726\$760, sendo 62\% representados pelo valor atribuído aos escravos. ${ }^{150}$ Os dois casos indicam a preferência dos escravistas pelo local, mas Ivaporunduva representava apenas uma parcela da freguesia, cuja ocupação se irradiava ao longo das margens do rio Ribeira em ambas as direções, possivelmente movidos pelo anseio de novas descobertas. Assim habitadas, as terras ribeirinhas ganharam nova importância com a multiplicação das lavouras de arroz.

No contexto da Capitania paulista, o Vale do Ribeira não guardava nenhuma característica peculiar: Francisco Vidal Luna observou que, entre 1777 e 1804, a taxa anual de crescimento da população escrava nas localidades paulistas igualou-se a 2,3\%; em Iguape esta taxa atingiu 2,7\% e, na freguesia, 0,9\% (cf. LUNA, 1998, p. 104). ${ }^{151}$ No período, o Oeste paulista expressou valor distinto da taxa global, com crescimento em torno de 4,4\% ao ano. ${ }^{152}$ Em 1777, o autor assinala que 81\% dos proprietários de escravos pertenciam ao sexo masculino, praticamente todos brancos e, entre os homens, partes iguais se distribuíam entre as idades de 30 a 49 anos e 50 anos ou mais (45\%), restando 10\% aos jovens escravistas,

\footnotetext{
${ }^{150}$ MHAI, caixa n. ${ }^{\circ} 197$.

${ }^{151}$ As localidades selecionadas para o referido ano foram: Guaratinguetá, Jacareí, Pindamonhangaba, São Luis do Paraitinga, Atibaia, Cotia, Guarulhos, Mogi das Cruzes, São Paulo, Itapeva, Itu, Jundiaí, Mogi Mirim, Curitiba, Itapetininga, Sorocaba, Santos e São Sebastião.

152 "No Oeste Paulista o crescimento dos escravos alcançou 3,9\% ao ano entre 1777 e 1829, com 4,4\% no primeiro período e 3,3\% no segundo. Os números demonstram excepcional expansão, particularmente no último quartel do século XVIII, pelo alargamento da atividade açucareira: mesmo em 1829, a cafeicultura ainda se mostrava pouco expressiva na região, que possuía importantes núcleos açucareiros como Campinas, Itú e Porto Feliz" (LUNA, 1998, p. 106.). Sobre a região litorânea, onde se inserem as localidades aqui estudadas, afirma o autor: "Considerado o período - 1777/1829 - esta área mostrou crescimento populacional relativamente baixo, principalmente entre os livres, com taxa anual de 1,2\%. Entretanto, pode-se identificar nessa região dois períodos distintos. No primeiro, até 1804, tanto escravos como livres expandiram-se a taxas significativas, em particular os cativos, cujo porcentual de aumento médio anual alcançou 2,3\%. Entretanto, entre 1804 e 1829 , a região apresentou baixo crescimento populacional, com taxa anual da ordem de 0,5\%, sendo pior o desempenho dos escravos, com apenas 0,2\% ao ano no período (...) Da região faziam parte áreas bastante distintas como o litoral norte (São Sebastião), a região de Santos, com seu porto e o litoral sul da Capitania (Cananéia e Iguape). Se tomarmos cada uma das áreas isoladamente talvez encontremos mais diferenças do que as verificadas entre as localidades das demais regiões” (LUNA, 1998, p. 108). De fato, conforme será visto ao longo do texto, a dinâmica populacional descrita por Vidal Luna sofre influência das localidades do litoral norte e santista, tanto no primeiro período como no segundo, não servindo de referência para o comportamento das localidades do litoral sul.
} 
sendo casados $85 \%$ dos casos. No caso das escravistas, 3 em cada 5 proprietárias possuíam 50 anos ou mais e metade delas eram viúvas (cf. LUNA, 1998, p. 114).

No Vale do Ribeira, um perfil dos proprietários pode ser assim retratado: 89\% pertenciam ao sexo masculino e detentores de 93\% dos escravos, 50,2 anos em média e, dentre aqueles com condição conjugal referida, predominavam os casados (93\%). ${ }^{153}$ Ademais, diferenciam-se os proprietários iguapenses pela menor presença relativa de escravistas com menos de 30 anos (4\% dos proprietários do sexo masculino, todos da vila de Iguape) contra 10\% na Capitania, segundo o mesmo autor.

Dentro da baixa diferenciação observada por Vidal Luna para o ano de 1777 em várias localidades paulistas, os indicadores estatísticos da posse de escravos em Iguape posicionavam-se aquém dos valores gerais: a média geral igualou-se a 5,2 escravos por proprietário e o índice de Gini atingiu 0,489, contra 4,6 em Iguape e 5,3 em Xiririca, com índices de Gini iguais a 0,404 e 0,585, respectivamente (cf. LUNA, 1998, p. 149). Esse conjunto preliminar de dados sugere que, não obstante as eventuais alterações resultantes das dinâmicas locais, estas não guardavam correspondência com o processo iniciado na década anterior com o intuito de ampliar a capacidade agrícola da Capitania. ${ }^{154}$ Esta exceção vale especialmente para Xiririca, onde a extração de ouro se revelou responsável pelo incremento na quantidade de cativos e nos indicadores estatísticos.

Portanto, as condições prévias para o desenvolvimento da rizicultura se colocam de forma distinta nas duas regiões aqui estudadas: em Iguape, além da localização que permitia maior fluxo de moradores e produtos, as atividades dos artesãos envolviam necessariamente contatos com outros centros portuários, notadamente Santos e Rio de Janeiro, facilitando o desenvolvimento de redes comerciais que tanto absorviam a produção de embarcações e o

\footnotetext{
${ }^{153}$ Para 18 proprietários não há informe sobre a idade, e para 88 deles não são conhecidas informações acerca do estado conjugal, correspondendo praticamente à totalidade dos escravistas de Iguape.

${ }^{154}$ Referimo-nos ao período conhecido como "renascimento agrícola" da Capitania paulista. No quadro mais amplo, refletia as preocupações do Marquês de Pombal com a defesa dos territórios do sul da América Portuguesa, traduzida pela autonomia administrativa do território piratiningano em 1765, com a nomeação do Morgado de Mateus para o cargo de Capitão-general.
} 
excedente de farinha da região, como garantiam o fornecimento de mercadorias e escravos. ${ }^{155}$ A freguesia, apesar de sua condição privilegiada em relação à posse de escravos, revelava-se dependente do núcleo iguapense para a realização de suas atividades comerciais. Ainda que não seja possível identificar a gênese do cultivo do arroz como gênero mercantil, sua disseminação ocorreu de forma mais ou menos simultânea, provavelmente em decorrência da aludida ligação entre as localidades. De qualquer forma, em ambas localidades havia um conjunto de escravistas e escravos que, ao que tudo indica, pôde ser realocado para a faina agrícola, favorecendo não apenas o impulso decisivo da lavoura do arroz como também o surgimento de ganhos diferenciais entre os rizicultores, como se verá ao longo das demais páginas.

Dentro desse quadro, os Gráficos 3.1 e 3.2 distribuem os escravistas existentes nos anos de 1801, 1815, 1828 e $1836^{156}$ na vila e freguesia, inicialmente apresentados segundo sexo e condição conjugal.

\footnotetext{
${ }^{155}$ Do ponto de vista lógico, tratar da conformação de um ambiente favorável ao enriquecimento mais intenso de parte dos escravistas iguapenses remete a uma discussão que os informes das listas do século XVIII não fornecem, acerca das atividades exercidas por esses proprietários. As principais atividades entre os iguapenses na segunda metade do Setecentos vinculavam-se à farinha de mandioca e ao setor manufatureiro de embarcações. Os preços recolhidos por Harold Johnson na praça do Rio de Janeiro para a farinha flutuaram bastante, porém tomando 1780 como ano-base, o preço na década anterior manteve-se abaixo de 100 e, na vintena seguinte, não superou em 20\% o valor referencial (cf. JOHNSON JR., 1973, p. 272). Não localizamos nenhum informe sobre o número ou valor das embarcações construídas nos ancoradouros iguapenses, parece razoável supor que tal atividade demandasse uma diferenciação técnica da mão-de-obra, redundando em provável aumento dos gastos, independente da natureza servil ou não desses artesãos.

${ }^{156}$ Conforme destacamos no Apêndice, a ausência de três quarteirões nesta lista nominativa em relação à configuração original indicada por Daniel Pedro Müller pode eventualmente provocar distorções tanto no número quanto no perfil de proprietários e escravos possuídos.
} 
Gráfico 3.1

Distribuição de escravistas segundo sexo e condição conjugal

(Iguape, 1801 a 1836)
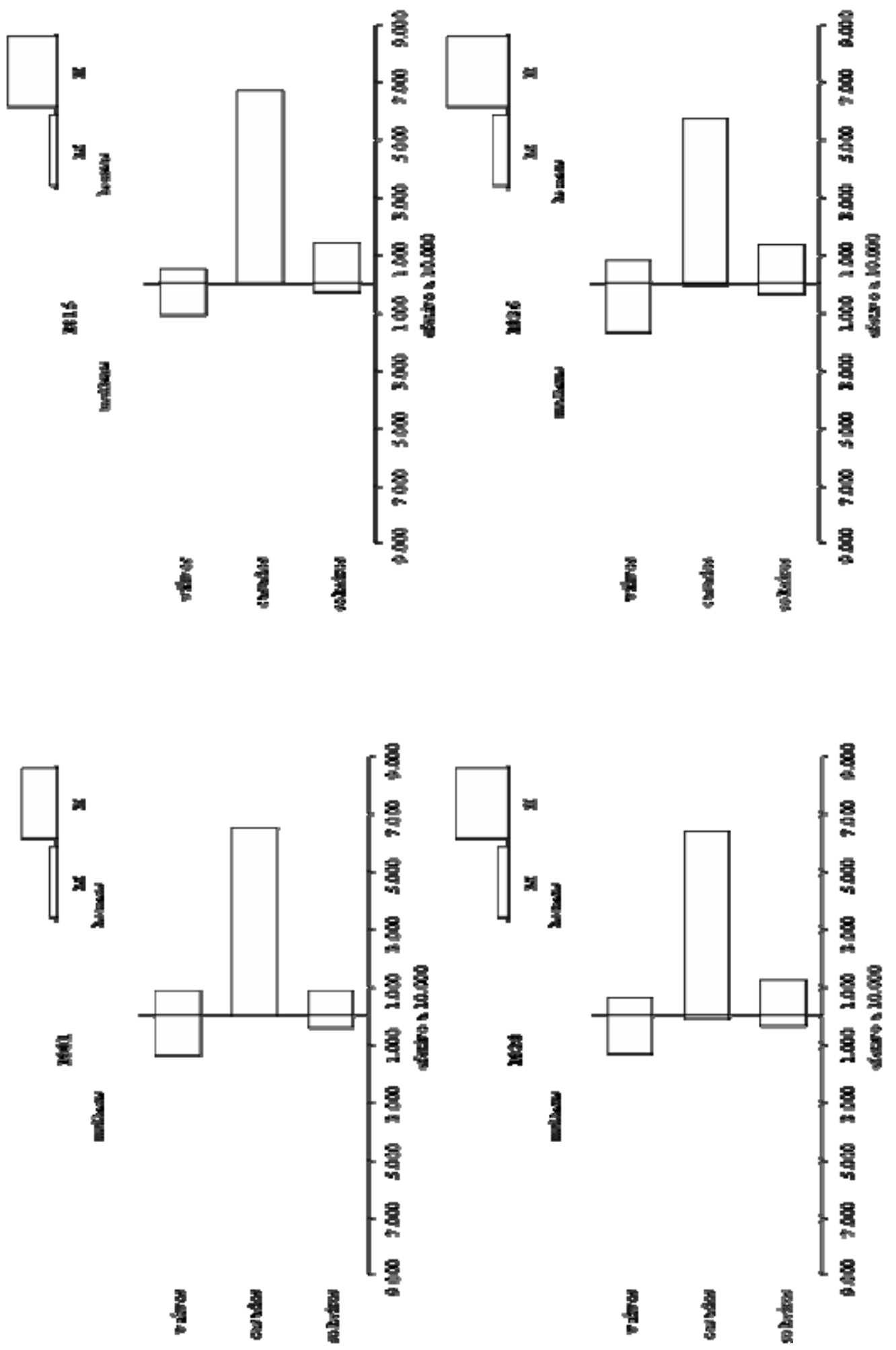
Gráfico 3.2

Distribuição de escravistas segundo sexo e condição conjugal

(Xiririca, 1801 a 1836)
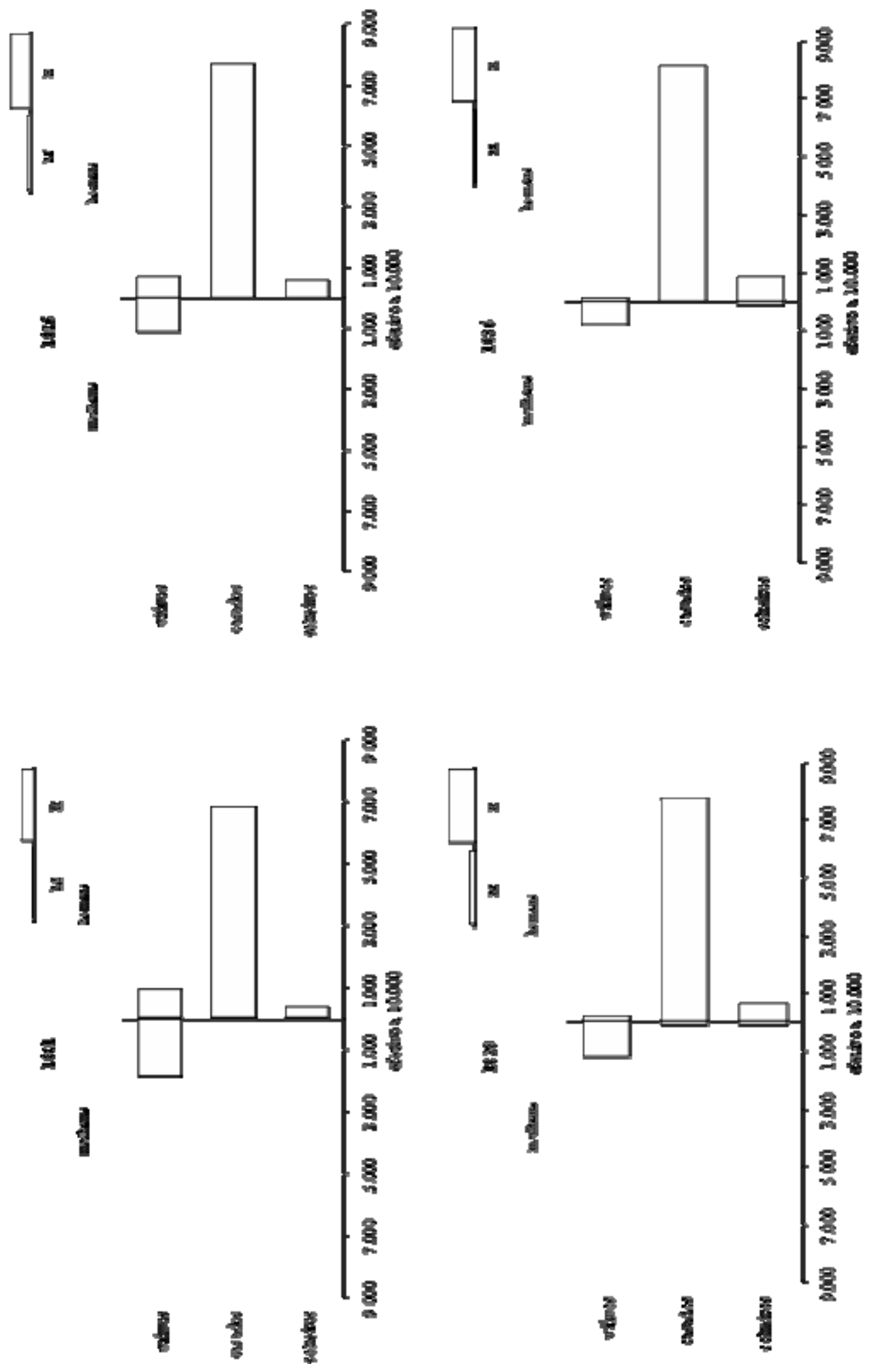
Nestes e em todos os demais que tratam do perfil demográfico, padronizamos o total de escravistas a 10.000 e as barras menores no canto superior direito guardam, para homens e mulheres, proporção com os valores absolutos registrados nas listas nominativas. Todos os valores numéricos, bem como a quantidade de total de proprietários e escravos possuídos podem ser observados no Anexo desta tese.

Se em 1789 Iguape contava com 140 proprietários, o acréscimo em relação a 1801, com 166 casos, representou uma variação de 18\% contra 50\% na freguesia de Xiririca, cuja quantidade passou de 36 para 54 escravistas. No intervalo entre as quatro listas, o total de proprietários praticamente dobrou nas duas localidades. Nos quatro anos amostrados, a participação masculina praticamente se manteve sempre acima dos $80 \%$, com maior predominância na freguesia de Xiririca; apenas no último dos anos as proprietárias iguapenses superaram a marca de $20 \% .{ }^{157}$ A maior presença de escravistas do sexo feminino em Iguape provavelmente guarda associação com o maior desenvolvimento urbano da vila: praticamente metade delas, em 1836, residia na vila de Iguape.

Casados e viúvos superavam 85\% dos casos. Constatamos na freguesia a menor participação de solteiros, sempre com parcelas inferiores a 10\%; já em Iguape este grupamento superou a marca de $15 \%$ em pelo menos três dos quatro anos. O departimento segundo sexo e condição conjugal evidencia diferenças importantes: entre os homens, os casados somavam cerca de oito décimos do total, seguidos pelos solteiros e, exceto em 1801, pelos viúvos. Em Iguape, solteiros e viúvos ocupavam maior importância do que na freguesia, estes últimos principalmente em 1828 e 1836. Verificamos ainda que 8 em cada 10 proprietárias eram viúvas, representando quase a totalidade dos casos em Xiririca e cerca de três quartos em Iguape, complementando nesta localidade uma pequena parcela de escravistas solteiras.

A distribuição em relação ao sexo pouco se diferenciava da verificada por Vidal Luna para as localidades paulistas entre 1801 e 1829, conforme ressaltamos anteriormente. Sobre o estado conjugal, destaca Luna que:

No caso das proprietárias, as viúvas perfaziam a metade, as solteiras cerca de $35 \%$ e as casadas participavam com porcentual entre 10 a 15\%. No segmento masculino, os casados respondiam por mais de oitenta por cento, os viúvos por menos de sete por cento e os solteiros por aproximadamente a décima parte (LUNA, 1998, p. 112).

\footnotetext{
157 Sobre a Capitania paulista, destaca Luna: “Os proprietários representavam um grupo essencialmente masculino, situação verificada sem alterações importantes no tempo e no espaço: de modo geral os homens representavam cerca de oitenta por cento dos senhores, porcentual este ultrapassado no Oeste Paulista e no Vale do Paraíba. Tal participação reproduzia-se entre os chefes de fogos e refletia um padrão daquela sociedade, fundamentalmente controlada por elementos do sexo masculino” (LUNA, 1998, p. 112).
} 
Em Iguape notamos algumas diferenças em relação às demais localidades, como a maior participação dos solteiros e a menor parcela de casados. Entre as mulheres, as viúvas representavam sempre mais de dois terços dos casos, além da quase ausência absoluta de escravistas casadas. Na freguesia, se entre os homens a participação dos casados superava o valor médio observado por Luna, as viúvas respondiam praticamente pela totalidade da pequena quantidade de escravistas lá registradas.

Nas localidades do Litoral Norte paulista, os proprietários do sexo masculino também correspondiam à classe com maior freqüência, oscilando entre 76\% e 85\%, assim como o predomínio de escravistas casados, entre 58\% e 73\% (cf. FERNÁNDEZ, 1992, p. 275-279). Em Lorena, Renato Marcondes verificou participação relativamente estável dos proprietários do sexo masculino, indicada a partir da razão de sexo, atingindo 553 homens para cada grupo de 100 mulheres em 1818, ano com maior participação masculina; em Iguape, este indicador atingiu valor máximo em 1815 (622) e, na freguesia, 1.022 em 1836. Notou o autor participação decrescente dos casados no conjunto dos proprietários: de 81\% em 1778 até $70 \%$ em 1829, pari passu o aumento relativo de solteiros e viúvos. Sobre isso, afirma Marcondes:

(...) o crescimento da chegada e da constituição de novos domicílios de proprietários de cativos com apoucadas posses relativamente maior do que o restante dos escravistas provocou a elevação da representatividade dos solteiros e a redução da idade média dos escravistas entre 1798 e 1818, arrefecendo a desigualdade da posse cativa. Posteriormente, o fluxo migratório e de formação de novos domicílios escravistas aumentou e passou a incluir pessoas jovens que possuíam recursos apreciáveis, continuando a manter o porcentual dos solteiros e a idade média dos escravistas nos mesmos patamares, mas acirrando a concentração de posse cativa de 1818 a 1829 (MARCONDES, 1998, p. 96).

Em Bananal o perfil se mostrou relativamente distinto: a participação feminina, ainda que crescente em valores absolutos, revelou-se declinante em termos proporcionais nos três anos investigados por José Flávio Motta, atingindo 11\% em 1829. Quanto à condição conjugal, a participação de solteiros entre os escravistas do sexo masculino saltou de $5 \%$ para $16 \%$ entre 1801 e 1817, recuando depois para 12\% em 1829; movimento semelhante se apresentou entre os viúvos, que inexistiam em 1801 e compareciam com 8\% e 5\% nos dois anos seguintes. Cruzando estes informes com a distribuição etária dos escravistas, o autor evidenciou a maior participação de jovens proprietários em 1817 em relação aos demais anos Dessa forma, salienta: 
Gráfico 3.3

Distribuição dos escravistas segundo sexo e origem

(Iguape, anos selecionados)
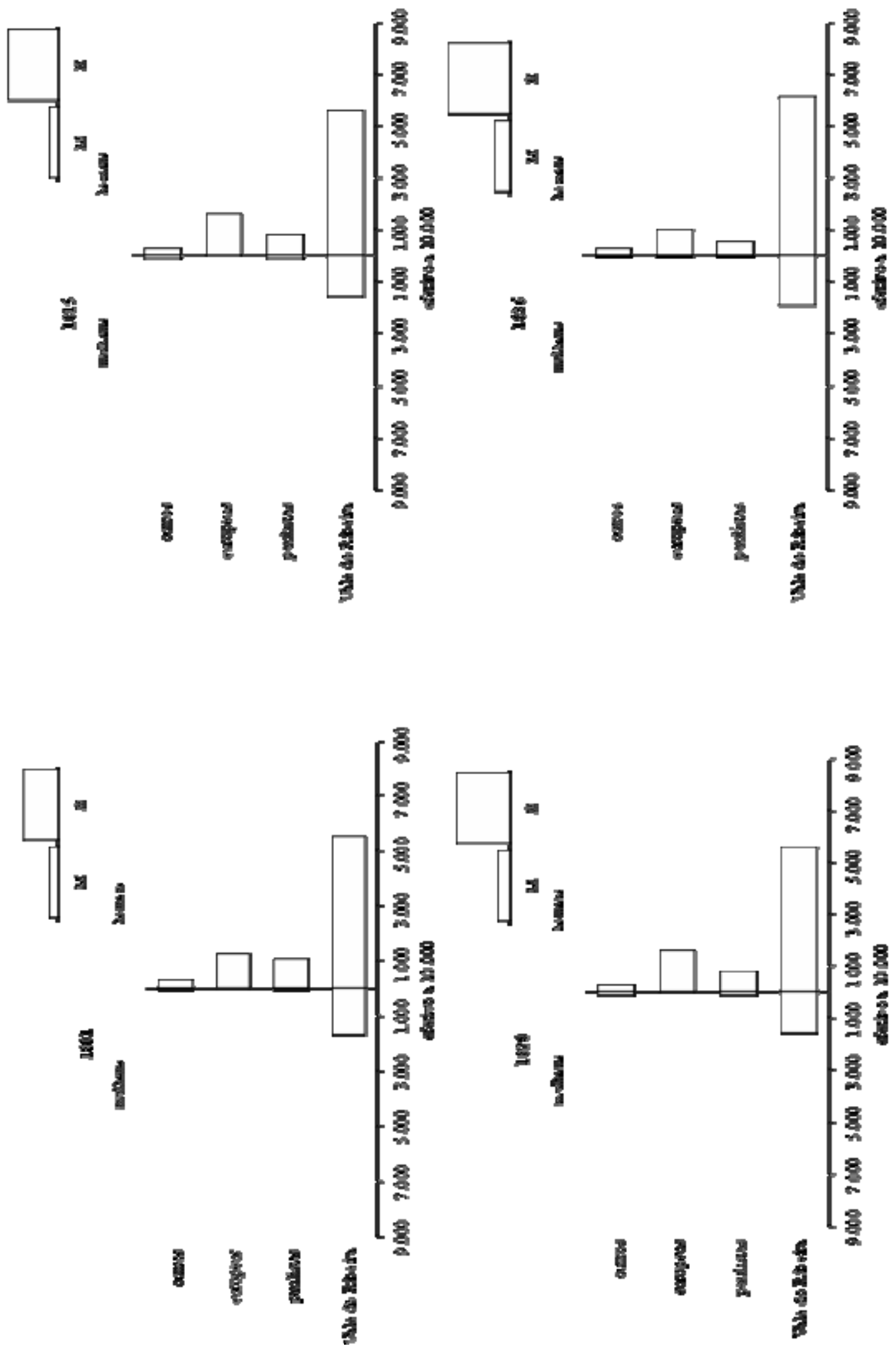
Gráfico 3.4

Distribuição dos escravistas segundo sexo e origem

(Xiririca, anos selecionados)
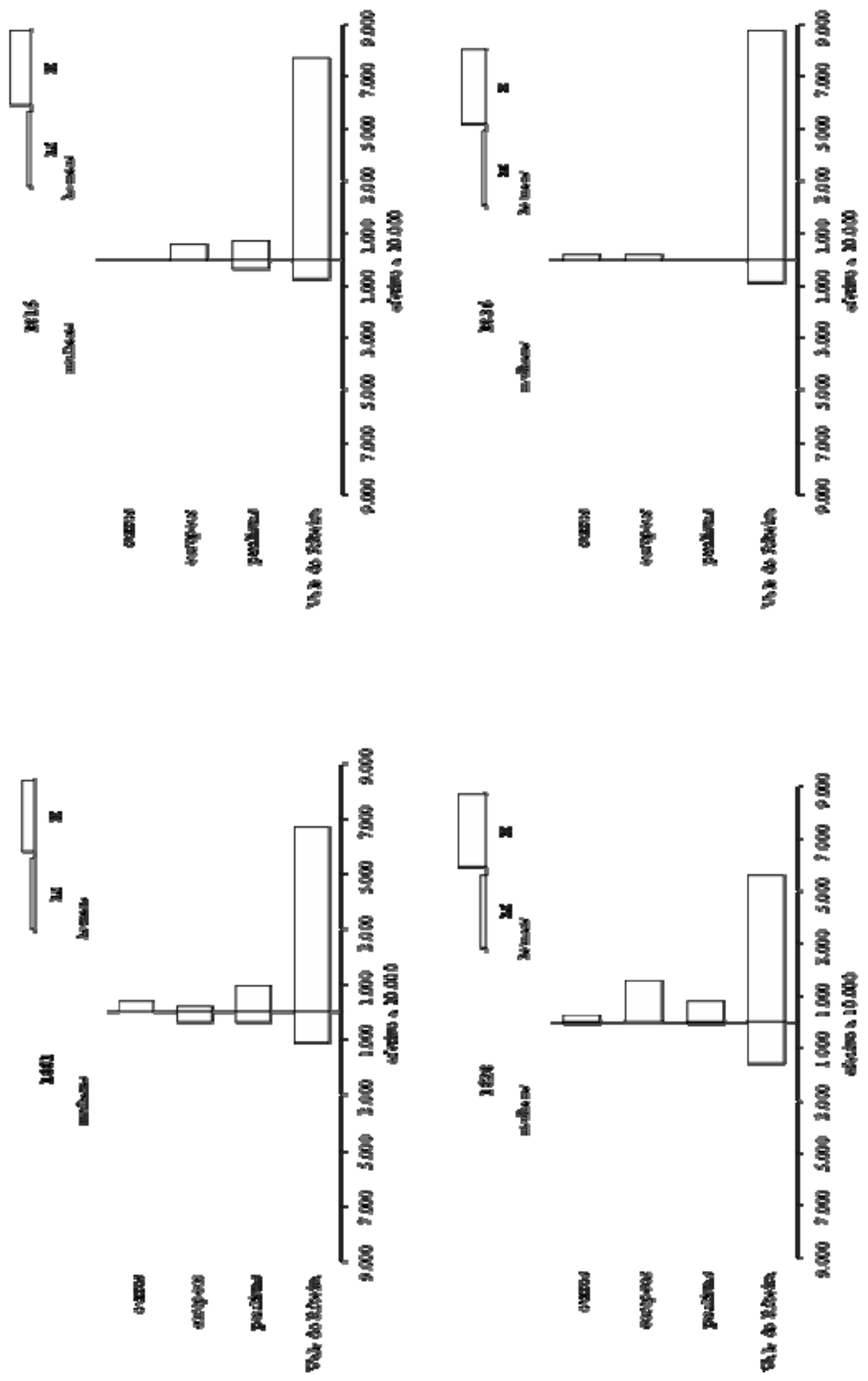
É possível que a maior importância relativa dos escravistas mais jovens em 1817 vis-àvis 1801, e novamente a diminuição naquela importância em 1829, reflitam a evolução populacional e o desenvolvimento econômico de Bananal nas décadas iniciais do século passado (...) Talvez o afluxo populacional direcionado para Bananal entre os dois primeiros anos referidos privilegiasse em certa medida os elementos mais jovens, iniciando a sua vida adulta - ou há pouco tendo nela adentrado - em uma região de povoamento relativamente recente MOTTA, 1999, p. 118-119).

As duas últimas localidades favoreceram-se de movimentos migratórios, provenientes principalmente do Rio de Janeiro e Minas Gerais: em Bananal, no ano de 1817, fluminenses e mineiros representavam 45\% dos escravistas contra 39\% de paulistas, incluso os próprios da vila (cf. MOTTA, 1999, p. 123). No caso de Lorena, em 1818 a maior parte dos escravistas originava-se da própria vila, porém entre este ano e 1829 recebeu um afluxo importante de escravistas, principalmente outros paulistas, mineiros e europeus (Cf. MARCONDES, 1998, p. 99). Nesse sentido, os Gráficos 3.3 e 3.4 apresentam os escravistas do Vale do Ribeira segundo sexo e origem.

Boa parte do crescimento no número de escravistas assenta-se na incorporação de proprietários do próprio Vale do Ribeira: três em cada quatro escravistas nos três primeiros anos e praticamente $85 \%$ dos casos em 1836. As diferenças entre Iguape e Xiririca são importantes e reafirmam a preponderância da primeira: na freguesia, além da ampla maioria de oriundos do próprio Vale, outros paulistas compunham, em 1801 e 1815, o principal grupo minoritário, posição esta assumida pelos europeus em 1828; já em 1836, praticamente todos os escravistas originavam-se do próprio Vale. Em Iguape notamos também a maior importância assumida pelos ribeirenses em 1836, porém com menor intensidade. Neste ano, os proprietários europeus mantiveram-se em cerca de 10\% dos casos e, nos anos anteriores, este grupo atingiu participações relativas mais expressivas, sempre superando a presença dos demais paulistas entre os proprietários na vila.

Associamos a elevada presença de europeus na vila de Iguape à sua posição geográfica, compondo a rota das embarcações que transportavam mercadorias entre o Rio de Janeiro e o sul da colônia, que recebeu nos períodos anteriores significativas levas de imigrantes açorianos, com representantes também em Iguape. Novamente comparando com os resultados fornecidos por Vidal Luna: tanto em 1804 como em 1829, escravistas portugueses possuíam participação significativa (acima de 10\%) apenas no Litoral, cabendo aos originários da própria Capitania paulista mais de $80 \%$ dos casos em todas as regiões, destacando-se ainda escravistas mineiros no Vale do Paraíba e Oeste Paulista, como já ressaltado nas localidades de Bananal e Lorena. Ainda sobre a presença de europeus no litoral norte, destaca Ramón Fernández: 
No que diz respeito aos portugueses, a presença dos naturais das Ilhas Atlânticas foi declinando com o passar dos anos (veja-se que eles representavam 12,5\% dos proprietários de Ubatuba no primeiro censo $[1778$, quando os portugueses representavam 29,7\% dos escravistas - AV], mas em 1808 seu peso não podia ser comparado com o daquela data), enquanto se observava uma presença em certos anos significativa dos naturais do Norte de Portugal (Porto e Braga, principalmente). Destaque-se, por último, a presença de outros europeus, notadamente franceses, que se estabeleceram principalmente com fazendas de café à época do auge desta lavoura em Ubatuba (FERNÁNDEZ, 1992, p. 287).

A participação de portugueses apresentou-se declinante tanto em Ubatuba como em São Sebastião, onde estes representavam um quinto dos proprietários em 1808 e apenas 7\% em 1836. Ao longo dos trinta primeiros anos do século XIX, os escravistas originários do próprio litoral norte sempre corresponderam à maioria dos casos, atingindo seu valor máximo em 1836 em São Sebastião (88\%) e em 1828 na vila de Ubatuba (71\%), destacando-se ainda nesta última parcela de escravistas cariocas e fluminenses (cf. FERNÁNDEZ, 1992, p. 286).

Apresentamos em seguida os Gráficos 3.5 e 3.6, contendo os escravistas do Vale do Ribeira segundo sexo e cor. Os brancos dominavam a posse de cativos em ambas as localidades com participações sempre em torno de 95\%. Nesse quesito os pardos constituíam os únicos proprietários de cor com alguma importância, representando em Iguape cerca de 3\% e pouco mais em Xiririca, porém com valores muito pequenos em termos absolutos. Nas localidades paulistas estudadas por Francisco Vidal Luna, a participação de brancos mantevese em torno de 94\% tanto em 1804 como em 1829. O autor realça a diferença entre a Capitania paulista e algumas localidades mineiras, como Vila Rica, onde os pardos representavam mais de quatro décimos dos escravistas (cf. LUNA, 1998, p. 115).

Os resultados verificados em Iguape e Xiririca também diferem significativamente daqueles observados para a localidade vizinha de Apiaí no mesmo período: em 1798, proprietários mulatos e pretos representavam um quarto dos 36 proprietários, mais de um terço dos 42 escravistas presentes em 1816 e 65\% dos 38 casos em 1835 (cf. VALENTIN, 2001, p. 153, 211 e 247). A condição original de Apiaí e Xiririca, ambas com história associada à extração de algum ouro de aluvião, revela que este passado em comum não se mostrou suficiente para a reprodução desse comportamento específico na participação de pardos e pretos na posse de escravos. 
Gráfico 3.5

Distribuição dos escravistas segundo sexo e cor

(Iguape, anos selecionados)
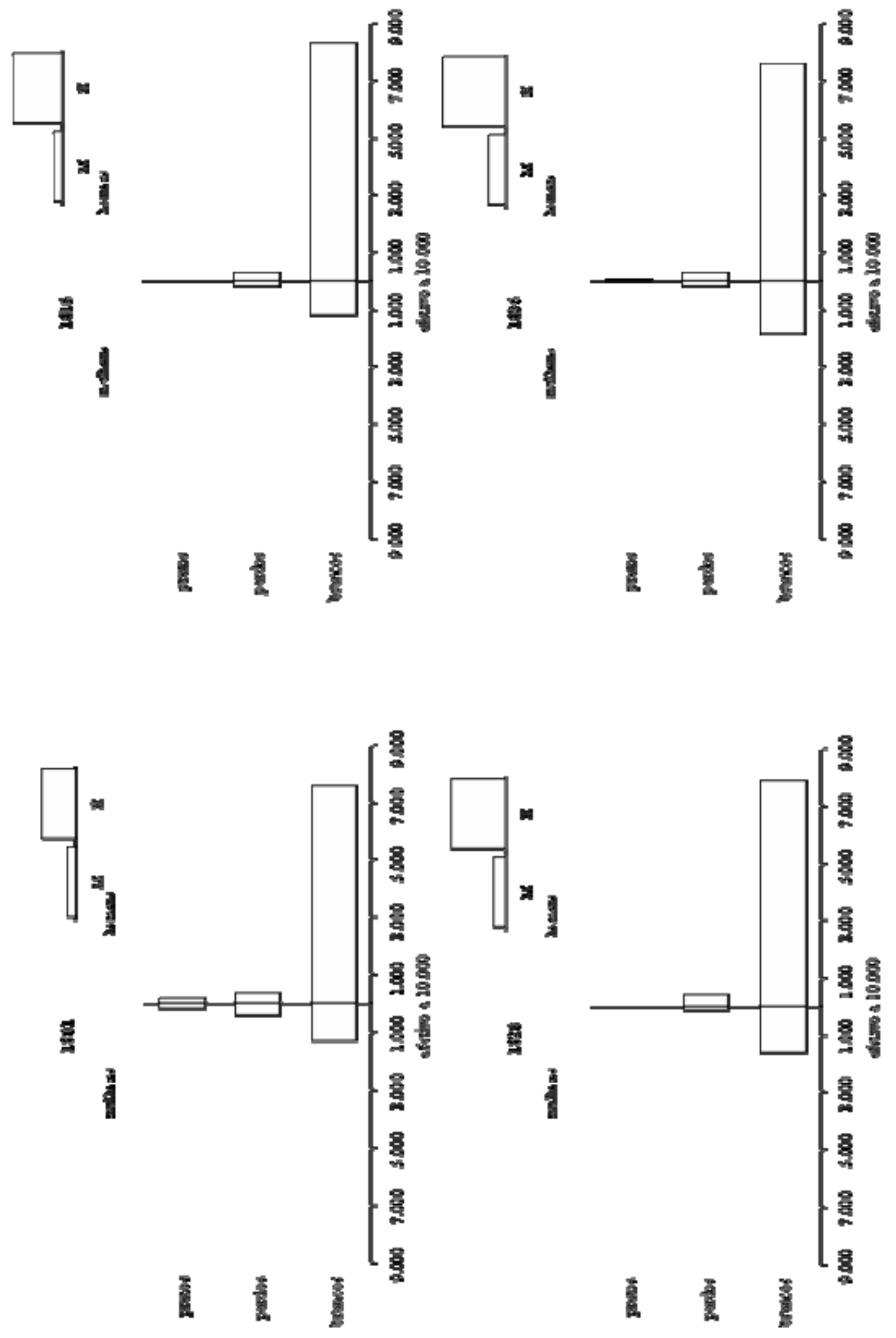
Gráfico 3.6

Distribuição dos escravistas segundo sexo e cor

(Xiririca, anos selecionados)
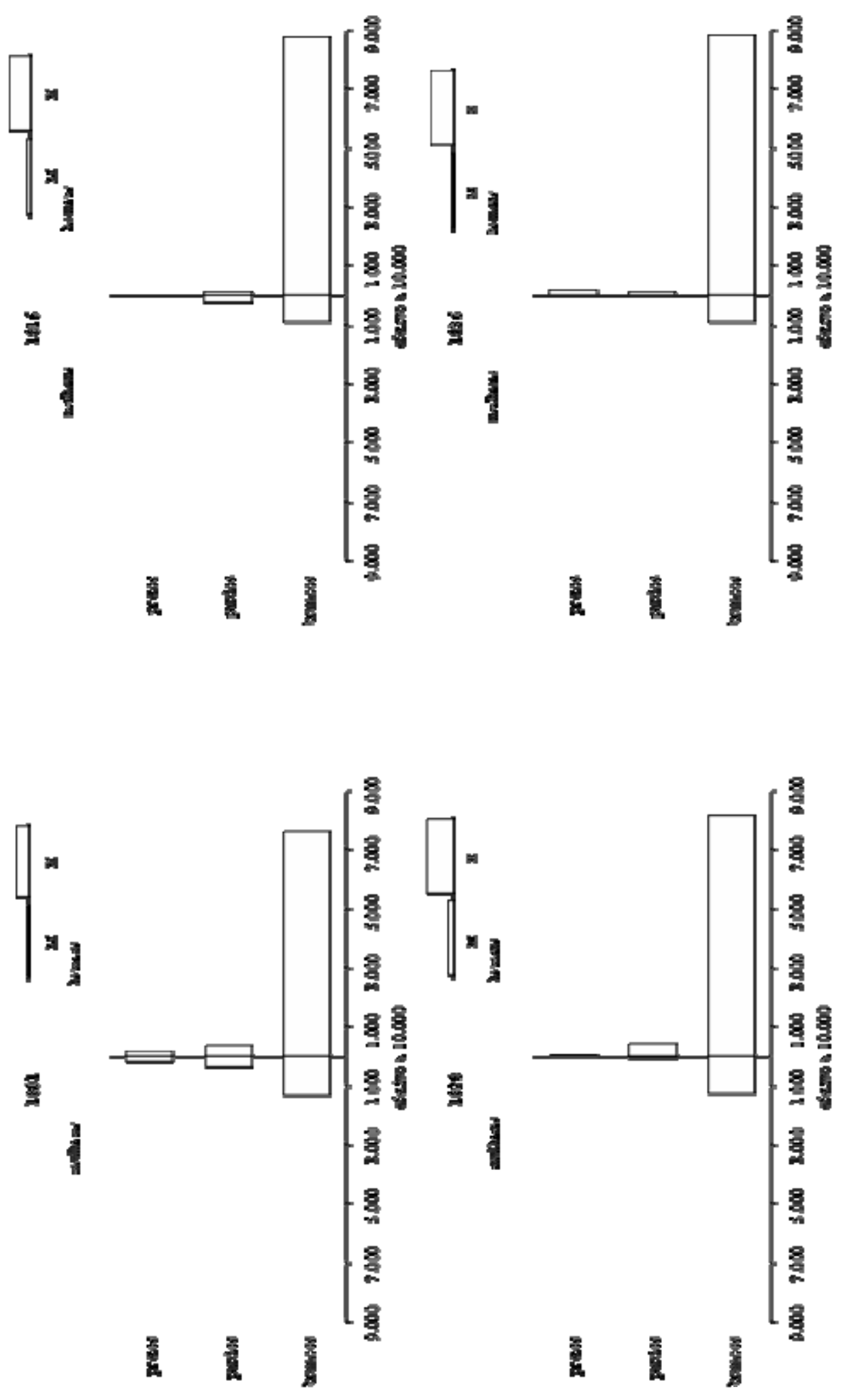
No caso específico de Xiririca, a predominância dos escravistas brancos aparentemente relaciona-se com a rápida transição da lida mineratória para o cultivo agrícola, impossibilitando a instalação de um quadro de estagnação econômica observado em Apiaí, um dos motivos da predominância de escravistas pardos em $1835 .{ }^{158}$

Completando a caracterização demográfica dos escravistas do Vale do Ribeira, os Gráficos 3.7 e 3.8 apresentam sua distribuição segundo faixas etárias decenais.

Em Iguape, notamos que as mulheres tendiam a se concentrar nas faixas etárias mais elevadas, resultado vinculado ao predomínio das viúvas sobre as solteiras. Dessa forma, se em 1801 não registramos mulher alguma proprietária de escravos com idade entre 20 e 39 anos, em 1836 estas representavam cerca de 15\% dos casos, porém a maioria possuía mais de 50 anos. Se tomarmos a idade média como indicador, verificamos a redução de 59 anos em 1801 para 51 em 1836, em constante queda. Entre os homens, idade média manteve-se em torno de 46 anos nas quatro listas, porém com distribuições distintas entre os anos considerados. Destacamos o grupo de escravistas entre 30 e 49 anos, com presença marcante nos três primeiros anos (principalmente em 1815), porém com participação menor em 1836, especialmente aqueles entre 30 e 39 anos.

Já na freguesia, a pequena quantidade de proprietárias distribuída entre as faixas etárias não permite avaliar qualquer semelhança com as escravistas iguapenses, apesar da redução da idade média de 60 anos em 1801 para 47 em 1836, porém de forma irregular. Menos irregular, todavia com menor amplitude, deu-se a redução deste valor entre os escravistas do sexo masculino, de 47 anos em 1801 para 40 anos em 1836, valor significativamente menor do que o observado para os escravistas iguapenses.

\footnotetext{
${ }^{158}$ No caso de Apiaí, atribuímos o crescimento desse segmento a um intrincado processo de partilhas das propriedades escravas, envolvendo a legitimação de diversos herdeiros naturais, filhos dos antigos proprietários brancos com escravas e ex-escravas (cf. VALENTIN, 2001, p. 247-251), associada com as condições geográficas da localidade, que mantiveram-na relativamente isolada tanto da expansão canavieira como do cultivo do arroz desenvolvido nas regiões serra abaixo. Da mesma forma, a dicotomia também aparece em localidades da Capitania de Minas Gerais, a exemplo de Sabará e Campanha “(...) ambas as localidades voltadas para a agricultura e o artesanato, mostrava números bastante diferentes entre si. Em Sabará, antiga área de mineração, a proporção de proprietários brancos era de apenas 57,2\%; os mulatos representavam 40,8\% e os negros 2,0\%. Em Campanha, a composição racial indicava os brancos representando 87,4\% do total dos proprietários de escravos; aos mulatos e negros cabia o porcentual de 12,6\%” (LUNA, 1998, p. 115).
} 
Gráfico 3.7

Distribuição dos escravistas segundo sexo e faixas etárias

(Iguape, anos selecionados)
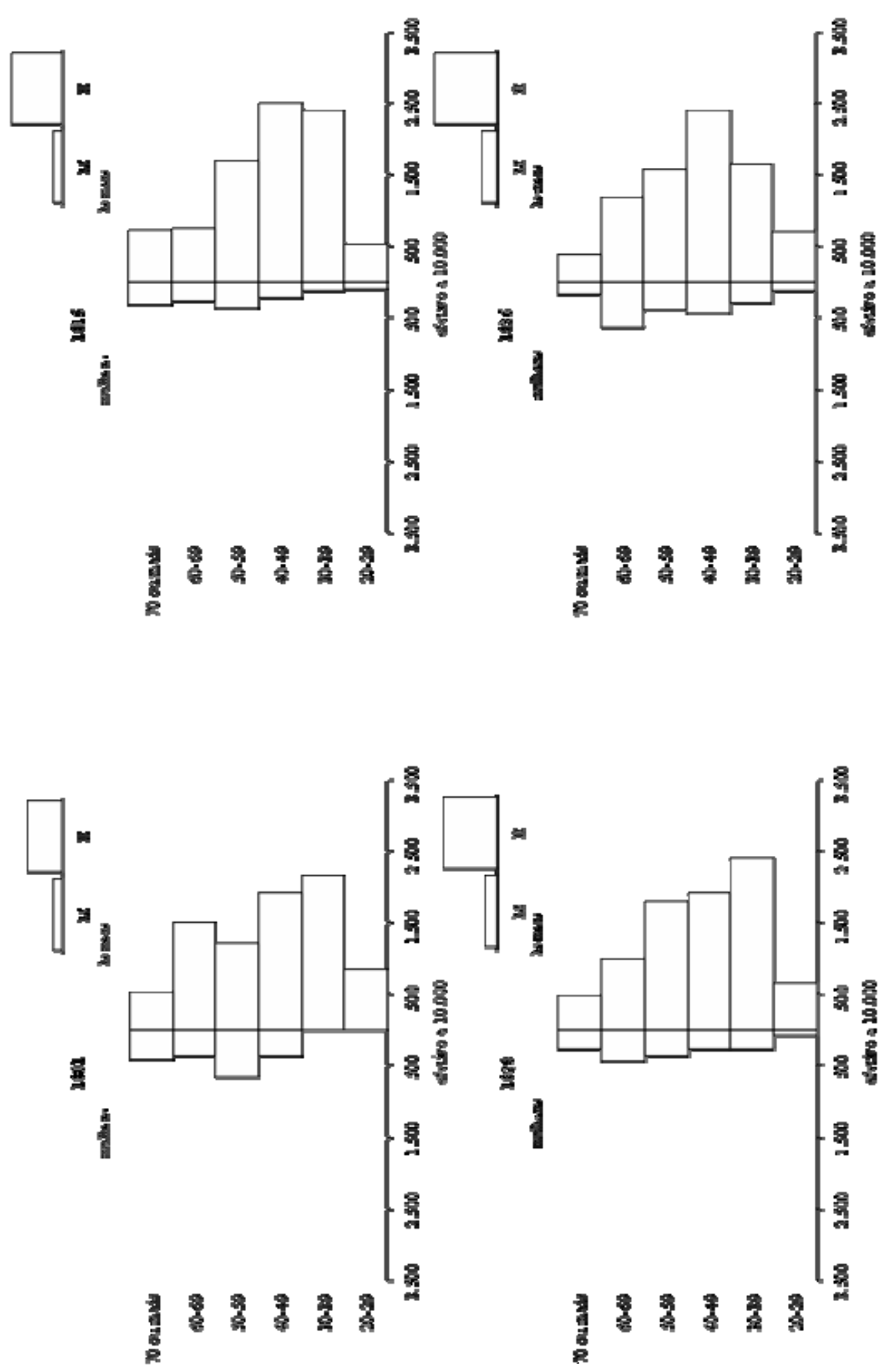
Gráfico 3.8

Distribuição dos escravistas segundo sexo e faixas etárias

(Xiririca, anos selecionados)
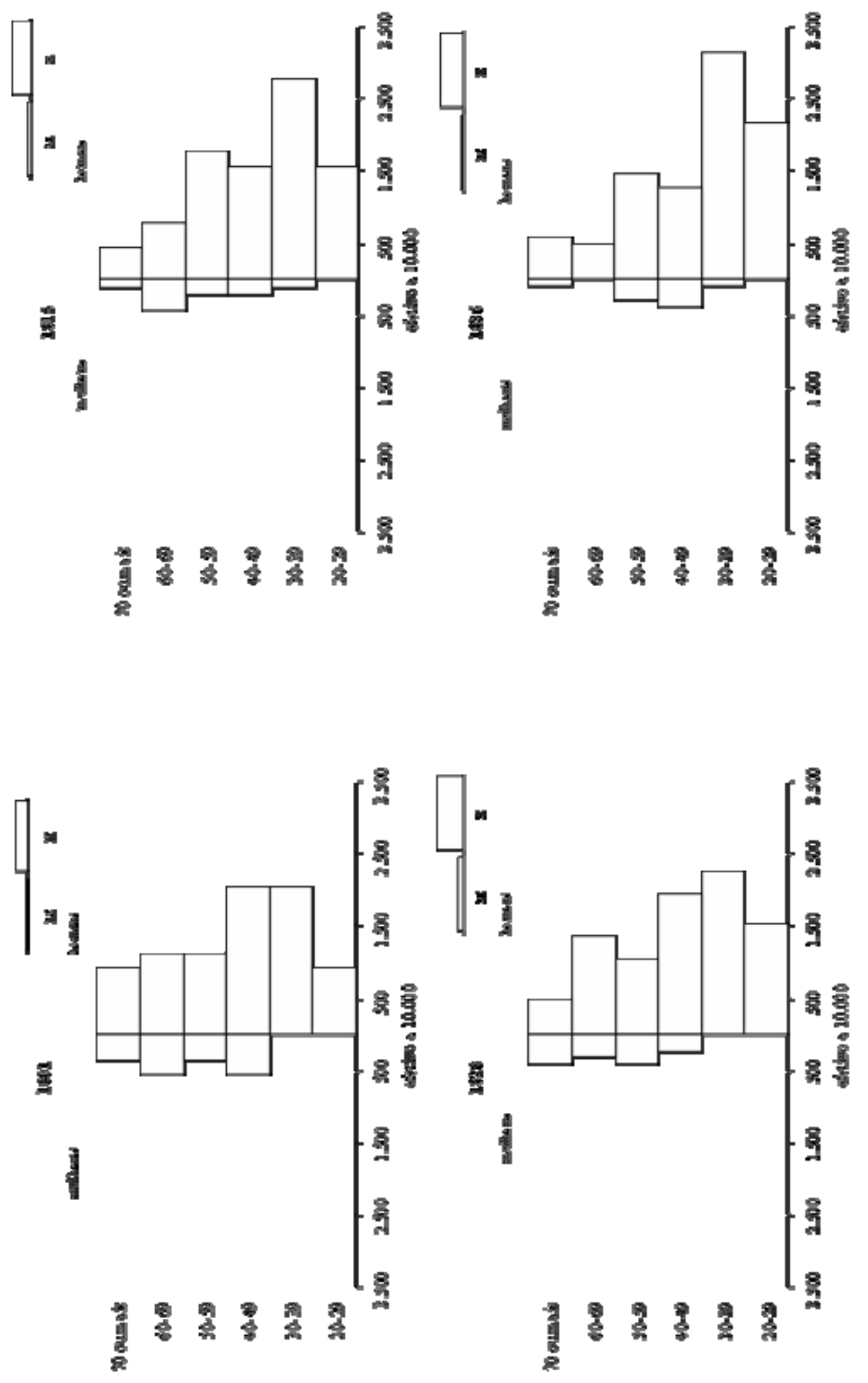
Os escravistas do sexo masculino nas 25 localidades eleitas por Vidal Luna, em 1804, dividiam-se igualmente nas faixas etárias de 30 a 49 anos e de 50 anos ou mais, restando 10\% aos jovens escravistas. Em 1829, os proprietários mais velhos perderam importância relativa, cabendo ao grupo intermediário a predominância e secundado por um ligeiro aumento entre os proprietários com até 29 anos. Entre as mulheres, a maioria possuía 50 anos ou mais, porém com valores decrescentes: de 62\% em 1801 a 54\% em 1829, mantendo, as mais jovens, parcela constante (em torno de 6\%) e, conseqüentemente, um relativo crescimento no grupamento intermediário. Sobre estas tendências, afirma o autor:

Como provavelmente parte do crescimento populacional em São Paulo, no período, fezse pela imigração, os resultados parecem indicar que a idade média dos imigrantes, com escravos ou recursos para adquiri-los, situava-se provavelmente abaixo da média dos já residentes (LUNA, 1998, p. 113).

Tal hipótese parece pouco provável diante da imensa maioria de escravistas oriundos da própria Capitania, conforme discutido anteriormente. Talvez seja mais razoável considerar que a redução da idade média dos escravistas nesta quadra decorra da expansão da oferta de cativos associado ao desenvolvimento da agricultura mercantil em parte da economia paulista, gerando renda excedente que possibilitou a ampliação do número de proprietários, incluindo parcelas mais jovens da população. ${ }^{159}$ No entanto, a conjectura estabelecida por Luna parece valer para Iguape. Como já destacamos, apesar da relativa constância da idade média dos proprietários, em 1815 registramos a menor participação de escravistas com 50 anos ou mais, 35\%, contra $40 \%$ nos demais anos; neste ano também ocorreu a menor participação de escravistas do sexo masculino originários do próprio Vale do Ribeira. Em Xiririca, a baixa freqüência de escravistas de outras regiões não permite a adesão ao modelo proposto; nota-se que lá a redução efetiva da idade média destes proprietários ocorreu concomitante ao aumento da parcela de escravistas solteiros, possivelmente beneficiários dos fatores relacionados acima sobre a maior oferta de cativos e de renda para sua aquisição ou favorecidos pela partilha das propriedades.

Propomos aqui uma breve síntese dos principais resultados expostos. Os dados até agora analisados evidenciam o maior dinamismo na vila de Iguape em relação a sua freguesia. Esta condição pode ser alinhada em torno do aumento de proprietários do sexo masculino, concentrados no grupo etário entre 30 e 49 anos e com importante participação dos imigrantes portugueses e açorianos. As maiores variações podem ser percebidas com intensidade pelo menos até o ano de 1828 e sua associação com o desenvolvimento da vocação agrícola da

\footnotetext{
159 Não obstante a elevação do preço dos escravos principalmente a partir da década de 1820, conforme apresentado no Capítulo 1 deste trabalho.
} 
região parece evidente, não apenas pela expansão do número de proprietários como pela capacidade em atrair novos escravistas. Já os resultados para o ano de 1836 sugerem sinais do esgotamento deste dinamismo, traduzidos pela maior participação feminina, o maior peso de escravistas originários do Vale do Ribeira e um perfil mais idoso dos proprietários de escravos.

Tais efeitos não se fazem presentes na mesma intensidade em Xiririca, como sugerem os dados, ou por outra, guardam traços praticamente imperceptíveis. Lembramos a pequena participação de escravistas solteiros e de outras regiões além do Vale do Ribeira, que nunca representaram valor digno de distinção. Ademais, a distribuição etária dos escravistas nos induz a acreditar que a ampliação do segmento escravista assentava-se principalmente através da sucessão das gerações.

\section{Gráfico 3.9}

\section{Posse média de escravos segundo sexo do proprietário}

(Iguape e Xiririca, anos selecionados)

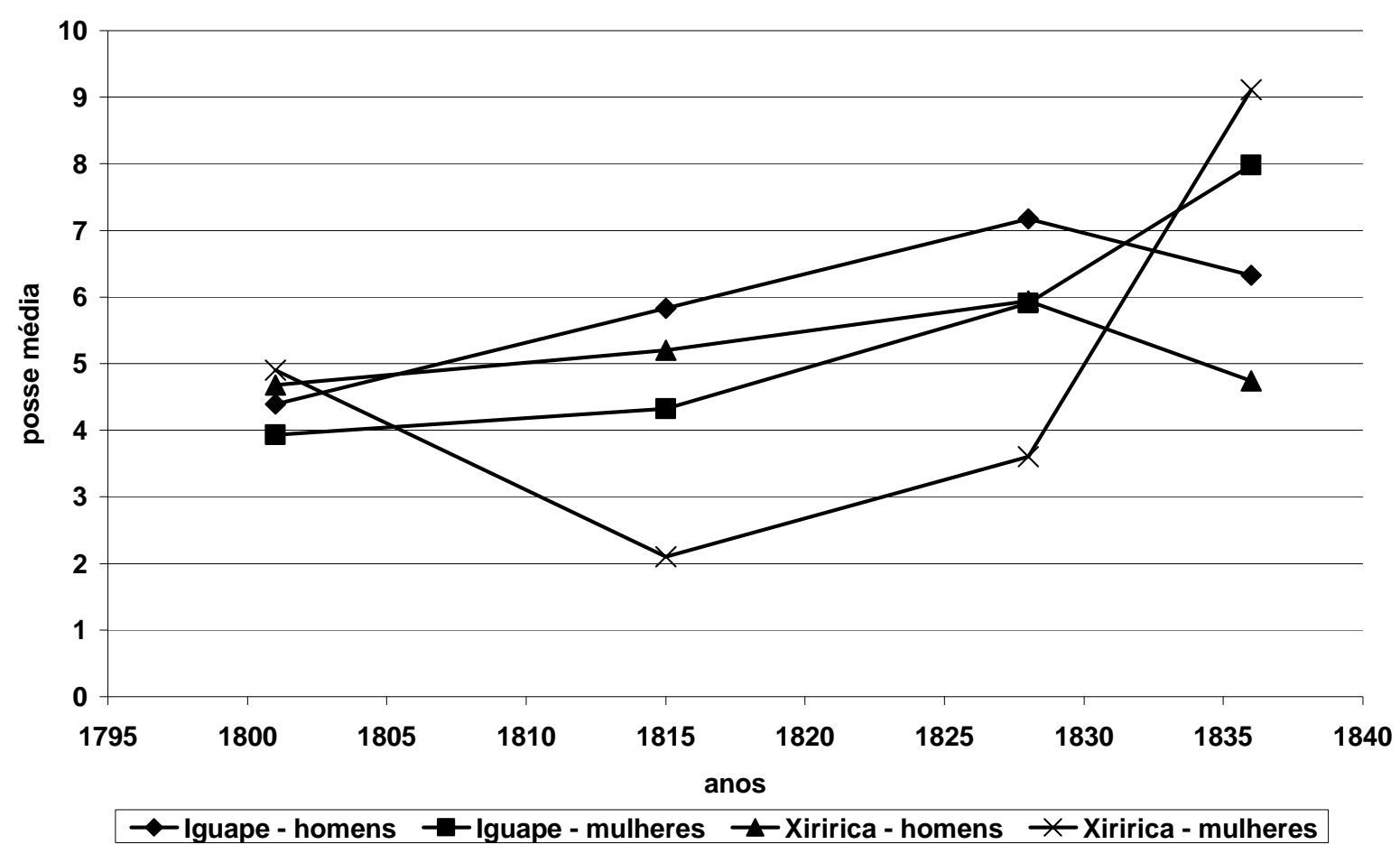

Estas diferenças também podem ser avaliadas através da posse média de iguapenses e xiririquenses. No Gráfico 3.9, visualizamos este indicador segmentado segundo o sexo do proprietário, em ambas as localidades. O destaque inicial cabe ao comportamento dos escravistas do sexo masculino cujo valor médio manteve-se ascendente até 1828, seguido por uma redução em 1836. Este crescimento ocorreu de forma mais intensa entre os iguapenses, que também apresentaram, em 1836, menor redução no valor médio do que seus pares 
xiririquenses. Como assinalamos anteriormente, este segmento representava cerca de oito décimos do total de proprietários nos quatro anos aqui investigados.

Entre as mulheres, a tendência de crescimento aparece após 1815 e de forma acentuada entre 1828 e 1836. Neste caso, como mostram nos Gráficos 3.10 e 3.11, a responsabilidade coube às posses pertencentes aos viúvos, condição conjugal com destaque entre as escravistas e único subconjunto com perfil discrepante. ${ }^{160}$ Entre casados e solteiros o comportamento do valor médio segue o traço geral verificado para os proprietários do sexo masculino.

Gráfico 3.10

Posse média de escravos segundo condição conjugal do proprietário

(Iguape, anos selecionados)

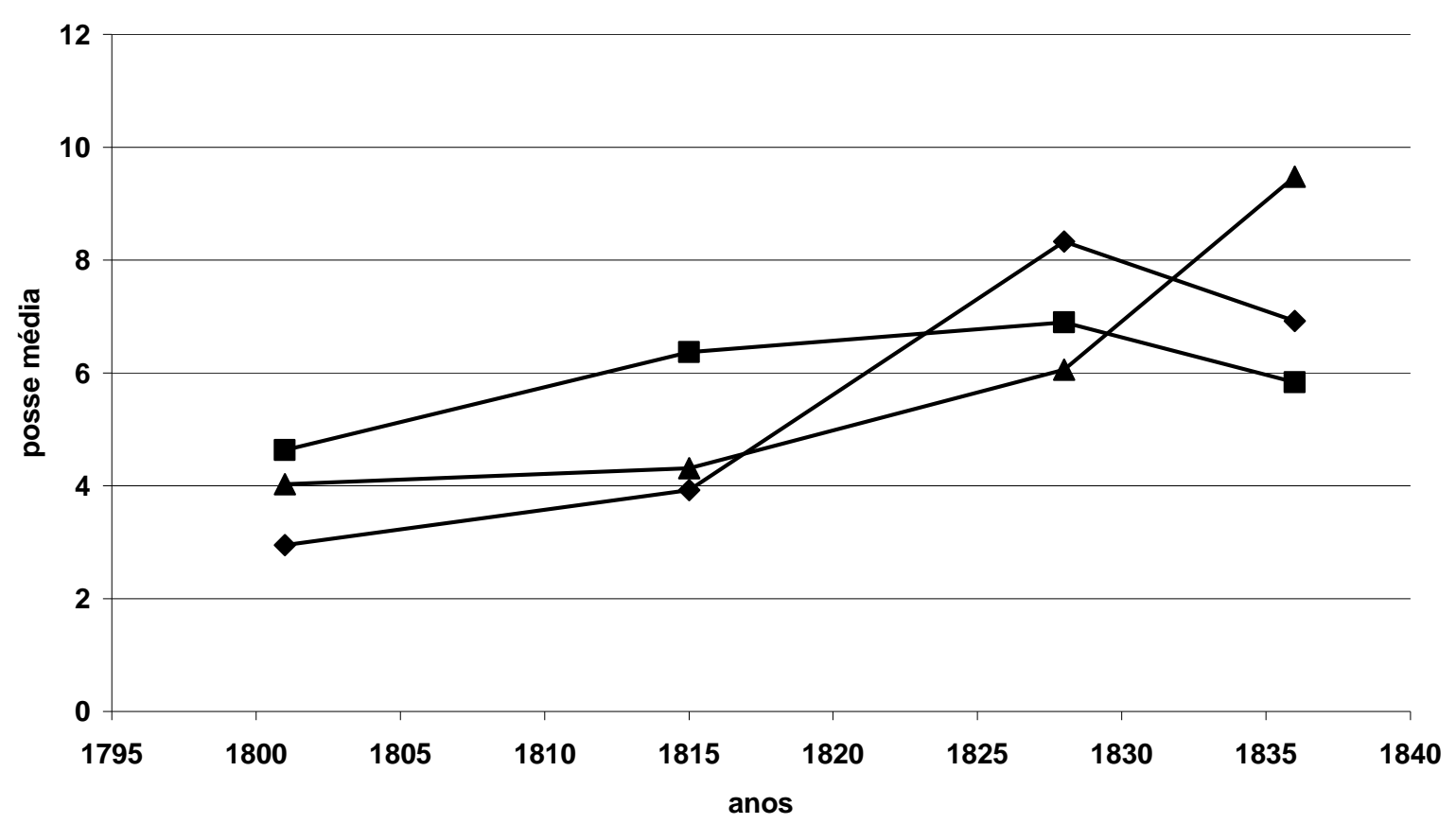

Iguape - solteiros $\rightarrow-$ Iguape - casados $\rightarrow$-Iguape - viúvos

\footnotetext{
${ }^{160}$ Nesse ano, um dos principais escravistas iguapenses, Bartolomeu da Costa Almeida Cruz, que teria morrido em 1829, já não constava na lista nominativa de 1828, com 69 cativos avaliados no inventário. Neste ano, chefiava o domicílio seu filho José Xavier de Almeida Cruz, não obstante a presença da viúva no fogo. Em 1836, a viúva Francisca Xavier de Paula encabeçava a lista do domicílio e José Xavier constava como um dos filhos coabitantes. Em suma, caso se adotasse a mesma ordenação existente em 1836, a posse média dos escravistas solteiros passaria de 8,3 para 6,9 e, entre os viúvos, de 6,1 para 7,2.
} 
Gráfico 3.11

Posse média de escravos segundo condição conjugal do proprietário

(Xiririca, anos selecionados)

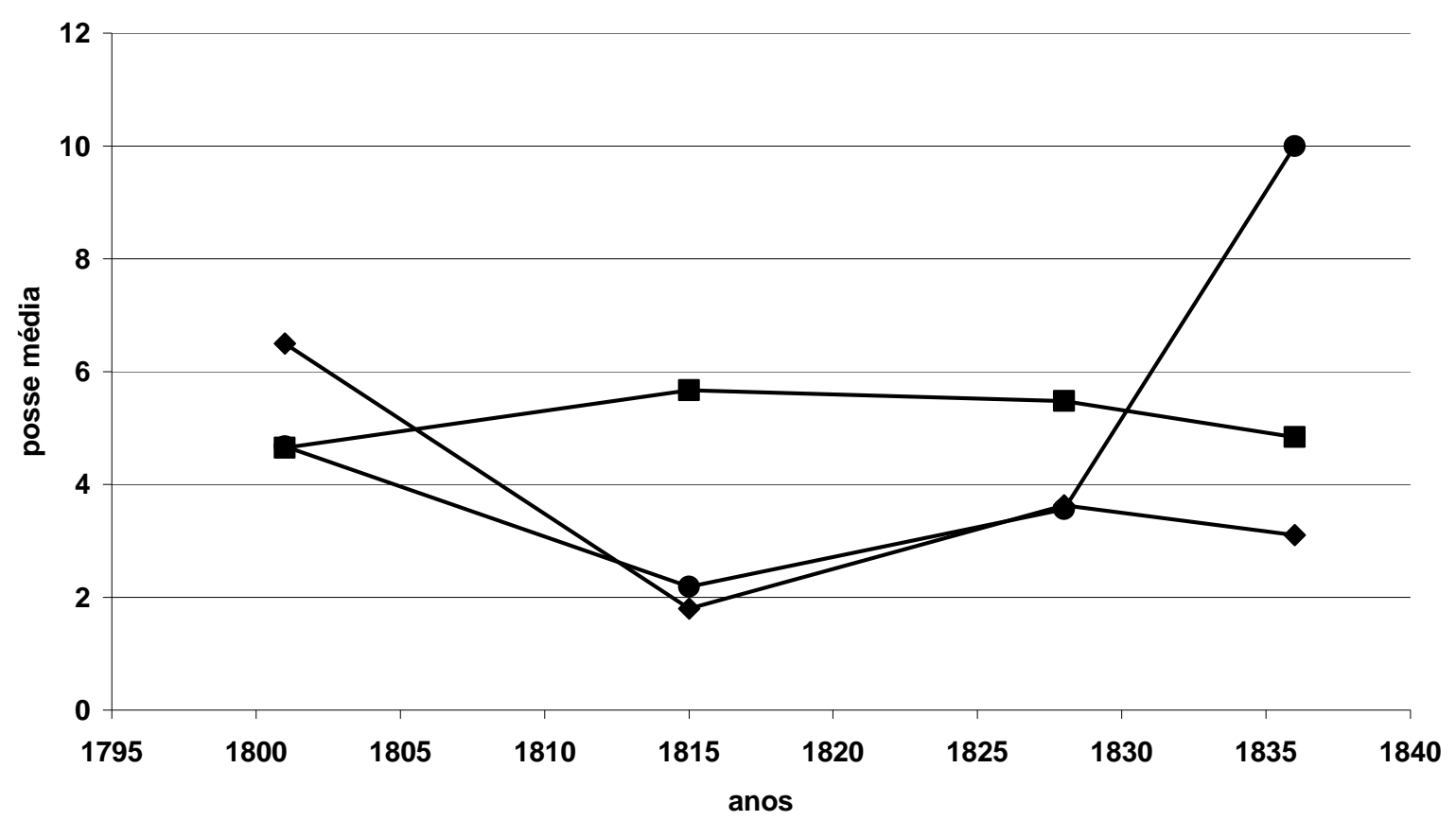

Xiririca - solteiros $\rightarrow$-Xiririca - casados $\rightarrow$ - Xiririca - viúvos

Os gráficos seguintes associam a posse média com a origem do escravista. A maioria dos proprietários, originários do Vale do Ribeira, apresentou valores crescentes entre 1801 e 1828, estabilizando-se em cerca de 6 escravos por proprietário. O mesmo movimento ocorreu entre os demais segmentos, com especial destaque aos europeus, com valores médios significativamente maiores. No caso de Xiririca a diferenciação entre proprietários europeus e do próprio Vale restringe-se aos extremos do período analisado e não atingem a mesma magnitude observada na vila. ${ }^{161}$

161 O conjunto dos “outros” proprietários, isto é, escravistas originários de outras Capitanias (ou Províncias), apesar de apresentarem posse média destacada no ano de 1836, não representam grupo de importância, conforme destacam os Gráficos 3.3 e 3.4 . 
Gráfico 3.12

Posse média de escravos segundo origem do proprietário

(Iguape, anos selecionados)

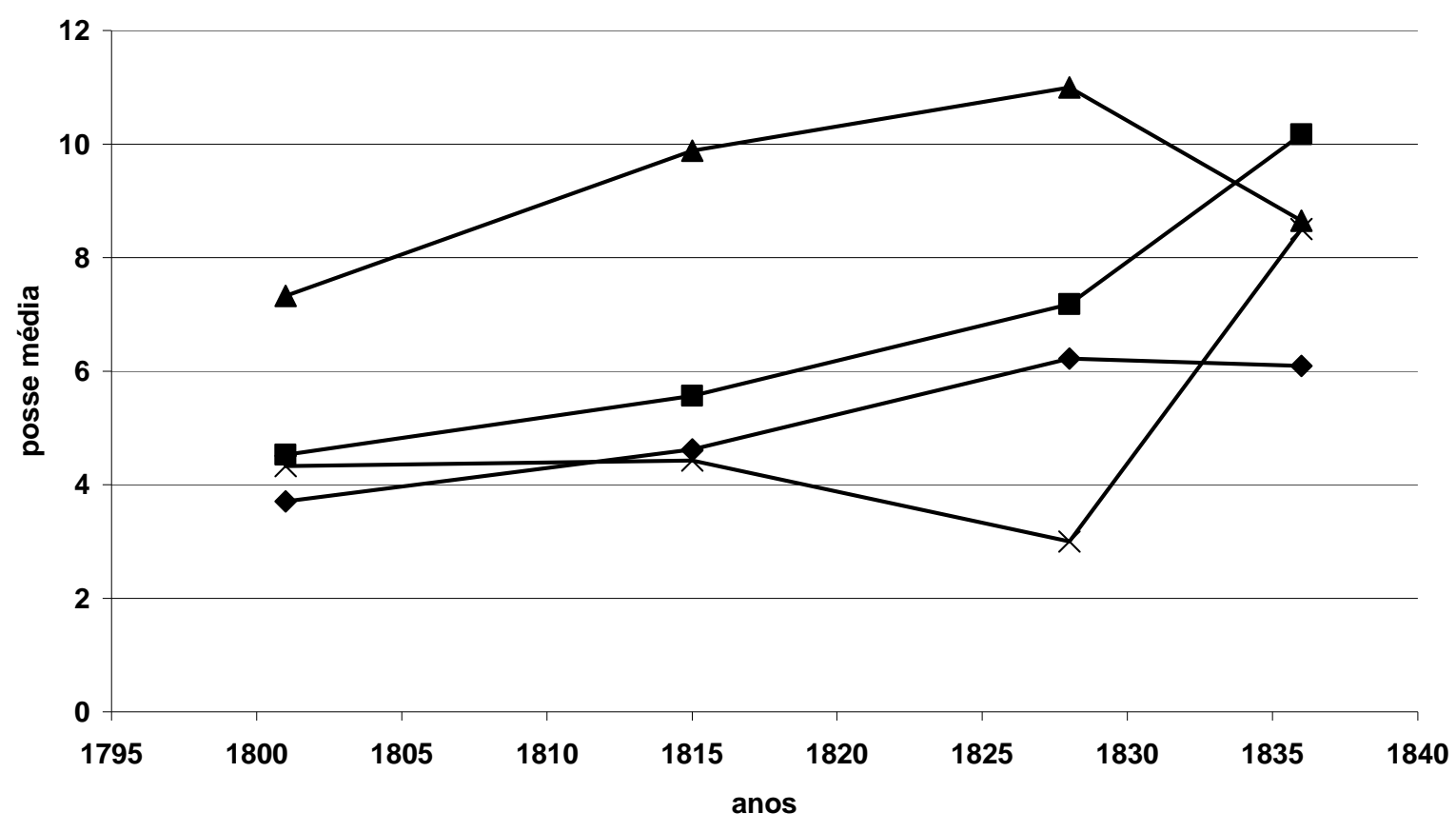

Vale do Ribeira $\rightarrow$-paulistas $\rightarrow$ europeus $*$ outros

Gráfico 3.13

Posse média de escravos segundo origem do proprietário

(Xiririca, anos selecionados)

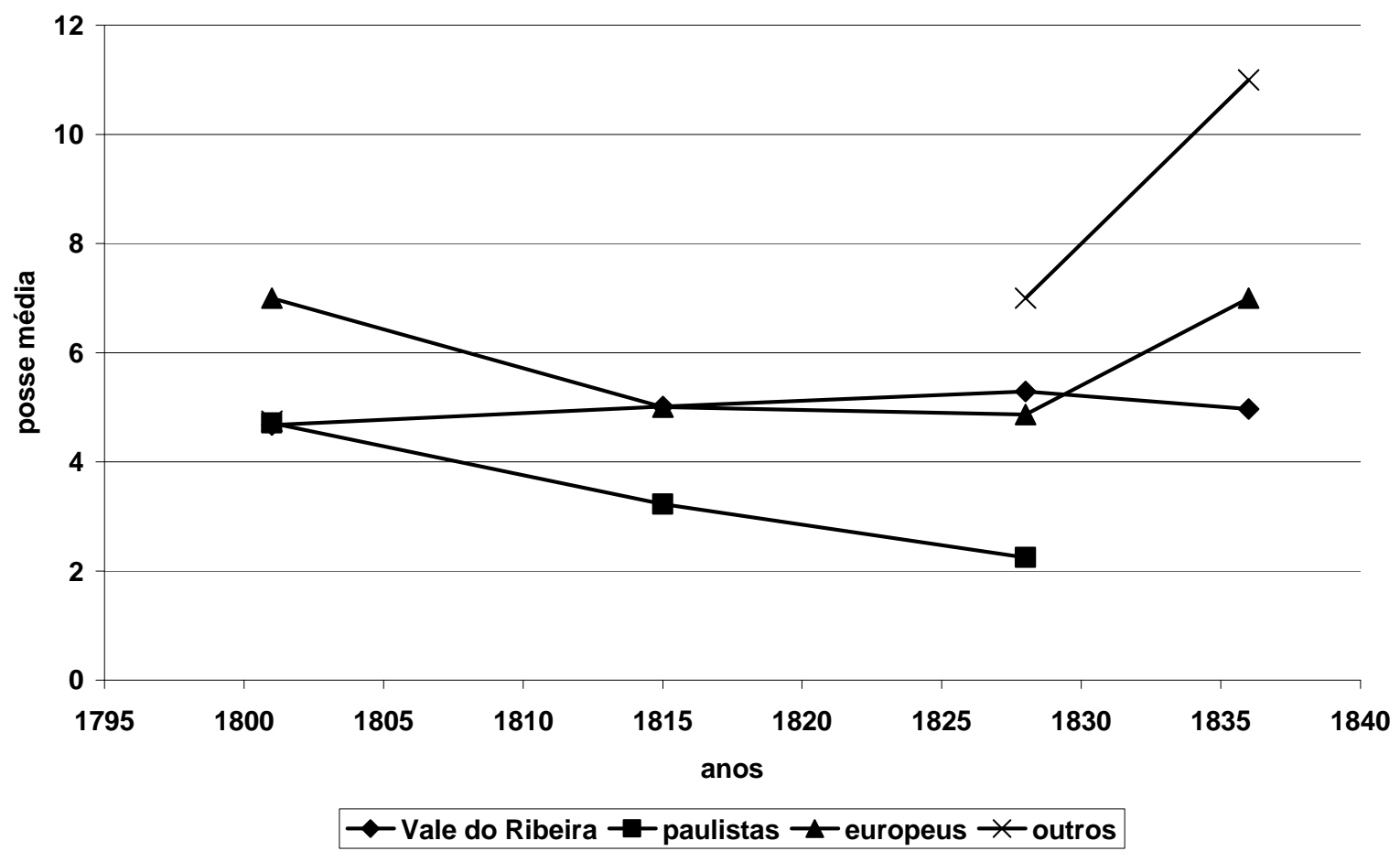


Quando a posse média é distribuída segundo as faixas etárias dos escravistas (Gráficos 3.14 e 3.15), verificamos em Iguape, de maneira geral, um comportamento próximo daquele esperado resultante do processo de acumulação durante o ciclo de vida desses proprietários. ${ }^{162}$ Dois destaques merecem ressalvas: o elevado número médio de escravos apresentado pelos proprietários com 70 anos ou mais em 1801 e também o elevado número médio pertencente aos jovens escravistas no ano de 1828. Este último deve-se ao arranjo já comentado no caso de Bartolomeu da Costa Almeida Cruz e, caso se adotasse o mesmo procedimento lá indicado, a média dos escravistas com idade entre 20 e 29 anos reduzir-se-ia de 7,7 para 4,7 e, entre aqueles com 50 a 59 anos, de 8,3 para 9,3. Sobre os escravistas mais idosos do início da centúria, cabe destacar que esta faixa etária possuía o maior valor mediano (4 escravos) e três deles detinham 10 ou mais escravos. Estes três já habitavam a região em 1789 e possuíam escravos em quantidade menor do que a observada em 1801; todos se dedicavam à lida agrícola, porém apenas um deles declarou colher alguma quantidade de arroz neste último ano.

\footnotetext{
${ }^{162} \mathrm{O}$ conceito aqui utilizado de ciclo de vida fundamenta-se nas notas de Iraci del Nero da Costa e José Flávio Motta. O primeiro considera que “(...) pode-se esperar que o número de escravos varie com a idade do proprietário. Assim, até a faixa dos sessenta-setenta anos verificar-se-ia uma correlação positiva entre as duas variáveis. Tal afirmativa parte do suposto de que o escravista tenderia a acumular riqueza - neste caso representada pelo número de escravos possuídos - no correr do período economicamente ativo de sua vida. Já para a faixa colocada após os setenta anos - como decorrência de uma eventual partilha de bens em vida ou da não-reposição de escravos falecidos - ocorreria uma relação inversa entre idade do proprietário e número de cativos” (COSTA, 1997, p.2-3). José Flávio Motta relembra a importância do aludido conceito dentro do modelo proposto por Hebert Gutman sobre a destruição, construção e dispersão da família escrava e redes de parentesco: "A influência do senhor [de escravos - AV] é marcante, por exemplo, no modelo cíclico de destruição, construção e dispersão da família escrava elaborado por Gutman. Esse movimento cíclico acompanha as diversas etapas da vida - e da atividade econômica - do proprietário de pequenas plantações. Este, ao iniciar sua vida adulta, procede à formação de sua força de trabalho, com isso acarretando amiúde a destruição de laços familiares anteriormente possuídos por seus escravos; tais laços vão-se recompondo e desenvolvendo, em um processo de estabilização e reprodução da mão-de-obra que marca a 'meia-idade' do senhor; por fim, a velhice ou a morte deste freqüentemente provoca a quebra de laços construídos na fase anterior, tendo lugar a dispersão da força de trabalho" (MOTTA, 1999, p. 205-6).
} 
Gráfico 3.14

Posse média de escravos segundo faixas etárias dos proprietários

(Iguape, anos selecionados)

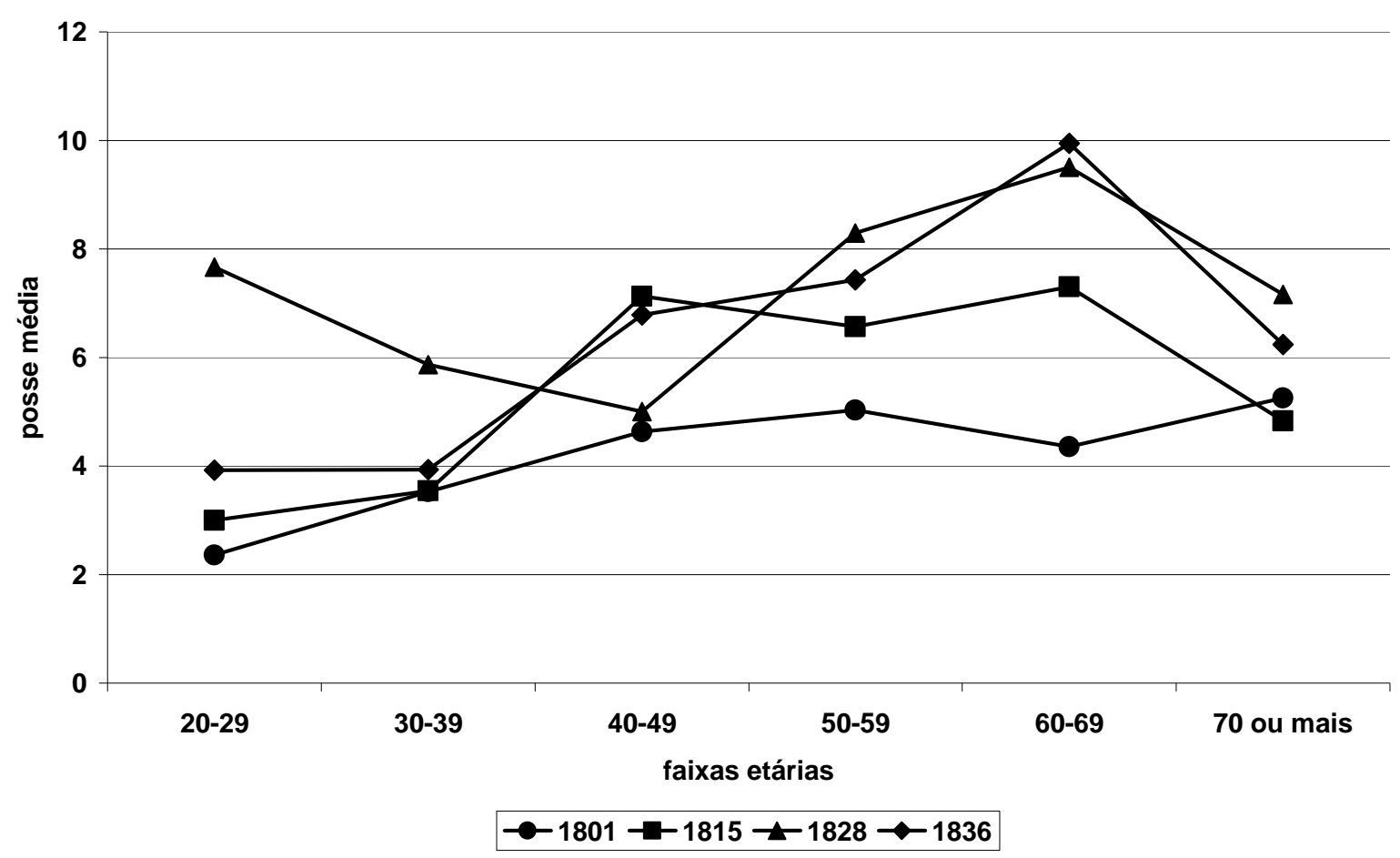

Já na freguesia de Xiririca, o resultado esperado a partir do ciclo de vida dos proprietários mostra-se mais visível em 1828 e 1836. A distribuição observada em 1801 aparentemente reflete os dois momentos econômicos da localidade. Entre os escravistas até 49 anos, o crescente valor médio provavelmente se associa à gênese da rizicultura, praticada na maioria dos fogos escravistas de Xiririca, conforme analisado no Capítulo 1; já no conjunto de proprietários com 50 anos ou mais, o aumento no valor médio entre aqueles com 60 a 69 anos possivelmente decorreu dos ganhos obtidos com as atividades mineratórias que, certamente, também responde pelo elevado valor médio dos escravistas com 70 anos ou mais em $1815 .{ }^{163}$ De qualquer forma, é preciso ressaltar que se trata de um pequeno número de proprietários, tornando a média mais suscetível a variações.

\footnotetext{
${ }^{163}$ Dos cinco casos registrados em 1815, quatro também constavam entre os escravistas presentes em 1801.
} 
Gráfico 3.15

Posse média de escravos segundo faixas etárias dos proprietários

(Xiririca, anos selecionados)

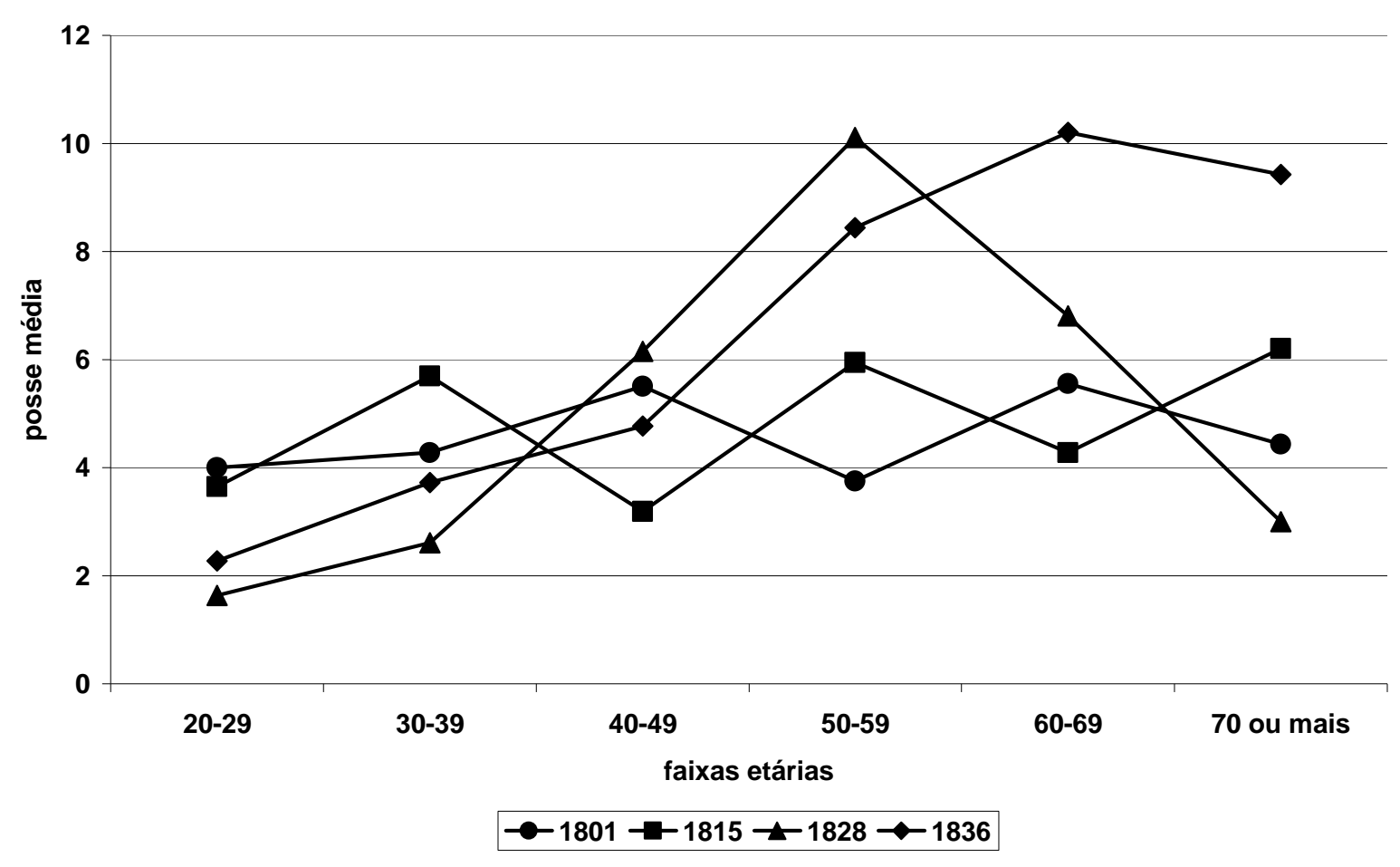

Se o delineamento do perfil demográfico dos escravistas no Vale do Ribeira permite-nos observar uma fase mais dinâmica entre os anos de 1801 e 1828, os resultados sobre a posse média de escravos corroboram este desenho. No entanto, os fatores estimulantes deste desempenho - essencialmente os ganhos obtidos com o cultivo e processamento do arroz - parecem não permitir a manutenção do ritmo de crescimento verificado nas duas primeiras décadas da centúria, como se vê através da posse média dos escravistas no Vale do Ribeira em 1836, tanto em Iguape como em Xiririca.

Pudemos também detectar segmentos específicos com maior distinção, como o caso dos escravistas de origem européia, que apresentaram uma súbita redução da posse média entre 1828 e 1836. Atribuímos esta redução à morte de alguns destes imigrantes e, de acordo com os Gráficos 3.10 e 3.11, pudemos captar a transferência dessas posses para as viúvas.

Apresentamos em seguida algumas características da população escrava presente nos anos em tela. Os Gráficos 3.16 e 3.17 distribuem os cativos segundo sexo e faixas etárias decenais em Iguape e Xiririca. 
Gráfico 3.16

Distribuição dos escravos segundo sexo e faixas etárias

(Iguape, anos selecionados)
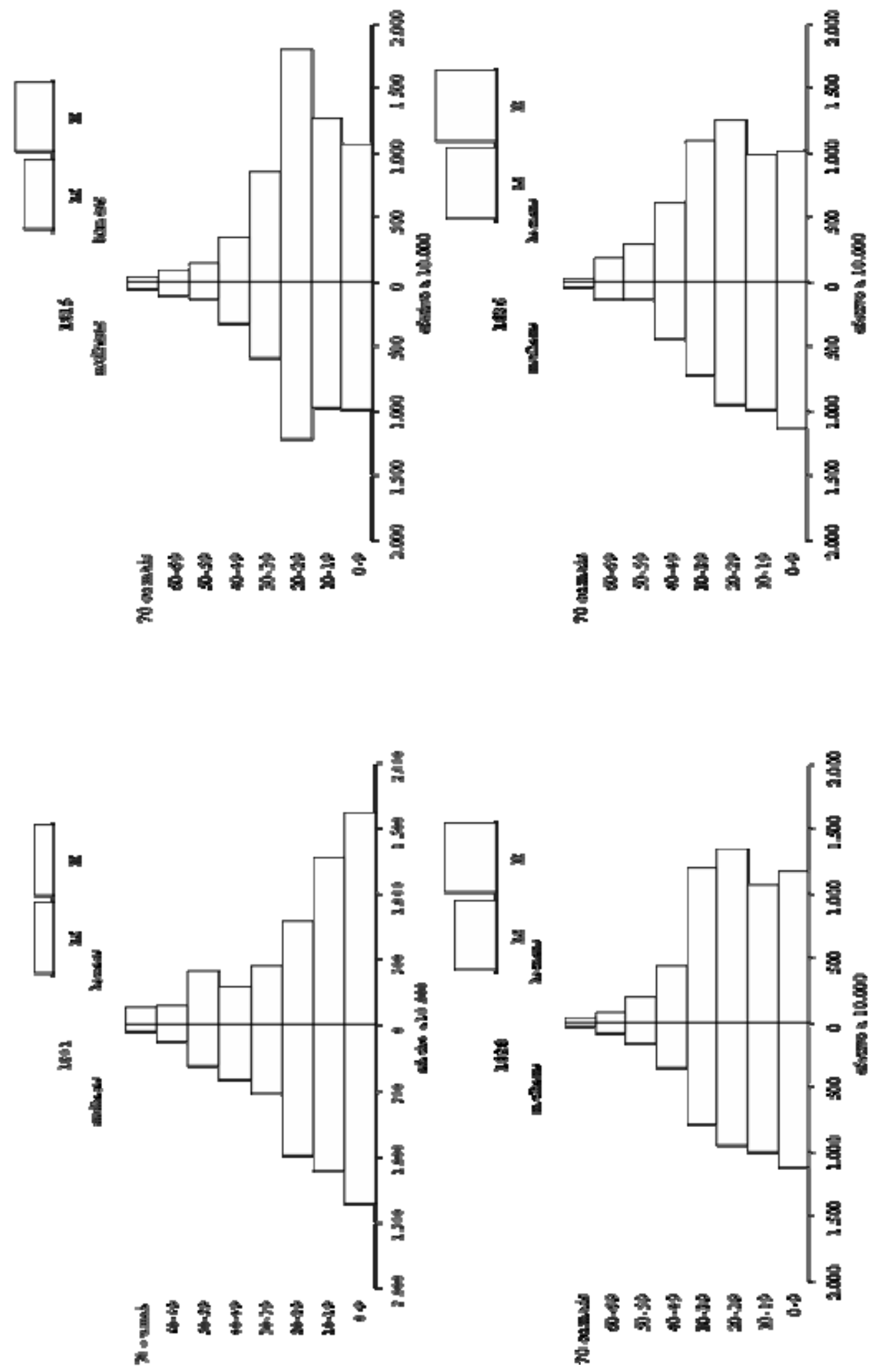
Gráfico 3.17

Distribuição dos escravos segundo sexo e faixas etárias

(Xiririca, anos selecionados)
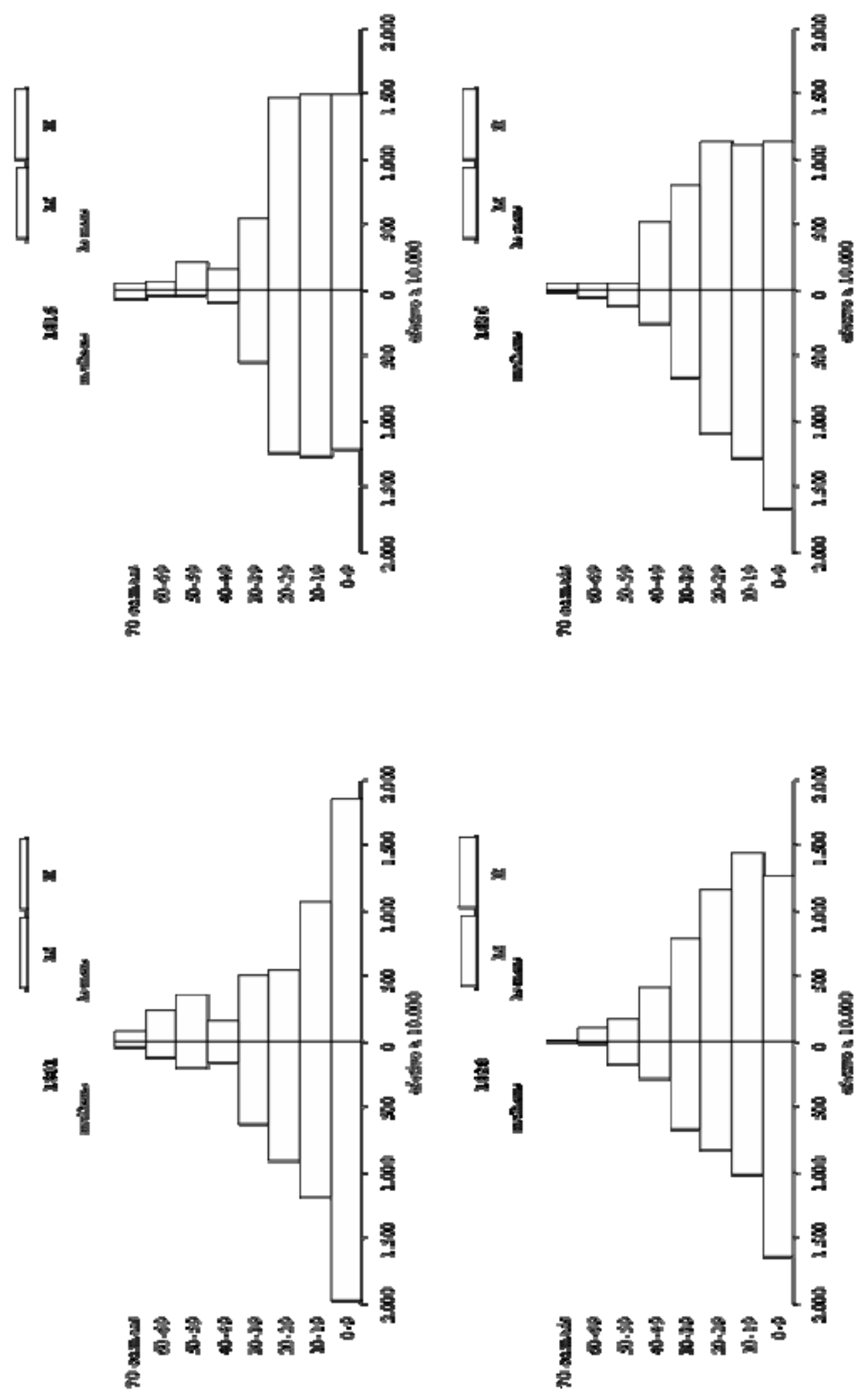
A distribuição da população cativa em Iguape no início do século XIX mostrou-se distinta em relação aos demais anos: em 1801, os escravos com menos de 20 anos representavam 53\% do contingente e nas faixas de maior vigor físico (20 a 49 anos) as mulheres predominavam. Em 1815, a faixa etária entre 20 e 29 anos aparece com maior participação, especialmente entre os homens, refletindo o maior fluxo de cativos nesta condição para a região. A partir deste ano os cativos do sexo masculino sempre corresponderam à maioria dos casos nas faixas etárias entre 20 e 49 anos. Entre 1801 e 1815, não verificamos diferenças na idade média tanto de homens quanto de mulheres - 22 anos porém a idade mediana para o sexo masculino passou de 17 para 21 anos e, entre as mulheres, de 19 para 20 anos. Para os demais anos, enquanto a idade média das cativas manteve-se a mesma, a dos homens atingiu 23 anos em 1828 e 25 anos em 1836, sugerindo que o aludido fluxo de jovens cativos do sexo masculino não se sustentou ao longo do tempo, como bem demonstra as menores participações masculinas na faixa etária de 20 a 29 anos tanto nos porcentuais relativos ao sexo como nas faixas etárias.

A mesma tendência pode ser verificada em Xiririca, porém com menor intensidade. Em primeiro lugar, os cativos com menos de 10 anos não apresentaram redução relativa tão significativa como em Iguape e apenas em 1828 a parcela da população com menos de 20 anos deixou de representar a maioria dos casos registrados na freguesia. Por outro lado, o ingresso de novos escravos com 20 anos ou mais, detectável em 1815 se comparado com as participações em 1801, gerou menor impacto nos anos posteriores se comparado com a distribuição de seus pares iguapenses. Esta menor influência também pode ser aferida através da idade média dos escravos, que passou de 21 anos em 1801 para 19 em 1815 entre os homens não obstante o aumento da idade mediana de 15 para 18 anos; entre as mulheres, o primeiro indicador manteve-se em 18 anos e o segundo, de 16 para 18 anos. Nos demais anos, a idade média dos cativos manteve-se em torno dos 21 anos e a das cativas repetiu o mesmo valor já registrado em 1801 e 1815. Neste caso, a manutenção das idades médias mais baixas associa-se à já aludida presença de cativos mais jovens, especialmente crianças.

O desequilíbrio entre os sexos nas faixas etárias mais jovens, especialmente naquelas de maior vigor físico apresentou-se em maior ou menor grau em toda a Capitania nas três primeiras décadas do século XIX. No Vale do Paraíba em 1804, a razão de sexo dos escravos com idade entre 20 e 29 anos atingia 146 e, em 1829, 217. No Oeste Paulista a presença masculina mostrava-se mais expressiva: 173 em 1804 e 254 em 1829. No conjunto das regiões litorâneas, este indicador passou de 118 para 155 (cf. LUNA, 1992, p. 463). Em Iguape, a razão de sexo na referida faixa etária atingiu 153 e, em Xiririca, 140. Em outras 
localidades paulistas, no entanto, atingiu valores bem superiores, como em Bananal, onde a razão de sexo na faixa etária passou de 118 em 1801 para 248 em 1829 (cf. MOTTA, 1999, p. 133.); em Ubatuba, oscilou de 92 em 1798 para 130 em 1828 e 178 em 1836. Já a vila de São Sebastião apresentou movimento inverso, possuindo a mais elevada razão de sexo para escravos entre 20 e 29 anos no início do Oitocentos, 172 e redução para 140 em 1828 e 133 em 1836 (cf. FERNÁNDEZ, 1992, p. 338-345).

Tais resultados podem ser melhor compreendidos a partir dos Gráficos 3.18 e 3.19, que distribuem apenas os cativos com 15 anos ou mais segundo sexo e condição conjugal. A participação dos solteiros na vila superou os sete décimos em todos os anos, com especial destaque entre os cativos do sexo masculino, com mais de $80 \%$ em três do quatro anos. Na freguesia, esta parcela não superou a marca de seis décimos em nenhum dos anos. Ademais, em Iguape o porcentual de casados e viúvos manteve-se em torno de um quinto nos três primeiros anos até atingir o menor valor em 1836, 16\%. Já em Xiririca, este conjunto oscilou de um terço a quatro décimos.

Em consonância com os dados expostos, Francisco Vidal Luna verificou que a região do Litoral possuía, tanto em 1804 como em 1829, a maior participação de solteiros entre todas as localidades paulistas por ele investigadas, atingindo $79 \%$ dos casos, enquanto o Oeste Paulista apresentava a menor porcentagem nos dois anos, com valor próximo a 64\% (cf. LUNA, 1992, p. 464). O autor sugere a associação entre a maior participação de solteiros e as menores posses médias, conforme proposto anteriormente por Costa e colaboradores. ${ }^{164}$ Distribuídos entre as diferentes faixas de tamanho de plantéis, estes verificaram uma desproporção entre casados e viúvos e o total de escravos: para a faixa de 1 a 4 escravos, apenas $13 \%$ dos escravos eram casados ou viúvos dentro de quase um quarto do total de escravos; já nos plantéis maiores, encontraram cerca de 63\% dos escravos casados ou viúvos, presentes no subconjunto que concentrava mais de $50 \%$ do total de cativos. Esse conjunto de dados levou os autores a sugerirem uma associação positiva entre o tamanho do plantel e a participação de escravos casados ou viúvos.

\footnotetext{
${ }^{164}$ COSTA, SLENES \& SCHWARTZ (1987), assim como GUTIÉRREZ (1986).
} 
Gráfico 3.18

Distribuição dos escravos com 15 anos ou mais segundo sexo e condição conjugal (Iguape, anos selecionados)
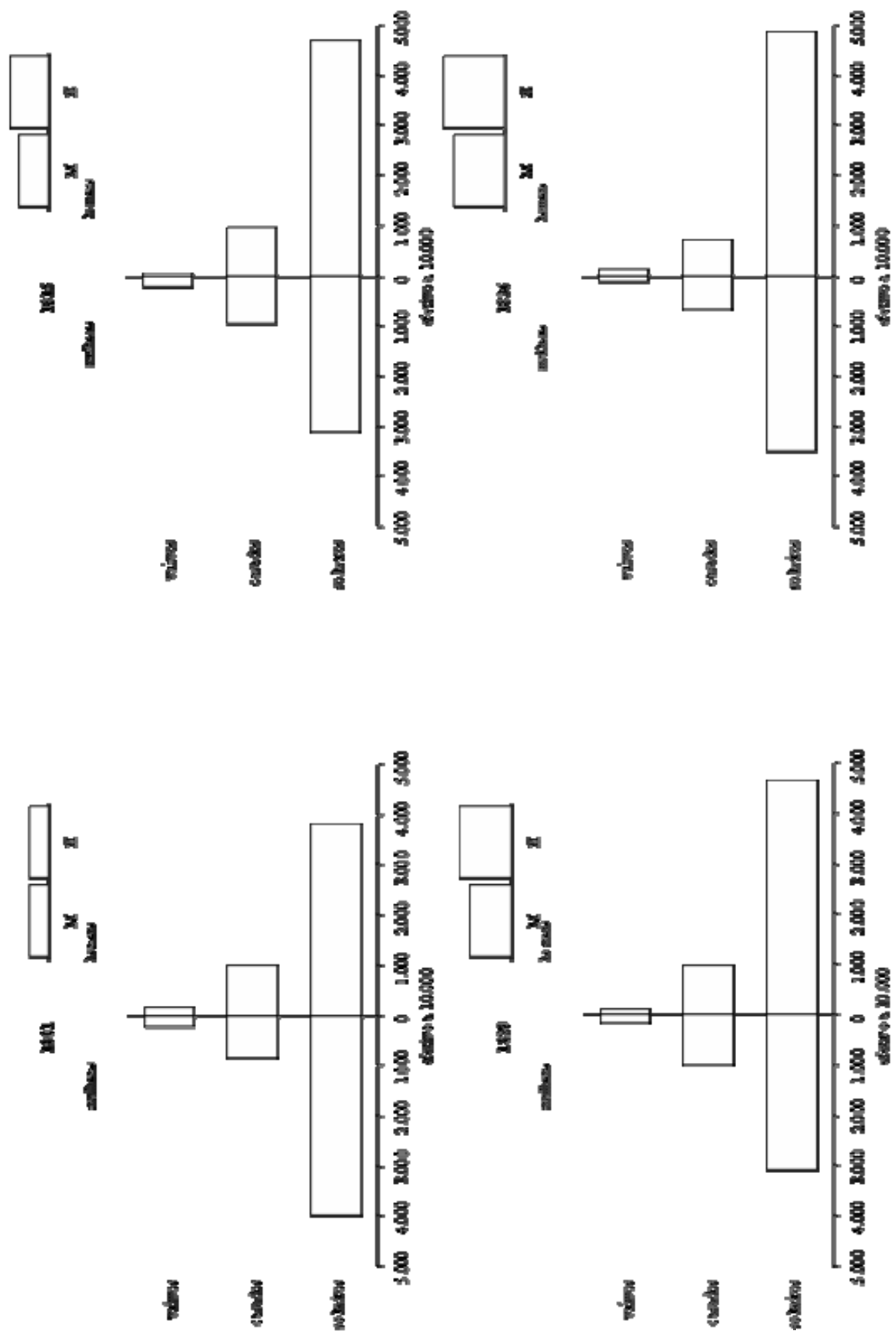
Gráfico 3.19

Distribuição dos escravos com 15 anos ou mais segundo sexo e condição conjugal (Xiririca, anos selecionados)
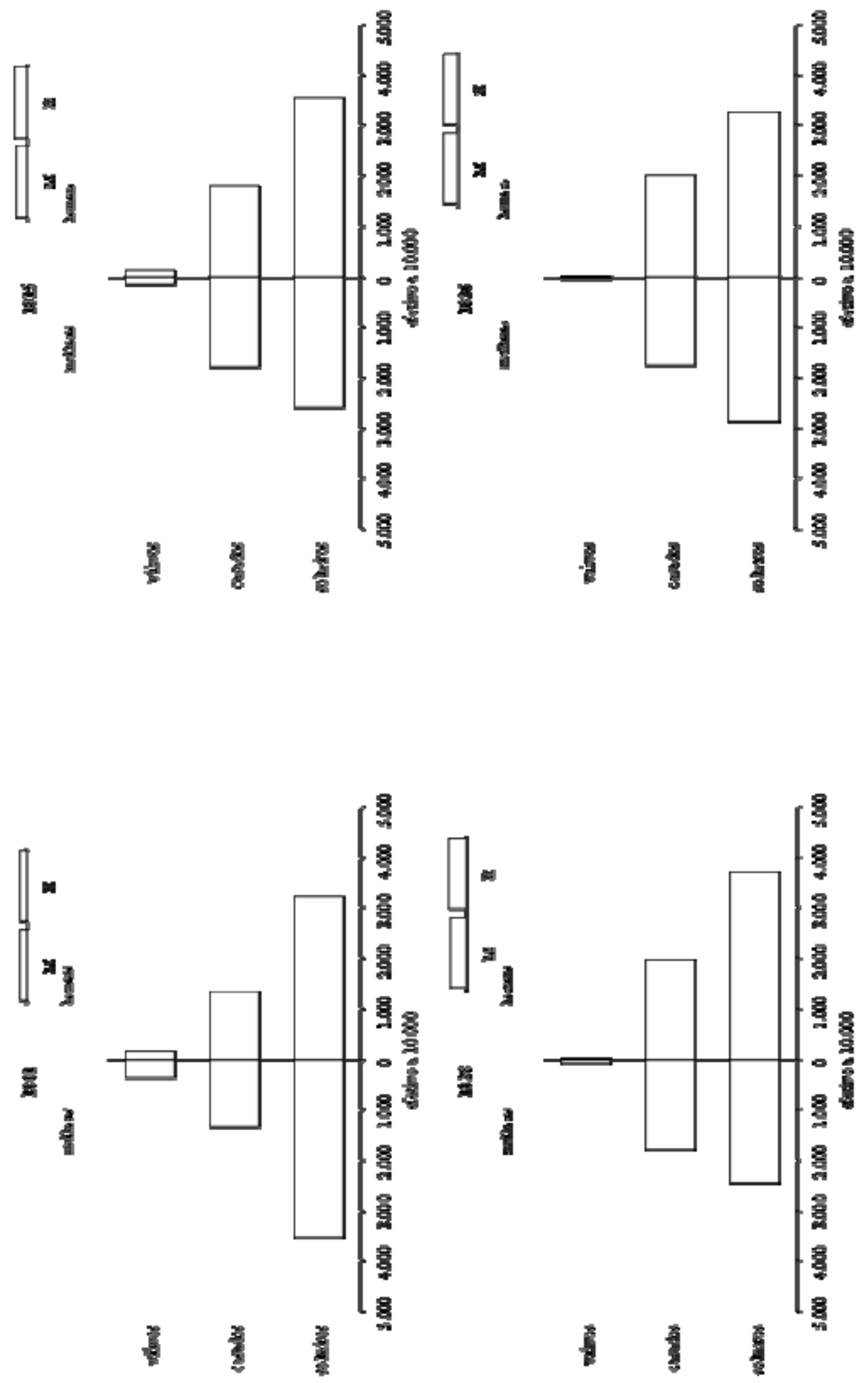
Tomando apenas os dados de 1828, verificamos que em Iguape 56\% dos escravos casados ou viúvos pertenciam aos plantéis com 20 escravos ou mais, porém nesta faixa de posse encontramos apenas 37\% dos cativos com 15 anos ou mais. Em Xiririca há que se observar a presença de apenas duas propriedades nesta faixa de posse, onde $63 \%$ dos cativos eram casados e, nas posses com 10 a 19 cativos, $48 \%$ eram casados ou viúvos contra $26 \%$ em Iguape. A maior presença de casados e viúvos na freguesia possivelmente contribuiu para a maior parcela de cativos com idade inferior a 10 anos observado no Gráfico 3.17. Corroborando este quadro, as estimativas do índice geral de fecundidade ${ }^{165}$ entre as duas localidades revelam diferenças significativas entre a vila e a freguesia: em 1801, este indicador atingia 639 em Iguape e 916 em Xiririca. Na freguesia observamos estimativas superiores nos anos seguintes: em 1815, 600 contra 436 em Iguape; em 1828660 versus 449 e, 1836, 560 e 417, respectivamente. Em 1804, Luna verificou que este índice variou de 347 no Oeste Paulista a 510 no Vale do Paraíba e, em 1829, de 320 novamente no Oeste Paulista a 408 no Caminho do Sul (cf. LUNA, 1992, p. 466). ${ }^{166}$

Muito provavelmente o crescimento no número de escravos na região aqui estudada, não obstante a importância das aquisições realizadas pelos proprietários, também se manteve graças aos mecanismos de reprodução natural, principalmente em Xiririca.

Os gráficos seguintes apresentam a população escrava segundo a cor registrada nas listas nominativas.

\footnotetext{
${ }^{165}$ Este indicador considera a relação entre a quantidade total de crianças de 0 a 4 anos e para cada 1.000 mulheres entre 15 e 44 anos.

${ }^{166}$ Para o autor, "Provavelmente em regiões dedicadas aos cultivos de subsistência, não necessariamente de autoconsumo, ocorreu a reprodução natural. Na Capitania de São Paulo, durante o século XVIII, a economia baseada em cultivos de subsistência, com relativa estabilidade da população escrava, possivelmente permitiu a reprodução natural dos escravos. No final do século XVIII, ao intensificar-se a atividade açucareira no Oeste Paulista e posteriormente com a introdução do café, inibiu-se o potencial reprodutivo" (LUNA, 1992, p. 450). No entanto, José Flávio Motta observou que o indicador de fecundidade na população escrava de Bananal oscilou menos do que o conjunto agregado do Vale do Paraíba, não obstante a maciça entrada de escravos, principalmente africanos e do sexo masculino: em 1801, a estimativa atingia 365 crianças de 0 a 4 anos para cada 1.000 mulheres entre 15 a 49 anos. Em 1815, reduziu-se a 313 e, em 1829, 352, constituindo-se um dos indicadores da manutenção da família escrava na região, apesar das intensas mudanças condicionadas pela rápida disseminação do café e pelo incremento expressivo da população cativa (cf. MOTTA, 1999, p. 353).
} 
Gráfico 3.20

Distribuição de escravos segundo sexo e cor

(Iguape, anos selecionados)
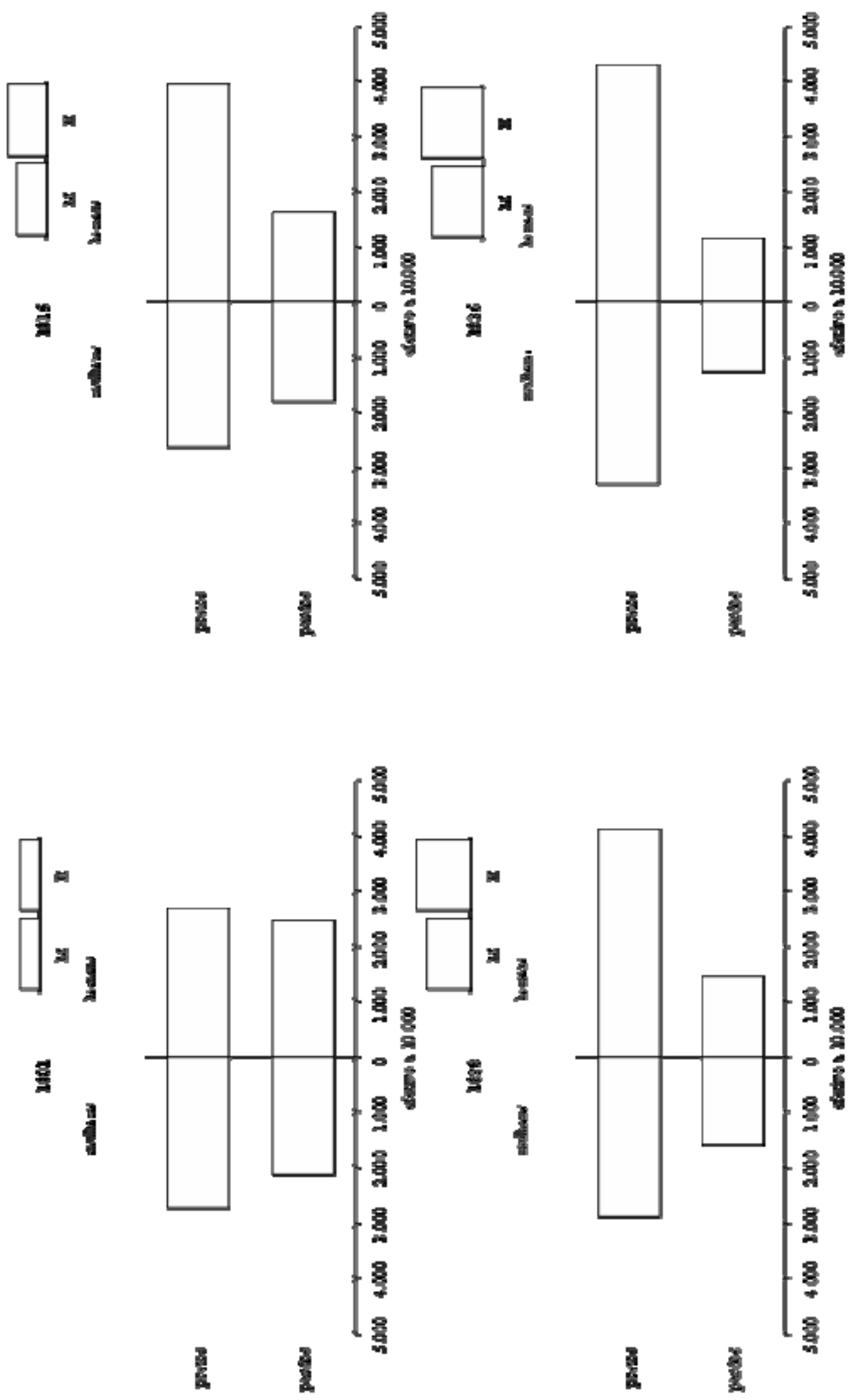
Gráfico 3.21

Distribuição de escravos segundo sexo e cor

(Xiririca, anos selecionados)
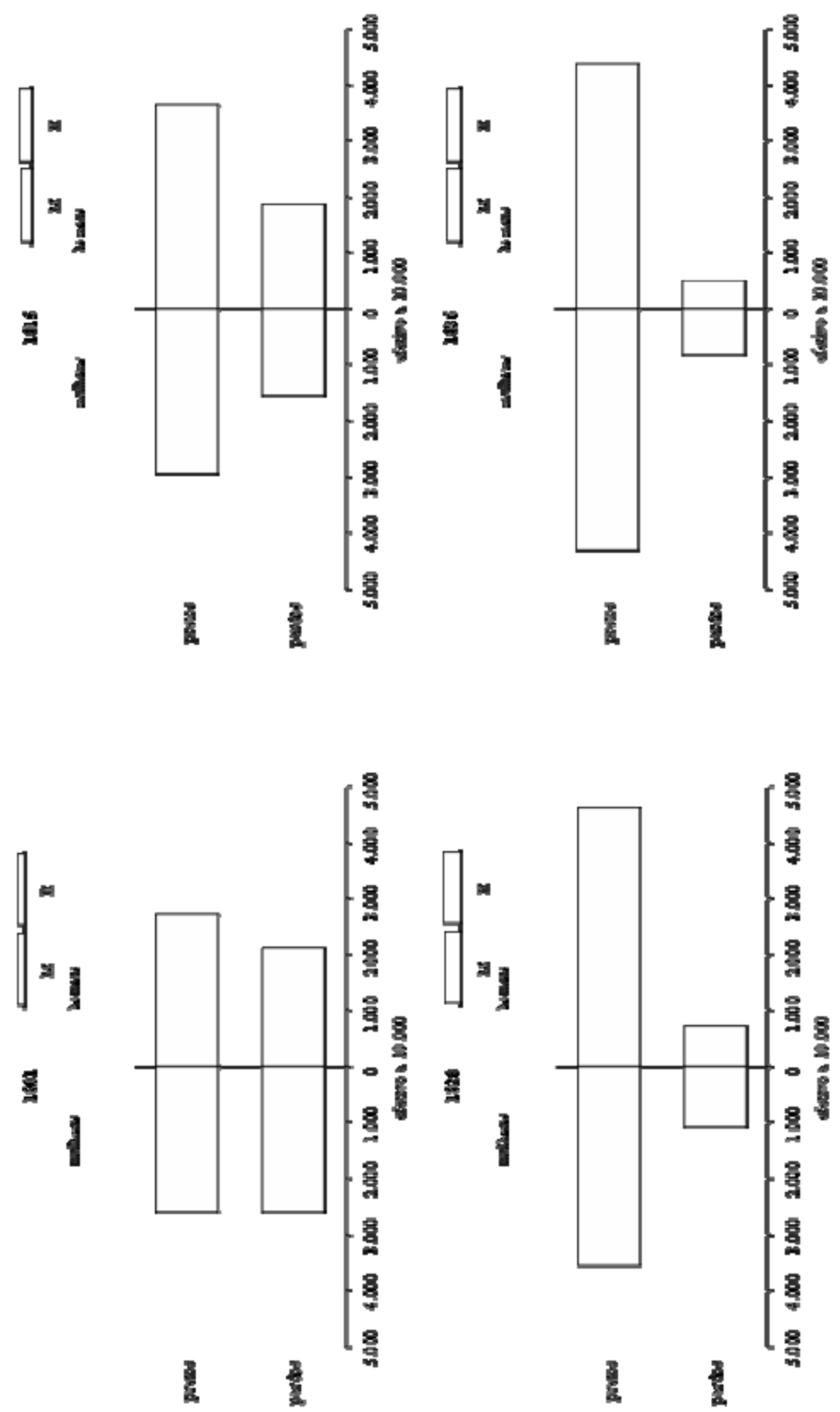
No ano de 1801, pardos e pretos apresentavam-se em relativo equilíbrio tanto em Iguape como em Xiririca, porém a partir de 1815 os pretos passaram a responder por parcelas cada vez maiores, principalmente na freguesia, atingindo 87\% dos escravos em 1836 contra $76 \%$ em Iguape. Nesta, notamos um menor desequilíbrio entre homens e mulheres pardos; entre os cativos de cor preta, predominavam os escravos do sexo masculino. O mesmo pode ser percebido em Xiririca, porém com menor intensidade. Apesar da importância relativa decrescente dos pardos, as participações indicadas acima superam os valores observados por José Flávio Motta em Bananal, atingindo o valor máximo de 12\% em 1801 (cf. MOTTA, 1999, p. 134). Em São Sebastião, esta parcela manteve-se em torno de $20 \%$ dos casos durante as três primeiras décadas do século XIX, porém caindo para 12\% em 1836 e em Ubatuba, os valores começaram a decrescer a partir de 1818, de 20\% para 8\% em 1828 e 6\% em 1836 (cf. FERNÁNDEZ, 1992, p. 293).

Tanto em Bananal como em Ubatuba os autores associam a menor presença de pardos com o intenso afluxo de escravos africanos. Em certa medida, o predomínio de cativos da cor preta no Vale do Ribeira também guarda relação com a origem dos cativos, cujos resultados são apresentados nos gráficos seguintes.

Ainda que os originários do próprio Vale do Ribeira representassem a maioria dos cativos de Iguape, a participação relativa dos africanos passou de 8\% para 30\% em 1815, mantendo valores assemelhados nos dois anos subseqüentes. Tais porcentagens decorrem principalmente das frações masculinas, que registraram 38\% em 1815 e 1836, representando ainda praticamente sete décimos do total de africanos. Novamente, o mesmo sentido pode ser observado na freguesia, porém em menor dimensão: a participação de cativos africanos passou de 9\% em 1801 para 29\% em 1815, com maior impacto entre os homens. ${ }^{167}$

Ao acoplarmos estes resultados com o perfil dos proprietários ribeirenses e a evolução da posse média, concluímos que o crescimento do setor escravista ocorreu de forma diferenciada entre as duas localidades. Em Iguape, onde registramos as maiores posses médias e a maior presença de proprietários de outras regiões, verificamos também a maior participação de cativos do sexo masculino nas faixas etárias de maior vigor físico, um maior peso dos cativos de origem africana e maior importância dos escravos solteiros.

\footnotetext{
${ }^{167}$ Africanos em Bananal constituíam a maioria dos escravos, passando de 57\% em 1801 para 78\% em 1829 (cf. MOTTA, 1999, p. 134).
} 
Gráfico 3.22

Distribuição dos escravos segundo sexo e origem

(Iguape, anos selecionados)
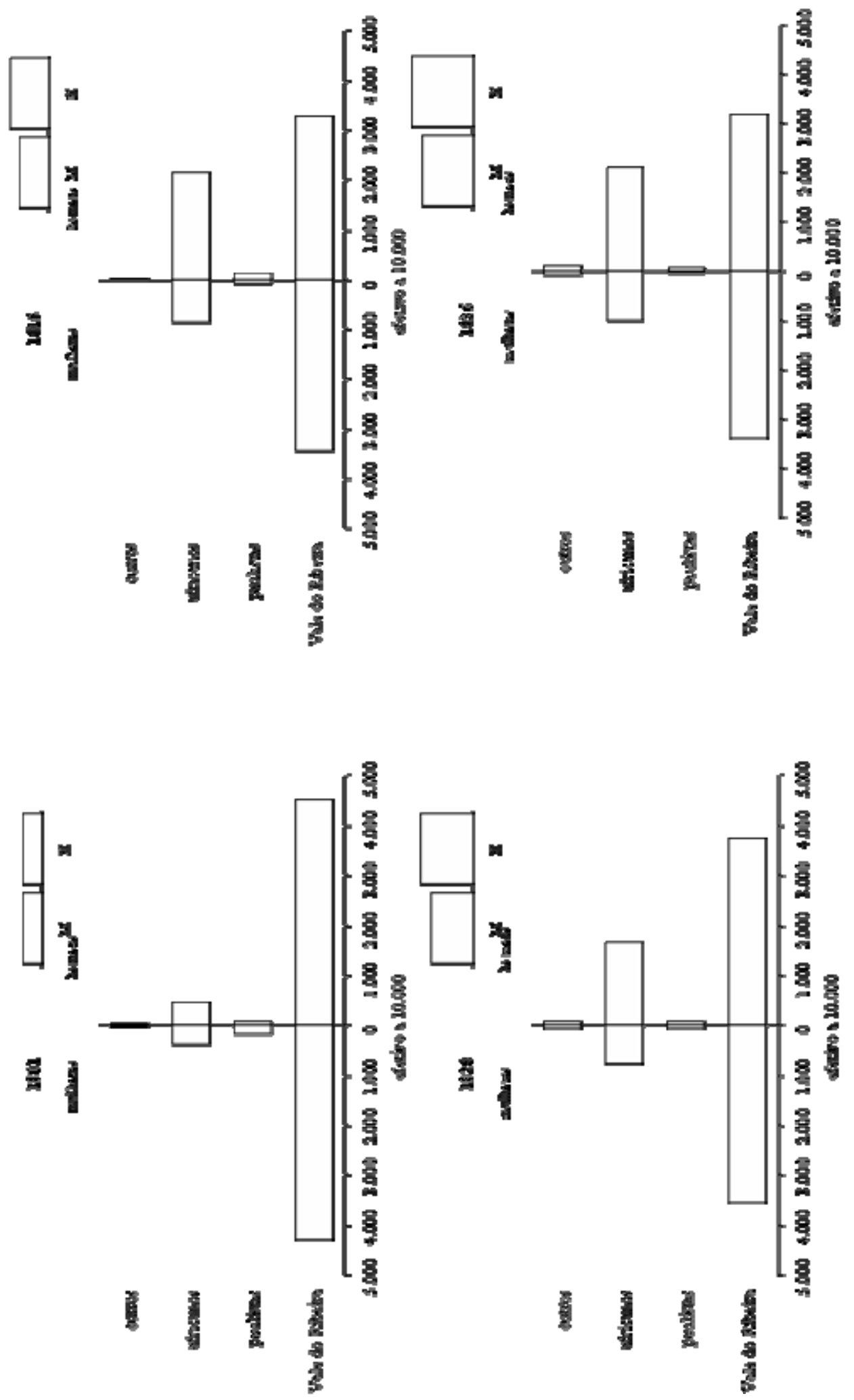
Gráfico 3.23

Distribuição dos escravos segundo sexo e origem

(Xiririca, anos selecionados)
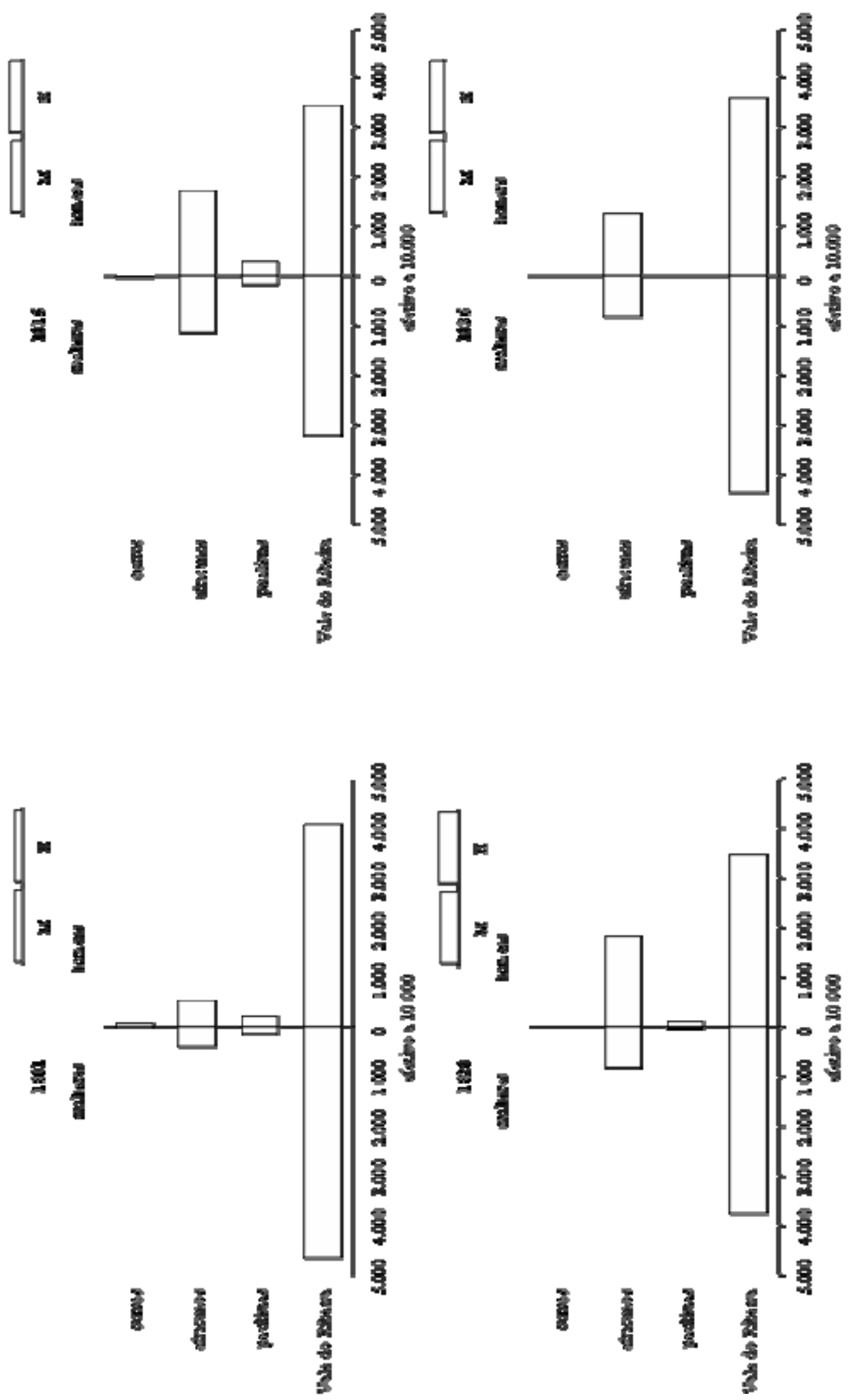
Tais traços revelam que parcela importante dos proprietários de escravos realizaram, principalmente entre 1801 e 1828, investimentos significativos na aquisição de escravos. Em Xiririca, também notamos sinais deste aporte, porém em escala mais modesta. É certo que esta onda de investimento atingia toda a região paulista e os números da Tabela 3.2 evidenciam as principais diferenças do Vale do Ribeira em relação a outras localidades paulistas.

Os resultados agregados tanto para proprietários como para os escravos mostram as mudanças em seus perfis, porém em menor magnitude do que as observadas para as áreas mais dinâmicas do território paulista, como o Oeste paulista e o Vale do Paraíba. Especialmente onde o cultivo do café progrediu de forma intensiva, como em Bananal, as diferenças ganharam maior acento com o passar dos anos e, mesmo para as regiões que mesclavam a cafeicultura com o cultivo de cana, como as vilas de Lorena e aquelas localizadas no Litoral Norte, o padrão de posse escrava do Vale do Ribeira mostrava-se mais modesto.

Observemos inicialmente os dados e indicadores das duas localidades ribeirenses. Em Iguape o número de proprietários cresceu 82\% entre 1801 e 1836 e a população escrava, 186\%, a taxas geométricas anuais de 1,7\% e 3,1\%, respectivamente. Já na freguesia, a quantidade de escravistas sofreu um acréscimo de $87 \%$ a uma taxa de $1,8 \%$ ao ano e o contingente cativo, $105 \%$ a $2,1 \%$ ao ano. As diferenças regionais tornam-se evidentes nos valores da posse média: em Iguape esta passou de 4,3 para 6,7 escravos por proprietário e em Xiririca a oscilação revelou-se muito menor, de 4,7 para 5,1 cativos por proprietário. Ainda em Iguape, não obstante a elevação da posse mediana de 3 para 4 escravos, a distribuição da massa cativa entre os proprietários apresentou gradual concentração entre 1801 e 1828, seguida por um pequeno arrefecimento em 1836, ano em que o valor médio e a razão de sexo entre os escravos também apresentaram ligeiro declínio em relação aos valores observados no final da década de 1820. 
Tabela 3.2

Indicadores estatísticos da posse de escravos

(várias localidades, anos selecionados)

\begin{tabular}{|c|c|c|c|c|c|c|c|c|}
\hline Localidade & ano & proprietários & escravos & média & mediana & moda & índice de Gini & Razão de Sexo \\
\hline Vale do Paraíba ${ }^{\text {a }}$ & 1804 & 1.227 & 6.979 & 5,7 & 3 & 1 & 0,546 & 127 \\
\hline Vale do Paraíba ${ }^{\text {a }}$ & 1829 & 2.200 & 16.593 & 7,5 & 4 & 1 & 0,604 & 174 \\
\hline Oeste Paulista ${ }^{a}$ & 1804 & 1.164 & 8.373 & 7,2 & 3 & 1 & 0,588 & 157 \\
\hline Oeste Paulista $^{a}$ & 1829 & 1.676 & 18.880 & 11,3 & 4 & 1 & 0,645 & 197 \\
\hline Litoral $^{\mathrm{a}}$ & 1804 & 897 & 5.525 & 6,1 & 3 & 1 & 0,544 & 121 \\
\hline Litoral $^{\mathrm{a}}$ & 1829 & 966 & 5.783 & 6,2 & 3 & 1 & 0,574 & 137 \\
\hline Caminho do Sul $^{\text {a }}$ & 1804 & 753 & 3.759 & 5,0 & 3 & 1 & 0,536 & 104 \\
\hline Caminho do Sul $^{\text {a }}$ & 1829 & 1.086 & 5.044 & 4,6 & 3 & 1 & 0,519 & 117 \\
\hline Capital $^{\text {a }}$ & 1804 & 1.633 & 8.404 & 5,2 & 3 & 1 & 0,519 & 100 \\
\hline Capital $^{\text {a }}$ & 1829 & 1.620 & 8.150 & 5,0 & 3 & 1 & 0,527 & 110 \\
\hline São Sebastião b & 1798 & 350 & 2.385 & 6,8 & 3 & 1 & 0,615 & 137 \\
\hline São Sebastião b & 1817 & 415 & 2.657 & 6,4 & 3 & 1 & 0,599 & 128 \\
\hline São Sebastião b & 1828 & 474 & 2.784 & 5,9 & 3 & 1 & 0,555 & 128 \\
\hline São Sebastião b & 1836 & 473 & 3.045 & 6,6 & 3 & 1 & 0,596 & 135 \\
\hline Ubatuba $^{\mathrm{b}}$ & 1798 & 105 & 513 & 4,9 & 3 & 1 & 0,549 & 118 \\
\hline Ubatuba $^{\mathrm{b}}$ & 1818 & 156 & 721 & 4,6 & 3 & 1 & 0,520 & 115 \\
\hline Ubatuba $^{\mathrm{b}}$ & 1828 & 245 & 1.748 & 7,1 & 4 & 1 & 0,597 & 131 \\
\hline Ubatuba $^{\text {b }}$ & 1836 & 315 & 2.661 & 8,4 & 4 & 1 & 0,634 & 143 \\
\hline Bananal $^{\mathrm{c}}$ & 1801 & 44 & 401 & 9,1 & 4 & 1 & 0,631 & 139 \\
\hline Bananal $^{\mathrm{c}}$ & 1818 & 121 & 1.010 & 8,4 & 4 & 1 & 0,649 & 180 \\
\hline Bananal $^{\mathrm{c}}$ & 1829 & 195 & 2.282 & 11,7 & 5 & 1 & 0,657 & 219 \\
\hline Lorena $^{\mathrm{d}}$ & 1798 & 150 & 770 & 5,1 & - & - & 0,527 & 123 \\
\hline Lorena $^{\mathrm{d}}$ & 1818 & 294 & 1.736 & 5,9 & - & - & 0,506 & 142 \\
\hline Lorena $^{\mathrm{d}}$ & 1829 & 410 & 2.561 & 6,3 & - & - & 0,554 & 165 \\
\hline Iguape & 1801 & 166 & 711 & 4,3 & 3 & 1 & 0,467 & 106 \\
\hline Iguape & 1815 & 224 & 1.264 & 5,6 & 3 & 1 & 0,532 & 127 \\
\hline Iguape & 1828 & 249 & 1.731 & 7,0 & 4 & 1 & 0,560 & 135 \\
\hline Iguape & 1836 & 303 & 2.035 & 6,7 & 4 & 1 & 0,553 & 120 \\
\hline Xiririca & 1801 & 54 & 255 & 4,7 & 3 & 1 & 0,471 & 93 \\
\hline Xiririca & 1815 & 90 & 436 & 4,8 & 3 & 1 & 0,474 & 121 \\
\hline Xiririca & 1828 & 123 & 627 & 5,1 & 3 & 1 & 0,502 & 115 \\
\hline Xiririca & 1836 & 102 & 523 & 5,1 & 3 & 1 & 0,491 & 94 \\
\hline
\end{tabular}

Fontes: (a) LUNA, 1992, p. 462 e LUNA, 1998, p.149; (b) FERNÁNDEZ, 1992, p. 258 e 338-345;

(c) MOTTA, 1999, p. 133 e 158; (d) MARCONDES, 1998, p. 86-104.

Exceto pela mudança no valor mediano, os demais indicadores concernentes à freguesia percorreram a mesma trajetória, porém com menor intensidade: a razão de sexo entre os cativos não atingiu as mesmas marcas observadas em Iguape, inclusive indicando maior presença das mulheres no último dos anos, assim como a concentração da propriedade escrava não atingiu níveis de desigualdade tão intensos.

Esse conjunto de resultados reafirma os limites do dinamismo fomentado pela rizicultura na região e os valores expressos em 1828 representam o ápice deste movimento. E ainda, estes limites se manifestaram com alguma antecedência na freguesia, resultado que 
aparenta alguma normalidade, tendo em vista sua condição subordinada na disposição geográfica.

Nas áreas mais dinâmicas do território paulista, os indicadores mostram maior robustez, como no Oeste Paulista, onde a quantidade de escravistas cresceu 44\% entre 1804 e 1829, a 1,5\% ao ano ao passo que a população escrava aumentou 154\% a uma taxa de 3,3\% ao ano. No Vale do Paraíba, o incremento no número de proprietários entre 1804 e 1829 atingiu $79 \%$ ou $2,4 \%$ ao ano e o de escravos, $138 \%$ a 3,5\% ao ano. Não é possível equiparar o ritmo de crescimento dos escravistas destas regiões com os do Vale do Ribeira, porém o incremento anual da população cativa, pelo menos em Iguape, não ficou muito abaixo destes verificados nas regiões mais dinâmicas da Capitania. Nas áreas onde o café se instalou com maior rapidez estas taxas mostraram-se mais expressivas: em Bananal, o número de proprietários aumentou a uma taxa de 5,5\% ao ano e o de escravos, 6,4\%. Na vizinha Lorena, que possuía em 1798 quantidades assemelhadas de senhores e cativos àquelas observadas em Iguape no ano de 1801, as taxas igualaram-se a 3,3\% e 3,9\%, respectivamente. Nas outras localidades litorâneas, enquanto São Sebastião manteve taxas relativamente modestas $(0,8 \%$ ao ano para escravistas e $0,6 \%$ ao ano para os cativos), em Ubatuba as taxas traduzem um crescimento mais impressionante: $2,6 \%$ ao ano para os proprietários e $4,4 \%$ ao ano entre os escravos entre 1798 e 1836.

Desse afluxo desproporcional de proprietários e escravos resultam as elevações nos valores médios e medianos indicados na Tabela 3.10. Destacamos os valores observados em Bananal, onde a média atingiu 11,7 escravos por proprietário em 1829, alcançando também a maior razão de sexo: 219 cativos do sexo masculino para cada grupo de 100 escravas, distinção também notável nos valores agregados fornecidos por Vidal Luna. Tais números evidenciam que os escravistas daquela localidade não mediram esforços para concentrar em seus plantéis escravos do sexo masculino, mais vigorosos e aptos à lida agrícola. Ao longo das décadas de 1820 e 1830 também registramos aumentos importantes no índice de Gini que, se cotejados com os incrementos registrados nas medidas de tendência central, sugerem a formação de algumas propriedades com grande quantidade de escravos, sinal de que a prosperidade econômica atingia diferencialmente o conjunto de escravistas paulistas no primeiro terço do século XIX. 
Gráfico 3.24

Distribuição relativa de proprietários e escravos segundo faixas de tamanho dos plantéis (Iguape e Xiririca, anos selecionados)
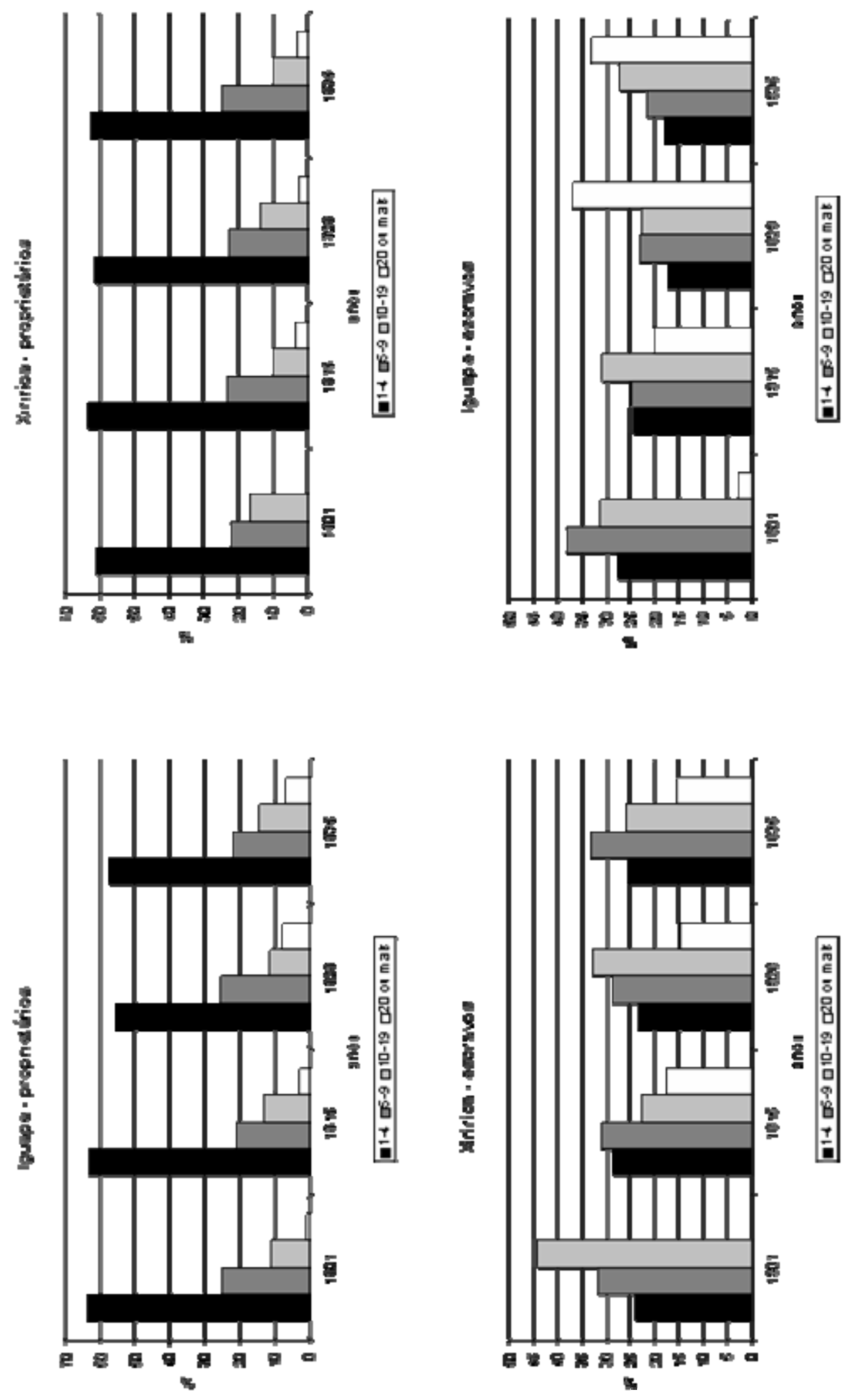
Sintetizando a análise da estrutura desenvolvida até o momento, o Gráfico 3.24 apresenta proprietários e escravos segmentados segundo faixas de tamanho dos plantéis. Conforme já anunciava o índice de Gini, notamos em Iguape a conformação de um pequeno grupo de proprietários com plantéis que continham 20 ou mais cativos, com maior destaque em 1828 em detrimento, inicialmente, da participação dos escravistas com posses entre 5 e 9 cativos e, depois, daqueles na menor faixa de posse. Estes grandes escravistas, entretanto, não detinham a maioria dos escravos, atingindo o valor máximo em 1828, com 37\% do contingente. Por seu turno, os pequenos proprietários mantinham não desprezível dos escravos, principalmente nos dois primeiros anos indicados e, apesar da redução relativa em 1828 e 1836, o quinhão possuído conservou-se relativamente constante. No caso da freguesia, a distinção dos maiores proprietários manteve-se em patamar bem mais discreto, com amplo predomínio daqueles com até 9 escravos, além destes deterem a maioria dos escravos em todos os anos, especialmente em 1815 e 1836, atingindo praticamente 3 em cada 5 escravos do território xiririquense.

O Gráfico seguinte apresenta proprietários e cativos segundo faixas de posse, no início do século XIX, comparando as localidades ribeirenses com as demais regiões paulistas, segundo dados fornecidos por Francisco Vidal Luna.

Todas as regiões no início do século XIX possuíam uma pequena porção de escravistas que detinham plantéis com mais de 20 escravos, atingindo maior valor no Oeste Paulista, com cerca de 9\% dos proprietários. No outro extremo, na maior parte das regiões os pequenos escravistas representavam cerca de sete décimos do conjunto de senhores. Dentro deste panorama, as duas localidades do Vale do Ribeira destoavam pela quase inexistência de proprietários na maior faixa de posse e, conseqüentemente, maior concentração nos menores intervalos Em Xiririca, a presença de um pequeno grupo com posse entre 11 e 20 escravos, possivelmente se associa com as atividades auríferas praticadas em meados do século XVIII. Artesãos e agricultores respondiam pelo pequeno grupo de escravistas nas faixas intermediárias em Iguape. 
Gráfico 3.25

Distribuição relativa de proprietários e escravos segundo faixas de tamanho dos plantéis (Iguape e Xiririca, 1801 e regiões paulistas, 1804)

\section{Proprietários}

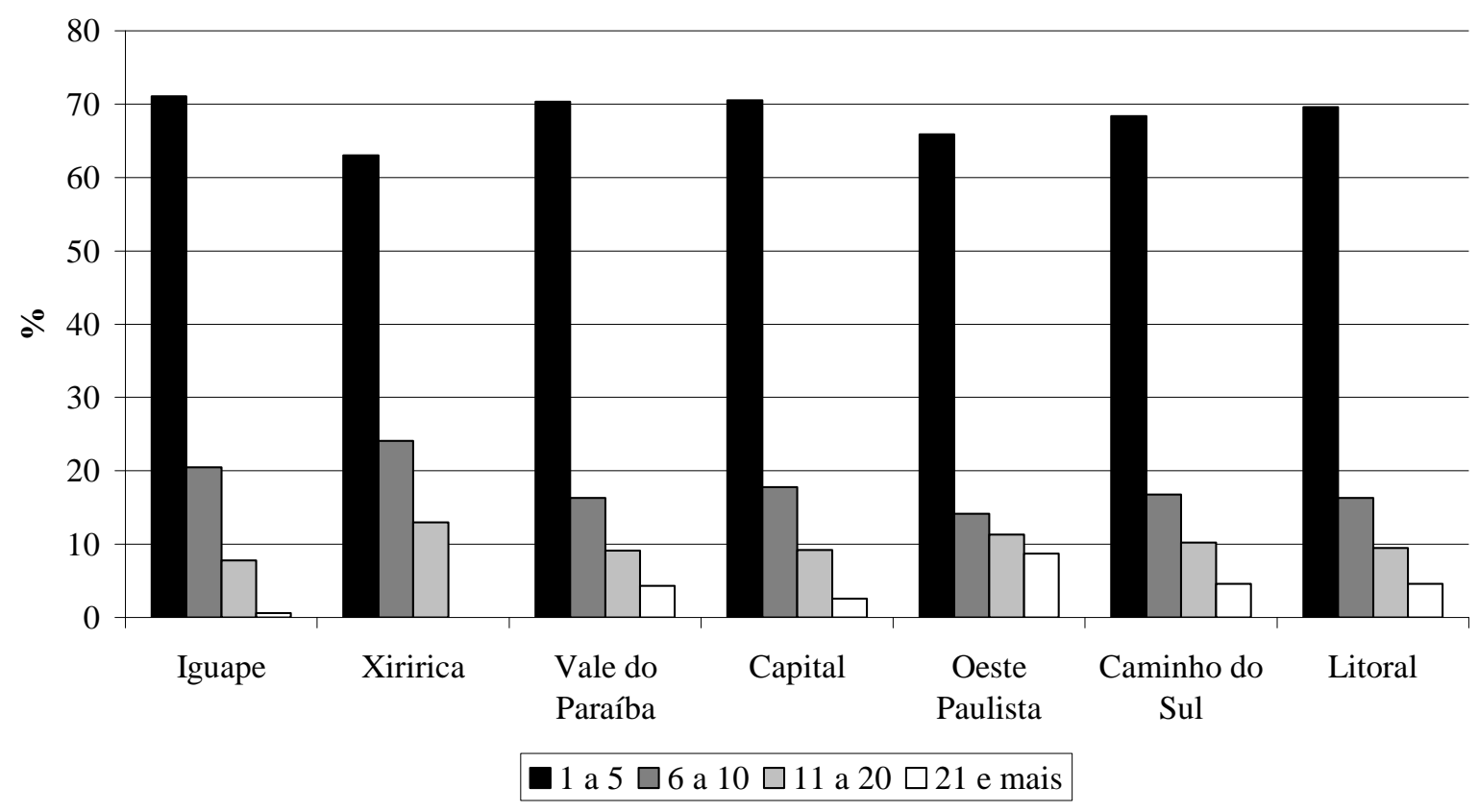

\section{Escravos}

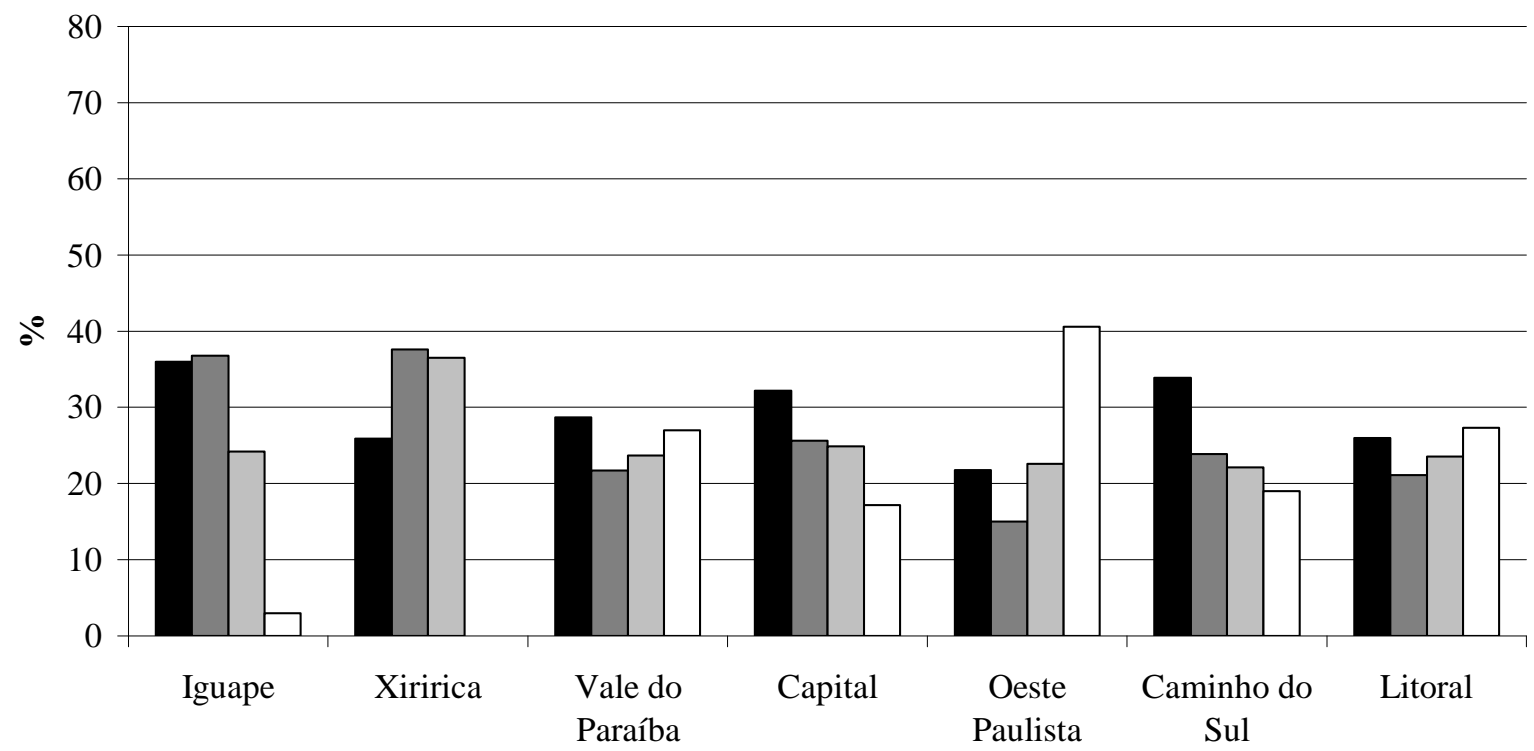

1 a $5 \square 6$ a $10 \square 11$ a $20 \square 21$ ou mais

Fonte: LUNA, 1998, p. 153.

Na distribuição dos escravos, o Oeste Paulista se destacava pela concentração de cativos nos maiores plantéis, compondo ainda o Vale do Paraíba e o Litoral áreas relativamente diferenciadas das demais regiões. No caso específico do Litoral, a distribuição 
decorre principalmente dos cativos presentes nas localidades ao norte, pois nenhuma das ribeirenses contribuiu para tal perfil. Na primeira, é evidente a concentração nas duas primeiras faixas de posse; já em Xiririca as faixas intermediárias predominavam, também herança da estrutura pretérita vinculada à lida aurífera.

O evolver econômico gerado pelo desenvolvimento das atividades agrícolas em São Paulo alterou a distribuição de escravistas e escravos tanto nas localidades paulistas como o próprio Vale do Ribeira, como revela o Gráfico 3.26.

Ao fim da década de 1820 os proprietários do Oeste Paulista com mais de 20 escravos superavam as duas faixas anteriores. Ademais, em valores relativos, nesta condição igualavam-se os senhores do Litoral e do Vale do Paraíba. Também foi no Oeste onde os escravistas na menor faixa de posse não superaram a marca dos $60 \%$, valor superado em todas as regiões, principalmente a Capital e o Caminho do Sul. Neste momento, Iguape, além de apresentar a distribuição dos proprietários muito assemelhada com a do próprio Litoral, pouco se diferenciava do perfil dos escravistas do Vale do Paraíba. O arranjo observado dos escravistas de Xiririca guardava mais relação com as áreas menos desenvolvidas da província, como a região da Capital ou o Caminho do Sul.

Pelo lado dos escravos, além do devido destaque ao Oeste Paulista, com mais de seis décimos dos escravos nos plantéis com mais de 20 escravos, notamos que no Vale do Paraíba mais de $60 \%$ dos cativos pertenciam às duas últimas faixas de posse, sinais inequívocos da dinâmica imposta pela cafeicultura. Nas áreas da Capital e Caminho do Sul esta concentração não se mostrava expressiva; no Litoral, as vilas do norte eram neófitas na cafeicultura, ainda não apresentando a diferenciação que se manifestaria na década seguinte. Nas vilas do sul, Iguape destacava-se pela elevada concentração na maior faixa de posse, porém com um hiato nas posses entre 11 e 20 cativos, além de elevada presença nas menores faixas. A distribuição observada na freguesia manteve muito daquela registrada no início do século, mitigada pela pequena parcela de escravos presente na maior faixa. 
Gráfico 3.26

Distribuição relativa de proprietários e escravos segundo faixas de tamanho dos plantéis

(Iguape e Xiririca, 1828 e regiões paulistas, 1829)

\section{Proprietários}

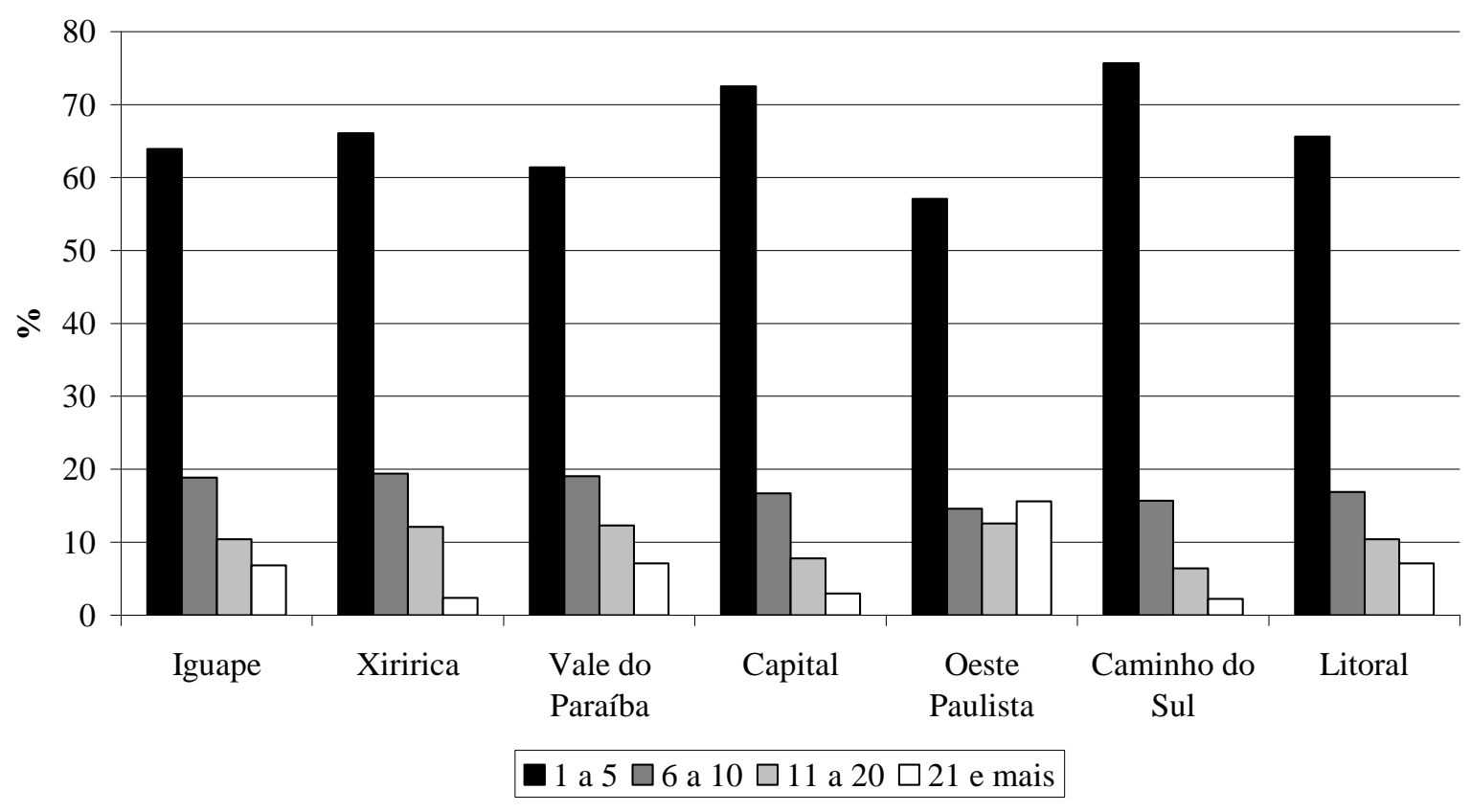

\section{Escravos}

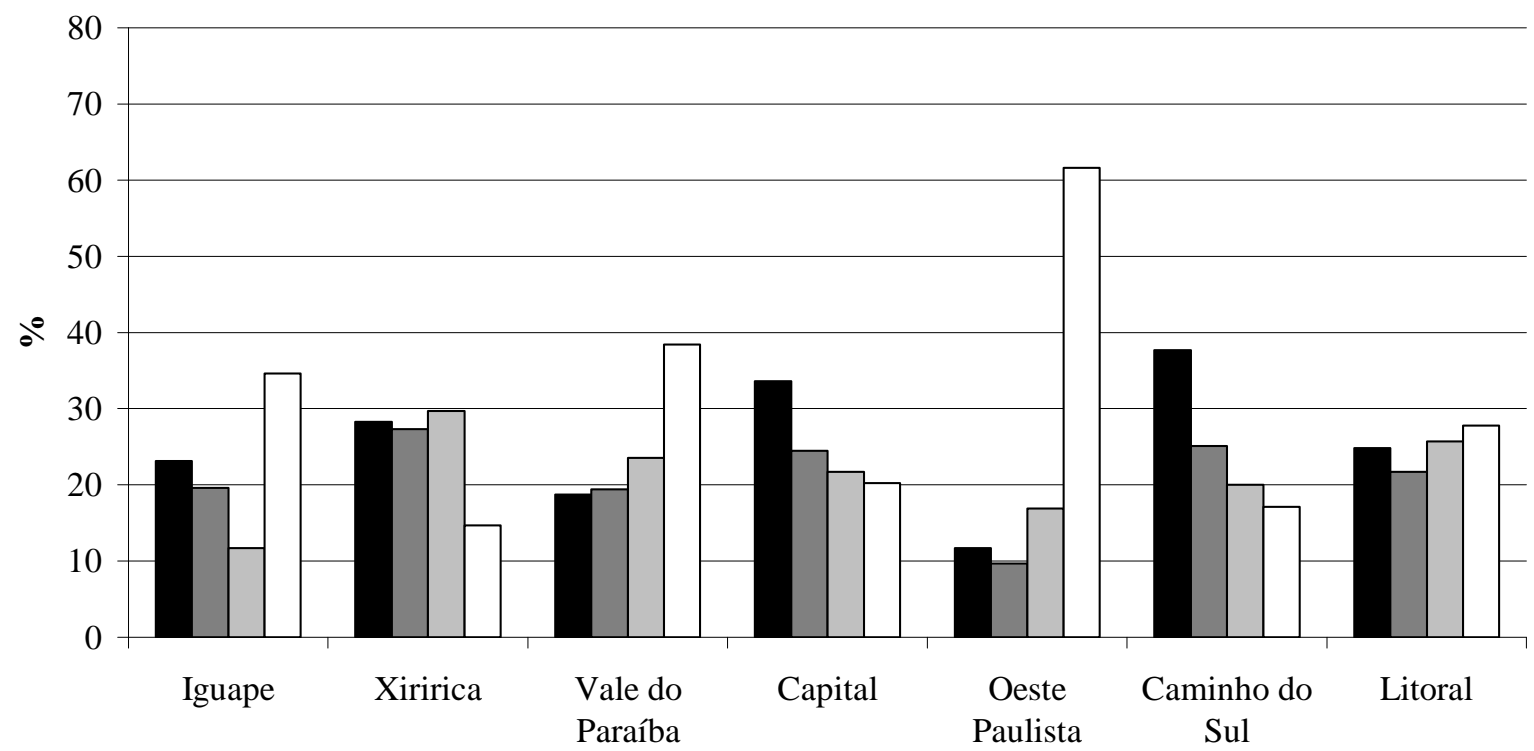

1 a $5 \square 6$ a $10 \square 11$ a $20 \square 21$ ou mais

Fonte: LUNA, 1998, p. 153.

Apesar dos sinais de dinamismo, nossos resultados sobre a década de 1830 já revelaram sinais do esgotamento dessa fase mais intensiva de mudanças na estrutura de posse do Vale do Ribeira. 
Nosso último recorte privilegiando as listas nominativas trata da associação entre proprietários e escravos com as atividades econômicas dos escravistas, utilizando os informes de 1801 e 1836. A Tabela 3.3 distribui escravistas e escravos segundo as atividades econômicas exercidas pelos proprietários em 1801.

Tabela 3.3

Indicadores estatísticos da posse de escravos segundo atividades econômicas

(Iguape e Xiririca, 1801)

\begin{tabular}{|c|c|c|c|c|c|c|c|c|c|}
\hline & Atividades econômicas & escravistas & $\%$ & escravos & $\%$ & $\begin{array}{c}\text { razão de } \\
\text { sexo }\end{array}$ & média & $\begin{array}{l}\text { desvio- } \\
\text { padrão }\end{array}$ & mediana \\
\hline \multirow{10}{*}{ 芯 } & Agricultura e manufatura rural & 84 & 50,6 & 365 & 51,3 & 95,2 & 4,3 & 3,8 & 3,0 \\
\hline & Atividades do mar & 5 & 3,0 & 19 & 2,7 & 171,4 & 3,8 & 5,2 & 2,0 \\
\hline & Artesanato & 37 & 22,3 & 128 & 18,0 & 88,2 & 3,5 & 3,4 & 2,0 \\
\hline & Igreja & 2 & 1,2 & 13 & 1,8 & 160,0 & 6,5 & 3,5 & 6,5 \\
\hline & Profissões liberais & 1 & 0,6 & 2 & 0,3 & - & 2,0 & - & 2,0 \\
\hline & Rentistas & 8 & 4,8 & 41 & 5,8 & 355,6 & 5,1 & 3,4 & 5,5 \\
\hline & Comércio & 26 & 15,7 & 137 & 19,3 & 114,1 & 5,3 & 5,1 & 3,0 \\
\hline & Jornaleiros & 2 & 1,2 & 3 & 0,4 & 50,0 & 1,5 & 0,7 & 1,5 \\
\hline & Atividades não classificadas & 1 & 0,6 & 3 & 0,4 & 200,0 & 3,0 & - & 3,0 \\
\hline & total & 166 & 100,0 & 711 & 100,0 & 106,1 & 4,3 & 3,9 & 3,0 \\
\hline \multirow{8}{*}{ : } & Agricultura e manufatura rural & 40 & 74,1 & 222 & 87,1 & 88,9 & 5,6 & 4,5 & 4,0 \\
\hline & Mineração de metais preciosos & 1 & 1,9 & 2 & 0,8 & - & 2,0 & - & 2,0 \\
\hline & Artesanato & 7 & 13,0 & 10 & 3,9 & - & 1,4 & 0,8 & 1,0 \\
\hline & Igreja & 1 & 1,9 & 3 & 1,2 & - & 3,0 & - & 3,0 \\
\hline & Rentistas & 1 & 1,9 & 6 & 2,4 & 200,0 & 6,0 & - & 6,0 \\
\hline & Comércio & 2 & 3,7 & 10 & 3,9 & 42,9 & 5,0 & 5,7 & 5,0 \\
\hline & Atividades não classificadas & 2 & 3,7 & 2 & 0,8 & 100,0 & 1,0 & 0,0 & 1,0 \\
\hline & total & 54 & 100,0 & 255 & 100,0 & 93,2 & 4,7 & 4,3 & 3,0 \\
\hline
\end{tabular}

A agricultura e manufatura rural concentrava cerca de metade dos escravistas e dos cativos de Iguape e mais de três quartos dos proprietários de Xiririca, correspondendo à posse de $87 \%$ dos escravos. Os artesãos compunham a segunda atividade com maior representatividade, envolvendo pouco mais de 22\% dos proprietários iguapenses e $13 \%$ dos casos na freguesia, porém neste caso a presença de escravos mostrou-se mais expressiva na primeira localidade: $18 \%$ contra $4 \%$. Se em Xiririca não encontramos nenhuma outra categoria digna de nota, em Iguape os comerciantes representavam valor não desprezível, com cerca de $16 \%$ dos escravistas e $19 \%$ dos cativos, inclusive possuindo o maior valor médio entre as três atividades com maior expressão.

Em Iguape, as posses médias mais elevadas pertenciam a dois grupos de atividades com pequena representatividade, o clero e os rentistas. $\mathrm{O}$ valor médio observado entre os agricultores, 4,3 escravos por proprietário, além de coincidir com o indicador no conjunto dos escravistas, posiciona-se de forma intermediária entre os artesãos e os comerciantes. Sobre a 
preponderância dos primeiros, vale recordar que muitos deles se vinculavam ao fabrico de embarcações; pelo lado dos comerciantes, alguns provinham dessa atividade manufatureira e outros já associavam o comércio com a posse de propriedades rurais onde se cultivava o arroz.

Outro dado a ser destacado respeita à maior posse média dos agricultores xiririquenses em relação aos seus pares de Iguape (5,6 e 4,3, respectivamente). Esse maior valor médio provavelmente guarda relação com a melhor situação dos escravistas da freguesia no último quartel do século XVIII, conforme indica a Tabela 3.1. Dessa forma, parece lícito afirmar que boa parte dos agricultores de Xiririca gozava de melhor posição comparativa em decorrência das atividades mineratórias, o que possibilitou a manutenção das posses, provavelmente através da reprodução natural da população escrava, como sugere a baixa razão de sexo e o elevado valor da estimativa de fecundidade, calculado anteriormente.

Tabela 3.4

Distribuição dos proprietários segundo atividades econômicas e faixas de tamanho dos plantéis (Iguape e Xiririca, 1801)

\begin{tabular}{|c|c|c|c|c|c|c|c|c|c|c|c|}
\hline & \multirow{3}{*}{ Atividades econômicas } & \multicolumn{8}{|c|}{ Faixas de tamanho dos plantéis } & \multirow{2}{*}{\multicolumn{2}{|c|}{ total }} \\
\hline & & \multicolumn{2}{|c|}{$1-4$} & \multicolumn{2}{|c|}{$5-9$} & \multicolumn{2}{|c|}{ 10-19 } & \multicolumn{2}{|c|}{20 ou mais } & & \\
\hline & & $\mathbf{N}$ & $\%$ & $\mathbf{N}$ & $\%$ & $\mathbf{N}$ & $\%$ & $\mathbf{N}$ & $\%$ & $\mathbf{N}$ & $\%$ \\
\hline \multirow{10}{*}{ 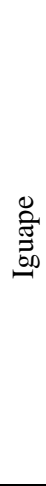 } & Agricultura e manufatura rural & 50 & 59,5 & 24 & 28,6 & 10 & 11,9 & - & - & 84 & 50,6 \\
\hline & Atividades do mar & 4 & 80,0 & - & - & 1 & 20,0 & - & - & 5 & 3,0 \\
\hline & Artesanato & 28 & 75,7 & 6 & 16,2 & 3 & 8,1 & - & - & 37 & 22,3 \\
\hline & Igreja & 1 & 50,0 & 1 & 50,0 & - & - & - & - & 2 & 1,2 \\
\hline & Profissões liberais & 1 & 100,0 & - & - & - & - & - & - & 1 & 0,6 \\
\hline & Rentistas & 3 & 37,5 & 4 & 50,0 & 1 & 12,5 & - & - & 8 & 4,8 \\
\hline & Comércio & 16 & 61,5 & 6 & 23,1 & 3 & 11,5 & 1 & 3,8 & 26 & 15,7 \\
\hline & Jornaleiros & 2 & 100,0 & - & - & - & - & - & - & 2 & 1,2 \\
\hline & Atividades não classificadas & 1 & 100,0 & - & - & - & - & - & - & 1 & 0,6 \\
\hline & total & 106 & 63,9 & 41 & 24,7 & 18 & 10,8 & 1 & 0,6 & 166 & 100,0 \\
\hline \multirow{8}{*}{ 苞 } & Agricultura e manufatura rural & 21 & 52,5 & 10 & 25,0 & 9 & 22,5 & - & - & 40 & 74,1 \\
\hline & Mineração de metais preciosos & 1 & 100,0 & - & - & - & - & - & - & 1 & 1,9 \\
\hline & Artesanato & 7 & 100,0 & - & - & - & - & - & - & 7 & 13,0 \\
\hline & Igreja & 1 & 100,0 & - & - & - & - & - & - & 1 & 1,9 \\
\hline & Rentistas & - & - & 1 & 100,0 & - & - & - & - & 1 & 1,9 \\
\hline & Comércio & 1 & 50,0 & 1 & 50,0 & - & - & - & - & 2 & 3,7 \\
\hline & Atividades não classificadas & 2 & 100,0 & - & - & - & - & - & - & 2 & 3,7 \\
\hline & total & 33 & 61,1 & 12 & 22,2 & 9 & 16,7 & - & - & 54 & 100,0 \\
\hline
\end{tabular}

A distribuição dos proprietários segundo faixas de tamanho dos plantéis encontra-se disposta na Tabela 3.4. Encontramos 64\% dos proprietários iguapenses na primeira faixa de posse, porém se consideradas as três atividades econômicas com maior número de escravistas, algumas diferenças merecem nota. Agricultores e comerciantes concentravam-se de maneira 
semelhante no intervalo entre 1 a 4 cativos, ainda que pese a diferença numérica dos dois grupos. Ainda ressalvando as distinções, entre os artesãos preponderavam os pequenos proprietários com maior intensidade. Como já ressaltamos em outros locais deste texto, parcela dos agricultores e comerciantes presentes em 1801 também pertencia ao grupo dos artesãos e esta migração de atividade econômica possivelmente corresponde à contrapartida da decisão de permanência definitiva em território iguapense.

Entre os xiririquenses, reafirma-se a melhor condição dos escravistas vinculados à agricultura e manufatura rural em relação aos presentes em Iguape, não apenas pela menor participação na menor faixa de posse como na maior concentração relativa nas propriedades formadas com 10 a 19 cativos. Destacamos ainda a majoritária presença de pequenos proprietários nas demais atividades, apesar da baixa freqüência absoluta - sinal inequívoco do apoucado desenvolvimento urbano da freguesia. A Tabela 3.5 trata, nos mesmos moldes, da distribuição dos escravos pertencentes a estes proprietários.

Tabela 3.5

Distribuição dos escravos segundo atividades econômicas e faixas de tamanho dos plantéis

(Iguape e Xiririca, 1801)

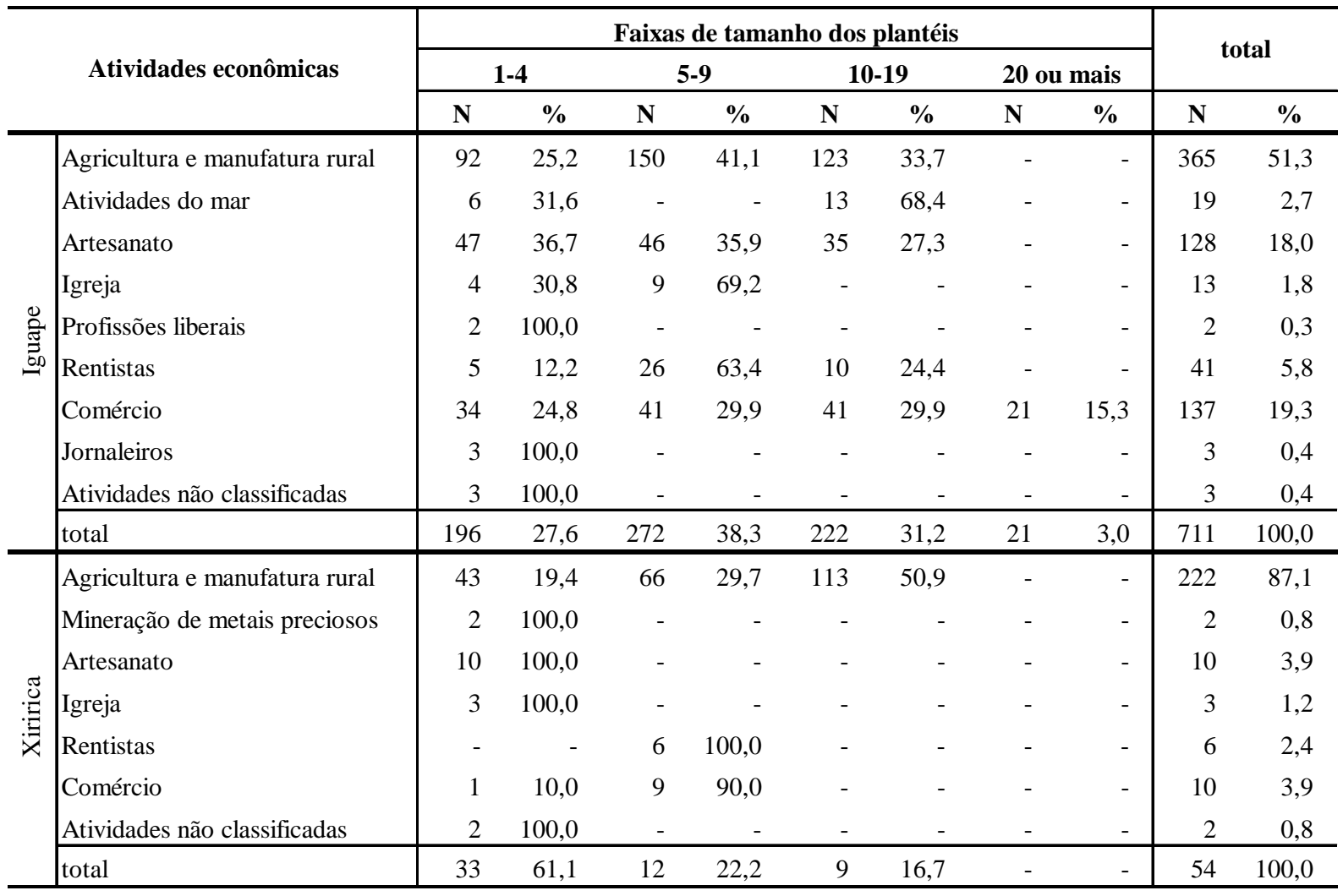

Da distribuição geral dos escravos de Iguape entre as distintas faixas de posse, depreende-se que a de maior concentração - 5 a 9 cativos, com 38\% dos casos - reflete a condição do conjunto de agricultores, que agregava cerca de quatro décimos de seus escravos. 
Porém, nesta mesma faixa encontramos parcela importante dos escravos pertencentes aos comerciantes e artesãos. Novamente os números referentes à freguesia indicam a distinção de seus agricultores, posto que mais da metade dos cativos a eles pertencentes constituíam plantéis na faixa de 10 a 19 cativos.

A primazia dos agricultores no início do Oitocentos englobava um conjunto de práticas e cultivos bastante distinto. Nesse sentido, a Tabela 3.6 apresenta os indicadores estatísticos desta atividade econômica segundo as distintas ocupações registradas na lista nominativa.

Tabela 3.6

Indicadores estatísticos da posse de escravos na agricultura e manufatura rural

(Iguape e Xiririca, 1801)

\begin{tabular}{|c|c|c|c|c|c|c|c|c|c|}
\hline & Ocupações & escravistas & $\%$ & escravos & $\%$ & $\begin{array}{c}\text { razão de } \\
\text { sexo }\end{array}$ & média & $\begin{array}{l}\text { desvio- } \\
\text { padrão }\end{array}$ & mediana \\
\hline \multirow{10}{*}{$\begin{array}{l}\text { 苛 } \\
\text { త్ర }\end{array}$} & engenho de arroz & 5 & 6,0 & 47 & 12,9 & 104,3 & 9,4 & 5,6 & 7,0 \\
\hline & plantadores de arroz exclusivamente & 32 & 38,1 & 152 & 41,6 & 105,4 & 4,8 & 3,8 & 3,5 \\
\hline & plantadores de arroz com outros cultivares & 1 & 1,2 & 3 & 0,8 & 50,0 & 3,0 & - & 3,0 \\
\hline & plantadores de mandioca exclusivamente & 14 & 16,7 & 51 & 14,0 & 82,1 & 3,6 & 2,8 & 2,5 \\
\hline & plantadores de mandioca e outros, exceto arroz & 1 & 1,2 & 3 & 0,8 & 50,0 & 3,0 & - & 3,0 \\
\hline & plantadores de arroz e mandioca exclusivamente & 5 & 6,0 & 25 & 6,8 & 78,6 & 5,0 & 4,1 & 4,0 \\
\hline & cultivos não especificados & 17 & 20,2 & 56 & 15,3 & 107,4 & 3,3 & 3,7 & 1,0 \\
\hline & madeireiros e lenhadores & 8 & 9,5 & 27 & 7,4 & 58,8 & 3,4 & 2,4 & 3,5 \\
\hline & carvoeiros & 1 & 1,2 & 1 & 0,3 & - & 1,0 & - & 1,0 \\
\hline & total & 84 & 100,0 & 365 & 100,0 & 95,2 & 4,3 & 3,8 & 3,0 \\
\hline \multirow{14}{*}{ : } & engenho de aguardente & 2 & 5,0 & 26 & 11,7 & 73,3 & 13,0 & 8,5 & 13,0 \\
\hline & engenho de arroz & 3 & 7,5 & 25 & 11,3 & 56,3 & 8,3 & 2,1 & 9,0 \\
\hline & cafeicultores & 1 & 2,5 & 5 & 2,3 & 150,0 & 5,0 & - & 5,0 \\
\hline & cultivo de tabaco e outros cultivares & 3 & 7,5 & 4 & 1,8 & 33,3 & 1,5 & 0,7 & 1,5 \\
\hline & plantadores de arroz exclusivamente & 1 & 2,5 & 7 & 3,2 & 40,0 & 7,0 & - & 7,0 \\
\hline & plantadores de arroz com outros cultivares & 10 & 25,0 & 34 & 15,3 & 61,9 & 3,4 & 1,9 & 3,0 \\
\hline & plantadores de mandioca exclusivamente & 2 & 5,0 & 14 & 6,3 & 100,0 & 7,0 & 7,1 & 7,0 \\
\hline & plantadores de mandioca e outros, exceto arroz & 3 & 7,5 & 27 & 12,2 & 125,0 & 9,0 & 6,9 & 13,0 \\
\hline & plantadores de arroz, mandioca e outros & 7 & 17,5 & 53 & 23,9 & 140,9 & 7,6 & 4,4 & 7,0 \\
\hline & cultivos não especificados & 2 & 5,0 & 4 & 1,8 & 33,3 & 2,0 & 1,4 & 2,0 \\
\hline & moradores novos & 2 & 5,0 & 7 & 3,2 & 75,0 & 3,5 & 3,5 & 3,5 \\
\hline & criadores de bovinos & 1 & 2,5 & 11 & 5,0 & 120,0 & 11,0 & - & 11,0 \\
\hline & madeireiros e lenhadores & 3 & 7,5 & 5 & 2,3 & 66,7 & 1,7 & 1,2 & 1,0 \\
\hline & total & 40 & 100,0 & 222 & 100,0 & 88,9 & 5,6 & 4,5 & 4,0 \\
\hline
\end{tabular}

Se agregarmos todas as ocupações vinculadas ao arroz, o resultado atingiria $51 \%$ dos escravistas e 62\% dos escravos. Há, no entanto, distinções importantes, como o pequeno grupo de proprietários de engenhos de arroz, cujas posses atingiam valores médios e medianos bem acima dos demais agricultores. Da mesma forma, os plantadores exclusivos de arroz, que isoladamente apresentavam a maior parcela de escravistas e cativos, também possuíam indicadores mais elevados em relação ao valor total destacado na tabela. 
Ressaltamos ainda que estas duas ocupações, além dos agricultores com cultivos não especificados, possuíam plantéis com relativo equilíbrio entre homens e mulheres, situação bem distinta nas demais ocupações, onde predominavam as mulheres. De qualquer forma, há que se relevar parcela significativa de escravistas que, no ano em tela, ainda não aderira à rizicultura. Os plantadores de mandioca são a melhor expressão desses casos, ainda que representassem apenas 18\% dos 84 escravistas e 15\% dos escravos.

Situação mais diversa apresentava a freguesia, onde boa parte das ocupações não superava a freqüência de 3 escravistas e a categoria com maior ocorrência, os plantadores de arroz que também cultivavam outras variedades, agregava um quarto dos escravistas e apenas $15 \%$ dos cativos. Porém, se agregados, todos os cultivadores de arroz respondiam por 52\% dos escravistas e $54 \%$ dos escravos. Aparentemente, a unidade produtiva escravista em Xiririca possuía um perfil mais amplo em relação aos cultivos praticados, fato já destacado quando se procedeu à análise dos bens de raiz e que também retornará na seção seguinte, que estudará a estrutura de posse de escravos a partir dos inventários. Na tabela, os "plantadores de arroz, mandioca e outros” são os que melhor traduzem esta condição "policultora” dos xiririquenses: apesar da baixa freqüência (7 ocorrências), possuíam 24\% dos escravos, além de destacados valores médios e medianos e razão de sexo mais elevada do que o conjunto das posses no Vale do Ribeira.

Ainda buscando pela melhor qualificação desta atividade econômica, as duas tabelas seguintes distribuem os escravistas e seus cativos segundo faixas de tamanho dos plantéis. 
Tabela 3.7

Distribuição dos proprietários da agricultura e manufatura rural segundo faixas de tamanho dos plantéis (Iguape e Xiririca, 1801)

\begin{tabular}{|c|c|c|c|c|c|c|c|c|c|c|c|}
\hline & \multirow{3}{*}{ Ocupações } & \multicolumn{8}{|c|}{ Faixas de tamanho dos plantéis } & \multirow{2}{*}{\multicolumn{2}{|c|}{ total }} \\
\hline & & \multicolumn{2}{|c|}{$1-4$} & \multicolumn{2}{|c|}{$5-9$} & \multicolumn{2}{|c|}{ 10-19 } & \multicolumn{2}{|c|}{20 ou mais } & & \\
\hline & & $\mathbf{N}$ & $\%$ & $\mathbf{N}$ & $\%$ & $\mathbf{N}$ & $\%$ & $\mathbf{N}$ & $\%$ & $\mathbf{N}$ & $\%$ \\
\hline \multirow{10}{*}{ 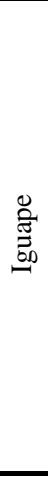 } & engenho de arroz & - & - & 3 & 60,0 & 2 & 40,0 & - & - & 5 & 6,0 \\
\hline & plantadores de arroz exclusivamente & 19 & 59,4 & 7 & 21,9 & 6 & 18,8 & - & - & 32 & 38,1 \\
\hline & plantadores de arroz com outros cultivares & 1 & 100,0 & - & - & - & - & - & - & 1 & 1,2 \\
\hline & plantadores de mandioca exclusivamente & 9 & 64,3 & 5 & 35,7 & - & - & - & - & 14 & 16,7 \\
\hline & plantadores de mandioca e outros, exceto arroz & 1 & 100,0 & - & - & - & - & - & - & 1 & 1,2 \\
\hline & plantadores de arroz e mandioca exclusivamente & 3 & 60,0 & 1 & 20,0 & 1 & 20,0 & - & - & 5 & 6,0 \\
\hline & cultivos não especificados & 12 & 70,6 & 4 & 23,5 & 1 & 5,9 & - & - & 17 & 20,2 \\
\hline & madeireiros e lenhadores & 4 & 50,0 & 4 & 50,0 & - & - & - & - & 8 & 9,5 \\
\hline & carvoeiros & 1 & 100,0 & - & - & - & - & - & - & 1 & 1,2 \\
\hline & total & 50 & 60,2 & 24 & 28,9 & 10 & 12,0 & - & - & 84 & 100,0 \\
\hline \multirow{14}{*}{ 苂 } & engenho de aguardente & - & - & 1 & 50,0 & 1 & 50,0 & - & - & 2 & 5,0 \\
\hline & engenho de arroz & - & - & 2 & 66,7 & 1 & 33,3 & - & - & 3 & 7,5 \\
\hline & cafeicultores & - & - & 1 & 100,0 & - & - & - & - & 1 & 2,5 \\
\hline & cultivo de tabaco e outros cultivares & 3 & 100,0 & - & - & - & - & - & - & 3 & 7,5 \\
\hline & plantadores de arroz exclusivamente & - & - & 1 & 100,0 & - & - & - & - & 1 & 2,5 \\
\hline & plantadores de arroz com outros cultivares & 8 & 80,0 & 2 & 20,0 & - & - & - & - & 10 & 25,0 \\
\hline & plantadores de mandioca exclusivamente & 1 & 50,0 & - & - & 1 & 50,0 & - & - & 2 & 5,0 \\
\hline & plantadores de mandioca e outros, exceto arroz & 1 & 33,3 & - & - & 2 & 66,7 & - & - & 3 & 7,5 \\
\hline & plantadores de arroz, mandioca e outros & 2 & 28,6 & 2 & 28,6 & 3 & 42,9 & - & - & 7 & 17,5 \\
\hline & cultivos não especificados & 2 & 100,0 & - & - & - & - & - & - & 2 & 5,0 \\
\hline & moradores novos & 1 & 50,0 & 1 & 50,0 & - & - & - & - & 2 & 5,0 \\
\hline & criadores de bovinos & - & - & - & - & 1 & 100,0 & - & - & 1 & 2,5 \\
\hline & madeireiros e lenhadores & 3 & 100,0 & - & - & - & - & - & - & 3 & 7,5 \\
\hline & total & 21 & 52,5 & 10 & 25,0 & 9 & 22,5 & - & - & 40 & 100,0 \\
\hline
\end{tabular}

Para além da predominância dos pequenos plantéis, 60\% em Iguape e 52\% em Xiririca, notamos que os poucos proprietários de engenhos de arroz dispunham de plantéis com quantidade diferenciada de cativos, principalmente se comparado com o padrão de posse da região. Esta observação vale tanto para Iguape como para Xiririca, inclusive para os dois únicos escravistas que possuíam engenho de aguardente na freguesia. Fato mais notável, porém, é a elevada participação dos plantéis de tamanho médio entre os plantadores exclusivos de arroz, representados por 13 dos 32 casos, condição correlata aos já citados plantadores de arroz, mandioca e outros cultivos em Xiririca, que contava com 5 dos 7 escravistas com posses entre 5 e 19 cativos. Como se vê na Tabela 3.8, os 13 proprietários de Iguape possuíam 73\% dos cativos daquela ocupação e os 5 da freguesia, pouco mais de $90 \%$. 
Tabela 3.8

Distribuição dos escravos da agricultura e manufatura rural segundo faixas de tamanho dos plantéis (Iguape e Xiririca, 1801)

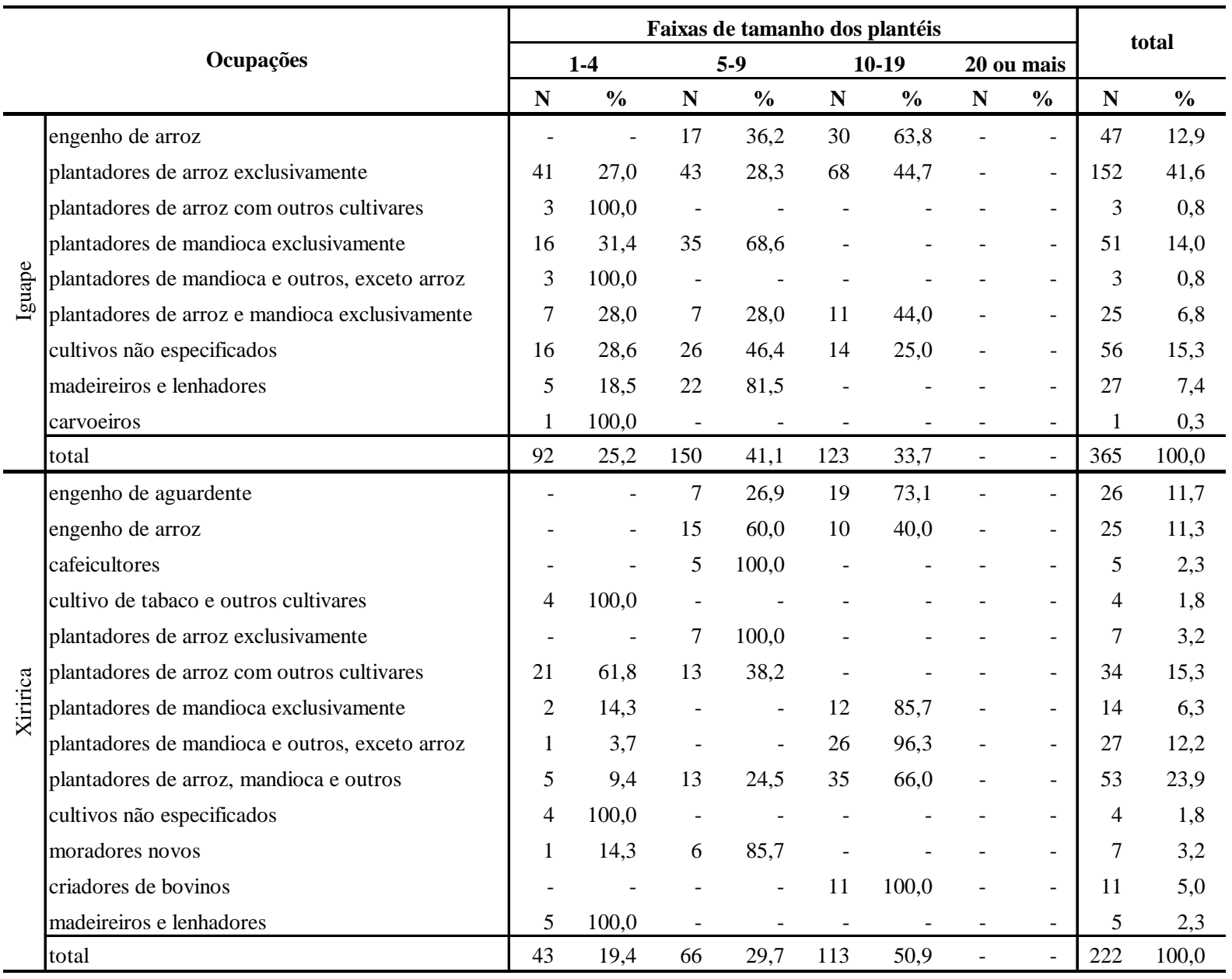

Salientamos, dessa forma, a posição diferenciada dos agricultores associados de alguma forma com o cultivo do arroz em relação aos demais agricultores. A origem dessa distinção poderia decorrer de ganhos já obtidos através da venda dos grãos, porém parece mais provável que os cativos associados a estes agricultores pertencessem a uma condição produtiva pretérita do escravista, como pleiteado ao longo desta seção. As atividades artesanais em Iguape e a exploração do ouro em Xiririca responderiam, nesse sentido, pela acumulação prévia de capital para a inversão em escravos. ${ }^{168}$

O quadro mais geral estabelecido no Capítulo 1 evidenciou uma redução importante na diversidade das atividades econômicas exercidas pelos chefes de domicílio em ambas as localidades em 1836. Também focamos a expansão da agricultura e manufatura rural,

\footnotetext{
${ }^{168}$ Através da razão de dependência - que inclui no numerador o número de escravos com idade entre 15 e 49 anos e, no denominador, a soma de cativos com até 14 anos e com 50 anos ou mais - nota-se a similitude entre os agricultores associados ao arroz $(0,77)$ e os que não cultivavam a gramínea $(0,73)$. Note-se ainda que estes valores se posicionam abaixo do valor geral $(0,84)$ e também são menores do que os verificados para os escravos pertencentes aos artesãos $(0,97)$ e comerciantes $(1,01)$.
} 
praticamente monopolizadora das atividades na freguesia e praticada por três quartos dos domicílios iguapenses, cabendo nesta vila posição de destaque aos comerciantes. Por outro lado, os principais resultados do presente capítulo revelam um importante crescimento do setor escravista na região, tanto no número de proprietários como no de escravos possuídos. Esmiuçamos o crescimento dos valores médios e medianos das posses, a maior participação de escravos do sexo masculino no conjunto da população escrava, o predomínio de cativos negros e a maior parcela de originários da África. Destacamos ainda que a distribuição destes cativos entre os proprietários tornou-se mais desigual, evidenciando a formação de um pequeno grupo de senhores de escravos que obteve ganhos diferenciais em relação aos seus pares, conformando assim um estrato de proprietários mais abastados. Comparado com a dinâmica observada no mesmo período na Capitania (e depois Província) de São Paulo, as alterações percebidas não podem ser igualadas àquelas gestadas nas áreas do Oeste Paulista ou Vale do Paraíba, porém as mudanças imprimidas pelo cultivo do arroz posicionaram o Vale do Ribeira numa posição intermediária entre as regiões paulistas. A Tabela 3.9 apresenta com maior detalhe as alterações na posse de escravos decorrentes da realocação econômica da região.

Tabela 3.9

Indicadores estatísticos da posse de escravos segundo atividades econômicas

(Iguape e Xiririca, 1836)

\begin{tabular}{|c|c|c|c|c|c|c|c|c|c|}
\hline & Atividades econômicas & escravistas & $\%$ & escravos & $\%$ & $\begin{array}{c}\text { razão de } \\
\text { sexo }\end{array}$ & média & $\begin{array}{l}\text { desvio- } \\
\text { padrão }\end{array}$ & mediana \\
\hline \multirow{9}{*}{ 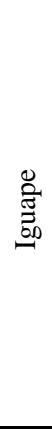 } & Agricultura e manufatura rural & 200 & 66,0 & 1.542 & 75,8 & 124,5 & 7,7 & 9,9 & 4,0 \\
\hline & Atividades do mar & 4 & 1,3 & 8 & 0,4 & 33,3 & 2,0 & 2,0 & 1,0 \\
\hline & Artesanato & 14 & 4,6 & 47 & 2,3 & 67,9 & 3,4 & 3,4 & 1,5 \\
\hline & Igreja & 2 & 0,7 & 29 & 1,4 & 190,0 & 14,5 & 0,7 & 14,5 \\
\hline & Magistratura e empregos civis & 2 & 0,7 & 21 & 1,0 & 200,0 & 10,5 & 12,0 & 10,5 \\
\hline & Profissionais liberais & 3 & 1,0 & 11 & 0,5 & 37,5 & 3,7 & 4,6 & 1,0 \\
\hline & Comércio & 59 & 19,5 & 299 & 14,7 & 118,2 & 5,1 & 7,2 & 3,0 \\
\hline & Atividades não classificadas & 19 & 6,3 & 78 & 3,8 & 85,7 & 4,1 & 6,3 & 2,0 \\
\hline & total & 303 & 100,0 & 2.035 & 100,0 & 120,0 & 6,7 & 9.0 & 4,0 \\
\hline \multirow{6}{*}{ 苛 } & Agricultura e manufatura rural & 95 & 93,1 & 512 & 97,9 & 94,7 & 5,4 & 5,7 & 4,0 \\
\hline & Artesanato & 2 & 2,0 & 2 & 0,4 & - & 1,0 & 0,0 & 1,0 \\
\hline & Igreja & 1 & 1,0 & 1 & 0,2 & - & 1,0 & - & 1,0 \\
\hline & Magistratura e empregos civis & 1 & 1,0 & 1 & 0,2 & - & 1,0 & - & 1,0 \\
\hline & Comércio & 3 & 2,9 & 7 & 1,3 & 133,3 & 2,3 & 0,6 & 2,0 \\
\hline & total & 102 & 100,0 & 523 & 100,0 & 94,4 & 5,1 & 5,6 & 3,0 \\
\hline
\end{tabular}

Dentre os escravistas, os agricultores representavam dois terços em Iguape e mais de nove décimos em Xiririca; a eles se associavam três quartos dos cativos na primeira localidade e praticamente todos os escravos presentes na freguesia. Se a condição dos 
agricultores na freguesia manteve-se relativamente igual em relação à posse média (5,6 em 1801 e 5,4 em 1836), entre os iguapenses este indicador passou de 4,3 para 7,7 escravos por proprietário, porém com aumento significativo do desvio-padrão, sugerindo a existência de posses bastante diversas dentro desta categoria. A maior presença de cativos do sexo masculino também compõe uma distinção importante entre os dois momentos, passando de 95 para 124 homens para cada grupo de 100 mulheres em Iguape; na freguesia a diferença não apresentou a mesma magnitude, porém o indicador evidencia melhor equilíbrio entre os cativos em 1836.

Como segunda atividade a agregar maior quantidade de proprietários e cativos, os comerciantes mantiveram também o mesmo perfil de posse, tanto nos indicadores de tendência central como na razão de sexo. O grupo de artesãos escravistas apresentou uma redução absoluta significativa, de 37 casos em 1801 para 14 em 1836, porém com manutenção da posse média. Conforme indica a Tabela 3.10, os escravistas destas duas últimas atividades apresentaram distribuição assemelhada à verificada no início do século, com amplo predomínio dos pequenos proprietários. Entre os agricultores, estes pequenos proprietários participavam com menor intensidade do que a verificada em 1801, destacandose aqueles que possuíam plantéis com 10 ou mais cativos.

Tabela 3.10

Distribuição dos proprietários segundo atividades econômicas e faixas de tamanho dos plantéis (Iguape e Xiririca, 1836)

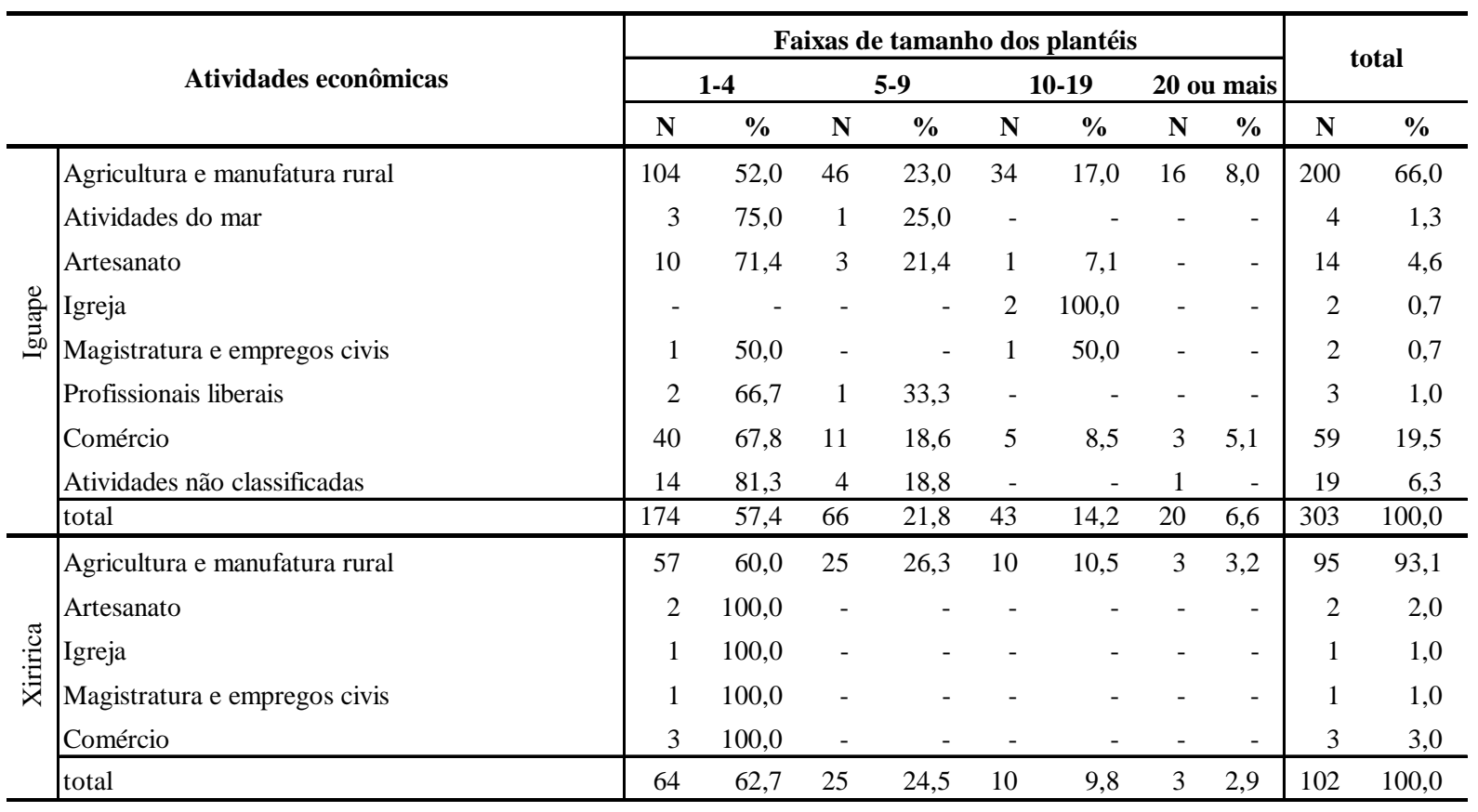


Tabela 3.11

Distribuição dos escravos segundo atividades econômicas e faixas de tamanho dos plantéis (Iguape e Xiririca, 1836)

\begin{tabular}{|c|c|c|c|c|c|c|c|c|c|c|c|}
\hline & \multirow{3}{*}{ Atividades econômicas } & \multicolumn{8}{|c|}{ Faixas de tamanho dos plantéis } & \multirow{2}{*}{\multicolumn{2}{|c|}{ total }} \\
\hline & & \multicolumn{2}{|c|}{$1-4$} & \multicolumn{2}{|c|}{$5-9$} & \multicolumn{2}{|c|}{$10-19$} & \multicolumn{2}{|c|}{20 ou mais } & & \\
\hline & & $\mathbf{N}$ & $\%$ & $\mathbf{N}$ & $\%$ & $\mathbf{N}$ & $\%$ & $\mathbf{N}$ & $\%$ & $\mathbf{N}$ & $\%$ \\
\hline \multirow{9}{*}{ 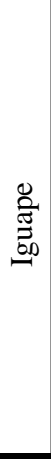 } & Agricultura e manufatura rural & 246 & 16,0 & 311 & 20,2 & 434 & 28,1 & 551 & 35,7 & 1.542 & 75,8 \\
\hline & Atividades do mar & 3 & 37,5 & 5 & 62,5 & - & - & - & - & 8 & 0,4 \\
\hline & Artesanato & 16 & 34,0 & 19 & 40,4 & 12 & 25,5 & - & - & 47 & 2,3 \\
\hline & Igreja & - & - & - & - & 29 & 100,0 & - & - & 29 & 1,4 \\
\hline & Magistratura e empregos civis & 2 & 9,5 & - & - & 19 & 90,5 & - & - & 21 & 1,0 \\
\hline & Profissionais liberais & 2 & 18,2 & 9 & 81,8 & - & - & - & - & 11 & 0,5 \\
\hline & Comércio & 77 & 25,8 & 67 & 22,4 & 62 & 20,7 & 93 & 31,1 & 299 & 14,7 \\
\hline & Atividades não classificadas & 22 & 28,2 & 28 & 35,9 & - & - & 28 & 35,9 & 78 & 3,8 \\
\hline & total & 368 & 18,1 & 439 & 21,6 & 556 & 27,3 & 672 & 33,0 & 2.035 & 100,0 \\
\hline \multirow{6}{*}{ 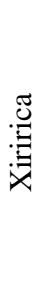 } & Agricultura e manufatura rural & 123 & 24,0 & 173 & 33,8 & 136 & 26,6 & 80 & 15,6 & 512 & 97,9 \\
\hline & Artesanato & 2 & 100,0 & - & - & - & - & - & - & 2 & 0,4 \\
\hline & Igreja & 1 & 100,0 & - & - & - & - & - & - & 1 & 0,2 \\
\hline & Magistratura e empregos civis & 1 & 100,0 & - & - & - & - & - & - & 1 & 0,2 \\
\hline & Comércio & 7 & 100,0 & - & - & - & - & - & - & 7 & 1,3 \\
\hline & total & 134 & 25,6 & 173 & 33,1 & 136 & 26,0 & 80 & 15,3 & 523 & 100,0 \\
\hline
\end{tabular}

$\mathrm{Na}$ freguesia, o perfil da distribuição dos escravistas apresentou pequenas diferenças, porém a estrutura verificada em 1836 apresentava menor participação dos proprietários na maior faixa de posse e um relativo aumento nas faixas intermediárias. Através da Tabela 3.11, é possível verificar que os escravos dos agricultores xiririquenses também se concentravam nestas faixas intermediárias, com 60\% deles nos plantéis entre 5 e 19 cativos. Distintamente, os cativos pertencentes aos agricultores iguapenses concentravam-se nas posses com 10 ou mais escravos, somando $64 \%$.

Entre os comerciantes, apesar da menor freqüência dos escravistas nas maiores faixas, parcela importante dos seus escravos pertenciam aos plantéis com 10 ou mais cativos, somando 52\%. Em 1801 esta participação atingia pouco menos de 45\%, sugerindo que alguns destes negociantes também atuariam nas atividades produtivas, como será abordado no Capítulo 4.

Especificando melhor o conjunto destes agricultores, a Tabela 3.12 apresenta os indicadores estatísticos das diversas ocupações lá anotadas. 
Tabela 3.12

Indicadores estatísticos da posse de escravos na agricultura e manufatura rural (Iguape e Xiririca, 1836)

\begin{tabular}{|c|c|c|c|c|c|c|c|c|c|}
\hline & Ocupações & escravistas & $\%$ & escravos & $\%$ & $\begin{array}{c}\text { razão de } \\
\text { sexo }\end{array}$ & média & $\begin{array}{l}\text { desvio- } \\
\text { padrão }\end{array}$ & mediana \\
\hline \multirow{10}{*}{ 䒕 } & engenho de aguardente & 5 & 2,5 & 27 & 1,8 & 145,5 & 5,4 & 3,4 & 4,0 \\
\hline & engenho de arroz & 22 & 11,0 & 433 & 28,1 & 135,3 & 19,7 & 17,0 & 13,5 \\
\hline & engenho de arroz e aguardente & 2 & 1,0 & 22 & 1,4 & 83,3 & 11,0 & 4,2 & 11,0 \\
\hline & plantadores de arroz exclusivamente & 93 & 46,5 & 580 & 37,6 & 125,7 & 6,2 & 8,7 & 4,0 \\
\hline & plantadores de mandioca exclusivamente & 3 & 1,5 & 11 & 0,7 & 57,1 & 3,7 & 4,6 & 1,0 \\
\hline & plantadores de arroz e mandioca exclusivamente & 16 & 8,0 & 68 & 4,4 & 161,5 & 4,3 & 3,5 & 3,0 \\
\hline & plantadores de arroz, mandioca e outros & 14 & 7,0 & 77 & 5,0 & 113,9 & 5,5 & 3,3 & 5,5 \\
\hline & cultivos não especificados & 44 & 22,0 & 307 & 19,9 & 110,3 & 7,0 & 7,3 & 4,0 \\
\hline & madeireiros e lenhadores & 1 & 0,5 & 17 & 1,1 & 112,5 & 17,0 & - & 17,0 \\
\hline & total & 200 & 100,0 & 1.542 & 100,0 & 124,5 & 7,7 & 9,9 & 4,0 \\
\hline \multirow{5}{*}{ 艺 } & engenho de aguardente & 2 & 2,1 & 4 & 0,8 & 300,0 & 2,0 & 0,0 & 2,0 \\
\hline & engenho de arroz & 34 & 35,8 & 249 & 48,6 & 94,5 & 7,3 & 7,8 & 5,5 \\
\hline & engenho de arroz e aguardente & 1 & 1,1 & 15 & 2,9 & 114,3 & 15,0 & - & 15,0 \\
\hline & plantadores de arroz exclusivamente & 58 & 61,1 & 244 & 47,7 & 92,1 & 4,2 & 3,6 & 3,0 \\
\hline & total & 95 & 100,0 & 512 & 100,0 & 94,7 & 5,4 & 5,7 & 4,0 \\
\hline
\end{tabular}

Em Iguape, os escravistas claramente envolvidos com o cultivo do arroz representavam cerca de três quartos dos casos, e praticamente a totalidade entre os xiririquenses. Observando ainda os altos valores médios e medianos daqueles cujo cultivo não possuía especificação na lista nominativa, parece razoável supor que parcela importante dos 22 escravistas também estivesse ligada ao amaino da gramínea. Vale ressaltar que a posse dos plantadores de arroz, associados ou não com outros cultivos, mostrou-se relativamente distinta, cabendo aos que praticavam apenas a rizicultura valores maiores do que as demais ocupações.

Ademais, os plantadores exclusivos de arroz representavam a maior parte dos escravistas nas duas localidades, porém se em Iguape estes também detinham a maior quantidade de escravos, na freguesia eram superados pelos proprietários de engenho de arroz. Esta ocupação, que em 1801 abrangia menos de uma dezena de casos, em 1836 somava 59 escravistas, incluindo aqueles que combinavam o processamento do arroz com a manutenção de engenhos de cana. Em Xiririca este grupo possuía posse média e mediana elevada, porém em Iguape estes indicadores revelam a diferenciação do grupo, atingindo praticamente o valor de 20 escravos por proprietário. Estas diferenças também podem ser verificadas na Tabela 3.13, que distribui os escravistas segundo as faixas de tamanho dos plantéis. 
Tabela 3.13

Distribuição dos proprietários da agricultura e manufatura rural segundo faixas de tamanho dos plantéis (Iguape e Xiririca, 1836)

\begin{tabular}{|c|c|c|c|c|c|c|c|c|c|c|c|}
\hline & \multirow{3}{*}{ Atividades econômicas } & \multicolumn{8}{|c|}{ Faixas de tamanho dos plantéis } & \multirow{2}{*}{\multicolumn{2}{|c|}{ total }} \\
\hline & & \multicolumn{2}{|c|}{$1-4$} & \multicolumn{2}{|c|}{$5-9$} & \multicolumn{2}{|c|}{ 10-19 } & \multicolumn{2}{|c|}{20 ou mais } & & \\
\hline & & $\mathbf{N}$ & $\%$ & $\mathbf{N}$ & $\%$ & $\mathbf{N}$ & $\%$ & $\mathbf{N}$ & $\%$ & $\mathbf{N}$ & $\%$ \\
\hline \multirow{9}{*}{$\begin{array}{l}\text { 苛 } \\
\text { ప્م }\end{array}$} & Agricultura e manufatura rural & 104 & 52,0 & 46 & 23,0 & 34 & 17,0 & 16 & 8,0 & 200 & 66,0 \\
\hline & Atividades do mar & 3 & 75,0 & 1 & 25,0 & - & - & - & - & 4 & 1,3 \\
\hline & Artesanato & 10 & 71,4 & 3 & 21,4 & 1 & 7,1 & - & - & 14 & 4,6 \\
\hline & Igreja & - & - & - & - & 2 & 100,0 & - & - & 2 & 0,7 \\
\hline & Magistratura e empregos civis & 1 & 50,0 & - & - & 1 & 50,0 & - & - & 2 & 0,7 \\
\hline & Profissionais liberais & 2 & 66,7 & 1 & 33,3 & - & - & - & - & 3 & 1,0 \\
\hline & Comércio & 40 & 67,8 & 11 & 18,6 & 5 & 8,5 & 3 & 5,1 & 59 & 19,5 \\
\hline & Atividades não classificadas & 14 & 81,3 & 4 & 18,8 & - & - & 1 & - & 19 & 6,3 \\
\hline & total & 174 & 57,4 & 66 & 21,8 & 43 & 14,2 & 20 & 6,6 & 303 & 100,0 \\
\hline \multirow{6}{*}{ : } & Agricultura e manufatura rural & 57 & 60,0 & 25 & 26,3 & 10 & 10,5 & 3 & 3,2 & 95 & 93,1 \\
\hline & Artesanato & 2 & 100,0 & - & - & - & - & - & - & 2 & 2,0 \\
\hline & Igreja & 1 & 100,0 & - & - & - & - & - & - & 1 & 1,0 \\
\hline & Magistratura e empregos civis & 1 & 100,0 & - & - & - & - & - & - & 1 & 1,0 \\
\hline & Comércio & 3 & 100,0 & - & - & - & - & - & - & 3 & 3,0 \\
\hline & total & 64 & 62,7 & 25 & 24,5 & 10 & 9,8 & 3 & 2,9 & 102 & 100,0 \\
\hline
\end{tabular}

Comparando os engenheiros de arroz das duas localidades, notamos que os iguapenses detinham posses maiores que seus pares de Xiririca, provavelmente indicando a presença de unidades produtivas menores na freguesia, possibilitando assim compreender o maior valor numérico lá registrado. Mesmo entre os plantadores de arroz, os pequenos escravistas de Iguape possuíam menor peso relativo do que os de Xiririca, cabendo a alguns da primeira localidade plantéis relativamente grandes, como os 16 casos que detinham 10 ou mais escravos contra apenas 4 proprietários na freguesia. Ainda em relação aos escravistas iguapenses, percebemos que os agricultores que associavam o arroz com outros cultivos concentravam-se nas duas primeiras faixas de posse, sugerindo que, pelo menos entre os iguapenses, a especialização associava-se à possibilidade de maiores posses, como também mostra a Tabela 3.14. 
Tabela 3.14

Distribuição dos escravos da agricultura e manufatura rural segundo faixas de tamanho dos plantéis (Iguape e Xiririca, 1836)

\begin{tabular}{|c|c|c|c|c|c|c|c|c|c|c|c|}
\hline & \multirow{3}{*}{ Ocupações } & \multicolumn{8}{|c|}{ Faixas de tamanho dos plantéis } & \multirow{2}{*}{\multicolumn{2}{|c|}{ total }} \\
\hline & & \multicolumn{2}{|c|}{$1-4$} & \multicolumn{2}{|c|}{ 5-9 } & \multicolumn{2}{|c|}{ 10-19 } & \multicolumn{2}{|c|}{20 ou mais } & & \\
\hline & & $\mathbf{N}$ & $\%$ & $\mathbf{N}$ & $\%$ & $\mathbf{N}$ & $\%$ & $\mathbf{N}$ & $\%$ & $\mathbf{N}$ & $\%$ \\
\hline \multirow{10}{*}{ 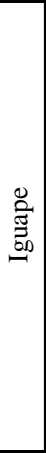 } & engenho de aguardente & 9 & 33,3 & 8 & 29,6 & 19 & 70,4 & - & - & 27 & 1,8 \\
\hline & engenho de arroz & 7 & 1,6 & 42 & 9,7 & 86 & 19,9 & 298 & 68,8 & 433 & 28,1 \\
\hline & engenho de arroz e aguardente & - & - & 8 & 36,4 & 14 & 63,6 & - & - & 22 & 1,4 \\
\hline & plantadores de arroz exclusivamente & 139 & 24,0 & 131 & 22,6 & 140 & 24,1 & 170 & 29,3 & 580 & 37,6 \\
\hline & plantadores de mandioca exclusivamente & 2 & 18,2 & 9 & 81,8 & - & - & - & - & 11 & 0,7 \\
\hline & plantadores de arroz e mandioca exclusivamente & 25 & 36,8 & 11 & 16,2 & 32 & 47,1 & - & - & 68 & 4,4 \\
\hline & plantadores de arroz, mandioca e outros & 9 & 11,7 & 47 & 61,0 & 21 & 27,3 & - & - & 77 & 5,0 \\
\hline & cultivos não especificados & 55 & 17,9 & 55 & 17,9 & 114 & 37,1 & 83 & 27,0 & 307 & 19,9 \\
\hline & madeireiros e lenhadores & - & - & - & - & 17 & 100,0 & - & - & 17 & 1,1 \\
\hline & total & 246 & 16,0 & 311 & 20,2 & 443 & 28,7 & 551 & 35,7 & 1.542 & 100,0 \\
\hline \multirow{5}{*}{ 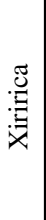 } & engenho de aguardente & 4 & 100,0 & - & - & - & - & - & - & 4 & 0,8 \\
\hline & engenho de arroz & 34 & 13,7 & 69 & 27,7 & 66 & 26,5 & 80 & 32,1 & 249 & 48,6 \\
\hline & engenho de arroz e aguardente & - & - & - & - & 15 & 100,0 & - & - & 15 & 2,9 \\
\hline & plantadores de arroz exclusivamente & 85 & 34,8 & 104 & 42,6 & 55 & 22,5 & - & - & 244 & 47,7 \\
\hline & total & 123 & 24,0 & 173 & 33,8 & 136 & 26,6 & 80 & 15,6 & 512 & 100,0 \\
\hline
\end{tabular}

Enquanto 54\% dos escravos pertencentes aos plantadores exclusivos de arroz concentravam-se nas posses com 10 ou mais escravos, nas duas outras ocupações de plantadores de arroz que possuíam alguma expressão numérica, a massa cativa pertencia a propriedades com até 9 escravos. Esta maior participação nas duas primeiras faixas de posse também é percebida de forma mais intensa na freguesia, aglomerando mais de oito décimos dos 244 escravos pertencentes a estes agricultores.

O destaque novamente cabe aos proprietários de engenhos, principalmente em Iguape, onde praticamente sete décimos pertenciam a posses com 20 ou mais escravos, ao passo que na freguesia esta proporção apresentava-se bem mais modesta, com 32\% dos cativos.

Estes valores traduzem as possibilidades de ganhos diferenciais entre os escravistas no Vale do Ribeira, pelo menos nesta fase de implantação e expansão da rizicultura. Esta especialização dos escravistas no cultivo do arroz mostra efeitos evidentes, como a redução da diversidade de ocupações. Ao mesmo tempo, ressalta a condição especial dos proprietários de engenho, maiores beneficiários neste período. Com menor intensidade, plantadores de arroz também puderam usufruir a fase mais próspera dessa lavoura. Esta dicotomia também se coloca nos resultados expressos através dos inventários pertencentes aos ribeirenses, como veremos em seguida. 


\section{A estrutura de posse nos inventários ribeirenses}

Apresentamos aqui os principais resultados sobre a posse de cativos observados nos inventários abertos entre os anos de 1800 e 1880 em Iguape e Xiririca. Além do sexo, idade e preço atribuído aos cativos, muito pouco pudemos obter acerca das variáveis demográficas dos cativos, de tal forma que privilegiamos essencialmente a estrutura de posse. O foco recai sobre as atividades econômicas exercidas pelos escravistas e todos os recortes contemplam a perspectiva comparada entre as duas localidades.

Dos 454 processos que possuíam escravos, pudemos identificar a idade em cerca de 46\% dos casos. Utilizamos esta parcela para avaliar o grau de representatividade da amostra, comparando com o perfil dos escravistas presentes em 1836. Nesse ano a participação de proprietários de escravos entre 20 a 39 anos atingia 34\% contra 15\% nos inventários; aqueles com idade entre 40 a 59 anos correspondiam a 45\% na lista nominativa e 39\% nos inventários. Por fim, os escravistas com 60 anos ou mais possuíam participações relativas iguais a $21 \%$ e $46 \%$, respectivamente. Em relação à posse média, os valores mantiveram-se relativamente próximos, porém maiores nos inventários. ${ }^{169}$ Tais desproporções nos alertam sobre o viés da fonte, privilegiando de forma diferencial uma fração da população ribeirense mais idosa. Dessa forma, todos os resultados aqui expostos guardam um caráter seletivo que não necessariamente reflete o conjunto dos escravistas da região.

Inicialmente expomos uma visão geral do conjunto de inventários, tendo em vista a pequena variação observada ao longo das 8 décadas investigadas. A Tabela 3.15 apresenta os valores relativos aos inventariados e aos escravos de Iguape e em Xiririca segundo atividades econômicas e ocupações.

\footnotetext{
${ }^{169}$ Entre os escravistas mais jovens, a média em 1836 atingiu 3,6 contra 4,5 nos inventários. No grupo etário seguinte, 7,0 e 8,1 e, para os mais idosos, 9,2 e 9,4. A média geral apresenta maior diferença: 6,3 escravos por proprietário na lista de 1836 e 8,2 nos inventários.
} 
Tabela 3.15

Distribuição relativa de inventariados e escravos avaliados segundo sexo e atividades econômicas

(Iguape e Xiririca, 1800-1880)

\begin{tabular}{|c|c|c|c|c|c|c|c|c|c|c|c|c|}
\hline \multirow{3}{*}{ Atividades econômicas/ocupações } & \multicolumn{6}{|c|}{ Iguape } & \multicolumn{6}{|c|}{ Xiririca } \\
\hline & \multicolumn{3}{|c|}{ inventariados } & \multicolumn{3}{|c|}{ escravos } & \multicolumn{3}{|c|}{ inventariados } & \multicolumn{3}{|c|}{ escravos } \\
\hline & $\mathbf{H}$ & $\mathbf{M}$ & $\mathbf{H}+\mathbf{M}$ & $\mathbf{H}$ & $\mathbf{M}$ & $\mathbf{H}+\mathbf{M}$ & $\mathbf{H}$ & $\mathbf{M}$ & $\mathbf{H}+\mathbf{M}$ & $\mathbf{H}$ & $\mathbf{M}$ & $\mathbf{H}+\mathbf{M}$ \\
\hline Agricultura e manufatura rural & 32,8 & 28,0 & 60,7 & 38,9 & 33,7 & 72,6 & 35,0 & 37,0 & 72,0 & 38,7 & 36,9 & 75,7 \\
\hline engenhocas de açúcar & - & - & & - & - & - & - & 1,4 & 1,4 & - & 0,6 & 0,6 \\
\hline engenhos de açúcar & 0,5 & 0,5 & 0,9 & 0,8 & 0,9 & 1,7 & 1,4 & 1,4 & 2,8 & 1,0 & 0,8 & 1,8 \\
\hline engenho de aguardente & - & - & - & - & - & - & 1,4 & - & 1,4 & 1,8 & 1,4 & 3,2 \\
\hline engenhocas de aguardente & 0,5 & - & 0,5 & 0,8 & 0,6 & 1,5 & 4,2 & 1,4 & 5,6 & 1,2 & 1,8 & 3,0 \\
\hline alambique de aguardente & - & 0,5 & 0,5 & 0,2 & - & 0,2 & - & - & - & - & - & - \\
\hline engenho de arroz & 20,9 & 13,5 & 34,4 & 29,6 & 24,8 & 54,4 & 16,7 & 6,9 & 23,6 & 15,8 & 14,2 & 30,0 \\
\hline engenho de arroz e aguardente & 1,9 & 0,9 & 2,8 & 2,2 & 1,8 & 4,0 & 2,8 & 6,9 & 9,7 & 10,9 & 8,5 & 19,4 \\
\hline plantadores de cana & 0,5 & - & 0,5 & - & 0,1 & 0,1 & 2,8 & 6,9 & 9,7 & 4,9 & 6,5 & 11,3 \\
\hline cafeicultores & 0,9 & - & 0,9 & 1,6 & 1,0 & 2,6 & - & - & - & - & - & - \\
\hline plantadores de arroz com outros cultivares & 14,4 & 12,6 & 27,0 & 10,2 & 8,9 & 19,1 & 9,7 & 15,3 & 25,0 & 8,5 & 6,9 & 15,4 \\
\hline plantadores de mandioca exclusivamente & 1,9 & 3,7 & 5,6 & 0,8 & 1,5 & 2,4 & - & - & - & - & - & - \\
\hline plantadores de mandioca e outros, exceto arroz & 0,5 & - & 0,5 & 0,2 & 0,1 & 0,2 & - & - & - & - & - & - \\
\hline plantadores de arroz e mandioca & 1,9 & 0,5 & 2,3 & 1,8 & 1,6 & 3,4 & 1,4 & - & 1,4 & 0,6 & 0,4 & 1,0 \\
\hline plantadores de arroz e cana & - & 0,9 & 0,9 & 0,2 & 0,1 & 0,4 & 4,2 & - & 4,2 & 3,4 & 3,6 & 7,1 \\
\hline cultivos não especificados & 9,3 & 12,1 & 21,4 & 4,4 & 4,6 & 9,1 & 4,2 & 9,7 & 13,9 & 3,0 & 3,8 & 6,9 \\
\hline criadores de b & 0,5 & 0,5 & 0,9 & 0,4 & 0,1 & 0,4 & - & - & - & - & - & - \\
\hline vive de criar animais & 0,5 & 0,5 & 0,9 & 0,4 & 0,3 & 0,6 & - & 1,4 & 1,4 & - & 0,2 & 0,2 \\
\hline Atividades marítimas & 2,8 & 1,4 & 4,2 & 1,1 & 1,2 & 2,3 & - & - & - & - & - & - \\
\hline pescadores & 33,3 & 26,7 & 60,0 & 35,2 & 35,2 & 70,4 & - & - & - & - & - & - \\
\hline homens & 26,7 & - & 26,7 & 9,3 & 9,3 & 18,5 & - & - & - & - & - & - \\
\hline mestres de barcos & 6,7 & 6,7 & 13,3 & 3,7 & 7,4 & 11,1 & - & - & - & - & - & - \\
\hline Artesanato & 2,3 & 0,8 & 3,1 & 1,0 & 1,1 & 2,1 & 3,0 & 2,0 & 5,0 & 1,2 & 1,1 & 2,3 \\
\hline construtores & - & 9,1 & 9,1 & 8,0 & 6,0 & 14,0 & - & - & - & - & - & - \\
\hline ferreiros & 9,1 & 9,1 & 18,2 & - & 4,0 & 4,0 & 40,0 & 20,0 & 60,0 & 40,0 & 20,0 & 60,0 \\
\hline carpinteiros & 54,5 & - & 54,5 & 40,0 & 38,0 & 78,0 & - & 20,0 & 20,0 & 6,7 & 6,7 & 13,3 \\
\hline sapateiros & 9,1 & 9,1 & 18,2 & - & 4,0 & 4,0 & - & - & - & - & - & - \\
\hline alfaiates & - & - & - & - & - & - & 20,0 & - & 20,0 & 6,7 & 20,0 & 26,7 \\
\hline Igreja & 0,6 & - & 0,6 & $\mathbf{0 , 4}$ & $\mathbf{0 , 2}$ & $\mathbf{0 , 6}$ & - & - & - & - & - & - \\
\hline padres & 100,0 & - & 100,0 & 64,3 & 35,7 & 100,0 & - & - & - & - & - & - \\
\hline Magistratura e empregos civis & 0,6 & - & 0,6 & $\mathbf{0 , 0}$ & $\mathbf{0 , 0}$ & $\mathbf{0 , 1}$ & - & - & - & - & - & - \\
\hline escrivães & 50,0 & - & 50,0 & 50,0 & - & 50,0 & - & - & - & - & - & - \\
\hline escruturários & 50,0 & - & 50,0 & - & 50,0 & 50,0 & - & - & - & - & - & - \\
\hline Profissionais liberais & 1,1 & 0,6 & 1,7 & 0,4 & 0,8 & 1,2 & - & - & - & - & - & - \\
\hline advogados & 33,3 & - & 33,3 & 10,7 & 3,6 & 14,3 & - & - & - & - & - & - \\
\hline boticários & 16,7 & 33,3 & 50,0 & 21,4 & 42,9 & 64,3 & - & - & - & - & - & - \\
\hline músicos & 16,7 & - & 16,7 & 3,6 & 17,9 & 21,4 & - & - & - & - & - & - \\
\hline Rentistas & 0,6 & $\mathbf{1 , 1}$ & 1,7 & 0,6 & 0,6 & 1,2 & - & - & - & - & - & - \\
\hline aluguel de casas e edifícios & - & 33,3 & 33,3 & 7,1 & - & 7,1 & - & - & - & - & - & - \\
\hline aluguel de es & - & 2 & 33,3 & 17,9 & 17,9 & 35,7 & - & - & - & - & - & - \\
\hline emprestadores de dinheiro & 33,3 & - & 33,3 & 28,6 & 28,6 & 57,1 & - & - & - & - & - & - \\
\hline Comércio & 11,9 & 6,2 & 18,1 & 8,2 & 7,1 & 15,3 & 13,0 & 2,0 & 15,0 & 10,9 & 6,3 & 17,2 \\
\hline negócio de fazenda seca & 1,9 & - & 1,9 & 0,6 & 0,8 & 1,4 & - & - & - & - & - & - \\
\hline venda de molhados & 1,9 & - & 1,9 & 0,3 & 0,3 & 0,6 & - & - & - & - & - & - \\
\hline comerciantes com engenho de arroz & 14,8 & 7,4 & 22,2 & 15,0 & 11,7 & 26,7 & 33,3 & 6,7 & 40,0 & 27,7 & 20,5 & 48,2 \\
\hline comerciante sem espeficação & 55,6 & 31,5 & 87,0 & 36,8 & 32,9 & 69,6 & 46,7 & 6,7 & 53,3 & 35,7 & 15,2 & 50,9 \\
\hline taberneiros & 3,7 & 1,9 & 5,6 & 1,1 & 0,6 & 1,7 & - & - & - & - & - & - \\
\hline mascates & - & - & - & - & - & - & 6,7 & - & 6,7 & - & 0,9 & 0,9 \\
\hline Atividades não identificadas & 3,7 & 5,6 & 9,3 & 2,2 & 2,4 & 4,6 & 4,0 & 4,0 & 8,0 & 1,8 & 3,1 & 4,9 \\
\hline total & 56,2 & 43,8 & 100,0 & 52,9 & 47,1 & 100,0 & 55,0 & 45,0 & 100,0 & 52,7 & 47,3 & 100,0 \\
\hline
\end{tabular}

As porcentagens para inventariados e escravos, em cada localidade, somam 100\% nas atividades e no conjunto de ocupações. 
Em Iguape, os 354 inventários possuíam 2.344 escravos, enquanto os 100 processos abertos em Xiririca totalizavam 653 cativos. ${ }^{170}$ Durante os 81 anos, a maioria dos casos pertencia às atividades de agricultura e manufatura rural, com $61 \%$ em Iguape e $72 \%$ em Xiririca, e agregava praticamente três quartos do total de escravos computados. A maior presença de inventários xiririquenses evidencia o caráter rural desta localidade, fato também que pode ser avaliado pela baixa freqüência de inventários nas demais categorias. Em Iguape, notamos a maior diversidade de ocupações, não obstante o pequeno número de ocorrências. Este conjunto, que além dos comerciantes, englobava atividades ligadas ao mar, rentistas, profissionais liberais, representantes da magistratura e empregos civis, do clero e do setor artesanal, soma $12 \%$ dos processos e cerca de $8 \%$ dos escravos; em Xiririca, se resumiam a 5 artesãos que possuíam 15 dos 653 cativos arrolados.

O comércio constituía a segunda atividade econômica com maior importância entre os inventariados. Em Iguape, somavam 18\% dos casos com 15\% dos cativos e, em Xiririca, $15 \%$ e $17 \%$, respectivamente. Levando-se em consideração a natureza da fonte, que para não fornece, em alguns casos, nenhum indício sobre a ocupação do inventariado (ou inventariante, se cônjuge do sexo masculino), destacamos a baixa freqüência dos não identificados, não superando um décimo dos processos em ambas as localidades. Os escravos a eles associados atingiam 8\% em Iguape e 5\% em Xiririca. ${ }^{171}$

Ao compararmos os resultados da Tabela 3.15 com a distribuição das atividades em 1836 (Tabela 3.9), é digno de nota a ausência de diferenças de grande magnitude na composição relativa. Em 1836, os escravistas iguapenses que se dedicavam à agricultura respondiam por $66 \%$ e os comerciantes por $20 \%$, contra $61 \%$ e $18 \%$ nos inventários. A maior discrepância aparece em Xiririca: no último recenseamento analisado, os agricultores representavam 93\% dos proprietários contra 72\% nos inventários, enquanto os comerciantes, $3 \%$ e 15\%, respectivamente. Além de refletir a própria composição da amostra dos inventários, esta mudança relativa também sugere o crescimento e desenvolvimento da localidade. Primordialmente rural, a prática das atividades agrícolas ensejou a consolidação de um pequeno segmento comercial que não só deveria atender as demandas das unidades produtoras como também propiciava as formas imediatas de comercialização do arroz colhido

\footnotetext{
${ }^{170}$ O número total de inventários de Iguape inclui seis inventários pertencentes a moradores da freguesia de Xiririca abertos antes de 1840, contendo 42 escravos avaliados. Procedemos à agregação desses casos para facilitar as análises ulteriores. Em Iguape, a quantidade de inventários difere da apresentada no Capítulo 1 pela exclusão de três deles que apresentavam a rubrica "serviços dos escravos" nos bens avaliados. Também não computamos as crianças, filhas de mães escravas, nascidas após a promulgação da Lei do Ventre Livre. Uma avaliação dessa exclusão pode ser encontrada no Apêndice desta tese.

${ }^{171}$ Esta classificação evidentemente não abarca a globalidade das ocupações exercidas pelo inventariado.
} 
pelos xiririquenses. Como já ressaltamos anteriormente, Iguape, ao início da fase rizicultora, já possuía uma estrutura de serviços comerciais relativamente bem desenvolvida, própria de aglomerados urbanos portuários.

Observando as diferentes ocupações exercidas pelos representantes da agricultura e manufatura rural, notamos a manutenção de alguns traços já evidenciados na análise da estrutura de posse de cativos feita com base nos censos. Em Iguape, os inventários de proprietários de engenho de arroz, inclusive aqueles que também processavam a cana, representavam 37\% dos casos dessa atividade econômica e possuíam 58\% dos cativos avaliados. Por seu turno, os plantadores de arroz perfaziam 30\% dos inventariados e 23\% dos cativos, somando $67 \%$ dos inventários e $81 \%$ dos cativos avaliados. Estas participações provavelmente correspondam a um valor mínimo, uma vez que dentre aqueles cujo cultivo não pôde ser identificado, alguns também deveriam praticar a rizicultura e representavam 21\% dos inventários desta atividade econômica e 9\% dos cativos.

Ademais, no rol de ocupações não vinculadas ao cultivo do arroz ainda deveriam constar outros rizicultores, porém a sazonalidade do cultivo e a ausência de outras informações sobre o inventariado em outras fontes primárias não permitiram estabelecer tal associação. Dentre estas, destacamos a permanência dos plantadores de mandioca, prática agrícola anterior ao cultivo do arroz e que aparece como ocupação principal em 12 dos 215 inventariados da atividade econômica em tela, porém associados a apenas 40 escravos avaliados. Nosso critério para assim classificá-los fundamenta-se na presença de mandiocais avaliados e, apesar dos valores relativamente baixos, destacamos novamente que praticamente todos os inventários descreviam a posse da roda, prensa e forno de cobre, instrumentos primordiais para o processamento deste tubérculo.

Em relação às demais ocupações, a cafeicultura e a lavoura canavieira, práticas predominantes entre os paulistas nas regiões mais dinâmicas da Província, aparecem de forma pouco expressiva entre os escravistas ribeirenses. A maioria dos casos associava-se aos moradores da região do rio Juquiá, conforme descrito no capítulo anterior. Apesar da posse escrava não desprezível, estes representavam, no total da categoria, pouco mais de $6 \%$ ou cerca de $10 \%$, se somado os que conjugavam o cultivo e/ou processamento do arroz.

Em Xiririca, os proprietários de engenho de arroz representavam um terço dos inventariados da categoria, possuindo praticamente metade dos cativos avaliados. Os cultivadores de arroz somavam 30\% com 23\% dos cativos, totalizando assim $64 \%$ dos inventários e 73\% dos escravos. Se comparado com Iguape, além de arregimentar menor parcela de cativos na rizicultura, em Xiririca os processos com menção ao cultivo e/ou 
processamento da cana atingiam valores bem mais expressivos: 21\% dos inventários e 20\% dos cativos ou $35 \%$ e $46 \%$, totalizando os casos que praticavam também o cultivo do arroz. Esta distinção, aparentemente de determinação ambiental, propiciou aos escravistas xiririquenses a possibilidade de maior diversificação de renda. Ao se pensar sobre o destino dessa produção de Xiririca, ficamos com a impressão que se direcionava ao atendimento da demanda estritamente regional, uma vez que os registros de exportação de açúcar e derivados representavam valores residuais nos mapas de exportação. O impacto desta maior diversidade não se resume na distribuição de inventários e escravos, mas também na avaliação dos bens de raiz e na própria riqueza bruta, posicionando os escravistas xiririquenses de forma diferenciada em relação aos seus pares de Iguape.

Se a organização mais ampla das atividades econômicas, observada na Tabela 3.15, não se diferencia substancialmente da distribuição obtida a partir do recenseamento de 1836, a comparação das ocupações revela um distinto perfil. Naquele ano, tanto na vila como na freguesia, observamos o predomínio dos fogos compostos por plantadores de arroz, que em Iguape também detinham a maior parcela de escravos. Os proprietários de engenho atingiam $11 \%$ dos escravistas em Iguape que possuíam 28\% dos cativos; em Xiririca a participação superava 35\% dos donos de escravos, que por sua vez representavam metade dos cativos da freguesia. Dessa forma, parece evidente que no conjunto dos inventários a parcela de proprietários de engenho de arroz, em consonância com o viés já explicitado acima, aparece superestimada em relação ao conjunto dos escravistas presentes em 1836, com implicações diretas na análise da riqueza pertencente a este grupo.

$\mathrm{Na}$ segunda categoria com maior representatividade entre os inventários, a dos comerciantes, os casos sem especificação representavam a maior parte em Iguape, além de agregar a maior parcela de cativos. Uma condição especial, dos que também possuíam engenho de arroz, destaca-se não apenas pela conjunção de atividades, como também pela posse desproporcional de escravos. Esta informação sugere que estes não atuariam somente no âmbito da mercantilização final dos grãos: além de executar o processamento dos grãos, eles também poderiam, dado o estoque de cativos avaliados, cumprir funções produtivas. Esta estratégia, se de fato potencializava o aumento de ganhos dentro da principal cadeia produtiva ribeirense, surpreende negativamente pela baixa freqüência de casos registrados. No Capítulo 4 este tema será retomado. Por ora, é preciso reter que a aludida associação parecia não ser possível (ou desejável) para parcela dos homens de negócio do Vale do Ribeira.

Qual é a representatividade de nossa amostra em relação a outros estudos que também utilizaram os inventários para a investigação da estrutura de posse? No Vale do 
Ribeira a posse média geral, 6,6 escravos por inventário, situa-se abaixo dos 14,5 registrados através dos casos acompanhados por Renato Leite Marcondes em Lorena entre os anos de 1830 e 1879. A ocupação com maior média correspondia aos que conjugavam, em 1829, o cultivo do café com a cana, atingindo 40 escravos por inventário; os que praticavam um ou outro cultivo possuíam média em torno de 12 cativos avaliados (cf MARCONDES, 1998, p. 146). No caso do Vale do Ribeira, os proprietários de engenho detinham cerca de 12 escravos por inventário e os plantadores de arroz, pouco menos de 6 escravos. Em Mogi Mirim, entre 1831 e 1880, o valor médio geral atingiu 10 escravos e, da mesma forma que em Lorena, os agricultores com cultivos de café e processamento de cana possuíam o maior valor médio, atingindo também a marca de 40 escravos por inventário, porém os proprietários de engenho de cana possuíam, em média maior número de escravos do que os cafeicultores (29 e 15 escravos por inventário, cf. SOARES, 2003, p. 105).

Ainda dentro do território paulista, a média geral obtida para 285 inventários com escravos em Batatais entre os anos de 1851 a 1887 igualou-se a 6 escravos por inventário, pertencendo aos lavradores e criadores as maiores posses, cerca de 11 escravos (cf. GARAVAZO, 2006, p. 142). Com a mesma vocação agro-pecuária, porém em território mineiro, Déborah Reis verificou em Araxá valores médios entre 7 e 8 escravos por inventário nas duas metades do século XIX (cf. REIS, 2005, p .116). Dessa forma, reafirma-se aqui a condição de similitude do Vale do Ribeira com regiões pouco vinculadas com as práticas agro-exportadoras, já apontadas no final do Capítulo 1. Também delimita a fase expansiva da economia regional aos anos iniciais do século XIX, conforme vimos nas páginas anteriores.

Tendo em vista este quadro geral revelado pelos inventários ribeirenses, as análises ulteriores apresentam a estrutura de posse destes cativos segundo as atividades econômicas nos três subperíodos estabelecidos. Em função da própria distribuição acima ressaltada, privilegiamos as ocupações da atividade econômica agricultura e manufatura rural, não apenas por traduzir a vocação precípua do Vale do Ribeira, mas também por concentrar a maior parcela de escravos descrita nos inventários.

Dedicamos especial atenção aos inventários post-mortem abertos entre 1800 e 1840. A principal intenção é, além de estimar o perfil da riqueza acumulada em cativos pelos inventariados, intensificar as eventuais medidas de correspondência entre esta fonte e o perfil delineado através das listas nominativas. As duas primeiras décadas do subperíodo em tela concentraram pouco mais de um quarto dos 90 casos e praticamente metade dos inventários foram abertos entre 1831 e 1840. Destarte, muito dos resultados que serão aqui descritos guardam estreita relação com o perfil obtido verificado em 1828 e 1836. 
Dos 53 homens e 37 mulheres, estimamos a idade ao morrer de 30 dos primeiros (idade média igual a 59 anos) e 20 das segundas (57 anos, em média). A idade média dos inventariados do sexo masculino mostrou-se bastante superior se comparada com os escravistas presentes nas listas nominativas, que se manteve ao redor de 46 anos. Entre as mulheres, o valor aqui observado aproxima-se das escravistas assinaladas nas páginas iniciais deste capítulo, cuja média decresceu de 59 para 51 anos entre 1801 e 1836. De acordo com os resultados expostos no Gráfico 3.14, a faixa etária que possuía maior valor médio de escravos correspondia àquela entre 60 e 69 anos em três dos quatro anos investigados. Dessa forma, parece razoável imaginar que parte dos inventariados, especificamente os mais jovens, esteja associado a posses aquém de um valor máximo, isto é, aquele atingido na referida faixa etária.

Esse conjunto de escravistas possuía 699 escravos avaliados, sendo 393 do sexo masculino e 306 do sexo feminino, resultando em razão de sexo igual a 128, valor intermediário entre os observados nas listas nominativas a partir de 1815. Nos menores plantéis, até 4 cativos, notamos equilíbrio entre os sexos, com razão de sexo igual a 102. Em todas as demais faixas registramos o predomínio de escravos do sexo masculino, com razões de sexo iguais a 125 no agrupamento de 5 a 9 escravos, 140 no de 10 a 19 cativos e 136 nos maiores plantéis.

Da informação sobre a idade, presente em 654 registros, verificamos a proximidade entre a idade média dos escravos do sexo masculino (23 anos) e feminino (22 anos). Estes valores, que guardam estreita proximidade com os observados nas listas nominativas, evidenciam certa similitude entre a população escrava total e a amostra obtida através dos inventários. Em todas as faixas etárias o número de homens superava o de mulheres, com maior intensidade naqueles com idade entre 20 e 49 anos, onde a razão de sexo atingiu 146 escravos do sexo masculino para cada grupo de 100 mulheres, chegando a 157 nas posses com 10 ou mais escravos.

As demais variáveis demográficas abordadas na seção anterior - cor, origem e condição conjugal - mostraram-se prejudicadas pela ausência de informações nos inventários. ${ }^{172}$ A com maior representatividade, sobre a origem dos cativos, dava conta de três quartos dos 699 escravos e os africanos correspondiam à menor parte, com 38\% dos 522 cativos. Este valor, ligeiramente superior ao observado em 1836, quando africanos representavam 31\% dos casos, guarda distinções significativas se segmentado por sexo. Dessa forma, se entre as mulheres a participação de africanas atingia $27 \%$, cerca de $46 \%$ dos cativos

\footnotetext{
${ }^{172}$ Apenas 81 escravos possuíam anotação sobre a condição conjugal e pouco mais da metade do contingente era caracterizado segundo a cor, correspondendo a $55 \%$ de pretos e $45 \%$, mulatos.
} 
do sexo masculino possuíam essa condição, reproduzindo a distinção observada pelas listas nominativas a partir de 1815.

Desse primeiro perfil da posse escrava descrita nos inventários percebemos que as maiores propriedades guardavam distinções em relação aos pequenos plantéis, especialmente no subgrupo de cativos do sexo masculino nas faixas etárias com maior vigor físico. No entanto, estas diferenciações também já puderam ser detectadas através das listas nominativas e lá ressaltamos que tal perfil manteve-se aquém do observado nas áreas mais dinâmicas do território paulista, especialmente na razão de sexo e na participação de africanos. Na Tabela 3.16 apresentamos os indicadores de posse de cativos segundo atividade econômica.

Tabela 3.16

Indicadores de posse escrava dos inventariados segundo atividade econômica

(Iguape e Xiririca, 1800-1840)

\begin{tabular}{|c|c|c|c|c|c|c|c|c|}
\hline Atividade econômica/ocupação & inventariados & $\%$ & escravos & $\%$ & razão de sexo & média & desvio-padrão & mediana \\
\hline Agricultura e manufatura rural & 55 & 61,1 & 521 & 74,5 & 134,7 & 9,5 & 12,3 & 5,0 \\
\hline engenho de arroz & 20 & 22,2 & 350 & 50,1 & 155,5 & 17,5 & 16,8 & 12,0 \\
\hline plantadores de arroz com outros cultivares & 11 & 12,2 & 90 & 12,9 & 109,3 & 8,2 & 6,9 & 6,0 \\
\hline plantadores de mandioca exclusivamente & 9 & 10,0 & 30 & 4,3 & 42,9 & 3,3 & 1,6 & 3,0 \\
\hline plantadores de mandioca e outros, exceto arroz & 1 & 1,1 & 4 & 0,6 & 300,0 & 4,0 & - & 4,0 \\
\hline plantadores de arroz e mandioca exclusivamente & 1 & 1,1 & 4 & 0,6 & 100,0 & 4,0 & - & 4,0 \\
\hline cultivos não especificados & 11 & 12,2 & 32 & 4,6 & 128,6 & 2,9 & 1,6 & 3,0 \\
\hline criadores de bovinos & 1 & 1,1 & 6 & 0,9 & 500,0 & 6,0 & - & 6,0 \\
\hline vive de criar animais & 1 & 1,1 & 5 & 0,7 & 66,7 & 5,0 & - & 5,0 \\
\hline Atividades do mar & 3 & 3,3 & 8 & 1,1 & 100,0 & 2,7 & 2,9 & 1,0 \\
\hline Artesanato & 8 & 8,9 & 43 & 6,2 & 95,5 & 5,4 & 7,9 & 1,5 \\
\hline Igreja & 1 & 1,1 & 1 & 0,1 & - & 1,0 & - & 1,0 \\
\hline Magistratura e empregos civis & 1 & 1,1 & 1 & 0,1 & - & 1,0 & - & 1,0 \\
\hline Comércio & 17 & 18,9 & 106 & 15,2 & 120,8 & 6,2 & 6,6 & 5,0 \\
\hline Atividades não identificadas & 5 & 5,6 & 19 & 2,7 & 90,0 & 3,8 & 2,2 & 5,0 \\
\hline total & 90 & 100,0 & 699 & 100,0 & 128,4 & 7,8 & 10,5 & 5,0 \\
\hline
\end{tabular}

De forma similar aos resultados da Tabela 3.14, os agricultores representavam cerca de seis décimos dos inventariados e detinham três quartos dos escravos. O segundo grupo, os comerciantes, também compareceram com parcela equivalente tanto no número de inventários como na quantidade de cativos avaliados. Os valores de posse média e mediana indicados na linha totalizadora superavam os observados em 1828 e 1836, porém de forma discreta. ${ }^{173}$ Estes indicadores, se segmentados nas diversas atividades econômicas, oscilaram positivamente em relação aos anotados em 1836. No entanto, da posse média geral observada no subperíodo, apenas os agricultores superavam esse valor, acompanhada por uma elevada dispersão. O desmembramento segundo ocupações revela diferentes estratos nos quatro grupamentos com maior número de casos.

\footnotetext{
${ }^{173}$ Em 1828, o valor médio atingia 7 escravos por proprietário e, em 1836, 6,7. Em ambos os anos, a mediana igualou-se a 4 cativos.
} 
Os proprietários de engenho de arroz constituíam posses bem diversas dos demais agricultores, não apenas pelos elevados valores da posse média e mediana, mas também pela maior presença de cativos do sexo masculino. Notamos a distinção entre este grupo e os plantadores de arroz, com posse média menor e relativo equilíbrio entre os cativos de ambos os sexos. Situação mais modesta apresentava o conjunto de agricultores que não cultivavam arroz, provavelmente representantes da condição agrícola prévia à disseminação do arroz no Vale do Ribeira.

Entre os comerciantes, a média apresentada na Tabela 3.16 oculta dois tipos: os que também possuíam engenho de arroz, cujo valor se aproximava da posse dos agricultores igualmente proprietários de engenho (15 escravos por inventário, com três ocorrências) e os demais, cujo valor médio manteve-se ao redor de 5 escravos por inventário. Como destacado anteriormente, a duplicidade de ocupações dentro desta atividade econômica manteve-se com freqüência bastante reduzida.

Neste subperíodo os representantes do setor artesanal atingiram as parcelas relativas mais expressivas de todo o lapso de tempo investigado. Da mesma forma, não mais conseguiriam reproduzir indicadores de posse tão elevados. Metade dos oito casos vinculavase à carpintaria, que remete, de forma idêntica ao registro dos plantadores de mandioca, ao período anterior à rizicultura, quando as atividades praticadas nos estaleiros iguapenses possivelmente demandavam estes especialistas.

A tabela seguinte distribui inventariados e escravos segundo faixas de tamanho dos plantéis, ainda recortados segundo atividades econômicas.

Os resultados das listas nominativas evidenciaram as taxas decrescentes dos pequenos proprietários (até 4 cativos) ao longo das três primeiras décadas do Oitocentos, porém em nenhum momento ela atingiu 49\%, valor observado no conjunto de inventários aqui considerados. Igualmente, a parcela de cativos associada, que entre 1801 e 1836 reduziuse de $27 \%$ a $18 \%$, superava a dos inventariados, $13 \%$. As faixas intermediárias, de 5 a 19 cativos, possuíam maior representatividade entre os inventariados do que no conjunto dos escravistas iguapenses, quer seja pelo total de proprietários, quer pelo número de escravos possuídos, permanecendo a maior faixa de posse com valor relativo semelhante aos observados em 1828 e 1836. 
Tabela 3.17

Distribuição relativa de inventariados e escravos segundo atividades econômicas e faixas de tamanho dos plantéis

(Iguape e Xiririca, 1800-1840)

\begin{tabular}{|c|c|c|c|c|c|c|c|c|}
\hline \multirow{3}{*}{ Atividades econômicas/ocupações } & \multicolumn{8}{|c|}{ Faixas de tamanho dos plantéis } \\
\hline & \multicolumn{2}{|l|}{$1-4$} & \multicolumn{2}{|l|}{ 5-9 } & \multicolumn{2}{|c|}{ 10-19 } & \multicolumn{2}{|c|}{20 ou mais } \\
\hline & inventariados & escravos & inventariados & escravos & inventariados & escravos & inventariados & escravos \\
\hline Agricultura e manufatura rural & 45,5 & 12,7 & 23,6 & 15,9 & 21,8 & 31,5 & 9,1 & 39,9 \\
\hline engenho de arroz & 10,0 & 0,9 & 25,0 & 10,0 & 45,0 & 36,9 & 20,0 & 52,3 \\
\hline plantadores de arroz com outros cultivares & 45,5 & 16,7 & 18,2 & 16,7 & 27,3 & 38,9 & 9,1 & 27,8 \\
\hline plantadores de mandioca exclusivamente & 77,8 & 63,3 & 22,2 & 36,7 & - & - & - & - \\
\hline plantadores de mandioca e outros, exceto arroz & 100,0 & 100,0 & - & - & - & - & - & - \\
\hline plantadores de arroz e mandioca exclusivamente & 100,0 & 100,0 & - & - & - & - & - & - \\
\hline cultivos não especificados & 81,8 & 65,6 & 18,2 & 34,4 & - & - & - & - \\
\hline criadores de bovinos & - & - & 100,0 & 100,0 & - & - & - & - \\
\hline vive de criar animais & - & - & 100,0 & 100,0 & - & - & - & - \\
\hline Atividades do mar & 66,7 & 25,0 & 33,3 & 75,0 & - & - & - & - \\
\hline Artesanato & 62,5 & 14,0 & 25,0 & 30,2 & - & - & 12,5 & 55,8 \\
\hline Igreja & 100,0 & 100,0 & - & - & - & - & - & - \\
\hline Magistratura e empregos civis & 100,0 & 100,0 & - & - & - & - & - & - \\
\hline Comércio & 47,1 & 14,2 & 35,3 & 36,8 & 11,8 & 23,6 & 5,9 & 25,5 \\
\hline Atividades não identificadas & 40,0 & 15,8 & 60,0 & 84,2 & - & - & - & - \\
\hline total & 48,9 & 13,4 & 27,8 & 22,5 & 15,6 & 27,0 & 6,7 & 37,1 \\
\hline
\end{tabular}

Obs.: as porcentagens somam $100 \%$ nas linhas

Parcela da responsabilidade pelas diferenças apontadas acima coube aos agricultores.

Em 1836, os proprietários com plantéis até 4 cativos nesta atividade econômica respondiam por $52 \%$ dos casos contra $46 \%$ conforme os dados da Tabela 3.17. É no conjunto dos comerciantes, porém, que reside a maior diferença: em 1836, 68\% deles detinha posses até 4 cativos contra $47 \%$ na amostra dos inventários. Estas distorções, no entanto, não afetam a essência da distribuição, vale dizer, o predomínio dos pequenos proprietários de escravos associado à posse de pequena quantidade do total de cativos, tônica também nas listas nominativas e na maior parte das regiões paulistas no mesmo período, conforme exposto na seção anterior.

Observando as diferentes ocupações da atividade agrícola, proprietários de engenho e plantadores de arroz compunham as únicas categorias com expressão em todas as faixas de posse. Os primeiros com a maioria dos casos nas faixas acima de 9 cativos e os demais principalmente nos dois menores intervalos. Não obstante, nas duas ocupações a maior parte dos escravos concentrava-se nas faixas superiores, e, apesar da magnitude assemelhada (70\% e 67\%), os cativos pertencentes aos proprietários de engenho predominavam na faixa dos 20 ou mais escravos. Guardadas as devidas proporções e ressalvada a baixa freqüência de casos, a mesma relação pode ser observada entre os comerciantes que possuíam engenho de arroz e os demais casos. 
Os resultados apresentados até o momento reafirmam o quadro já esboçado quando apresentamos a estrutura da posse de escravos através das listas nominativas. O principal grupo de escravistas, os proprietários de engenho de arroz, conseguiu durante o primeiro subperíodo lograr sucesso no acúmulo de riqueza, secundado pelos plantadores de arroz. Este resultado, mais visível quando observamos o tamanho e a composição da posse escrava descrita nos inventários, também pode ser medido através do índice de Gini. Conforme mostram os resultados apresentados na Tabela 3.2, este indicador manteve-se em ascensão entre 1801 e 1828, atingindo 0,560 neste ano e 0,553 em 1836. O valor calculado para os 90 inventários do subperíodo em tela, 0,554, praticamente reproduz a distribuição da posse cativa das duas últimas listas nominativas, anos de consolidação das maiores propriedades escravas.

A medida de concentração de outras formas de riqueza evidencia maior desigualdade na distribuição da riqueza dos inventariados. Por exemplo, se considerada a riqueza bruta (também em libras), o índice atinge 0,643. Cabe aqui, portanto, analisar a distribuição da posse de escravos segundo faixas de riqueza bruta dos inventários com escravos, conforme apresentado na Tabela 3.18 .

Tabela 3.18

Indicadores de posse de escravos segundo faixas de riqueza bruta

(Iguape e Xiririca, 1800-1840)

\begin{tabular}{l|rrrrrrrrr}
\hline $\begin{array}{c}\text { Faixas de riqueza } \\
\text { bruta (libras) }\end{array}$ & inventários & $\mathbf{\%}$ & escravos & $\mathbf{\%}$ & $\begin{array}{c}\text { \% na riqueza } \\
\text { bruta }\end{array}$ & $\begin{array}{c}\text { \% da riqueza } \\
\text { bruta }\end{array}$ & média & mediana & $\begin{array}{c}\text { desvio- } \\
\text { padrão }\end{array}$ \\
\hline $0-500$ & 63 & 70,0 & 249 & 35,6 & 55,0 & 21,8 & 3,9 & 3,0 & 2,9 \\
$500-1.000$ & 13 & 14,4 & 114 & 16,3 & 33,0 & 16,2 & 8,8 & 9,0 & 7,8 \\
$1.000-2.000$ & 8 & 8,9 & 131 & 18,7 & 37,8 & 18,7 & 16,4 & 17,0 & 7,1 \\
acima de 2.000 & 6 & 6,7 & 205 & 29,3 & 23,6 & 43,3 & 34,2 & 34,0 & 22,2 \\
\hline total & 90 & 100,0 & 699 & 100,0 & 46,3 & 100,0 & 7,8 & 5,0 & 10,5 \\
\hline
\end{tabular}

Na menor das faixas de riqueza concentrava-se a maioria dos inventários e a maior parcela de cativos, resultando daí os valores médio e mediano abaixo dos registrados no total da amostra. Nesta categoria também se verifica o maior comprometimento da riqueza bruta em escravos, evidenciando a significativa importância deste ativo no conjunto dos bens pertencentes aos escravistas mais pobres. Pari passu ao aumento da riqueza bruta, decrescia este comprometimento, confirmando a importância da posse de cativos como um dos principais mecanismos de reafirmação das desigualdades na sociedade ribeirense nas quatro primeiras décadas do Oitocentos. Em outras palavras, o que a Tabela 3.18 informa é que, nos 
casos de maior riqueza (acima de 1.000 libras) a posse média de escravos superava em muito o valor geral da amostra, não obstante a menor parcela da riqueza imobilizada em cativos. ${ }^{174}$

Esta diferenciação através da riqueza bruta também se reflete na composição dos plantéis: exceto nos inventários que compõem a primeira faixa de riqueza, em todos os demais a razão de sexo indicava o predomínio de cativos do sexo masculino, atingindo 153 homens para cada 100 mulheres entre aqueles com mais de 2.000 libras. ${ }^{175}$ Ao relembrarmos que as maiores posses médias e os plantéis com maior predomínio de cativos do sexo masculino pertenciam aos proprietários de engenho de arroz, conforma-se a dupla condição da referida diferenciação: a propriedade de unidades processadoras de arroz conduzida por proprietários de plantéis mais extensos. ${ }^{176}$

Assim, torna-se mais claro o significado do índice de Gini obtido para a distribuição da riqueza bruta, mais elevado do que aquele calculado para a posse de escravos. Os maiores escravistas, em que pese o montante expressivo alocado neste ativo, também detinham bens de raiz - terras, benfeitorias, moradas de casas - que, agregados ao valor dos escravos, distanciava-os do conjunto dos inventários cuja riqueza não suplantava a marca das 500 libras.

Este diferencial naturalmente não poderia emergir da análise das listas nominativas, sugerindo que os índices lá calculados devam ser tomados como valores mínimos da real distribuição da riqueza entre ribeirenses. Mesmo levando-se em conta o viés já detectado na amostra dos inventários para o período, com predomínio destes proprietários de engenhos, não há motivo para crer-se que um aumento no número de casos possa produzir alterações substanciais nos resultados acima expressos. Este acréscimo aumentaria, com muita probabilidade, a proporção de patrimônios com apoucada soma, apenas reiterando a distinção já observada. ${ }^{177}$

\footnotetext{
${ }^{174} \mathrm{O}$ coeficiente de correlação de Pearson entre a riqueza bruta e o valor dos escravos atingiu 0,907 e entre a riqueza bruta e o número de cativos avaliados, 0,904 (este índice, quanto mais próximo da unidade, indica o maior grau de associação entre as duas variáveis).

${ }^{175} \mathrm{O}$ predomínio masculino ganha maior expressividade se considerados os cativos entre 15 e 49 anos: 170 nos inventários com mais de 1.000 libras contra 114 nas duas menores faixas de riqueza.

${ }^{176}$ Os 14 casos com mais de $£ 1.000,9$ possuíam engenhos de arroz, sendo que um deles associava esta ocupação com a comercial, que englobava outros 3 casos neste restrito grupo. Completando, um deles dedicavase ao cultivo de arroz com outras práticas agrícolas e o outro era carpinteiro. Ressalte-se ainda que apenas dois deles não pertenciam à década de 1830 .

${ }^{177}$ Esta distinção nos índices de concentração entre riqueza bruta e escravos também foi observada por Juliana Garavazo analisando os inventários abertos na segunda metade do século XIX em Batatais. Da mesma forma que para o Vale do Ribeira, "A comparação dos Índices de Gini calculados para a posse cativa e para a riqueza bruta inventariada indica que, para a Batatais daquele período, a posse cativa não seria uma boa proxy do nível de riqueza dos indivíduos inventariados" (GARAVAZO, 2006, p. 146).
} 
O perfil de riqueza observado na fase de disseminação do cultivo do arroz revela-se peculiar por retratar um momento de maiores oportunidades para a expansão da empresa escravista. Como será analisada posteriormente, a trajetória de alguns destes escravistas evidencia o enorme sucesso na adoção de estratégias que envolviam uma certa disponibilidade de recursos para a aquisição de escravos associada com o estabelecimento de relações sociais que favoreceram o acesso à posse fundiária. Com a consolidação das novas práticas agrícolas, a reprodução das alianças familiares manteve-se como um dos mecanismos de concentração de renda entre a elite ribeirense. A manutenção da lavoura de arroz, entrementes, reduziu qualquer possibilidade de exploração de novos nichos econômicos e, impossibilitada de acompanhar o ritmo de crescimento de outras regiões paulistas que se especializavam no cultivo do café, tem-se como resultado final o arrefecimento da posse escrava, como será evidenciado através dos resultados expostos a seguir.

Dos 172 inventários abertos entre 1840 e 1861, 146 pertenciam a Iguape e 26 a Xiririca. Nesta, a proporção de homens e mulheres inventariados se igualava, enquanto em Iguape predominaram as pessoas do sexo masculino (84 contra 62 mulheres). Em metade dos casos, foi possível determinar a idade ao morrer, 55 anos em média, ou ainda 56 anos entre os 49 homens e 52 anos entre as 37 mulheres, valores ligeiramente inferiores aos observados no subperíodo anterior. Os 14 casos identificados em Xiririca possuíam idade média superior (63 anos) em relação aos 72 iguapenses (53 anos), e em ambas as localidades a diferença entre homens e mulheres se reproduzia.

Os inventários de Iguape continham 1.025 cativos avaliados, razoavelmente bem distribuídos segundo sexo (525 homens e 500 mulheres). Em Xiririca, somavam os 110 homens e 81 mulheres 191 casos, resultando em uma razão de sexo igual a 136 homens para cada grupo de 100 mulheres em Xiririca contra 105 em Iguape. Atribuímos esta desproporção a peculiaridades da amostra em Xiririca - bastante diminuta em relação à quantidade registrada em Iguape - que privilegiou posses com maior número de jovens escravos do sexo masculino. Esta impressão pode ser constatada através da idade média dos cativos de Xiririca (19 anos, 179 pessoas), menor do que os de Iguape (23 anos, 918 pessoas), assim como a idade mediana (14 anos e 20 anos, respectivamente). Ademais, esse predomínio masculino em Xiririca ocorria principalmente nas faixas etárias de 0 a 19 anos, que concentravam praticamente 58\% dos cativos e que apresentavam razão de sexo igual a 160. Dessa forma, acreditamos na ausência de qualquer associação entre o perfil geral dos escravos inventariados em Xiririca e uma representação de maior dinamismo econômico. Ainda em relação aos atributos demográficos dos escravos, identificamos a origem para $60 \%$ dos casos 
ou 732 escravos. Destes, 21\% provinham da África, porcentual menor do que o registrado no subperíodo anterior. Em relação à cor, metade dos 325 era descrita como pretos e 37\% como mulatos.

Tabela 3.19

Indicadores da posse de escravos dos inventários segundo atividades econômicas

(Iguape e Xiririca, 1841-1860)

\begin{tabular}{|c|c|c|c|c|c|c|c|c|c|}
\hline & Atividades econômicas/ocupações & inventários & $\%$ & escravos & $\%$ & razão de sexo & média & desvio-padrão & mediana \\
\hline \multirow{20}{*}{ 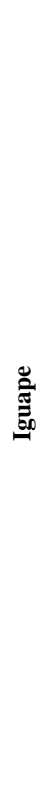 } & Agricultura e manufatura rural & 88 & 60,3 & 772 & 75,3 & 109,2 & 8,8 & 10,3 & 5,5 \\
\hline & engenho de açúcar & 2 & 1,4 & 29 & 2,8 & 93,3 & 14,5 & 7,8 & 25,0 \\
\hline & engenho de aguardente & 1 & 0,7 & 25 & 2,4 & 127,3 & 25,0 & - & 25,0 \\
\hline & engenho de arroz & 26 & 17,8 & 363 & 35,4 & 106,3 & 14,0 & 13,8 & 9,5 \\
\hline & engenho de arroz e aguardente & 3 & 2,1 & 49 & 4,8 & 145,0 & 16,3 & 3,5 & 16,0 \\
\hline & cafeicultures & 1 & 0,7 & 44 & 4,3 & 158,8 & 44,0 & - & 44,0 \\
\hline & plantadores de arroz com outros cultivares & 28 & 19,2 & 119 & 11,6 & 101,7 & 4,3 & 3,4 & 3,0 \\
\hline & plantadores de mandioca exclusivamente & 3 & 2,1 & 10 & 1,0 & 100,0 & 3,3 & 3,2 & 2,0 \\
\hline & plantadores de arroz e mandioca exclusivamente & 4 & 2,7 & 54 & 5,3 & 107,7 & 13,5 & 7,9 & 14,5 \\
\hline & plantadores de arroz e cana & 1 & 0,7 & 1 & 0,1 & - & 1,0 & - & 1,0 \\
\hline & cultivos não especificados & 18 & 12,3 & 72 & 7,0 & 89,5 & 4,0 & 3,0 & 3,0 \\
\hline & vive de criar animais & 1 & 0,7 & 6 & 0,6 & 200,0 & 6,0 & - & 6,0 \\
\hline & Atividades do mar & 8 & 5,5 & 29 & 2,8 & 81,3 & 3,6 & 2,4 & 3,5 \\
\hline & Artesanato & 2 & 1,4 & 6 & 0,6 & 100,0 & 3,0 & 2,8 & 3,0 \\
\hline & Igreja & 1 & 0,7 & 13 & 1,3 & 160,0 & 13,0 & - & 13,0 \\
\hline & Magistratura e empregos civis & 2 & 1,4 & 12 & 1,2 & - & 6,0 & $\mathbf{0 , 0}$ & 6,0 \\
\hline & Rentistas & 5 & 3,4 & 27 & 2,6 & 107,7 & 5,4 & 5,0 & 3,0 \\
\hline & Comércio & 27 & 18,5 & 128 & 12,5 & 109,8 & 4,7 & 5,0 & 3,0 \\
\hline & Atividades não identificadas & 12 & 8,2 & 37 & 3,6 & 60,9 & 3,1 & 1,9 & 3,0 \\
\hline & total & 146 & 100,0 & 1.025 & 100,0 & 105,0 & 7,0 & 8,2 & 4,0 \\
\hline \multirow{12}{*}{ 㺼 } & Agricultura e manufatura rural & 21 & 80,8 & 161 & 84,3 & 133,3 & 7,7 & 8,2 & 4,0 \\
\hline & engenho de aguardente & 1 & 3,8 & 16 & 8,4 & 128,6 & 16,0 & - & 16,0 \\
\hline & engenho de arroz & 9 & 34,6 & 95 & 49,7 & 137,5 & 10,6 & 10,9 & 4,0 \\
\hline & engenho de arroz e aguardente & 3 & 11,5 & 19 & 9,9 & 111,1 & 6,3 & 4,9 & 4,0 \\
\hline & plantadores de cana & 1 & 3,8 & 10 & 5,2 & 100,0 & 10,0 & - & 10,0 \\
\hline & plantadores de arroz com outros cultivares & 5 & 19,2 & 14 & 7,3 & 180,0 & 2,8 & 2,2 & 2,0 \\
\hline & plantadores de arroz e mandioca exclusivamente & 1 & 3,8 & 5 & 2,6 & 150,0 & 5,0 & - & 5,0 \\
\hline & cultivos não especificados & 1 & 3,8 & 2 & 1,0 & 100,0 & 2,0 & - & 2,0 \\
\hline & Artesanato & 3 & 11,5 & 12 & 6,3 & 140,0 & 3,0 & 2,0 & 4,0 \\
\hline & Comércio & 1 & 3,8 & 12 & 6,3 & 500,0 & 12,0 & - & 12,0 \\
\hline & Atividades não identificadas & 1 & 3,8 & 6 & 3,1 & 20,0 & 6,0 & - & 6,0 \\
\hline & total & 26 & 100,0 & 191 & 100,0 & 135,8 & 7,4 & 7,5 & 4,0 \\
\hline
\end{tabular}

A Tabela 3.19 apresenta os indicadores de posse do subperíodo segundo as atividades econômicas. Os valores reafirmam a condição predominantemente agrícola de Xiririca em relação à maior diversidade de atividades econômicas de Iguape. Naquela, vinculavam-se à agricultura 21 dos 26 inventários abertos entre 1841 e 1860 e praticamente 85\% dos cativos, sendo os demais distribuídos entre um comerciante, dois artesãos e um caso cuja atividade não foi identificada. Em Iguape, seis décimos dos 146 inventários aparecem alocados entre aqueles que praticavam atividades agrícolas, detendo três quartos do total de cativos arrolados nos inventários. Apesar da diversidade de atividades em Iguape, a maior parte das categorias possuía apenas um ou dois representantes. Novamente os comerciantes 
constituíam o segundo maior agrupamento, com 18\% dos inventários e $12 \%$ dos cativos, seguidos pelas atividades marítimas, que totalizavam 8 inventários e 29 escravos, além daqueles com atividade não identificada.

A média geral em Iguape, 7 escravos por proprietário, não se diferenciou da observada no subperíodo anterior, porém o menor desvio-padrão assinalado na tabela acima indica maior homogeneidade entre os plantéis avaliados, além da redução do valor mediano de 5 para 4 escravos. A razão de sexo dos cativos, ao reduzir-se de 128 para 105, sinaliza a incapacidade da economia regional em manter o fluxo de escravos observado no início da centúria. O valor médio da posse nas duas atividades econômicas com maior expressividade mostrou-se menor do que o registrado entre 1800 e 1840, porém não representam diferenças estatisticamente significativas.

As duas ocupações agrícolas com maior número de representantes - os proprietários de engenho de arroz e seus plantadores - também apresentaram valores médios menores, porém apenas entre os cultivadores da gramínea a diferença revelou-se estatisticamente significativa. O desvio-padrão associado ao valor médio da posse escrava de engenheiros de arroz evidencia que esta ocupação continuava a agregar um grupo com características bem distintas quanto ao número de escravos avaliados. No entanto, reside na razão de sexo dos cativos o maior sinal de descontinuidade do padrão observado nas décadas de 1820 e 1830: este indicador decaiu de 155 para 106 homens em cada grupo de 100 mulheres.

Da análise conjunta da média e desvio-padrão dos rizicultores, o principal resultado indica uma posição desvantajosa em relação ao primeiro subperíodo, pois além da redução no valor médio, a dispersão em torno desta média revelou-se menor do que a registrada no subperíodo anterior. Parece-nos clara a associação entre estes dados e o desempenho das exportações de arroz, descritos no Capítulo 1. O menor crescimento no ritmo das exportações ribeirenses e a tendência altista do preço dos escravos com certeza alinham-se como causas das mudanças detectadas, dificultando o acesso por parte dos agricultores ribeirenses ao mercado de escravos. Vale relembrar que neste subperíodo pelo menos dois fatores constituíam barreira para a aquisição de escravos: o primeiro refere-se ao fim do tráfico atlântico; o segundo à consolidação da cafeicultura no Vale do Paraíba e o início da expansão em direção ao Oeste Paulista, regiões onde os escravistas provavelmente dispunham de capital mais abundante para a execução da compra de escravos.

Nesse sentido, merece destaque a presença de inventários associados ao cultivo e processamento da cana e do café. Apesar do pequeno número de ocorrências, os proprietários de engenho de açúcar ou aguardente e o único cafeicultor presentes na Tabela 3.19 destacam- 
se pela significativa posse de escravos, além de possuírem plantéis com presença expressiva de cativos do sexo masculino. Vale dizer, entre os escravistas ribeirenses que ainda detinham algum poder de compra, nem todos acreditavam que a opção pela rizicultura seria a mais razoável economicamente. Os três casos que conjugavam engenhos de arroz e aguardente, mesmo número registrado entre os inventariados de Xiririca, representam a síntese desta preocupação em manter alguma diversidade produtiva.

Sobre os comerciantes, apesar do menor valor médio registrado no subperíodo entre 1841 e 1860, não há diferença significativa entre os dois valores. Os demais indicadores também assinalam reduções importantes, como o valor mediano, de 5 para 3 cativos e a menor participação de escravos do sexo masculino. Neste intervalo não foi registrado nenhum caso que também possuísse engenho de arroz.

A disposição dos poucos inventários pertencentes aos xiririquenses, além de reafirmar a condição agrícola (81\% dos inventários e 84\% dos cativos), não difere em linhas gerais dos resultados já verificados em Iguape. Exceto pela razão de sexo, a média geral possui valor bem próximo ao verificado em Iguape e as medianas são idênticas. No entanto, os proprietários de engenho de arroz compunham a ocupação agrícola com maior representatividade, 12 casos se considerados os três que também possuíam engenho de aguardente, envolvendo a posse de praticamente seis décimos dos 191 escravos avaliados. A baixa freqüência de casos não permite tecer maiores considerações acerca do valor médio, porém esta não apresentou diferença significativa em relação aos seus pares iguapenses. A Tabela 3.20 distribui os dados aqui abordados segundo faixas de tamanho dos plantéis.

Em Xiririca, de forma idêntica aos resultados observados em 1836, notamos uma escassez de plantéis com 20 ou mais cativos: apenas um proprietário, engenheiro de arroz, possuía em seu inventário 34 escravos. A posse de engenhos não se associava à quantidade de escravos, como se percebe através dos dois conjuntos majoritários: os que detinham até 4 escravos e os com posses entre 10 e 19 cativos. 
Tabela 3.20

Distribuição relativa de inventariados e escravos segundo atividades econômicas e faixas de tamanho dos plantéis

(Iguape e Xiririca, 1841-1860)

\begin{tabular}{|c|c|c|c|c|c|c|c|c|c|}
\hline & \multirow{3}{*}{ Atividades econômicas/ocupações } & \multicolumn{8}{|c|}{ Faixas de tamanho dos plantéis } \\
\hline & & \multicolumn{2}{|c|}{$1-4$} & \multicolumn{2}{|c|}{$5-9$} & \multicolumn{2}{|c|}{$10-19$} & \multicolumn{2}{|c|}{20 ou mais } \\
\hline & & inventários & escravos & inventários & escravos & inventários & escravos & inventários & escravos \\
\hline \multirow{21}{*}{$\begin{array}{l}\text { 空 } \\
\text { ప్ర }\end{array}$} & Agricultura e manufatura rural & 44,3 & 10,9 & 25,0 & 19,7 & 17,0 & 24,6 & 13,6 & 44,8 \\
\hline & engenho de açúcar & - & - & 50,0 & 31,0 & - & - & 50,0 & 69,0 \\
\hline & engenho de aguardente & - & - & - & - & - & - & 100,0 & 100,0 \\
\hline & engenho de arroz & 23,1 & 4,4 & 26,9 & 14,6 & 23,1 & 21,5 & 26,9 & 59,5 \\
\hline & engenho de arroz e aguardente & - & - & - & - & 66,7 & 59,2 & 33,3 & 40,8 \\
\hline & cafeicultures & - & - & - & - & - & - & 100,0 & 100,0 \\
\hline & plantadores de arroz com outros cultivares & 60,7 & 27,7 & 28,6 & 43,7 & 10,7 & 28,6 & - & - \\
\hline & plantadores de mandioca exclusivamente & 66,7 & 30,0 & 33,3 & 70,0 & - & - & - & - \\
\hline & plantadores de arroz e mandioca exclusivamente & 25,0 & 7,4 & - & - & 50,0 & 53,7 & 25,0 & 38,9 \\
\hline & plantadores de arroz e cana & 100,0 & 100,0 & - & - & - & - & - & - \\
\hline & cultivos não especificados & 66,7 & 37,5 & 22,2 & 34,7 & 11,1 & 27,8 & - & - \\
\hline & vive de criar animais & - & - & 100,0 & 100,0 & - & - & - & - \\
\hline & Atividades do mar & 75,0 & 51,7 & 25,0 & 48,3 & - & - & - & - \\
\hline & Artesanato & 50,0 & 16,7 & 50,0 & 83,3 & - & - & - & - \\
\hline & Igreja & - & - & - & - & 100,0 & 100,0 & - & - \\
\hline & Magistratura e empregos civis & 100,0 & 100,0 & - & - & - & - & - & - \\
\hline & Profissionais liberais & - & - & 100,0 & 100,0 & - & - & - & - \\
\hline & Rentistas & 60,0 & 22,2 & 20,0 & 29,6 & 20,0 & 48,1 & - & - \\
\hline & Comércio & 70,4 & 32,0 & 14,8 & 21,1 & 11,1 & 30,5 & 3,7 & 16,4 \\
\hline & Atividades não identificadas & 75,0 & 54,1 & 25,0 & 45,9 & - & - & - & - \\
\hline & total & 50,0 & 14,0 & 24,4 & 21,5 & 15,0 & 24,8 & 10,7 & 39,7 \\
\hline \multirow{12}{*}{ : } & Agricultura e manufatura rural & 57,1 & 19,3 & 9,5 & 6,8 & 28,6 & 52,8 & 4,8 & 21,1 \\
\hline & engenho de aguardente & - & - & - & - & 100,0 & 100,0 & - & - \\
\hline & engenho de arroz & 55,6 & 14,7 & - & - & 33,3 & 49,5 & 11,1 & 35,8 \\
\hline & engenho de arroz e aguardente & 66,7 & 36,8 & - & - & 33,3 & 63,2 & - & - \\
\hline & plantadores de cana & - & - & - & - & 100,0 & 100,0 & - & - \\
\hline & plantadores de arroz com outros cultivares & 80,0 & 57,1 & 20,0 & 42,9 & - & - & - & - \\
\hline & plantadores de arroz e mandioca exclusivamente & - & - & 100,0 & 100,0 & - & - & - & - \\
\hline & cultivos não especificados & 100,0 & 100,0 & - & - & - & - & - & - \\
\hline & Artesanato & 66,7 & 50,0 & 33,3 & 50,0 & - & - & - & - \\
\hline & Comércio & - & - & - & - & 100,0 & 100,0 & - & - \\
\hline & Atividades não identificadas & - & - & 100,0 & 100,0 & - & - & - & - \\
\hline & total & 55,3 & 19,3 & 12,8 & 9,7 & 27,7 & 51,7 & 4,3 & 19,3 \\
\hline
\end{tabular}

Obs.: as porcentagens somam $100 \%$ nas linhas

Entre os iguapenses, os resultados gerais da Tabela 3.20 não se revelam distintos dos observados do subperíodo anterior: metade dos inventariados possuía posses com até 4 escravos, porém representando apenas $14 \%$ dos cativos avaliados. No outro extremo, cerca de $11 \%$ dos processos detinham 20 ou mais cativos arrolados, que por sua vez respondiam por praticamente quatro décimos dos 1.025 escravos avaliados. Na atividade econômica com maior número de ocorrências o destaque, como não poderia deixar de ser, corresponde aos proprietários de engenho de arroz. Praticamente metade deles possuía 10 ou mais escravos e concentravam mais de 80\% dos escravos presentes nesta ocupação. Este subperíodo evidencia com maior intensidade a presença de pequenos proprietários (até 4 cativos) entre os donos de 
engenho, reforçando a idéia de pequenas plantas processadoras, semelhante às existentes em Xiririca. Nesta mesma condição alinhavam-se seis décimos dos plantadores de arroz e dois terços daqueles cujos cultivos não foram identificados, sendo que em nenhum desses casos verificamos posses com 20 ou mais escravos. Esses resultados sugerem uma menor desigualdade na distribuição de cativos entre as atividades agrícolas se confrontada com o subperíodo anterior.

O perfil apresentado pelos comerciantes coaduna-se com a ressalva já anunciada sobre a ausência de proprietários de engenho de arroz: 70\% deles possuíam até 4 escravos e apenas um deles detinha 21 escravos entre os bens avaliados. No entanto, essa maior homogeneidade na distribuição geral da posse não se manifesta de forma tão intensa no índice de Gini, antes igual a 0,554 e que, no subperíodo em tela, atingiu 0,530; já a medida para a riqueza bruta reduziu-se de 0,643 para 0,600. Estes resultados ganham maior nitidez se sopesados com os informes da Tabela 3.21.

Tabela 3.21

Indicadores de posse de escravos segundo faixas de riqueza bruta

(Iguape e Xiririca, 1841-1860)

\begin{tabular}{|c|c|c|c|c|c|c|c|c|c|c|}
\hline \multicolumn{2}{|c|}{$\begin{array}{c}\text { Faixas de riqueza } \\
\text { bruta (libras) }\end{array}$} & inventários & $\%$ & escravos & $\%$ & $\begin{array}{c}\% \text { na riqueza } \\
\text { bruta }\end{array}$ & $\begin{array}{c}\% \text { da riqueza } \\
\text { bruta }\end{array}$ & média & mediana & $\begin{array}{l}\text { desvio- } \\
\text { padrão }\end{array}$ \\
\hline \multirow{5}{*}{ 芯 } & $0-500$ & 86 & 58,9 & 281 & 27,4 & 59,7 & 17,6 & 3,3 & 2,5 & 2,5 \\
\hline & $500-1.000$ & 31 & 21,2 & 230 & 22,4 & 47,9 & 17,1 & 7,4 & 6,0 & 4,9 \\
\hline & $1.000-2.000$ & 16 & 11,0 & 201 & 19,6 & 41,8 & 19,0 & 12,6 & 10,0 & 7,3 \\
\hline & acima de 2.000 & 13 & 8,9 & 313 & 30,5 & 40,4 & 46,2 & 24,1 & 20,0 & 16,5 \\
\hline & total & 146 & 100,0 & 1.025 & 100,0 & 53,5 & 100,0 & 7,0 & 4,0 & 8,6 \\
\hline \multirow{5}{*}{ : } & $0-500$ & 14 & 53,8 & 48 & 25,1 & 48,4 & 21,1 & 3,4 & 3,0 & 2,5 \\
\hline & $500-1.000$ & 7 & 26,9 & 46 & 24,1 & 46,9 & 24,5 & 6,6 & 4,0 & 3,8 \\
\hline & $1.000-2.000$ & 3 & 11,5 & 47 & 24,6 & 65,3 & 22,0 & 15,7 & 17,0 & 3,2 \\
\hline & acima de 2.000 & 2 & 7,7 & 50 & 26,2 & 70,6 & 32,4 & 25,0 & 25,0 & 12,7 \\
\hline & total & 26 & 100,0 & 191 & 100,0 & 51,7 & 100,0 & 7,4 & 4,0 & 7,5 \\
\hline
\end{tabular}

comprometimento médio da riqueza bruta com o valor atribuído aos escravos, não obstante a ligeira redução nos valores médio e mediano da posse escrava. Esta característica geral, no entanto, não se repete nos estratos de riqueza bruta. Os alocados na primeira faixa de riqueza, além do menor peso relativo se comparado com o subperíodo anterior (59\% e 70\%), também detinham menor parcela de escravos avaliados (27\% contra 36\%), apesar do maior comprometimento da riqueza bruta com cativos (60\% e 55\%). A participação de inventários cuja riqueza bruta se concentrava nas faixas intermediárias da Tabela 3.21, atingiu 32\% contra 
23\% no intervalo anterior, ainda restando um pequeno aumento para aqueles cuja riqueza bruta ultrapassava as duas mil libras (7\% para 9\%).

O valor atribuído aos escravos também ocupava maior espaço na composição da riqueza bruta dos inventariados mais abastados em concomitância com reduções no tamanho médio das posses, especialmente no segmento mais rico, onde a referida parcela passou de 29\% para $40 \%$ e o número médio de escravos avaliados, de 34 para 24. Vale dizer, a valorização desse ativo, conforme será visto posteriormente, atingiu todos os segmentos produtivos e também os distintos grupos econômicos, ainda que de forma desigual. Entre os inventariados menos aquinhoados, a posse de cativos per se já representava parte extraordinária da riqueza. Para os demais, a redução no número médio de escravos não guardou proporcionalidade com o valor a eles atribuído, imobilizando assim parcela crescente da riqueza. Dessa forma, ainda que a distribuição da riqueza bruta indique que os inventários mais ricos não possuíam esta condição apenas exclusivamente pela quantidade de escravos avaliados, a maior redução relativa deste índice de Gini reflete a expressiva participação dos escravos na composição da riqueza dos iguapenses com inventários abertos entre 1841 e 1860.

Os inventários e escravos pertencentes a Xiririca, ressalvada sua baixa freqüência, apresentaram uma distribuição assemelhada à verificada em Iguape, inclusive em relação aos valores médios de posse. Chama a atenção, entretanto, o elevado comprometimento da riqueza bruta em cativos entre os cinco casos com riqueza bruta acima de 1.000 libras. Essa baixa diversificação no conjunto de ativos novamente evidencia a baixa diferenciação econômica da localidade, quadro delineado ao longo de todo este capítulo. O indicador de concentração da riqueza bruta, 0,487 , bem revela esta condição.

O último dos subperíodos, como descrevemos no capítulo inicial desta tese, foi marcado pela estagnação do ritmo de exportações ribeirenses. Esta incapacidade de expansão na quantidade de grãos exportados pela região reflete-se na quantidade de escravos presentes nos inventários. A este subperíodo associam-se 118 inventários em Iguape e outros 74 em Xiririca, com ligeiro predomínio de inventariados do sexo masculino (53\% e 57\%, respectivamente). Em 72 casos foi possível identificar a idade ao morrer, 39 em Iguape (58 anos para os 28 homens e 52 anos entre as 11 mulheres) e 33 em Xiririca (62 e 64 anos, respectivamente).

A quantidade de escravos avaliados em Iguape atingiu 622 e, em Xiririca, 460 casos. Conforme indicam as linhas totalizadoras da Tabela 3.22, estes conjuntos apresentavam razões de sexo bem equilibradas. A idade média dos cativos entre as duas localidades não se 
revelou díspare: 26 anos entre os homens e 25 anos para as mulheres em Iguape e 23 e 25 anos em Xiririca. Ainda em Iguape, dispomos de informações sobre a origem para 288 cativos, onde apenas 16\% correspondiam a africanos; em Xiririca esta parcela representava 6\% dos 264 casos com identificação. Sobre a cor, apenas 152 cativos possuíam informação em Iguape, predominando os pretos (46\%), seguido por mulatos (36\%) e fulos (12\%). Em Xiririca a cobertura atingia 147 pessoas, a maior parte pretos (42\%), seguidos pelos mulatos (27\%) e fulos (17\%).

Tabela 3.22

Indicadores da posse de escravos dos inventários segundo atividades econômicas

(Iguape e Xiririca, 1861-1880)

\begin{tabular}{|c|c|c|c|c|c|c|c|c|c|}
\hline & Atividades econômicas/ocupações & inventários & $\%$ & escravos & $\%$ & razão de sexo & média & desvio-padrão & mediana \\
\hline \multirow{17}{*}{ 㝕 } & Agricultura e manufatura rural & 72 & 61,0 & 410 & 65,9 & 104,0 & 5,7 & 4,9 & 4,0 \\
\hline & alambique de aguardente & 1 & 0,8 & 3 & 0,5 & - & 3,0 & - & 3,0 \\
\hline & engenho de arroz & 28 & 23,7 & 213 & 34,2 & 95,4 & 7,6 & 6,8 & 6,0 \\
\hline & engenho de arroz e aguardente & 3 & 2,5 & 19 & 3,1 & 72,7 & 6,3 & 6,8 & 4,0 \\
\hline & plantadores de cana & 1 & 0,8 & 1 & 0,2 & - & 1,0 & - & 1,0 \\
\hline & cafeicultores & 1 & 0,8 & 1 & 0,2 & - & 1,0 & - & 1,0 \\
\hline & plantadores de arroz com outros cultivares & 19 & 16,1 & 117 & 18,8 & 129,4 & 6,1 & 4,2 & 5,0 \\
\hline & plantadores de arroz e cana & 1 & 0,8 & 5 & 0,8 & 150,0 & 5,0 & - & 5,0 \\
\hline & cultivos não especificados & 17 & 14,4 & 50 & 8,0 & 85,2 & 2,9 & 2,1 & 2,0 \\
\hline & criadores de bovinos & 1 & 0,8 & 1 & 0,2 & - & 1,0 & - & 1,0 \\
\hline & Atividades do mar & 4 & 3,4 & 17 & 2,7 & 112,5 & 4,3 & 2,6 & 3,5 \\
\hline & Artesanato & 1 & 0,8 & 1 & 0,2 & - & 1,0 & - & 1,0 \\
\hline & Profissionais liberais & 4 & 3,4 & 16 & 2,6 & 77,8 & 4,0 & 3,5 & 3,0 \\
\hline & Rentistas & 1 & 0,8 & 1 & 0,2 & - & 1,0 & - & 1,0 \\
\hline & Comércio & 20 & 16,9 & 125 & 20,1 & 119,3 & 6,3 & 7,0 & 3,5 \\
\hline & Atividades não identificadas & 16 & 13,6 & 52 & 8,4 & 126,1 & 3,3 & 3,5 & 2,0 \\
\hline & total & 118 & 100,0 & 622 & 100,0 & 108,0 & 5,3 & 5,1 & 3,5 \\
\hline \multirow{15}{*}{ كُّ } & Agricultura e manufatura rural & 51 & 68,9 & 331 & 72,0 & 94,7 & 6,5 & 5,9 & 5,0 \\
\hline & engenhocas de açúcar & 1 & 1,4 & 3 & 0,7 & - & 3,0 & - & 3,0 \\
\hline & engenhos de açúcar & 2 & 2,7 & 9 & 2,0 & 125,0 & 4,5 & 4,9 & 4,5 \\
\hline & engenhocas de aguardente & 4 & 5,4 & 15 & 3,3 & 66,7 & 3,0 & 3,6 & 2,5 \\
\hline & engenho de arroz & 8 & 10,8 & 51 & 11,1 & 82,1 & 6,4 & 4,2 & 6,0 \\
\hline & engenho de arroz e aguardente & 4 & 5,4 & 77 & 16,7 & 133,3 & 19,3 & 8,2 & 17,5 \\
\hline & plantadores de cana & 6 & 8,1 & 46 & 10,0 & 70,4 & 7,7 & 5,2 & 7,5 \\
\hline & plantadores de arroz com outros cultivares & 13 & 17,6 & 62 & 13,5 & 113,8 & 4,8 & 3,9 & 3,0 \\
\hline & plantadores de arroz e cana & 3 & 4,1 & 35 & 7,6 & 94,4 & 11,7 & 5,0 & 11,0 \\
\hline & cultivos não especificados & 9 & 12,2 & 32 & 7,0 & 77,8 & 3,6 & 2,8 & 2,0 \\
\hline & vive de criar animais & 1 & 1,4 & 1 & 0,2 & - & 1,0 & - & 1,0 \\
\hline & Artesanato & 2 & 2,7 & 3 & 0,7 & 50,0 & 1,5 & 0,7 & 1,5 \\
\hline & Comércio & 14 & 18,9 & 100 & 21,7 & 156,4 & 7,1 & 10,4 & 3,5 \\
\hline & Atividades não identificadas & 7 & 9,5 & 11 & 2,4 & 73,3 & 3,7 & 2,7 & 3,0 \\
\hline & total & 74 & 100,0 & 460 & 100,0 & 103,5 & 6,2 & 6,7 & 4,0 \\
\hline
\end{tabular}

Destacamos inicialmente a redução do número médio de escravos entre os dois últimos subperíodos. Em Iguape, este indicador passou de 7,0 para pouco mais de 5,2 cativos por inventários e em Xiririca, de 7,4 para 6,2. Esta oscilação não guarda correspondência com o valor mediano, invariável em Xiririca e ligeiramente menor em Iguape, passando de 4 para 
3,5 escravos, sugerindo que a referida redução do valor médio decorra principalmente do desaparecimento das maiores posses. Tal indicativo também pode ser percebido na menor dispersão em torno do valor médio neste último subperíodo, principalmente em Iguape. Ademais, os efeitos específicos que geraram uma elevada razão de sexo entre os escravos presentes nos inventários de Xiririca não se repetem no último intervalo, prevalecendo aqui o equilíbrio entre homens e mulheres.

Os indicadores gerais confirmam a tendência já destacada de redução gradual da posse escrava ao longo dos três subperíodos. No caso de Iguape esta se faz presente entre os agricultores de forma generalizada e em especial entre os proprietários de engenho, com a posse média reduzindo-se de 14,0 para 7,6 escravos por inventário e o valor mediano, de 9,5 para 6 escravos, mantendo ainda a tendência na redução relativa do número de cativos do sexo masculino. Verificamos que entre os plantadores de arroz, no entanto, ocorreu uma elevação tanto no valor médio (de 4,3 para 6,1 escravos por inventário) como no mediano (3 para 5 cativos), além de uma surpreendente razão de sexo de 130 homens para cada grupo de 100 mulheres. Provavelmente esta variação retrate a partilha de maiores plantéis existentes nos subperíodos anteriores, como se nota nos casos dos plantadores de arroz João Pinto de Faria e Maximiano Pinto de Faria, ambos falecidos no subperíodo em tela e filhos de João Pinto de Faria, proprietário de engenho falecido em 1828. No inventário de João, falecido em 1862, consta a presença de oito décimos de um engenho de arroz no rio Pindu e 10 escravos avaliados em igual quantidade de homens e mulheres. ${ }^{178}$ No de seu irmão, aberto 10 anos depois, apenas um sítio no rio Una, com água para engenho e 15 escravos, sendo 9 homens e 6 mulheres. ${ }^{179}$ Na terceira ocupação com maior freqüência de inventários, os cultivos não especificados, a posse média passou de 4,0 para 2,9 escravos por inventário, seguindo a tendência geral.

Sobre as demais atividades econômicas, destacamos novamente os comerciantes, que detinham um quinto dos escravos inventariados, superando assim a parcela registrada no subperíodo anterior. Ademais, a posse média, 7,1 escravos por inventário, também superou o valor anterior, 5,4. Porém, diferentemente dos resultados apresentados para o primeiro subperíodo, quando comerciantes que também possuíam engenho de arroz detinham maior número de cativos, os 9 casos na mesma condição com inventários abertos entre 1861 e 1880 possuíam, em média, 5,4 escravos contra 7,4 entre os 13 casos que não conseguimos detectar a posse de engenho de arroz.

\footnotetext{
${ }^{178}$ MHAI, caixa n. ${ }^{\circ} 152$.

${ }^{179}$ MHAI, caixa n. ${ }^{\circ} 173$.
} 
Em Xiririca, o setor agrícola também apresentou redução na posse média de escravos, porém em menor intensidade do que em Iguape: o valor médio reduziu-se de 7,7 para 6,5 escravos por proprietário. O maior deslocamento ocorreu entre proprietários de engenho de arroz (de 10,6 para 6,4) e plantadores destes grãos (7,3 para 4,8), porém outras ocupações apresentaram valores médios acima do total setorial, como os 4 casos que conjugavam o processamento de arroz e aguardente e os 3 agricultores que mantinham cultivados com as duas espécies. Escravistas enfronhados com o cultivo e processamento da cana já apresentavam posses relativamente distintas no subperíodo anterior e os dados aqui apresentados coroam uma constatação já destacada na seção anterior: as condições geográficas e climáticas desta localidade permitiram a manutenção de unidades com aproveitamento tanto das áreas alagáveis como do solo mais seco, possibilitando a coexistência das lavouras de arroz e cana, muitas vezes associadas com áreas de pasto para a criação de pequena quantidade de animais. Da mesma forma que em Iguape, os representantes do comércio detinham posses médias elevadas, inclusive com valor superior aos seus pares iguapenses. Neste caso, aqueles associados com engenhos de arroz (5 casos) possuíam, em média, 8,4 escravos contra 7,1 entre aqueles (8 inventários) que não identificamos na mesma condição.

O principal resultado aqui expresso - a diminuição das posses escravas pertencentes aos proprietários de engenho - também pode ser observado na Tabela 3.23, que distribui inventariados e cativos segundo faixas de tamanho dos plantéis. Vejamos inicialmente os resultados gerais. Se no subperíodo anterior pelo menos metade dos inventariados se posicionava na menor faixa de posse, notamos que na vintena em tela esta tendência aparece de forma acentuada, principalmente em Iguape, com 59\% dos inventários. Nesta localidade, a parcela de escravos nesta faixa passou de $14 \%$ para $24 \%$. Ainda em Iguape, a faixa de posse posterior, apesar de manter a participação relativa de inventários, concentrou 34\% dos cativos contra 24\% entre 1841 a 1860. Nesse sentido, a maior alteração relativa ocorreu entre as posses com 20 ou mais cativos, que no subperíodo anterior congregava 11\% dos inventários e $40 \%$ dos cativos contra pouco menos de $2 \%$ dos casos e cerca da $10 \%$ dos escravos avaliados entre 1861 e 1880. Por seu turno, identificamos em Xiririca uma certa estabilidade na participação relativa de inventariados e escravos nas faixas extremas, porém um deslocamento de concentração do grupo de 10 a 19 escravos para o intervalo anterior, evidenciando os maiores prejudicados pelo arrefecimento das atividades na região. 
Tabela 3.23

Distribuição relativa de inventariados e escravos segundo atividades econômicas e faixas de tamanho dos plantéis

(Iguape e Xiririca, 1861-1880)

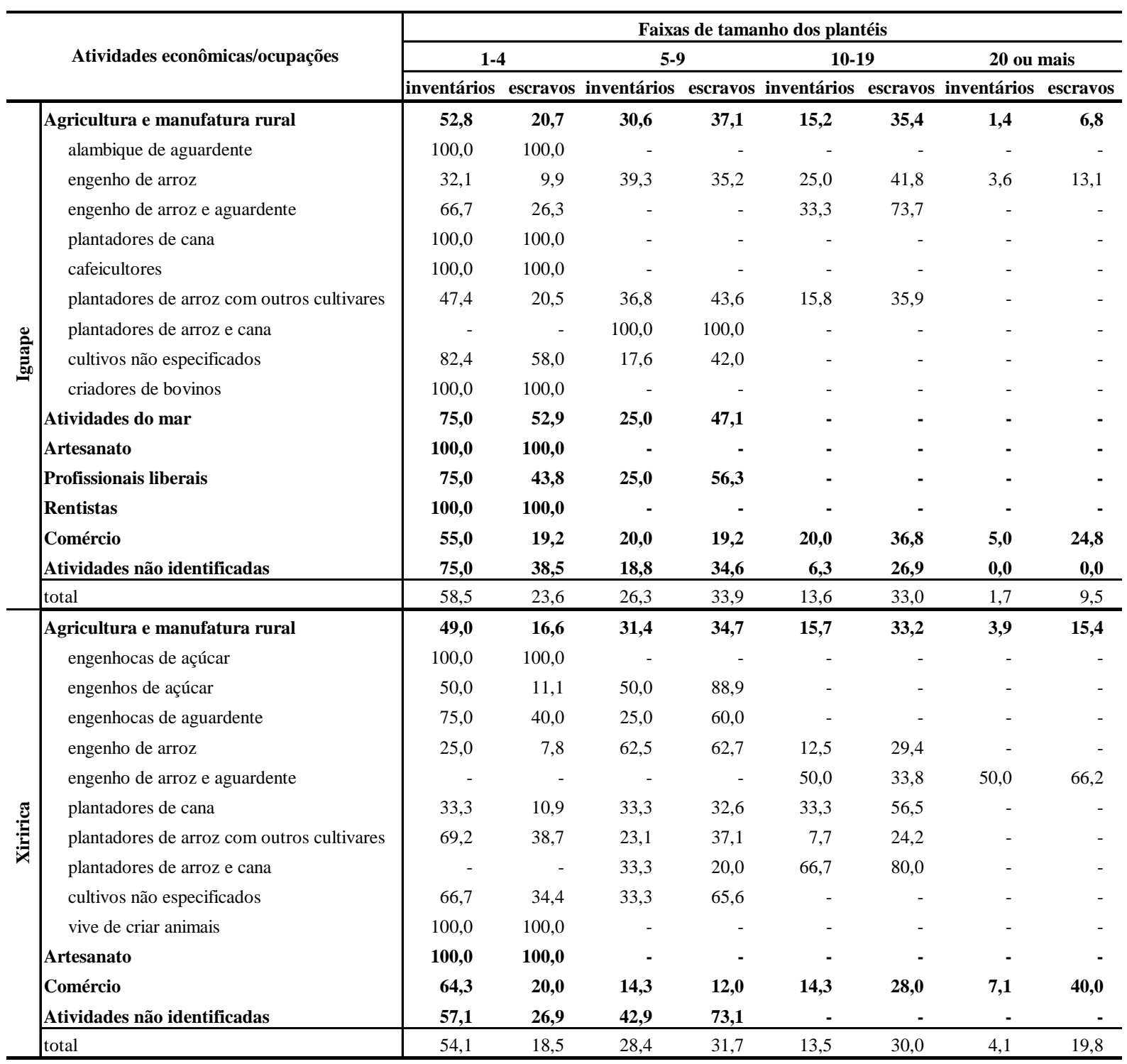

Obs.: as porcentagens somam $100 \%$ nas linhas

O quadro geral acima delineado representa o perfil da atividade agrícola na região e novamente recaímos sobre os proprietários de engenho e os plantadores de arroz. Se no subperíodo anterior, um quarto dos senhores de engenho possuía plantéis com 20 ou mais escravos e detinha praticamente $60 \%$ dos cativos nesta ocupação, os dados da Tabela 3.23 indicam uma retração acentuada, pois apenas pouco menos de $4 \%$ dos inventariados pertenciam a esta faixa de posse, acumulando 13\% dos cativos. Resultado da liquidação das maiores posses, as faixas intermediárias concentraram participações expressivas tanto de inventários como de cativos. Como já argumentamos anteriormente, atribuímos a este movimento a elevação do valor médio registrado entre os plantadores de arroz; na tabela 
acima, este resultado aparece também nas faixas intermediárias, que aglutinaram mais da metade dos inventários e $80 \%$ dos cativos avaliados.

A distribuição dos proprietários de engenho de arroz em Xiririca também se concentra nas faixas intermediárias de posse, distintamente do observado no subperíodo anterior, quando pouco mais da metade pertencia à menor faixa de posse e o restante nos grupos com 10 ou mais escravos. Entre os plantadores de arroz, praticamente $70 \%$ deles detinham plantéis com até 4 cativos, porém os demais concentravam mais de seis décimos dos escravos nas duas faixas posteriores. Ressaltamos a importância da associação do arroz com outras atividades naquela localidade, evidenciada na Tabela 3.23 pelos plantadores de arroz e cana e nos proprietários de engenho de arroz e aguardente.

Entre os comerciantes, nas duas localidades, apesar de a maioria dos casos pertencer à menor faixa, notamos a presença de alguns poucos detentores de maiores plantéis: 25\% dos casos em Iguape com 10 ou mais cativos e 21\% em Xiririca, representando a posse de 51\% e 68\% dos escravos, respectivamente. Já destacamos também que alguns destes comerciantes mantinham a posse de engenhos de arroz e, mesmo que a documentação consultada não permita a associação de alguns deles com as atividades produtivas, provavelmente estas deveriam ocorrer, mesmo que de forma secundária.

A condição mais igualitária da distribuição da posse de escravos em Iguape também pode ser avaliada através do índice de Gini, que passou de 0,530 no subperíodo anterior para 0,469 no intervalo aqui focado. Já em Xiririca o indicador sugere um pequeno aumento na concentração, passando de 0,481 para 0,497. No entanto, a distribuição da riqueza bruta revelou-se mais concentrada: de 0,600 para 0,626 em Iguape e 0,487 para 0,548 em Xiririca.

Tabela 3.24

Indicadores de posse de escravos segundo faixas de riqueza bruta

(Iguape e Xiririca, 1861-1880)

\begin{tabular}{|c|c|c|c|c|c|c|c|c|c|c|}
\hline \multicolumn{2}{|c|}{$\begin{array}{c}\text { Faixas de riqueza } \\
\text { bruta (libras) }\end{array}$} & inventários & $\%$ & escravos & $\%$ & $\begin{array}{c}\text { \% na riqueza } \\
\text { bruta }\end{array}$ & $\begin{array}{c}\text { \% da riqueza } \\
\text { bruta }\end{array}$ & média & mediana & $\begin{array}{l}\text { desvio- } \\
\text { padrão }\end{array}$ \\
\hline \multirow{5}{*}{ مِّ } & $0-500$ & 56 & 47,5 & 147 & 23,6 & 52,3 & 10,9 & 2,6 & 2,0 & 1,9 \\
\hline & $500-1.000$ & 31 & 26,3 & 145 & 23,3 & 41,1 & 17,3 & 4,7 & 5,0 & 2,7 \\
\hline & $1.000-2.000$ & 21 & 17,8 & 200 & 32,2 & 48,9 & 20,7 & 9,5 & 10,0 & 4,0 \\
\hline & acima de 2.000 & 10 & 8,5 & 130 & 20,9 & 23,6 & 51,0 & 13,0 & 14,0 & 10,2 \\
\hline & total & 118 & 100,0 & 622 & 100,0 & 46,3 & 100,0 & 5,3 & 3,5 & 5,1 \\
\hline \multirow{5}{*}{ : } & $0-500$ & 35 & 47,3 & 89 & 19,3 & 56,0 & 12,2 & 2,5 & 2,0 & 1,7 \\
\hline & $500-1.000$ & 16 & 21,6 & 103 & 22,4 & 54,2 & 16,8 & 6,4 & 7,0 & 2,3 \\
\hline & $1.000-2.000$ & 16 & 21,6 & 159 & 34,6 & 41,8 & 31,0 & 9,9 & 10,0 & 6,2 \\
\hline & acima de 2.000 & 7 & 9,5 & 109 & 23,7 & 24,1 & 40,1 & 15,6 & 13,0 & 14,4 \\
\hline & total & 74 & 100,0 & 460 & 100,0 & 49,6 & 100,0 & 6,2 & 4,0 & 6,7 \\
\hline
\end{tabular}


O conjunto dos inventários com menor riqueza bruta possuía menor participação relativa e menor parcela de escravos em relação aos subperíodos anteriores, ao mesmo tempo em que os pertencentes às faixas intermediárias ampliavam sua presença. Em Iguape estes respondiam por $44 \%$ dos inventários e 55\% dos cativos avaliados (contra 32\% e 40\%, respectivamente, no subperíodo anterior); em Xiririca, estes porcentuais atingiram $47 \%$ e $57 \%$, ante $37 \%$ e $49 \%$ no intervalo entre 1841 a 1860 . Essa aparente melhora não se associa com o número médio de cativos por inventário, que apresentou no subperíodo em tela valores menores em todas as faixas de riqueza nas duas localidades. Ademais, a parcela da riqueza bruta relacionada aos escravos manteve-se alta em todas as faixas de riqueza, exceto na maior delas.

De outra forma, aos inventariados com riqueza bruta até 2.000 libras (mais de $90 \%$ nas duas localidades), os demais bens adquiriam uma menor expressividade, principalmente se sopesado com os poucos representantes da faixa mais elevada, onde o peso dos cativos não representava mais do que um quarto riqueza bruta. Este desenho ajuda a compreender os resultados dos índices de Gini acima apontados: a maior desigualdade na distribuição da riqueza bruta associa-se a este “descolamento” do pequeno grupo de inventários com soma de bens acima de 2.000 libras. Como já anunciamos no Capítulo 1 - e que será aprofundado posteriormente - este excedente de riqueza concentrava-se principalmente em dívidas ativas. Por outro lado, a conformação de um grupo mais homogêneo entre aqueles que possuíam menor riqueza contribuiu para os menores valores observados sobre a distribuição de escravos e seu valor monetário.

Os gráficos seguintes sintetizam os resultados aqui descritos através da comparação com a estrutura de posse obtida através dos inventários e a registrada na lista nominativa de 1836 e na lista de classificação de cativos de 1873, ambas contemplando apenas Iguape. 
Gráfico 3.27

Distribuição relativa de proprietários segundo faixas de tamanho dos plantéis (Iguape, 1800-1880)

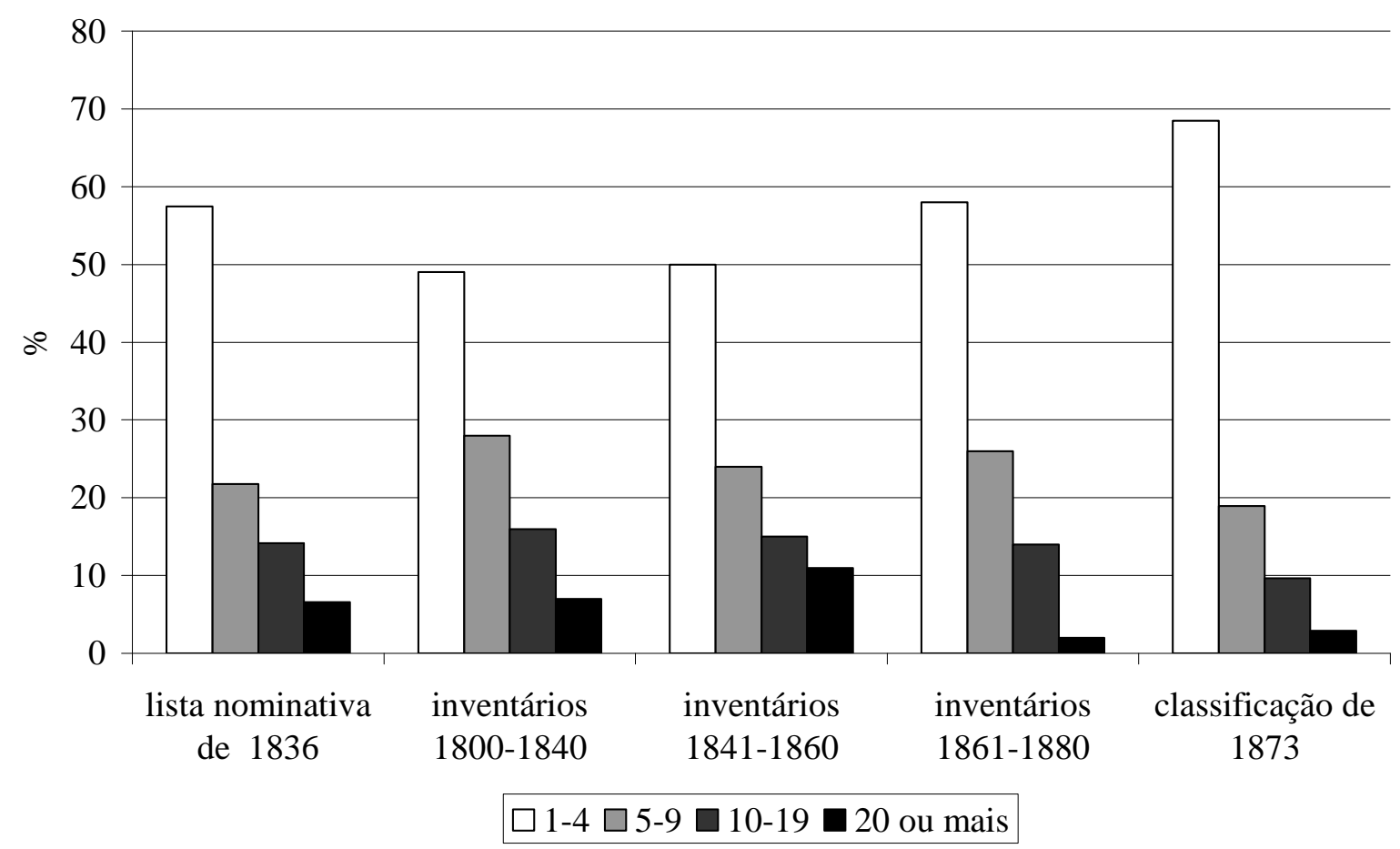

Entre os anos de 1836 e 1873, os pequenos proprietários aumentaram sua participação de 57\% para 69\%, com redução em todas as demais faixas de posse, porém com maior acento entre os senhores com 10 ou mais cativos (de 21\% para 13\%), resultado já esperado diante da conjuntura econômica de Iguape. Destacamos que em relação às listas nominativas, os inventários abertos entre 1800 e 1840 subestimavam a presença dos pequenos e jovens proprietários; o mesmo efeito aparece naqueles pertencentes ao terceiro subperíodo em relação à lista de classificação de 1873, ambos em favor dos escravistas detentores de posses intermediárias (entre 5 e 19 cativos). Nesse sentido, vale destacar que os inventários do período intermediário guardam muito da estrutura distributiva pretérita, ao passo que os do último subperíodo melhor retratam o quadro de agonia da escravidão na região. Esta condição também pode ser observada no Gráfico 3.28, que apresenta a distribuição relativa dos escravos segundo as faixas de posse.

Em correspondência à maior importância dos plantéis com até 4 escravos, notamos entre 1836 e 1873 diferenças significativas na distribuição dos escravos: no primeiro ano esta faixa de posse concentrava 18\% dos escravos contra 29\% em 1873; no outro extremo, a parcela reduziu-se de $33 \%$ para $17 \%$. 
Gráfico 3.28

Distribuição relativa de escravos segundo faixas de tamanho dos plantéis

(Iguape, 1800-1880)

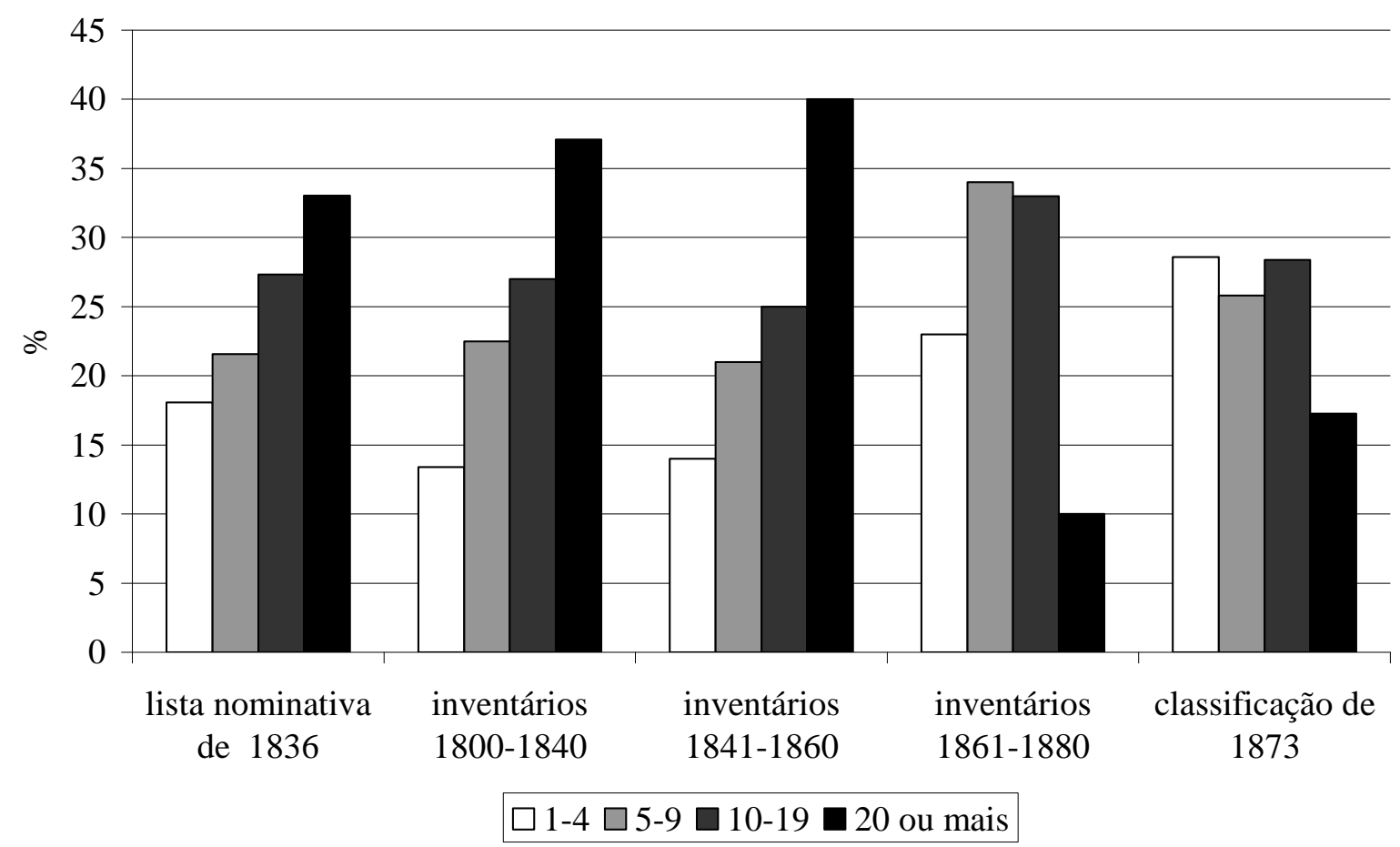

Correlatamente, nos dois primeiros subperíodos a distribuição guardou semelhanças com a de 1836, exceto na primeira faixa de posse, com valores relativos menores. O último subperíodo aproxima-se da distribuição obtida na lista de classificação não apenas pelo baixo valor nos plantéis com 20 ou mais cativos, mas também pelo predomínio nas faixas intermediárias.

Cabe aqui, antes de analisarmos o comportamento dos preços destes cativos, um breve sumário dos resultados obtidos. Os informes sobre a posse de escravos e alguns de seus atributos durante o primeiro terço do século XIX evidenciaram sinais de um dinamismo econômico que, se não era comparável ao observado no Vale do Paraíba e Oeste Paulista, apresentavam o mesmo sentido. Referimo-nos principalmente à desproporção de cativos do sexo masculino, à maior participação de escravos africanos e à diferenciação de um segmento com posses bem acima do valor médio. Do cruzamento com as atividades econômicas e ocupações, emergiram plantadores de arroz e principalmente proprietários de engenho como os principais beneficiários da disseminação desta cultura. No entanto, os resultados de 1836 já forneciam indícios do esgotamento deste surto. Dessa forma, o perfil da posse cativa observada através dos inventários nos dois primeiros subperíodos retrata esta estagnação, não obstante o viés da amostra. 
Do quadro mais geral da segunda metade do século XIX - a estabilidade na quantidade de arroz produzida e a redução da população escrava - emerge uma distribuição de escravos bastante distinta da até então verificada. $\mathrm{Na}$ impossibilidade de realizar a reposição dos escravos acumulados ao longo dos primeiros 40 anos da centúria, encontramos uma massa de escravistas com posses de pequeno e médio porte, independente da ocupação exercida pelo proprietário.

Nesse sentido, análise do preço atribuído a estes escravos propicia a localização do gargalo que interrompeu o fluxo virtuoso da economia ribeirense, como veremos adiante.

\section{Os escravos avaliados nos inventários ribeirenses}

Os inventários de Iguape e Xiririca fornecem dados sobre 2.997 cativos, com 77\% das ocorrências entre os iguapenses. Em 231 casos não obtivemos informação sobre a idade. A Tabela 3.25 congrega os 2.766 registros estratificados segundo localidade, subperíodos, sexo e faixas etárias.

Tabela 3.25

Distribuição dos escravos avaliados segundo sexo e faixas etárias

(Iguape e Xiririca, 1800-1880)

\begin{tabular}{|c|c|c|c|c|c|c|c|c|}
\hline \multirow{2}{*}{ Localidades } & \multirow{2}{*}{ subperíodos } & \multirow{2}{*}{$\begin{array}{l}\text { faixas } \\
\text { etárias }\end{array}$} & \multicolumn{2}{|c|}{ homens } & \multicolumn{2}{|c|}{ mulheres } & \multicolumn{2}{|c|}{ total } \\
\hline & & & $\overline{\mathbf{N}}$ & $\%$ & $\mathbf{N}$ & $\%$ & $\mathbf{N}$ & $\%$ \\
\hline \multirow{12}{*}{ 芯 } & \multirow{4}{*}{$\begin{array}{l}0 \\
\text { o } \\
\infty \\
1 \\
0 \\
0 \\
\infty \\
-1 \\
-1\end{array}$} & $0-14$ & 127 & 19,4 & 109 & 16,6 & 236 & $\overline{36,0}$ \\
\hline & & $15-40$ & 199 & 30,3 & 146 & 22,3 & 345 & 52,6 \\
\hline & & 41 ou mais & 44 & 6,7 & 31 & 4,7 & 75 & 11,4 \\
\hline & & total & 370 & 56,4 & 286 & 43,6 & 656 & 100,0 \\
\hline & \multirow{4}{*}{ 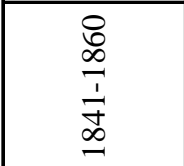 } & $0-14$ & 182 & 19,8 & 172 & 18,7 & 354 & 38,6 \\
\hline & & $15-40$ & 234 & 25,5 & 206 & 22,4 & 440 & 47,9 \\
\hline & & 41 ou mais & 62 & 6,8 & 62 & 6,8 & 124 & 13,5 \\
\hline & & total & 478 & 52,1 & 440 & 47,9 & 918 & 100,0 \\
\hline & \multirow{4}{*}{ 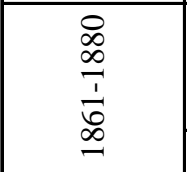 } & $0-14$ & 108 & 19,0 & 92 & 16,2 & 200 & 35,2 \\
\hline & & $15-40$ & 122 & 21,5 & 128 & 22,5 & 250 & 44,0 \\
\hline & & 41 ou mais & 64 & 11,3 & 54 & 9,5 & 118 & 20,8 \\
\hline & & total & 294 & 51,8 & 274 & 48,2 & 568 & 100,0 \\
\hline \multirow{8}{*}{ 弟 } & \multirow{4}{*}{$\begin{array}{l}0 \\
\bigotimes \\
\infty \\
\overrightarrow{1} \\
\overrightarrow{+} \\
\infty \\
\end{array}$} & $0-14$ & 55 & 30,7 & 38 & 21,2 & 93 & $\overline{52,0}$ \\
\hline & & $15-40$ & 36 & 20,1 & 33 & 18,4 & 69 & 38,5 \\
\hline & & 41 ou mais & 11 & 6,1 & 6 & 3,4 & 17 & 9,5 \\
\hline & & total & 102 & 57,0 & 77 & 43,0 & 179 & 100,0 \\
\hline & \multirow{4}{*}{ 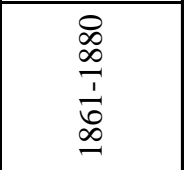 } & $0-14$ & 90 & 20,2 & 78 & 17,5 & 168 & 37,8 \\
\hline & & $15-40$ & 106 & 23,8 & 95 & 21,3 & 201 & 45,2 \\
\hline & & 41 ou mais & 34 & 7,6 & 42 & 9,4 & 76 & 17,1 \\
\hline & & total & 230 & 51,7 & 215 & 48,3 & 445 & 100,0 \\
\hline
\end{tabular}

Em Iguape, no primeiro subperíodo, notamos a predominância de cativos do sexo masculino e com idades entre 15 e 40 anos, representando 30\% das 656 avaliações. Já assinalamos que o perfil geral observado no primeiro subperíodo guarda relação com os dados 
registrados nas listas nominativas de 1828 e 1836. Esta concentração associa-se ao período de maior dinamismo da atividade rizicultora na região, o que permitiu a expansão dos plantéis principalmente através de compras realizadas diretamente no Rio de Janeiro, como indicamos no Capítulo 1.

Nos intervalos seguintes, enquanto a quantidade de arroz exportada aumentava a taxas decrescentes (segundo subperíodo) até atingir a estabilidade (terceiro subperíodo), a participação deste grupo de cativos mostrou-se decrescente, atingindo pouco mais de $21 \%$ no último subperíodo. Esta associação evidencia a inter-relação entre o desempenho econômico da região e os traços mais gerais do contingente cativo, na medida em que os ganhos obtidos com o cultivo e comercialização do arroz não mais permitiam aos iguapenses a manutenção da parcela especialmente desejada para a execução da lida agrícola. Ainda associada a esta redução da participação de jovens escravos do sexo masculino, notamos uma paulatina tendência ao equilíbrio entre os sexos.

Evidente também é o relativo envelhecimento da população escrava: a parcela de cativos com idade superior a 40 anos praticamente dobrou ao longo das oito décadas, ainda que a idade média não apresente alterações significativas, passando de 23 para 25 anos.

Já destacamos que em Xiririca, no segundo subperíodo, uma peculiar combinação de inventários privilegiou a acentuada participação de escravos com menos de 15 anos e com peso desproporcional para os cativos do sexo masculino. Na vintena seguinte o perfil geral pouco se diferenciava daquele registrado em Iguape, isto é, um relativo equilíbrio entre os sexos e assemelhadas participações de escravos mais jovens e mais idosos. Conforme destacamos ao discorrer sobre as listas nominativas, a então freguesia de Iguape não apresentava os mesmos sinais de dinamismo registrados entre os escravistas iguapenses, ao mesmo tempo em que se evidenciam os indicadores sobre a possibilidade de manutenção do contingente através da reprodução natural.

Nossas considerações subseqüentes centram atenção no grupo etário de escravos entre 15 a 40 anos e passamos a apresentar os resultados sobre os preços atribuídos a estes cativos nos inventários ribeirenses. O Gráfico 3.29 apresenta o preço médio destes cativos, em mil-réis, ao longo das oito décadas aqui estudadas. 
Gráfico 3.29

Preço médio dos escravos de 15 a 40 anos segundo sexo

(Iguape e Xiririca, 1801-1879)

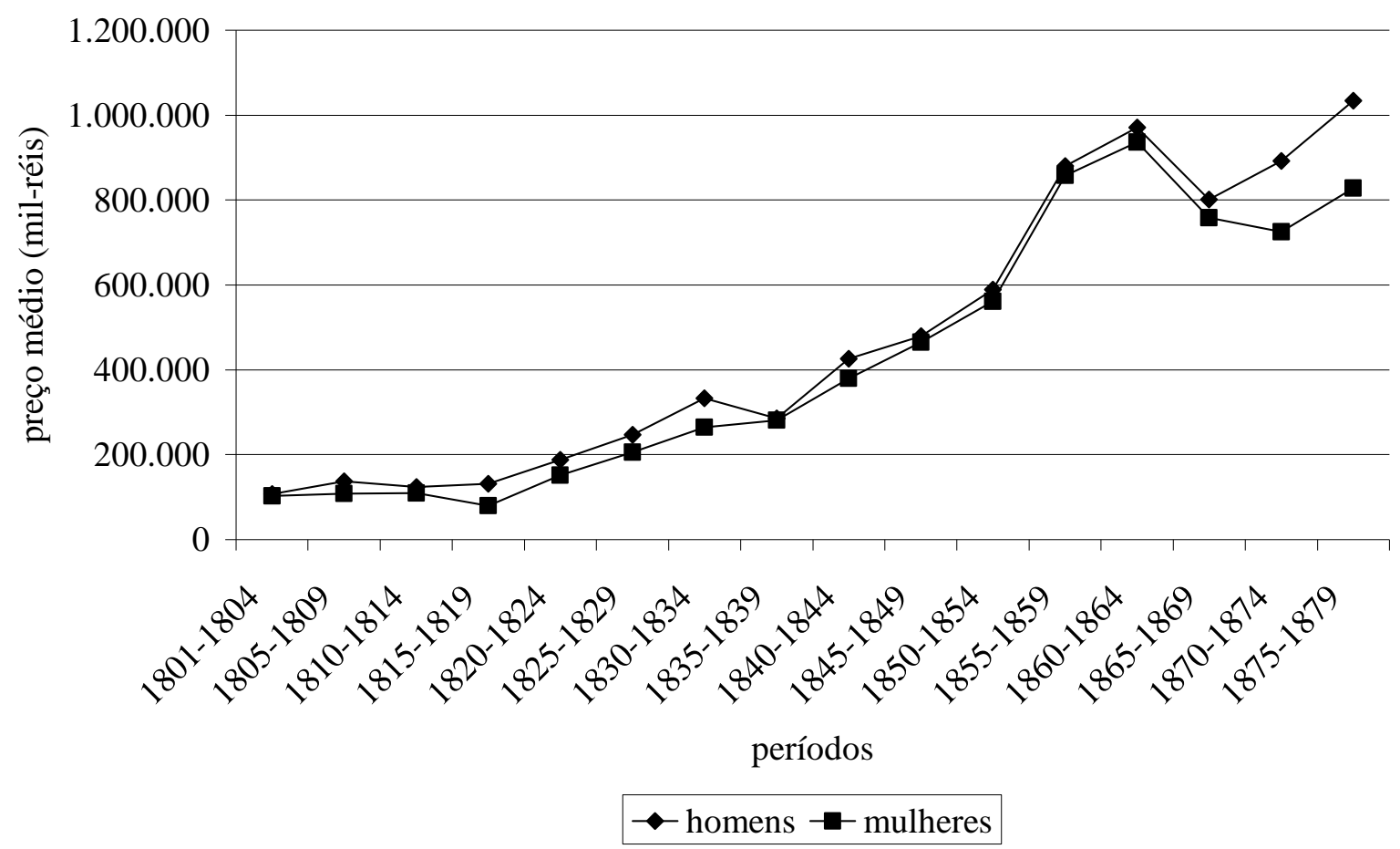

Nas duas primeiras décadas da centúria, nossa amostra contempla apenas 45 escravos dentro da faixa etária referida (21 homens e 24 mulheres). Em que pese esta pequena quantidade, notamos uma relativa manutenção do preço médio em torno de Rs. 130:000 para os homens e Rs. $100 \$ 000$ para as mulheres. A partir de 1820 notamos uma clara tendência de aumento nos preços médios, mais acentuado nos qüinqüênios entre 1840 a 1844 e 1855 a 1859. O período posterior a 1864 caracteriza-se por oscilações: inicialmente registramos uma redução média de 18\% no valor médio em ambos os sexos. A partir daí, notamos um descolamento no comportamento do preço para homens e mulheres: os primeiros recuperam a trajetória ascendente e terminam com preço médio acima do valor registrado no início da década de 1860. Já o preço médio das mulheres manteve-se em queda, apresentando recuperação apenas no último qüinqüênio.

A redução no preço médio dos escravos - a partir de 1862 para as mulheres e 1863 para os homens - manteve-se até 1867, quando observamos valores assemelhados aos do início da década de 1850, retomando então a trajetória ascendente. O mesmo fenômeno já fora registrado por Warren Dean em Rio Claro (cf. DEAN, 1997, p. 66) e Zélia Maria Cardoso de Mello observou a mesma oscilação no preço de escravos pertencentes a paulistanos e buscou associá-la a variações, de mesmo sentido, no preço do café (cf. MELLO, 1980, p. 117-120). 
No caso do Vale do Ribeira, conforme indica o Gráfico 1.3 do Capítulo 1, o preço nominal do arroz apresentou um movimento ascendente entre 1861 e 1867, período também marcado por uma forte desvalorização da moeda nacional. Poder-se-ia supor que, diante do fraco desempenho do café, um efeito inverso se propagaria nos preços dos bens de consumo nacionais, estimulando o preço do arroz em Iguape. De qualquer forma, acreditamos que este assunto deva merecer um estudo pormenorizado, buscando correlacionar outros produtos e outros centros produtores.

Para além das causas sobre a movimentação dos preços médios, notamos que os valores médios acima registrados guardam estreita correlação com valores tomados na mesma fonte em outras localidades, como indicam os gráficos seguintes. Inicialmente, comparamos os resultados com os obtidos por Flávio Rabelo Versiani e José Raimundo Oliveira Vergolino para 4.085 escravos da província de Pernambuco, com preços recolhidos também de inventários post-mortem (Gráfico 3.30)

O preço médio dos escravos em Pernambuco apresenta um ligeiro crescimento nas duas primeiras décadas do século XIX, aumentando este incremento a partir de 1830 e, especialmente, no qüinqüênio entre 1855 a 1959, atingindo aí o seu valor máximo para os escravos do sexo masculino. Este auge, no Vale do Ribeira, ocorre no período seguinte, onde a redução posterior é mais acentuada, assim como recuperação na década de 1870.

Em Pernambuco, os cativos do sexo masculino apresentavam preços $10 \%$ superiores ao valor das cativas, que atingiram o maior valor médio no qüinqüênio entre 1865 a 1869, porém com relativa estabilidade desde a segunda metade da década de 1850 . No caso das cativas do Vale do Ribeira, a tendência altista manteve-se até a primeira metade da década de 1860 e, nos anos de 1870, novamente registramos um comportamento distinto dos preços médios: se em Pernambuco nota-se uma acentuada queda no valor das escravas, esta não apresentou a mesma magnitude entre as ribeirenses, que registram ao final do período uma ligeira recuperação, marcando neste qüinqüênio a maior diferença entre os valores, cerca de $42 \%$, contra $22 \%$ entre os escravos do sexo masculino. Os autores atribuem esta maior redução à expectativa destas cativas poderem gerar crianças também escravas, rompida com a promulgação da Lei do Ventre Livre em 1871. Ademais, argumentam que as oscilações verificadas na segunda metade do século XIX não devam ser atribuídas exclusivamente ao fim do tráfico atlântico, mas também derivadas da dinâmica local, pontuando especificamente o aumento do preço do açúcar a partir de 1855 e o surto algodoeiro na década seguinte (cf. VERSIANI \& VERGOLINO, 2002, p. 4-5). 
A mesma linha interpretativa segue Laird W. Bergad ao apresentar a variação de preços dos escravos avaliados em inventários de São João Del Rei, Diamantina e Mariana (Gráfico 3.31). Para o autor, o incremento observado a partir da década de 1820 deve-se à inserção da economia mineira no âmbito nacional, encerrando um período de relativa estagnação econômica em território mineiro, marcado tanto pela depressão causada pelo fim da mineração como pela ausência de repercussão de perturbações econômicas externas, como as guerras napoleônicas e a instalação da Corte portuguesa no Rio de Janeiro. A partir da década de 1820, o período de forte ascensão dos preços é atribuído por Bergad ao dinamismo imposto pela expansão da cafeicultura e este autor também relativiza a importância do final do tráfico atlântico neste movimento. Para Bergad, a fase preços crescentes entre 1820 e 1860 explica-se pelo aumento da demanda, na Europa, por produtos americanos, provocando aumentos expressivos no preço dos escravos tanto em Minas Gerais como em Cuba e nos Estados Unidos, locais que não conheceram o impacto do fim da oferta abrupta de cativos a partir de 1850.

Por fim, aventa o autor que a repentina queda de preços na década de 1860 decorra principalmente de injunções sobre o futuro da escravidão, reverberadas pela Guerra Civil americana (1861-1865), pelo aumento da pressão da Inglaterra sobre o tráfico de escravos para Cuba e, internamente, pela maior manifestação abolicionista. No entanto, a ausência de conseqüências práticas rapidamente estimulou a elevação dos preços, que novamente sofreriam um estremecimento com a promulgação da Lei do Ventre Livre em 1871, novamente recuperando-se a partir da segunda metade da década 1870, prova da elevada lucratividade que o uso da mão-de-obra escrava proporcionava a seus proprietários (cf. BERGAD, 2004, p. 246-258). 
Gráfico 3.30

Preço médio dos escravos de 15 a 40 anos

(Vale do Ribeira e Pernambuco, 1801 a 1879)

homens
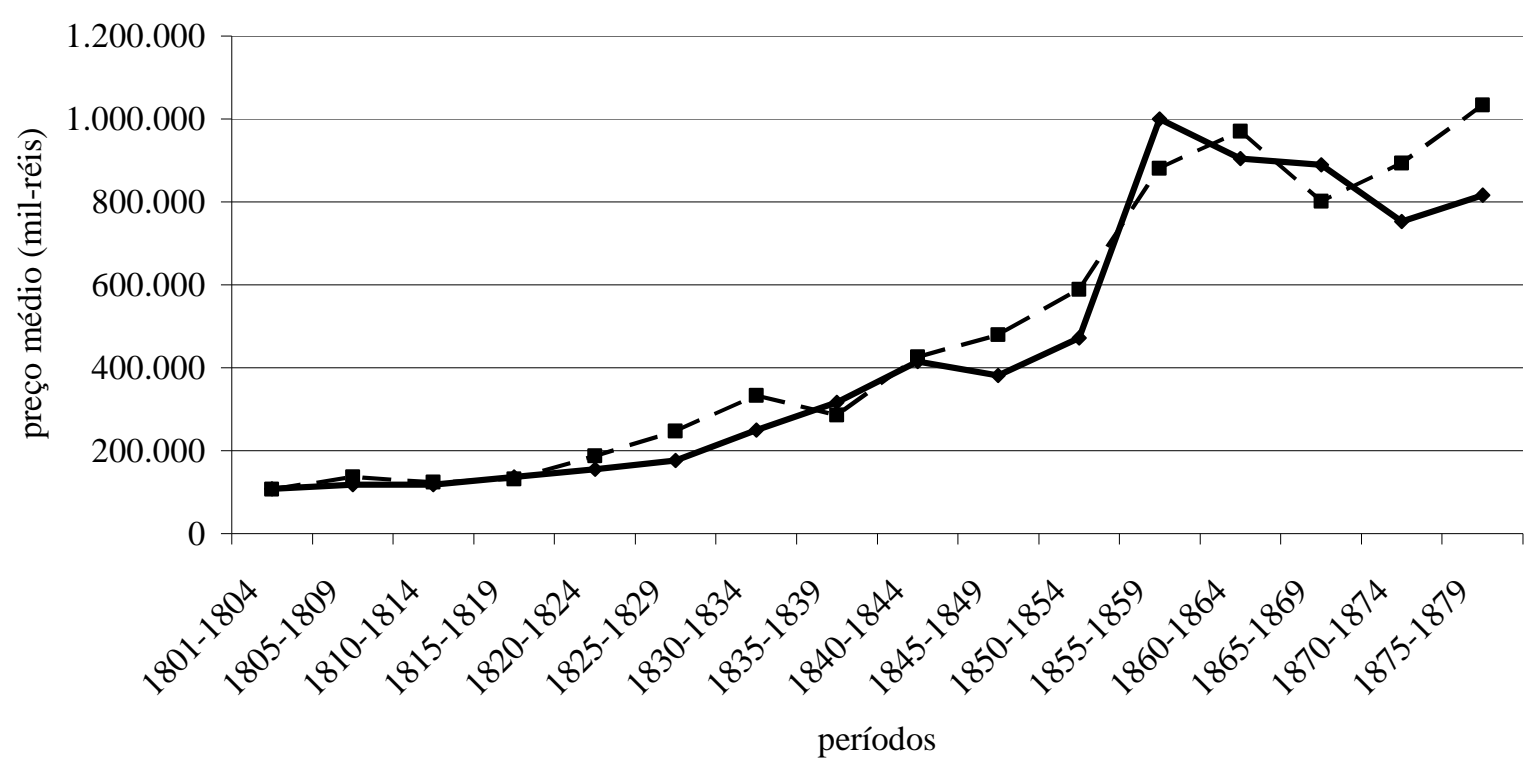

$\rightarrow-$ Vale do Ribeira $\longrightarrow$ Pernambuco

mulheres
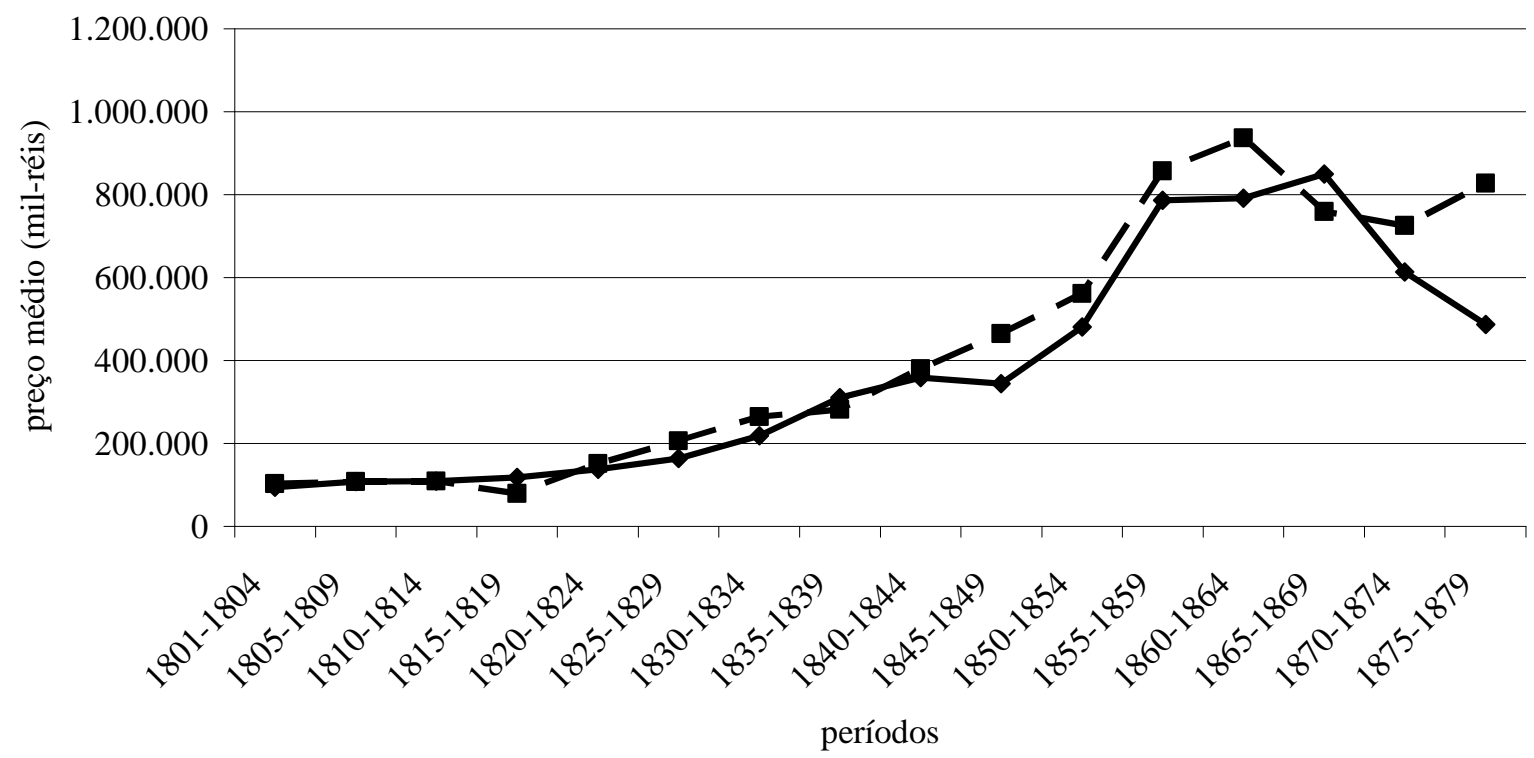

- Vale do Ribeira ^Pernambuco

Fonte: VERSIANI \& VERGOLINO, 2002, p. 13. 
Gráfico 3.31

Preço médio dos escravos de 15 a 40 anos - médias móveis trienais

(Vale do Ribeira e Minas Gerais, 1800 a 1880)

homens

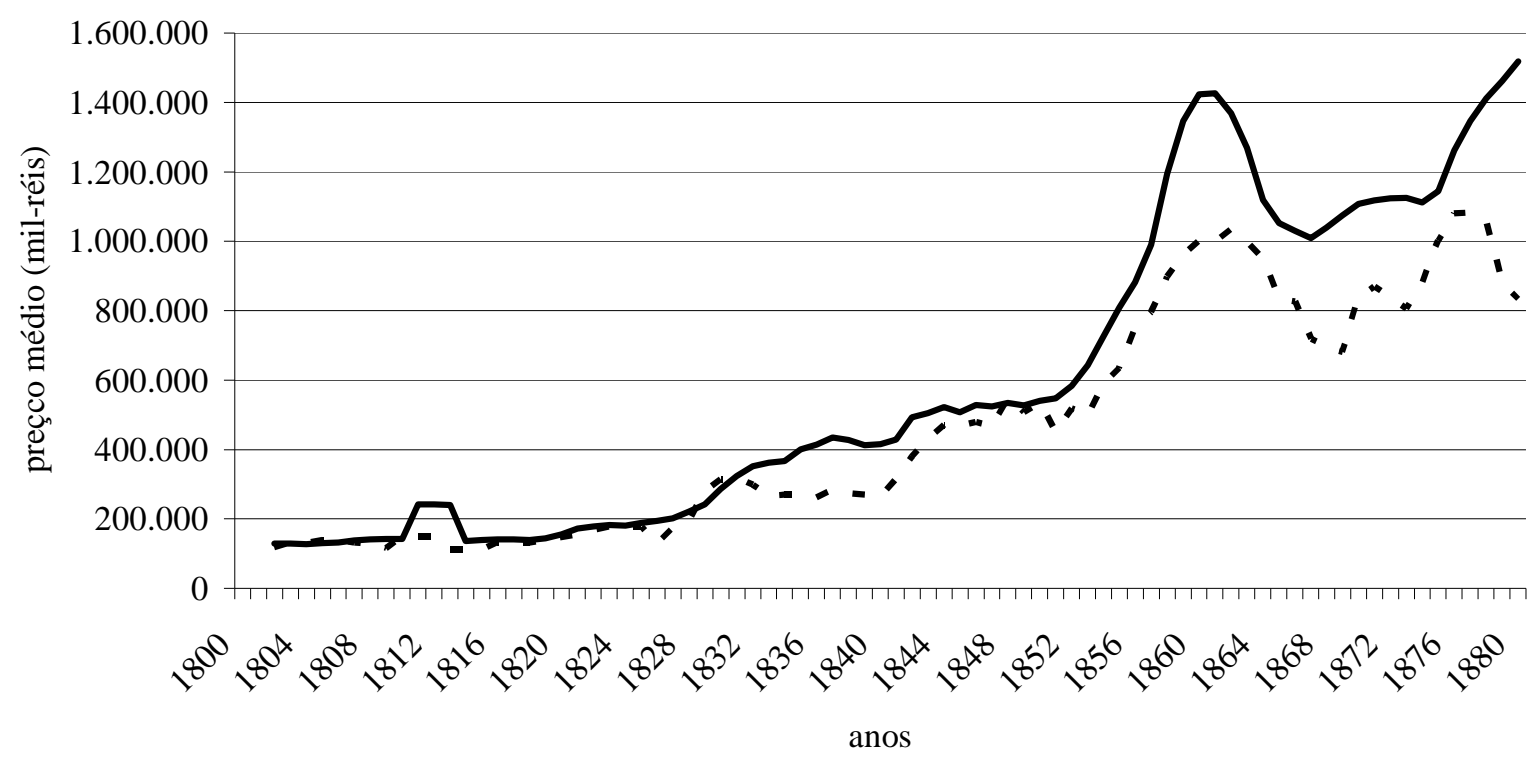

- - Vale do Ribeira — Minas Gerais

mulheres

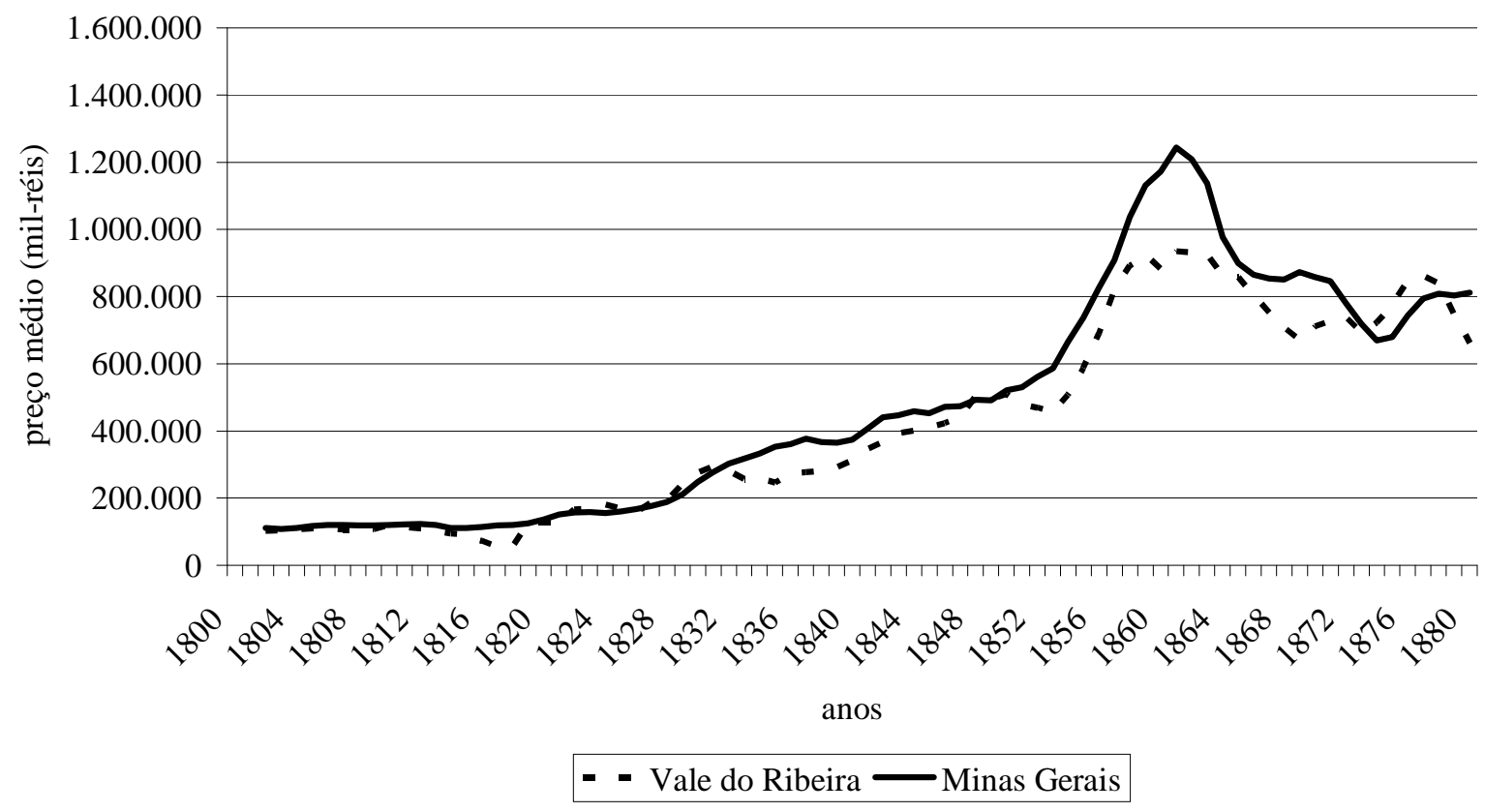

Fonte: BERGAD, 2004, p. 362-363. 
Pelo exposto, notamos que as argumentações desenvolvidas guardam semelhanças e contradições. Uma delas diz respeito ao comportamento dos preços no início do século XIX. A relativa estabilidade que Bergad atribui a uma condição específica mineira aparece também em Pernambuco e no próprio Vale do Ribeira. Os dados sugerem que nestas duas primeiras décadas o preço dos cativos encontrava-se em um patamar generalizadamente baixo nas três regiões. Em todas elas o período inicial de maior crescimento é percebido a partir da segunda metade da década de 1820, com maior inflexão nos primeiros anos da segunda metade da centúria.

Especialmente em relação aos valores registrados em Minas Gerais, impressiona a similitude do desenho obtido através das médias móveis, porém em um nível de preços bem menor no Vale do Ribeira, principalmente após a década de 1860, quando notamos tendências diversas entre as localidades. Até este momento, as supostas influências locais possivelmente contribuem para ajudar a compreender variações específicas, porém parece-nos mais apropriado considerar a hipótese de um comportamento relativamente homogêneo para o mercado de escravos. Como evidencia Robert Slenes, o final da década de 1870 e início dos anos 1880 é marcado por uma maior disparidade no preço dos escravos entre as diversas províncias em relação aos preços praticados em fins da década de $1850 .{ }^{180}$ Neste caso, a conjunção da promulgação da Lei do Ventre Livre e a distintas dinâmicas econômicas de cada região parece compor o quadro explicativo dos resultados expressos nos gráficos anteriores.

No gráfico seguinte, apresentamos o valor médio dos escravos ribeirenses através de seu equivalente em alqueires de arroz, também calculado através das médias qüinqüenais.

\footnotetext{
180 Cf. SLENES, 1976, p. 183. O autor se utiliza dos preços observados em Campinas e confrontados com informes registrados em relatórios do Consulado Britânico para a década de 1850 e dados do Fundo de Emancipação para o período seguinte.
} 
Gráfico 3.32

Valor médio dos escravos de 15 a 40 anos em alqueires de arroz

(Iguape e Xiririca, 1800-1880)

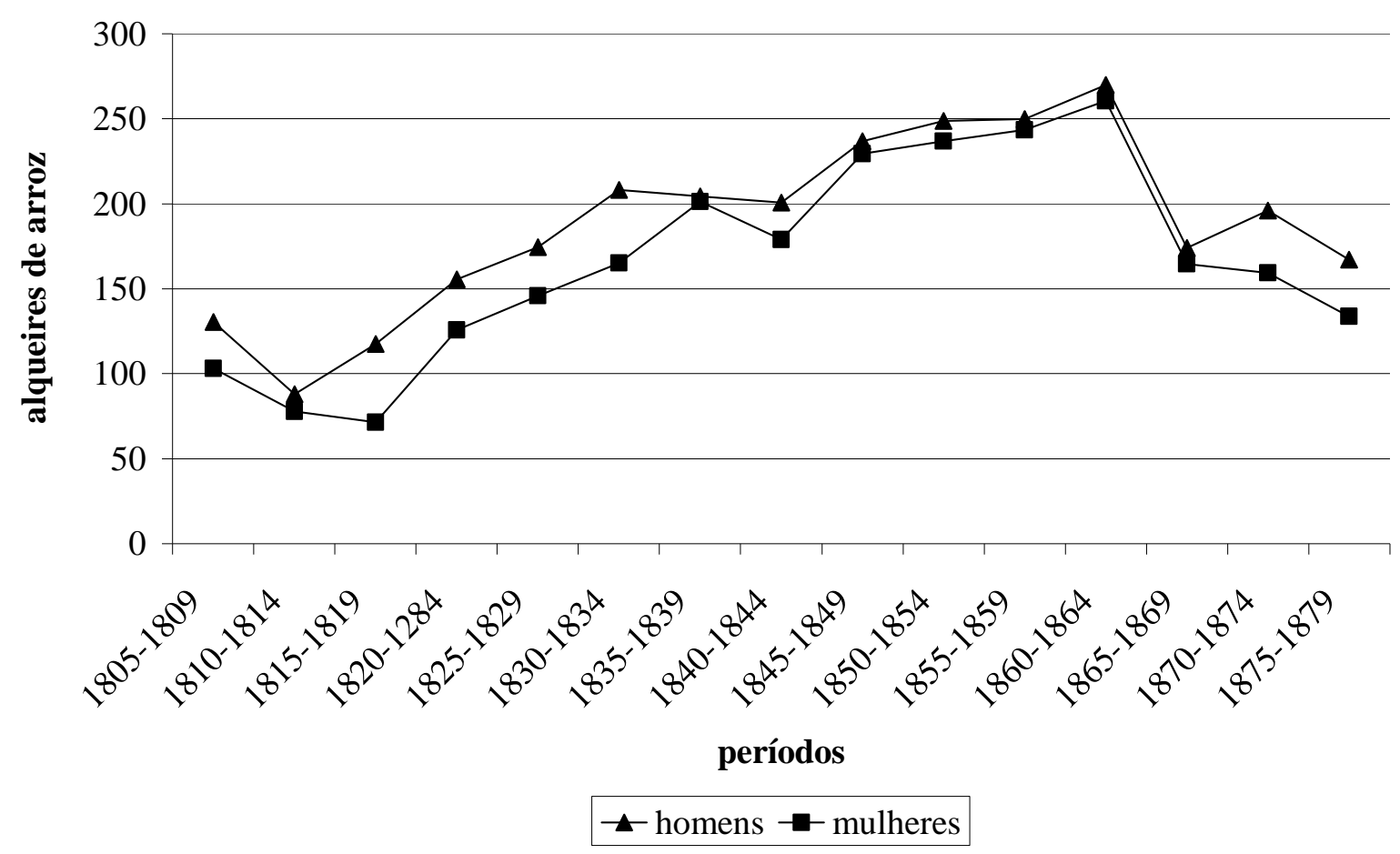

De início, ressalvamos o cuidado necessário com os valores aqui utilizados, pois confrontam o preço corrente do arroz embarcado no porto de Iguape com valor atribuído nos inventários, certamente menor do que os praticados nas transações de compra e venda de cativos. ${ }^{181} \mathrm{O}$ gráfico assinala que o período mais favorável aos ribeirenses para a compra de cativos concentrou-se nas duas primeiras décadas do século XIX, quando um escravo do sexo masculino na faixa etária indicada valia algo em torno de 80 a 130 alqueires de arroz.

Conforme os números resgatados nas listas nominativas, o intervalo entre 1801 e 1815 apresentou uma forte expansão no número total de escravos e propiciou a consolidação das maiores posses, principalmente em Iguape. Ainda segundo os informes da lista nominativa de 1801, a produção média de arroz em fogos escravistas atingia 54 alqueires e 27 em unidades sem escravos. Embora a produtividade em ambos os casos tenha crescido (245 e

\footnotetext{
181 Os próprios inventários trazem pistas confirmatórias. Por exemplo, em 1810 Manoel Antonio Ferreira abriu inventário por falecimento de sua esposa e teve seus 3 de seus 4 cativos, avaliados por Rs 173\$200, arrematados por Rs. 290\$000 (MHAI, caixa n. ${ }^{\circ}$ 12). Em 1843 os escravos pertencentes a Ana Tereza de Moraes também foram vendidos em praça pública por Rs. 2:616\$300, ao passo que o valor atribuído somava Rs. 1:850\$000 (MHAI, caixa n. ${ }^{\circ}$ 162). O mesmo destino ocorreu com 10 dos 12 escravos pertencentes a Manoel Pedroso de Moraes, falecido em 1860. O crioulo Anastácio, 20 anos, avaliado por Rs. 1:200\$000 foi arrematado por Rs. 1:530\$000; já a cativa Florinda, 14 anos, preta, com valor atribuído igual a Rs. $800 \$ 000$ foi vendida por Rs.1:250\$000 (FEP, caixa n. ${ }^{\circ}$ 37).
} 
78 alqueires, respectivamente, em 1836), à maior parte do segmento não-escravista não se colocava a possibilidade da aquisição de escravos. Ademais, a partir de 1820 o preço médio do alqueire de arroz não acompanhou a valorização do preço dos escravos, tendência mantida até fins dos anos 1830, comprometendo inclusive parcela dos rizicultores escravistas cuja produção anual não equivalia ao valor de um escravo. Atribuímos a este momento o ponto de inflexão na economia ribeirense, quando as inversões realizadas na compra de cativos provavelmente tenderam a se reduzir, produzindo os primeiros efeitos quantitativos na lista nominativa de 1836, porém com consolidação definitiva na segunda metade do século XIX.

Após três lustros de relativa estabilidade, com equivalência ao redor de 200 alqueires por escravo, observamos um novo incremento, atingindo o valor máximo na segunda metade da década de 1860, quando um escravo valia cerca de 250 alqueires de arroz. Desnecessário afirmar que tal valor se traduzia em uma firme barreira ao acesso a novos escravos. Relembramos aqui os dados da Tabela 3.25, que caminham no mesmo sentido ao evidenciarem uma tendência ao equilíbrio entre os sexos no contingente cativo registrado nos inventários e um esvaziamento relativo do grupamento de escravos na faixa etária entre 15 e 40 anos, em benefício do aumento na participação de cativos mais idosos e da manutenção de parcela constante daqueles com idade até 14 anos.

Desse conjunto de considerações e tendo em vista a redução da população cativa ribeirense ao longo da segunda metade do século XIX, podemos afirmar com relativa segurança que a persistência da mão-de-obra cativa em Iguape e Xiririca manteve-se, sobretudo, graças à reprodução natural. Os resultados das listas nominativas evidenciaram que esta possibilidade se fazia mais presente na freguesia de Xiririca, onde a estimativa do índice geral de fecundidade oscilou ao redor de 600 contra 420 em Iguape. ${ }^{182}$ Ainda que os valores fornecidos pelos inventários não traduzam o mesmo sentido do indicador gerado pelas listas

\footnotetext{
${ }^{182}$ Crianças de 0 a 4 anos em relação ao total de mulheres de 15 a 44 anos.
} 
nominativas, os números revelam-se expressivos: na década de 1820, 618; 782 no decênio seguinte, 625 e 605 nas duas décadas posteriores e 662 entre 1860 e $1869 .^{183}$

As considerações acima compõem um retrato nítido da importância da força de trabalho escrava no Vale do Ribeira. A partir da instalação da rizicultura, em fins do século XVIII, concorre a favorável relação dos grãos para a aquisição de cativos durante as duas primeiras décadas do Oitocentos, período de acelerada expansão da população cativa. Relembramos aqui que ao longo da década de 1820, a diferença entre as exportações e importações realizadas pelo porto de Iguape propiciou o acúmulo de déficits sucessivos. Se confrontado com o Gráfico 3.32, poder-se-ia supor que os ribeirenses não souberam interpretar a mudança relativa nos preços de escravos e arroz; no entanto, acreditamos que a propensão ao gasto decorra da confiança estabelecida durante os decênios anteriores. Ao longo das décadas de 1840 e 1850, a quantidade de arroz exportada manteve-se em crescimento, assim como a receita auferida, porém as despesas não mais superavam o quantum das exportações e, a partir de meados dos anos de 1850, o Gráfico 1.5 evidencia uma seqüência superavitária até o início da década de 1870. Porém, este período representa a fase dos maiores preços relativos dos escravos em alqueires de arroz, inibindo novas inversões.

Nesse contexto, resta elucidar o destino deste superávit da balança comercial ribeirense. Este será o assunto do próximo capítulo.

183 Se compararmos com os valores de crianças de 0-9 anos/mulheres de 15-49 anos encontrados para Minas Gerais (cf. BERGAD, 2004, p. 219), temos:

$\begin{array}{ccc} & \text { Vale do Ribeira } & \text { Minas Gerais } \\ 1820-1829 & 1.105 & 1.147 \\ 1830-1839 & 1.152 & 966 \\ 1840-1849 & 1.168 & 1.084 \\ 1850-1859 & 1.219 & 1.025 \\ 1860-1869 & 1.307 & 1.064\end{array}$

Ainda que o recenseamento de 1874 contenha o viés de subestimar o numerador do índice, uma vez que exclui os filhos de mulheres escravas nascidos a partir da Lei do Ventre Livre, o indicador (crianças de 0 a 10 anos/mulheres de 16-50 anos) revela-se maior em Xiririca (1.021) do que em Iguape (448), se bem que para esta a lista de classificação de 1873 fornece um valor mais elevado (748). Para as duas últimas décadas acima destacadas, o indicador em Iguape igualou-se a 1.092 e 1.305 e em Xiririca, a 1.778 e 1.309. 


\section{A ELITE AGRÁRIA E COMERCIAL NO VALE DO RIBEIRA}

A dualidade entre a elite agrária e comercial no Brasil Oitocentista tem merecido uma atenção especial por parte de muitos pesquisadores. ${ }^{184}$ Parte deste cuidado dispensado deve-se à investigação encetada por João Fragoso. Dos resultados obtidos através de variadas fontes primárias, conclui o autor:

(...) temos a possibilidade da confecção de um capital mercantil colonial, formado em meio às operações coloniais de abastecimento e das trocas no ultramar português, que se apodera de frações de sobretrabalho, tanto da agroexportação como dos segmentos produtivos do mercado interno. Uma vez que este capital é autônomo - detém as suas linhas de crédito, os seus navios, os seus seguros, controla o tráfico atlântico de escravos, o custeio da plantation; e participa do comércio de importação-exportação -, sua existência redefine o estatuto da dependência da economia estudada. A dependência passa a ser, em parte, controlada endogenamente, transformando-se em um mecanismo de acumulação interna à sociedade colonial, ou melhor, de reiteração das desigualdades econômicas e sociais nela presentes (FRAGOSO, 1998, p. 378).

A rede tentacular dos negociantes fluminenses proposta por Fragoso propiciou a emergência de reflexões teóricas e empíricas. ${ }^{185}$ Por exemplo, ao analisar a origem do capital financiador da cafeicultura no Vale do Paraíba, notou Renato Leite Marcondes que

A entrada em maior volume dos financiamentos bancários oriundos principalmente do Rio de Janeiro e de São Paulo não alterou significativamente a presença dos credores locais no volume concedido de crédito na região. (...) Embora oscilasse muito a parcela dos financiadores locais no conjunto dos empréstimos, ela chegava a 58,6\% em Lorena e a 50,2\% em Guaratinguetá no período 1865-87 (MARCONDES, 2002, p. 165).

Diante dos resultados apresentados no Capítulo 1, temos ciência da relativa incompatibilidade entre padrão de acumulação de riqueza entre os dois Vales. ${ }^{186}$ Nesse sentido, a mineira São João del Rei aproxima-se do perfil que verificamos na região aqui estudada, posto que aquela funcionava como entreposto comercial entre o Rio de Janeiro e a miríade de povoamentos espalhados na antiga Comarca do Rio das Mortes. Além de uma produção local de produtos agropecuários (especialmente toucinho, lombo, banha, gado vacum, queijos, cereais diversos e aguardente), chegavam a esta localidade panos de algodão e algodão em caroço, tudo redirecionado à capital do Império. A diversificada pauta de exportações e o associado equilíbrio do rendimento destes diversos produtos constituem os

\footnotetext{
${ }^{184}$ Não obstante os clássicos estudos de Mafalda Zemella (1990) e Alcir Lenharo (1992).

${ }^{185}$ Ver, por exemplo, MARIUTTI et alli, 2001, p. 369-393 e também OSÓRIO, 1999.

${ }^{186}$ Para que o leitor possa aquilatar o "abismo" entre os dois Vales, a dívida hipotecária em Iguape na década de 1860 somava Rs. 339:492\$180 ou Rs. 33:949\$218/ano; em Lorena, apenas entre os anos de 1866 e 1870, este valor somava Rs. 615:023\$000 (ou Rs. 123:004\$600/ano) e em Guaratinguetá, entre 1865 e 1870, Rs. 1:175:504\$000 ou Rs. 195:917\$333/ano (cf. MARCONDES, 2002, p. 155-156; os valores de Iguape encontram-se em correspondência do Juiz de Direito de Iguape ao Presidente da Província, AESP, ordem n. ${ }^{\circ}$ 4.780).
} 
traços estruturais que distinguem as duas localidades. ${ }^{187}$ A Tabela 4.1 apresenta o padrão de riqueza acumulado pelos ribeirenses e sanjoanenses ao longo do século XIX. ${ }^{188}$

Tabela 4.1

Distribuição dos inventários segundo faixas de riqueza

(Vale do Ribeira, 1800-1880 e São João del Rei, 1831-1885)

\begin{tabular}{l|rrr|rrr}
\hline \multirow{2}{*}{$\begin{array}{c}\text { Riqueza } \\
\text { (contos de réis) }\end{array}$} & \multicolumn{3}{|c|}{ Vale do Ribeira } & \multicolumn{3}{c}{ São João del Rei } \\
\cline { 2 - 7 } & $\mathbf{N}$ & \% & \% da riqueza & $\mathbf{N}$ & \% & \% da riqueza \\
\hline até 0,2 & 39 & 5,8 & 0,12 & 29 & 3,6 & 0,03 \\
0,2 a 1 & 182 & 26,8 & 2,47 & 164 & 20,4 & 1,02 \\
1 a 2 & 103 & 15,2 & 3,75 & 97 & 12,1 & 1,38 \\
2 a 10 & 257 & 37,9 & 30,32 & 282 & 35,1 & 13,03 \\
10 a 50 & 89 & 13,1 & 40,75 & 195 & 24,3 & 42,75 \\
50 a 200 & 7 & 1,0 & 16,85 & 29 & 3,6 & 24,75 \\
acima de 200 & 1 & 0,1 & 5,75 & 7 & 0,9 & 17,06 \\
\hline
\end{tabular}

Parece evidente a maior condição de pobreza dos ribeirenses em relação aos mineiros: nos grupos até 2 contos de réis, encontramos $48 \%$ dos casos do Vale do Ribeira contra 36\% em São João del Rei, porém em ambos os casos associados a uma pequena parcela da riqueza (6\% e 2\%, respectivamente). No grupamento intermediário, de 2 a 10 contos de réis, encontramos 51\% dos inventários do Vale e 59\% dos mineiros, porém com parcelas de riqueza bem distintas: $71 \%$ e 56\%, respectivamente. A elite ribeirense (com riqueza acima de 50 contos) representava tão-somente $1 \%$ e detinha $23 \%$ da riqueza versus 5\% dos casos em São João, com 42\% da riqueza. De resto, estas diferenças mantêm o mesmo padrão assinalado no Capítulo 1.

Não obstante, as formas de atuação dos representantes da atividade comercial na localidade mineira guardam semelhança com as verificadas no Vale do Ribeira, conforme apresentaremos ao longo deste capítulo. Naquele contexto, destaca Afonso de Alencastro: “ $O$ modelo paradigmático do crédito mercantil sanjoanense foi o da concessão de pequenos valores a inúmeras pessoas” (GRAÇA FILHO, 2002, p. 73). Este autor verificou nos

\footnotetext{
187 Apesar das ressalvas feitas por Afonso de Alencastro Graça Filho quanto à confiabilidade dos números, a população no termo de São João del Rei em 1833 somava 12.229 livres e 9.836 escravos contra 6.174 e 2.558 no Vale do Ribeira em 1836, isto é, metade do contingente livre e praticamente um quarto da força de trabalho cativa. Muito mais desproporcional mostram-se os valores de exportação em 1854, que renderam Rs. 3:508:800\$000 em São João del Rei e Rs. 296:498\$000 no Vale do Ribeira, representando cerca de 8\% do rendimento da localidade mineira (cf. GRAÇA FILHO, p. 43 e 57).

${ }^{188}$ A comparação deve ser relativizada, pois, diferentemente de Graça Filho, não utilizamos o monte-mor como medida de riqueza mas a soma dos bens avaliados.
} 
inventários de comerciantes uma parcela significativa da riqueza alocada em diversas modalidades de dívidas ativas, muitas delas insolváveis:

Ao comerciante poderiam ser solicitadas quantias para compra de terras, escravos e outras necessidades da vida rural, incluindo o adiantamento para tratamento médico, funerais ou pequenos valores, por exemplo, que custeassem a ida ao Teatro em São João del Rei. O valor do crédito era abatido aos poucos, em contas que pareciam intermináveis, e que poderiam ser lentamente quitadas através da entrega da produção. O cliente-produtor acabava obrigado a entregar seus produtos ao negociante-credor, como parte do pagamento dos créditos adiantados (GRAÇA FILHO, 2002, p. 76).

E mais,

Os inventários que vimos parecem indicar duas formas de atuação na concessão de empréstimos. Uma delas, com racionalidade pré-capitalista e caracterizada pelos pequenos valores, de acesso mais popular (...) A outra prática, mais conservadora, como vimos, buscava selecionar devedores, sacrificando o prestígio social de crédito amplo (GRAÇA FILHO, 2002, p. 76-80).

Alencastro também destaca que muitos destes comerciantes estabeleceram casas comerciais na Corte, eliminando a influência do atravessador fluminense. Dessa forma, dominavam amplamente a liquidez do mercado regional. As maiores riquezas inventariadas dos comerciantes locais somavam valores entre 20 a 30 mil libras. Analisando a composição da riqueza de 31 comerciantes, Alencastro destaca que alguns deles acumulavam dupla atividade, indicado pela elevada participação das propriedades rurais, porém que

(...) o investimento de capitais nas atividades produtivas (terras, lavouras, animais e escravos) era inferior ao esterilizado em imóveis urbanos, apólices e dívidas ativas. Resulta disto, que os negociantes de grosso trato não eram grandes fazendeiros e nem aplicavam a maior parte de seus capitais nas atividades do campo ou em escravos (GRAÇA FILHO, 2002, p. 89).

Relembra o autor o mesmo traço de diversificação da riqueza observada entre os comerciantes fluminenses, especialmente em bens de raiz urbanos como reserva de valor e fonte de renda de aluguéis, além de significativa participação dos títulos do Tesouro Nacional e ações de empresas cariocas e mineiras.

Boa parte de nossa análise mantém diálogo com o perfil acima delineado dos comerciantes de grosso trato sanjoanenses. No entanto, dada a natureza específica da produção agrária do Vale do Ribeira, optamos por tracejar um acompanhamento delimitando os diferentes espaços disputados por comerciantes e proprietários de engenho de arroz, conforme ressaltamos no Capítulo 1. 


\section{Comerciantes e proprietários - uma visão geral}

Isolados da amostra, comerciantes e proprietários de engenho somavam 217 inventários, 174 deles pertencentes a iguapenses. ${ }^{189}$ Nesta localidade, identificamos 93 proprietários de engenho e 81 comerciantes; em Xiririca, os proprietários de engenho totalizavam 26 casos e os comerciantes, 17. As proporções para as duas localidades reafirmam o quadro de maior diferenciação das atividades econômicas dos iguapenses em relação ao predomínio rural em Xiririca. Ao compararmos a riqueza bruta total desse conjunto, $£$ 282.574 (ou 66\% da riqueza bruta do total dos inventários) e a sua representatividade no conjunto de inventários (32\%), não resta dúvida que se trata de uma parcela expressiva do segmento mais abastado da sociedade ribeirense Oitocentista e partida de forma mais ou menos igualitária entre comerciantes (54\%) e proprietários de engenho (46\%).

Esta distribuição não se mostrou homogênea ao longo do tempo. Nos dois primeiros subperíodos, em Iguape, a riqueza bruta média dos proprietários de engenho superava a dos comerciantes, invertendo-se no último subperíodo: a riqueza média dos proprietários manteve-se estável em torno de $£ 1.315$ nos dois subperíodos e reduziu-se a $£ 874$ no último intervalo. Entre os comerciantes, passou de $£ 770$ para $£$ 960, atingindo $£ 2.945$ na vintena entre 1861 e 1880. Já em Xiririca os comerciantes sempre apresentaram riqueza bruta média superior: $£ 955$ versus $£ 842$ entre 1841 a 1860 e $£ 1.913$ contra $£ 1.174$ no subperíodo posterior.

Antes de acompanhar a partição destas riquezas brutas segundo os grupos de bens, algumas considerações sobre os valores merecem destaque. A primeira diz respeito à melhor situação dos proprietários de engenho de Xiririca em relação aos iguapenses no terceiro subperíodo. Conforme apresentamos anteriormente, alguns dos xiririquenses que possuíam engenho de arroz conjugavam esta atividade com o processamento de cana, o que adicionava maior valor aos estabelecimentos rurais e, portanto, maior riqueza bruta. Ademais, trata-se de uma comparação relativamente desproporcional, pois em Iguape encontramos 40 inventários contra 13 em Xiririca e destes, o número de não-escravistas em Iguape somava 9 casos e apenas 1 em Xiririca. Como expusemos no capítulo sobre a estrutura de posse, nos inventários dos agricultores de Xiririca o número médio de escravos avaliados superava o registrado entre os iguapenses, o que também contribui para o aumento da riqueza bruta dos xiririquenses.

\footnotetext{
189 Ainda dentro das características mais gerais, nas duas localidades predominavam inventariados do sexo masculino (65\%) e, dos casos que pudemos identificar a idade do inventariado, constatamos a idade média igual a 54 anos entre os iguapenses (96 casos) e 62 anos para os 21 representantes de Xiririca.
} 
Da mesma forma, a desproporcionalidade numérica se revela expressiva entre os comerciantes das duas localidades: entre 1841 e 1880 computamos 58 casos em Iguape e 17 em Xiririca.

Se o vínculo com o cultivo de arroz se revela de forma inconteste entre os proprietários de engenho, não pudemos verificar tal liame com a mesma clareza entre todos os comerciantes. Uma das formas de estreitar esta ligação consiste na verificação sobre a execução de remessas de arroz. Em nossa amostra, a riqueza bruta média dos remetentes de arroz ( $£$ 1.874) mostrou-se estatisticamente superior à dos que não foram localizados nos manifestos de carga (£ 831), ${ }^{190}$ evidenciando a possibilidade de ganhos diferenciados através desta prática mercantil. Vejamos como esta distinção se apresenta entre comerciantes e proprietários de engenho.

Dos inventários abertos em Iguape a partir de $1840,{ }^{191}$ metade possuía registro correlato nos manifestos de cargas, cabendo aos comerciantes $77 \%$ dos casos. Em Xiririca, dos 26 proprietários de engenho apenas 3 constavam entre os remetentes e, no caso dos comerciantes, 7 dos 17 inventariados (ou inventariantes) constavam entre os remetentes de arroz. Deste primeiro conjunto de resultados, notamos a menor possibilidade dos xiririquenses em exercer remessas de arroz. Com certeza a proximidade em relação ao porto tem influência na disparidade entre os remetentes nas duas localidades. Nesse sentido, ressaltamos um dado já exposto no Capítulo 1 acerca da posição privilegiada ocupada por Miguel Antonio Jorge, comerciante radicado em Xiririca, com maior quantidade de arroz remetido. Vale dizer, se em Iguape produtores e comerciantes possuíam maiores chances de executar suas remessas e incorporar os ganhos relativos a esta etapa da cadeia de comercialização, os seus pares xiririquenses se viam impelidos a subordinar esta atividade a alguns poucos agentes com capacidade efetiva para manter as remessas em fluxo adequado. Nesse contexto, a centralidade de Miguel Antonio Jorge representa o maior aproveitamento destas oportunidades.

Acrescentamos que as quantidades associadas a comerciantes e proprietários revelam-se bastante distintas: entre os proprietários de engenho iguapenses, o número total de remessas, 1.315 , totalizava 45.140 sacos de arroz contra 4.650 remessas feitas por comerciantes, somando 192.533 sacos. Em Xiririca o padrão se repetia: proprietários de engenho executaram 191 remessas com 9.238 sacos e comerciantes, 464 remessas com 28.375

\footnotetext{
${ }^{190}$ Ressaltamos que os manifestos indicam nominalmente os remetentes até 1865 . Vale dizer, os casos não localizados podem ter executado remessas nos anos posteriores.

${ }^{191}$ Esta é a data a partir da qual possuímos informações sobre os manifestos de carga.
} 
sacos. Além de reiterar a distinção entre iguapenses e xiririquenses, é preciso ressaltar que os valores totais representam 35\% das remessas e 31\% dos sacos com remetente identificado. Conforme indicado no Capítulo 1, as quantidades vinculadas aos inventários parecem reproduzir o perfil geral dos remetentes de arroz, com predomínio dos comerciantes neste segmento das atividades econômicas praticadas no Vale do Ribeira, especialmente entre os iguapenses.

Vejamos agora a composição da riqueza bruta dos inventários pertencentes a proprietários de engenho e comerciantes. O Gráfico 4.1 apresenta primeiramente a riqueza dos iguapenses.

\section{Gráfico 4.1}

Distribuição relativa da riqueza bruta de proprietários de engenho e comerciantes segundo grupos de bens

(Iguape, 1800-1880)
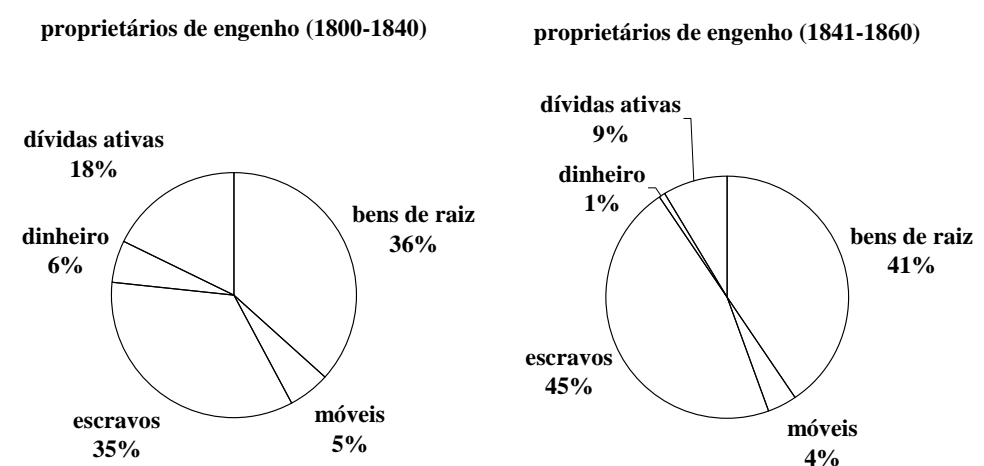

proprietários de engenho (1861-1880)

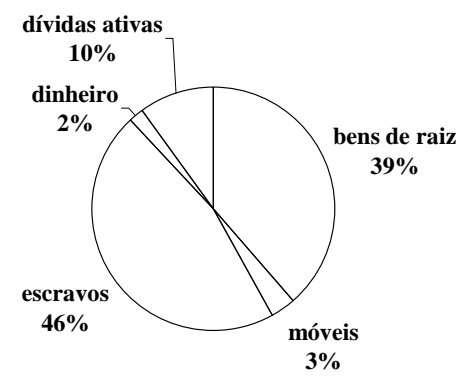

comerciantes (1800-1840)

comerciantes (1841-1860)

comerciantes (1861-1880)
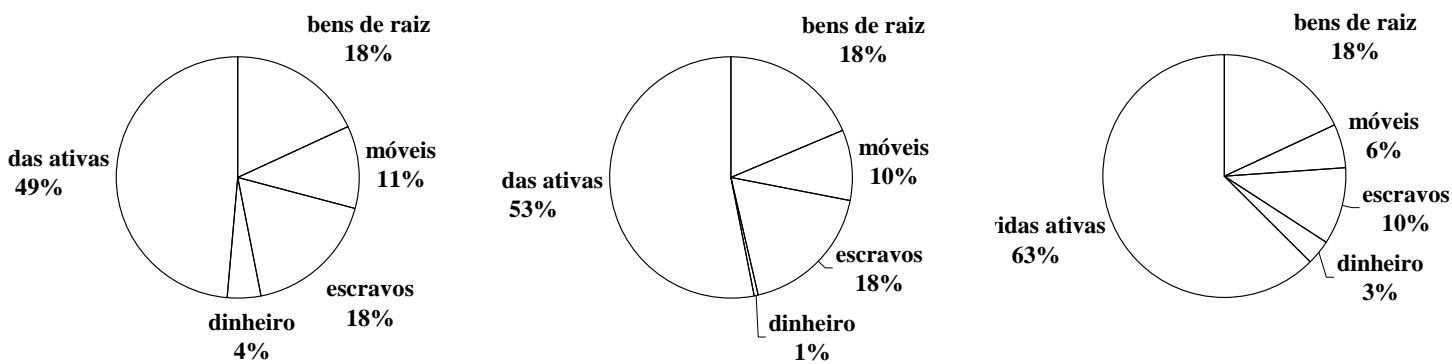

Entre os proprietários de engenho observamos um persistente equilíbrio entre bens de raiz e escravos, dois grupos a compor a maior parte da riqueza bruta, com um ligeiro predomínio do segundo nos subperíodos finais. Exceto entre 1800 e 1840, quando atingiu $18 \%$ da riqueza bruta, as dívidas ativas ocupavam uma participação modesta, ao redor de $10 \%$. Entre os comerciantes notamos um aumento na parcela relativa às dívidas ativas principal grupo da riqueza bruta - em detrimento da redução em bens móveis e escravos. A 
parcela relativa aos bens de raiz entre comerciantes manteve-se praticamente constante ao longo do período, porém em proporção bem inferior à verificada para os proprietários de engenho.

\section{Gráfico 4.2}

Distribuição relativa da riqueza bruta de proprietários de engenho e comerciantes segundo grupos de bens

(Xiririca, 1841-1880)

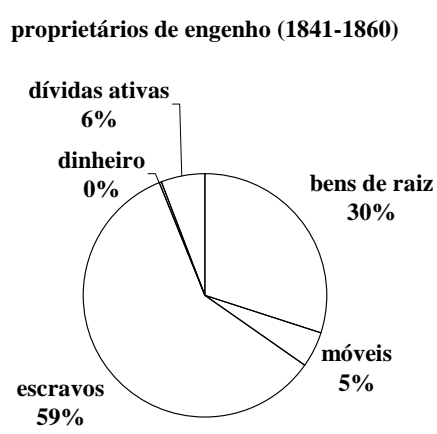

proprietários de engenho (1861-1880)

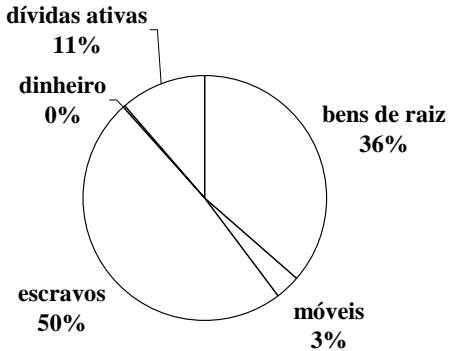

comeciantes (1841-1860)

comerciantes (1861-1880)
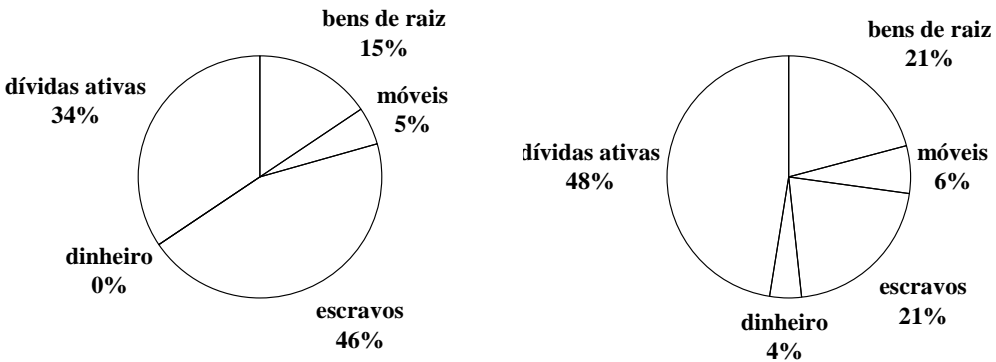

Em Xiririca (Gráfico 4.2), a maior parcela da riqueza bruta dos proprietários de engenho concentrava-se em escravos seguida pelos bens de raiz e dívidas ativas. A flagrante diferença em favor dos escravos parece associar-se mais à composição da amostra do que a alguma estratégia distinta de disposição da riqueza. Conforme ressaltamos acima, há uma evidente diferença na participação de escravistas em Iguape e Xiririca no último subperíodo, bem como o maior número de escravos arrolados nos processos pertencentes aos moradores de Xiririca.

Já entre os comerciantes, embora as dívidas ativas apareçam com importante peso na composição da riqueza, estas não apresentam a mesma magnitude observada em seus pares iguapenses. Novamente a gênese desta distinção parece residir no caráter pouco diferenciado das atividades econômicas desenvolvidas nesta localidade, onde comerciantes também se ocupavam com atividades agrícolas. De outra forma, se entre os negociantes iguapenses há 
alguma dificuldade em estabelecer hierarquia entre as práticas comerciais e agrícolas, em Xiririca a delimitação mostra-se muito mais nebulosa, conforme tentaremos explicitar mais adiante.

Tabela 4.2

Indicadores de tendência central da riqueza bruta e riqueza líquida de proprietários de engenho e comerciantes

(Iguape e Xiririca, 1800-1880)

\begin{tabular}{|c|c|c|c|c|c|c|c|c|c|c|}
\hline & \multirow{3}{*}{\multicolumn{2}{|c|}{ Localidade/ocupação }} & \multicolumn{8}{|c|}{ faixas anuais } \\
\hline & & & \multicolumn{2}{|c|}{$1800-1840$} & \multicolumn{2}{|c|}{$1841-1860$} & \multicolumn{2}{|c|}{$1861-1880$} & \multicolumn{2}{|c|}{ total } \\
\hline & & & $\begin{array}{c}\text { riqueza } \\
\text { bruta }\end{array}$ & $\begin{array}{l}\text { riqueza } \\
\text { líquida }\end{array}$ & $\begin{array}{c}\text { riqueza } \\
\text { bruta }\end{array}$ & $\begin{array}{l}\text { riqueza } \\
\text { líquida }\end{array}$ & $\begin{array}{c}\text { riqueza } \\
\text { bruta }\end{array}$ & $\begin{array}{l}\text { riqueza } \\
\text { líquida }\end{array}$ & $\begin{array}{c}\text { riqueza } \\
\text { bruta }\end{array}$ & $\begin{array}{l}\text { riqueza } \\
\text { líquida }\end{array}$ \\
\hline \multirow{10}{*}{ 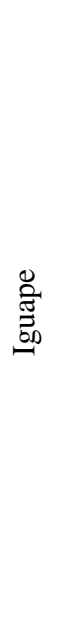 } & \multirow{5}{*}{$\begin{array}{l}\text { proprietários } \\
\text { de engenho }\end{array}$} & inventários & 21 & 21 & 32 & 32 & 40 & 40 & 93 & 93 \\
\hline & & média (£) & 1.318 & 1.210 & 1.315 & 1.154 & 874 & 713 & 1.126 & 977 \\
\hline & & desvio-padrão & 1.879 & 1.839 & 1.805 & 1.841 & 780 & 798 & 1.474 & 1.483 \\
\hline & & mediana (£) & 488 & 441 & 704 & 541 & 669 & 492 & 693 & 507 \\
\hline & & $\%$ riqueza & 61 & - & 56 & - & 33 & - & 46 & - \\
\hline & \multirow{5}{*}{ comerciantes } & inventários & 23 & 23 & 34 & 34 & 24 & 24 & 81 & 81 \\
\hline & & média (£) & 770 & 610 & 960 & 721 & 2.945 & 2.543 & 1.494 & 1.229 \\
\hline & & desvio-padrão & 862 & 932 & 1.460 & 1.263 & 5.673 & 5.201 & 3.352 & 3.068 \\
\hline & & mediana $(£)$ & 518 & 264 & 426 & 248 & 968 & 710 & 631 & 385 \\
\hline & & $\%$ riqueza & 39 & - & 44 & - & 67 & - & 54 & - \\
\hline \multirow{10}{*}{ 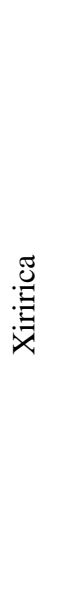 } & \multirow{5}{*}{$\begin{array}{l}\text { proprietários } \\
\text { de engenho }\end{array}$} & inventários & - & - & 13 & 13 & 13 & 13 & 26 & 26 \\
\hline & & média (£) & - & - & 842 & 642 & 1.174 & 924 & 1.008 & 783 \\
\hline & & desvio-padrão & - & - & 955 & 997 & 1.003 & 787 & 974 & 892 \\
\hline & & mediana $(£)$ & - & - & 500 & 313 & 738 & 607 & 569 & 390 \\
\hline & & $\%$ riqueza & - & - & 85 & - & 35 & - & 46 & - \\
\hline & \multirow{5}{*}{ comerciantes } & inventários & - & - & 2 & 2 & 15 & 15 & 17 & 17 \\
\hline & & média $(£)$ & - & - & 955 & 664 & 1.913 & 1.765 & 1.800 & 1.636 \\
\hline & & desvio-padrão & - & - & 1.128 & 1.089 & 2.746 & 2.714 & 2.603 & 2.579 \\
\hline & & mediana $(£)$ & - & - & 955 & 664 & 1.006 & 1.006 & 1.006 & 1.006 \\
\hline & & $\%$ riqueza & - & - & 15 & - & 65 & - & 54 & - \\
\hline
\end{tabular}

Vejamos agora o grau de comprometimento da riqueza bruta com dívidas passivas, expressos na Tabela 4.2. Entre os proprietários de engenho de Iguape este percentual mostrouse crescente ao longo do tempo, passando de $9 \%$ no primeiro subperíodo para $12 \%$ entre 1841-1860 e 18\% no intervalo posterior. Nos proprietários de Xiririca, esta parcela mantevese ao redor de $22 \%$ nos dois últimos subperíodos. No conjunto dos comerciantes iguapenses há uma tendência diversa: maior nos dois primeiros subperíodos (21\% e 24\%, 
respectivamente), o comprometimento da riqueza bruta atingia 14\% entre os anos de 1861 a 1880. Nesse mesmo intervalo os comerciantes de Xiririca possuíam apenas 8\% de sua riqueza bruta comprometida com dívidas passivas. Apresentamos na Tabela 4.2 os valores médios da riqueza bruta e da riqueza líquida para os dois grupos econômicos.

Em Iguape, os valores da riqueza líquida no primeiro subperíodo acentuam ainda mais o distinto nível médio de acumulação entre proprietários de engenho e comerciantes. Como já foi destacado ao longo desta tese, o período entre 1800 e 1840 corresponde ao de maior dinamismo da economia ribeirense, possibilitando um acúmulo intensivo de riqueza por parte dos proprietários de engenho. O subperíodo seguinte ainda apresenta sinais evidentes das oportunidades geradas pela rizicultura, porém a maior parcela de dívidas passivas sinaliza, assim cremos, a incapacidade de expansão para um patamar distinto ao observado no subperíodo anterior. Por fim, a última vintena evidencia um acentuado ritmo de empobrecimento por parte dos possuidores de engenhos: além da redução da riqueza bruta, indicando a incapacidade destes agricultores em manter o mesmo padrão de propriedade de seus antecessores, o maior endividamento contribuiu para a redução drástica na riqueza líquida média. Em relação aos xiririquenses, os efeitos da elevada parcela de dívidas passivas também geraram diferenças significativas entre as riquezas bruta e líquida. No entanto, as características vinculadas à atuação produtiva desses proprietários garantiram não apenas a manutenção, mas um apreciável crescimento da riqueza bruta e líquida.

A Tabela 4.3 apresenta uma outra forma de aferir as diferenças na distribuição da riqueza entre as duas atividades econômicas, considerando o cálculo do índice de Gini tanto para a riqueza bruta como para a riqueza líquida nos três subperíodos.

Tabela 4.3

Índices de Gini para a riqueza bruta e riqueza líquida de proprietários de engenho e comerciantes (Iguape e Xiririca, 1800-1880)

\begin{tabular}{c|c|c|c|c}
\hline \multirow{2}{*}{ Subperíodos } & \multicolumn{2}{|c|}{ proprietários de engenho } & \multicolumn{2}{c}{ comerciantes } \\
\cline { 2 - 5 } & riqueza bruta & riqueza líquida & riqueza bruta & riqueza líquida \\
\hline $1800-1940$ & 0,594 & 0,637 & 0,544 & 0,703 \\
$1841-1860$ & 0,538 & 0,638 & 0,597 & 0,712 \\
$1861-1880$ & 0,454 & 0,535 & 0,649 & 0,707 \\
\hline
\end{tabular}

Enquanto a distribuição da riqueza bruta dos proprietários de engenho de arroz apresentou uma nítida tendência de redução da desigualdade, o movimento entre os comerciantes se deu no sentido oposto. De forma análoga, se observamos uma redução das fortunas diferenciadas entre os engenheiros de arroz, o inverso ocorreu entre os comerciantes: a participação das riquezas brutas acima de 2.000 libras no último subperíodo atingia $10 \%$ dos 
proprietários de engenho contra 26\% dos comerciantes. O desconto das dívidas passivas evidencia em cada subperíodo a maior desigualdade nos dois segmentos de atividades econômicas. No entanto, se entre os proprietários de engenho notamos a mesma tendência de redução da desigualdade verificada na riqueza bruta, entre comerciantes predomina a manutenção de elevados índices, evidenciando a desigualdade ao longo de todo o período estudado. Comparativamente, o comportamento da riqueza dos proprietários de engenho revela-se mais homogêneo em relação às dívidas passivas do que entre os comerciantes, principalmente aqueles com pequena riqueza bruta, onde os descontos das dívidas provocaram oscilações relativas desproporcionalmente maiores vis-à-vis os mais abastados.

Nesse contexto, chama a atenção o elevado nível de riqueza atingido pelos comerciantes ribeirenses no último subperíodo, seja no seu valor bruto ou líquido, especialmente no último subperíodo. Como bem demonstraram os gráficos anteriores, a maior parcela desta riqueza apresentava-se sob a forma de dívidas ativas, conjunto de pouca expressividade entre os proprietários de engenho de arroz. Entre os inventários de nossa amostra, 13 comerciantes e 48 proprietários de engenho não possuíam nenhuma espécie de dívida ativa. Nos processos de outros 17 comerciantes e 6 proprietários de engenho o inventariante não apresentou o rol de devedores, indicando apenas o valor total das dívidas. Apresentamos na tabela seguinte os casos daqueles que discriminavam as dívidas ativas, organizados em faixas de número de créditos e segmentados pelo tamanho da riqueza bruta.

Tabela 4.4

Distribuição dos inventários de comerciantes e proprietários de engenho segundo número de créditos e faixas de riqueza bruta

(Iguape e Xiririca, 1800-1880)

\begin{tabular}{|c|c|c|c|c|c|c|}
\hline \multirow{2}{*}{ Ocupação } & \multirow{2}{*}{$\begin{array}{c}\text { faixas de } \\
\text { riqueza bruta } \\
(£)\end{array}$} & \multicolumn{4}{|c|}{ número de créditos } & \multirow{2}{*}{ total } \\
\hline & & 1 & 2 a 9 & 10 a 49 & 50 ou mais & \\
\hline \multirow{5}{*}{$\begin{array}{l}\text { proprietários } \\
\text { de engenho }\end{array}$} & 0 a 500 & 2 & 4 & 5 & 2 & 13 \\
\hline & 500 a 1.000 & 8 & 10 & 3 & 2 & 23 \\
\hline & 1.000 a 2.000 & 4 & 8 & 5 & - & 17 \\
\hline & acima de 2.000 & 3 & 4 & 2 & 1 & 10 \\
\hline & total & 17 & 26 & 15 & 5 & 63 \\
\hline \multirow{5}{*}{ comerciantes } & 0 a 500 & 1 & 4 & 11 & 9 & 25 \\
\hline & 500 a 1.000 & 1 & 1 & 2 & 16 & 20 \\
\hline & 1.000 a 2.000 & - & - & - & 10 & 10 \\
\hline & acima de 2.000 & - & 1 & 3 & 9 & 13 \\
\hline & total & 2 & 6 & 16 & 44 & 68 \\
\hline
\end{tabular}

Entre os proprietários de engenho, independente do padrão de riqueza bruta, predominou o pequeno número de créditos (menos de 10), representando 68\% dos casos 
acima assinalados. Apenas 8 casos nesta condição foram observados entre os comerciantes, enquanto 88\% possuíam valores acima de 9 créditos. Ademais, entre os 20 inventários com maior quantidade de dívidas ativas, 16 pertenciam a comerciantes e apenas 4 possuíam engenho de arroz, porém 3 deles exerceram atividades comerciais em algum momento pretérito. Entre os casos indicados acima, alguns impressionavam pela quantidade de devedores indicados: Rafael Descio, comerciante estabelecido na freguesia de Iporanga possuía em seus livros 754 devedores; Antonio Martins Ribeiro, um comerciante de Iguape, 675 devedores; José Bonifácio de Andrada, também de Iguape, 583 devedores.

Pelo lado das dívidas passivas, dos 159 casos com este tipo de registro, 139 discriminavam todos os credores. Entre os proprietários de engenho, pouco mais de três quartos apresentavam até 4 dívidas ao passo que 57\% dos comerciantes deviam a mais de 4 credores.

No primeiro subperíodo, o perfil da dívida passiva dos proprietários de engenho de arroz envolvia, além de acertos tardios de legítimas devidas e pagamentos relativos aos inventariantes (que denominamos conjuntamente de "dívidas domésticas”), créditos tomados a outros iguapenses. Nos comerciantes, além das “dívidas domésticas”, aparecem também negociantes do Rio de Janeiro, envolvendo créditos pelo fornecimento de mercadorias. Ao tomarmos o conjunto de credores com identificação precisa, os iguapenses detinham $67 \%$ das dívidas contra 33\% pertencentes aos comerciantes fluminenses. Entre os credores locais, ocupam posições de igual destaque Antonio José Peniche, Antonio Borges Diniz, Bento Pupo de Gouveia, Filadelfo de Souza Castro, Francisco dos Santos Carneiro, Joaquim de Souza Castro, Vitorino José Franco e José Bonifácio de Andrada.

Entre 1841 e 1860, das dívidas passivas dos proprietários de engenho de arroz, um quarto do valor nominal correspondia aos ajustes das dívidas domésticas. Apenas uma das dívidas arroladas provinha do Rio de Janeiro e, apesar de alguns dos credores do subperíodo anterior ainda constarem no rol, como Antonio Borges Diniz e Filadelfo de Souza Castro, alguns outros ribeirenses passaram a ocupar lugar de destaque, como João Mâncio da Silva Franco, José Jacinto de Toledo, José Ferreira de Aguiar Silva, José Xavier de Almeida Cruz, Luis Álvares da Silva e Miguel Antonio Jorge. Para os comerciantes, os credores fluminenses representavam 34\% do valor nominal das dívidas e as domésticas, pouco menos de 5\%. Ao conjunto dos credores acima citado acrescentamos Antonio dos Anjos Silva e João Batista da Silva Carneiro, porém nenhum deles se destacava no conjunto dos credores de comerciantes.

No último subperíodo, a parcela de dívidas domésticas dos proprietários de engenho de arroz respondia por $9 \%$ do valor nominal. Localizamos apenas três dívidas pertencentes à 
pessoas do Rio de Janeiro com pouco mais de 1,5\% das dívidas. João Mâncio da Silva Franco se manteve entre os principais credores, seguido por Luis Álvares da Silva, Antonio de Magalhães Mesquita e Miguel Antonio Jorge. Para os comerciantes, as dívidas domésticas representavam cerca de 3\% e os credores do Rio de Janeiro, 45\%. O maior número de ocorrências, porém representando apenas 14\% das dívidas, pertencia à Mendes Filho \& Lemos, que controlou as linhas regulares de vapor entre Iguape e o Rio de Janeiro durante as décadas de 1860 e 1870, além de deter a posse de alguns dos navios que realizavam o transporte de arroz. Antonio de Magalhães Mesquita, João Mâncio da Silva Franco, Joaquim José Rebelo, Joaquim Antonio de Souza Castro, José Ferreira de Aguiar e Silva (posteriormente Viúva Aguiar \& Filhos) e Miguel Antonio Jorge constituíam os principais credores locais destes comerciantes.

\section{Quadro 4.1}

Relação dos 20 maiores credores nos inventários por número de ocorrências e valor dos créditos (Iguape e Xiririca, 1800 a 1880)

\begin{tabular}{|l|c|l|c|}
\hline \multicolumn{1}{|c|}{ credor } & ocorrências & \multicolumn{1}{|c|}{ credor } & valor (mil-réis) \\
\hline Miguel Antonio Jorge & 39 & Miguel Antonio Jorge & $34: 846 \$ 700$ \\
João Mancio da Silva Franco & 37 & João Mancio da Silva Franco & $34: 805 \$ 980$ \\
José Ferreira de Aguiar e Silva & 31 & José Jacinto de Toledo & $23: 395 \$ 690$ \\
José Xavier de Almeida Cruz & 28 & José Bonifácio de Andrada & $19: 459 \$ 519$ \\
José Bonifácio de Andrada & 25 & José Xavier de Almeida Cruz & $14: 658 \$ 849$ \\
Luis Álvares da Silva & 23 & Manoel Ferreira da Silva & $14: 308 \$ 364$ \\
José Jacinto de Toledo & 19 & José Ferreira de Aguiar e Silva & $11: 221 \$ 151$ \\
Antonio de Magalhães Mesquita & 18 & Viúva Ferreira Aguiar \& Filhos & $10: 004 \$ 678$ \\
Antonio Vaz Ferreira & 17 & Luis Álvares da Silva & $9: 590 \$ 153$ \\
João Batista da Silva Carneiro & 15 & Carvalho \& Pereira & $9: 067 \$ 077$ \\
José Ferreira da Silva & 13 & Antonio de Magalhães Mesquita & $8: 498 \$ 286$ \\
Filadelfo de Souza Castro & 13 & Mendes Filho \& Lemos & $7: 216 \$ 833$ \\
Antonio José Gonçalves & 13 & Manoel Alvarenga Braga & $6: 118 \$ 561$ \\
Gregório José da Silva & 12 & Joaquim José Rebelo & $5: 649 \$ 014$ \\
Domingos Rodrigues Cunha & 12 & Manoel Ferreira Pacheco & $5: 384 \$ 098$ \\
Manoel Ferreira da Silva & 11 & Fonseca Leite \& Oliveira & $4: 969 \$ 757$ \\
José Alves da Costa Pacca & 11 & João Antonio de França & $4: 815 \$ 704$ \\
Bento Antonio de França & 11 & Antonio Borges Diniz & $4: 472 \$ 565$ \\
Antonio Francisco de Ataíde Peniche & 11 & José Gonçalves Maia & $4: 468 \$ 077$ \\
Antonio Borges Diniz & José Ferreira da Silva & $4: 151 \$ 888$ \\
\hline
\end{tabular}

Tomando o conjunto de inventários de nossa amostra, notamos uma associação fraca entre o número de ocorrências dos principais credores iguapenses que aparecem nos inventários e o volume de crédito a eles associados, como mostra o Quadro 4.1. A parcela aí 
destacada representa 21\% dos registros nos inventários e os valores nominais, 42\%. Como parâmetro de comparação, os credores com menor freqüência nos inventários ( 1 a 4 citações) correspondiam a $61 \%$ do total de ocorrências e $48 \%$ do valor nominal das dívidas.

Exceto pelos dois primeiros nomes da lista, onde coincidem as maiores ocorrências e também os maiores valores nominais dos créditos, os demais credores alternam-se em diferentes locais, alguns inclusive aparecendo em apenas uma das listas. É preciso lembrar que a própria distribuição temporal dos inventários favorece a ocorrência de nomes com maior expressão na segunda metade do século XIX. Detalhes sobre as estratégias de alguns personagens da lista acima serão abordados ao longo deste capítulo. Em que pese o possível viés decorrente da própria fonte, importa-nos destacar algumas das características detectáveis no conjunto acima.

Uma delas diz respeito aos dois primeiros nomes da lista. Tanto Miguel Antonio Jorge como João Mâncio da Silva Franco, apesar do elevado valor total de créditos, possuíam, na maior parte dos registros, valores modestos: para ambos, apenas 7 superavam a marca de um conto de réis. Ambos também detinham apenas um crédito de maior valor, favorecendo o destaque no conjunto de credores: Miguel Antonio Jorge deveria receber de José Felizardo Rodrigues um crédito de 11 contos de réis segundo o inventário aberto em $1863 .{ }^{192}$ Já João Mâncio da Silva Franco possuía um crédito de pouco mais de 11 contos de réis a ser recebido de Rafael Dias dos Reis, falecido em 1864. ${ }^{193}$

O terceiro maior credor em número de ocorrências, José Ferreira de Aguiar e Silva, aparece em oitavo lugar no rol dos valores, antecedendo a firma comercial encabeçada por sua mulher, criada após sua morte em 1868; se os considerássemos como um único credor, ocupariam a quarta posição. Assim como Aguiar e Silva, cujo crédito médio oscilava em torno de 360 mil-réis, José Xavier de Almeida Cruz e Luis Álvares da Silva também possuíam a maior parte dos créditos entre 400 e 500 mil-réis. Outros como Antonio Vaz Ferreira e João Batista da Silva Carneiro, apesar do elevado número de ocorrências, não constam na lista dos valores monetários, assim como as firmas Carvalho \& Pereira, ${ }^{194}$ de Iguape e Mendes Filho \&

\footnotetext{
192 FEP, caixa n. ${ }^{\circ} 38$.

193 MHAI, caixa n. ${ }^{\circ} 236$.

194 Isoladamente, temos: Claudino Pereira da Silva (2 ocorrências, Rs. 1:908\$372) e Bernardino da Rocha Carvalho (6 ocorrências, Rs. 2:248\$870). Se somados com os registros da firma comercial, temos 16 registros e um valor nominal de Rs. 13:279\$919. Claudino Pereira da Silva deteve a posse do maior engenho a vapor de Iguape, atuante especialmente em fins da década de 1870 e durante o decênio posterior. Já Bernardino da Rocha Carvalho empreendeu uma firma que controlava o transporte fluvial entre Iguape e Xiririca em meados da década de 1870.
} 
Lemos, do Rio de Janeiro, com valores nominais expressivos, porém com baixo número de ocorrências até 1880 .

É necessário destacar ainda a intersecção entre os nomes listados no Quadro 4.1 e os remetentes de arroz. Dos 20 maiores remetentes em quantidade de sacos, 11 deles constam também no quadro acima; o número de coincidências se eleva para 12 se considerada a quantidade de remessas realizadas. Dessa forma, fecha-se um circuito importante: ao controlar o fornecimento de crédito e o fluxo de exportações de arroz, este pequeno conjunto de negociantes (e, eventualmente, proprietários de engenho) praticamente dominava toda a cadeia produtiva ribeirense.

Uma apelação movida por Joaquim Antonio de Souza Castro contra a firma Carvalho \& Pereira, em 1877, permite-nos elucidar como funcionava o referido sistema. ${ }^{195} \mathrm{Na}$ apelação, o suplicante requeria uma indenização pela perda de 11 sacos de arroz a bordo do iate “Claudino 20", que naufragou antes de ancorar no Rio de Janeiro. Souza Castro alegava que não teria dado permissão para que o arroz fosse embarcado em tal navio, mesmo porque tinha conhecimento de que as condições de navegabilidade do mesmo não permitiriam uma viagem segura.

Pelos relatos de ambas as partes remontamos o caminho do arroz: segundo o advogado dos réus, no dia 29 de janeiro de 1877 Souza Castro embarcou os 11 sacos de arroz no vapor "São Paulo", que fazia a rota ao longo do rio Ribeira. Recomendou ao seu comandante, José Francisco Cancella, que entregasse o arroz à firma Carvalho \& Pereira. Dois dias depois Souza Castro, retornando de seu sítio, soube que o arroz fora embarcado no iate e solicitou ao guarda-livros que enviasse o manifesto de embarque com a declaração de pagamento dos dízimos e frete. Sua indisposição contra a firma comercial ocorreu apenas em 6 de março, quando chegou em Iguape a notícia do naufrágio. Como provas de inocência, o advogado de Carvalho \& Pereira, consignatária do navio e proprietária da maior parte da carga por ele transportado afirmou que a própria firma não fizera seguro do embarque, crente na plena condição de funcionamento da embarcação. Apresentou ainda um documento emitido pela casa comercial fluminense Caldas Bastos \& Cia confirmando a ordem de Souza Castro para receber o arroz no porto carioca e solicitando sua posterior venda. Segundo Souza Castro, a ordem repassada ao comandante do vapor "São Paulo” solicitava a armazenagem dos sacos de arroz nos armazéns da Companhia do vapor e que posteriormente ele próprio se encarregaria de embarcá-los em um navio da Companhia Intermediária, proprietária dos

\footnotetext{
${ }^{195}$ MHAI, caixa n. ${ }^{199 .}$
} 
vapores que faziam a rota regular entre o Rio de Janeiro e os portos do sul. O juiz, em primeira decisão, absolveu os réus e condenou Souza Castro ao pagamento das custas do processo.

Interessa-nos destacar a forma como o arroz era destinado ao embarque. Caso detivesse a posse de um engenho, o próprio produtor se encarregava de seu processamento e o remetia, por conta própria ou através de terceiros, até a vila de Iguape. Caso não possuísse, encaminhava o arroz em casca a um proprietário de engenho (que poderia ser um comerciante), que realizaria o processamento e eventualmente, o embarque do arroz. Uma vez descascado e na vila, o arroz era embarcado pelo consignatário local, que pagava as taxas e impostos devidos, ao mesmo tempo em que o produtor (ou o próprio consignatário) emitia ordem de aviso ao receptor da carga no Rio de Janeiro, que deveria realizar a venda e remeter o dinheiro para Iguape ou registrá-lo contabilmente em favor do produtor, que poderia utilizar o entreposto como fornecedor de mercadorias para seu consumo. Só então as custas envolvendo o beneficiamento dos grãos, o ensacamento e o seu transporte seriam saldadas pelo produtor e o consignatário local poderia fazer o papel de fornecedor dos bens de consumo do produtor, responsabilizando-se financeiramente não apenas pelas custas de remessa de arroz como também pela aquisição dos bens demandados pelo produtor, com promessa de pagamento mediante a venda dos grãos. Dessa forma, expandia-se a lista de devedores nos registros destes negociantes, que muitas vezes incluía o próprio processamento do arroz, como é o caso da firma Carvalho \& Pereira, proprietária de um engenho a vapor na vila de Iguape.

Como já ressaltamos, quanto maior a distância em relação ao núcleo urbano de Iguape, maior seria a dificuldade do produtor em executar os passos desta cadeia, permitindo a concentração destas atividades nas mãos de alguns poucos negociantes, representados no Quadro 4.1 por José Ferreira de Aguiar e Silva, que atuava na região de Jacupiranga, por Miguel Antonio Jorge em Xiririca e ainda por Rafael Descio na freguesia de Iporanga, que não consta entre os principais credores, mas seu inventário revelou uma imensa quantidade de créditos cedidos aos moradores da região, como já destacamos anteriormente. ${ }^{196}$ Utilizaremos este caso para introduzir a análise acerca da qualidade destas dívidas declaradas por comerciantes e proprietários de engenho de arroz.

O napolitano Rafael Descio aparentemente estabeleceu domicílio em Iporanga no início da década de 1830. Na lista nominativa dos moradores da vila de Apiaí de 1835,

\footnotetext{
${ }^{196}$ Rafael Descio não consta no Quadro 4.1 devido à baixa freqüência de inventários pertencentes a Iporanga, correspondendo a apenas $2 \%$ dos 678 inventários.
} 
quando Iporanga ainda pertencia a esta vila, Rafael Descio aparece como italiano, 41 anos, negociante e proprietário de engenho de arroz, detentor de 7 escravos e ainda contava com a presença de outros 6 agregados em seu fogo, todos pardos. Produzia 400 alqueires de arroz, 26 de feijão, 150 de farinha de mandioca e auferia uma renda anual de um conto de réis. Ainda na lista referia o inspetor de quarteirão: “Sabe ler e escrever em várias línguas e em outras ciências”. Naquele ano, a produção total de arroz em Apiaí superava 16 mil alqueires, praticamente toda ela proveniente da freguesia de Iporanga. Além de Rafael Descio, encontramos outros 14 proprietários de engenho de arroz, alguns com produção expressiva, como Gordiano Dias Baptista, com 1.000 alqueires, Joaquim de Moura e José da Silva Gomes, com 800 alqueires. Os três constavam entre os que realizaram remessas de arroz, porém nenhum deles atingiu a marca de Rafael Descio, que entre 1837 e 1864, executou 238 remessas, totalizando 19.081 sacos de arroz.

Rafael Descio faleceu em 10 de fevereiro de $1865 .{ }^{197}$ Em seu testamento, feito em Iguape no dia primeiro do mesmo mês, Descio afirmava residir em Iporanga há 35 anos e que tivera dois casamentos. Do primeiro, duas filhas, uma casada com Eugenio Mallet, residente no Rio de Janeiro, e outra casada com Domingos Puygari, este último casal falecido. Do segundo casamento, outros dois filhos. Não temos notícia alguma sobre estes, porém o inventário de Domingos faz parte de nossa amostra e no processo tomamos conhecimento que ele veio a falecer em 1855. No ano de sua morte Domingos possuía uma casa comercial na Rua da Glória, em Iguape, porém nas dívidas ativas registradas no livro de conta, predominavam moradores de Iporanga e Apiaí, representando 69\% de sua riqueza bruta, $£$ 1.023. O restante da riqueza dividia-se entre bens móveis (20\%) e de raiz (11\%), sendo que no primeiro grupo estavam as mercadorias pertencentes à loja e no segundo um único bem, uma casa na vila de Iguape. As dívidas passivas de Domingos, $£ 1.253$, todas associadas a casas comerciais fluminenses, produziram uma riqueza líquida negativa de $£ 230 .{ }^{198}$

O inventário de Rafael Descio contém inúmeras peculiaridades. Desde o testamento, onde Descio nomeia a própria esposa como testamenteira, único caso de uma mulher a receber esta incumbência em todos testamentos localizados dentro dos processos, até o intrincado método de avaliação dos bens, resultando um volume de mais de 350 folhas. A avaliação dos bens, iniciada em 19 de junho de 1865 e realizada pelos avaliadores João da Silva Cardim e João de Moura Oliveira durou 5 dias e também se constitui em caso único

\footnotetext{
${ }^{197}$ FEP, caixa n. ${ }^{\circ} 39$.

${ }^{198}$ MHAI, caixa n. ${ }^{\circ} 134$.
} 
onde os avaliadores afirmavam, ao final de um dia de trabalho, não poderem continuar realizando sua tarefa por não haver mais tempo.

A riqueza bruta total, $£$ 11.137, distribuía-se entre bens de raiz (12\%), escravos (21\%), dívidas ativas (59\%), dinheiro (5\%) e móveis (3\%) e as doações realizadas representavam $12 \%$ da riqueza bruta. As dívidas passivas correspondiam a $3 \%$ da riqueza bruta, duas pertencentes a casas comerciais cariocas e uma outra a João José Martins de Iguape. As propriedades rurais, 14 em seu total, concentravam-se em Iporanga e Apiaí e, segundo as descrições, guardavam um aspecto de abandono. A presença de engenho de arroz ocorria em duas delas, uma divisa com o rocio da freguesia e outra em um local denominado “Ribeirãozinho”. Quatro casas na freguesia e uma em Iguape completavam a lista dos bens de raiz. Foram avaliados ainda 40 escravos, a um valor médio de Rs. 567\$750. Entre os bens móveis, além das mercadorias da loja, dois alambiques e os móveis da residência, Rafael Descio possuía 432 livros redigidos em português, espanhol e francês, avaliados por Rs. $50 \$ 000$.

A forma como as dívidas ativas foram apresentadas merece destaque: os 476 registros em conta de livro, que somavam $£$ 3.528, viram-se distribuídos em três lotes distintos: cobráveis (17\% dos devedores e 9\% do montante), de difícil cobrança (26\% dos devedores e $14 \%$ do montante) e incobráveis (57\% dos devedores e $77 \%$ do montante). Já os 172 créditos, totalizando $£$ 2.506, indicavam maior solvência: 70\% deles eram cobráveis, correspondendo a $56 \%$ do montante; os demais foram classificados como incobráveis. No conjunto das dívidas ativas, 35\% do valor compunham a parte recebível, segundo a opinião dos herdeiros de Descio. Se este critério for correto, então a riqueza bruta de Rafael Descio atingiria $£$ 6.880, equivalendo a uma redução de $38 \%$.

Esta acumulação de créditos e contas de livro compõe a principal forma de transação comercial no Vale do Ribeira durante o Oitocentos, como bem sugere o caso de José Bonifácio de Andrada e Silva, um dos principais comerciantes iguapenses durante as décadas de 1840 a 1860. Os pais de José Bonifácio de Andrada residiam em Iguape pelo menos desde 1801, quando os santistas Mariano da Trindade e Adelindes compunham um fogo juntamente com 6 filhos (entre eles, José, com 5 anos), 4 agregados e 6 escravos. ${ }^{199}$ Segundo a anotação na lista, o mestre de capela Mariano também atuava como pintor, possuía uma venda de molhados e obtinha renda através do jornal de seus escravos, um deles através da atividade de sapateiro e outros dois, jornaleiros. Em 1815 a descrição para a ocupação econômica de

\footnotetext{
${ }^{199}$ Segundo Roberto Fortes, Adelindes seria irmã de José Bonifácio de Andrada, chefe do primeiro gabinete de D. Pedro I (cf. FORTES, Roberto. Vultos Iguapenses, ed. preliminar em suporte eletrônico, cortesia do autor).
} 
Mariano restringia-se a de músico, atividade atribuída a 4 de seus filhos (inclusive José, 19 anos) e o escravo Joaquim, um dos dez pertencentes a Mariano. Entre 1815 e 1828 este domicílio desintegrou-se e no último ano encontramos José Bonifácio, 32 anos, chefiando um domicílio e proprietário de 6 escravos. Em 1836, José Bonifácio de Andrada, 39 anos, solteiro, possuía uma casa comercial em Iguape que lhe rendia um conto de réis e detinha a posse de três escravos.

Em nenhuma das relações de proprietários de engenho José Bonifácio é mencionado. Ele próprio confirma esta situação em 1845, em correspondência dirigida ao presidente da Província, acerca de conflitos envolvendo a posse de terras: “(...) eu faço esta representação sem motivo algum de interesse, se não a bem da tranqüilidade e interesse dos povos, porque não sou lavrador e sim comerciante e por isso não tenho questões alguma de terras (...)”." ${ }^{200}$ Nesta época José Bonifácio ocupava o cargo de juiz de direito, também exercendo a função de vereador por vários anos. Na década de 1840, possuía o patacho “Flor da Verdade” e manteve sua casa comercial sempre no Largo de São Francisco (outrora Pátio das Casinhas). O registro de pagamento de sisa sobre compra de bens de raiz revela um perfil assemelhado ao de outros comerciantes: parte substancial das transações referia-se a execuções judiciais ou arrematações de bens; também realizou vendas importantes como o sítio no rio Bananal ao francês Frederico Krecherly em 1855, o qual retomaria a posse alguns anos depois pelo não pagamento da transação.

Entre 1837 e 1861, José Bonifácio executou 277 remessas de arroz pelo porto de Iguape, totalizando 16.172 sacos, ficando atrás somente dos também comerciantes Luis Álvares da Silva e João Mâncio da Silva Franco, considerando apenas os iguapenses. A partilha amigável de seus bens, realizada em 1865, informa que Bonifácio faleceu em 1863 e sua riqueza bruta somava $£$ 20.729, a segunda maior registrada entre os 678 inventários analisados. ${ }^{201}$ Entre os bens, os de raiz representavam $10 \%$ da riqueza bruta e os rurais, apenas 1\%. Não obstante a posse de 31 escravos, estes correspondiam a $9 \%$ da riqueza bruta, cabendo ao conjunto das dívidas ativas 78\%, agregadas a partir de 389 registros de conta de livro e 194 créditos. Sua posição como negociante em 1836 sugere que a principal parte de sua riqueza foi acumulada após este momento, pois naquele ano, então com 39 anos, José Bonifácio possuía apenas três escravos, apesar de auferir renda anual de um conto de réis. Dos cinco herdeiros de José Bonifácio, pelo menos duas filhas encontravam-se casadas com outros dois comerciantes iguapenses e uma terceira também se casaria com outro comerciante alguns

\footnotetext{
${ }^{200}$ AESP, Ofícios diversos de Iguape, ordem n. ${ }^{\circ} 1.041$.

${ }^{201}$ MHAI, caixa n. ${ }^{\circ} 110$.
} 
anos após a morte do pai - vale dizer, os herdeiros receberam, essencialmente, um conjunto de papéis de dívidas.

Cabe aqui novamente o questionamento sobre a qualidade destas dívidas. No próprio arrolamento dos bens de José Bonifácio houve o cuidado em classificá-las como de primeira e de segunda classes, sugerindo maior chance de execução de algumas em detrimento de outras. Para o conjunto das dívidas de segunda classe, os próprios herdeiros atribuíram uma depreciação de 50\% de seu valor, de tal forma que dos 399 registros de conta de livro (Rs. 33:284\$727) e 194 de dívidas ativas e créditos (Rs. 121:928\$870), os herdeiros partilharam um valor nominal de Rs. 114:084\$727, representando uma redução de $25 \%$. $^{202}$

Outro caso onde o inventariante distinguia a qualidade das dívidas ocorreu no inventário do comerciante José Ferreira da Silva, aberto em 1880. Para seu filho, João Ferreira da Silva, dos 298 créditos e dívidas de rol, apenas 51 foram considerados cobráveis, representando $38 \%$ do total dos haveres. ${ }^{203}$ Neste caso, as dívidas ativas representavam 58\% da riqueza bruta, avaliada em $£$ 6.128. O caso de José Ferreira mostra-se interessante, pois em 1863 ele abriu inventário por conta do falecimento de sua esposa Rita Ferreira da Silva. ${ }^{204} \mathrm{~A}$ riqueza bruta, $£ 1.944$, concentrava-se principalmente em bens de raiz (40\%) e as dívidas ativas representavam cerca de $18 \%$ do montante. Naquele momento, José Ferreira dividia a casa de negócio no bairro dos Engenhos com Joaquim Ferreira Machado e, por conta da sociedade, as dívidas ativas foram contabilizadas pela metade do valor. Não conseguimos descobrir se a sociedade se manteve, porém José Ferreira da Silva, no ano da morte da esposa, possuía uma casa de comércio na rua do Funil e, em 1868, recolheu os tributos relativos a uma loja no bairro dos Engenhos.

Podemos também acompanhar a composição do item bens de raiz. No inventário de sua esposa, José Ferreira da Silva declarou possuir um sítio com casa assobradada no bairro dos Engenhos, uma morada de casas na rua da Glória, três outras na rua do Funil, e dois terrenos, um na rua do Funil e outro na rua da Glória. Entre 1866 e 1876, realizou 16 aquisições, sendo 11 bens urbanos, totalizando um valor declarado de cerca de 10 contos de réis, inclusive um engenho a vapor no porto da Ribeira, pertencente ao falecido José Pacheco da Costa em 1867, por Rs. 3:640\$000 e vendido no ano seguinte a Luciano e Davi Barnes por 5 contos de réis. Também vendeu as casas na rua da Glória e na rua do Funil, declaradas no inventário. Os bens de raiz avaliados por conta de seu falecimento somavam 26 propriedades,

\footnotetext{
${ }^{202}$ Em nossos cálculos, utilizamos os valores totais.

${ }^{203}$ MHAI, caixa n. ${ }^{\circ} 132$.

${ }^{204}$ MHAI, caixa n. ${ }^{\circ} 4$.
} 
compondo-se por terras no Una, rio Pindu, rio Mirim e Juquiá e moradas de casas no Largo da Matriz (3), na rua das Neves (5) e na rua da Glória (3) e terrenos em outros logradouros. No inventário de 1863, José Ferreira possuía 8 escravos; destes, apenas um constava entre os 5 escravos declarados por Ferreira da Silva na lista de classificação, porém outros três foram relacionados como propriedade de seu filho João Ferreira da Silva. Por fim, no inventário de José Ferreira, onde cinco escravos foram avaliados, três deles pertenciam ao rol de 1872.

Um outro caso, o do comerciante José Ferreira de Aguiar e Silva, favorece a elucidação da classificação das dívidas ativas. Assim, como Andrada e Silva, José Ferreira realizou 260 remessas envolvendo 21.073 sacos de arroz. Não há na lista do Museu Histórico e Arqueológico de Iguape referência ao seu inventário, porém lá existe um libelo movido pelo cunhado, Antonio Ferreira de Aguiar, contra a casa comercial Viúva Ferreira Aguiar \& Filhos, datado em 7 de fevereiro de 1879, cujo teor de abertura segue abaixo:

Diz Antonio Ferreira de Aguiar que Tristão Augusto Carneiro dos Santos e sua sogra Justina Umbelina Ferreira tendo entre si celebrado uma sociedade comercial sob a firma de Viúva Ferreira Aguiar \& Filhos e no grupo mercantil veio envolvido todas as dívidas ativas pertencentes ao espólio do finado José Ferreira de Aguiar e Silva, de quem é o suplicante legítimo herdeiro por cabeça de casal e nas quais dívidas lhe cabia a importância de Rs.16:058\$134, cobraram quase a totalidade da dívidas e não têm previsto indenizar o suplicante a parte que nelas lhe tocava e nem à respeito se quiseram conciliar como prova o documento que aqui junto, por isso quis fazer citar os suplicados para na audiência deste juízo que deverá ter lugar a 7 de fevereiro do próximo vindouro virem oferecer um libelo cível em que melhor exporá sua intenção ficando desde logo os suplicados citados para todos os demais termos e atos judiciais até final sentença e sua execução. Nestes termos o suplicante como requer para VS se sirva mandar que sejam citados os suplicados sendo sua sogra Justina Umbelina Ferreira com a devida venia por todo o retro expendido. É o que requer, Iguape 11 de novembro de 1878. João Dias da Silva Martins, procurador. $^{205}$

No processo encontra-se a transcrição da partilha amigável dos bens homologada em 31 de setembro de 1867. Os herdeiros, além da viúva, foram José Rebello, casado com Margarida Cândida da Silva; Justina Marcelina Ferreira Martins; Tristão Augusto dos Santos Carneiro, casado com Joana Luiza Ferreira Carneiro, João Ferreira de Aguiar e Silva e Francisca Augusta Ferreira. Entre os bens, as dívidas ativas por conta de livro, créditos e hipotecas somavam $£ 17.010$ ou praticamente $80 \%$ da riqueza bruta ( $£ 21.125$, a maior da amostra), não obstante constarem da avaliação 14 escravos e 26 imóveis rurais e urbanos. Metade coube à viúva e a outra metade, dividida pelos 5 herdeiros.

Consta no processo que no dia 27 de setembro de 1867, tendo a viúva a posse dos livros de contabilidade da empresa do falecido, reuniu-se com seu filho João Ferreira de Aguiar e Silva e com seu genro Tristão Augusto dos Santos Carneiro e criaram a Viúva

\footnotetext{
${ }^{205}$ MHAI, caixa n. ${ }^{\circ} 86$.
} 
Ferreira Aguiar \& Filhos, cabendo a ela a responsabilidade da liquidação da extinta firma do inventariado José Ferreira de Aguiar e Silva, procedendo à cobrança de seu ativo e à solução do passivo e reforma das obrigações. Desta ação obteve-se Rs. 121:031\$655, sendo, entre outras fontes, Rs. 20:500\$515 pelas contas de livro e Rs. 21:051\$120 pelas obrigações e títulos com hipoteca com prêmios contados até 31 de agosto de 1877 e, com o novo nome da firma comercial, reformaram outros débitos no valor de Rs. 50:516\$680 perfazendo o total de Rs. 175:118 \$205. Excluídas as despesas, restariam Rs. 150:501\$245, tocando a cada herdeiro Rs. 15:050\$134, parte reclamada por Antonio Ferreira Aguiar. O processo também transcreve os livros de contas recebidas, créditos e contas correntes liquidadas ou renegociadas desde 1867 até 1877, somando 467 registros de diferentes modalidades de crédito. Ora, das dívidas ativas computadas em fins da década de 1860, após 10 anos, apenas 22\% dos créditos foram recuperados em dinheiro ou em espécie, sugerindo não apenas um elevado nível de inadimplência entre os devedores como a própria fragilidade do sistema de crédito.

Em 1861, o comerciante e remetente de arroz João Francisco Mendes, estabelecido no Porto da Ribeira, abriu inventário por falecimento de sua esposa. Entre os bens constavam as dívidas ativas em conta de livro e créditos, que somavam Rs. 2:431\$568 e mercadorias avaliadas em Rs. 1:100:000. As diversas dívidas passivas acumuladas perante credores locais e do Rio de Janeiro totalizavam Rs. 9:263\$180, ${ }^{206}$ muito mais do que sua riqueza bruta, Rs. 6:698\$500 ou $£$ 713. Todos os seus bens foram arrematados, incluindo três escravos, as mercadorias e as dívidas ativas, rendendo os dois últimos, respectivamente, Rs. 550\$000 e Rs. 500\$000, desvalorizados para que a arrematação pudesse ter efeito. As dívidas ativas foram vendidas por $20 \%$ do valor nominal, percentual bastante próximo daquele observado no caso anterior. $^{207}$

Dois anos depois, faleceu o também comerciante xiririquense José Gonçalves Pontes, estabelecido na Rua da Praia. A riqueza bruta estimada com base no inventário, £ 904, compunha-se principalmente por um rol de 237 devedores, representando praticamente $80 \%$ do montante. Por solicitação da viúva, a arrematação das dívidas ativas, adquiridas por José Ferreira de Aguiar e Silva, que recebia o arroz remetido por Pontes para Iguape, rendeu $£ 93$ ou pouco mais de $10 \%$ do seu valor nominal. ${ }^{208}$

\footnotetext{
${ }^{206}$ Os maiores credores eram João Mâncio da Silva Franco, de Iguape (29\%), e as firmas cariocas Jorge, Mâncio \& Pereira (21\%) e Guedes, Silva \& Cia (28\%).

${ }^{207}$ MHAI, caixa n. ${ }^{\circ} 195$.

${ }^{208}$ FEP, caixa n. ${ }^{\circ} 38$.
} 
No dia oito de outubro de 1864, Ana Felícia Pereira, por seu procurador Joaquim Dias da Silva Martins, exigia providências quanto ao fato de seu genro, o comerciante Manoel Cardoso Pires, não ter providenciado abertura de inventário dos bens por falecimento de sua filha, que fora casada com Manoel, na qualidade de única e universal herdeira. Os bens avaliados somavam $£ 625$ e, descontadas as dívidas passivas, restava como riqueza líquida $£$ 182, sendo $£ 108$ créditos a receber. Em certo momento do processo, argumentou o procurador da mãe da falecida, em observação à pretensão do inventariante em manter a casa comercial com os recursos recebidos após a partilha:

Terá pois o inventariante e legatário na sua folha de partilha o valor supra [Rs. 424\$516] ainda sujeitos às custas dos processo e dedução da taxa que lhe deixará reduzido aquela quantia em menos da metade; e será com um tão insignificante valor que talvez só possa tocar em dívidas quase no seu total incobráveis que o inventariante desagravará seu futuro? Negociar no estado atual de Iguape e pagar dívidas passivas, se isso the fosse permitido, aqui negamos, com o valor de uma tão insignificante quantia a prêmio de $1 \%$ ao mês? Se a Justiça se levasse por comoções patéticas, ninguém teria melhor direito que o inventariante. ${ }^{209}$

Praticamente todos os exemplos citados datam do terceiro subperíodo por nós estipulado, aqui caracterizado como de estagnação da economia ribeirense. Mesmo assim, as atividades comerciais atraíam um número considerável de pessoas. Em 1836, Iguape possuía 84 chefes de domicílios identificados como negociantes e outros 12 estavam presentes em Xiririca. Em 1855, a Mesa de Rendas de Iguape coletou tributos sobre 65 estabelecimentos comerciais abertos exclusivamente na área urbana de Iguape e 27 também recolheram os impostos em Xiririca. Em 1868, os números atingiam, respectivamente, 83 e 24 unidades. $^{210}$

Tais casos sugerem que o valor real efetivo da riqueza acumulada por comerciantes possivelmente não correspondia aos resultados apresentados nos Gráficos 4.1 e 4.2, os quais mostram-se inequivocamente superestimados. A nosso juízo impõe-se, pois, a necessidade de uma revisão desses montantes. Dessa forma, uma redução de $50 \%$ nos valores das dívidas ativas $^{211}$ - que, pelos casos acima expostos, pode ser considerado um corte conservador consolida a diferença entre a riqueza bruta média de comerciantes e proprietários de engenho nas duas primeiras fases ( $£ 582$ e $£ 1.202$ entre 1800 e 1840 e $£ 710$ e 1.130 entre 1841 e 1860 ) e comprime o valor, entre os primeiros, de $£ 2.548$ para $£ 1.806$ no último período, ao passo que entre os proprietários de engenho, a média se move de $£ 937$ para $£ 887$.

\footnotetext{
${ }^{209}$ MHIA, caixa n. ${ }^{\circ} 122$.

210 AESP, Livros de Sisa, ordem n. 8.414 a 8.416.Em 1868, incluso casas comercias nas áreas rurais e freguesias. Entre as causas das diferenças observadas na lista nominativa de 1836 e os registros de sisa, a natureza das fontes deve pesar significativamente, pois a primeira não possuía o caráter tributário da segunda.

211 Aplicamos a redução para as duas atividades econômicas, pois, em nossa amostra, a presença de dívidas ativas mostrava-se generalizada, ocorrendo em maior ou menor grau e intensidade consoante a ocupação do inventariado.
} 
Ao operarmos a redução acima, impõe-se de imediato a constatação de que o conjunto de comerciantes - principalmente no terceiro intervalo por nós considerado - que parecia descolado do esgotamento das práticas rizicultoras as quais definiam-se como dominantes no âmbito da economia regional, na verdade também foi afetado pela perda de dinamismo que se abateu sobre a produção do arroz durante a segunda metade do século XIX, como bem mostra a redução dos valores médios da riqueza bruta por eles detida. A riqueza possuída pelos proprietários de engenho também se viu abalada, porém em menor escala, pois, como enfatizado no corpo deste trabalho, estes últimos acumulavam parcelas reduzidas de sua riqueza na forma de dívidas ativas. Se tomarmos como indicador a riqueza mediana, a aplicação do redutor não afeta o valor concernente aos proprietários de engenho nos dois primeiros subperíodos ( $£ 488$ e $£$ 607, respectivamente), porém passa de $£ 644$ para $£ 581$ no último intervalo. No caso dos comerciantes, a redução ocorre em todos os subperíodos: de $£$ 518 para $£ 407$ entre 1800 a 1840, de $£ 425$ para $£ 345$ no subperíodo seguinte e de $£ 967$ para £ 792 no intervalo entre 1861 a 1880 .

Mesmo assim, é inegável a primazia dos comerciantes sobre os proprietários de engenho a partir da década de 1860. Os resultados apresentados na Tabela 4.5 evidenciam este predomínio. A aglomeração ali apresentada utiliza parâmetros oferecidos pelos próprios inventários. Dessa forma, tomamos as participações relativas de escravos, bens de raiz (rural e urbanos isoladamente) e dívidas ativas ${ }^{212}$ na riqueza bruta, assim como o comprometimento da riqueza bruta com as dívidas passivas, sempre com os valores em libras. ${ }^{213}$ Através de um procedimento de análise multivariada optamos pela conformação de 5 agrupamentos, onde privilegiamos os valores médios e medianos da riqueza bruta e riqueza líquida. ${ }^{214}$

\footnotetext{
${ }^{212}$ Utilizamos os valores originais.

${ }^{213}$ Excluímos 3 inventários que possuíam dívidas passivas muito superiores à riqueza bruta.

${ }^{214}$ Utilizamos a técnica multivariada conhecida com "K-means" ou "K-médias", cujo algoritmo permite o agrupamento de dados a partir de medidas de similaridades. Nesta técnica, o número de grupos é determinado $a$ priori e as distâncias são computadas através de distâncias Euclidianas simples.
} 
Tabela 4.5

Indicadores de tendência central da riqueza bruta e riqueza líquida de proprietários de engenho e comerciantes

(Iguape e Xiririca, 1800-1880)

\begin{tabular}{|c|c|c|c|c|c|c|c|c|c|}
\hline & \multirow{3}{*}{ Agrupamentos } & \multicolumn{8}{|c|}{ Faixas anuais } \\
\hline & & \multicolumn{2}{|c|}{$1800-1840$} & \multicolumn{2}{|c|}{$1841-1860$} & \multicolumn{2}{|c|}{ 1861-1880 } & \multicolumn{2}{|c|}{ total } \\
\hline & & $\begin{array}{c}\text { riqueza } \\
\text { bruta }\end{array}$ & $\begin{array}{l}\text { riqueza } \\
\text { líquida }\end{array}$ & $\begin{array}{c}\text { riqueza } \\
\text { bruta }\end{array}$ & $\begin{array}{l}\text { riqueza } \\
\text { líquida }\end{array}$ & $\begin{array}{c}\text { riqueza } \\
\text { bruta }\end{array}$ & $\begin{array}{l}\text { riqueza } \\
\text { líquida }\end{array}$ & $\begin{array}{c}\text { riqueza } \\
\text { bruta }\end{array}$ & $\begin{array}{l}\text { riqueza } \\
\text { líquida }\end{array}$ \\
\hline \multirow{4}{*}{ Grupo 1} & inventários & 3 & 3 & 6 & 6 & 5 & 5 & 14 & 14 \\
\hline & riqueza média (£) & 322 & 238 & 550 & 528 & 1.311 & 1.184 & 773 & 700 \\
\hline & desvio-padrão & 253 & 189 & 531 & 542 & 780 & 761 & 698 & 671 \\
\hline & riqueza mediana $(£)$ & 412 & 264 & 358 & 294 & 1.581 & 1.421 & 465 & 375 \\
\hline \multirow{4}{*}{ Grupo 2} & inventários & 4 & 4 & 16 & 16 & 12 & 12 & 32 & 32 \\
\hline & riqueza média ( $£$ ) & 489 & 24 & 317 & -42 & 459 & -27 & 392 & -28 \\
\hline & desvio-padrão & 599 & 117 & 257 & 65 & 301 & 147 & 324 & 107 \\
\hline & riqueza mediana $(£)$ & 225 & 34 & 272 & -26 & 454 & -18 & 354 & -19 \\
\hline \multirow{4}{*}{ Grupo 3} & inventários & 3 & 3 & 6 & 6 & 13 & 13 & 22 & 22 \\
\hline & riqueza média ( $($ ) & 905 & 876 & 786 & 601 & 301 & 234 & 516 & 421 \\
\hline & desvio-padrão & 717 & 736 & 769 & 654 & 250 & 240 & 544 & 497 \\
\hline & riqueza mediana $(£)$ & 1.148 & 1.105 & 433 & 271 & 220 & 172 & 316 & 254 \\
\hline \multirow{4}{*}{ Grupo 4} & inventários & 20 & 20 & 37 & 37 & 40 & 40 & 97 & 97 \\
\hline & riqueza média ( $£$ ) & 1.114 & 1.033 & 1.342 & 1.219 & 1.199 & 1.065 & 1.236 & 1.117 \\
\hline & desvio-padrão & 1.742 & 1.706 & 1.720 & 1.742 & 893 & 860 & 1.429 & 1.422 \\
\hline & riqueza mediana $(£)$ & 471 & 432 & 750 & 609 & 992 & 867 & 847 & 745 \\
\hline \multirow{4}{*}{ Grupo 5} & inventários & 11 & 11 & 16 & 16 & 22 & 22 & 49 & 49 \\
\hline & riqueza média (£) & 1.533 & 1.462 & 1.552 & 1.245 & 3.893 & 3.492 & 2.599 & 2.303 \\
\hline & desvio-padrão & 1.503 & 1.466 & 1.951 & 1.649 & 5.994 & 5.510 & 4.333 & 3.970 \\
\hline & riqueza mediana $(£)$ & 816 & 652 & 760 & 504 & 1.331 & 1.068 & 966 & 816 \\
\hline
\end{tabular}

Apresentados em ordem hierarquia, os representantes do Grupo 5 constituem o topo da estrutura econômica ribeirense, não apenas pela manutenção da elevada riqueza média em relação ao conjunto como pelo expressivo destaque no último subperíodo. No entanto, como concentram a maior parcela da riqueza em dívidas ativas, tal posicionamento requer um cuidado maior em sua interpretação, pois como sugerimos anteriormente, parte dessas dívidas ativas não representavam valor algum. Os inventários que compõem o Grupo 4, que apresentam valores médios e medianos menores do que o antecessor, praticamente compartilham a posição de destaque, porém com riqueza constituída por escravos e bens de raiz, isto é, principalmente os proprietários de engenho com maiores posses. O pequeno Grupo 3 agrega pequenos comerciantes com riqueza bruta crescente ao longo do tempo. O 
Grupo 4 representa os proprietários de engenho com menor nível de riqueza, determinada principalmente pelas propriedades rurais e o Grupo 3 agrega os mais endividados de ambas as atividades econômicas. Apresentamos na seqüência uma caracterização mais detalhada de cada um dos grupos.

Grupo 1 - Agrega inventários principalmente de comerciantes que possuíam peso desproporcional para os bens de raiz urbanos (57\% da riqueza bruta, em média) e pequeno valor em dívidas ativas (10\%) e em escravos (20\%, sendo 4 não-escravistas). ${ }^{215}$ Os dois indicadores de tendência central, tanto para a riqueza bruta como para a riqueza líquida evidenciam um aumento significativo da riqueza, principalmente no terceiro subperíodo. Nesse grupo encontramos o comerciante de secos e molhados Antonio Dias Teixeira, falecido em 1869. ${ }^{216}$ Natural de Portugal, a riqueza bruta de Teixeira somava $£ 2.016$, divididas em bens de raiz (42\%), dívidas ativas (22\%), dinheiro (16\%), escravos (5\%) e bens móveis e mercadorias (5\%); suas dívidas passivas representavam $12 \%$ da riqueza bruta, reduzindo a riqueza líquida para £ 1.779 .

Entre os seus credores encontramos apenas uma casa comercial no Rio de Janeiro e os demais residentes em Iguape, inclusive duas escravas de Tereza de Mendonça. Além das atividades comerciais, evidenciadas pela presença dos tecidos de algodãozinho, chita, morim, riscado, zuarte, linhas, lenços, louças, talheres, aguardente, vinho, vinagre, azeite, carne seca, açúcar, toucinho, sabão, bem como pela longa lista de devedores em conta de livro, completava a renda deste português o aluguel dos bens urbanos. As 23 dívidas ativas representavam 53\% dos créditos, complementadas pelos 278 registros de conta de livro. Além de dinheiro amoedado, Teixeira possuía valores monetários em poder de duas casas comerciais fluminenses e na arrendatária do transporte marítimo Mendes Filho \& Lemos. Ainda possuía 157 alqueires de arroz em casca distribuídos em três diferentes engenhos de Iguape. Provavelmente a captação do cultivo em casca e o processamento em engenhos de terceiros expliquem as 89 remessas feitas entre 1839 e 1865, totalizando 1.570 sacos.

Grupo 2 - Encontramos aqui 11 proprietários de engenho e 21 comerciantes. O elevado endividamento constitui a principal característica deste grupo (113\% da riqueza bruta, em média), como também evidencia a diferença entre os valores médios e medianos da riqueza bruta e riqueza líquida. Notamos que, no conjunto, os 32 casos possuíam as menores

\footnotetext{
${ }^{215}$ Há um único caso de proprietária de engenho, Inácia Pereira, falecida em 1840, cujo inventariante foi o viúvo Inácio da Silva Moreira, um não-proprietário de escravos. O engenho e terras em Jacupiranga foi avaliado em Rs. 500\$000, mesmo valor da morada de casas em Iguape. A riqueza bruta somava $£ 132$ (MHAI, caixa n. $^{\circ} 127$ ). ${ }^{216}$ MHAI, caixa n. ${ }^{\circ} 71$.
} 
riquezas brutas, tanto em seu valor médio como mediano. A este grupo de apoucadas posses, a importância das dívidas passivas ganha uma dimensão especial atingindo, em média, 32\% da riqueza bruta. Ademais, entre os casos que pudemos reconhecer a idade, os inventariados deste grupo apresentavam a menor idade média ao falecer (45 anos para 14 falecidos contra 57 anos nos demais 117 inventariados), sugerindo que o endividamento pudesse estar associado com a fase de expansão do patrimônio.

Manoel Bento de Andrada faleceu com idade um pouco mais elevada do que a média do grupo, provavelmente 54 anos, em $1861 .{ }^{217}$ O inventário, aberto no mesmo ano, informanos que sua riqueza bruta somava $£$ 644, principalmente em escravos (62\%), dívidas ativas (30\%), bens de raiz e móveis (3\% cada), no entanto as dívidas passivas somavam $£$ 802, resultando daí a riqueza líquida negativa igual a $£$ 158. Manoel possuía um engenho de arroz no rio Una, divisa com Antonio Borges Diniz e Ricardo Pinto, avaliado em 2,4 contos de réis, além de uma pequena casa no Porto da Ribeira, valorada no inventário a Rs.50\$000. Acreditamos que as 37 dívidas de conta de livro se relacionavam com as atividades de processamento de arroz e transporte até o Porto da Ribeira, local onde Manoel deveria estocálo para posterior transporte até o Porto Grande, ${ }^{218}$ assim como com a venda de produtos da pequena olaria instalada em sua propriedade. Além da conta de livro, verificamos a existência de 15 créditos fornecidos, com valor médio superior ao rol de contas (Rs. 89\$566 e Rs. 14\$303, respectivamente). Manoel possuía 6 escravos, porém 4 deles com menos de 15 anos.

Em 1836, Manoel Bento, 29 anos, ainda residia com o pai Antonio Bento de Andrada, proprietário de 10 escravos, entre eles Caetano, um negrinho de 6 anos e que no inventário de Manoel foi identificado com 35 anos e provavelmente compunha família com Maria, 35 anos, pais dos escravos mais jovens. Ao falecer, Antonio devia a 12 credores, todos de Iguape. Sua maior dívida, 4,5 contos de réis, pertencia a João Mâncio da Silva Franco, porém o inventário não traz especificações sobre sua natureza. Outras 4 dívidas superavam cem mil-réis, incluso valores a seu pai e a seu irmão, além do comerciante Antonio de Magalhães Mesquita e a seu vizinho Antonio Borges Diniz.

O caso do comerciante Antonio Carlos de Toledo ganha especial interesse por se tratar do único negociante preto instalado em Iguape. Na lista nominativa de 1836, morava na vila de Iguape com outros dois agregados e possuía uma renda anual de Rs. 300\$000. Antonio faleceu em 1841, com cerca de 35 anos e o inventário foi aberto por solicitação dos credores, tendo como inventariante a viúva Rita Maria de Souza, outrora uma das agregadas ao fogo. A

\footnotetext{
${ }^{217}$ MHAI, caixa n. ${ }^{\circ} 224$.

${ }^{218}$ Manoel realizou 38 remessas de arroz entre 1837 e 1857, totalizando 828 sacos de arroz.
} 
riqueza bruta inventariada atingia $£ 297$, repartidas entre bens de raiz (13\%), escravos (50\%) e dívidas ativas (34\%), porém as dívidas passivas atingiam $£ 337 .^{219}$

Aparentemente Antonio Carlos buscava diversificar suas atividades, pois no inventário não há avaliação de mercadorias, porém encontramos ferramentas de construção e acompanhava na avaliação de um de seus três escravos a anotação “oficial pedreiro”. Outro indicativo da mudança de atividade era a presença de três terrenos na vila, talvez destinados a futuras construções. Em seu único bem de raiz rural, no rio Una, Antonio mantinha o cultivo de mandioca e arroz e 65 pessoas constavam em sua conta de livro, provavelmente resultado de ambas atividades. Por fim, entre as dívidas passivas encontramos dois créditos, um fornecido por José Bonifácio de Andrada no valor de pouco mais de 1 conto de réis e outro a Antonio Tertuliano dos Santos, do Rio de Janeiro, equivalente a cerca de 750 mil-réis, provavelmente resultado da aquisição dos escravos. Constam ainda outras dívidas por conta de livro e uma a um credor fluminense chamado José Joaquim Machado, também por conta de livro. A pedido dos credores, alguns bens passaram por reavaliação para ajuste do preço com fins de permitir a arrematação em praça pública. Assim, o sítio, inicialmente avaliado por Rs. $200 \$ 000$, foi reformado por Rs. $150 \$ 000$; os três terrenos passaram de Rs. $150 \$ 000$ para Rs. $80 \$ 000$.

Grupo 3 - alinham-se exclusivamente proprietários de engenho e agrega inventários utilizando como critério o maior peso relativo dos bens de raiz rurais, com riqueza bruta em torno de 71\%, em média, pequena parcela em escravos (11\%, sendo 12 não-escravistas) e poucas dívidas ativas (4\%, em média). A proximidade dos valores médios e medianos em cada subperíodo e o menor desvio-padrão sugere uma relativa homogeneidade e os valores em si evidenciam o empobrecimento relativo deste subconjunto nas duas décadas finais do período aqui estudado. Por outro lado, não verificamos diferenças expressivas entre a riqueza bruta e a riqueza líquida nestes casos: o comprometimento médio das dívidas passivas manteve-se em torno de $27 \%$. Neste conjunto encontramos alguns dos casos que iremos detalhar mais adiante, como alguns representantes da família Lopes Trigo (José, Joaquim e Agostinho) e Antonio José Peniche.

Destacamos aqui o inventário de Narcisa Dias Baptista, aberto em 1824, que bem ilustra os membros deste grupo. Em 1801 encontramos Narcisa, viúva, 51 anos, moradora na Enseada, chefiando um fogo com 7 filhos, 9 escravos e 2 agregados. Em 1789, encabeçava o domicílio o seu marido Joaquim Antonio Gomes, 44 anos e Narcisa possuía 42 anos. Naquele

\footnotetext{
${ }^{219}$ MHAI, caixa n. ${ }^{\circ} 100$.
} 
ano Joaquim possuía 7 escravos. Pudemos identificar apenas 3 escravos comuns às duas listas. A lista de 1789 não fornece a ocupação exercida pelo chefe do fogo, porém em 1801 consta a anotação: “planta para comer e vende 20 alqueires de farinha”. Em 1815, Narcisa, 63 anos, viúva, lavradora, continuava a chefiar o fogo. Dos filhos, apenas José ainda coabitava o fogo, que contava com 9 escravos e 3 agregados. Dos 9 cativos, pelo menos 4 também constavam na lista de 1801.

Entre os escravos avaliados no inventário de Narcisa, todos os 6 adultos já pertenciam ao plantel registrado em 1815, os 5 demais possuíam idades inferiores a 12 anos. Parece razoável aceitar que a posse de Narcisa manteve-se ao longo do primeiro quarto da centúria praticamente através da reprodução natural dos cativos. A escravaria avaliada respondia por $20 \%$ da riqueza bruta, $£ 1.148$. Cerca de $72 \%$ da riqueza correspondia aos bens de raiz, principalmente os rurais. O principal correspondia a uma morada de casas coberta de telhas com paredes de pedra e cal e engenho de pilar arroz na mesma com 12 mãos e uma cachoeira de água que joga no mesmo engenho abaixo desta vila com uma sorte de terras que principia da parte de cima de uma pedra chamada Itaguá e da parte de baixo no lugar denominado Pocinho com pasto de gado e mais pertences, ${ }^{220}$ avaliado por 3,2 contos de réis.

Além dessa propriedade, constavam ainda um sitio com casa de morada na Enseada e uma morada de casas na rua da Glória, o primeiro avaliado por Rs. $500 \$ 000$ e a segunda por Rs. 450\$000. Acreditamos que, pelo menos até 1801, Narcisa e seus filhos ocupavam a propriedade na Enseada e posteriormente incorporaram a propriedade do Itaguá, porém não é possível determinar se esta foi empreendimento de Narcisa ou se ela já existia previamente. A única referência posterior que encontramos sobre esta propriedade diz respeito a um registro de pagamento de sisa, em 1861, relacionado com a venda de um terço do engenho feita por João Batista da Silva Carneiro a Florinda Maria de Jesus por um conto de réis.

As ruínas do Itaguá ainda hoje podem ser observadas em uma área próxima ao núcleo urbano de Iguape. O inventário de sítios arqueológicos na faixa litorânea de Iguape realizado por Cleide Franchi mapeou a existência de mais de duas dezenas de propriedades com evidências de construções que possivelmente possuíam também instalações para o funcionamento de engenhos de arroz. Em praticamente todos os casos, a autora verificou

(...) as possibilidades do uso das vertentes de água para movimentação das rodas que moviam as mãos do pilão. Essas rodas, de acordo com as informações orais, eram implantadas ao lado das construções, ficando ao ar livre. Podemos ver (...) que em quase todas as ruínas com presença de pilares que vão em direção ao morro (sempre acompanhando uma vertente) se alinham paralelamente a uma das paredes laterais da

\footnotetext{
${ }^{220}$ MHAI, caixa n. ${ }^{\circ} 99$.
} 
construção em ruínas. ${ }^{221}$

Construções deste tipo provavelmente agregavam valor aos bens de raiz, justificando assim a existência do agrupamento.

Grupo 4 - Reúne o maior número de inventários: 78 proprietários de engenho e 19 comerciantes. As características comuns a estes casos residem na preponderância dos escravos na composição da riqueza (53\%, em média) e menores valores relativos dos bens de raiz rurais (cerca de $24 \%$ ), além de baixo endividamento (16\%). No entanto, se tomados os indicadores de riqueza, notamos uma elevada dispersão em torno do valor médio e, pelo menos nos dois primeiros subperíodos, uma diferença considerável entre o valor médio e o mediano. Encontramos aqui o maior grau de associação entre a riqueza bruta e o número de escravos inventariados. ${ }^{222}$ Nesse sentido, é possível interpretarmos os dados em arranjos estratificados segundo o tamanho da posse de escravos, como mostra a tabela seguinte.

Tabela 4.6

Indicadores de tendência central da riqueza bruta e riqueza líquida de proprietários de engenho e comerciantes do Grupo 4 segundo faixas de tamanho dos plantéis

(Iguape e Xiririca, 1800-1880)

\begin{tabular}{|c|c|c|c|c|c|c|c|c|c|}
\hline \multirow{3}{*}{\multicolumn{2}{|c|}{ Faixas de tamanho dos plantéis }} & \multicolumn{8}{|c|}{ Faixas anuais } \\
\hline & & \multicolumn{2}{|c|}{$1800-1840$} & \multicolumn{2}{|c|}{$1841-1860$} & \multicolumn{2}{|c|}{ 1861-1880 } & \multicolumn{2}{|c|}{ total } \\
\hline & & $\begin{array}{c}\text { riqueza } \\
\text { bruta }\end{array}$ & $\begin{array}{l}\text { riqueza } \\
\text { líquida }\end{array}$ & $\begin{array}{c}\text { riqueza } \\
\text { bruta }\end{array}$ & $\begin{array}{l}\text { riqueza } \\
\text { líquida }\end{array}$ & $\begin{array}{c}\text { riqueza } \\
\text { bruta }\end{array}$ & $\begin{array}{l}\text { riqueza } \\
\text { líquida }\end{array}$ & $\begin{array}{l}\text { riqueza } \\
\text { bruta }\end{array}$ & $\begin{array}{l}\text { riqueza } \\
\text { líquida }\end{array}$ \\
\hline \multirow{4}{*}{1 a 4} & inventários & 4 & 4 & 9 & 9 & 7 & 7 & 20 & 20 \\
\hline & riqueza média $(£)$ & 99 & 78 & 346 & 274 & 586 & 516 & 380 & 319 \\
\hline & desvio-padrão & 69 & 63 & 140 & 139 & 341 & 365 & 280 & 280 \\
\hline & riqueza mediana $(£)$ & 99 & 84 & 351 & 246 & 495 & 378 & 333 & 241 \\
\hline \multirow{4}{*}{5 a 9} & inventários & 4 & 4 & 6 & 6 & 16 & 16 & 26 & 26 \\
\hline & riqueza média ( $($ ) & 419 & 289 & 472 & 386 & 765 & 652 & 644 & 535 \\
\hline & desvio-padrão & 64 & 138 & 144 & 190 & 399 & 412 & 353 & 367 \\
\hline & riqueza mediana $(£)$ & 421 & 297 & 443 & 377 & 614 & 483 & 521 & 436 \\
\hline \multirow{4}{*}{10 a 19} & inventários & 8 & 8 & 12 & 12 & 14 & 14 & 34 & 34 \\
\hline & riqueza média ( $($ ) & 828 & 766 & 1.114 & 939 & 1.622 & 1.464 & 1.256 & 1.114 \\
\hline & desvio-padrão & 419 & 417 & 462 & 503 & 704 & 749 & 642 & 659 \\
\hline & riqueza mediana $(£)$ & 843 & 843 & 990 & 913 & 1.490 & 1.238 & 1.143 & 1.038 \\
\hline \multirow{4}{*}{20 ou mais } & inventários & 4 & 4 & 10 & 10 & 3 & 3 & 17 & 17 \\
\hline & riqueza média (£) & 3.399 & 3.267 & 3.035 & 2.905 & 2.975 & 2.685 & 3.110 & 2.951 \\
\hline & desvio-padrão & 3.100 & 3.033 & 2.606 & 2.679 & 1.398 & 1.280 & 2.428 & 2.451 \\
\hline & riqueza mediana $(£)$ & 2.488 & 2.306 & 2.315 & 1.996 & 3.286 & 2.625 & 2.701 & 2.171 \\
\hline
\end{tabular}

${ }^{221}$ FRANCHI, 1999, p. 145.

${ }^{222}$ O coeficiente de correlação de Pearson igualou-se a 0,888. No Grupo 3 verificamos também uma forte associação $(0,790)$, assim como no Grupo 5 (0,611). Os dois primeiros grupos apresentaram fraca associação (0,432 e 0,553, respectivamente). 
Na primeira faixa de posse encontramos $11 \%$ dos proprietários de engenho e $47 \%$ dos comerciantes. Entre estes pequenos proprietários é possível perceber os efeitos da valorização dos escravos a partir da década de 1840, tanto através da riqueza média como da mediana, que apresentaram um expressivo aumento nos dois últimos subperíodos. Esta tendência diminui nas faixas intermediárias e desaparece no grupo de maior posse cativa, sugerindo a importância relativa dos demais grupos de bens na composição da riqueza, em especial as propriedades rurais. A riqueza destes maiores escravistas mostra-se mais heterogênea, como indica o elevado desvio-padrão. Agrupam-se nesta faixa de posse casos já citados, como Bartolomeu da Costa Almeida Cruz (com riqueza bruta igual a $£$ 7.758), Francisco Carneiro da Silva Braga (£ 9.822) e outros não citados, como Francisco Augusto de Oliveira Muniz ( $£$ 4.192), Rita Joaquina Junqueira, casada que foi com Antonio Francisco Gonçalves ( $£$ 3.453) e João Pinto de Faria ( $£$ 870, a menor do grupo).

Grupo 5 - Agrega riquezas com maior ponderação para as dívidas ativas (56\%), pequena parcela em escravos (13\%) e com maior peso para as propriedades urbanas (11\%) do que as rurais (8\%), contando com 6 proprietários de engenho e 43 comerciantes. Pelos resultados da Tabela 4.5, notamos que nos dois primeiros subperíodos os valores médios se mantêm relativamente próximos aos do grupo antecessor, porém no terceiro subperíodo há um acentuado distanciamento, principalmente do valor médio, porém com dispersão desproporcional em relação aos anos anteriores. Assim como no Grupo 4, os membros deste grupo possuíam pequeno comprometimento da riqueza bruta com dívidas passivas, cerca de 20\%, em média.

Entre os proprietários de engenho, destacamos o caso de Bento Pupo de Gouveia, falecido em 1832 e com inventário aberto em janeiro do ano seguinte. Filho de João Pupo de Gouveia, que em 1765 chefiava uma das Companhias de Ordenanças de Iguape, em 1778 Bento, 22 anos, possuía um escravo chamado Alexandre, de 23 anos. Em 1789, com 38 anos, solteiro, Bento possuía a patente de capitão e mantinha Alexandre como seu único escravo. Em 1801, já com 50 anos, Bento aparece casado com Joaquina Maria, 24 anos, natural de Paranaguá, com quem tivera três filhos. Além de Alexandre, seu plantel possuía mais 13 escravos, incluindo dois carpinteiros e um pedreiro. Informava o recenseador que Gouveia era “comerciante de fazenda seca, plantava para comer, tem parte de embarcações e ganhava com o jornal de escravos”. Em 1815, aos 65 anos, Bento ainda mantinha seu negócio de fazendas secas e possuía 22 escravos.

$\mathrm{Na}$ lista de 1828, Bento aparece com 77 anos e sua posse atingia 33 cativos. Esta lista não oferece a atividade do chefe de domicílio, mas aparentemente Bento já não possuía a casa 
comercial quando faleceu, quatro anos depois, pois não encontramos mercadorias avaliadas em seu inventário. No entanto, possuía metade da sumaca “Aurolinda”, avaliada em um conto de réis. Ademais, as dívidas ativas acumuladas representavam $41 \%$ da riqueza bruta, que atingia $£$ 4.895. As contas de livro representavam $24 \%$ desse valor, cabendo aos créditos o restante das $£$ 2.025. Bens de raiz e escravos ocupavam posições semelhantes na composição da riqueza, com $25 \%$ e $23 \%$, respectivamente. Sobre o primeiro grupo de bens, a maior parte concentrava-se nas 16 propriedades urbanas em Iguape e em apenas 5 bens de raiz rurais, inclusive 80 braças de terras com casa assobradada e engenho de arroz no Porto da Ribeira. O segundo era composto por 44 escravos, isto é, um acréscimo de um terço em relação à quantidade declarada 4 anos antes. Pelo menos 4 destes escravos possuíam qualificação para o trabalho, sendo um pedreiro, um sapateiro e dois alfaiates. ${ }^{223}$

Pelo conjunto, nota-se que a classificação de Bento como proprietário de engenho não dá conta das múltiplas formas de atuação deste iguapense. É possível imaginar que sua morte propiciou a alavancagem de outros negociantes - temos em mente o caso já descrito de José Jacinto de Toledo, que aparentemente operava no mercado iguapense da mesma forma de Gouveia. Em 1836 não encontramos a viúva, falecida neste ano; dos sete herdeiros, localizamos Antonio Feliciano Pupo, lavrador e proprietário de 28 escravos; Joaquim Pio Pupo, negociante, detentor de dois cativos e Maria das Dores Bruna (ou Buena), viúva, senhora de 8 escravos e que vivia de agências. Nota-se que da partilha dos bens, coube a Joaquim a parte referente aos negócios mercantis e a Antonio a manutenção das práticas agrícolas empreendidas pelo pai. No entanto, não encontramos valores expressivos nas remessas de arroz realizadas por ambos, sugerindo que os herdeiros de Bento não conseguiram manter o mesmo ritmo imposto pelo pai na condução dos negócios.

Entre os comerciantes pertencentes ao Grupo 5, destacamos os casos já mencionados de Rafael Descio, José Ferreira da Silva, José Bonifácio de Andrada e Silva, José Ferreira de Aguiar e Silva e outros que ainda iremos enfocar, como Francisco Carneiro da Silva Braga Filho e João Mâncio da Silva Franco.

Os casos citados acima, por mais que tenhamos nos esforçado no sentido de resgatar alguns informes acerca dos agentes em outras fontes, representam uma seqüência desconectada do grupo de convivência. Nesse sentido, nas páginas seguintes apresentamos a trajetória de algumas famílias estreitamente vinculadas às duas atividades econômicas. Buscamos revelar como os agricultores passaram a ocupar uma posição secundária na cadeia

\footnotetext{
${ }^{223}$ MHAI, caixa n. ${ }^{\circ} 37$.
} 
produtiva ribeirense, permitindo aos demais emergirem na economia local como os principais beneficiários, pelo menos em valores nominais, da estagnação que se abateu na região a partir da segunda metade do século XIX. De antemão, advertimos que estas trajetórias não se revelaram lineares e que não conseguimos isolar casos “ideais”. As pistas aqui indicadas sugerem aproximações, como não poderia deixar de ser através da metodologia proposta, que é o acompanhamento intergeracional da gestão dos recursos acumulados (e perdidos) ao longo dos 80 anos aqui estudados.

\section{Estritos proprietários de engenho de arroz}

Lourenço Lopes Trigo representa mais do que a primeira geração de proprietários de engenho de arroz. Estabelecido em Iguape pelo menos desde 1789, então com 55 anos, este português natural do Porto vivia com a mulher Escolástica Gonçalves, quatro filhos e oito escravos. A julgar pela idade da filha mais velha, Lourenço estabeleceu-se em Iguape em meados da década de 1770, porém não encontramos seu registro na lista de 1778, que arrolava apenas os proprietários de escravos. Seu sogro, Miguel Gonçalves dos Reis constava entre os moradores de Iguape desde 1765, com 35 anos e detentor de 3 escravos. Em 1778, Miguel possuía 8 escravos e, em 1789, com 55 anos, detinha a posse de 5 escravos. Em 1801, Miguel Gonçalves dos Reis vivia no rocio da vila de Iguape, onde cultivava mandioca e produzia 30 alqueires de farinha para venda com o auxílio de 5 escravos.

Devido ao falecimento de sua esposa, Miguel Gonçalves dos Reis abriu inventário aos 12 de setembro de $1807 .{ }^{224}$ A riqueza bruta, avaliada em $£ 166$, concentrava-se em escravos (66\%) e bens de raiz (22\%), porém Miguel fizera doações aos filhos que representavam 73\% de sua riqueza bruta. Através do inventário podemos inferir que, além de mandioca, Miguel cultivava algodão nas terras do rocio da vila de Iguape e que também possuía uma morada de casas na mesma localidade. A única filha que permaneceu na região foi Escolástica, já viúva, enquanto os demais viviam em São Paulo, Viamão e Santa Catarina. Dos quatro escravos avaliados, três constavam na posse arrolada em 1801. No inventário, não há nenhuma referência que possa estabelecer alguma ligação entre Miguel e o cultivo do arroz, sugerindo que o cultivo praticado por Lourenço Lopes Trigo tenha sido induzido pelo sogro.

Em 1801, Lourenço Lopes Trigo, 67 anos, casado com Escolástica Gonçalves, possuía os seguintes filhos: Francisco 22, Manoel 26, Inácio 15; José 13 e Joaquim 9, além de

\footnotetext{
${ }^{224}$ MHAI, caixa n. ${ }^{149 .}$
} 
12 escravos. Duas de suas filhas apareciam compondo outras unidades domiciliares: Ana Maria, 26 anos, esposa do galego Antonio Neves e Tomásia, 19 anos, casada com o açoriano Vitorino José Lopes, ambos agricultores não-escravistas. Nesse ano, Lourenço Trigo aparece identificado como proprietário de engenho de arroz, porém sem nenhum informe sobre a produção agrícola ou comercial do domicílio. Já destacamos que a lista nominativa de 1801 arrolava menos de uma dezena de proprietários de engenho de arroz. Ainda que seja uma contagem subestimada, é inegável sua associação à recente gênese da rizicultura no Vale do Ribeira. Dessa forma, Lopes Trigo representa o perfil pioneiro da nova empreitada na região: imigrante, estabeleceu relações com representantes da classe proprietária de escravos e terras através do matrimônio, caso evidente de seu sogro, o farinheiro Miguel Gonçalves. A descontinuidade em relação às atividades exercidas pelo sogro provavelmente resultou de um conjunto de conhecimentos adquiridos por Lopes Trigo e que deveriam incluir, entre outros, o êxito da nova cultura em outras regiões com mesmas características ambientais e a relativa facilidade de escoamento dos grãos.

O inventário de Lourenço Lopes Trigo, ${ }^{225}$ aberto aos 6 dias de outubro de 1806, totalizava uma riqueza bruta de $£ 1.074$, riqueza sensivelmente maior do que a declarada por seu sogro um ano depois, porém muito próxima do valor médio dos proprietários de engenho no primeiro subperíodo. Os três bens de raiz compunham a maior parte do patrimônio: uma sorte de terras com casa e engenho de pilar arroz, paiol e plantação de café na Ribeira, avaliada em $£$ 350, uma morada de casas na vila de Iguape e 700 braças de terras no rio Paiol, logo abaixo do Porto da Ribeira, totalizando $£$ 433. Além de arroz e café vendidos em Santos, Lopes Trigo comercializava feijão e farinha de mandioca, extraia madeira e utilizava couros de boi para a secagem do arroz, utensílio que nos serviu de guia para auxiliar a identificação das práticas rizicultoras. Para o transporte do arroz, Lourenço utilizava 6 canoas feitas de canela e angelim, outro item constante na maioria dos inventários ribeirenses.

Os 10 escravos somavam $£ 317$ e outros três escravos foram doados junto com outros bens a três herdeiros, cujo valor total atingia $£ 199$. Se comparados aos escravos presentes em 1801, apenas 6 apareciam nas duas listas. Não por acaso, os cativos presentes apenas no inventário eram todos africanos com idade em torno de 20 anos, sugerindo compras recentes feitas por Lopes Trigo.

As 47 dívidas ativas pertencentes a moradores em Iguape e Xiririca somavam $£ 188$ e encontramos alguns escravos e forros. Entre eles, Inácio e Gabriel, escravos jornaleiros de

\footnotetext{
${ }^{225}$ Grupo 4 da Tabela 4.5; MHAI, caixa n. ${ }^{\circ} 50$.
} 
Raimundo Pinto de Almeida, também natural do Porto, morador na mesma região da Ribeira, construtor de embarcações e rizicultor. Também constavam três escravos de um certo Inácio Franco, que não conseguimos localizar nas listas nominativas. A referência ao arroz em alguns casos nos leva a crer que alguns destes créditos decorriam do uso do engenho de arroz para o processamento dos grãos cultivados pelos devedores.

Em 1815 a viúva Escolástica Gonçalves, agricultora, chefiava o domicílio composto pelos filhos Inácio e Joaquim, uma agregada e 15 escravos. Sete deles já constavam no inventário de Lourenço e outros quatro possuíam menos de 10 anos, possivelmente nascidos no interior do plantel de Escolástica. Além do acréscimo no número total de escravos em relação ao total inventariado cerca de 9 anos antes, os outros membros da família também apresentavam sinais inequívocos de prosperidade. O genro Antonio Neves, proprietário de engenho de arroz na Ribeira, possuía 13 escravos e Vitorino José Lopes, lavrador, detinha 19 cativos. O filho José Lopes Trigo, também agricultor, possuía 7 escravos, totalizando assim 54 cativos, quantidade 4,5 vezes maior do que a possuída por Lourenço no início da centúria. ${ }^{226}$ No inventário de terras de 1818, Escolástica declarou três propriedades rurais na Ribeira; o filho José Lopes Trigo também uma posse de terras na Ribeira. Vitorino José Lopes ocupava um lote de 500 braças de frente por 0,5 légua de profundidade no rio Pequeno e Antonio Neves mantinha-se na Ribeira ao lado das terras da sogra.

Nenhum dos Lopes Trigo aparece nas listas de movimento do porto como importadores de mercadorias; o genro Vitorino José Lopes realizou, em 1822, compras de algodão e mercadorias diversas, aparentemente associadas ao atendimento de demandas próprias. Vale dizer, durante todo o período de expansão da rizicultura, o clã manteve-se arraigado nas práticas agrícolas. Em 1823 José Lopes Trigo procedeu à abertura do inventário dos bens pertencentes à sua mãe Escolástica Gonçalves dos Reis. ${ }^{227} \mathrm{O}$ testamento incorporado ao processo, redigido em 1818, informa-nos que Escolástica, natural de Iguape, filha de Miguel Gonçalves dos Reis e Maria Pereira de Santo Antonio e casada com Lourenço Lopes Trigo, possuía 13 escravos e um sítio com engenho de arroz. A riqueza bruta somava £ 1.470, sendo 65\% em bens de raiz e 29\% em escravos. Entre os primeiros, constava um sítio e dois engenhos, denominados “engenho debaixo” e “engenho de cima”, além de propriedades urbanas na vila de Iguape e no Porto da Ribeira. Dentre os 17 escravos avaliados, apenas 5 possuíam idade inferior a 15 anos.

\footnotetext{
${ }^{226}$ Não localizamos Manoel Lopes Trigo na referida lista.

${ }^{227}$ Grupo 3 da Tabela 4.5; MHAI, caixa n. ${ }^{\circ} 150$.
} 
Se comparada com a de seu marido, a riqueza bruta avaliada no inventário de Escolástica revela-se expressivamente maior, pois as cerca de $£ 500$ libras a ela destinadas por conta da meação praticamente triplicaram no lapso de 17 anos entre os dois eventos. Merece destaque a valorização das terras na Ribeira onde se encontravam os engenhos: no inventário de seu marido, elas foram avaliadas por 1,2 contos e por mais de 4 contos de réis no inventário de Escolástica. Além da manutenção do engenho no conjunto de suas propriedades; outra parcela deve ser atribuída à coabitação de alguns dos filhos, concentrando a riqueza e possibilitando seu melhor aproveitamento durante a fase mais dinâmica da rizicultura. Ademais, o grupo familiar aparentemente não sofreu nenhuma desagregação espacial após a morte de Lourenço Lopes Trigo: tanto os dois cunhados como os filhos casados mantiveramse em propriedades contíguas aos engenhos, sugerindo a concentração da atividade rizicultora em torno da principal posse da família.

Esta condição pode ser observada claramente na lista nominativa de 1828, ano em que localizamos três dos filhos de Lourenço Lopes Trigo e os dois cunhados em fogos praticamente adjacentes: o primeiro deles compunha-se pela família de José Lopes Trigo, 39 anos, a esposa, 6 filhos e 15 escravos; em seguida o de Joaquim Lopes Trigo, 38 anos, também com esposa e um filho, além de dois agregados e também 15 escravos. Em seguida aparece Vitorino José Lopes, 53 anos, com três filhos e 33 escravos, vizinho de Antonio Neves Pinheiro, 67 anos, com mulher, dois filhos e 12 escravos; seguido por um neto de Lourenço Lopes Trigo, Feliciano Neri, 27 anos, casado, com 2 escravos. Dois fogos adiante aparece Inácio Lopes Trigo, solteiro, com um filho e 5 escravos. Resulta daí a posse de 85 escravos, isto é, um aumento de 56\% em relação ao total assinalado em 1815.

Em 1836 os descendentes localizados foram: José Lopes Trigo, casado, 46 anos, 18 escravos; Joaquim Lopes Trigo, 43 anos, casado, 15 escravos; Inácio Lopes Trigo, solteiro, 4 escravos; Vitorino José Lopes, 61 anos, casado, 33 escravos e Ana Maria, viúva de Antonio Neves, 57 anos, 11 escravos, somando 81 cativos. No bairro dos Engenhos, onde todos moravam, os fogos não possuíam especificação sobre a ocupação. Porém, como o próprio nome do bairro já adianta, lá predominava o cultivo e processamento do arroz.

Ao longo da década de 1840, faleceram dois dos filhos de Lourenço Lopes Trigo e uma de suas cunhadas, o que nos permite acompanhar algumas mudanças relativas à alocação da riqueza nesta segunda geração de proprietários de engenho. O primeiro a falecer foi José Lopes Trigo, em 1839, tendo como inventariante a viúva Josefa Maria do Espírito Santo. ${ }^{228}$

\footnotetext{
${ }^{228}$ Grupo 4 da Tabela 4.5; MHAI, caixa n. ${ }^{\circ} 142$.
} 
Em seu inventário, aberto em julho de 1840 , a soma dos bens atingia $£ 1.414$, não possuindo nenhuma dívida passiva. Esta riqueza encontrava-se distribuída entre bens de raiz (54\%) e escravos (40\%). Relativo aos primeiros, José Lopes possuía parcela importante (45\%) em bens urbanos. Entre os rurais, além de um sítio com casa de morada no bairro dos Engenhos, detinha a posse do chamado "engenho de cima” e um terço do "engenho de baixo", e ainda terras no rio Peroupava, no Baú e um outro engenho de arroz no rio Una - Cambixo - com um princípio de plantação de café. ${ }^{229}$ Dos 18 escravos avaliados, três eram recém-nascidos e outros dois possuíam menos de cinco anos.

Em 1843, tomamos conhecimento da situação econômica de Joaquim Lopes Trigo, por falecimento de sua esposa Clara Maria de Moraes. ${ }^{230}$ Dos três filhos presentes em 1836, apenas duas constavam como herdeiras: Isabel Lopes de Aquino casada com Francisco José Borges Pizarro e Escolástica Lopes, 15 anos. De sua riqueza bruta (£ 1.595), 65\% encontravase nos bens de raiz e 32\% em escravos. Diferentemente de seu irmão, a parcela dos bens de raiz rurais superava os $85 \%$, sendo o maior deles dois terços de um engenho de arroz avaliado em 6 contos de réis, além de moradas de casas no dito engenho e terras na Ribeira. Os escravos avaliados somavam 10 pessoas. Assim como o irmão, não possuía dívidas passivas e detinha apenas quatro créditos que não representavam parcela importante da riqueza bruta.

O terceiro filho, Manoel Lopes Trigo, cujo inventário foi aberto em 1842, possuía riqueza bruta bem menor do que os irmãos, composta por um lote de terras no Porto da Ribeira, três escravos e duas dívidas ativas, somando tudo cerca de $£ 236$, repartidas entre os irmãos. $^{231}$

Em 1850 foi aberto o inventário de Josefa Maria do Espírito Santo, viúva de José Lopes Trigo, cuja riqueza bruta atingia $£$ 1.930, divididas em bens de raiz (45\%), escravos (36\%) e dívidas ativas (11\%), estas últimas decorrentes das legítimas do inventário de José Lopes. Os 20 escravos arrolados foram avaliados, em média, por Rs. 295\$000. Praticamente

\footnotetext{
${ }^{229}$ O sítio do Cambixo parece ser uma das poucas propriedades rurais até hoje conservadas em Iguape, porém com profundas modificações. Plácido Cali assim o descreve: $O$ sobrado, que possui 23,70 metros de comprimento e 9,50 metros de largura, tem características do final do século XIX. Possui um porão alto e, como os edifícios da época, apenas o pavimento superior era utilizado como espaço familiar, servindo o inferior para armazenagem de alimentos e outras atividades. O piso superior atualmente possui oito cômodos, composto por uma cozinha, seis quartos, uma ampla sala e uma varanda. A parte inferior tem sete cômodos, sendo o maior deles um salão (...) A cerca de 100 metros do edifício sede, existem ruínas em alvenaria de pedra e cal que podem ter sido um engenho, pois um valo de vários quilômetros capta água do morro, passa próximo a casa e tem sua água represada num pequeno tanque junto a essas ruínas. Daí a água prossegue pelo valo até desembocar no rio Una d'Aldeia, oitocentos metros distante (CALI, 1999, p. 81-93).

${ }^{230}$ Grupo 3 da Tabela 4.5; MHAI, caixa n. ${ }^{\circ}$ 198. Clara era filha de Tomas Trudes de Normandia, rizicultor escravista xiririquense que em 1836 residia em Juquiá.

${ }^{231}$ MHAI, caixa n. ${ }^{\circ} 150$. Este caso não compõe a amostra analisada neste capítulo.
} 
todos os bens de raiz rurais avaliados na morte de seu marido continuavam em sua posse: o terço do "engenho debaixo" e a casa assobradada no mesmo local somavam 5 contos de réis, o engenho e a casa de vivenda no Cambixo, 3 contos de réis, além de um outro engenho avaliado em 2 contos de réis. ${ }^{232}$

Exceto pelo caso de Manoel Lopes Trigo, verificamos que os herdeiros de Lourenço atingiram um padrão de riqueza superior ao do pai e comparável ao da mãe. De fato, tanto a mãe como os filhos puderam expandir o valor monetário do patrimônio baseado na valorização dos bens de raiz e relativa manutenção do número de cativos. Conforme mostram os números acima apontados, exceto Vitorino José Lopes, todos detinham plantéis pouco numerosos, entre 10 e 19 cativos. Sobre a riqueza bruta dos filhos, a influência da valorização dos escravos mostra-se de forma evidente: no inventário do pai, o preço médio do escravo atingia Rs. 108\$720; no processo da mãe, Rs. 124\$825. Os escravos de José Lopes Trigo foram avaliados, em média, por Rs. $227 \$ 840$ e os de Joaquim, por conta do falecimento de sua esposa, por Rs. 425\$000. Já referimos também a valoração das propriedades rurais, referendada nos inventários dos herdeiros: a parte de José Lopes Trigo, que possuía a casa, o “engenho de cima” e um terço do "engenho debaixo”, foi avaliada por 2,9 contos de réis e a de Joaquim Lopes, dois terços do “engenho debaixo” com duas moradas de casas, em 7 contos de réis. Trata-se, como se pode perceber, de uma composição de riqueza essencialmente conservadora, assentada em dois grupos de ativos e mantidos através das mesmas práticas agrícolas implantadas pelo patriarca.

O engenho de arroz constituía o pilar desta estrutura de riqueza. No relatório enviado pela Câmara Municipal de Iguape em 1852, os filhos de José Lopes Trigo constavam como proprietários de três engenhos de arroz: o maior deles, no rio Una, pertencia a Agostinho Lopes Trigo e processava 2.500 sacos de arroz por ano. Joaquim Lopes Trigo Sobrinho possuía um engenho na Ribeira com produção de 1.800 sacos anuais e, na mesma região, Candido Lopes Trigo comandava um engenho com produção de 1.200 sacos. Os 5.500 sacos representavam praticamente $13 \%$ da capacidade total arrolada no relatório. Ainda na lista encontramos Francisco José Borges Pizarro, casado com uma das filhas de Joaquim Lopes Trigo, que possuía uma engenhoca de aguardente com produção de 11 pipas por ano.

O quadro seguinte apresenta as remessas de arroz realizadas pelos Lopes Trigo e agregados entre os anos de 1837 a 1865.

\footnotetext{
${ }^{232}$ Grupo 4 da Tabela 4.5; MHAI, caixa n. ${ }^{\circ} 150$.
} 
Quadro 4.2

Remessas de sacos de arroz realizadas pelos Lopes Trigo

\begin{tabular}{|c|c|c|c|c|c|}
\hline Nome & ano inicial & ano final & remessas & quantidade & sacos por remessa \\
\hline Joaquim Lopes Trigo Sobrinho & 1839 & 1861 & 121 & 3.524 & 29,1 \\
\hline Candido Lopes Trigo & 1842 & 1865 & 97 & 3.785 & 39,0 \\
\hline Agostinho Lopes Trigo & 1840 & 1861 & 82 & 3.365 & 41,0 \\
\hline Manoel Lopes Trigo & 1842 & 1864 & 71 & 1.690 & 23,8 \\
\hline Fidencio Lopes Trigo & 1848 & 1865 & 37 & 827 & 22,4 \\
\hline Florido Lopes Trigo & 1848 & 1853 & 30 & 727 & 24,2 \\
\hline Galdino Lopes Trigo & 1849 & 1857 & 10 & 237 & 23,7 \\
\hline Maximiano Lopes Trigo & 1853 & 1858 & 9 & 156 & 17,3 \\
\hline Ildefonso Lopes Trigo & 1857 & 1862 & 7 & 180 & 25,7 \\
\hline Prudêncio Lopes Trigo & 1855 & 1855 & 2 & 30 & 15,0 \\
\hline José Lopes Trigo & 1838 & 1838 & 1 & 70 & 70,0 \\
\hline Francisco Lopes Trigo & 1849 & 1849 & 1 & 14 & 14,0 \\
\hline Magalhães \& Trigo & 1855 & 1857 & 31 & 827 & 26,7 \\
\hline Pizarro \& Trigo & 1848 & 1853 & 4 & 252 & 63,0 \\
\hline Trigo \& Irmãos & 1864 & 1864 & 1 & 43 & 43,0 \\
\hline Belchior Francisco Goulart & 1837 & 1864 & 192 & 9.149 & 47,7 \\
\hline Francisco José Borges Pizarro & 1837 & 1853 & 174 & 15.729 & 90,4 \\
\hline Luis Ferreira da Silva & 1850 & 1864 & 130 & 14.348 & 110,4 \\
\hline Manoel Ferreira da Silva & 1837 & 1855 & 233 & 19.732 & 84,7 \\
\hline
\end{tabular}

Se comparadas com as capacidades de processamento declaradas no relatório de 1852, notamos grandes diferenças entre as quantidades assinaladas no quadro acima. No entanto, vemos que os quatro últimos nomes, casados com mulheres da família, se destacam do conjunto tanto pela quantidade de remessas feitas como pelo número de sacos remetidos. Suspeitamos que os Lopes Trigo acima arrolados não se envolviam diretamente com o transporte do arroz que deixava seus engenhos, delegando esta função a outras pessoas. Neste caso, Belchior Francisco Goulart e Francisco José Borges Pizarro poderiam agir como agentes portuários da família, garantindo o fluxo dos grãos para o Rio de Janeiro. Não dispomos de nenhuma documentação que possa comprovar esta ligação, porém vale destacar que nenhum dos dois agregados possuía engenho de arroz em 1852 e ainda não constavam em nenhum dos anos disponíveis como proprietários de casas de comércio em Iguape, fortalecendo a hipótese de exercerem a função específica indicada acima. ${ }^{233}$

\footnotetext{
${ }^{233}$ Belchior Francisco Goulart consta entre os moradores da vila de Iguape em 1836, sendo identificado como "comerciante".
} 
Manoel Ferreira da Silva representa o único caso que conseguimos localizar a partir das filhas de Lourenço Lopes Trigo, pois se casou com Antonia Maria Lopes, filha de Tomásia e Vitorino José Lopes. No relatório de 1852, Manoel detinha a posse de dois engenhos, um na Ribeira com capacidade para 1.800 sacos e outro no rio Pequeno, com produção de 1.500 sacos. $^{234}$ Seu filho Luis Ferreira da Silva, que em 1852 administrava o engenho da Ribeira parece ter assumido as funções do pai a partir de meados da década de 1850, como sugere o elevado valor médio de sacos por remessa, valor que também pode ser resultado da produção dos engenhos da família.

Em 1860, por falecimento da esposa Maria Rita Neves, Agostinho Lopes Trigo abriu inventário para dar conta da partilha dos bens do casal. ${ }^{235}$ Maria Rita Neves era filha de Adrião Trudes de Normandia, irmão de Clara Maria de Moraes, por sua vez casada com o tio de Agostinho, Joaquim Lopes Trigo. Aqui evidenciamos uma condição diferente dos demais casos analisados, pois da riqueza bruta $£ 1.913$, parte foi destinada ao pagamento de dívidas passivas, restando $£ 1.260$ como riqueza líquida. O patrimônio compunha-se por bens de raiz (61\%) e escravos (34\%), e uma pequena parte em dívidas ativas (5\%), composta por 10 vales de pequeno valor. Entre os bens de raiz, uma fração do sitio Cambixe, metade de um dos engenhos da Ribeira e uma morada de casas na mesma propriedade, que somavam $82 \%$ destes ativos. Naquele momento o casal contava com a posse de 8 escravos, sendo um deles muito doente, avaliados por um conto de réis, em média. Agostinho Lopes Trigo devia a seis credores, todos comerciantes de Iguape, representando 33\% da riqueza bruta. Para a solução das dívidas, Agostinho solicitou a arrematação de três escravos e uma sorte de terras localizadas no Baecó, o que rendeu 3,5 contos de réis, valor insuficiente para a cobertura das mesmas, avaliadas em pouco mais de 6 contos de réis, restando a alguns credores o recebimento de alguns bens do inventário. ${ }^{236}$

Aparentemente nenhum dos integrantes da terceira geração dos Lopes Trigo dedicouse às atividades comerciais de forma intensiva. No registro do pagamento de sisa sobre lojas, há apenas dois casos: Ildefonso Lopes Trigo recolheu a taxa, durante um ano, na década de 1860, sobre uma loja no bairro dos Engenhos e Manoel Lopes Trigo, na mesma época, detinha um comércio na Rua da Cadeia, pagando os impostos por três anos. Entre os credores presentes nos inventários de nossa amostra, Candido Lopes Trigo aparece em seis registros,

\footnotetext{
${ }^{234}$ Se contabilizarmos os engenhos de Ferreira da Silva, o clã passa a responder por $20 \%$ dos sacos de arroz em 1852. Aparentemente não há nenhuma relação parental entre Manoel Ferreira da Silva e o comerciante José Ferreira da Silva, citado anteriormente.

${ }^{235}$ Grupo 3 da Tabela 4.5; MHAI, caixa n. ${ }^{\circ} 107$.

${ }^{236}$ MHAI, caixa n. 213.
} 
com créditos em torno de 2,6 contos de réis; depois José Lopes Trigo com 1,7 contos em quatro créditos. Agostinho Lopes Trigo aparece com um registro com 890 mil-réis, mesmo número de Ildefonso, com 713 mil-réis. Também não são muitos os registros de pagamento de sisa sobre compra de bens de raiz: Candido Lopes Trigo registrou sete aquisições. Duas delas envolvia o irmão Agostinho: as terras arrematadas no Baecó em 1863 e, 12 anos antes, a sua parte no "Engenho de cima”. As demais aquisições foram terras na Ribeira e três moradas de casas na vila de Iguape. Fidêncio Lopes Trigo realizou 3 transações, uma delas também envolvendo o irmão Agostinho na aquisição de terras na Ribeira para a instalação de engenho em 1871. Encontramos outras transações entre os Lopes Trigo envolvendo partes de casas urbanas, provavelmente ajustes de partilha, mas não notamos nenhuma tendência na aquisição de mais terras em outras regiões do Vale ou ainda a venda do cerne do patrimônio - as terras dos engenhos - para outras pessoas estranhas ao clã.

Na lista de classificação de 1872, encontramos vários netos de Lourenço Lopes Trigo: Candido Lopes Trigo com 7 escravos, Fidêncio Lopes Trigo com 9, Florido Lopes Trigo com 12, Ildefonso Lopes Trigo com 3 escravos, Joaquim Lopes Trigo Sobrinho com 15 escravos, Manoel Lopes Trigo com 1 escravo e Maximiano Lopes Trigo com 3 cativos, somando 50 escravos.

O último dos inventários envolvendo um Lopes Trigo foi aberto em 1878 com a morte de Maximiano Lopes Trigo, tendo como inventariante a viúva Maria Isabel das Neves Trigo. ${ }^{237}$ Pela quantidade de escravos a ele pertencente em 1872, nota-se que Maximiano não possuía posição privilegiada entre seus primos proprietários de escravos. De fato, a riqueza bruta foi a menor entre todos os casos localizados, somando $£$ 979. Os bens de raiz (46\%), compunham a principal parte, possuindo ainda uma parcela em dinheiro (24\%), fato pouco comum entre os ribeirenses, $19 \%$ em escravos e outros 10\% em ações da Companhia de Navegação a Vapor da Ribeira, não se registrando nenhuma dívida passiva. O casal possuía apenas os mesmos três escravos da lista de 1872, avaliados por Rs. 660\$000, em média. Entre os bens de raiz, duas propriedades no bairro dos Engenhos, ambas engenhos de arroz, uma morada de casas na vila e um outro lote de terras no rio Peroupava.

Os dados apresentados indicam uma ascensão da riqueza bruta, no entanto com valores próximos às medias nos subperíodos e com manutenção do perfil do patrimônio. Alguns de seus parentes mantiveram posses escravas até no momento final da escravidão, como Joaquim Lopes Trigo Sobrinho: 5 de suas escravas batizaram, entre 1873 e 1885, 13

\footnotetext{
${ }^{237}$ Grupo 4 da Tabela 4.5; MHAI, caixa n. ${ }^{\circ} 201$.
} 
ingênuos. Outras 4 escravas de Candido Lopes Trigo geraram 7 ingênuos batizados entre 1874 e 1882; no mesmo período foram batizados 6 ingênuos pertencentes a escravas de Fidêncio Lopes Trigo. Pelo menos até o final da centúria alguns dos Lopes Trigo mantiveramse no ramo do arroz: segundo o “Almanach Iguapense” de 1899, Sisernando Trigo possuía um engenho movido a água, assim como Isabel Lopes Trigo e parentes.

A julgar pelo perfil dessa riqueza apresentada pelos Lopes Trigo, acumular grande quantidade de escravos não seria uma condição necessária para a prática da principal atividade agrícola da economia ribeirense ao longo do século XIX, assim como ampliar a extensão das propriedades rurais. Como mostramos no capítulo sobre os bens de raiz, os casos de ribeirenses com grande quantidade de bens rurais nos inventários ou elevado número de registros no pagamento da sisa por compra de bens de raiz constituíam-se exceções. Nesse sentido, os Lopes Trigo evidenciam este comportamento de esforço na manutenção da terra. Recorrentemente notamos que os agregados ao clã, desde aqueles que se casaram com as filhas de Lourenço Lopes Trigo, apresentaram sinais de maior riqueza do que os descendentes diretos de Lourenço tanto na posse de escravos como na quantidade de remessas de arroz realizadas. Esta constatação pode revelar algo sobre a escolha das pessoas que passariam a compor o clã, porém acreditamos que se tratava da própria feição do empreendimento agrícola, como será visto no próximo caso.

\section{Ampliando o campo de atividades econômicas}

Não sabemos muita coisa sobre Francisco Xavier Gonçalves. Casado com Joana Alves da Silva, na lista de 1778 ele constava como proprietário de cinco escravos, então com 60 anos. Em 1789, nenhum dos dois aparecia arrolado entre os moradores de Iguape, o mesmo ocorrendo em 1801. Enfim, nada há nas listas nominativas que permita associá-lo a qualquer evento importante acerca da economia iguapense, afora a posição de pequeno escravista em meados da segunda metade do século XVIII. 
Quadro 4.3

Genealogia de Francisco Xavier Gonçalves

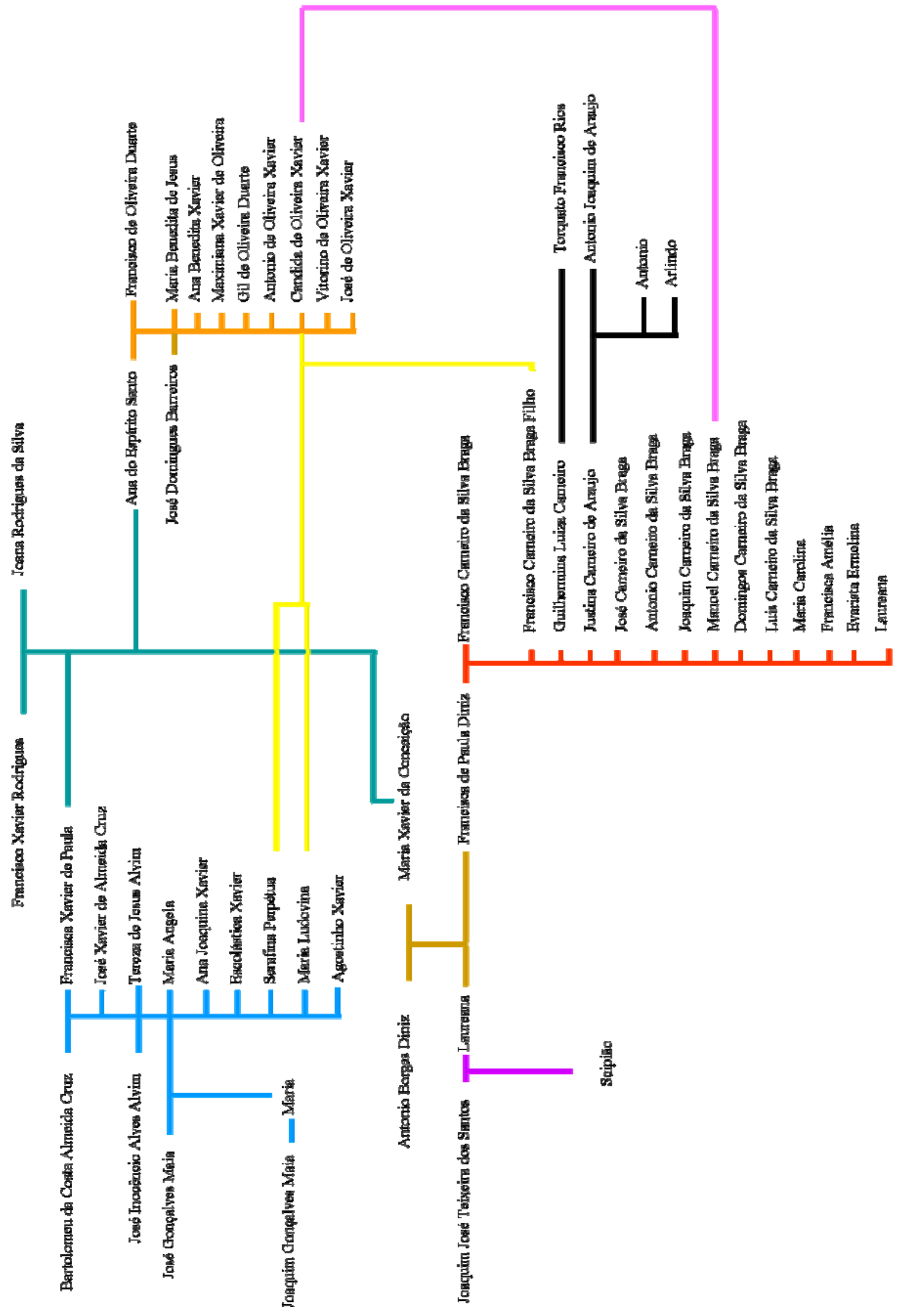


Tudo permaneceria assim, exceto pelo fato de, no cadastro de bens rurais de 1818, três proprietários declararem a posse de terras doadas pelo sogro Francisco Xavier Gonçalves. Os genros em questão, Antonio Borges Diniz, Bartolomeu da Costa Almeida Cruz e Francisco de Oliveira Duarte, foram nomes fundamentais nos primórdios da empresa rizicultora ribeirense. As relações familiares destes proprietários de engenho e sua descendência - objeto das próximas páginas - podem ser vislumbradas no Quadro 4.3, que apresenta a genealogia gerada a partir de Francisco Xavier Gonçalves.

O quadro acima esboçado não tem a pretensão de esgotar as ligações parentais entre os ramos gerados a partir do patriarca, mesmo porque se baseia essencialmente nos informes das listas nominativas e na qualificação dos herdeiros nos inventários pesquisados. Um nível maior de detalhamento exigiria consultas aos registros paroquiais, fonte primária bastante rica, porém complexa e que pouco acrescentaria para a consecução dos objetivos desta pesquisa. Não obstante, a amostra acima delineada permite-nos afirmar com relativa segurança o estabelecimento das redes de parentesco entre os três grupos primários. Acompanhemos estas histórias.

O açoriano Antonio Borges Diniz possivelmente instalou-se em Iguape entre 1789 e 1801. Neste último ano, com 26 anos, compunha um domicílio na Ribeira abaixo juntamente com sua esposa Maria da Conceição, 27 anos, natural de Iguape e duas filhas: Francisca de 6 anos e Laureana de 5 anos. Possuía 5 escravos, sendo 4 deles naturais de Iguape e um de Cananéia, que tocavam um engenho de arroz. Os lustros seguintes foram decisivos para o sucesso da empreitada de Diniz, pois em 1815, aos 42 anos, este engenheiro de arroz possuía 62 escravos entre africanos e coloniais, compondo assim o segundo maior plantel de Iguape. Conviviam no fogo a esposa e a filha Laureana, porém não mais Francisca, casada com o comerciante de fazendas secas Francisco Carneiro da Silva Braga, natural da cidade do Porto, 31 anos, senhor de 17 escravos.

No inventário de bens rurais de 1818 consta que Antonio Borges Diniz possuía 5 domínios de terra: uma de 800 braças de testada por meia légua de profundidade no rio Una, outra no mesmo rio com 750 braças de testada por meia légua, e três propriedades no rio Ribeira, sendo duas de 160 braças de testada e mesma profundidade e outra com 200 braças de testada. Além disso, havia doado ao genro um lote de terras no rio Una com 750 braças, motivo da contenda com Francisca Galdina, já apresentada no Capítulo 2. Em 1828, Antonio Borges Diniz, 55 anos e a esposa Maria da Conceição, 54 anos, compunham um domicílio já sem nenhuma das duas filhas, porém constava a presença do agregado Francisco Vaz da 
$\operatorname{Costa}^{238}$ e 51 escravos. Além de Francisca, casada com Francisco Carneiro, então proprietário de 35 escravos, Laureana compunha um domicílio com seu esposo, o açoriano Joaquim José Teixeira dos Santos. O casal, além do filho de nome Scipião com apenas 1 ano, detinha a posse de 22 escravos.

Na última das listas nominativas, Antonio Borges Diniz, 64 anos, proprietário de 61 escravos, atuava na rizicultura como de proprietário de engenho, feitorado por Francisco Vaz e mantinha atividades comerciais auxiliado pelo caixeiro Torquato Francisco Rios. Os negócios do genro Francisco Carneiro da Silva Braga também prosperavam através da mescla de atividades comerciais e rizicultoras, para a qual contava com 20 escravos. Caso distinto ocorria com Joaquim José Teixeira dos Santos, que neste ano contava com apenas três escravos e em seu domicílio já não mais contava com a presença de Laureana e nem do filho Scipião. Segundo as anotações da lista, Joaquim vivia no Porto da Ribeira, onde exercia atividades comerciais. ${ }^{239}$

A lista dos proprietários de engenho elaborada por Alves Alvim em 1845 não faz referência a Diniz como proprietário de engenho, mas arrola os dois cunhados nesta condição: Francisco Carneiro da Silva Braga na Ribeira abaixo e Joaquim José Teixeira no rio Peroupava. A lista produzida pela Câmara em 1852 também não traz o nome de Antonio Borges Diniz; nesta encontramos sua filha Francisca de Paula Diniz Carneiro, detentora de um engenho na Ribeira com capacidade para processar 1.900 sacos de arroz por ano. O cunhado Joaquim José Teixeira dos Santos é apresentado como proprietário de um engenho de arroz e aguardente no rio Peroupava, capaz de processar 600 sacos de arroz e 16 pipas de aguardente. O primeiro era administrado por Domingos Carneiro da Silva Braga, filho de Francisca de Paula e o segundo por Antonio Ferreira Goulart.

No registro de sisas, Antonio Borges Diniz aparece apenas duas vezes como comprador, os dois casos envolvendo bens urbanos de pequeno valor e executou uma única venda de terras no rio Una. Segundo os informes na abertura do testamento, Borges Diniz faleceu em 1861. Os registros de remessa de arroz não sugerem que esta fosse uma prática comum: entre 1837 e o ano de sua morte, realizou 67 remessas, totalizando 2.438 sacos, a maioria delas concentradas no início do período coberto pelos mapas. A ausência de Diniz como proprietário de engenho e a baixa quantidade de remessas por ele realizada sugerem

\footnotetext{
${ }^{238}$ Francisco Vaz da Costa, segundo os informes de seu inventário processado em 1842, era irmão de Antonio Borges Diniz, que foi seu inventariante (cf. MHAI, caixa n. $\left.{ }^{0} 54\right)$.

239 Em seu testamento, redigido aos 15 de janeiro de 1861, Antonio Borges Diniz afirma que, das duas filhas, Laureana e seu marido faleceram e não deixaram filhos. Provavelmente, em 1836 Laureana já falecera, o que justificaria a redução no número de escravos pertencentes a Joaquim José Teixeira dos Santos em relação a 1828.
} 
que, a partir da década de 1840, este escravista tenha se afastado das atividades rizicultoras, provavelmente delegando-as a terceiros. No entanto, durante as décadas de 1840 e 1850 Antonio Borges Diniz participou ativamente (ou pelo menos fornecia capital) do transporte do arroz do porto de Iguape até o Rio de Janeiro através da posse do patacho “Aurora”, de 96 toneladas, do brigue-escuna “Triunfo da Monarquia” de 136 toneladas e da lancha "Nossa Senhora do Socorro", de 50 toneladas, na maior parte do tempo como único proprietário e em sociedade com Antonio dos Anjos Silva a partir de meados da década de $1850{ }^{240}$ Conforme informa a Tabela 1.13, no Capítulo 1, as embarcações de Antonio Borges Diniz respondiam por 22\% das saídas de navios pertencentes a iguapenses no período entre 1842 e 1850 e por 25\% na década seguinte, cabendo a seu sócio Antonio dos Anjos Silva a primazia no intervalo posterior, com cerca de um quarto das partidas.

De fato, as atividades comerciais sempre compuseram o cotidiano de Borges Diniz, como destacam as Tabelas 1.4 e 1.5, no mesmo Capítulo 1, que relacionam os principais comerciantes e compradores de escravos nas três primeiras décadas do Oitocentos. No entanto, pelo menos durante as décadas de 1840 e 1850, Diniz não possuía nenhuma casa comercial aberta em Iguape, ou pelo menos não constava entre aqueles que recolhiam os tributos anuais relativos a este tipo de negócio. Provavelmente a avançada idade propiciou também a ausência de Borges Diniz dos negócios: em 1850, tomando a idade apresentada em 1801, ele já estaria com 75 anos.

O conjunto diversificado de atividades econômicas praticadas por Antonio Borges Diniz não impediu, em seu testamento, de reconhecer aquela que considerava a central para seu bom desempenho:

(...) serão avaliados os bens que possuo sitio, casas, terras, escravos, móveis e semoventes, particular ou judicial, conforme se convencionarem meu testamenteiro e minha herdeira e determinar e cumprir minha última vontade. Declaro que o melhor bem de meu casal se dê a minha herdeira que foi o engenho de socar arroz e mais interessante, e todos os móveis da casa, sem avaliação nem valor. ${ }^{241}$

Não é possível dimensionar a riqueza de Antonio Borges Diniz no momento de seu falecimento, porém parece evidente que sua ausência permitiu que outros empreendedores iguapenses ganhassem novas posições dentro da hierarquia econômica da região. Decerto seria desejo de Diniz que um de seus próprios parentes ocupasse o vácuo por ele deixado. Vejamos a trajetória de alguns deles.

\footnotetext{
${ }^{240}$ Conforme apresentaremos adiante, anteriormente à sociedade com Antonio dos Anjos, Borges Diniz dividia a posse das embarcações com Torquato Francisco Rios, seu antigo caixeiro.

${ }^{241}$ MHAI, caixa n. ${ }^{\circ} 102$.
} 
Única herdeira de Antonio Borges Diniz, Francisca de Paula Diniz Carneiro gerou 13 filhos do casamento com Francisco Carneiro da Silva Braga. Entre 1837 e 1846, ano de falecimento de Silva Braga, com cerca de 55 anos, este realizou 67 remessas, envolvendo 8.445 sacos de arroz. Seu inventário, aberto aos 5 de setembro do mesmo ano, dá conta de uma riqueza bruta de $£$ 9.822, sendo $43 \%$ em bens de raiz, 32\% em escravos e $25 \%$ em dívidas ativas, além de bens e dinheiro existentes em Portugal e não avaliados no inventário. $^{242}$

Entre os bens de raiz rurais, destacavam-se o engenho e casa de vivenda no rio Una, fronteira com o sogro Antonio Borges Diniz e um outro engenho de arroz no bairro dos Engenhos, divisa com José Lopes Trigo, além de terras na Ribeira e no rio Una. Na vila, Silva Braga possuía 10 propriedades, sendo a principal delas um sobrado na Rua Grande entre casas do sogro e de Antonio Maia e outra delas chama atenção pela natureza: uma casa de ópera. O plantel pertencente a Silva Braga totalizava 67 escravos, quantidade bem superior à registrada em 1836, avaliados em média por Rs. 414\$000. Não há transcrição do livro de contas pertencente ao falecido, mas apenas o valor total das dívidas julgadas cobráveis pela inventariante, totalizando pouco mais de 20 contos de réis. A riqueza acumulada por Silva Braga o coloca como o segundo maior proprietário de escravos entre os inventários que compõem nossa amostra e a quarta maior riqueza bruta em libras.

A viúva Francisca de Paula manteve-se à frente do engenho de arroz, conforme indicam a relação dos proprietários de engenho de 1852 (se bem que administrado pelo filho Domingos Carneiro da Silva Braga) e as 50 remessas de arroz por ela realizadas, totalizando 3.044 sacos. Em 1873, com presumíveis 78 anos, Francisca de Paula possuía 26 escravos classificados, o quinto maior plantel na referida lista. A última informação sobre esta escravista que pudemos localizar data de 1883, quando o vigário da paróquia de Iguape (e seu filho) Antonio Carneiro da Silva Braga batizou a ingênua Laura, filha da escrava Margarida, correspondendo ao oitavo batismo realizado desde 1871. Francisca de Paula também aparece três vezes no registro de pagamento de sisa, todos por venda de bens rurais. O maior valor data de 1867 e corresponde à sexta parte de um engenho de arroz na Ribeira comprado por João José de Carvalho, por um conto de réis.

Candidato natural à sucessão nos negócios de Borges Diniz, a morte impediu que Francisco Carneiro assumisse tal posição. Aparentemente, o próprio Francisco possuía relativa consciência, encaminhando seu filho Braga Filho como condutor dos negócios da

\footnotetext{
${ }^{242}$ Grupo 4 da Tabela 4.5; MHAI, caixa n. ${ }^{\circ} 2$.
} 
família. Francisco Carneiro da Silva Braga Filho, no entanto, faleceu dois anos após a morte do pai, com cerca de 36 anos. Conforme indica o Quadro 4.3, houve um esforço considerável no estabelecimento de alianças dentro do clã. Do casamento com Serafina Perpétua Xavier, filha de Bartolomeu da Costa Almeida Cruz, Braga Filho abriu inventário em 1842, totalizando $£ 796$ em riqueza bruta. ${ }^{243}$ Dois anos depois, um novo inventário foi aberto pelo falecimento da próxima esposa, Maria Ludovina Xavier, irmã de Serafina, com riqueza bruta avaliada em $£ 749 .{ }^{244}$ Finalmente, em 1848, a viúva Cândida Maria Xavier Carneiro, filha de Francisco de Oliveira Duarte, abria o inventário por falecimento de Braga Filho, ocorrido em 7 de agosto de $1848 .^{245}$ Resultou deste inventário uma riqueza bruta igual a $£ 1.430$, porém deduzidas as dívidas passivas, a riqueza líquida atingiu $£$ 873. O valor dos bens avaliados distribuía-se entre escravos (36\%), dívidas ativas (34\%) e bens de raiz (25\%). O conjunto dos haveres incluía 59 devedores por conta de livro e outros 8 créditos de maior valor. Entre as dívidas passivas, além dos ajustes relativos aos inventários anteriores, Braga Filho devia a comerciantes do Rio de Janeiro e a Torquato Francisco Rios, provavelmente valores relativos ao transporte de mercadorias. O inventário ainda detalha as mercadorias armazenadas na loja, que incluíam principalmente tecidos, acessórios de vestuário, louças e ferragens. Os dois lotes de terras representavam a menor parte nos bens de raiz, que incluíam outras seis propriedades urbanas. Com três inventários realizados em um curto intervalo de tempo e Braga Filho aparece em dois grupos distintos de riqueza na Tabela 4.5, parece proveitoso compararmos os cativos avaliados, conforme mostra o Quadro 4.4.

Dos seis escravos presentes em 1842, quatro mantiveram-se até 1848. Entre 1842 e 1845 houve um acréscimo importante de cativos, aparentemente sem relação com o falecimento de seu pai, pois na folha de partilha de Braga Filho não constava nenhum escravo como parte de sua legítima. De fato, o único escravo recebido por Braga Filho foi Teodoro, doação feita pelo pai e ajustada na partilha. Dos 13 escravos presentes em 1845, 9 também constavam em 1848, porém é notável a oscilação nos valores atribuídos, resultado de uma subvaloração em 1845 em relação aos demais anos. ${ }^{246}$ Aparentemente, o súbito aumento de 6

\footnotetext{
${ }^{243}$ Grupo 5 da Tabela 4.5; MHAI, caixa n. ${ }^{\circ} 1$.

${ }^{244}$ Grupo 4 da Tabela 4.5; MHAI, caixa n. ${ }^{\circ} 239$.

${ }^{245}$ Grupo 5 da Tabela 4,5; MHAI, caixa n. 139.

246 Diferenças como estas reafirmam as ressalvas necessárias na interpretação dos valores monetários obtidos através deste tipo de fonte documental. Neste caso, porém, é interessante notar que um dos avaliadores, José Gonçalves Maia, atribui valores aos bens em dois processos, justamente em 1842 e 1848, anos em que os cativos apresentavam maior valor. Um acompanhamento de casos semelhantes a este poderia evidenciar associações entre as oscilações no valor dos bens e o perfil do avaliador designado para sua execução.
} 
para 13 cativos entre 1842 e 1845 corresponde à principal causa para a mudança na classificação da Tabela 4.5

\section{Quadro 4.4}

Escravos avaliados de Francisco Carneiro da Silva Braga Filho

\begin{tabular}{|c|c|c|c|c|c|c|c|c|}
\hline \multicolumn{3}{|c|}{1842} & \multicolumn{3}{|c|}{1845} & \multicolumn{3}{|c|}{1848} \\
\hline Nome & idade & valor & Nome & idade & valor & Nome & idade & valor \\
\hline Sinfrônio & 18 & $550 \$ 000$ & Sinfrônio & 25 & $400 \$ 000$ & Sinfrônio & 28 & $700 \$ 000$ \\
\hline Teodoro & 10 & $280 \$ 000$ & & & & & & \\
\hline Manoel & & $260 \$ 000$ & & & & & & \\
\hline Lúcio & 3 & $120 \$ 000$ & Lúcio & 5 & $100 \$ 000$ & Lúcio & 9 & $450 \$ 000$ \\
\hline Monica & 26 & $500 \$ 000$ & Monica & 30 & $200 \$ 000$ & Monica & 33 & $650 \$ 000$ \\
\hline \multirow[t]{11}{*}{ Francisca } & 40 & $300 \$ 000$ & Francisca & & $150 \$ 000$ & Francisca & & $150 \$ 000$ \\
\hline & & & Juvencio & 24 & $400 \$ 000$ & & & \\
\hline & & & Francisco & 25 & $400 \$ 000$ & Francisco & 28 & $700 \$ 000$ \\
\hline & & & Gonçalo & & $100 \$ 000$ & Gonçalo & & $350 \$ 000$ \\
\hline & & & Bruno & 12 & $300 \$ 000$ & & & \\
\hline & & & Alípio & 6 & $150 \$ 000$ & & & \\
\hline & & & Marta & 26 & $200 \$ 000$ & Marta & 34 & $530 \$ 000$ \\
\hline & & & Ana & & $200 \$ 000$ & Ana & & $350 \$ 000$ \\
\hline & & & Juliana & 1 & $50 \$ 000$ & & & \\
\hline & & & Luciano & 2 & $80 \$ 000$ & Luciano & 7 & $350 \$ 000$ \\
\hline & & & & & & Zacarias & 13 & $560 \$ 000$ \\
\hline
\end{tabular}

Além de Francisco Carneiro da Silva Braga Filho, outros dois filhos estabeleceram ligações familiares ao desposarem filhas de representantes do setor agrário ribeirense. Luis Carneiro da Silva Braga casou-se com Joaquina Eugênia, filha de Joaquim Pedro do Canto, residente em Xiririca, escravista e proprietário de engenho. José Carneiro da Silva Braga contraiu matrimônio com Maria da Dores, filha de João Dias Baptista e Maria Leocádia de Mendonça. $^{247}$

No primeiro dos casos as relações ainda se mantinham na esfera ampliada do clã: a mãe de Joaquim Pereira do Canto, Francisca das Chagas Alvim, era irmã de José Inocêncio Alves Alvim, indicado no Quadro 4.3 como marido de Tereza de Jesus, filha de Bartolomeu da Costa Almeida Cruz. A família Morato do Canto consta como moradora na Ribeira acima desde 1765 e pelo menos um deles, Joaquim Morato do Canto, praticou atividades mineratórias em Ivaporunduva, na freguesia de Xiririca, conforme apresentado no início do capítulo sobre a estrutura da posse de escravos. Em 1836, Joaquim Pedro do Canto aparece instalado como comerciante na freguesia de Xiririca, então com 30 anos, possuindo 2

\footnotetext{
${ }^{247}$ Maria Leocádia era filha de João Antonio Mendonça, artesão e rizicultor, proprietário de 24 escravos quando faleceu, em 1835.
} 
escravos. Na segunda metade do século XIX seu nome não apareceu entre comerciantes daquela localidade que recolheram os tributos relativos às casas de comércio, porém na relação de proprietários de engenho de 1852, constava como possuidor de engenho de arroz, cana e aguardente, e detinha a posse de 40 escravos. Entre 1837 e 1861 Joaquim realizou 136 remessas de arroz, enviando 7.464 sacos. Em 1873, quando abriu inventário por conta do falecimento de sua esposa, a riqueza bruta de Joaquim Pedro do Canto somava $£ 3.286$ e, descontadas as dívidas passivas, $£ 2.624$. Os 30 escravos representavam $65 \%$ da riqueza bruta e os bens de raiz, 31\%, dentre os quais se destacavam um sítio na localidade denominada “Salto”, com casa de morada, paiol e engenho de arroz e cana, avaliada por 5 contos de réis e outra na “Primeira Ilha”, com paiol e engenho de arroz, por 3 contos de réis. ${ }^{248}$

Já o inventário de João Dias Baptista, aberto em 1855, indica que as atividades com o engenho de arroz permitiram o acúmulo de uma riqueza equivalente a $£ 2.701$, principalmente em 31 escravos (64\%) e bens de raiz (35\%). João Dias mantinha uma unidade policultora no rio Subauma, onde cultivava arroz, cana e mandioca e uma sorte de terras na localidade denominada "Pinheiro", cada uma avaliada em 1,6 contos de réis. As doações feitas por Dias Baptista ao genro José Carneiro da Silva Braga foram vultosas, representando cerca de 23\% da riqueza bruta avaliada, incluindo móveis, terras e 8 escravos. ${ }^{249}$ Apesar da posse do engenho, as remessas de João Dias Baptista não atingiram grande volume: entre 1842 e 1852 fez 13 remessas, somando 312 sacos.

Pelo lado das mulheres, também dois casamentos estabeleceram alianças estratégicas para o controle da riqueza. O primeiro deles refere-se à união de Guilhermina com Torquato Francisco Rios. Como foi destacado anteriormente, Torquato constava na lista nominativa de 1836 como caixeiro de Antonio Borges Diniz. Em 1850, ele recolheu aos cofres públicos a taxa referente a uma casa comercial localizada na rua do Funil, sendo este o único momento que seu nome aparece entre os contribuintes. Segundo consta nos mapas de carga, Torquato realizou 31 remessas de arroz entre 1837 e 1852, somando 1.934 sacos de arroz. A única transação imobiliária realizada por Torquato foi em 1849, quando em conjunto com João Mâncio da Silva Franco adquiriu 80 palmos de terrenos no Porto da Ribeira, pertencente ao falecido Joaquim Manoel Junqueira do Canto.

A morte de Torquato Francisco Rios, em 1852, com cerca de 42 anos, gerou a abertura do inventário no mesmo ano, tendo como inventariante a viúva Guilhermina Luiza

\footnotetext{
${ }^{248}$ Grupo 4 da Tabela 4.5; FEP, caixa n. ${ }^{\circ} 42$.

${ }^{249}$ Grupo 4 da Tabela 4.5; MHAI, caixa n. ${ }^{\circ} 97$.
} 
Carneiro Rios. ${ }^{250}$ A riqueza bruta, £ 1.607, dividia-se em dívidas ativas (33\%), móveis (30\%), escravos (21\%) e bens de raiz (30\%). As dívidas ativas, todas de conta de livro, não possuíam discriminação por devedores. Rios possuía ainda um terço nas embarcações “Triunfo da Monarquia” e “Aurora”, a primeira valendo 3,5 contos de réis e a segunda 400 mil-réis. Apenas um bem de raiz rural constava entre os bens, 550 braças de terras no rio Una, divisa com Antonio Borges Diniz; os demais bens urbanos compunham-se principalmente por terrenos em várias ruas do núcleo urbano de Iguape. Os 6 escravos foram avaliados, em média, por Rs. 491\$000 e as mercadorias da loja somavam pouco mais de 150 mil-réis. As duas embarcações citadas aparecem nos registros de movimentação do porto como pertencentes a Antonio Borges Diniz. ${ }^{251}$ Em 1861, falecia a viúva Guilhermina, com uma riqueza bruta bem mais modesta que a de seu marido: $£$ 392. Depois de descontadas as dívidas passivas, restou pouco menos de $£ 20$ a serem partilhadas entre os 4 herdeiros, se bem que as dívidas concentravam-se entre os próprios herdeiros, provavelmente legítimas ainda não pagas. Entre os bens avaliados constavam apenas um escravo, alguns poucos móveis e dois bens de raiz: uma chácara no Caminho da Fonte e uma parte na casa de ópera, herança de seu pai Francisco Carneiro da Silva Braga. ${ }^{252}$

A outra filha de Francisco Carneiro da Silva Braga, Justina, casou-se com Antonio Joaquim de Araújo, cujo inventário data de 1854. A riqueza bruta registrada não superava $£$ 560, metade em bens de raiz e a outra metade em escravos. Antonio Joaquim de Araújo Aguiar atuou como comerciante em Iguape na década de 1850, possuindo uma loja na rua Direita. ${ }^{253}$ No decênio seguinte, seu filho Antonio manteve outra casa comercial na Travessa das Dores. Entre os proprietários registrados em 1872, Arlindo e Antonio, filhos do casal, detinham a posse de 5 escravos cada um.

A distinção entre os casamentos realizados pelos filhos parece evidente: aos homens cabia a possibilidade de ampliar o controle sobre a produção e escoamento do arroz cultivado no Vale do Ribeira através da associação com outras famílias que já detinham a posse de

\footnotetext{
${ }^{250}$ Grupo 5 da Tabela 4.5; MHAI, caixa n. 100.

251 No inventário de Maria Luiza do Carmo, aberto em 1854 pelo viúvo Antonio dos Anjos Silva, foram avaliados a terça parte das mesmas embarcações por 4 contos de réis e 1 conto de réis, respectivamente (MHAI, caixa n. ${ }^{\circ}$ 237). Não pudemos esclarecer se Diniz, Rios e Anjos Silva já eram sócios nas embarcações ou se o último obteve a posse após a morte de Torquato. No mesmo ano, os herdeiros de Antonio dos Anjos Silva, Antonio Francisco de Ataíde Peniche e Antonio Joaquim Vieira venderam suas partes a Antonio Tibúrcio, correspondendo a quatro décimos da terça parte pertencente ao falecido. A transação foi realizada por Rs. 200\$000, enquanto que, segundo o inventário, esta fração correspondia a Rs. 400\$000. Neste caso, as suspeitas podem recair tanto em um excesso de valoração por parte dos avaliadores como em uma redução proposital do valor de venda objetivando menor recolhimento de impostos, correspondente a $5 \%$ da transação.

${ }^{252}$ MHAI, caixa n. ${ }^{\circ} 195$. Este caso não compõe a amostra analisada neste capítulo.

${ }^{253}$ Grupo 4 da Tabela 4.5; MHAI, caixa n. ${ }^{\circ} 131$.
} 
engenhos de arroz. Quanto às mulheres, não se tratava de agregar novas fortunas na esfera familiar, mas primeiramente garantir uniões com pessoas que não representassem ameaça à manutenção da riqueza que circulava entre as gerações. No entanto, casos como o de Borges Diniz e Silva Braga representam evidentes exceções na medida que, entre os descendentes que pudemos rastrear, o padrão de riqueza obtido por ambos não se manteve. Esta constatação reafirma a vantagem comparativa da primeira metade do século XIX em relação ao período seguinte como momento de maior favorecimento para a acumulação de riqueza. No entanto, como veremos em outros casos, isto não impediu que outros ribeirenses conseguissem obter ganhos expressivos nas décadas de 1850 e posteriores. Tal alerta serve apenas para lembrar que a associação entre menor desenvoltura destes descendentes de Borges Diniz e o quadro de estagnação da economia ribeirense não se revela suficiente para justificar a menor riqueza acumulada por estas pessoas.

Retomemos a genealogia. Outro genro de Francisco Xavier Gonçalves, o lisboeta Francisco de Oliveira Duarte aparece como morador na vila de Iguape em 1815, com 30 anos, já casado com Ana, com quem tivera 5 filhos e seu plantel compunha-se de 9 escravos, utilizando-os na faina agrícola. No inventário de terras de 1818 Francisco possuía apenas um lote de terras adjunto ao de Antonio Borges Diniz, com 160 braças de testada por 0,5 légua de profundidade, obtida por herança do sogro Francisco Xavier Rodrigues. Em 1828, além do casal e 8 filhos, 19 escravos completavam o domicílio chefiado por Oliveira Duarte, aos 50 anos. Em 1836, Francisco de Oliveira Duarte, 57 anos, chefiava o domicílio composto pela esposa, 8 filhos e 22 escravos no bairro dos Engenhos, onde se dedicava à lavoura, sem qualquer outra informação sobre a produção agrícola. Em nenhuma das listas nominativas constam informações sobre a posse de engenho por parte de Francisco.

Segundo as declarações iniciais da inventariante Ana Joaquina Xavier, Francisco faleceu em dezembro de $1844 .{ }^{254}$ A riqueza bruta, $£$ 1.468, dividia-se entre bens de raiz (45\%) e escravos (49\%). No primeiro grupo destacavam-se um sítio e casa na localidade denominada "Boiquara”, divisa com Manoel Carneiro da Silva Braga, com um engenho de 12 mãos, casa de farinha, alambique e plantações de arroz e mandioca, 200 braças de terras no rio Pindu, uma morada de casas na rua Franca e um terreno na rua do Campo. Antes de falecer, Francisco despachou 81 sacos de arroz consignados a dois comerciantes fluminenses, Francisco Inácio Mendes e Machado, Irmãos \& Cia. Os 23 escravos foram avaliados, em média, por Rs. 300\$000. Se comparado com os escravos presentes em 1836, 17 deles constam

\footnotetext{
${ }^{254}$ Grupo 4 da Tabela 4.5; MHAI, caixa n. ${ }^{\circ} 177$.
} 
nas duas listas e os demais, ausentes na lista nominativa, possuíam menos de 10 anos, provavelmente nascidos no interior do plantel. Esta característica, aliás, aparece de forma evidente nos dois anos: em 1836, 7 escravos possuíam menos de 10 anos e entre os inventariados, 6 casos. Vale dizer, entre os 8 anos que separam o inventário e lista nominativa, aparentemente Francisco de Oliveira Duarte não realizou nenhuma compra de cativos.

Entre 1837 e sua morte, Francisco de Oliveira Duarte realizou 22 remessas de arroz, totalizando 1.070 sacos do grão. A própria viúva Ana Joaquina realizou em seu nome 9 remessas com 199 sacos. Seu filho Gil de Oliveira Duarte também aparece na relação de remetentes: até 1861, realizou 83 remessas, somando 2.226 sacos de arroz. Outro filho, Vitorino de Oliveira Xavier, realizou 27 remessas contendo 537 sacos e Antonio de Oliveira Xavier, enviou 20 remessas com 665 sacos. ${ }^{255}$ Os números mostram-se parecidos com os assinalados pelos Lopes Trigo, sugerindo que parcela do arroz processado pela família seguia caminho através dos agentes comerciais de Iguape.

A filha Cândida, após o falecimento de seu primeiro marido, Francisco Carneiro da Silva Braga Filho, casou-se com o cunhado Manoel Carneiro da Silva Braga, neto e um dos testamenteiros de Antonio Borges Diniz. Manoel Carneiro realizou 62 remessas com 1.371 sacos de arroz e constava como proprietário de 14 escravos em 1873. Outra das filhas contraiu matrimônio com José Domingues Barreiros, um pequeno escravista iguapense no início de século XIX e remetente de arroz com pequenas quantidades. Em 1873, José Domingues Barreiros possuía 10 escravos, segundo a lista de classificação. Pelo menos outros três filhos de Francisco de Oliveira Duarte também constavam como proprietários naquele ano: Antonio de Oliveira Xavier, com 18 escravos, Vitorino de Oliveira Xavier, com 5 cativos e Francisco de Oliveira Xavier, com 1 cativo. Dois anos depois, falecia um dos filhos, José de Oliveira Xavier, cuja riqueza bruta atingia $£$ 692, porém não constava a posse de nenhum escravo. Entre os bens avaliados, metade do sítio e engenho no "Boiquara” e duas dívidas ativas por empréstimos realizados ao irmão Vitorino de Oliveira Xavier em 1869 e ao cunhado Manoel da Silva Braga em 1871, ambas de um conto de réis, o primeiro com prêmio de 1\% ao mês e o segundo a $9 \%$ ao ano. ${ }^{256}$ A escassez de bens de raiz no inventário de José parece traduzir uma condição da família: entre todos os herdeiros, apenas Gil de Oliveira Duarte consta nos

\footnotetext{
${ }^{255}$ Entre os demais filhos de Francisco Oliveira Duarte, João de Oliveira Xavier realizou 13 remessas com 215 sacos e José de Oliveira Xavier, 3 remessas e 56 sacos.

${ }^{256}$ Grupo 5 da Tabela 4.5; MHAI, caixa n. ${ }^{\circ} 130$.
} 
registros de pagamento de sisa, porém apenas em dois casos, envolvendo uma compra e uma venda de bens rurais.

Os casos assinalados aqui revelam uma nítida distinção entre os dois ramos já expostos. A riqueza amealhada por Francisco de Oliveira coloca-o em um nível inferior se comparada com o acúmulo realizado por Borges Diniz e este diferencial repercutiu de maneira significativa entre seus descendentes. Trata-se, como veremos em seguida, do ramo familiar descendente de Francisco Xavier Gonçalves com menor aporte de riqueza.

A terceira pessoa a compor os beneficiários de Francisco Xavier Rodrigues, Bartolomeu da Costa Almeida Cruz, já ganhou algum destaque no Capítulo 1 desta tese. Em 1801, então com 31 anos, esse português, natural do Porto, casado com Francisca Xavier, possuía 7 escravos na Ribeira Abaixo, com os quais tocava um engenho de socar arroz. Em 1815, o engenheiro de arroz detinha 49 escravos. Em 1818 suas posses fundiárias (8 registros) estendiam-se desde a Ilha do Mar Pequeno até a freguesia de Xiririca, somando, pelo menos, 1.184 alqueires. ${ }^{257}$ As formas de obtenção desse patrimônio revelam-se diversificadas, porém comuns entre os maiores proprietários de terras: além de duas sesmarias, Almeida Cruz apossou-se de algumas áreas e comprou outras, afora a doação recebida pelo sogro. As terras com utilização mais intensa situavam-se no Rio de Peroupava e na Ribeira Abaixo, concentrando 48 escravos e pelo menos um engenho de arroz.

Seu inventário, aberto aos 18 de dezembro de 1830, totalizava um conjunto de bens no valor de $£ 7.748$, além de $£ 199$ doadas aos filhos. ${ }^{258}$ Bens de raiz (as duas sesmarias, ${ }^{259}$ as terras no arraial de Ivaporunduva e na Ribeira Abaixo e 7 moradas de casas na vila de Iguape, compondo 32\% da riqueza bruta), 69 escravos (27\%), dinheiro em espécie em Santos e no Rio de Janeiro (14\%) e dívidas ativas de empréstimos e conta de livro (23\%) representavam 96\% da riqueza inventariada. Desse conjunto suspeita-se que Bartolomeu manteve-se presente nos vários nichos economicamente viáveis no Vale do Ribeira, desde a extração de ouro em Xiririca até a construção de embarcações, como indica a posse de terras na localidade denominada "Estaleiro Velho" e a presença de vários escravos qualificados como carpinteiros. O sítio do "Morro do Pinheiro" concentrava a maior parte da riqueza em bens de raiz, com duas casas assobradadas e o engenho de arroz, avaliada em 20 contos de réis. Mais de três quartos das dívidas compunham o livro de contas, porém no inventário só temos o

\footnotetext{
${ }^{257}$ No registro das terras de Xiririca não consta a profundidade e, portanto, não foi adicionada ao cálculo.

${ }^{258}$ Grupo 4 da Tabela 4.5; MHAI, caixa n. ${ }^{\circ} 12$.

${ }^{259}$ Uma de 0,5 légua de testada e a outra com 800 braças, ambas no Rio de Peroupava (cf. AESP, Repertório de Sesmarias, 1994, p. 90).
} 
valor total. Como não há, nem nas listas e nem no inventário, evidências de que Almeida Cruz possuísse uma casa comercial, parece razoável supor que a origem desse montante tenha estreita ligação com o cultivo do arroz sob diversas modalidades: aluguel de escravos, utilização do engenho, custas de remessa do arroz de terceiros para o Rio de Janeiro etc.

Ademais, Almeida Cruz fazia-se presente no mercado iguapense através de seu cunhado José Gonçalves Maia, casado com a filha Maria Angélica Xavier, já falecida quando da morte do pai. Além de Gonçalves Maia, outra de suas filhas casou-se com José Inocêncio Alves Alvim, vereador, deputado provincial e diretor da Mesa de Rendas de Iguape. Almeida Cruz também ocupou postos públicos na Câmara de Iguape, inspetor da construção da estrada entre Juquiá e Sorocaba e também das obras do canal que ligaria o Mar Pequeno e o rio Ribeira em seus primeiros anos. Na lista de arrecadação para compor a subscrição voluntária para a Marinha de Guerra Imperial, em 1824, Almeida Cruz ocupava a segunda posição entre os doadores, atrás somente do Capitão-mor José Antonio Peniche e à frente de seu cocunhado Antonio Borges Diniz.

A viúva Francisca Xavier de Paula Almeida, na lista elaborada por seu genro, constava como a proprietária do engenho situado na Ribeira abaixo. Porém, na lista de engenhos de 1852, o filho José Xavier de Almeida Cruz detinha a posse do engenho na Ribeira com capacidade para processar 1.900 sacos por ano. Entre 1837 e 1862, realizou 101 remessas de arroz, totalizando 28.296 sacos. Se acrescidas às realizadas pelo irmão Agostinho Xavier e remessas conjuntas, totalizam-se 220 remessas e 29.814 sacos.

A participação da família Almeida Cruz nos registros de pagamento de sisa por transações de compra e venda de bens de raiz não é muito expressiva: José Xavier de Almeida Cruz realizou apenas três aquisições de terras, todas na década de 1850 e de baixo valor monetário. Além disso, concretizou apenas duas vendas, também de terras rurais de baixo valor. O irmão Agostinho vendeu, em 1846, as terras existentes em Ivaporunduva a Salvador Pupo por Rs. 450\$000. Nenhum dos Almeida Cruz constavam como comerciantes contribuintes dos tributos sobre lojas em Iguape. No entanto, José Xavier de Almeida Cruz, no cômputo dos credores indicados nos inventários ribeirenses, ocupava a quarta posição entre os maiores valores nominais, pouco mais de 14 contos de réis em 28 registros de dívidas passivas nos inventários abertos entre 1837 e 1870. Possivelmente parte destas dívidas decorria do uso das instalações do engenho de arroz e dos fretes relativos ao transporte de arroz realizados pelo patacho “Santa Cruz”, de propriedade de José Xavier na década de 1840. É provável que uma parte destas dívidas ainda guarde relação com o rol de créditos 
pertencentes ao seu pai em fins da década de 1820. Nossa documentação não permitiu qualquer outro esclarecimento acerca da natureza destes créditos.

Ao longo da década de 1850 a posição econômica de José Xavier sofreu uma sensível piora e localizamos 5 processos, todos abertos em 1864, envolvendo cobranças judiciais que sugerem sua situação falimentar. Roso Lucas Lagoa e José Domingues Barreiros abriram libelo para conseguirem receber créditos fornecidos a José Xavier, o primeiro por fornecimento de mantimentos e o segundo por crédito fornecido. Seu tio Antonio Borges Diniz e Manoel de Andrada e Silva recorreram ao Tribunal da Relação com o intuito de obter o pagamento por créditos fornecidos em fins da década de 1850. Por fim, o comerciante fluminense José Pacheco da Costa acionou o Juízo Comercial de Iguape para executar a cobrança de uma dívida reconhecida por José Xavier, cujo valor ultrapassava os 12 contos de réis. Neste último caso ficamos sabendo que José Xavier possuía pouquíssimos bens, pois boa parte fora encaminhada para arrematação em cumprimento de ordem de pagamento a outro credor, José Bonifácio de Andrada e Silva. ${ }^{260}$

Em 1873 apenas dois filhos de Bartolomeu constavam como proprietários de escravos: Agostinho Xavier de Almeida Cruz possuía 9 escravos e Ana Joaquina Xavier Cruz detinha 18 cativos. Do primeiro, duas escravas tiveram filhos ingênuos batizados até 1874, ano do último registro. Ana Joaquina apareceu como proprietária em 12 registros de batismos até o ano de 1879.

Já apontamos o casamento de uma das filhas de Bartolomeu da Costa Almeida Cruz com o português José Gonçalves Maia, residente na vila de Iguape pelo menos desde o ano de 1815, quando exercia atividades comerciais e detinha a posse de apenas um escravo. Na lista nominativa de 1828 Maia aparecia como chefe de domicílio, 45 anos, casado com Maria Ângela e com uma filha chamada Maria, então com apenas 1 ano, além de deter a posse de seis escravos. Em 1836, o negociante Maia, 52 anos, viúvo, residia na vila de Iguape e possuía cinco escravos. Entre 1837 e 1855, Maia realizou 143 remessas de arroz, somando 7.827 sacos. Nos registros das taxas por lojas abertas em Iguape não há pagamento efetuado por Maia, cuja morte não sabemos quando ocorreu.

Sua filha Maria Angélica contraiu matrimônio com Joaquim Gonçalves Maia, que faleceu em setembro de $1860 .{ }^{261} \mathrm{O}$ inventário revelou uma riqueza bruta de $£$ 3.432, dividida

\footnotetext{
${ }^{260}$ Não localizamos o processo de cobrança envolvendo Andrada e Silva. Os principais bens arrematados para o pagamento das dívidas com a firma carioca, as dívidas ativas e livros contábeis de José Xavier, foram leiloadas em praça pública pela metade do valor atribuído inicialmente (MHAI, caixa n. ${ }^{\circ} 122$, todos os processos).

${ }^{261}$ MHAI, caixa n. ${ }^{\circ} 162$. Este caso não compõe a amostra analisada neste capítulo.
} 
em dívidas ativas (43\%), bens de raiz urbanos (23\%) e escravos (27\%). Os créditos pertencentes ao falecido são peculiares pela pequena quantidade de devedores e, conseqüentemente, pelo elevado valor individual. Por exemplo, constava um crédito fornecido ao comerciante e proprietário de engenho arroz de Xiririca, Miguel Antonio Jorge, fornecido em 1860, cujo principal e juros (9\% ao ano) somavam pouco mais de 8 contos de réis; um outro empréstimo feito a José Xavier de Almeida Cruz em agosto de 1859, também remunerado a $9 \%$ ao ano, totalizando 2,3 contos de réis. ${ }^{262}$ Por outro lado, o elevado número de escravos, 14 no total, e a ausência de bens de raiz rurais, sugerem que este escravista utilizava seus cativos como escravos de aluguel. Joaquim Gonçalves não atuava no mercado de remessas de arroz, realizando apenas três remessas, todas em 1855. Também não o encontramos entre os que recolheram a sisa sobre transações imobiliárias e nem como proprietário de estabelecimento comercial.

Maria Angélica, após a morte de Joaquim Gonçalves, contraiu núpcias com João José de Carvalho, vindo a falecer em outubro de $1872 .{ }^{263}$ A riqueza bruta avaliada, $£$ 3.913, dividia-se em bens de raiz (26\%), escravos (25\%) e dívidas ativas (48\%). Apesar de se repetir a elevada participação das dívidas ativas, sua composição revelou-se distinta daquela observada no inventário do primeiro marido: dos 24 créditos e vales, nenhum dos devedores relacionados constavam no primeiro processo e apenas dois, ambos comerciantes, superavam a marca de um conto de réis: Antonio Francisco de Ataíde Peniche, que devia cerca de 8 contos e José Carlos de Toledo, com pouco mais de 2 contos de réis. Alguns destes devedores, que totalizavam $61 \%$ dos créditos, receberam por parte do inventariante a qualificação de “duvidosa por falta de garantia material”. Entre os bens de raiz, destacava-se uma propriedade rural no bairro dos Engenhos, com dois engenhos de arroz, duas casas de sobrados e rancho de escravos, avaliado em 5 contos de réis e outras terras, provavelmente trazidas ao patrimônio por conta do segundo casamento. ${ }^{264}$ Dos 14 escravos avaliados, apenas 6 constavam no primeiro inventário.

Um balanço das trajetórias acima delineadas evidencia que a capacidade de acumulação manifesta na geração de proprietários de engenho beneficiários das doações realizadas no início do século XIX por Francisco Xavier Gonçalves, especialmente nos casos

\footnotetext{
262 Este crédito compunha, junto com o empréstimo feito por Antonio Borges Diniz, o valor necessário para pagamento de dívidas contraídas por José Xavier junto a comerciantes fluminenses.

${ }^{263}$ MHAI, caixa n. ${ }^{\circ} 104$. Este caso não compõe a amostra analisada neste capítulo.

${ }^{264}$ Conforme relatado anteriormente, João José de Carvalho adquiriu, em 1867, a sexta parte do engenho na Ribeira pertencente a Francisca de Paula Diniz Carneiro. Na verdade, entre 1866 e 1869, Carvalho adquiriu partes da propriedade de diversos herdeiros de Francisco Carneiro da Silva Braga.
} 
de Almeida Cruz e Borges Diniz, não se manteve na mesma intensidade em seus herdeiros. É certo que estes casos devam ser encarados como exceções na economia ribeirense, mesmo no ambiente diferenciado das primeiras décadas do Oitocentos, que favoreceu a acumulação de riqueza para vários proprietários de engenho. As características mais gerais verificadas no conjunto dos inventários - redução do número médio de escravos, decrescentes valores de riqueza bruta, aumento do comprometimento da riqueza com dívidas passivas - aparecem em menor ou maior intensidade entre os descendentes da tríade original.

É certo também que na segunda metade do século XIX as condições da economia ribeirense se mostravam bem distintas e, adicionadas com o relativo rigor da partilha da riqueza e o elevado número de herdeiros, compõem parte das razões que podem ajudar a explicar as dificuldades dos herdeiros na manutenção de níveis de riquezas assemelhados à geração anterior. No entanto, casos como o de José Xavier de Almeida Cruz, totalmente desprovido de bens na primeira metade da década de 1860 surpreendem pela inabilidade na condução dos negócios.

Caso semelhante ocorreu na mesma época com o filho do Capitão-mor José Antonio Peniche. Como destacamos no Capítulo 1, pai e filho encabeçavam as transações comerciais na região, respondendo cerca de $16 \%$ do total de mercadorias recebidas no porto iguapense, assim como os maiores responsáveis pelo tráfico local de escravos. José Antonio Peniche, natural da freguesia de Peniche, pertencente ao distrito de Leiria, tradicional região portuguesa de pesca e manufatura de embarcações, consta nas listas nominativas pelo menos desde 1789, então com 29 anos e proprietário de 8 escravos. Segundo a lista de 1801, o já Capitão-mor José Antonio, 40 anos, comerciante, construtor e proprietário de barcos, detinha a posse de 31 cativos, vários deles com distintos graus de especialização para o trabalho, como carpinteiros, calafates, ferreiros e marinheiros, além de coabitarem como agregados dois caixeiros e outros artesãos. Também já praticava o cultivo do arroz, porém não há informe sobre a quantidade colhida. Em 1828, última lista em que pôde ser encontrado, constava que José Antonio Peniche, 62 anos, negociante, detinha a segunda maior posse em Iguape e Xiririca, com 62 escravos.

O inventário de Peniche não aparece na lista existente no Museu Histórico e Arqueológico de Iguape, mas segundo informações fornecidas por Roberto Fortes, Peniche teria falecido em $1831 ;{ }^{265}$ as evidências acima indicam que seu patrimônio deveria compor o topo das grandes fortunas iguapenses da primeira metade do século XIX. Durante toda a vida,

\footnotetext{
${ }^{265}$ Cf. FORTES, s/d.
} 
parece que Peniche manteve conjugadas as atividades comerciais e agrícolas, como se pode depreender da identificação utilizada na lista nominativa de 1828 e das posses fundiárias constantes no inventário de bens rústicos de 1818. Suas 5 posses somavam mais de 4.400 alqueires em distintas regiões de Iguape, ${ }^{266}$ duas obtidas por herança do sogro Gregório Alves da Silva, ${ }^{267}$ uma por sesmaria e as demais por compra. Três delas, entretanto, permaneciam incultas ou se achavam cultivadas pelos vizinhos. Apenas a localizada na Ribeira Acima, na paragem denominada Ponta Grossa, possuía engenho de arroz e o empreendimento contava com a presença de 52 escravos.

Já o filho Antonio José Peniche, que em 1828 tinha 33 anos, possuía 13 escravos. Em 1836, então com 41 anos, como o pai, navegava entre o comércio e a rizicultura, detendo a posse de 40 escravos e auferindo renda anual de 1 conto de réis, além de manter o fabrico de embarcações. Segundo os manifestos de carga, Antonio José participou ativamente da exportação de arroz entre 1837 e 1858, com 169 remessas com 6.785 sacos de arroz. Aparentemente, Antonio José Peniche assumiu todos os negócios conduzidos pelo pai, dedicando-se tanto ao cultivo e processamento do arroz como ao transporte através da posse de embarcações, em sociedade com João Mâncio da Silva Franco no brigue “União”. ${ }^{268} \mathrm{Na}$ lista de engenhos de 1852, Antonio José constava como proprietário de uma unidade no Ribeira com capacidade para processar 1.600 sacas por ano.

O inventário de Antonio José, iniciado em abril de 1861, informa que seus bens somavam pouco menos de 3 contos de réis, incluindo 2 escravos idosos, algumas terras, ferramentas de carpintaria e trastes do engenho de arroz. O processo também revela que parte não avaliada dos bens foi destinada aos herdeiros sob a forma de doação, envolvendo 18 escravos e 6 imóveis. Os herdeiros abriram mão da herança para não arcarem com o ônus das dívidas passivas, cujo valor não consta do processo, ${ }^{269}$ mas deveriam envolver cifras consideráveis: entre os inventários do Museu Histórico e Arqueológico de Iguape constam dois processos de cobrança de dívidas, um movido pelo administrador da fazenda de Antonio José Peniche, João Batista da Silva Carneiro, demandando a quantia de pouco mais de um conto de réis referentes a salários, pagamentos de vales e dívidas em outras praças. O outro

\footnotetext{
${ }^{266}$ Costeira da terra firme, Ilha do Mar Pequeno, Capivari, Rio da Ribeira, Lagoa de Brajatuba e Ribeira Acima.

${ }^{267}$ Gregório Alves da Silva consta nas listas nominativas de Iguape desde 1765, quando ocupava o posto de alferes na Companhia de Viana e era proprietário de 5 escravos; em 1789 continuava com o mesmo número de cativos. Em 1801, ainda com o título de alferes, o viúvo Gregório Alves, 63 anos, natural de Iguape, contava com 10 escravos dedicados ao cultivo de arroz e extração de cal.

${ }^{268}$ Em 1852, Antonio José Peniche vendeu a João Mâncio da Silva Franco o brigue-escuna "União” por Rs. 6:000\$000, conforme consta nos registros de compra e venda de embarcações nacionais do livro de sisa da coletoria de Iguape (AESP, ordem n..$^{\circ}$ 8.414).

${ }^{269}$ Grupo 3 da Tabela 4.5; MHAI, caixa n. ${ }^{\circ} 162$.
} 
processo, encabeçado por João Mâncio da Silva Franco, solicitava a arrematação de 12 escravos e terras pertencentes ao falecido para solução de dívidas, cujos valores não são mencionados no documento. ${ }^{270}$

Os casos de Peniche e José Xavier Almeida Cruz, ambos ocorridos no início da década de 1860, parecem representar pontos extremos de uma tendência já detectada: destacamos no começo deste capítulo que, entre 1861 e 1880, a parcela da riqueza bruta comprometida por dívidas passivas atingiu, em média, 20\% nos inventários de proprietários de engenho de arroz ante os 9\% medidos nos primeiros 40 anos da centúria. Associada com a redução da riqueza média indicada na Tabela 4.2, constituem sinais evidentes do empobrecimento do principal setor produtivo da economia iguapense. Por outro lado, verificamos também a consolidação de representantes do setor comercial como proprietários de riquezas bem mais expressivas, mesmo levando-se em conta a fragilidade de sua composição, especialmente no grupo das dívidas ativas. Dedicamos as próximas páginas ao acompanhamento das trajetórias de alguns destes representantes.

\section{Comerciantes e comerciantes}

O desenvolvimento das atividades artesanais associadas à construção de embarcações e a posição geográfica da vila de Iguape favoreceram a fixação de vários comerciantes na vila. Seus objetivos poderiam envolver a comercialização de arroz e o fornecimento de mercadorias para a região, o aproveitamento das chances permitidas através da construção e utilização das embarcações construídas na região ou ambas alternativas, como parece ser o caso do Capitão-mor Peniche. São sugestivas as pistas que associam estes empreendedores ao pleno desenvolvimento da rizicultura na região, estabelecendo dessa forma espaços distintos de atuação, seja através da rizicultura (e da posse de engenho de arroz), seja através do comércio. Tarefa mais árdua reside na hierarquização destas duas atividades, como mostraram os casos de Borges Diniz e seu cunhado Silva Braga.

Outros personagens se apresentam de maneira bastante clara, como Isidoro Nicolau de Brito. William Puntschart, em seu estudo sobre comerciantes paulistas, arrola Isidoro Nicolau de Brito, que em 1810 residia na Travessa da Banca de Peixe n. ${ }^{\circ}$ 8, em Santos, como proprietário das galeras Nossa Senhora da Vitória (1810) e São Francisco de Paula (1817), além do bergantim “Delfina” (1809 a 1813; essa embarcação aparece posteriormente como propriedade de Manoel de Alvarenga Braga, outro negociante santista cujas embarcações

${ }^{270}$ MHAI, caixa n. ${ }^{\circ} 5$. 
também aportavam em Iguape), a lancha "São Joaquim”, as sumacas “Casqueiro” e "Santa Cruz” e o penque “Marimbondo” (Cf. PUNTSCHART, 1998, p. 29).

Mesmo possuindo embarcações próprias para o comércio transatlântico, muitos negociantes paulistas perceberam que para realizar bons negócios não seria necessário alcançar a Europa, África ou Ásia. Bastaria, por exemplo, restringir o seu raio de ação, intensificando as transações comerciais com determinada localidade ou região mais próxima. Esta estratégia mercantil foi adotada, por exemplo, por Isidoro Nicolao de Brito. Conforme atestam os passaportes de suas embarcações, freqüentemente enviava seus artigos para os portos meridionais da colônia e Bacia do Prata. Em tais operações, empregava principalmente seus navios mercantes, capazes de transportar grande capacidade de carga (PUNTSCHART, 1998, p. 28).

Não sabemos em que ano Brito fixou residência em Iguape. Em uma prestação de contas datada de 25 de maio de 1825, acerca da contribuição voluntária para a manutenção da marinha nacional, a Câmara de Iguape redigiu uma lista dos pagamentos recebidos no ano anterior, onde constava o donativo do tenente Isidoro Nicolau de Brito, com a devida anotação “faleceu em 1824”. Nesse rol ele ocupava a quinta posição entre os contribuintes, atrás apenas do capitão-mor José Antonio Peniche, dos sargentos Bartholomeu da Costa Almeida Cruz e Bento Pupo de Gouveia e do capitão Antonio Borges Diniz. Nas relações de comércio anexas às listas nominativas, Isidoro aparece apenas três vezes, todas em 1822, responsável pela compra de dois lotes de fazendas secas e um de louças, totalizando Rs. 1:939\$400. Entre os inventários amostrados das três primeiras décadas do século XIX, ele não consta como credor ou devedor.

No seu inventário encontramos a transcrição do testamento, assinado no Rio de Janeiro aos 9 de outubro de 1814. Consta que Isidoro Nicolau de Brito, lisboeta, filho de Gonçalo José Gomes e Rosa Maria Joaquina, solteiro, não possuía filhos e instituía como herdeiras duas irmãs moradoras em Lisboa, Ana Rita Joaquina e Maria Rita, assim como primeiro testamenteiro Manoel de Alvarenga Braga. Reconhece dívidas ativas e passivas em diversos portos do litoral até Buenos Aires, declara ser possuidor de uma tropa de burros em Sorocaba, sendo 750 vindos por sua conta em sociedade com o compadre Antonio José Pereira Machado do continente do Rio Grande. Possuía uma sociedade com o Coronel Souza em um bergantim e outra com Domingos Gonçalves do Espírito Santo, Bento José de Villas Boas, moradores em Porto Alegre, Manoel da Costa da Silveira e Manoel Joaquim Pinheiro, morador no Rio de São Francisco, na construção de uma nova galera que ali se achava a seu cargo e do capitão Manoel José Teixeira, em cujo estaleiro estava um escravo de nação, Antonio, que deveria ser alforriado. ${ }^{271}$

\footnotetext{
${ }^{271}$ MHAI, caixa n. ${ }^{5}$. O inventário de Isodoro foi um dos excluídos da Tabela 4.5.
} 
O inventário de Isidoro Nicolau de Brito, aberto aos 4 de maio de 1824, não reflete a pujança indicada por Puntschart e reafirmada no testamento. Os bens arrolados incluíam três escravos, objetos pessoais, fazendas secas e parte de um navio chamado "Delfina" - único que restou das embarcações identificadas por Puntschart - somando pouco mais de 2 contos de réis. O valor devido ao único credor, o testamenteiro nomeado e provavelmente sócio Manoel de Alvarenga Braga, superava o valor dos bens inventariados (Rs. 6:118\$851), levando parte dos bens à arrematação pública a pedido do testamenteiro à época do inventário, Manoel Francisco dos Santos. ${ }^{272}$

Ainda que as aludidas condições de Iguape indicadas no início desta seção possam ter exercido alguma influência na vinda de Brito para a região, os bens avaliados e as dívidas passivas sugerem que a condição falimentar pouca relação guardava com a dinâmica econômica local e não há como associá-lo aos casos descritos acima, ocorridos na segunda metade do século XIX.

Alguns comerciantes que iniciaram suas atividades na fase mais dinâmica da rizicultura apresentaram um desempenho estreitamente associado a este crescimento, como é o caso do comerciante José Jacinto de Toledo que, em 1815, possuía uma loja de fazendas secas. À época, com 29 anos, morava com sua mãe Ana do Canto e detinha a posse de 3 escravos. Na lista nominativa de 1801, Ana do Canto Lara, mãe de José Jacinto, aparecia casada com Carlos Muniz de Gusmão e José, 18 anos, constava como agregado ao fogo. Naquele ano, Carlos Muniz não possuía nenhum escravo e, segundo o recenseador, vivia de agências.

Em 1828, Toledo era senhor de 14 escravos e vivia com o filho José Carlos. Em 1836, José Jacinto de Toledo, 48 anos, residia na vila de Iguape com seu filho José Carlos de Toledo, proprietário de uma casa comercial e dispunha de 16 escravos. Segundo as anotações do recenseador, a renda anual de José Jacinto atingia 1,5 contos de réis, obtidas também através do cultivo de arroz, porém em quantidade não informada. As outras filhas de José Jacinto, Delfina Maria e Maria do Carmo residiam como agregadas no fogo chefiado por Maria das Dores de Jesus, adjunto ao domicílio de José Jacinto. A renda anual atribuída a Toledo só era superada por Antonio Borges Diniz, com 2 contos de réis e Francisca Xavier de Paula, viúva de Bartolomeu da Costa Almeida Cruz, com Rs. 1,6 contos de réis.

\footnotetext{
${ }^{272}$ A indicação no inventário acerca dos bens arrematados mostra que estes somavam Rs. 467\$505; os autos da arrematação, cujo início data de 14 de setembro de 1824, revelam que os bens renderam Rs. 540\$430, isto é, 15,5\% além dos preços de avaliação, valor insuficiente para saldar a dívida. O processo se arrasta por cerca de uma década e aparentemente envolveu pelo menos uma transferência da dívida, uma vez que em 1835, o carioca Manoel Coelho da Rocha declarava ter recebido Rs. 2:938\$619.
} 
A atuação de José Jacinto em Iguape não se restringia ao comércio. Vereador da Câmara de Iguape, diversos documentos depositados no Arquivo do Estado de São Paulo revelam sua intensa participação na construção do canal que faria a ligação entre o Ribeira e o Mar Pequeno em fins da década de 1820. Correspondência enviada pelo administrador das obras do canal, José Inocêncio Alves Alvim ao governo provincial, em 1832, relatava o andamento das obras e informava sobre a oferta feita por José Jacinto de Toledo, que estaria disposto a bancar a continuidade das obras e ceder os escravos necessários para sua consecução. No mesmo ano, José Jacinto de Toledo foi eleito juiz de paz de Iguape. ${ }^{273} \mathrm{Em}$ 1837, assumiu o encargo de administrador das obras do canal em substituição a Alves Alvim. Possuía a patente de tenente-coronel e chefiou as tropas da Guarda Nacional em Iguape. Agraciado com o título de comendador, as últimas funções públicas exercidas por Toledo, delegado de polícia e deputado provincial, ocorreram no início da década de 1850, falecendo em $1855 .^{274}$

Nas primeiras décadas do Oitocentos, José Jacinto de Toledo aparece entre os comerciantes que menos recebiam as mercadorias no porto de Iguape, conforme apontado no Capítulo 1. Sua atuação provavelmente acentuou-se em fins da década de 1820, quando também já detinha a propriedade de pelo menos duas embarcações, as sumacas "Ligeira” e “Piedade”. Nos primeiros anos da década de 1840, Toledo atuava nesta área através de duas embarcações, a sumaca "Piedade" e o patacho "Primavera", esta última vendida a Luis Álvares da Silva em 1843. Em 1845, Toledo possuía parte do brigue “29 de Julho” e, em 1849, José Jacinto em sociedade com o genro João Mâncio da Silva Franco e Manoel Gomes de Araújo adquiriram o patacho "Bonfim”, fabricado em Iguape por Manoel Pereira dos Santos, pagando o valor de 9 contos de réis.

José Jacinto de Toledo também detinha a posse de engenho: em 1845, sua propriedade se localizava no Mar Pequeno, estrategicamente localizada nas proximidades do porto de embarque do arroz e beneficiária do canal que ligava o Ribeira a este braço; possivelmente daí emanava o especial interesse de Toledo na consecução da obra. Segundo a relação de 1852, este engenho tinha a capacidade de processar 2.000 sacos por ano. Não conseguimos confirmar se Toledo também cultivava arroz de forma expressiva ou se em seu engenho predominava o processamento de grãos de outros agricultores a serem transportados em seus navios. Fato é que, entre 1837 e 1854, Toledo realizou 277 remessas de arroz, somando 25.212 sacos.

\footnotetext{
${ }^{273}$ AESP, Ofícios diversos de Iguape, 1832-1838, ordem n. ${ }^{\circ} 1.039$.

${ }^{274}$ Cf. FORTES, Roberto. Vultos Iguapenses, ed. preliminar em suporte eletrônico, cortesia do autor.
} 
Entre 1835 e 1849 José Jacinto recolheu a sisa por 17 transações de compra, a maior parte delas de propriedades pertencentes a falecidos ou geradas por execução judicial, sugerindo a associação destas aquisições como forma de pagamento de dívidas. O valor nominal dos imóveis, Rs. 4:600\$000 representa apenas uma parte dos Rs. 23:395\$690 constantes nos 18 registros que Toledo aparece como credor nos inventários iguapenses, que por sua vez deveriam representar apenas parte do total das dívidas ativas pertencentes a Toledo, cujo inventário não possuímos. ${ }^{275}$

José Jacinto não aparece na lista dos contribuintes do imposto sobre casas de comércio na segunda metade do século XIX, porém seu filho e seu neto constam como proprietários de uma casa de negócios na rua do Comércio, o primeiro em alguns anos da década de 1850 e o segundo na década seguinte. Pouco mais sabemos sobre a atuação de José Carlos de Toledo: entre 1838 e 1861 José Carlos realizou 54 remessas de arroz com 1.411 sacos. Ademais, entre 1846 e 1862, registrou o pagamento de sisa por 8 compras de bens de raiz, sendo metade relativo à arrematação de bens. Em 1874, uma disputa entre pai e filho evidencia a frágil condição financeira de José Carlos de Toledo:

Diz José Carlos de Toledo Júnior, negociante de Xiririca, que seu pai José Carlos de Toledo proprietário morador nesta cidade lhe é acredor da quantia de Rs. 3:212\$300 [firmada em 31/12/1870] até 13 de fevereiro deste corrente ano (...) quer o suplicante visto nada ter conseguido no Juízo Conciliatório e comprova com documento também junto, fazê-lo citar para na primeira audiência deste juízo vir oferecer um libelo cível no qual o suplicante melhor pretende expor sua intenção ficando o suplicado citado para os mais termos e atos judiciários da ação até final sentença e execução. ${ }^{276}$

O principal da dívida referia-se a um valor devido por conta do falecimento do sogro de Toledo Júnior e que ficou em mãos de seu pai. Durante o processo, o pai não se manifestou e a sentença final favoreceu o filho, porém não sabemos se o pagamento foi ou não realizado.

Quatro anos mais tarde, através de seu procurador, João Mâncio da Silva Franco (genro de José Jacinto de Toledo) acionava os herdeiros de José Carlos de Toledo para tentar obter o pagamento de um crédito de cerca de 7 contos de réis a ele devido, cabendo aos herdeiros o ônus do pagamento, uma vez que José Carlos de Toledo falecera neste mesmo ano. A dívida referia-se a uma escritura de hipoteca, no valor de 4 contos de réis, tendo como garantia uma casa na rua do Comércio e outros imóveis urbanos de menor valor. Os bens foram encaminhados para leilão em praça pública e todos os imóveis foram arrematados por Arlindo Carneiro de Araújo Aguiar, cunhado de José Carlos de Toledo, por preço mínimo,

\footnotetext{
275 Ainda que bastante tosco, se tomarmos como parâmetro outro comerciante iguapense, José Bonifácio de Andrada, que do total das dívidas ativas arroladas em sua partilha cerca de $9 \%$ aparecia nos demais inventários de nossa amostra, podemos estimar as dívidas ativas de Toledo em um valor ao redor de 250 contos de réis.

${ }^{276}$ MHAI, caixa n. ${ }^{\circ} 86$.
} 
que terminou resultando em um depósito de pouco mais de 5 contos de réis a favor de Silva Franco. $^{277}$

É importante ressaltar a recorrência das uniões matrimoniais dentro do mesmo grupo social. José Carlos de Toledo contraiu matrimônio com uma descendente da família Peniche e uma de suas filhas casou-se com Arlindo Carneiro de Araújo Aguiar, filho de Antonio Joaquim de Araújo Aguiar, comerciante com loja na Travessa das Dores em Iguape. ${ }^{278}$

A condição secundária do filho de José Jacinto de Toledo pode ser parcialmente entendida através da importância atribuída a seu cunhado João Mâncio da Silva Franco. Apenas para que se possa aquilatar, Mâncio aparece citado como credor nos inventários em 37 processos, totalizando um valor nominal de quase 35 contos de réis, superando inclusive seu sogro. Estes créditos aparecem nos inventários abertos entre 1842 e 1874 e alguns deles indicavam a natureza da dívida, envolvendo aluguéis, fornecimento de fazendas secas e penhora de bens. João Mâncio possuía casa de negócios em Iguape, primeiramente na rua das Casinhas, depois na rua Augusta e finalmente na rua Direita.

A família de João Mâncio possuía tradição no comércio e na posse de embarcações. Em 1801 seu pai, Vitorino José Franco, natural de Lisboa, 33 anos, possuía uma loja de fazendas secas e um navio que realizava viagens regulares para o porto fluminense. A Tabela 1.4 do Capítulo 1 evidencia a posição de destaque do comerciante Vitorino como o quarto maior consignatário de mercadorias entre 1809 e 1822. Em 1828 o fogo chefiado pela viúva Josefa Joaquina contava com 18 escravos. Em 1836, dos quatro filhos homens de Vitorino José Franco, três compunham domicílios independentes, todos se dedicando ao comércio, inclusive João Mâncio, 21 anos, proprietário de dois escravos, que possuía uma renda anual de 100 mil-réis. Nenhum dos Silva Franco aparece como proprietários de engenho nas listas de 1845 e 1852 e, a julgar pelos inventários de seus irmãos, mantiveram-se nesta posição.

O primeiro a falecer foi José Bento, em $1850 .{ }^{279}$ O inventário aberto pela viúva registrou uma riqueza bruta que totalizava $£ 1.461$, tendo sete décimos atribuídos a créditos, vales, hipotecas e conta de livro, cabendo ao dois bens de raiz urbanos e aos três escravos a complementação da riqueza. Ainda em 1850, Laureano da Silva Franco abriu inventário por falecimento de sua primeira esposa, Maria Vieira Franco. ${ }^{280}$ As $£ 1.200$ concentravam-se principalmente em bens de raiz (63\%), dívidas ativas (15\%) e escravos (13\%). Dos 5 bens de

\footnotetext{
${ }^{277}$ MHAI, caixa n. ${ }^{\circ} 223$.

${ }^{278}$ O próprio Antonio Joaquim de Araújo Aguiar desposou uma das filhas de Manoel Carneiro da Silva Braga, comerciante e proprietário de engenho, sogro de Antonio Borges Diniz, descrito na seção anterior.

${ }^{279}$ Grupo 1 da Tabela 4.5; MHAI, caixa n. ${ }^{\circ} 54$.

${ }^{280}$ Grupo 1 da Tabela 4.5; MHAI, caixa n. ${ }^{\circ} 50$.
} 
raiz, todos urbanos, nenhum possuía grande valor, exceto três quartos de uma morada de casas na rua Grande. As dívidas ativas não discriminavam os devedores e as mercadorias, pelo valor atribuído (Rs. 258\$620) indicavam um pequeno comércio.

Dez anos depois falecia Vitorino José Franco, solteiro e sem herdeiros. ${ }^{281}$ A riqueza bruta, $£$ 533, constituía-se principalmente por dinheiro (41\%), escravos (35\%) e bens de raiz (22\%). No início da década de 1850, Vitorino José Franco possuía uma casa comercial na rua da Praia Finalmente, em 1871 falecia Laureano da Silva Franco, tendo como inventariante a viúva Lourença Joaquina Carneiro. A riqueza bruta, $£$ 613, foi comprometida pelas dívidas passivas que atingiam 62\%, restando $£ 230$ como riqueza líquida. Bens de raiz urbanos respondiam por $41 \%$ da riqueza bruta, $40 \%$ em escravos e $17 \%$ em dívidas ativas. A maior parte das dívidas ativas referia-se a legítimas não pagas aos filhos por decorrência do inventário anterior, porém também constavam dívidas a outros iguapenses, como Antonio de Magalhães Mesquita, Rozo Lucas Lagoa e outros. O único crédito referia-se a Antonio Francisco de Ataíde Peniche, pouco mais de 1 conto de réis. O inventário ainda dava conta da avaliação de 5 escravos e não há nenhuma menção a mercadorias ou dívidas por conta de livro, sugerindo que Laureano já não atuasse como comerciante nesta época.

O próprio João Mâncio abriu inventário por falecimento de sua primeira esposa, Delfina Belmira de Toledo em $1850 .{ }^{282}$ Os bens avaliados somavam $£$ 4.878, divididos em dívidas ativas (59\%), bens de raiz (21\%), escravos (11\%) e bens móveis (9\%). Mâncio não declarou nenhuma dívida passiva, assim como não detalhou a natureza das dívidas ativas. Dos 15 bens de raiz, todos urbanos, destacavam-se a casa no Largo das Casinhas, avaliado em 3 contos de réis e um terreno com paredes para sobrado na esquina da rua Direita, por 2,25 contos de réis. Mâncio possuía um terço do patacho "Bonfim”, avaliado em 2,5 contos de réis e 8 escravos. A falecida era filha de José Jacinto de Toledo e, no ano seguinte, João Mâncio contraiu matrimônio com a outra filha, Maria do Carmo de Toledo.

Assim como seu pai e seu sogro, João Mâncio, conforme indica o inventário, possuía embarcações que realizavam o transporte de arroz. Foi sócio de Antonio José Peniche no brigue "União", tornando-se o único dono posteriormente; também foi dono dos patachos “Bonfim”, “Safa Rascada” e “Conceição”, além dos brigues “Iguapense” e “Triunfo da Monarquia”. Estes navios transportaram, entre 1840 e 1880, cerca de 250 mil sacos de arroz ou 200 contos de réis apenas em frete; provavelmente um valor menor deveria totalizar o montante obtido pela carga trazida do porto fluminense. Segundo Antonio Paulino de

\footnotetext{
${ }^{281}$ Grupo 4 da Tabela 4.5; MHAI, caixa n. ${ }^{\circ} 94$.

${ }^{282}$ Grupo 5 da Tabela 4.5; MHAI, caixa n. ${ }^{\circ} 85$.
} 
Almeida, João Mâncio ocupou a presidência da "Companhia Iguapense de Navegação do Ribeira” tendo Bernardino da Rocha Carvalho como principal acionista. ${ }^{283}$

Entre 1837 e 1864, João Mâncio enviou 43.606 sacos de arroz em 409 remessas, o que corresponde à maior quantidade de remessas entre os iguapenses. ${ }^{284}$ É possível que Mâncio tenha herdado o engenho de seu sogro, mantendo assim o controle do processamento e transporte dos grãos. Conforme apresentamos no capítulo referente aos bens de raiz, João Mâncio destacou-se não apenas por realizar o maior número de pagamento de sisa por bens de raiz como também por concentrar estas compras em imóveis urbanos, como bem indica os bens arrolados no inventário acima citado.

Não pudemos determinar quando João Mâncio partiu de Iguape. Ainda em 1872, na lista de classificação de cativos, ele constava como proprietário de 20 escravos. Segundo Roberto Fortes, isto teria ocorrido depois de 1876, onde faleceria 20 anos depois. No ano de 1884, seu nome consta na Comissão Fiscal do Conselho Diretor do Banco Comercial do Rio de Janeiro. Em 1885 assumiu o cargo de secretário do conselho e, em 1889, assumiria a vicepresidência do Conselho. A mudança de João Mâncio parece sinalizar o fim da "belle époque" iguapense. Não temos como avaliar a riqueza de Silva Franco, porém em 1885, o capital emitido do Banco Comercial somava 12 mil contos de réis e o capital realizado, 6 mil contos. Em 1889, estes valores passaram, respectivamente, para 20 mil contos e 10 mil contos, parcela decorrente do aporte realizado por Silva Franco juntamente com o novo presidente da instituição, o Barão do Flamengo.

A trajetória de João Mâncio revela-se bem sucedido na continuidade dos negócios iniciados por seu sogro. De uma forma mais geral, é possível perceber que a economia ribeirense não suportava a presença de muitos agentes comerciais com relativo sucesso de forma simultânea. Dessa forma, entendemos a emergência de José Jacinto de Toledo e José Bonifácio da Andrada e Silva como reflexo da morte do Capitão-mor Peniche e de Bartolomeu da Costa Almeida Cruz. Da mesma forma, João Mâncio da Silva Franco beneficiou-se da ausência dos dois primeiros e de Borges Diniz, favorecendo outros comerciantes, como Luis Álvares da Silva, José Ferreira da Silva e José Ferreira de Aguiar e Silva, todos eles listados como importantes credores registrados nos inventários e também grandes remetentes de arroz.

\footnotetext{
${ }^{283}$ A companhia foi fundada em 1875 e extinta em 1887. (cf. ALMEIDA, 1945, p. 57-69)

${ }^{284}$ O irmão de João Mâncio da Silva Franco, Laureano da Silva Franco, também realizou remessas de arroz, exportando 2.068 sacos de arroz em 94 remessas entre 1837 e 1855. Outros Silva Franco aparecem com menor quantidade remetida, assim como também aparecem como credores nos inventários, porém na mesma condição secundária em relação aos créditos pertencentes a João Mâncio.
} 
Acreditamos possuir uma quantidade suficiente de elementos para proceder a uma breve comparação entre os comerciantes ribeirenses e os que atuavam em São João del Rei, destacados no início deste capítulo. Iniciemos pela riqueza acumulada. A amostra levantada por Afonso de Alencastro registrou as maiores riquezas na faixa de 20 a 30 mil libras; das 10 maiores riquezas brutas de nossa amostra, 6 pertenciam a comerciantes, porém o maior valor atingia pouco mais de 21 mil libras e a décima maior fortuna não superava 5 mil libras. Tais resultados não causam estranheza se observados os resultados da Tabela 4.1, da matriz produtiva de ambas as regiões, e o próprio contingente populacional.

Sobre a forma de fornecimento de crédito, entretanto, o Vale do Ribeira e São João del Rei apresentam semelhanças indiscutíveis, como a prevalência da concessão de pequenos valores a um número grande de pessoas. No rol de contas dos comerciantes apareciam créditos de qualidade duvidosa. No caso dos ribeirenses, pudemos estimar o impacto desses “calotes” na riqueza bruta dos comerciantes, situando-os em uma posição menos privilegiada no âmbito da acumulação de riqueza local. Diferentemente de seus congêneres sanjoanenses, os negociantes ribeirenses mantiveram atuação através dos consignadores fluminenses e não encontramos nenhuma referência indicando a extensão das casas comerciais locais na praça mercantil do Rio de Janeiro, exceto João Mâncio da Silva Franco, porém em um outro contexto. Alternativamente, verificamos que o espaço de atuação dos ribeirenses atingia, no máximo, a propriedade das embarcações que transportavam arroz e mercadorias entre os dois portos.

Tanto aqui como lá os comerciantes também investiam em atividades produtivas, principalmente em escravos. Também detectamos, entre os ribeirenses, parte da riqueza bruta em bens de raiz urbanos, porém entendemos esta acumulação de forma distinta à conjectura alinhada por Graça Filho, que destaca as funções de reserva de valor e fonte de renda, além de representar um certo ideal enobrecedor que os distinguia do mundo do trabalho, nos mesmos moldes da proposição original de João Fragoso para os comerciantes cariocas. Verificamos no Vale do Ribeira, através dos registros de sisa, que a maior parte das aquisições feitas por comerciantes ocorriam sob determinadas condições, com o proprietário já falecido ou em execução judicial. Em vários inventários pudemos notar que o arrematador dos bens apregoados em praça pública era o próprio credor, realizando uma operação contábil estranha, pois reiterava o prejuízo monetário. Talvez estes credores tivessem a expectativa de realização da venda do bem por um valor maior, minimizando a perda pelo fornecimento de crédito. Para tanto, poderiam contar com a benevolência dos avaliadores, que poderiam atribuir valores aquém de um certo "valor de mercado", bem como exercer uma certa pressão sobre os 
herdeiros no sentido de não demandarem valores justos e até solicitarem reavaliação para que os bens pudessem ser leiloados por preços menores do que os anuídos inicialmente.

Estas estratégias e outras formas legais amparadas na legislação do Código Comercial, além daquelas que obviamente não pudemos detectar através da documentação consultada constituíam as armas disponíveis para os comerciantes ribeirenses tentarem reduzir a margem de inadimplência de suas contas. Longe de um ideal enobrecedor, interessava mais ao negociante a posse de um terreno, de uma morada de casas ou de uma sorte de terras ${ }^{285}$ do que o acúmulo de papéis de declaração de dívidas. Nessa perspectiva, enxergamos o segmento representado pelo Grupo 5 da Tabela 4.5 como prisioneiros de uma cadeia perversa, obstáculo fundamental para a realização de inversões que pudessem promover um salto produtivo como o verificado no primeiro subperíodo do século XIX. De todos os casos analisados, o único que conseguiu superar esse limite foi João Mâncio da Silva Franco; sua liberdade, porém, representou o golpe de misericórdia para o frágil sistema de crédito ribeirense.

\section{Delineando o espaço agrário}

Encerramos este capítulo com uma breve, porém necessária comparação entre os proprietários de engenho e os plantadores de arroz. A dicotomia é sugestiva e imediatamente nos remete à principal delas para a economia das Américas durante os três primeiros séculos de colonização, envolvendo o cultivo e processamento de cana. Nesse sentido, lembramos aqui as palavras de Stuart Schwartz:

(...) estruturalmente, o engenho consistia na propriedade principal, que normalmente incluía alguns canaviais em suas próprias terras, mas que também dependia da cana fornecida por lavradores ligados ao engenho, alguns dos quais eram moradores, parceiros ou arrendatários, e outros que eram proprietários independentes. Os senhores de engenho tinham de calcular os custos relativos de usar os dependentes como parte das operações do engenho e comparar esses custos com as vantagens de dividir os riscos e as despesas do plantio com outros produtores. A calamidade provocada por uma safra ruim ou uma queda de preços não recaia, assim, apenas sobre o senhor de engenho, mas era compartilhada por seus lavradores. Estes, por sua vez, estavam dispostos a correr tais riscos porque a cultura da cana podia ser lucrativa e porque eles próprios aspiravam à posição de senhor de engenho e às vantagens que ela proporcionava (SCHWARTZ, 1999, p. 178).

De início, precisamos recordar que, conforme indicado no Capítulo 2, a presença de engenho nas propriedades ribeirenses acrescia valor, porém o investimento no engenho propriamente dito aparentemente nunca representou uma inversão vultosa. Movidos por energia hidráulica e construídos com madeira local, sua manutenção também não deveria

\footnotetext{
${ }^{285}$ Pensamos aqui no comerciante xiririquense Miguel Antonio Jorge, descrito no Capítulo 2 como o maior comprador de terras da localidade.
} 
requisitar dispêndios excessivos por parte do proprietário. Entendemos, portanto, que o principal fator limitante à expansão destas unidades processadoras residia nas condições físicas ideais para a captação da água necessária para seu movimento. Deste requisito emerge a valorização de propriedades rurais com estas condições, principalmente em Iguape, onde a maior parte do território é conformado por áreas planas e com baixa declividade, proporcionando pequena energia potencial para a movimentação das rodas. Encontramos tal disposição com maior freqüência em Xiririca, cuja área cultivável restringia-se a uma estreita faixa às margens do Ribeira e que divisavam com os contrafortes da Serra de Paranapiacaba, daí gerando as quedas d’água capazes de tocar os engenhos.

Esta provavelmente constitui a principal causa da elevada desproporcionalidade de engenhos naquela região, como indicam as listas nominativas. Seguindo uma lógica estritamente econômica, estaríamos diante de um problema de vantagens comparativas: ao plantador de arroz iguapense que eventualmente almejasse possuir um engenho, porém sem recursos naturais disponíveis em suas terras, restaria a opção de tentar a sorte em paragens xiririquenses, sob o risco de não conseguir o almejado terreno e ainda com o ônus do custo extra do transporte do arroz até o porto de Iguape. ${ }^{286}$

Muito mais caro do que a instalação do engenho era a aquisição de escravos para mantê-lo em funcionamento. É certo que encontramos não-escravistas como proprietários de engenho, porém com baixa freqüência: na lista nominativa de 1836, eles representavam 3 dos 27 casos em Iguape e 13 dos 47 engenheiros em Xiririca. Em nossa amostra de inventários, a quantidade de não-proprietários de cativos atingia 13 entre 93 engenheiros em Iguape e apenas 2 entre 28 casos de Xiririca. ${ }^{287}$

A maior das vantagens comparativas, no entanto, residia nos custos do processamento dos grãos e na possibilidade de incorporar a produção de pequenos rizicultores, aproximando nosso caso ao modelo da plantation açucareira. Dois casos recolhidos dos inventários nos ajudam a elucidar estes cálculos.

Antonio Joaquim da Silva faleceu em 1841, com cerca de 60 anos. Na lista nominativa de 1836, Antonio vivia com a esposa e um escravo na barra da Ribeira, onde cultivava 100 alqueires de arroz. Seu inventário revelou uma riqueza bruta de $£ 127$, um terço

\footnotetext{
${ }^{286}$ Na lista nominativa de 1815 verificamos a presença de 110 iguapenses em Xiririca, o que representava 9,7\% da população livre e nenhum xiririquense em Iguape; em 1828, a proporção de iguapenses na freguesia atingia $5,2 \%$ ou 79 pessoas contra 11 xiririquenses em Iguape, o que representava $0,2 \%$ da população. Apesar da precariedade de informações sobre ocupação, para o primeiro ano temos informação sobre 8 fogos de Xiririca encabeçados por iguapenses e em 7 deles ocorriam engenhos de arroz.

${ }^{287}$ Por conta destas baixas freqüências, concentramos nossa análise apenas entre os inventariados que detinham escravos. No próximo capítulo abordaremos plantadores e engenheiros sem cativos.
} 
dela associada ao escravo de nome João, 24 anos, o mesmo presente no arrolamento de 1836. Os bens de raiz, todos rurais, consistiam em 2 lotes de terras na barra da Ribeira e representavam 13\% da riqueza bruta. Metade das 127 libras concentrava-se em dinheiro e, segundo declarações da viúva inventariante, parte deste resultava da venda de arroz. Antes de falecer, Silva entregara 96 alqueires de arroz em casca para processamento no engenho de José Xavier de Almeida Cruz. Tal quantidade rendeu 42 alqueires de arroz pilado ou 21 sacos, vendidos a Rs. 5\$000 cada um. Do total da venda, Rs. 105\$000, a viúva declarou possuir apenas Rs. 67\$520, pois o restante (praticamente 36\%) fora retido por José Xavier como pagamento pelo uso do engenho e venda do arroz. ${ }^{288}$

Cerca de 4 anos depois, no inventário de Francisco de Oliveira Duarte e Silva, já apresentado nas páginas anteriores, a inventariante declarou que o espólio possuía 81 sacos de arroz consignados no Rio de Janeiro, negociados a Rs. $5 \$ 600$ e $6 \$ 600$. Afirmara ainda que do valor bruto da venda foram descontados as custas do frete (600 réis por saco) e 3\% de comissão ao consignador carioca. ${ }^{289}$ Se acrescermos o valor do saco de algodão, que na época valia 320 réis, ${ }^{290}$ o imposto de $4 \%$ sobre as exportações de arroz e a taxa 40 réis para o fundo de construção do canal de comunicação entre o rio Ribeira e o Mar Pequeno, o custo total atinge cerca de $24 \%$ do valor bruto de venda no menor preço e $20 \%$ no maior, considerando que o produtor internalizasse os custos de processamento do arroz, do transporte até o porto de Iguape e da estocagem dos grãos até o embarque para o Rio de Janeiro. Caso contrário, estimamos em cerca de $26 \%$ a $30 \%$ a parcela relativa ao custo total devido ao beneficiamento e venda do arroz.

Este é o nosso limite para o cálculo de receitas e despesas envolvendo o comércio do arroz. Como parte dos custos eram fixos, uma conjuntura altista promovia menor custo total; no entanto, acreditamos que o proprietário de engenho buscava sempre minimizar este ônus. Uma outra estratégia que objetivava a redução dos custos, ao mesmo tempo em que ampliava a rede de dependentes do bom sucesso da lavoura rizicultora envolvia a confecção dos sacos de algodão que acondicionavam os grãos. Segundo os mapas de importação, o item "algodão de Minas” invariavelmente compunha a lista das mercadorias mais demandadas, representando, na década de 1840,11\% do valor nominal dos gastos nestas transações e cerca de $7 \%$ nas duas décadas posteriores. ${ }^{291}$ Por outro lado, desde a lista nominativa de 1801

\footnotetext{
${ }^{288}$ MHAI, caixa n. ${ }^{\circ} 224$.

${ }^{289}$ MHAI, caixa n. ${ }^{\circ} 177$.

290 Preço atribuído pelos avaliadores em inventários de comerciantes.

${ }^{291}$ Nas décadas de 1840 e 1850, o preço médio da vara de algodão manteve-se em torno de 200 réis, passando para 450 réis nos anos de 1860 e 600 réis na década seguinte.
} 
identificamos pelo menos 10 fogos na vila de Iguape cuja ocupação provavelmente envolvia a costura dos sacos de arroz e acreditamos que parcela dos casos indicados nas listas posteriores sob a rubrica "vive de suas agências" também se dedicavam a esta atividade, ${ }^{292}$ atendendo as necessidades dos remetentes de arroz a valores provavelmente menores do que o citado anteriormente.

A quantidade de sacos remetida também poderia influenciar na redução dos custos das remessas, criando assim um estrito grupo de "clientes preferenciais” no porto fluminense. Pensamos naqueles listados na Tabela 1.16 do Capítulo 1 e também naqueles com remessas entre 101 a 200 sacos, muitos deles com contrapartida em mercadorias que abasteciam suas lojas em Iguape e em Xiririca. Também lembramos daqueles que possuíam embarcações próprias para realizar o transporte de arroz até o Rio de Janeiro, como destacamos ao longo deste capítulo. Dessa forma, entendemos que o ganho potencial transcendia a mera posse do engenho e que tal condição era percebida pelos plantadores de arroz, de tal sorte a desestimulá-los no sentido de galgarem a condição de engenheiros de arroz.

${ }^{292}$ Em 1836 estes casos representavam 17\% dos 181 fogos da vila de Iguape e 84\% eram chefiados por mulheres. 


\section{Gráfico 4.3}

Distribuição relativa da riqueza bruta de proprietários de engenho e plantadores de arroz escravistas segundo grupos de bens

(Iguape, 1800-1880)

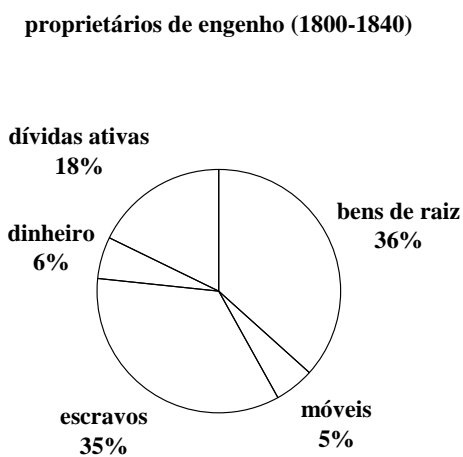

proprietários de engenho (1841-1860)

proprietários de engenho (1861-1880)
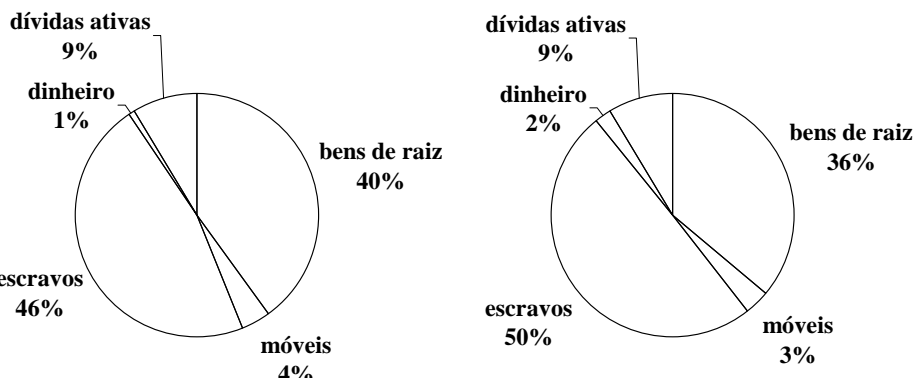

plantadores de arroz (1800-1840)

plantadores de arroz (1841-1860)

plantadores de arroz (1861-1880)
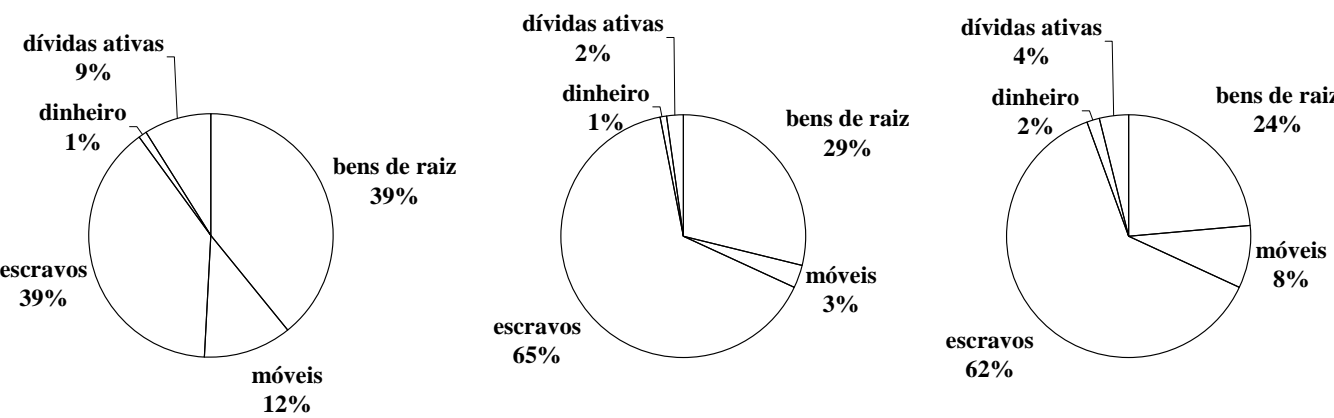

Assinalada a demarcação mais geral que separa as duas ocupações em tela, apresentamos em seguida a composição da riqueza bruta de proprietários de engenho e plantadores de arroz. Vejamos inicialmente o caso de Iguape (Gráfico 4.3).

No primeiro subperíodo, a principal diferença na composição da riqueza bruta entre as duas ocupações assenta-se na maior participação das dívidas ativas entre os proprietários de engenho e vis-à-vis a maior proporção dos móveis entre os plantadores de arroz. As participações assemelhadas dos bens de raiz e escravos aparentemente guardam relação estreita com a fase de maior dinamismo da rizicultura na localidade, que combinou a expansão da fronteira agrícola com a conjunção de preços favoráveis à aquisição de escravos. Nos dois intervalos posteriores a composição dos grupos apresenta-se relativamente estável internamente, porém com dessemelhanças importantes nas duas atividades. Apesar de em ambos os casos o grupo de bens relativos aos escravos representar o maior segmento entre os ativos avaliados, o maior peso dos bens de raiz para os proprietários de engenho e a desproporcional participação dos escravos entre os plantadores de arroz evidenciam uma desigualdade que podemos atribuir, por um lado, à significativa valoração atribuída a este 
ativo após a década de 1830, conforme salientamos no capítulo anterior e, por outro, com a tendência observada de estabilidade do valor atribuído às terras. Neste caso, a relevância atribuída aos bens de raiz dos proprietários de engenho indica a condição diferenciada destas propriedades, uma vez que muitas continham, além do engenho, a própria habitação do engenheiro.

Em Xiririca (Gráfico 4.4) a disposição revela-se distinta. Relembramos aqui a existência de práticas agrícolas mais diversificadas naquela localidade e a tendência, destacada no Capítulo 2, a se atribuir maiores valores aos bens de raiz pertencentes aos xiririquenses em relação aos observados em Iguape. Podemos notar esta maior importância dos bens de raiz comparando os plantadores de arroz nas duas localidades no último subperíodo. Não obstante, notamos que em ambos os grupos, nos dois intervalos, os escravos respondiam quase sempre por mais da metade da riqueza bruta.

\section{Gráfico 4.4}

Distribuição relativa da riqueza bruta de proprietários de engenho e plantadores de arroz escravistas segundo grupos de bens

\section{(Xiririca, 1841-1880)}

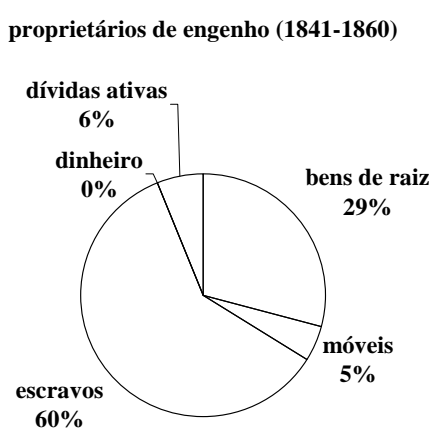

proprietários de engenho (1861-1880)

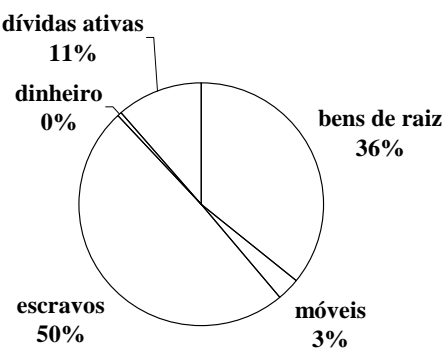

plantadores de arroz (1841-1860)

plantadores de arroz (1861-1880)

dívidas ativas

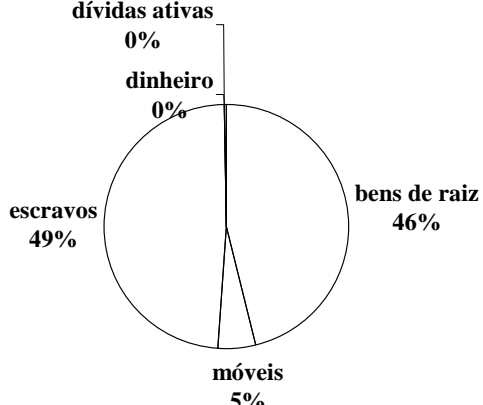

dívidas ativas

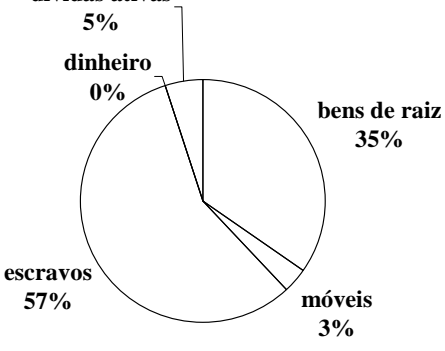

Ademais, a semelhança da distribuição entre os dois setores no último intervalo parece reiterar nossa proposição acerca das facilidades na instalação de engenhos de arroz entre os xiririquenses e o pequeno valor que ele representava no conjunto dos bens de raiz. 
Tabela 4.7

Indicadores de tendência central da riqueza bruta e riqueza líquida de proprietários de engenho e plantadores de arroz escravistas

(Iguape e Xiririca, 1800-1880)

\begin{tabular}{|c|c|c|c|c|c|c|c|c|c|c|}
\hline & & & \multicolumn{8}{|c|}{ faixas anuais } \\
\hline & \multicolumn{2}{|c|}{ Localidade/ocupação } & \multicolumn{2}{|c|}{$1800-1840$} & \multicolumn{2}{|c|}{$1841-1860$} & \multicolumn{2}{|c|}{ 1861-1880 } & \multicolumn{2}{|c|}{ total } \\
\hline & & & $\begin{array}{c}\text { riqueza } \\
\text { bruta }\end{array}$ & $\begin{array}{l}\text { riqueza } \\
\text { líquida }\end{array}$ & $\begin{array}{c}\text { riqueza } \\
\text { bruta }\end{array}$ & $\begin{array}{l}\text { riqueza } \\
\text { líquida }\end{array}$ & $\begin{array}{c}\text { riqueza } \\
\text { bruta }\end{array}$ & $\begin{array}{l}\text { riqueza } \\
\text { líquida }\end{array}$ & $\begin{array}{c}\text { riqueza } \\
\text { bruta }\end{array}$ & $\begin{array}{l}\text { riqueza } \\
\text { líquida }\end{array}$ \\
\hline \multirow{10}{*}{ 芯 } & \multirow{5}{*}{$\begin{array}{c}\text { proprietários } \\
\text { de engenho }\end{array}$} & inventários & 20 & 20 & 29 & 29 & 31 & 31 & 80 & 80 \\
\hline & & média (£) & 1.379 & 1.268 & 1.434 & 1.266 & 1.045 & 866 & 1.270 & 1.112 \\
\hline & & desvio-padrão & 1.906 & 1.867 & 1.857 & 1.901 & 797 & 840 & 1.540 & 1.557 \\
\hline & & mediana $(£)$ & 679 & 656 & 746 & 584 & 844 & 745 & 837 & 621 \\
\hline & & $\%$ riqueza & 82 & - & 74 & - & 73 & - & 76 & - \\
\hline & \multirow{5}{*}{$\begin{array}{c}\text { plantadores } \\
\text { de arroz }\end{array}$} & inventários & 12 & 12 & 33 & 33 & 20 & 20 & 65 & 65 \\
\hline & & média $(£)$ & 515 & 449 & 450 & 360 & 598 & 532 & 507 & 429 \\
\hline & & desvio-padrão & 664 & 672 & 470 & 490 & 464 & 412 & 504 & 504 \\
\hline & & mediana $(£)$ & 379 & 263 & 293 & 209 & 421 & 388 & 347 & 277 \\
\hline & & $\%$ riqueza & 18 & - & 26 & - & 27 & - & 24 & - \\
\hline \multirow{10}{*}{ : } & & inventários & - & - & 12 & 12 & 12 & 12 & 24 & 24 \\
\hline & & média (£) & - & - & 901 & 687 & 1.256 & 986 & 1.078 & 836 \\
\hline & proprietarios & desvio-padrão & - & - & 972 & 1.028 & 1.002 & 787 & 982 & 909 \\
\hline & & mediana $(£)$ & - & - & 515 & 326 & 1.066 & 821 & 673 & 461 \\
\hline & & $\%$ riqueza & - & - & 83 & - & 62 & - & 68 & - \\
\hline & \multirow{5}{*}{$\begin{array}{c}\text { plantadores } \\
\text { de arroz }\end{array}$} & inventários & - & - & 6 & 6 & 16 & 16 & 22 & 22 \\
\hline & & média $(£)$ & - & - & 373 & 316 & 592 & 511 & 532 & 458 \\
\hline & & desvio-padrão & - & - & 191 & 198 & 508 & 495 & 451 & 438 \\
\hline & & mediana $(£)$ & - & - & 353 & 256 & 327 & 311 & 327 & 285 \\
\hline & & $\%$ riqueza & - & - & 17 & - & 38 & - & 32 & - \\
\hline
\end{tabular}

A partição da riqueza bruta entre proprietários de engenho e plantadores de arroz em nossa amostra mostra-se mais igualitária em Xiririca do que em Iguape, conforme os dados da Tabela 4.7. Na primeira localidade os proprietários de engenho correspondem a 52\% dos casos e detinham 68\% da riqueza bruta contra os $76 \%$ pertencentes aos seus pares iguapenses, que respondem por 55\% dos inventários. Ainda observando a coluna totalizadora, destacamos que os valores médios da riqueza bruta e líquida dos proprietários de engenho iguapenses e xiririquenses não apresentam diferenças estatisticamente significativas, o mesmo ocorrendo entre os plantadores de arroz. Internamente às duas localidades, a riqueza bruta dos proprietários de engenho superava a dos plantadores de arroz, porém em Xiririca a riqueza 
líquida dos primeiros não se mostrou estatisticamente diferente da apresentada pelos plantadores de arroz. De fato, se para todas as demais categorias a riqueza líquida representava valores sempre acima dos $85 \%$ da riqueza bruta, entre os proprietários de engenho esta porcentagem atingiu 78\%. Observando os valores de dispersão, notamos que as duas ocupações em Iguape apresentavam maior heterogeneidade do que em Xiririca.

Os valores totais, no entanto, mascaram algumas diferenças importantes a cada subperíodo. Em Iguape, nos dois primeiros subperíodos notamos que a riqueza bruta média dos proprietários de engenho superava o valor geral, bem como a dispersão apresentava-se mais elevada. Nesses mesmos dois intervalos a riqueza média dos plantadores de arroz correspondeu aos menores valores. Tomando como referência o intervalo final, quando os proprietários de engenho possuíam a menor riqueza bruta média e os plantadores de arroz, a maior, parece-nos que as diferenças entre as duas ocupações tendem a diminuir, mais pelo empobrecimento relativo dos engenheiros do que pela melhor situação dos rizicultores. Observando a riqueza líquida, vemos novamente a mesma tendência já ressaltada do maior comprometimento da riqueza bruta com as dívidas passivas entre os proprietários de engenho, não observável nos plantadores de arroz. No caso de Xiririca, como já expusemos em outros momentos, os resultados são diversos. Para ambos os segmentos a riqueza bruta média apresentou uma elevação nos dois últimos subperíodos, porém minimizada entre os engenheiros de arroz pelo peso das dívidas passivas, como mostram os valores da riqueza líquida. Os índices de concentração apresentados na Tabela 4.8 evidenciam estes movimentos.

Tabela 4.8

Índices de Gini para a riqueza bruta e riqueza líquida de proprietários de engenho e plantadores de arroz escravistas

(Iguape e Xiririca, 1800-1880)

\begin{tabular}{c|cc|cc}
\hline \multirow{2}{*}{$\begin{array}{c}\text { Faixas } \\
\text { anuais }\end{array}$} & \multicolumn{2}{|c|}{ riqueza bruta } & \multicolumn{2}{c}{ riqueza líquida } \\
\cline { 2 - 5 } & Iguape & Xiririca & Iguape & Xiririca \\
\hline $1800-1840$ & 0,603 & - & 0,656 & - \\
$1841-1860$ & 0,564 & 0,460 & 0,644 & 0,576 \\
$1861-1880$ & 0,397 & 0,475 & 0,462 & 0,493 \\
\hline $1800-1880$ & 0,523 & 0,403 & 0,593 & 0,543 \\
\hline
\end{tabular}

A tendência de desconcentração da riqueza entre os iguapenses acentua-se de forma drástica no último subperíodo, independente da forma de mensuração. Como em todas as outras situações em que comparamos as riquezas bruta e líquida, o expurgo das dívidas passivas desvela uma pior condição da distribuição da riqueza em todos os subperíodos. No caso de Xiririca, se os valores calculados para a riqueza bruta evidenciam um ligeiro aumento 
na concentração, atribuído aos maiores valores médios, os índices para a riqueza líquida mostram o inverso, refletindo a importância do endividamento daqueles proprietários de engenho.

Notamos ao longo deste capítulo que os proprietários de engenho apresentavam cada vez mais condição secundária em relação aos comerciantes, que por sua vez detinham uma riqueza assentada sob frágeis bases. O quadro delineado neste último bloco revela uma outra situação relativamente incômoda, qual seja, o achatamento do grau hierárquico na esfera produtiva. Inseridas no contexto econômico da região, a maior diferenciação entre estas duas ocupações da atividade agrícola ocorreu justamente na fase de maior dinamismo da rizicultura, ao qual associamos o rápido crescimento da força de trabalho cativa e marcado, ao seu final, por sucessivos déficits no saldo das exportações. Apesar de registramos gastos parcimoniosos nas décadas posteriores, este esforço não resultou em expansão da produção agrícola. Ao contrário, o efeito observado redundou no aumento do endividamento, aqui medido pelas extensas listas de devedores presentes nos inventários dos comerciantes da região. Submetidos aos ditames daqueles que dominavam as redes de comercialização dos grãos - único foco capaz de gerar riqueza - proprietários de engenho e plantadores de arroz cumpriam estritamente o seu papel: plantavam, colhiam e processavam no ritmo e na forma praticados por seus ancestrais. No próximo capítulo exploramos a reificação dessa forma de produção nos demais segmentos da sociedade ribeirense, com especial atenção ao conjunto de não-proprietários de escravos. 


\section{CAPUARAS, RIBEIRINHOS, REMEDIADOS E EMPENHADOS}

No capítulo anterior selecionamos os representantes das duas ocupações com maior expressão no cenário produtivo ribeirense e delimitamos seus espaços possíveis de atuação, tendo como fundo o evolver econômico da região. No entanto, os resultados apresentados nos três primeiros capítulos desta tese evidenciam que a prática rizicultora não se restringiu a este segmento, atingindo praticamente todos os núcleos populacionais do Vale do Ribeira e de forma independente da posse de escravos.

Neste último capítulo objetivamos demonstrar o entrelaçamento das relações produtivas e sociais nos diferentes estratos populacionais de Iguape e Xiririca no século XIX. Tratamos, pois, de conjugar o determinante comum à maior parte do contingente populacional - o cultivo e a comercialização do arroz - com fatores extra-econômicos, vinculados à hierarquia social e às relações de poder. ${ }^{1}$ Como não poderia deixar de ser, lançamos mão dos informes contidos nos inventários consultados, mas também fizemos uso de outros processos localizados no Museu Histórico e Arqueológico de Iguape. Tais volumes tratam de contendas envolvendo o pagamento de créditos fornecidos e também de alguns processos-crime, constituindo espaço privilegiado da manifestação de nossos atores, espontânea ou através de seus procuradores legais. Temos claro que, no último caso, podemos ser induzidos ao engano, pois muitas vezes a estratégia adotada pelo procurador procede segundo a legislação vigente, como notamos no caso de Lourenço, ex-escravo do padre Joaquim Francisco de Mendonça.

\section{Livres, libertos e escravos na economia ribeirense}

Não sabemos quando Lourenço obteve sua liberdade, uma vez que no inventário do pároco, aberto aos 28 de abril de 1854, Lourenço, 37 anos, constava da lista dos 19 cativos avaliados que cultivavam arroz nas 1.500 braças de terras localizadas no rio de Pariqueraçu. Também não foi possível verificar qual o destino do escravo, pois Tereza Maria, a única menor das duas filhas herdeiras de Joaquim Francisco de Mendonça contraiu matrimônio com Francisco Eusébio Gonçalves, encerrando o trâmite do processo no Juízo de Órfãos. ${ }^{2}$ Lourenço reaparece nos processos judiciais de Iguape em 1878, acusado por Manoel Franco de Oliveira Canto pelo uso indevido de terras de sua propriedade no mesmo rio de

\footnotetext{
${ }^{1}$ A existência deste capítulo reflete a leitura de trabalhos clássicos como os de PRADO JÚNIOR (1989), FRANCO (1997), GORENDER (1978) e MARCÍLIO (1986). Ainda destacamos EISENBERG (1987), CASTRO (1987), COSTA (1992), e MOURA (1998). Entre os mais recentes, FERREIRA (2005) e CASTELUCCI JÚNIOR (2005), além do autor ao qual devemos o título desta tese (HOLANDA, 1994).

${ }^{2}$ MHAI, caixa n. ${ }^{\circ} 64$.
} 
Pariqueraçu para abrir uma roça de arroz, exigindo de Lourenço o pagamento de uma indenização de Rs 900\$000, equivalente a cerca de 170 alqueires de arroz pilado. Lourenço, identificado inicialmente como ex-escravo do padre Mendonça, passa a ser nomeado como Lourenço Mendonça e tem sua defesa efetuada por Manoel Eusébio Gonçalves, possivelmente cunhado de Tereza Maria, posto também ter sido seu procurador no inventário de seu falecido esposo Francisco Eusébio Gonçalves em 1863.

O processo decorreu através de contraditórios: segundo a defesa, Lourenço ocupara terras devolutas há 8 anos e que não pertenciam à propriedade de Manoel Franco. O argumento utilizado pelo embargante dizia ter o ex-escravo invadido as terras 3 anos antes sem permissão do proprietário, terra essa havida por compra realizada a um certo José Inácio da Silva o qual, por sua vez, adquirira do próprio padre Mendonça ou de seus herdeiros. A estratégia adotada por Manoel Eusébio Gonçalves centrou-se em questões legais relacionadas aos princípios gerais do direito processual. Acusou a ausência do recibo do pagamento da sisa da primeira transação, indicou uma irregularidade formal no pedido inicial do embargo e, por fim, apontou, ao longo do processo, várias irregularidades concernentes ao cumprimento dos prazos legais, caracterizando-se, assim, a possibilidade de torná-lo nulo. ${ }^{3}$ A nulidade foi aceita no julgamento final e o juiz de direito ainda condenou Manoel Franco ao pagamento das custas. Dessa forma, pôde Lourenço continuar a roçar nas referidas terras. ${ }^{4}$

Do caso exposto dois tipos de considerações merecem destaque. A primeira diz respeito ao enfrentamento jurídico estabelecido entre um liberto e um representante do setor escravista, com antepassados presentes na região pelo menos desde o século XVIII e com vários ramos familiares estabelecidos em Iguape e Xiririca. A segunda afeta as relações interpessoais de Lourenço e as ligações com a sua época de cativeiro. A mobilização do advogado de defesa, estreitamente vinculado aos herdeiros do padre Mendonça, sugere que não se tratava somente dos interesses do liberto, mas também da preservação da propriedade dos herdeiros do vigário. Ainda assim, ao optar por permanecer fisicamente próximo aos descendentes de seu ex-proprietário, Lourenço pôde contar com uma rede de proteção construída através da manutenção de vínculos pouco distintos daqueles estabelecidos no

\footnotetext{
${ }^{3}$ Márcia Menendes Motta também verificou o uso freqüente destas estratégias, por parte dos advogados, para evidenciar irregularidades nos processos de embargo na região de Paraíba do Sul na primeira metade do século XIX (Cf. MOTTA, 1998, p. 102 e seguintes).

${ }^{4}$ MHAI, caixa n. ${ }^{\circ} 54$.
} 
âmbito do cativeiro, possivelmente assentada em relações de lealdade e prestação de serviços, conforme sugerem passagens do processo aqui contemplado. ${ }^{5}$

Sorte distinta teve Francisco de Moura, falecido em 1863, na freguesia de Iporanga, pertencente à vila de Xiririca. ${ }^{6}$ Seu inventário, aberto dois anos após sua morte a pedido da casa comercial Jorge \& Rocha, reproduz os bens avaliados - um tacho de cobre, uma moenda e alambique, um cavalo, um boi e sitio com terras lavradias na paragem denominada Praia Grande - totalizando Rs. 380\$000, porém as dívidas passivas ultrapassavam esses valores, resultando um saldo devedor de pouco mais de Rs. 400\$000. Na conta corrente apresentada pelos credores constava um crédito em favor de Francisco por conta de livro e cobertura de um crédito antigo feito por Gonçalo da Silva Gomes, remunerado a 1,5\% ao mês e que Francisco realizou pagamentos mediante a entrega de arroz e galinhas aos credores.

Pouco mais se saberia a respeito de Francisco se não fosse apresentada outra conta, de Gertrudes Maria de Oliveira Roza, através de seu filho João de Moura Oliveira. O rol, iniciado em 1840, descrevia que Francisco devia a Gertrudes o valor de Rs. 22\$400 por resto de sua liberdade, além de dinheiro emprestado para pagamento de contas, para a compra do cavalo e o fornecimento de alguns alimentos como carne seca e sal. Até 1845, Francisco realizou pagamentos em arroz e em dinheiro, porém após essa data o liberto não mais travou relações financeiras com sua ex-proprietária. Em 1835, Gertrudes Maria de Oliveira Roza era casada com Joaquim de Moura Rolim, proprietário de um engenho de arroz em Iporanga e detentor de 24 escravos, entre eles um certo Francisco, crioulo, solteiro, 36 anos, natural de Iporanga. Do inventário de Rolim, registramos que possuía, ao falecer em 1858, 34 cativos, isto é, 10 a mais do que o registrado no censo de 1835 e que representavam três quartos da riqueza bruta, avaliada em $£ 3.720 .^{7}$ Na principal propriedade rural, na paragem "Caracol”, Rolim matinha engenho de arroz e cana, além de plantação de mandioca. Também possuía

\footnotetext{
${ }^{5}$ Em outro contexto, notamos a mesma relação no seguinte relato do juiz municipal ao governo provincial, em 1836: "Tendo alguns escravos que seus senhores não lhe dão o merecido castigo, como metido em desordens $e$ até injuriando a homens brancos com palavras obscenas, mormente uma escrava de nome Catarina que é tida e havida desordeira por viver absoluta por seu senhor andar ausente fora da vila, e não podendo já conter as queixas que diariamente se me fazia por pessoas que não podiam ser diante da falta de meios, passei a processar policialmente a dita escrava com 20 dias de prisão e castigo de bolas dentro da mesma prisão. E como Filadelfo de Souza Castro se veio empenhar comigo para não castigar a dita escrava e eu não quis anuir porque devia seguir o que a lei determinava, este Castro em qualidade que diz ser de administrador da casa do senhor da escrava apelou da sentença para a junta do Paço a fim de aparecer à dita escrava que eles ocultaram e até me desobedeceu quando mandei vir a minha presença a dita escrava, ensinando a outros escravos a insubordinação (...)” (AESP, Ofícios diversos de Iguape, ordem n. ${ }^{\circ} 1.039$ ).

${ }^{6}$ FEP, caixa n. ${ }^{\circ} 38$.

${ }^{7}$ FEP, caixa n. ${ }^{\circ} 37$.
} 
uma pequena lavra em um local denominado “Camargo”, reminiscência do passado aurífero da região.

Se a idade de Francisco na lista de 1835 for correta, ele faleceu com aproximadamente 66 anos e, durante o cativeiro ou após a obtenção da liberdade, constituiu família e deixou 5 filhos, que nada receberam da pequena quantidade de bens acumulada pelo ex-escravo. Decerto os descendentes de Francisco, assim como outros libertos constituíram grupos de convivência espalhados pelo médio Vale do Ribeira, compondo as várias comunidades quilombolas que até hoje povoam a região.

O confronto das histórias de Francisco e Lourenço revela-nos estratégias bem distintas. Enquanto Lourenço buscou se manter sob a influência de seus antigos proprietários, Francisco arriscou um novo tipo de arranjo. Nesta opção, provavelmente buscou juntar-se a outros de mesma condição social, porém sem negar as ligações estruturadas no tempo de cativeiro, como demonstram os acertos realizados com sua ex-senhora e com os credores da casa comercial. Não é possível descobrirmos as causas que levaram Francisco a romper o fluxo de pagamento de suas dívidas. Teria ele consciência de que ainda possuía débitos? Sua ao decidir estabelecer moradia em região distinta das propriedades de Rolim poderia indicar que o aludido arranjo também representasse um isolamento econômico, rompendo a sua ligação com o universo mercantil ribeirense. O cultivo de arroz, no entanto, parece-nos denunciante da plena inserção de ambos os ex-escravos no universo apreendido durante o tempo de cativeiro.

Mas quantos de fato se mantinham na órbita do arroz? Longe de uma idéia de isolamento econômico, temos evidências de que parte importante do setor não-escravista vinculava-se à mesma lida exercida pelos proprietários de cativos. ${ }^{8}$ No entanto, conforme os dados apresentados no Capítulo 1, no início do século XIX registramos um leque produtivo bastante diversificado. Em 1801, 58\% das unidades escravistas e 68\% daquelas sem cativos dedicavam-se à agricultura e manufatura rural. Neste segundo conjunto, destacavam-se ainda, em ordem de maior freqüência, os artesãos (12\%), jornaleiros (9\%) e atividades do mar (6\%); entre os proprietários, além dos artesãos (19\%), os comerciantes compareciam com freqüência expressiva (13\%).

\footnotetext{
${ }^{8}$ Para parcela das localidades paulistas no final do século XVIII, a população livre não-proprietária de escravos oscilava entre $50 \%$ e $80 \%$ do contingente, valores que se repetem no início do segundo quarto da centúria seguinte. Em relação à cor, predominavam entre os proprietários de escravos e seus dependentes as pessoas brancas, sempre com valores acima de três quartos da população, marca esta que não raramente atingia mais de nove décimos. No conjunto dos não-proprietários, também o segmento branco respondia pela maioria das pessoas livres, cabendo a pardos e pretos participações em torno de 15\% a 30\% (Cf. COSTA, 1992, especialmente capítulos 3 e 4).
} 
A Tabela 5.1 apresenta outras características demográficas dos domicílios escravistas e não-escravistas do Vale do Ribeira entre 1801 e 1836.

Tabela 5.1 - Atributos demográficos de domicílios escravistas e não-escravistas

(Iguape e Xiririca, anos selecionados)

\begin{tabular}{|c|c|c|c|c|c|c|c|c|}
\hline \multirow{2}{*}{ Atributos } & \multicolumn{2}{|c|}{1801} & \multicolumn{2}{|c|}{1815} & \multicolumn{2}{|c|}{1828} & \multicolumn{2}{|c|}{1836} \\
\hline & $\begin{array}{c}\text { com } \\
\text { escravos }\end{array}$ & $\begin{array}{c}\text { sem } \\
\text { escravos }\end{array}$ & $\begin{array}{c}\text { com } \\
\text { escravos }\end{array}$ & $\begin{array}{c}\text { sem } \\
\text { escravos }\end{array}$ & $\begin{array}{c}\text { com } \\
\text { escravos }\end{array}$ & $\begin{array}{c}\text { sem } \\
\text { escravos }\end{array}$ & $\begin{array}{c}\text { com } \\
\text { escravos }\end{array}$ & $\begin{array}{c}\text { sem } \\
\text { escravos }\end{array}$ \\
\hline $\begin{array}{l}\text { idade média do } \\
\text { chefe de domicílio }\end{array}$ & 49,5 (220) & 44,6 (529) & $46,6(314)$ & $41,2(314)$ & $46,8(372)$ & 40,9 (912) & 45,8 (403) & 40,4 (955) \\
\hline filhos por domicílio & 3,1 & 3,1 & 3,4 & 2,9 & 3,3 & 3,0 & 3,3 & 3,1 \\
\hline $\begin{array}{l}\text { idade média dos } \\
\text { filhos }\end{array}$ & 12,2 & 10,7 & 10,9 & 9,5 & 10,8 & 9,1 & 10,8 & 10,0 \\
\hline $\begin{array}{l}\text { agregados por } \\
\text { domicílio }^{\text {b }}\end{array}$ & $0,9(2,3)$ & $0,5(1,7)$ & $1,0(2,9)$ & $0,7(2,0)$ & $0,6(1,8)$ & $0,4(2,2)$ & $0,7(2,3)$ & $0,3(2,0)$ \\
\hline $\begin{array}{l}\text { idade média dos } \\
\text { agregados }\end{array}$ & 22,1 & 22,2 & 22,8 & 24,3 & 23,5 & 23,3 & 24,7 & 23,6 \\
\hline $\begin{array}{c}\text { escravos por } \\
\text { domicílio }\end{array}$ & 4,4 & - & 5,4 & - & 6,3 & - & 6,3 & - \\
\hline $\begin{array}{l}\text { idade média dos } \\
\text { escravos }\end{array}$ & 21,8 & - & 21,6 & - & 22,0 & - & 23,4 & - \\
\hline
\end{tabular}

${ }^{a}$ idade média e número total de chefes de domicílio

${ }^{\mathrm{b}}$ número médio para o total de fogos e exclusivamente para fogos com agregados.

Os números acima indicam algumas regularidades, como a diferença na idade média em favor dos chefes de domicílio dos fogos escravistas e que se reflete tanto no número médio de filhos como na idade média dos mesmos. ${ }^{9}$ Não obstante, tais diferenças não caracterizam um elemento de distinção entre proprietários e não-proprietários. Em 1801, por exemplo, 54\% dos fogos escravistas e 52\% daqueles sem cativos possuíam o núcleo familiar composto pelo casal com filhos e se o arranjo considerado envolver apenas um dos genitores, a participação atinge 86\% em ambos os segmentos. Já em 1836, os casais com filhos ainda representavam a maioria dos casos (51\% e 54\%, respectivamente). No arranjo maior, temos $85 \%$ dos domicílios não-escravistas contra $76 \%$ no outro segmento, reflexo da presença de fogos singulares, correspondendo a 2 casos em cada 10 unidades escravistas. ${ }^{10}$

Observando ainda os dados da Tabela 5.1, não parece restar dúvida que em ambos os casos, parcela importante dos fogos existentes no Vale do Ribeira contava com alguma força

\footnotetext{
${ }^{9} \mathrm{O}$ número médio de filhos indicado na Tabela 5.1 não pode ser confundido com qualquer aproximação acerca da fecundidade das mulheres do Vale do Ribeira, uma vez que a contagem considera apenas os filhos coabitando com os genitores no momento do recenseamento.

${ }^{10}$ A categoria é composta por pessoas solteiras, viúvos solitários ou pessoas casadas sem filhos e cônjuge ausente.
} 
de trabalho familiar, porém as diferenças entre escravistas e não-proprietários são maiores nesse quesito. Além dos próprios escravos, a participação dos agregados revelou-se maior nestes fogos. Os escravos, que correspondiam a $21 \%$ da população total em 1801, respondiam por 25\% no ano de 1815 e 29\% em 1828 e 1836. Já a participação dos agregados na população livre caiu de 13\% em 1801 a 10\% em 1815 e a 9\% nos anos de 1828 e 1836 . O aumento da população cativa coaduna-se com a expansão do cultivo do arroz, que também ajuda a compreender a redução da população agregada, uma vez que a abertura de novas fronteiras possivelmente estimulou a mobilidade regional fazendo com que parcela das pessoas livres estabelecesse novas unidades domiciliares, abandonando assim a condição anterior. $^{11}$

Atentemos ao primeiro dos setores econômicos. Aos fogos escravistas cabiam as atividades mais complexas da manufatura rural, como a posse dos engenhos de arroz, porém naquele ano uma em cada quatro unidades com escravos e praticamente um quinto das despossuídas de cativos cultivavam exclusivamente arroz. Entre os não-proprietários prevaleciam, entretanto, descrições inespecíficas sobre os cultivos, geralmente denotando práticas voltadas para o auto-consumo. ${ }^{12} \mathrm{O}$ arroz rivalizava com as plantações de mandioca, associadas ou não com outros cultivares, inclusive o próprio arroz. Praticamente $15 \%$ dos domicílios vinculados à atividade agrícola dedicavam-se ao cultivo exclusivo de mandioca e outros $4 \%$ faziam-no concomitante ao arroz, especialmente entre os não-escravistas, com cerca de 22\% dos 369 casos registrados na lista nominativa.

As listas de 1801 e 1836 fornecem, para parte dos domicílios, as quantidades colhidas destes cultivos, especialmente o arroz. Em 1801 a produção média desse grão nos 117 fogos não-escravistas (27 alqueires) igualava-se à metade da colhida nas unidades com escravos (54 alqueires), porém o valor mediano não apresentava a mesma distinção (20 e 28 alqueires, respectivamente). Ademais, é praticamente impossível afirmar que a produção média dos rizicultores sem posses escravas fosse distinta dos escravistas detentores de até 4 cativos. ${ }^{13}$ Vale dizer, nos primórdios da rizicultura a produtividade familiar concorria com a

\footnotetext{
${ }^{11}$ Essa hipótese merece ressalvas, pois não é possível uma interpretação clara do significado do termo "agregado" nos recenseamentos paulistas. Em muitos casos ele pode expressar a existência de força de trabalho subordinada ao chefe do domicílio, como bem sugere a semelhança das idades médias de agregados e escravos indicadas na Tabela 5.1. Verificamos, porém, que a presença de agregados oculta arranjos domiciliares mais complexos, envolvendo a troca do chefe do domicílio entre um recenseamento e outro e a reclassificação do restante da família como agregados. Sobre este assunto, além das obras já citadas de Maria Sylvia de Carvalho Franco e Iraci del Nero da Costa, ver também MARCÍLIO, 2000 e MESQUITA, 1975.

${ }^{12}$ Planta para seu sustento, planta e colhe para a sua família são algumas das expressões que indicam esta condição.

${ }^{13}$ Os primeiros, como já citado, colhiam 27 alqueires, em média; os demais, 33 alqueires.
} 
obtida através de poucos braços cativos. A emergência do arroz, conforme ressaltamos anteriormente, ocorreu em um contexto onde a prática de um cultivo anterior - a mandioca conformava um ambiente de competição entre os cultivares na preferência dos agricultores.

Dentro da manufatura rural merecem realce os madeireiros e lenhadores, que somavam outros $15 \%$ do total de casos e 18\% dos não-proprietários de cativos. Acerca desta atividade, destacava Freire de Andrade em 1828, que o

“(...) contínuo corte de madeiras das matas nacionais, tudo se bota abaixo indiferentemente, sejam ou não paus de lei, e quem o faz corta e vende para o contínuo fabrico de sumacas e lanchas que se fazem em diferentes lugares deste rio. Não digo que se proíbam as construções destas embarcações, todos conhecem suas utilidades; porém que se reservem algumas madeiras para a Marinha de Guerra e que o Estado receba das suas matas o que qualquer indivíduo lhe usurpa quando as vende a quem faz a embarcação: cortando sem descrição as árvores para fazerem roçadas, canoas e venderem, em breve se extinguirão, paus capazes para a construção naval não se fazem em poucos anos e por isso julgo que o Governo deve tomar isto em consideração: ordens só passadas aos capitães-mores e juizes ordinários que não lhe importam mais do que os seus próprios interesses e que dependem só do povo que eles governam e nada do Estado são quase nunca ou muito mal cumpridas. O que tenho presenciado me dá grandes motivos de poder fazer estas afirmativas."

Em concordância com a dinâmica observada ao longo das três primeiras décadas do Oitocentos, o segmento não-escravista da população também apresentou taxas de crescimento expressivas: entre 1801 e 1828, a população livre residente em fogos sem escravos passou de 2.565 para 4.075 pessoas, um aumento de 60\% contra 50\% em domicílios escravistas no mesmo período, que passou de 1.112 para 1.657. Em 1836, os fogos vinculados à agricultura e manufatura rural - praticamente $80 \%$ das unidades listadas - atingiam $73 \%$ dos casos escravistas e $82 \%$ dos não-proprietários de cativos. ${ }^{14}$

Com o desenvolvimento da lavoura de arroz, a posse de engenhos deixou de ser primazia de proprietários de escravos: 16 das 74 unidades registradas em 1836 pertenciam a não-escravistas, assim como 5 dos 15 engenhos de aguardente. ${ }^{15}$ Praticamente 6 em cada 10 unidades não-escravistas vinculadas à agricultura e manufatura rural cultivavam exclusivamente arroz, parcela que atingia também metade dos fogos com cativos. De outro lado, aqueles que se dedicavam exclusivamente ao plantio e processamento de mandioca

\footnotetext{
${ }^{14}$ Entre os escravistas, exceto a atividade comercial, que congregava 15\% dos domicílios, as demais práticas econômicas apresentaram participações reduzidas nos dois grupos, como as atividades do mar e artesanato que reuniam cerca de $4 \%$ dos fogos tanto no conjunto de proprietários de cativos como entre os não-escravistas.

${ }^{15}$ A posse de um engenho de arroz poderia render ganhos significativos, como se infere do inventário de Antonio Joaquim da Silva, falecido em 1841. Segundo declarações da viúva inventariante, Silva teria entregue 96 alqueires de arroz em casca para processamento no engenho de José Xavier de Almeida Cruz. Tal quantidade rendeu 42 alqueires de arroz pilado ou 21 sacos, vendidos a Rs. $5 \$ 000$ cada um. Do total da venda, Rs. 105\$000, a viúva declarou possuir apenas Rs. $67 \$ 520$, pois o restante (praticamente $35 \%$ ) foi destinado para pagamento pelo uso do engenho (MHAI, caixa n. $\left.{ }^{\circ} 224\right)$.
} 
representavam apenas 39 dos 1.067 fogos agrupados neste setor econômico, porém ainda era possível encontrá-los na mescla de outros cultivos, somando mais 154 casos.

Tal fato merece algumas ressalvas, pois não estamos sugerindo, como poderiam indicar os números, que a produção de farinha de mandioca perdeu espaço entre os agricultores ribeirenses. O próprio caso de Miguel dos Passos indica a condição secundária, porém presente, das atividades de farinheiro. Ao que tudo indica, a produção de farinha perdeu espaço nas relações mercantis para se tornar uma fonte exclusiva de subsistência. Já destacamos que praticamente todos os inventários consultados entre 1800 e 1880 arrolavam a roda, a prensa e o forno de cobre, elementos básicos deste ramo de atividade. O mesmo tipo de observação vale para os 7 casos de madeireiros indicados na lista nominativa.

Os ganhos obtidos com a expansão da área cultivada e com o volume de exportação possivelmente favoreceram a especialização das unidades escravistas no amanho do arroz, de tal forma que a diferença produtiva entre fogos com e sem a presença de cativos superava a observada no início do século. Por exemplo, os domicílios com escravos colheram, em média, 278 alqueires de arroz em casca contra 105 alqueires nos fogos sem cativos; a diferença aumenta se a modalidade for o arroz pilado: 245 versus 72 alqueires, respectivamente. Mesmo a aludida indistinção observada em 1801 entre não-proprietários e pequenos escravistas (com até 4 cativos) desaparece, pois estes colheram, em média, 157 alqueires de arroz pilado.

No entanto, o avanço da rizicultura minou o quadro embrionário da diversidade produtiva registrada no início da centúria. Nos dois anos cujas listas permitem uma aproximação maior das ocupações exercidas pelos ribeirenses, ainda verificamos o predomínio de não-escravistas em certos ramos de atividades. Dentre elas, as marítimas que, em 1801, eram desenvolvidas em 35 fogos, dos quais 30 associavam-se a não-escravistas; em 1836 esses últimos correspondiam a 42 dos 46 casos. Acreditamos que esta redução relativa ao total de fogos guarde relação com uma subenumeração dos casos, mas a impressão que fica através da leitura dos inventários é que tais atividades se apresentavam de forma muito complementar à agricultura, como é o caso do português Raimundo Pinto de Almeida, cuja mulher faleceu em 1809. Em 1801 exercia a atividade de construtor de embarcações e cultivador de arroz. Através do inventário, sabe-se que, além das ferramentas de carpintaria e dos 7 escravos, Raimundo possuía duas redes de lançar com 40 braças cada. Outros deveriam exercer esta atividade de forma mais sistemática, porém as listas não trazem tais especificações. $^{16}$

\footnotetext{
${ }^{16}$ MHAI, caixa n. ${ }^{\circ} 38$.
} 
Certamente o número real de pessoas que também exerciam as atividades de pesca deveria superar a quantidade registrada nas listas nominativas, como revela o caso do nãoescravista André Lopes, morador na Ilha do Mar Pequeno e falecido aos 9 de julho de 1850. Na lista nominativa de 1836 o domicílio chefiado por André continha o apontamento “trabalha para viver” e assinalava a produção de 100 alqueires de farinha de mandioca. Sua mulher, Maria Domingues, faleceu em 1843 e o inventário foi aberto 3 anos depois. Entre os bens avaliados, além das ferramentas de processamento da mandioca, constavam três lotes de terras na Ilha do Mar Pequeno, uma casqueira, e uma morada de casas na vila de Iguape. A riqueza bruta atingiu $£ 93$, cabendo metade deste valor ao inventariante. ${ }^{17}$

Através dos bens arrolados no inventário posterior, percebemos a multiplicidade de ocupações exercidas por André, pois além do tráfico de farinha, possuía uma serra braçal, uma rede de pesca, dois lotes de terras - um na Ilha do Mar Pequeno (que já constava no inventário da esposa) e outro (novo) no rio de Subauma -, a morada de casas em Iguape, duas casqueiras na mesma Ilha e duas canoas, fundamentais para a execução das atividades agrícolas, pesqueiras e extrativas. ${ }^{18}$ A avaliação resultou em $£$ 85, valor bastante próximo ao obtido no inventário de sua esposa. Pelo primeiro inventário não percebemos as atividades pesqueiras e, no intervalo entre os dois processos, André Lopes incorporou uma nova área de extração de cal e uma nova propriedade rural, responsáveis por praticamente $80 \%$ do acréscimo à sua meação. Ainda que em nenhum momento possamos vincular André Lopes ao cultivo de arroz, certamente a cal extraída destinava-se às construções urbanas em Iguape, erigidas com os ganhos obtidos através do arroz.

Nesse sentido, não causa estranhamento o confinamento dos núcleos populacionais pesqueiros em alguns trechos da faixa marinha: barra da Ribeira, Capara, Enseada e praia da Juréia. Das 173 pessoas livres que viviam nestes fogos em 1801, a maioria era branca e originária da própria vila de Iguape, características essas também observadas em 1836. A elevada freqüência de famílias nucleares sugere que tais comunidades desde há muito mantinham-se nessas regiões, porém a inspeção dos sobrenomes desses moradores indica uma certa dispersão dentro do Vale, como os Colaço, Cubas e Muniz. Em 1818, dos 115

\footnotetext{
${ }^{17}$ MHAI, caixa n. ${ }^{\circ} 157$.

${ }^{18}$ MHAI, caixa ${ }^{\circ} 149$.
} 
proprietários localizados nos bairros pesqueiros, ${ }^{19} 66$ detinham as terras por herança e/ou doação e outros 37 através de compras, sendo apenas 3 os casos de obtenção da terra mediante posse, fato esse a reafirmar a antigüidade desses núcleos.

O setor de atividade econômica mais afetado por transformações entre 1801 e 1836 foi o artesanato. Em 1801, os fogos vinculados a esta atividade congregavam 663 pessoas, compondo o segundo maior grupo de atividade econômica, isto é, pouco menos de $15 \%$ do total de pessoas em Iguape e Xiririca; em 1836 agrupavam 307 pessoas ou cerca de 4\% da população. Ainda em 1801, dois grupos de ocupações se destacavam, tanto pelo número de fogos como pela quantidade de escravos associada: os carpinteiros e construtores de barcos e canoas. A parte escravista, majoritariamente branca, detinha plantéis entre 1 e 13 escravos, com média igual a 4 escravos por proprietário. Entre os não-proprietários, apesar do predomínio branco, a participação dos pardos atingia cerca de um terço dos 33 artesãos nas duas ocupações.

Em 1836 os sinais de estagnação da atividade de construção de embarcações refletem-se não apenas no número de fogos aglutinados, como também na quantidade de escravos ali presentes: apenas 10 cativos pertencentes a três carpinteiros, restando outros 19 sem escravos e apenas um canoeiro, também não-escravista. ${ }^{20}$ Em compensação, uma parte dos artesãos vinculados ao espaço urbano - padeiros, alfaiates, pintores - destacava-se como pequenos senhores de escravos, refletindo a relativa complexidade da vila de Iguape decorrente não apenas do crescimento populacional, mas também dos ganhos obtidos por parte da população com a exportação do arroz.

Associamos os primórdios da agricultura do arroz com a presença destes construtores de embarcações no final do século XVIII. Possivelmente, outros foram impelidos, abandonando seus empreendimentos originais ou ainda mantendo-os, porém de forma subsidiária. Francisco Xavier da Silva, filho do português Francisco Xavier Rodrigues, retrata tal situação. Em 1828 Francisco, estabelecido com família no bairro da Enseada, possuía 4 escravos. Entre 1828 e 1836 Francisco ficou viúvo e perdeu seus quatro escravos. No último

\footnotetext{
${ }^{19}$ Costeira do Mar e Praia da Juréia, Porto do Prelado, Suamirim, Barra da Ribeira, Prainha, Boiporanga, Capara, Geiava, Iquatinga e Enseada (cf. AESP, Tombamentos, 1817-1818, Iguape, maço n. ${ }^{\circ} 20$ ). Preponderavam posses com até 5 alqueires, representando $36 \%$ dos casos cuja área foi possível calcular e apenas 7 propriedades ou $6 \%$ possuíam área com mais de 50 alqueires.

${ }^{20}$ Em atendimento a uma solicitação do governo provincial, o Capitão-mor José Antonio Peniche produziu, em 1824, uma lista dos carpinteiros de machado e calafates que moravam na vila, resultando 10 carpinteiros e 5 calafates. Acrescenta ainda "Não há número certo de pessoas empregadas neste serviço, que sendo atualmente os habitantes lavradores, se ocupam em tirar alguma madeira, serrar algum taboado nas estações vagas de sua lavoura e quando provisão para seu mister ou de algum particular que nisso os ocupam" (AESP, Ofícios diversos 1818-1831, ordem n. $\left.{ }^{\circ} 1.038\right)$.
} 
ano, consta que este iguapense dedicava-se à atividade rizicultora, possuindo um engenho de arroz que lhe rendia Rs. $700 \$ 000$ anuais. Francisco morreu em dezembro de 1836 e o inventário dá conta do falecimento do casal. Em seu testamento, feito após a morte da mulher, não há menção sobre escravos, porém lá Francisco reconhece ser devedor a várias pessoas. Também declarou o falecido que pagava foro pelo engenho de arroz na Enseada, de propriedade das almas. Da riqueza bruta, $£$ 98, praticamente metade foi destinada ao pagamento dessas dívidas, restando a ser partilhado a cada um dos sete filhos $£ 54 .{ }^{21}$ Cremos que Francisco, assim como seu pai, dedicava-se à manufatura de embarcações e com a redução do número de encomendas, foi obrigado a enveredar na prática rizicultora. Porém, o empreendimento não logrou sucesso, obrigando-o a se desfazer de seus escravos e acumular dívidas para a sustentação de sua família.

Durante a segunda metade do século XIX mudanças significativas alteraram o perfil demográfico da população do Vale do Ribeira. Se entre 1801 e 1854 a população aumentou a uma taxa geométrica anual equivalente a 3,0\%, no período compreendido entre anos de 1854 e 1874, o crescimento igualou-se a 1,9\% ao ano, sugerindo um arrefecimento do dinamismo observado na primeira metade da centúria. ${ }^{22}$ Ademais, os escravos, que em 1854 respondiam por mais de um quarto da população total, com 5.592 homens e mulheres, reduzir-se-iam a 2.318 pessoas em $1874 .^{23}$ No âmbito desse quadro, a partição étnica da população livre também sofreu modificações em relação aos censos do primeiro terço do século, quando o segmento branco representava cerca de sete décimos do contingente. Em 1874, pardos, pretos e caboclos somavam 8.416 pessoas contra 10.735 brancas, reduzindo a participação destas a $56 \%$ do total de pessoas livres na região.

O evolver demográfico acima descrito mantém uma relação de duplo condicionamento com a atividade agrícola mercantil, isto é, o arroz. Relembrando, após atingir o auge das exportações na década de 1850, com cerca de 100 mil alqueires anuais, a quantidade de arroz embarcada no porto de Iguape manteve-se, até fins da década de 1880, com valores oscilando entre 60 e 80 mil alqueires. Nesse sentido, o menor crescimento da população livre, a redução da população cativa e a maior participação de homens livres de cor revelam-se como a outra face da estagnação econômica verificada no cultivo e comercialização do arroz.

\footnotetext{
${ }^{21}$ MHAI, caixa n. ${ }^{\circ} 35$.

${ }^{22}$ Estas taxas devem ser observadas com cautela pois, como mostramos no Apêndice, os números do censo de 1854 aparentemente contêm problemas de totalização.

${ }^{23}$ Em 1886, antevéspera da abolição, a população de Iguape e Xiririca somava 24.461 pessoas, sendo apenas 851 os escravos presentes.
} 
Não possuímos conhecimento de levantamentos semelhantes aos das listas nominativas para a segunda metade do século XIX, porém um evento trágico - uma grande enchente que atingiu a região em 1858 - resultou no levantamento dos prejuízos acumulados por moradores de 13 quarteirões de Iguape. ${ }^{24}$ A lista resultante informava, em 10 deles, a natureza das perdas, que reproduzimos na Tabela 5.2.

Tabela 5.2

Quantidade de moradores e prejuízo com as enchentes

(Iguape, 1858)

\begin{tabular}{|c|c|c|c|c|c|c|c|c|c|}
\hline Local & moradores & arroz & valor & feijão & valor & milho & valor & mandioca & valor \\
\hline Itatins e São Lourenço & 11 & 6 & 292.000 & 6 & 115.000 & 7 & 88.000 & 2 & 30.000 \\
\hline Juquiá $^{\mathrm{a}}$ & 63 & 46 & 1.985 .000 & 14 & 409.000 & 52 & 969.000 & 23 & 607.000 \\
\hline quarteirão 6 & 10 & 5 & 1.286 .400 & - & - & - & - & 6 & 256.720 \\
\hline quarteirão 15 & 15 & 14 & 3.130 .000 & - & - & - & - & 10 & 710.000 \\
\hline quarteirão 24 & 20 & 20 & 5.530 .000 & - & - & - & - & 2 & 83.200 \\
\hline quarteirão 27 & 27 & 25 & 4.340 .000 & - & - & 4 & 1.949 .600 & 6 & 1.020 .000 \\
\hline quarteirão 28 & 29 & 22 & 2.952 .160 & - & - & 12 & 456.480 & 8 & 284.000 \\
\hline quarteirão 30 & 10 & 5 & 330.000 & - & - & 7 & 400.000 & - & - \\
\hline quarteirão 33 & 15 & 12 & 2.060 .000 & 1 & 8.000 & 3 & 75.000 & 2 & 220.000 \\
\hline quarteirão $37^{\text {b }}$ & 24 & 24 & 5.045 .000 & - & - & 14 & 830.000 & 7 & 986.000 \\
\hline quarteirão 42 & 34 & 29 & 5.056 .000 & 5 & 149.000 & 20 & 1.891 .200 & 3 & 51.000 \\
\hline total & 258 & 210 & 32.006 .560 & 26 & 681.000 & 119 & 6.659 .280 & 63 & 4.247 .920 \\
\hline
\end{tabular}

É possível que o total de moradores listados não representasse mais do que $10 \%$ dos domicílios iguapenses e justamente por ocuparem áreas naturalmente mais alagáveis, a participação dos plantadores de arroz fosse tão significativa, com valores não inferiores a 70\% em praticamente todos os quarteirões. Contudo, conforme demonstramos no Capítulo 2, a ocupação do espaço agrário no Vale do Ribeira acompanhou o leito dos rios, isto é, não há motivos para se duvidar que nos demais quarteirões de Iguape e mesmo em Xiririca a freqüência de rizicultores se posicionasse muito abaixo da acima registrada.

A tabela ainda fornece outros informes interessantes. O primeiro a ser destacado é a permanência do cultivo de mandioca, que no início da centúria representava uma alternativa econômica real aos agricultores de Iguape e que perdeu espaço com o avanço do arroz. O milho, no entanto, surpreende por superar os mandiocais tanto no número de moradores como no valor associado. Ademais, em alguns quarteirões observamos que o milho representava mais do que um complemento, isto é, em boa parte dos casos onde encontramos elevada freqüência de milharais, a participação relativa de plantadores de mandioca tendia a ser menor do que a observada em outros quarteirões onde o milho não se fazia presente.

\footnotetext{
${ }^{24}$ AESP, Ofícios diversos de Iguape, ordem n. ${ }^{\circ}$ 1.043a.
} 
Em síntese, se os resultados da tabela acima notabilizam práticas agrícolas com alguma diversidade entre os ribeirenses, também confirmam a importância do arroz como o principal gerador de renda, como se pode deduzir dos valores monetários acima registrados.

Isto nos remete novamente aos rizicultores Francisco e Lourenço e suas opções. Do ponto de vista econômico, estabelecer-se próximo a um proprietário de engenho de arroz poderia representar ganhos monetários importantes na comercialização dos grãos cultivados por Lourenço. Dessa forma, Lourenço poderia, em troca de prestação de serviços, conseguir encaixar sua pequena produção nas remessas realizadas pelos descendentes de seu exproprietário e assim incorporar de $5 \%$ a $9 \%$ além da receita obtida por seus pares que não possuíam engenho.

É provável que os custos de produção de Lourenço fossem muito pequenos, pois nada desembolsou pela terra, utilizava sua própria força de trabalho para o plantio e colheita dos grãos e provavelmente garantia parte de sua subsistência com os produtos da terra. Tais hábitos, entretanto, não impediriam a sua inclusão entre as centenas de devedores que encontramos nos inventários de comerciantes iguapenses. Ainda que não tenhamos coletado sistematicamente o conteúdo das contas de livro apresentadas por estes comerciantes para comprovação da dívida passiva, notamos que freqüentemente, além dos bens de consumo importados do Rio de Janeiro (especialmente tecidos, carne seca, sal, velas e bebidas), constava o fornecimento de gêneros da terra como feijão e milho. E, lembrando que o exescravo Francisco fornecia galinhas como forma de pagamento de sua dívida, parece razoável imaginar a contrapartida, isto é, alguém que não se dispusesse a criá-las. Recordamos aqui um trecho já citado do relatório produzido por José Inocêncio Alves Alvim:

Nos presentes tempos tudo tem mudado. Com o aumento da população e sua disseminação pelos rios ao interior a caça tem desaparecido, o peixe já não abunda nos rios e alagoas; o luxo tem introduzido até pelos sertões necessidades que os antigos desconheciam, tanto respeito ao trajar como ao passadio; assim os lavradores presentemente são obrigados por suas circunstâncias a comprar para si e para suas famílias fazendas de custo, bem como a pagar por altos preços a carne de porco e o toucinho que Ihes vem das vilas de Serra Acima e a carne seca do Rio Grande e outros comestíveis indispensáveis; por isso quando mesmos tenham a fortuna de ter uma boa safra de arroz, todo seu produto se lhes vai em despesas e se não podem adiantar; e se por desgraça falha a safra, a necessidade os obriga a contraírem dívidas com os negociantes da vila pagando prêmios de 1, 1 e meio, 2, 2 e meio por cento ao mês, conforme o maior ou menor grau de cobiça e dureza de coração daqueles que então ditam a lei aos necessitados; e ei-los, os pobres lavradores caídos em um abismo de que jamais se podem levantar, ficam por toda a sua vida cativos dos negociantes (ALVIM, 1845, p. 10-11).

As vítimas da cadeia de endividamento foram muitas. Porém poucas vezes pudemos identificar a origem étnica do devedor. Em algum dia do mês de maio de 1842 faleceu Miguel dos Passos, deixando viúva Vitorina Gonçalves com seis herdeiros, todos moradores no rio 
Pequeno e vizinhos de Patronilha de Veras e Antonio Pupo da Rocha. O inventário de Passos iniciou-se aos nove dias do mês de setembro de 1843, através de solicitação do vizinho Antonio Pupo da Rocha, tutor dos órfãos do falecido José Francisco Pupo da Rocha que havia emprestado uma certa quantia a Miguel. No decorrer do processo, a referida dívida, Rs. 450\$790, passou para as mãos de Manoel Bento de Andrade e Silva. Os bens deixados por Miguel, segundo os avaliadores nomeados, somavam Rs. $423 \$ 520$, sendo o principal deles 350 braças de terras com casa velha coberta de palha no rio Pequeno, valorado em Rs. 350\$000 além de um cultivado nas mesmas terras, um tráfico de fazer farinha de mandioca (roda, prensa e forno de cobre), três canoas e alguns poucos móveis e ferramentas. No entanto, após a arrematação dos bens a pedido da inventariante para saldar a dívida e as custas do inventário, registraram os partidores um monte-mor de Rs. 386\$420, sendo destinado 54 \$315 para o pagamento das custas e Rs. 322\$105 para o credor Manoel Bento, que terminou por arcar com um prejuízo de Rs. $118 \$ 685{ }^{25}$

Casos semelhantes ao reportado acima são relativamente comuns no Vale do Ribeira durante todo o século XIX, quando o rateio dos bens, em espécie ou após arrematação, não suportava o valor das dívidas passivas indicadas no processo. Já em 1828, o funcionário do governo provincial paulista, Paulo Freire de Andrade, incumbido de averiguar a demarcação das propriedades rurais ao longo dos rios da Ribeira, observou que

Quem quer, sobe pelo rio olha para os lados ou entra por qualquer um dos seus ramos, desembarca no lugar que lhe parece não ter dono, faz das árvores que próximas estão uma barraca, cobrem de palha e principia a deitar abaixo as árvores; secas elas, botamIhes fogo e semeiam arroz no espaço de vinte ou trinta braças e marca conforme a sua ambição de um lado e outro da barraca, cem ou duzentas braças e logo chama o terreno de seu; ainda que ele cultive só as vinte braças próximas à barraca, não consente que pessoa alguma vá plantar no lugar que a seu bel prazer, ele só com a vista, marcou; recolhe o arroz, fica naquele lugar ou se retira, tanto num como noutro caso não consente ninguém naquele terreno, ou o vende chamando-lhe os seus cultivados e por estes rios tem havido quem desta maneira tenha vendido por seis ou sete vezes os seus cultivados de sorte que o terreno que pertence ao Estado, anda em contínuas compras e vendas pelos particulares e o caso é que devendo algum dinheiro o possuidor do cultivado os juizes consentem que se ponha em público leilão as terras do Estado para pagamento do credor que muitas vezes the fia para lhe tomar o terreno que eles antes tem tomado. Pelo expendido facilmente se poderá fazer idéia das contínuas desordens que tal costume ocasiona e a perda que disto resulta ao Estado. ${ }^{26}$

A história do iguapense Miguel dos Passos parece confirmar o relato de Freire Andrade. Consta que, pelo menos desde 1815, Miguel vivia em Iguape, então indicado na lista nominativa consultada como pardo, 34 anos e já casado com Vitorina. Nessa época ele possuía terras no rio Pequeno com 100 braças de frente e 0,5 légua de profundidade, obtidas

\footnotetext{
${ }^{25}$ MHAI, caixa n. ${ }^{\circ} 189$.

${ }^{26}$ AESP, Tombamentos (1817-1818), Iguape.
} 
por posse. Aliás, dos 24 proprietários de terras dessa paragem, apenas dois declararam possuílas por compra e outros três detinham suas posses por concessão de sesmaria, sugerindo um processo de ocupação recente, como destacamos no Capítulo 2. Na lista de 1828, identificamos Miguel dos Passos como preto, 49 anos e com 5 filhos, morando no rio Pequeno. Em 1836, no fogo chefiado por Miguel dos Passos, pardo, 58 anos, natural de Iguape, encontravam-se sua mulher Vitorina, parda, 45 anos e suas filhas Benedita (30), Felicidade (24), Maria (22) Felicia (11), também pardas. Segundo os informes acerca da produção do fogo, Miguel colhia 100 alqueires de arroz, proporcionando-lhe uma renda anual de Rs. $100 \$ 000$. Considerando a idade na última das listas, Miguel teria falecido aos 64 anos, com apenas umas das filhas casada, Florência, com Sebastião José, que também habitava a mesma região do pai.

Em 1836, Miguel dos Passos pertencia a um pequeno grupo de homens livres de cor que chefiavam domicílios no Vale do Ribeira: dos 1.359 fogos listados na lista nominativa daquele ano, pardos e pretos encabeçavam 365 casos e apenas 19 detinham a posse de escravos. Entre os brancos, cerca de um terço dos casos compunha-se por proprietários de escravos. Recuperando alguns dados sobre a estrutura de posse, se os escravistas brancos detinham 2.479 cativos, os escravos pertencentes a pardos e pretos somavam apenas 50 pessoas. ${ }^{27}$ Essa desproporção também aparece no cômputo da população livre total em Iguape e Xiririca, porém de maneira menos dramática: o segmento branco somava 4.437 pessoas, seguido pelos pardos e pretos (1.532 e 278, respectivamente).

O predomínio branco entre a parcela livre parece associar-se ao período inicial da colonização da região, de tal sorte que em 1801, das 3.677 pessoas livres os brancos representavam 64\%, os pardos 32\% e pretos, apenas 4\%. No entanto, mesmo entre os brancos, a condição escravista limitava-se a uma parcela minoritária, pois dos 521 fogos chefiados por eles, a maioria (315) não possuía cativos. Nesse mesmo ano apenas 18 proprietários de escravos eram pardos ou pretos. ${ }^{28}$

O florescimento da rizicultura ainda atraiu várias pessoas para a região que tentaram auferir algum tipo de ganho. Alguns casos revelam-se pitorescos, como o francês Nicolas Dreys, que em 1836, então com 54 anos, habitava o Porto da Ribeira, onde possuía uma casa

\footnotetext{
${ }^{27}$ Exceto um proprietário arrolado como “falecido”. De outra forma, enquanto a posse média dos proprietários brancos atingia 6,4 escravos, pardos e pretos detinham propriedades em torno de 2,7 cativos por senhor.

${ }^{28}$ Os valores médios não se mostravam tão diferenciados como em 1836: brancos possuíam, em média, 4,5 escravos e pardos e pretos, 3,3.
} 
comercial. Seu inventário foi aberto em 1843, assim justificado pelo diretor da Mesa de Rendas de Iguape:

Sendo de pública notoriedade e constando mesmo pelo Jornal do Comércio do Rio de Janeiro página 4, aqui junto, haver falecido naquela corte no dia 24 de janeiro do corrente ano Nicolas Dreys, de nação francesa, que fôra por muitos anos residente e domiciliado nesta Vila e sendo também notório haver o mesmo falecido deixado no Porto da Ribeira uma casa deteriorada, terras e madeiras de uma máquina de novo invento de socar arroz que projetara fazer mas que não surtiu efeito algum, a que tudo se acha em total abandono, pelo que já caiu uma parte do edifício, quebrando-se as telhas e aliás as madeiras estão expostas a serem furtadas por estar tudo em aberto; o abaixo assinado administrador da Mesa de Rendas desta Vila em observância do artigo 18 do Regulamento de 9 de maio de 1842 requer a V. S. se sirva da execução aos artigos 11 e 12, tendo também em vista o artigo 48 e outros a respeito, consignados no mesmo Regulamento, e tanto mais se torne urgente a arrecadação destes bens abandonados quanto estão eles sujeitos ao pagamento de uma dívida do falecido nesta repartição; para tanto requer o abaixo assinado que $\mathrm{V}$. S. quanto antes se sirva da execução ao citado Regulamento. Iguape 22 de julho de 1843. Manoel Antonio de Camargo. ${ }^{29}$

No inventário deste empreendedor não tomamos conhecimento do valor das dívidas, porém os bens avaliados se resumiam à morada de casas e ao terreno adjunto, somando $£ 24$. Nada sabemos sobre o invento de Dreys, mas o local onde se instalara revelava-se estratégico para a recepção do arroz que chegava das diversas paragens ao longo do rio Ribeira. Em 1836 o Porto da Ribeira possuía 36 moradores, sendo que a maior parte (17 casos) vivia de agências, além de 6 negociantes, 7 artesãos, 4 pescadores e 2 agricultores.

Entre os que viviam de agências encontramos o espanhol João Giral, 50 anos, casado com a iguapense Isabel Maria, com quem tivera 7 filhos. Encontramos seu nome em alguns inventários, mormente associado ao transporte fluvial de pessoas e mercadorias ao longo do Ribeira e seus afluentes. Giral faleceu em 1842 e seu único bem consistia numa morada de casas no Porto da Ribeira, avaliada em Rs. 300\$000 e arrematada por Rs. 540\$000 para pagamento das dívidas passivas. ${ }^{30}$ Talvez por sua posição estratégica, adquirira "má fama” entre os vereadores da Câmara de Iguape, que em 1832 aprovaram o seguinte artigo de postura:

Que fica proibido tabernas, botequins, armazéns de molhados e toda venda de líquido espitituoso no Porto da Ribeira desta vila, excetua-se porém as que se vendem por atacado na exportação e importação. Os transgressores são multados pela primeira vez em dez mil réis e quatro dias de prisão e a dobrar havendo reincidência. Ficam revogadas todas as disposições em contrário. Iguape em Sessão Ordinária de 18 de agosto de $1832 .^{31}$

Entre o conjunto de justificativas apresentadas pelos vereadores, destacamos:

Dista desta vila aquele porto 800 braças e sendo com efeito circundado de algumas

\footnotetext{
${ }^{29}$ MHAI, caixa n. ${ }^{\circ} 12$.

${ }^{30}$ MHAI, caixa n. ${ }^{\circ} 12$.

${ }^{31}$ AESP, Ofícios diversos de Iguape, ordem n. ${ }^{\circ} 1.039$.
} 
casas, são estas divididas e muito pouco habitadas, sendo ele o único de embarque e desembarque seguindo-se por isso poderem vir todos, mais especialmente cativos os quais roubando seus senhores em sítios distantes, receosos de avançarem sem serem pressentidos já dos mesmos senhores, já de seus amigos, já da polícia e mesmo para evitar a condução de um saco que monta em mais de quatro arrobas e tendo os taberneiros naquele porto como seguro e fácil auxílio de seus crimes, a eles correm a toda hora do dia e noite, vendendo os efeitos roubados por uma diminutíssima parte de seu justo valor, ainda isso em troca de efeitos e bebidas de comum corrompidas, falsificadas em medidas e pesos, acompanhando aos escravos os traficantes que por não pagar a seus acredores obram da mesma sorte, com prejuízo decidido do comércio $(\ldots)^{32}$

Alegavam ainda que, embriagados, os cativos poderiam se ferir ou morrerem afogados, acarretando mais prejuízos aos seus senhores. Resultado do expressivo crescimento do segmento escravo nas três primeiras décadas do Oitocentos, as tensões entre cativos e seus proprietários mostram-se evidentes em vários documentos consultados, como os boatos de uma insurreição que deveria ocorrer no natal de 1840, obrigando o Juiz municipal a ordenar o patrulhamento permanente das ruas da vila. ${ }^{33}$ Alguns anos antes, o mesmo Juiz relatava:

Vagando umas notícias de que certos cativos desta vila na fonte da mesma faziam certos ajuntamentos e que entre eles tinham uns que se intitulavam Juiz de Paz, outros Juiz de Direito e outros camaristas, porteiro, escrivão, secretário, quis entrar no conhecimento, indaguei maduramente e até fiz perguntas ao intitulado secretário, o qual me disse que eram brincadeiras e que nada se escrevia nem era com má intenção; (...) Iguape, 7 de março de 1836. Juiz de paz José Bonifácio de Andrada. ${ }^{34}$

Se apenas potencial na urbe, a violência entre escravistas e cativos manifestou-se no espaço rural em pelo menos três ocasiões. Em 1837 o rizicultor Bento José Figueiredo e sua família foram assassinados pelos seus 4 escravos. ${ }^{35}$ Não localizamos o processo-crime relativo a este caso, porém encontramos outro, já da segunda metade do Oitocentos, também envolvendo o confronto entre senhores e escravos.

No dia 11 de dezembro de 1865, Francisco, crioulo, escravo, 35 anos, assassinou com golpes de machado o casal Antonio Correa de Azevedo e sua esposa Francisca Rosa de Paula, seus proprietários. Uma das testemunhas arroladas, a escrava Luiza, também pertencente a Azevedo, assim narrou o assassinato:

(...) tendo eles já jantado, no dia de domingo, e estando seu senhor deitado em sua rede na sala, debulhando feijão, entrou o escravo Francisco e pediu uma espiga de milho ao senhor que era para plantar em sua roça; o senhor deu-lhe o milho e quando o escravo saía censurou-lhe que não andasse passeando pela vizinhança afim de não trazer moléstias para a casa e só por isto o dito escravo principiou a descompor o seu senhor, o qual pegou em casa um chicote para ir castigá-lo. E nessa ocasião em que o senhor quis castigá-lo, o escravo arvorou-se com ele e saindo ambos para a rua o dito escravo Francisco pôde lançar mão de um machado que estava fora da porta e armado então ele principiou a perseguir o seu senhor, de maneira que este não tinha tempo para defender-

\footnotetext{
${ }^{32}$ AESP, Ofícios diversos de Iguape, ordem n. ${ }^{\circ} 1.039$.

${ }^{33}$ AESP, Ofícios diversos de Iguape, ordem n. ${ }^{\circ} 1.040$.

${ }^{34}$ AESP, Ofícios diversos de Iguape, ordem n. ${ }^{\circ} 1.039$.

${ }^{35}$ AESP, Ofícios diversos de Iguape, ordem n. ${ }^{\circ} 1.039$.
} 
se. Tendo o escravo já dado uma machadada e querendo seu senhor pular uma cerca, nessa ocasião tropeçou e caiu e pode o referido escravo matá-lo dando-lhe uma machadada no pescoço. Disse mais que quando o referido escravo saiu a correr atrás do seu senhor e passou por sua senhora, já lhe deu um empurrão que a atirou no chão e depois por mais que ela corresse atrás do dito escravo que perseguia o seu marido pedindo que não o matasse, mais baldados os seus esforços, porque o mencionado escravo não deixou de perseguir seu senhor enquanto não o matou. Disse ainda que, depois que Francisco matou o seu senhor, entrou para a casa e foi ao quarto aonde estava a sua senhora, principiou a injuriá-la e foi logo dando-lhe com o machado até que a matou. ${ }^{36}$

As motivações que podem elucidar o comportamento de Francisco aparecem difusas ao longo do processo e, aparentemente, revolvem o limite entre o cativeiro e a liberdade. A saga remonta ao final do século XVIII: desde 1789, os irmãos Manoel Rodrigues da Rocha e Gregório Gonçalves da Rocha, naturais de Taubaté, aparecem estabelecidos em Iguape, dedicando-se ao comércio e à construção de embarcações. Em 1801, ambos detinham 27 escravos, vários deles descritos como carpinteiros ou calafates. Nesse recenseamento, Venâncio, o pai de Francisco, então com 7 anos, constava como escravo do capitão Gregório Gonçalves da Rocha. Em 1815, Venâncio, 25 anos, pertencia ao filho do capitão Gregório, Candido Pupo da Rocha.

Os negócios de Candido Pupo da Rocha pareciam bem, pois sua posse saltou de 7 para 20 cativos entre os dois últimos anos indicados, sendo 8 menores de 10 anos. Diferentemente de seu pai, Candido possuía um engenho de arroz no rio de Una e encontramos na lista tanto Venâncio como seu filho Francisco, com idades iguais a 45 e 1 ano, respectivamente. Candido faleceu em 12 de julho de 1856, com cerca de 70 anos, deixando, além da viúva, 7 filhos. Em seu inventário constavam 16 escravos, além de outros 6 doados aos filhos, três moradas de casas e dois terrenos na vila de Iguape e três propriedades rurais, sendo a principal delas no rio Itimirim, com 1.700 braças de frente, com casa de vivenda, engenho de arroz, tráfico de farinha, fazendo divisas com João Domingues e Antonio Correa de Azevedo (o assassinado por Francisco), o que rendeu uma riqueza bruta de $£$ $2.008 .^{37}$

À época deste inventário, Antonio Correa encontrava-se casado com Ana Cândida do Espírito Santo, uma das filhas de Candido Pupo da Rocha. Da legítima que coube ao casal, pouco menos de dois contos de réis, constavam o escravo Caetano (irmão de Francisco), um quarto do escravo Venâncio (pai de Francisco) e parte das terras do rio de Una e do rio Itimirim, além dos escravos Martinho e Luiza, recebidos em dote pelo casamento. O escravo

\footnotetext{
${ }^{36}$ MHAI, caixa n. ${ }^{\circ} 106$.

${ }^{37}$ MHAI, caixa n. ${ }^{\circ} 97$.
} 
Francisco constava como doação feita ao filho Torquato Pupo da Rocha, então solteiro. Após a morte do pai, Torquato casou-se com Francisca Rosa de Paula, que enviuvou aos 2 de março de 1863. Compunham os bens avaliados as terras no rio de Una, Itimirim e Juquiá, além de 7 escravos, entre eles Francisco, então com 25 anos. ${ }^{38}$ Cerca de dois anos mais tarde, aos 6 de junho de 1865, seria a vez de Antonio Correa tornar-se viúvo devido ao falecimento da esposa Ana Cândida do Espírito Santo. Além das atividades rizicultoras, Correa também se dedicava ao comércio de secos e molhados, conforme consta do inventário de sua esposa. ${ }^{39}$

Ao que tudo indica, o casamento de Antonio Correa com Francisca Rosa ocorreu logo depois do falecimento de Ana Cândida, resultando daí a inclusão de Francisco às suas posses. Conforme relata no processo sobre o assassinato, Francisco referiu a troca de dono “há cerca de seis meses”, reencontrando-se com seu irmão Caetano e outros escravos com quem conviveu à época de Candido Pupo da Rocha, se bem o rompimento da pequena comunidade escrava aqui descrita de fato não tenha existido, pois os herdeiros de Candido Pupo mantiveram-se como vizinhos e o uso do engenho de arroz possivelmente organizava a vida dos escravos em jornadas de trabalho coletivas. O próprio depoimento de Francisco, acerca das atividades realizadas no fatídico domingo, revela essa mobilidade:

Disse mais que, no domingo, ao amanhecer, na forma de costume, por ser ele interrogado quem pescava para seus senhores, foi visitar o caís, depois do que foi à casa de Joaquim da Silva Tavares ajustar suas contas e depois à casa de um vizinho João Cassiel buscar uma parrilha de roupa que havia mandado fazer. Disse mais que saindo da casa de João Cassiel foi à roça de seu irmão Caetano, também escravo da casa, e achou este plantando milho; aí o dito irmão pediu-lhe que o ajudasse, mas ele intrigado respondeu-Ihe que não podia porque ia em casa pedir também milho ao seu senhor para plantar. ${ }^{40}$

Não obstante se tratar de um domingo, tradicionalmente dedicado ao descanso dos escravos, o roteiro cumprido por Francisco impressiona pelas relações: acerto de contas, aquisição de roupas e o acesso à terra para cultivo, cujo produto deveria resultar em forma de pagamento dos compromissos assumidos.

A negociação com o escravista acerca da possibilidade de manutenção das roças próprias não garantia o êxito da comercialização, ainda que alguns pudessem transacioná-la com o próprio proprietário. Porém, a presença de escravos nas contas de livros revela-se significativa. No inventário do comerciante de secos e molhados Antonio Dias Teixeira, do ano de 1869, o livro de contas, com 278 devedores, incluía a presença de 53 escravos

\footnotetext{
${ }^{38}$ A riqueza bruta somava $£ 743$ (MHAI, caixa n. ${ }^{\circ} 237$ ).

${ }^{39}$ Os bens avaliados somavam $£ 416$ (MHAI, caixa n. ${ }^{\circ}$ 97).

${ }^{40}$ MHAI, caixa n. ${ }^{\circ} 97$.
} 
pertencentes a 39 proprietários. ${ }^{41}$ Se a parcela da dívida representa pequena monta (cerca de 11\% do total das dívidas), a presença de escravos como devedores de comerciantes em vários processos consultados sugere a aceitação dos produtos que os cativos conseguiam obter através de suas roças e que lhe permitiam o acesso a alguns bens, como roupas, fumo, ferramentas, aguardente, bijuterias etc. Tal prática percorre, com maior ou menor freqüência, praticamente todo o século XIX. No inventário de Antonio Martins Ribeiro, comerciante estabelecido na vila de Iguape e falecido em 1846, o livro de contas registrava 481 créditos de Iguape, Cananéia, Xiririca, Iporanga e até Sorocaba, incluindo 96 escravos e ex-escravos, responsáveis por praticamente $16 \%$ dos oito contos e quinhentos mil réis contabilizados. ${ }^{42}$

Não obstante, a perspectiva da liberdade permeia todo o processo contra Francisco. Ao identificar-se, Francisco refere seu pai, Venâncio, como liberto. Sabemos que tal condição foi alcançada após o inventário de Candido Pupo da Rocha, pois na partilha dos bens, Venâncio foi igualmente repartido entre os 5 herdeiros. A única dívida ativa presente no processo referia-se a um empréstimo feito a um certo João liberto, com a indicação que tal valor foi utilizado para a sua alforria, porém não havia nenhum escravo com este nome na lista dos cativos pertencentes a Candido em 1836. No depoimento prestado por Caetano, há referências sobre a intenção de Francisco estabelecer uma negociação entre seu dono e um certo João Franco envolvendo a sua compra e ainda, ao ser indagado sobre as motivações do assassino alegou que Francisco sempre falava em sua liberdade e que sua senhora teria queimado o papel, deixado pelo finado Torquato, no qual a alforria lhe era conferida.

Nesse sentido, a documentação disponível para o Vale do Ribeira sugere a maior ocorrência de episódios envolvendo a obtenção da liberdade a partir da segunda metade do século XIX, especialmente após a promulgação da Lei do Ventre Livre, em conformidade com a criação de uma jurisprudência favorável às demandas de escravos e libertos. Em testamento lavrado aos 14 de julho de 1871, a xiririquense Maria Madalena de Gouveia, viúva, deixava libertos e nomeados como herdeiros universais seus escravos Rita, Luís, Laurindo e Joaquim. ${ }^{43}$

Em 18 de junho de 1889, Manoel Krecherly, outrora escravo pertencente a um condomínio de senhores, pleiteou e recebeu a devolução de um depósito realizado em 1877, no valor original de Rs. $100 \$ 000$ com vistas a compor o pecúlio necessário para sua

\footnotetext{
${ }^{41}$ MHAI, caixa $n{ }^{\circ} 71$.

${ }^{42}$ MHAI, caixa n. ${ }^{\circ} 1$.

${ }^{43}$ MHAI, caixa n. ${ }^{\circ} 38$.
} 
emancipação. ${ }^{44}$ Em 1882, os escravos Manoel, Antonio, Joana, Sebastiana e Eugênia, pertencentes a Pedro Laragnoit, morador na Prainha litigaram a liberdade por se considerarem africanos livres, ingressos no país após a extinção definitiva do tráfico em $1850 .{ }^{45}$ Muitos negociaram a liberdade através de acordos de prestação de serviços, muito embora alguns deles se caracterizassem pela continuidade do trabalho compulsório. Essa situação aparece de forma extrema no caso do escravo Antonio, que pertenceu ao português Joaquim de Moraes Freitas Coutinho. Manoel Pinto de Almeida Júnior depositou Rs. 400\$000, valor referente à avaliação do escravo em troca de sua liberdade mediante a prestação de 7 anos de serviço. $\mathrm{O}$ procurador nomeado do escravo tentou negociar um prazo menor que acabou não sendo aceito por Manoel. Este caso destaca-se pela data da celebração do contrato, agosto de 1885 quando, mesmo em Iguape, os rumores acerca da abolição tornavam-se mais constantes. ${ }^{46}$

A fuga, considerando-se a baixíssima freqüência registrada nos inventários de escravos fugidos, não representava uma prática comum entre os cativos do Vale do Ribeira, não obstante, em 1827, o juiz de paz José Inocêncio Alves Alvim relatar ao vice-presidente da Província a necessidade de se nomear três ou quatro capitães-do-mato, pois “(...) felizmente neste distrito não há quilombo algum mas de vez em quando fogem a seus senhores alguns escravos que costumam roubar pelas vizinhanças da vila. ${ }^{\text {47 }}$

O carpinteiro Lourenço, escravo de Jovina Constância Chaves revela a diversidade de estratégias possíveis para alcançar a condição liberta. Quando ocorreu o falecimento da viúva Jovina, em 25 de abril de 1870, a inventariante, sua nora, solicitou a arrematação do casal Lourenço e Inácia, ambos com 40 anos, para saldar as dívidas do espólio. Nesse ínterim, Lourenço requereu o depósito de sua pessoa e a nomeação de um curador que o fizesse ser reconhecido livre, direito que supunha assisti-lo. Deferida a pretensão, foi suspensa a praça de venda de ambos os escravos.

O procurador dos herdeiros recorreu da decisão, derrotando Lourenço nas duas instâncias e o escravo foi entregue ao tutor dos menores filhos de Jovina. Em 1874 requereuse novamente a execução da praça, com nova avaliação dos escravos. Cerca de um ano depois, o procurador alegou que a praça não foi realizada devido à fuga de Lourenço que partiu serra acima e estaria alojado em Paranapanema, exercendo a função de carpinteiro e solicitava ao juiz a emissão de ordem de busca e recondução para Iguape. O processo

\footnotetext{
${ }^{44}$ MHAI, caixa n. ${ }^{\circ} 159$.

${ }^{45}$ MHAI, caixa $n .{ }^{\circ} 108$.

${ }^{46}$ MHAI, caixa n. ${ }^{\circ} 118$.

${ }^{47}$ AESP, Ofícios diversos, ordem n. ${ }^{\circ} 1038$.
} 
continua em 1879 com os mesmos impasses: o escravo ainda não fora recapturado e as dívidas do inventário continuavam abertas.

Em abril do mesmo ano, um dos herdeiros localizou o escravo numa localidade chamada Varginha e pediu a arrematação do mesmo, sob risco e conta do arrematante as custas da captura do escravo, pedido que não foi atendido pelo Juiz. Em 1880 o herdeiro mais jovem emancipou-se e o processo pára de tramitar no Juízo de Órfãos. ${ }^{48}$ Dessa forma, não sabemos o destino final de Lourenço e Inácia, porém a conjugação de recursos jurídicos e a fuga permitiram, durante boa parte do período em que o processo tramitou no Juízo de Iguape, que o escravo usufruísse a condição liberta. Do ponto de vista do escravo, a distinção acerca da legalidade daquela condição deveria pesar na decisão de seus atos, fato que provavelmente o levou a fugir, um recurso extremo, como se vislumbra no caso acima descrito.

A posse de escravos no Vale do Ribeira, em franca decadência a partir da segunda metade do século XIX, apesar de propiciar maior possibilidade de obtenção da liberdade, não arrefeceu as nervosas relações entre proprietários e escravos, como revelam os casos acima e reafirma o seguinte relato:

Participo a VS em que tendo notícia em que tendo em como o escravo Antonio de Modesto Ribeiro de Mendonça estava morto dentro do seu rancho fui ao lugar com Manoel Candido da Silva e José Nóbrega e achamos o negro morto e atribuímos morrer de bichas e fome, pois o dito Modesto retirando-se para Pariquera a perto de um mês deixando o dito negro sem um bocado para comer e nem se recomendar a ninguém o quanto consta. Como o mau cheiro do dito escravo era muito sepultamos dentro do mesmo rancho onde estava Marcelina mulher do dito, também se acha em estado muito ruim causadas das bichas ao ponto de ninguém querer em sua casa (...) 16 de abril de 1864. Jeremias de Lara Maciel, inspetor do quarteirão n. $31 .{ }^{49}$

Em dezembro do mesmo ano procedeu-se ao interrogatório de Modesto Ribeiro de Mendonça, que confirmou a estada em Pariquera quando da morte do escravo e que este com a mulher ficaram no Baecó, quando adoeceu e a mulher Marcelina foi contar aos vizinhos, que constataram a doença e ao final veio a falecer, segundo haviam lhe contado. Questionado ainda se era verdade que o escravo teria morrido na miséria, Mendonça respondeu que não, que sempre deixava comida para os dois e que também pedia aos vizinhos para que suprissem com algo se faltasse alimento. Não obstante, o inspetor de quarteirão manteve seu relato acerca das condições em que encontrou o escravo e afirmou que estivera na casa no dia anterior, quando o cativo ainda estava vivo. Um dos vizinhos afirmou que só tomou conhecimento por conta de Marcelina que o procurou para pedir ajuda e afirmou desconhecer qualquer recomendação de Mendonça para acudir os escravos em caso de necessidade. $\mathrm{O}$

\footnotetext{
${ }^{48}$ MHAI, caixa n. ${ }^{\circ} 33$.

${ }^{49}$ MHAI, caixa n. ${ }^{\circ} 110$.
} 
parecer final do Juiz não associou o comportamento do proprietário com a morte do escravo, encerrando assim o trâmite do processo.

Acreditamos que o conjunto de relatos e informes aqui agrupados forneceram ao leitor um perfil bastante amplo da sociedade ribeirense, fortemente marcada pelas relações de produção associadas ao cultivo do arroz. Resta-nos investigar a conformação da assimetria entre os setores enfocados no capítulo anterior e o conjunto dos não-escravistas, nosso objeto específico nas próximas páginas.

\section{A riqueza nos inventários de não-escravistas}

Entre os 221 inventariados (181 de Iguape e 40 de Xiririca) predominavam pessoas do sexo masculino (65\%) e o inventariante, em 83\% dos processos, possuía algum grau de parentesco com o falecido, preponderando o cônjuge (54\%) ${ }^{50}$ ou filhos (14\%). Em $42 \%$ dos casos não foi possível calcular o intervalo entre o falecimento e abertura do inventário, geralmente por imprecisão na data da morte, o que sugere uma distância considerável entre os dois momentos. Entre os demais, 36\% dos casos foram abertos após 90 dias do falecimento e outros $21 \%$ após um ano, restando $43 \%$ com lapso acima de um ano entre as duas datas. Apenas 32 inventariados constavam em uma das listas nominativas entre 1801 e 1836 e destes, sete detiveram escravos em algum momento. Do cruzamento das listas nominativas e dos próprios informes contidos nos títulos dos herdeiros, determinamos a idade de 51 inventariados, resultando em idade média igual a 56 anos. A distribuição temporal e ocupacional de nossa amostra pode ser visualizada na Tabela 5.3.

Em certa medida, a distribuição dos casos nos subperíodos, em ambas as localidades, não reproduz o padrão observado para o conjunto da amostra: em Iguape, o primeiro subperíodo abarca 20\% dos 678 inventários contra 10\% dos 221 casos de não-escravistas; o último intervalo congrega $37 \%$ do total e $43 \%$ dos casos aqui considerados. O mesmo desequilíbrio ocorre em Xiririca: entre 1861 e 1880 foram abertos 88\% dos processos envolvendo os não-escravistas contra 78\% na amostra total.

$\mathrm{Na}$ distribuição dos casos segundo atividades e ocupações, evidenciamos o predomínio dos agricultores, com 63\% dos iguapenses e 78\% dos xiririquenses; a desproporção em favor do menor povoamento novamente reflete o leque ampliado de ocupações fora dessa atividade econômica em Iguape, como comerciantes e artesãos, porém

\footnotetext{
${ }^{50}$ Em 20 processos o inventário dá conta do falecimento do casal.
} 
também indica nossa dificuldade em determinar a atividade econômica e/ou a ocupação em parcela importante dos casos em Iguape, atingindo 17\% contra 8\% em Xiririca.

Tabela 5.3

Distribuição relativa dos inventários de não-escravistas segundo atividades econômicas e ocupações (Iguape e Xiririca, 1800-1880)

\begin{tabular}{|c|c|c|c|c|c|c|c|}
\hline \multirow{2}{*}{ Atividades econômicas/ocupações } & \multicolumn{4}{|c|}{ Iguape } & \multicolumn{3}{|c|}{ Xiririca } \\
\hline & $1800-1840$ & 1841-1860 & 1861-1880 & total & 1841-1860 & $1861-1880$ & total \\
\hline agricultura e manufatura rural & 4,4 & 28,3 & 30,6 & 63,3 & 7,5 & 70,0 & 77,5 \\
\hline engenho de aguardente & - & - & - & - & - & 3,2 & 3,2 \\
\hline engenhocas de aguardente & - & 0,9 & 0,9 & 1,8 & - & 6,5 & 6,5 \\
\hline alambique de aguardente & - & 0,9 & - & 0,9 & - & - & - \\
\hline engenho de arroz & 0,9 & 2,6 & 7,0 & 10,5 & 3,2 & 3,2 & 6,5 \\
\hline engenho de arroz e aguardente & - & - & 0,9 & 0,9 & - & - & - \\
\hline plantadores de cana & - & 0,9 & - & 0,9 & - & 9,7 & 9,7 \\
\hline cafeicultores & - & - & 1,8 & 1,8 & - & 3,2 & 3,2 \\
\hline plantadores de arroz com outros cultivares & 1,8 & 13,2 & 10,5 & 25,4 & - & 19,4 & 19,4 \\
\hline plantadores de mandioca exclusivamente & 2,6 & 1,8 & - & 4,4 & - & - & - \\
\hline plantadores de arroz e mandioca exclusivamente & - & 0,9 & 0,9 & 1,8 & - & - & - \\
\hline plantadores de arroz e cana & - & 1,8 & - & 1,8 & - & 3,2 & 3,2 \\
\hline cultivos não especificados & 1,8 & 21,1 & 22,8 & 45,6 & 6,5 & 38,7 & 45,2 \\
\hline criadores de bovinos & - & 0,9 & 3,5 & 4,4 & - & - & - \\
\hline vive de criar animais & - & - & - & - & - & 3,2 & 3,2 \\
\hline atividades do mar & 0,6 & 1,7 & 1,1 & 3,3 & - & - & - \\
\hline pescadores & 16,7 & 50,0 & 33,3 & 100,0 & - & - & - \\
\hline artesanato & 1,7 & 3,9 & 1,1 & 6,7 & - & 10,0 & 10,0 \\
\hline produtores de cal & - & 16,7 & 8,3 & 25,0 & - & - & - \\
\hline oleiros e telheiros & - & 8,3 & - & 8,3 & - & - & - \\
\hline paneleiros e produtores de gamelas & 8,3 & - & - & 8,3 & - & - & - \\
\hline canoeiros & - & 8,3 & 8,3 & 16,7 & - & - & - \\
\hline carpinteiros & 16,7 & 16,7 & - & 33,3 & - & 100,0 & 100,0 \\
\hline sapateiros & - & 8,3 & - & 8,3 & - & - & - \\
\hline profissões liberais & - & 0,6 & - & 0,6 & - & - & - \\
\hline boticários & - & 100,0 & - & 100,0 & - & - & - \\
\hline rentistas & - & 0,6 & - & 0,6 & - & - & - \\
\hline aluguel de imóveis & - & 100,0 & - & 100,0 & - & - & - \\
\hline comércio & 3,3 & 3,9 & 2,2 & 9,4 & 2,5 & 2,5 & 5,0 \\
\hline negócio de fazenda seca & - & 5,9 & - & 5,9 & - & - & - \\
\hline comerciante sem espeficação & 35,3 & 29,4 & 23,5 & 88,2 & 50,0 & 50,0 & 100,0 \\
\hline mascates & - & 5,9 & - & 5,9 & - & - & - \\
\hline atividades não identificadas & 0,6 & 8,3 & 7,8 & 16,7 & 2,5 & 5,0 & 7,5 \\
\hline total & 10,6 & 46,7 & 42,8 & 100,0 & 12,5 & 87,5 & 100,0 \\
\hline
\end{tabular}

A mesma agrura pode ser observada no grupo dos agricultores, porém com proporção muito maior, representando cerca de 4 inventários a cada 10 analisados nas duas localidades aqui classificados como “cultivos não especificados”. A segunda ocupação com maior participação, como esperado, agrega os plantadores de arroz e, em Iguape, seguidos pelos proprietários de engenho de arroz. A quantidade de não-escravistas em Xiririca envolvida com o cultivo e processamento da cana atingiu a expressiva marca de 23\% 
considerando todas as ocupações contra $29 \%$ entre aquelas que abrangiam a lida com o arroz, reafirmando a maior diversidade de cultivos entre os xiririquenses.

Merece destaque, no caso de Iguape, o número de proprietários de engenho de arroz. Na lista nominativa de 1836, encontramos apenas 3 casos de não-escravistas com a posse de engenhos, valor ratificado no primeiro subperíodo, com apenas uma ocorrência. Dos 3 registros no subperíodo seguinte, a quantidade soma 8 casos no último intervalo. Em Xiririca, naquela lista, contabilizamos 13 ocorrências na mesma condição, porém a amostra dos inventários contemplou apenas dois proprietários.

Apresentamos nos gráficos seguintes a composição da riqueza bruta nos inventários dos não-escravistas ribeirenses. Em Iguape (Gráfico 5.1) a partição da riqueza no primeiro subperíodo mostrou-se sensivelmente distinta dos demais, quando o grupo dos bens de raiz correspondia à maior parte da riqueza bruta, acompanhado pelas dívidas ativas e móveis. 


\section{Gráfico 5.1}

Distribuição da riqueza bruta segundo grupo de bens

(Iguape, 1800-1880)

1800-1840

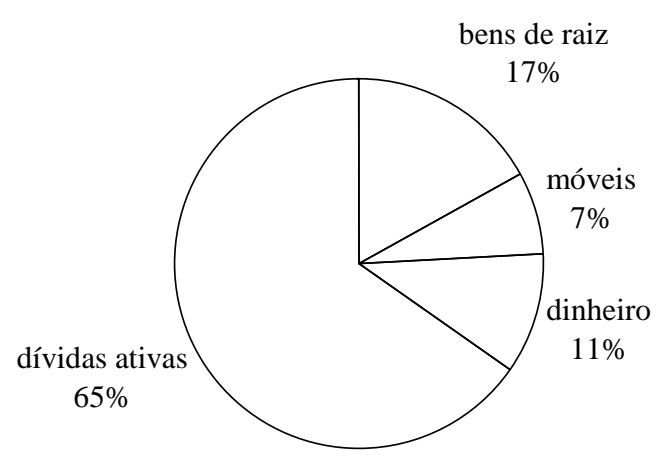

1841-1860

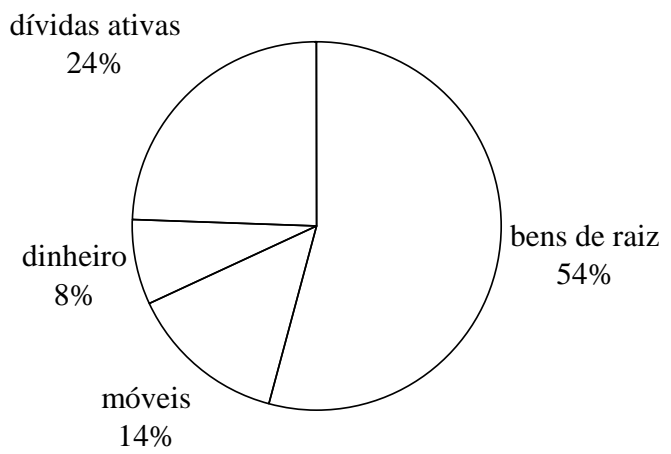

1800-1840*

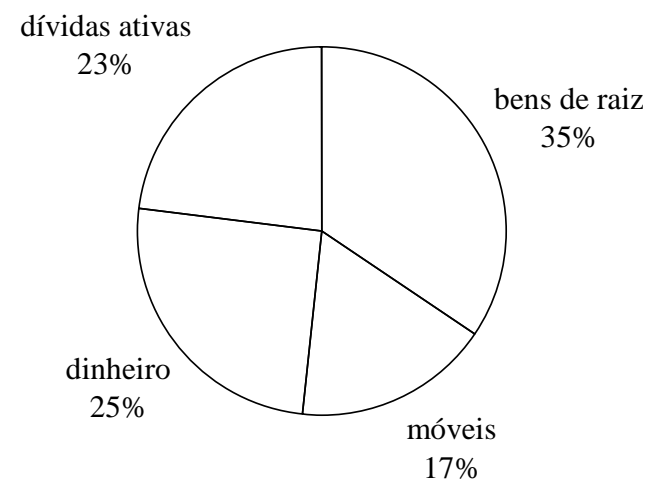

* Exceto Manoel Rodrigues do Rosário

1861-1880

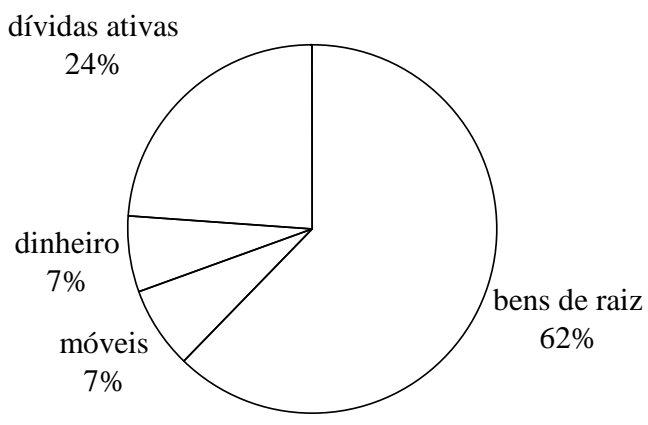

Entre os anos de 1800 e 1840, a presença ou não de Manoel Rodrigues do Rosário altera de forma significativa a referida composição. Este comerciante, como destacamos no Capítulo 1, faleceu em 1840, provavelmente com 70 anos. Localizamos Manoel nas listas nominativas de 1828 e 1836, sempre exercendo a ocupação de comerciante e proprietário de 2 escravos na primeira e 1 cativo na segunda. A riqueza bruta, $£ 2.642$, correspondia essencialmente ao conjunto de 216 dívidas ativas (96\%) e bens de raiz (4\%) e não encontramos nenhuma menção aos escravos. ${ }^{51}$

\footnotetext{
${ }^{51}$ MHAI, caixa n. ${ }^{\circ} 1$.
} 
A exclusão de Rosário coloca os bens de raiz como o principal grupo de bens na composição da riqueza, porém menor participação do que a registrada nos demais intervalos. Isso se deve aos outros 5 comerciantes aí presentes, correspondendo a um quarto do total de inventários; nos demais subperíodos estes representavam 8\% e 5\%, respectivamente.

O mesmo perfil pode ser observado em Xiririca: entre 1841 e 1860, encontramos um único comerciante entre os cinco inventários abertos no intervalo, mesma quantidade registrada entre os 35 pertencentes ao subperíodo seguinte. Destarte, os bens de raiz novamente compunham o grupo com maior participação na riqueza.

\section{Gráfico 5.2}

\section{Distribuição relativa da riqueza bruta segundo grupos de bens}

\section{(Xiririca, 1841-1880)}

1841-1860

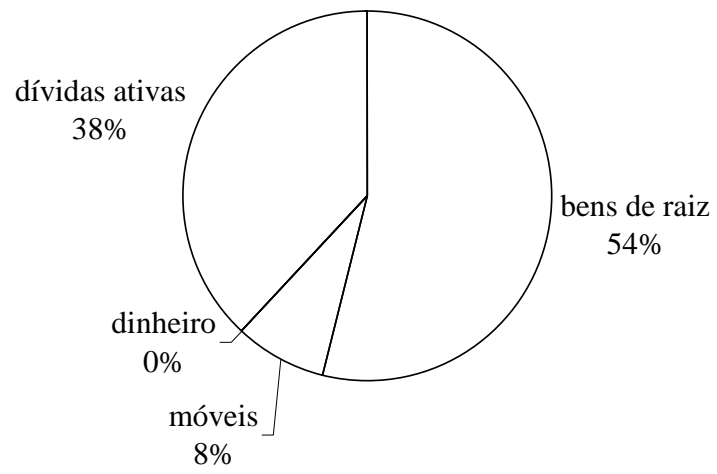

1861-1880

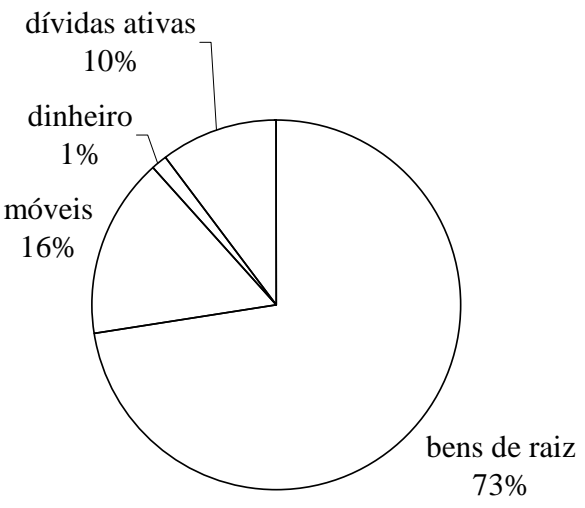

No Capítulo 1 destacamos que o nível da riqueza associado a estes casos, além de corresponder a uma riqueza bruta média, $£ 119$, cerca de 8 vezes menor do que a dos escravistas, oscilou bastante nos três subperíodos. A riqueza mediana, porém, manteve-se relativamente constante ao redor de $£ 56$, também 7 vezes menor do que a dos escravistas. A exclusão das dívidas passivas evidencia a situação econômica mais frágil dos nãoproprietários: a riqueza líquida média equivalia a menos de $10 \%$ do valor registrado para os escravistas ou $12 \%$ da riqueza mediana.

Ademais, notamos que a distribuição da riqueza bruta sugere que os casos nos dois últimos subperíodos compunham grupos relativamente homogêneos, com índice de Gini ao redor de 0,57, enquanto as riquezas do primeiro intervalo se distribuíam de forma mais assimétrica $(0,745)$. Se confrontado com os gráficos acima, não resta dúvidas quanto à responsabilidade do pequeno grupo de comerciantes pela maior desigualdade no primeiro 
subperíodo, também responsável pelo destaque das dívidas ativas. A distribuição da riqueza líquida, por seu turno, retratava um quadro de maior desigualdade, permanente em todo o lapso de tempo aqui estudado.

Nesse sentido, os resultados indicados na Tabela 5.4, que reafirmam a variabilidade da medida de riqueza segundo as atividades econômicas associadas aos inventariados, não surpreendem. Tal situação vale especialmente para os iguapenses, porém ressalvamos, em ambos os casos, os necessários cuidados por conta do pequeno número de casos em algumas atividades econômicas. A baixa freqüência de casos no primeiro subperíodo também exerce influência forte no elevado valor médio total anotado. De fato, se excluirmos Manoel Rodrigues do Rosário da amostra, a riqueza bruta passa de $£ 239$ para $£ 106$ e a líquida, de $£$ 226 para $£ 92$.

Para os representantes da agricultura e manufatura rural, em ambas localidades, apesar dos valores crescentes da riqueza bruta, estas diferenças não são estatisticamente significativas. Nos três subperíodos a riqueza bruta apresentou o mesmo padrão de dispersão e, em geral, com elevado grau de comprometimento com as dívidas passivas, atingindo até $50 \%$ entre os anos de 1841 e 1860. 
Tabela 5.4

Indicadores da riqueza bruta e riqueza líquida dos inventariados sem escravos

(Iguape e Xiririca, 1800-1880)

\begin{tabular}{|c|c|c|c|c|c|c|c|c|c|c|}
\hline \multirow{3}{*}{\multicolumn{3}{|c|}{ Localidades/atividades econômicas }} & \multicolumn{8}{|c|}{ Faixas anuais } \\
\hline & & & \multicolumn{2}{|c|}{$1800-1840$} & \multicolumn{2}{|c|}{$1841-1860$} & \multicolumn{2}{|c|}{$1861-1880$} & \multicolumn{2}{|c|}{ total } \\
\hline & & & $\begin{array}{c}\text { riqueza } \\
\text { bruta }\end{array}$ & $\begin{array}{l}\text { riqueza } \\
\text { líquida }\end{array}$ & $\begin{array}{c}\text { riqueza } \\
\text { bruta }\end{array}$ & $\begin{array}{l}\text { riqueza } \\
\text { líquida } \\
\end{array}$ & $\begin{array}{c}\text { riqueza } \\
\text { bruta }\end{array}$ & $\begin{array}{l}\text { riqueza } \\
\text { líquida } \\
\end{array}$ & $\begin{array}{c}\text { riqueza } \\
\text { bruta }\end{array}$ & $\begin{array}{l}\text { riqueza } \\
\text { líquida } \\
\end{array}$ \\
\hline \multirow{16}{*}{ 芯 } & \multirow{2}{*}{$\begin{array}{c}\text { agricultura e } \\
\text { manufatura rural }\end{array}$} & média (£) & 63 & 51 & 71 & 36 & 107 & 67 & 88 & 52 \\
\hline & & desvio-padrão & 68 & 66 & 76 & 51 & 146 & 137 & 116 & 103 \\
\hline & \multirow{2}{*}{ atividades do mar } & média (£) & 55 & 10 & 143 & 107 & 50 & 50 & 97 & 72 \\
\hline & & desvio-padrão & - & - & 44 & 93 & 52 & 52 & 62 & 76 \\
\hline & \multirow{2}{*}{ artesanato } & média (£) & 51 & 51 & 70 & 59 & 262 & 211 & 97 & 82 \\
\hline & & desvio-padrão & 21 & 21 & 49 & 41 & 280 & 224 & 121 & 96 \\
\hline & \multirow{2}{*}{ profissões liberais } & média $(£)$ & - & - & 110 & -96 & - & - & 110 & -96 \\
\hline & & desvio-padrão & - & - & - & - & - & - & - & - \\
\hline & \multirow{2}{*}{ rentistas } & média (£) & - & - & 317 & 317 & - & - & 317 & 317 \\
\hline & & desvio-padrão & - & - & - & - & - & - & - & - \\
\hline & \multirow{2}{*}{ comércio } & média (£) & 637 & 620 & 279 & 21 & 516 & 414 & 461 & 325 \\
\hline & & desvio-padrão & 1.004 & 1.014 & 360 & 166 & 500 & 474 & 661 & 670 \\
\hline & \multirow{2}{*}{$\begin{array}{l}\text { atividades não } \\
\text { identificadas }\end{array}$} & média (£) & 6 & -3 & 68 & 43 & 81 & 50 & 72 & 45 \\
\hline & & desvio-padrão & - & - & 57 & 60 & 104 & 111 & 81 & 86 \\
\hline & \multirow{2}{*}{ total } & média (£) & 239 & 226 & 94 & 42 & 126 & 86 & 123 & 80 \\
\hline & & desvio-padrão & 599 & 603 & 132 & 76 & 193 & 178 & 248 & 235 \\
\hline \multirow{10}{*}{ 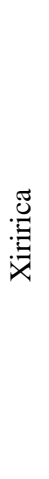 } & \multirow{2}{*}{$\begin{array}{c}\text { agricultura e } \\
\text { manufatura rural }\end{array}$} & média (£) & - & - & 69 & 51 & 118 & 55 & 114 & 55 \\
\hline & & desvio-padrão & - & - & 63 & 55 & 136 & 277 & 131 & 263 \\
\hline & \multirow{2}{*}{ artesanato } & média (£) & - & - & - & - & 43 & 26 & 43 & 26 \\
\hline & & desvio-padrão & - & - & - & - & 7 & 15 & 7 & 15 \\
\hline & \multirow{2}{*}{ comércio } & média (£) & - & - & 158 & -106 & 53 & -24 & 105 & -65 \\
\hline & & desvio-padrão & & - & - & - & - & - & 74 & 58 \\
\hline & \multirow{2}{*}{$\begin{array}{l}\text { atividades não } \\
\text { identificadas }\end{array}$} & média (£) & - & - & 19 & 19 & 42 & 10 & 34 & 13 \\
\hline & & desvio-padrão & - & - & - & - & 7 & 23 & 14 & 17 \\
\hline & \multirow{2}{*}{ total } & média (£) & - & - & 77 & 13 & 104 & 47 & 100 & 43 \\
\hline & & desvio-padrão & - & - & 67 & 78 & 125 & 248 & 119 & 233 \\
\hline
\end{tabular}

Um outro recorte possível isola aqueles que sabidamente possuíram escravos, registrados nas listas nominativas ou indicados nos próprios processos, mormente nos testamentos por conta de alforrias e quinhões da terça a estes destinadas. Mesmo não contando com o valor monetário dos cativos entre os bens avaliados, a presença pretérita dessa força de trabalho reflete-se tanto na riqueza bruta como na riqueza líquida. Nesta condição encontramos 15 inventários, cuja riqueza bruta média atingiu $£ 374$ e a líquida $£$ 253, contra $£ 106$ e $£ 67$ para os demais inventariados. ${ }^{52}$

Uma outra divisão privilegia a ocorrência de remessas de arroz, que totalizava 24 casos dos 221 inventários. A riqueza bruta média dos remetentes atingia $£ 315$ contra $£ 95$ nos

\footnotetext{
${ }^{52}$ A distribuição em torno do valor mediano não revelou distinções significativas entre os dois grupos.
} 
demais casos, porém com maior grau de endividamento (63\% contra 50\%). Ademais, o número médio de remessas (10 embarques) e a quantidade de sacos remetidos (300 sacos) não refletem o perfil do conjunto. O valor mediano das remessas, 4 embarques e a quantidade de sacos embarcados, 68,5 sacos, evidenciam a influência, no valor médio, da presença de alguns poucos casos com quantidades díspares dentro deste conjunto, como as realizadas de João Maurício Chaves, que efetuou 41 remessas entre 1840 e 1848, totalizando 1.687 sacos remetidos ou Antonio Rodrigues Pereira, que apenas entre 1838 e 1840 (ano também de sua morte), fez 38 remessas contendo 1.186 sacos. ${ }^{53}$ Cabe ainda destacar Antonio José Gonçalves, falecido em 1874, com registro de 40 remessas entre 1837 e 1854 e 979 sacos de arroz remetidos. $^{54}$

O caso de João Mauricio Chaves permite-nos compreender este restrito universo dos remetentes de arroz de nossa amostra de não-escravistas. De início, chama-nos a atenção o curto período de atuação de João Mauricio Chaves, uma vez que, aparentemente, manteve-se na região pelo menos até 1875, quando abriu inventário de sua esposa Antonia Martins Chaves. Seu sogro, João Martins da Costa, possuía um engenho de arroz na região de Juquiá, local de sua moradia pelo menos desde 1828, quando detinha a posse de três cativos. Através da lista de 1836 tomamos conhecimento que este apiaiense, além do engenho de arroz, que processava 150 alqueires, possuía uma engenhoca de aguardente que produzia 800 medidas por ano. Para tanto, contava com a presença de 8 escravos. A produção de aguardente aparece como uma tradição familiar, pois o pai de João possuía, em 1809, um engenho em Apiaí que tocava com 4 cativos.

Na lista dos engenhos de 1852, o de João Martins da Costa, em Juquiá, possuía capacidade para processar 1.000 sacos de arroz, um crescimento expressivo se comparado com o valor constante no rol de moradores de 1836. Ao falecer em 1874, além da viúva João Martins deixou 12 herdeiros. Seu patrimônio bruto somava $£ 2.347,{ }^{55}$ principalmente em 14 escravos (59\%) e nas cinco propriedades rurais e urbanas em Juquiá e Registro (31\%), onde além do arroz e cana, cultivava algum café. Parte importante da riqueza de Costa, £ 940, foi adiantada aos herdeiros sob a forma de doações e dotes. Após a meação da viúva, coube a cada herdeiro pouco mais de $£ 110$. A escrava Antonia, destinada a João Mauricio Chaves, e

\footnotetext{
${ }^{53}$ No testamento, declarou Antonio Rodrigues Pereira, natural da Ilha de Faiol, não possuir descendentes, nomeando as duas irmãs e o sobrinho como herdeiros. Também deixa livre seu único escravo, Francisco. Antonio Rodrigues Pereira matinha relações comerciais no Rio de Janeiro com José Pereira da Rosa, a quem remetia arroz e madeiras e recebia mercadorias (MHAI, caixa n. ${ }^{\circ}$ 50).

${ }^{54}$ No inventário de Antonio José Gonçalves, natural da cidade do Porto, há uma declaração datada aos 2 de dezembro de 1865 concedendo a liberdade aos seus escravos (MHAI, caixa n. ${ }^{\circ} 79$ ).

${ }^{55}$ O patrimônio líquido somava £ 2.139 .
} 
avaliada em Rs. 1:400\$000 (ou $£ 150$ ), superava sua legítima, obrigando-o a repor a diferença aos demais herdeiros. ${ }^{56}$

Segundo o inventário de sua esposa, a riqueza bruta de João Mauricio somava $£ 122$ e as dívidas passivas $£$ 434, resultando em um saldo negativo de $£$ 312. Destas, pelo menos uma pertencia a um dos co-herdeiros de João Martins da Costa, porém as maiores pertenciam ao comerciante Francisco de Souza da Silveira Gatto, por dois créditos a juros de 1\% ao mês, somando Rs. 1:987\$336 e uma hipoteca pertencente à Antonia Maria Lopes da Silva, originalmente contratada em 1869 no valor de um conto de réis e atualizada em Rs. 1:710\$000..$^{57}$ Esse conjunto de dívidas passivas, a impossibilidade de manter a escrava que recebera como herança do sogro e a venda de propriedades rurais ao longo da década de 1860, inclusive um sítio em Juquiá por um conto de réis a Bento Martins Coelho, irmão de sua esposa, sugerem uma má quadra para os negócios de João Mauricio. A última notícia que localizamos sobre esta pessoa foi uma transação realizada em 1876, envolvendo um sítio em São Lourenço, avaliado no inventário em Rs. 600\$000 e vendido a Francisco de Souza Silva por Rs. 614\$504, dinheiro provavelmente utilizado para saldar parte de suas dívidas passivas.

O caso de João mostra-nos que nem pretérita posse de escravos e muito menos a prática de remessas de arroz não contribuíam no sentido de distinguir os não-escravistas. Dessa forma, utilizando a mesma técnica de análise multivariada aplicada no capítulo anterior, elegemos seis parâmetros (as participações relativas dos bens rurais e urbanos, das dívidas ativas, dos bens móveis, do dinheiro e o comprometimento da riqueza bruta com as dívidas passivas) e distribuímos nossos casos entre 4 grupos, cujos indicadores de riqueza encontram-se sumariados na Tabela 5.5, onde agregamos iguapenses e xiririquenses. De início, advertimos que, dada a dispersão da amostra, cada grupo de classificação reproduz o padrão de heterogeneidade. ${ }^{58}$

\footnotetext{
${ }^{56}$ MHAI, caixa n. ${ }^{\text { } 38 . ~ P a r a ~ c o b r i r ~ a ~ d i f e r e n c ̧ a ~ M a u r i c i o ~ s o l i c i t o u ~ a ~ v e n d a ~ d a ~ e s c r a v a . ~}$

${ }^{57}$ MHAI, caixa n. ${ }^{\circ} 62$.

${ }^{58}$ Não obstante termos excluímos 4 casos cuja dívida passiva superava em mais de três vezes a riqueza bruta.
} 
Tabela 5.5 - Indicadores de riqueza de inventários sem escravos

(Iguape e Xiririca, 1800-1880)

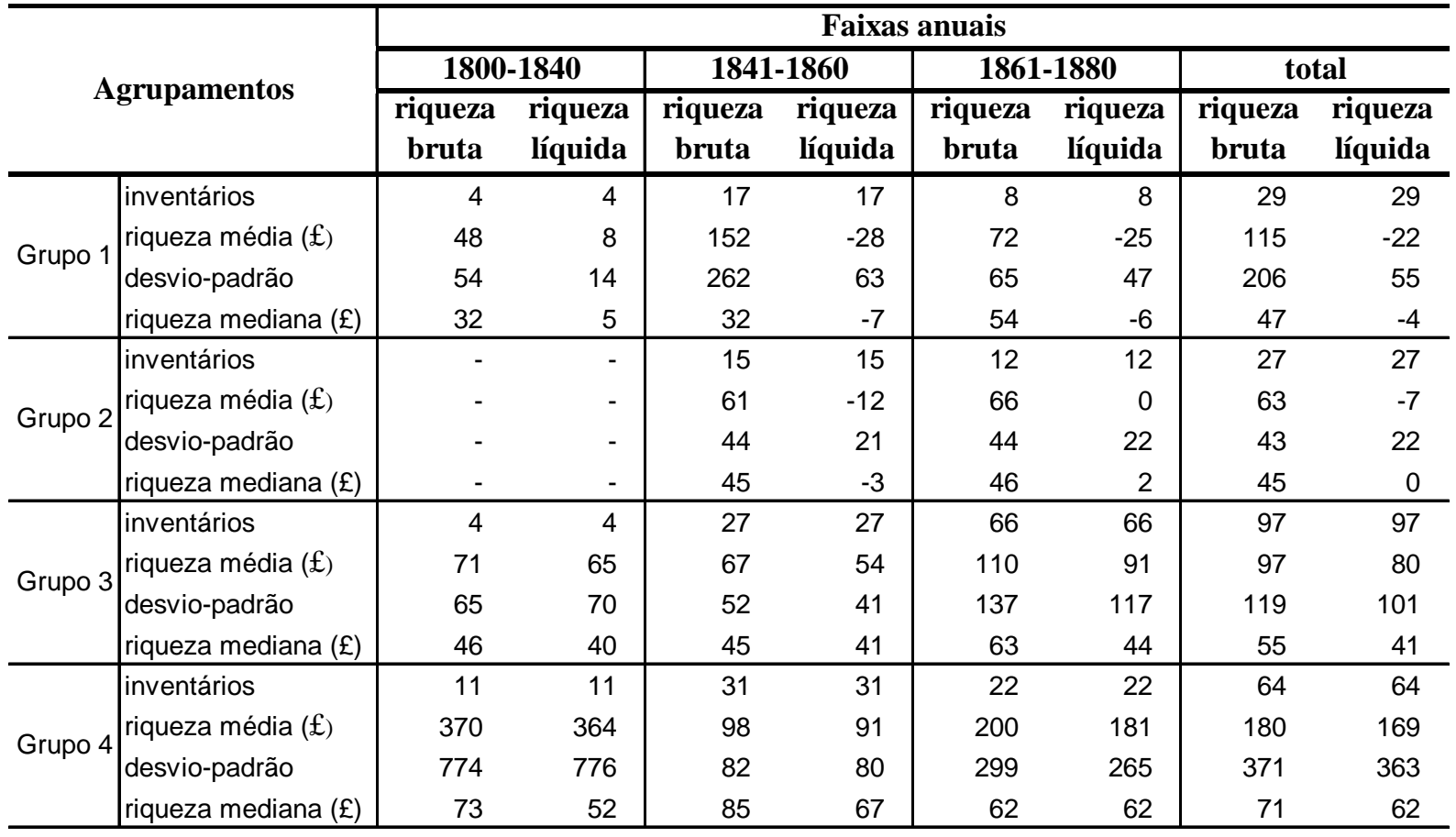

O Grupo 1 aglutina os casos com maior peso entre os bens de raiz urbanos (33\%, em média), móveis (34\%) e dívidas ativas (23\%), porém com elevado endividamento (125\% da riqueza bruta, em média). Dos 29 casos, identificamos 10 agricultores, 9 comerciantes e 7 sem atividade identificada, além de um artesão, um profissional liberal e um pertencente às atividades do mar. A comparação entre os valores médios e medianos da riqueza bruta assim como a elevada dispersão em torno da média revelam a heterogeneidade do grupo, atingindo nas décadas de 1840 e 1850 tanto o maior valor bruto como o menor valor líquido. O grau de endividamento destes casos também pode ser visto pelas significativas diferenças entre a riqueza bruta e riqueza mediana, porém com as mesmas discrepâncias já assinaladas para os valores brutos.

O elevado endividamento (122\% da riqueza, em média) também constitui característica do Grupo 2, porém com posses eminentemente rurais (83\% da riqueza bruta, em média). Entre os 27 casos deste grupo predominavam agricultores (23 casos), um com atividades ligadas ao mar e três não identificados. Nos dois subperíodos, são os que possuem menor riqueza bruta média e uma dispersão moderada, arregimentando os casos com menor riqueza de nossa amostra e nada ou muito pouco coube aos herdeiros.

O Grupo 3 possuí o maior número de inventários e traz como característica o elevado peso dos bens rurais (75\% em média) e móveis (14\%) e um pequeno comprometimento da riqueza bruta com dívidas passivas (17\%, em média). Dos 97 casos, 79 associavam-se à 
atividade agrícola, além de 7 artesãos, 1 comerciante, 1 com atividades marítimas e 9 não identificados. Trata-se, novamente, de um grupamento com riqueza heterogênea, porém em nível relativamente baixo ( $£ 97$ no total) se comparado com os valores médios de seus congêneres escravistas.

Por fim, o Grupo 4 agrega inventários com maior peso nos bens urbanos (43\% em média) e, com menor importância, as dívidas ativas (17\%) e bens móveis (12\%). Verificamos aqui novamente o menor comprometimento com dívidas passivas (7\% da riqueza bruta). Sua composição agrega 29 agricultores, 9 comerciantes, 8 artesãos, 3 ligados a atividades do mar, 1 rentista e 14 sem identificação. A eles é atribuída a maior riqueza bruta média geral ( $£$ 180), bem como o maior valor mediano ( $£ 78)$.

Em síntese, tomando como premissa a composição interna dos grupos de bens, a classificação acima permite distinguir dois grandes grupos: aqueles vinculados ao espaço urbano versus os representantes da área rural, ambos subdivididos segundo o grau de comprometimento da riqueza bruta com as dívidas passivas. Os valores médios e medianos da riqueza bruta (e da riqueza líquida no caso dos Grupos 3 e 4), melhor posicionam aqueles com perfil urbano em relação aos demais, evidenciando a relação hierárquica que já descrevemos no capítulo anterior.

Apresentamos em seguida alguns casos que ilustram cada um dos grupos. Pelo exposto, não tratamos de evidenciar estratégias distintas dentro de uma mesma faixa de riqueza, mas trajetórias que guardam a dualidade assinalada no parágrafo anterior. Nesse sentido, a história de nossos protagonistas se entrecortam, evidenciando não apenas os limites de nossa amostra, mas também os limites da própria ação econômica no Vale do Ribeira do século XIX.

Grupo 1 - Destacamos o caso de Antonio Vicente Andrade, falecido em 1858. O primeiro registro sobre Antonio data de 1798, com 4 anos, quando junto com outros três irmãos, constava como morador na vila de Apiaí, filho do casal José de Andrade, 24 anos e Isabel Maria, 23 anos, todos brancos. Segundo o responsável pela elaboração da lista, aquele fogo compunha-se apenas por pessoas pobres e nada colhiam de mantimentos. Este segmento congregava praticamente $15 \%$ das 1.139 pessoas, entre livres e cativos, que habitavam a vila. Em 1809, José de Andrade Resende, 36 anos, constava como agricultor, porém não há informes sobre os gêneros e quantidades colhidas. Em 1816, o domicílio de José de Andrade constava na lista nominativa, porém os filhos mais velhos Ana e Antonio já compunham novas unidades. Antonio, então com 22 anos, desposara Maria Rodrigues, 18 anos, ainda sem filhos. Decorridos oito anos, Antonio Vicente Andrade e Maria, proprietários de um sítio, 
possuíam uma filha chamada Ana, então com dois anos. Na lista de 1835 não há registro de sua presença.

Reencontramos notícias de Antonio em 1863, quando da abertura de seu inventário, a pedido da viúva exclusivamente para pagamento das dívidas:

"Diz Joaquina Maria do Prado viúva que por falecimento de seu marido Antonio Vicente de Andrade, ficou em posse e cabeça de casal dos poucos bens pertencentes a ele e como o referido seu marido ficou devendo várias dívidas a diversos credores e por alguns destes sendo já executado e querendo a suplicante proceder o arrolamento, avaliação e venda dos ditos bens para com o líquido pagar aos credores e quando haja saldo será partilhado por quem de direito for, nestes termos requer a V. S. ${ }^{a}$ que prestando juramento para descrever os poucos bens que existe fazendo perante os louvados que desde já os nomeie sendo Domingos Rodrigues Cunha e João Crisóstemo da Cunha para estimarem os ditos bens e estando eles intimados de expedir editais de praça para venda dela portanto, para V.S. ${ }^{a}$ se deixar assim mandar, e requer mercê, [assina] Joaquina Maria do Prado."

Os herdeiros de Antonio Vicente pertenciam a dois casamentos: do primeiro, além da filha Ana de Andrade, Antonio Vicente de Andrade e Manoel de Andrade Resende; do segundo, com a inventariante, Maria das Dores e Antonio, já falecido.

As três dívidas passivas declaradas somavam Rs. 300\$029, a Domingos Rodrigues da Cunha por fornecimento de secos e molhados, ao próprio filho Manoel de Andrade Resende por madeiras e ao comerciante Miguel Antonio Jorge, sem especificação. Imediatamente à avaliação dos bens, a viúva apresentou um requerimento pedindo dispensa dos procedimentos normais da arrematação, eliminando os pregões e praças. O edital de arrematação foi publicado aos 12 de setembro de 1863. O quadro seguinte apresenta os bens avaliados e o resultado da arrematação. ${ }^{60}$

Quadro 5.1 - Arrematação dos bens de Antonio Vicente de Andrade

\begin{tabular}{|c|l|c|c|c|}
\hline Quantidade & bem & avaliação (R\$) & arrematação (Rs) & arrematante \\
\hline 1 & tacho de cobre velho & $8 \$ 000$ & & \\
diversas & ferramentas & $25 \$ 000$ & $33 \$ 000$ & Manoel Andrade Resende \\
1 & mesa de jantar velha & $1 \$ 000$ & & \\
\hline 1 & baú & $2 \$ 500$ & & \\
1 & mesa com duas gavetas & $2 \$ 000$ & $7 \$ 500$ & Domingos Ribeiro Cunha \\
1 & tacho de cobre pequeno & $3 \$ 500$ & & \\
\hline 1 & morada de casas na Rua da Praia & $120 \$ 000$ & $185 \$ 000$ & Manoel Andrade Resende \\
\hline 1 & morada de casas na rua do Lageado & $60 \$ 000$ & \multirow{2}{*}{$137 \$ 000$} & João Batista Guimarães e \\
1 & morada de casas na mesma rua & $60 \$ 000$ & & Bento Antonio de França \\
\hline
\end{tabular}

\footnotetext{
${ }^{59}$ FMEP, caixa n. ${ }^{\circ} 38$.

${ }^{60}$ No arrolamento a viúva também descreve a posse de um sítio em Apiaí e duas dívidas ativas com moradores daquela localidade, não inclusas na arrematação.
} 
A soma dos bens avaliados atingiu Rs. 282\$000 (ou $£ 42$ ) e o resultado líquido da arrematação somou Rs. 368\$750, valor suficiente para a cobertura das dívidas. Tudo leva a crer que a arrematação resultou de um acordo prévio entre a viúva, os credores e os arrematantes, como dá a entender a presença do próprio enteado e credor Manoel Andrade Resende entre os compradores dos bens.

Acompanhamos também a trajetória do filho Manoel Andrade Resende. A propriedade arrematada do espólio do pai foi vendida a Manoel Caetano Batista em 1866 por Rs. $212 \$ 000$ ou um aumento de 14\% em relação ao valor pago na arrematação. Pelo menos desde 1849 Manoel comprava terras em Xiririca: naquele ano ele adquiriu de Manoel Roberto Pires terras no rio do Gado no valor de Rs. 300\$000; até 1869, Resende realizou nove transações de compras, inclusa a do espólio, somando Rs. 1:650\$000, três delas em um lugar denominado “Água Parada”, outra no “Morro Grande” e outras duas moradas de casas, uma na rua do Lajeado e outra na rua das Flores canto com a Labiado.

Em 1870, Manoel de Andrade Resende abriu inventário de sua esposa Martinha de Azevedo, falecida no mesmo ano. Apesar de não possuir escravos, a riqueza bruta do inventário superava os seis contos de réis ou $£$ 572, a maior parte em bens de raiz (65\%), seguidos dos bens móveis (22\%) e dívidas ativas (13\%), classificado entre os inventários pertencentes ao Grupo 3 da Tabela 5.5. A principal propriedade rural, um sítio denominado “Cabeceira” no Braço Delgado, divisa com Salvador Luis da Costa, possuía morada de casas, engenho de arroz, pasto e cafezal. Lá provavelmente Manoel criava as 22 cabeças de gado, 4 machos, 5 mulas, 6 cavalos e 30 porcos, além de colher alguma quantidade de café (à época do inventário, possuía três arrobas de café em casca). Em outras terras lavradias - Água Parada, Braço do Gado, Morro Grande - além de plantar arroz, cultivava milho e cana, esta última destinada à produção de aguardente e de algum açúcar, como se deduz da presença da moenda, de um alambique de cobre, nove formas de açúcar, 50 garrafões de vidro e uma pipa vazios e 78 medidas de aguardente. Completam a lista as ferramentas de carpintaria, o tráfico de farinha e uma tenda de ferreiro. As dívidas ativas compunham-se por um rol de conta de livro com 51 devedores, cujo valor médio atingia Rs. 9\$140 e outros cinco créditos de maior vulto (Rs. 63\$102, em média). ${ }^{61} \mathrm{O}$ baixo valor médio da conta de livro sugere que tais dívidas decorram do aluguel das instalações, ferramentas e animais presentes no sítio "Cabeceira”.

Se pudermos aceitar a condição de pobreza indicada pelo recenseador apiaiense no final do século XVIII, Antonio Vicente de Andrade, pelo menos contabilmente, não possuía

\footnotetext{
${ }^{61}$ FMEP, caixa n. ${ }^{\circ} 41$.
} 
situação distinta de seus pais ao falecer. No entanto, reconhecemos em seu conjunto de bens sinais de alguma prosperidade econômica, ainda que todos eles tenham se esvaído para o pagamento de suas dívidas. Condição mais arrojada demonstrou seu filho Manoel, com riqueza bruta que superava em mais de dez vezes a quantidade acumulada pelo pai. Ressaltamos que casos como este, onde representantes de uma geração posterior puderam acumular riqueza maior do que a antecessora, representam exceção no Vale do Ribeira, ainda mais na magnitude aqui registrada.

Grupo 2 - Entre estes casos encontramos o de Miguel dos Passos, já descrito neste capítulo. Acrescentamos aqui o caso de Inácio dos Passos Martins, falecido em 1850.

Localizamos o iguapense Inácio dos Passos na lista de 1828, branco, 40 anos e casado com Ana Maria, 24 anos, natural de Cananéia. O fogo se completava com seus três filhos. Em 1836 Inácio, junto com esposa e filhos, morava na barra do rio Sorocaba e possuía uma renda de Rs 150\$000, provavelmente obtida através da comercialização dos 150 alqueires de arroz colhidos. Ao longo da década seguinte, Inácio participou como avaliador em pelo menos três inventários (inclusive o aberto por André Lopes por falecimento de sua esposa, já descrito anteriormente). O traço comum aos três processos residia na posse de terras na Ilha do Mar Pequeno. Em seu inventário, verificamos que Inácio também possuía terras com casqueira naquela paragem, além de um lote de terras no rio Sorocaba e também um terreno na vila de Iguape. ${ }^{62}$ Estes bens de raiz representavam 50\% de sua riqueza bruta, avaliada em $£$ 105, cabendo aos bens móveis 34\% e 16\% para as dívidas ativas. Entre os primeiros, encontramos o tráfico de farinha, duas canoas, uma rede de pesca com 20 braças; as dívidas ativas se resumiam a 13 devedores, a maior parte deles com valores abaixo de 10 mil-réis. As suas dívidas passivas, entretanto, somavam quase 800 mil-réis (ou $£$ 99), resultando daí uma riqueza líquida de pouco mais de $£$. Entre os credores, encontramos boa parte daqueles descritos no capítulo anterior, como José Xavier de Almeida Cruz, Torquato Francisco Rios, Antonio José Peniche e José Bonifácio de Andrade e Silva.

Pelos bens descritos e a localização das propriedades rurais, Inácio dos Passos aproxima-se muito de André Lopes, porém com resultados bem distintos em relação à riqueza líquida preservada aos descendentes. Poderíamos atribuir o maior endividamento de Inácio a sua própria inserção na estrutura social iguapense, como sugerem suas atividades como avaliador de bens. Seja como for, a comparação reafirma a diversidade em um mesmo estrato

\footnotetext{
${ }^{62}$ MHAI, caixa n. ${ }^{o} 130$.
} 
social: não por acaso, o inventário de André Lopes compõe o rol dos classificados no Grupo 3 da Tabela 5.5, que melhor detalhamos na seqüência.

Grupo 3 - O lavrador Manoel Antonio de Aguiar constava como morador em Iguape pelo menos desde 1815, então com 32 anos e casado com Maria Alves com quem possuía cinco filhos. Naquele ano também detinha a posse de um escravo chamado Antonio, africano, de 29 anos. Em 1818 Manoel declarou possuir duas propriedades: uma na Ribeira abaixo, com 700 braças de testada e 200 de profundidade, com cultivos, obtida por compra a Manoel Damásio e outra no outro lado da Ribeira, por posse, com 100 braças de testada e 200 de profundidade, também cultivada. Em 1828, o escravo já não mais constava no fogo chefiado por Manoel de Aguiar, então com 43 anos e 10 filhos. A mesma situação se repetiu em 1836: Manoel Antonio, 52 anos, branco, morador em Engenhos, casado com Maria, 47 anos, todos de Iguape, colhia 200 alqueires de arroz, o que lhe rendeu Rs. $150 \$ 000$.

Manoel Antonio de Aguiar faleceu aos 22 de setembro de 1847, com cerca de 63 anos, e seu inventário foi aberto em janeiro do ano seguinte, tendo como inventariante a viúva Maria Alves do Nascimento. Da riqueza bruta, $£$ 198, constavam um tráfico de farinha, um pequeno engenho de socar arroz com seis mãos, duas correntes de ouro, 2.600 telhas novas, uma novilha e três propriedades: uma morada de casas na Rua Direita, vila de Iguape, entre Francisco Neves de Souza e Francisco Manoel dos Passos, 700 braças de terras no Conduquara, divisa com Joaquim Fagundes, além de mais 100 braças de terras adjuntas à anterior. O único credor, o filho Agostinho Ribeiro de Aguiar, recebeu sua parte de tal forma que a riqueza líquida atingiu pouco mais de $£ 96 .{ }^{63}$

Apesar de não constar como proprietário de engenho na lista nominativa de 1836, é provável que naquele ano Manoel realizasse o processamento do arroz em pequena escala, contando exclusivamente com mão-de-obra familiar. Nesse sentido, verificamos a presença de dois de seus filhos, Agostinho e Gregório, na lista de remetentes de arroz, porém com quantidades irrisórias.

Em 1865, um dos filhos de Manoel, Antonio Pedro de Aguiar, possivelmente com 39 anos, abriu o inventário por falecimento de sua esposa Clara Maria Franca. Além do tráfico de farinha, uma canoa e alguns objetos de ouro, na lista de bens constavam casa e 240 braças no Conduquara, parte da casa na Rua Direita e duas outras propriedades, uma na Vila e outra no Capara, resultante da partilha dos bens da sogra e do sogro, somando tudo $£ 79$, também

\footnotetext{
${ }^{63}$ MHAI, caixa n. 201.
} 
pertencente ao Grupo 3 da Tabela 5.5. ${ }^{64}$ Em 1879, com a morte de Antonio Pedro (provavelmente com 52 anos), um outro inventário foi aberto pelo seu filho João Batista de Aguiar, tendo como herdeiros os mesmos três filhos do casamento com Clara. Os bens, apenas um tráfico de farinha, quatro propriedades rurais e uma parte na casa da rua Direita, foram todos arrematados para pagamento das dívidas, resultando ainda em um saldo negativo de $£ 29 .^{65}$

Localizamos também inventários envolvendo outro filho, Gregório Ribeiro de Aguiar. No primeiro, de 1864, Gregório aparece como inventariante de sua esposa e a riqueza bruta somava $£ 73$ libras, principalmente em bens rurais (73\%), representadas por terras no Conduquara e uma parte da casa na rua Direita. A parcela de dívidas passivas representava apenas $2 \%$ da riqueza bruta e este inventário pertence ao Grupo 4 da Tabela 5.5. ${ }^{66}$ Cinco anos depois, Antonio Pedro de Aguiar abriu inventário por falecimento de seu irmão Gregório Ribeiro de Aguiar, cujos bens se resumiam ao tráfico de farinha e terras da herança paterna, totalizando $£ 39 .{ }^{67}$ Os dois casos aparecem na Tabela 5.5 classificados no Grupo 4.

Notamos que a redução da riqueza entre os Aguiar inicia-se com o próprio pai ao perder a condição de escravista entre 1815 e $1828 .^{68}$ No caso dos filhos com processos localizados, nenhum conseguiu compor patrimônio que se aproximasse ao amealhado pelo pai, possivelmente obtido durante o processo de implantação e expansão da rizicultura. Conforme já sugerimos em outros momentos, esta característica intergeracional aparece de forma recorrente entre os casos ribeirenses, tanto entre escravistas como entre nãoproprietários e sua vinculação ao evolver econômico da região parece indissociável.

Grupo 4 - Destacamos dentro deste grupo as trajetórias dos herdeiros de João Fagundes de Medeiros, morador na vila de Iguape pelo menos desde 1789. Em 1801, com 59 anos, o carpinteiro e rizicultor João Fagundes, natural da Ilha de São Miguel, sua mulher, cinco filhos e um escravo Inácio viviam na Ribeira abaixo, vizinhos de Bartolomeu da Costa Almeida Cruz e de Antonio Borges Diniz. Em 1815, já com 72 anos, Fagundes detinha a posse de três cativos e apenas a mulher e o filho Joaquim coabitavam no mesmo fogo. Tanto no recenseamento de 1815 como na relação das propriedades rurais de 1818, João Fagundes

\footnotetext{
${ }^{64}$ MHAI, caixa n. 99.

${ }^{65}$ MHAI, caixa n. ${ }^{\circ}$ 200. O inventário de Antonio Pedro de Aguiar não se encontra na Tabela 5.2 por constar entre os quatro casos onde as dívidas passivas superavam em mais de três vezes a riqueza bruta, porém com perfil assemelhado àqueles pertencentes ao Grupo 2.

${ }^{66}$ MHAI, caixa n. ${ }^{\circ} 12$.

${ }^{67}$ MHAI, caixa n. ${ }^{\circ} 38$.

${ }^{68}$ Neste caso, vale comparar a riqueza bruta de Manoel José de Aguiar, £ 198, com o valor médio dos 92 inventários com plantéis unitários, £ 323.
} 
aparecia como vizinho de Manoel Antonio de Aguiar, destacado acima. A propriedade descrita no inventário de bens rústicos possuía 200 quadras em braça, obtidas por posse.

O inventário de João Fagundes ou o de sua esposa não fazem parte de nossa amostra. Em 1828, os filhos Antonio Fagundes de Medeiros, Manoel Damásio de Medeiros e José Damásio de Medeiros chefiam três fogos distintos, sendo Manoel o único a possuir escravos. Na lista nominativa de 1836, Manoel Damásio, proprietário de seis escravos, aparecia como vizinho da viúva de Bartolomeu da Costa Almeida Cruz no bairro dos Engenhos, ao passo que o irmão não-escravista Joaquim Fagundes de Medeiros e família viviam na Prainha, onde colhia 100 alqueires de arroz e produzia farinha para seu consumo. José Damásio constava como agregado no fogo de uma certa Maria Afonsa, moradora na vila de Iguape e, segundo as anotações na lista, exercia a atividade de carpinteiro.

A condição de escravista de Manoel Damásio em relação a seu irmão Joaquim parece ter exercido relativa influência na trajetória econômica do segundo e de seus herdeiros. Em 1838, Joaquim Fagundes de Medeiros abriu inventário por falecimento de sua esposa Rosa Maria, falecida aos 13 de junho de 1836. Dos três filhos presentes na lista nominativa, apenas dois constam como herdeiros, Manoel com 8 anos e Antonio, $4 .{ }^{69}$ A lista dos bens avaliados incluía 37 braças de terras com casa na Prainha, uma morada de casas com uma porta na rua do Carmo, vila de Iguape, alguns móveis e ferramentas, somando pouco mais de $£ 32$ e compondo o Grupo 4 da Tabela 5.5. ${ }^{70}$

Não sabemos quando Joaquim Fagundes faleceu, mas seu filho Antonio contraiu matrimônio com Miquelina Antonia, cuja morte ocorreu em 1866. O inventário revelou uma riqueza bruta de $£$ 133, reduzida a $£ 28$ após o pagamento das dívidas passivas a sete diferentes credores, alocado entre os inventários pertencentes ao Grupo 2 da Tabela 5.5. Os bens de raiz compunham o item com maior valor, sendo 140 braças de terras no rio de Setanduva com casa de vivenda e engenho de arroz, divisas com João de Lara Fagundes de Medeiros e Francisco Pupo de Mendonça, avaliado em um conto de réis e outras 250 braças de terras no lado oposto do mesmo sítio por Rs. 250\$000. ${ }^{71}$ Apesar do engenho, Antonio Fagundes fez apenas quatro remessas de arroz entre 1852 e 1855, totalizando 62 sacos.

As duas transações envolvendo propriedades de Antonio Fagundes de Medeiros ocorreram após sua morte: a venda do sítio do rio de Setanduva pelo mesmo valor apontado

\footnotetext{
${ }^{69}$ Na lista, Manoel constava com 6 anos e Antonio 1. Joaquim Fagundes de Medeiros, branco, natural de Iguape, com 42 anos.

${ }^{70}$ MHAI, caixa n. ${ }^{\circ} 233$.

${ }^{71}$ MHAI, caixa n. ${ }^{\circ} 142$.
} 
no inventário a Belisário Fagundes e João Joaquim de Lara em 1867 e de 7,5 braças de terras no rio de Setanduva a João Joaquim de Lara em 1869. ${ }^{72}$ Estes dois bens provavelmente correspondem à legítima recebida pela filha Ana, uma vez que João Joaquim de Lara aparecia no inventário de Miquelina Antonia como co-herdeiro, casado com Serafina, a outra filha de Antonio Fagundes de Medeiros. Esta veio a falecer em 1870 e seu inventário foi aberto em outubro de 1871. Novamente as 140 braças de terras com engenho de arroz no rio de Setanduva foram avaliadas, desta vez por Rs. 700\$000, porém constava que estavam divididas meio a meio com o sócio Belisário Fagundes de Medeiros, além de 220 braças de terras fronteiriças com o engenho. As duas dívidas passivas, uma a Bernardo da Silva Franco e outra a Joaquim Martins Tavares, entretanto, reduziram a riqueza de $£ 93$ para $£ 15$, também alocada no Grupo 2 da Tabela 5.5. ${ }^{73}$

Por seu turno, Manoel Damásio de Medeiros manteve-se no bairro dos Engenhos, onde possuía, em 1852, um engenho de arroz com capacidade para processar 500 sacos. Encontramos apenas três registros de remessas de arroz por ele realizadas, todas no início da década de 1850. Não sabemos quando Manoel faleceu, mas localizamos o inventário da viúva Mecias Maria do Espírito Santo. Aberto em 1871, a riqueza bruta somava $£ 253$, resultado da terras no bairro dos Engenhos e no rio Pequeno e uma morada de casas na vila (54\%), dois escravos (32\%) e algumas dívidas ativas (13\%). No ano seguinte, o inventariante João Fagundes de Medeiros, filho de José Damásio, possuía na lista de classificação 7 escravos, além de realizar entre 1849 e 1857 o envio de 845 sacos de arroz em 37 remessas.

Os casos descritos ao longo deste capítulo permitem delimitar o espaço de negociação e conflito decorrente da assimetria econômica e social inerente a um sistema alimentado pela reprodução da diferença. Os casos com respeito aos quais fez-se necessário o apelo ao judiciário podem não refletir a maioria das relações sociais entre os diferentes estratos da sociedade ribeirense; não obstante, a diversidade e, paradoxalmente, a recorrência de determinados contextos sugerem que o microcosmo acima delineado perpassava espacial e temporalmente a sociedade, ajudando-nos a compreender a tênue ligação entre o passado e o presente. Nesse sentido, brancos pobres e pessoas livres de cor conformam um conjunto impelido, para sobreviver, a se infiltrar nos poros do espaço dominante, embora a tônica da manutenção do poder ainda continuasse a ser a desigualdade, base de qualquer estrutura social organizada sobre distinções de classe.

\footnotetext{
${ }^{72}$ A informação sobre a morte consta apenas no registro de pagamento da sisa, o seu inventário não foi localizado.

${ }^{73}$ MHAI, caixa n. ${ }^{0} 51$
} 


\section{CONSIDERACÕ̃ES FINAIS}

Em 1898, segundo os informes publicados no Almanach Iguapense, a receita das exportações através do porto de Iguape somou 1.167 contos de réis e as importações, 907 contos de réis. Em libras, estes valores correspondiam, respectivamente, a $£ 27.500$ e $£$ 21.400. Pelo lado das exportações, este valor equivale aos resultados obtidos no início da década de 1850, porém o saldo líquido revela-se bem menor do que o registrado naquele decênio e nos posteriores.

Se os valores por si evidenciam a continuidade da trajetória de decadência econômica da região, os resultados desmembrados por produto exportado são mais desoladores: o arroz pilado respondia por $42 \%$ (ou pouco mais de $£ 11.500$ ) do valor contra mesma participação do café, não obstante a quantidade de arroz produzida apenas em território iguapense no ano anterior atingir cerca de 85 mil alqueires, equivalente ao valor médio registrado na segunda metade do século XIX. A quantidade de café colhida naquele ano não superava 950 toneladas de grãos.

Buscamos ao longo deste trabalho delinear a produção e comercialização da lavoura arrozeira no Vale do Ribeira desde a sua gênese e a sua influência na riqueza acumulada entre os ribeirenses. Nossa periodização, baseada na quantidade exportada através do porto de Iguape, delimitou três fases distintas ao longo das oito décadas acompanhadas. No intervalo entre 1800 e 1840 observamos quantidades crescentes de alqueires exportados. Na organização produtiva, a disseminação da rizicultura e o avanço da fronteira agrícola ganharam materialização tanto através da comparação entre as listas nominativas de 1801 e 1836 como através da fotografia fundiária fornecida pelo inventário de bens rústicos de 1818.

Além das práticas agrícolas, pudemos notar um expressivo crescimento na quantidade de engenhos de arroz. Não obstante nossa percepção de que estas não exigiam inversões de grande monta, pudemos captar que as propriedades rurais que possuíam unidades de processamento dos grãos ou mesmo terras com atributos naturais que possibilitassem sua instalação ganhavam valor diferenciado no universo rural ribeirense.

Se o investimento na construção de engenhos não representava um dispêndio de capital significativo, o mesmo não pode ser dito a respeito do gasto realizado na aquisição de escravos. Nesse sentido, o primeiro subperíodo delimita a fase pró-cíclica da economia regional. Além das características acima mencionadas, o dinamismo manifestou-se na expansão da propriedade escrava, na conformação de posses com grande quantidade de 
cativos, na maior freqüência de africanos nesse contingente e também no maior peso de escravos do sexo masculino nas faixas etárias com maior vigor físico.

Parte do empreendimento rizicultor se deve ao afluxo de portugueses e açorianos, postados na vanguarda da exploração da energia hídrica para a movimentação dos engenhos e senhores de alguns dos maiores plantéis registrados no Vale do Ribeira. Alguns, capitalizados através da manufatura de embarcações e outros, beneficiados pela posição estratégica de Iguape como entreposto comercial, puderam amealhar riqueza considerável potencializando o uso das instalações rurais, se apropriando dos ganhos derivados do transporte dos grãos até o porto do Rio de Janeiro e compondo um setor oligopolista na oferta de bens de consumo e escravos para a hinterlândia, ao mesmo tempo em que controlavam a oferta de crédito aos ribeirenses.

No contexto mais amplo, pudemos perceber que as décadas de 1800 e 1810 revelaram-se particularmente propícias às inversões em mão-de-obra cativa. Nosso parâmetro, a relação entre o valor atribuído aos escravos inventariados e o preço do arroz, atingiu a menor proporção neste período e, sintomaticamente, a balança comercial do fluxo de bens através do porto iguapense passou a registrar sucessivos déficits no decênio posterior. Entendemos estes resultados como sinais do clima de otimismo gerado pelo franco crescimento da economia regional nos anos anteriores; identificamos sinais evidentes desse arrebatamento em atitudes como o início da construção do canal de comunicação entre o rio Ribeira e o Mar Pequeno. Contudo, o longo período para sua consecução, cerca de 30 anos, sinalizava a mudança de humores dos ribeirenses.

Destarte, o subperíodo seguinte nos mostra que a quantidade de arroz exportada pelo Vale do Ribeira aumentou a taxas decrescentes, atingindo a quantidade máxima no início da década de 1850. O preço do arroz, apesar da tendência de crescimento, deixou de acompanhar a variação no valor dos outros produtos agrícolas importados pelos ribeirenses. A quantidade de arroz necessária equivalente à avaliação de um escravo com idade entre 15 a 40 anos manteve-se crescente entre as décadas de 1820 a 1860. De fato, a estrutura de posse de escravos desenhada a partir dos informes da lista nominativa de 1836 indica que o perfil mais arrojado presente nos anos anteriores não se sustentara e os dados concernentes aos inventários nos dois últimos intervalos confirmam a mudança lá descoberta.

A riqueza média acumulada pelos agricultores, relativamente baixa se comparada com a de seus congêneres em outras localidades, manteve-se em queda, com especial destaque para os proprietários de engenho de arroz no último subperíodo. Dentre esses, apenas a elite agrária escravista apresentou manutenção do nível de riqueza, resultado esse 
associado à valoração dos ativos, especialmente escravos. Em sentido oposto, os representantes do comércio apresentaram riqueza média crescente, superando em muito o valor médio da região.

Estas modificações guardam relação com as mudanças imprimidas pela expansão da rizicultura. A ocupação de novas regiões destinadas ao cultivo do arroz consolidou a formação de novos núcleos populacionais, promovendo a valorização de terras e sítios no interior do Vale. Este movimento também ensejou o surgimento de novos pontos de articulação entre os setores agrícola e comercial, aumentando a disputa pelo domínio territorial entre os últimos. Sua principal conseqüência - a extensão da rede de crédito entre os ribeirenses - coloca-se na gênese da riqueza diferenciada dos comerciantes em relação aos demais segmentos produtivos.

A conciliação dessa dinâmica com o quadro de estagnação econômica vivido a partir da segunda metade do século XIX compõem uma trama perversa. Evidenciamos que parte dessa riqueza acumulada em dívidas ativas não se constituía em riqueza real, mas tão-somente um conjunto de "papéis podres”. Resultado da persistência dos ribeirenses na manutenção da prática agrícola secular que se revelou viável, do ponto de vista da rentabilidade, apenas durante um pequeno punhado de anos, condenou credores e devedores a um vínculo perpétuo e autodestrutivo.

Diante do exposto, não podemos deixar de tecer algumas considerações sobre o atual estado de desenvolvimento do Vale do Ribeira. O Índice de Desenvolvimento Humano (IDH) calculado pela Organização das Nações Unidas posiciona, no final do século XX, os municípios do Vale do Ribeira numa situação muito distinta da observada no território paulista. Dos 10 municípios com pior IDH, 8 pertencem ao Vale do Ribeira. Outro indicador, gerado pela Fundação SEADE, localiza os municípios do Vale do Ribeira entre as “(...) localidades tradicionalmente pobres, caracterizadas por baixos níveis de riqueza municipal, longevidade e escolaridade. Seus 114 municípios localizam-se em áreas bem específicas do Estado, com o Vale da Ribeira e as Serras do Mar e da Mantiqueira” (TORRES et. alli, 2003, p. 88).

No caso específico do Vale do Ribeira, nossos resultados sugerem que o ciclo econômico sustentado pelo cultivo do arroz não permitiu que o nível de riqueza atingisse o mesmo estatuto das regiões da plantation paulista. Mesmo no âmbito das localidades com vocação essencialmente voltada para o mercado interno, a posição dos ribeirenses manteve-se aquém da registrada. Dessa forma, longe de representar um ciclo virtuoso de 
desenvolvimento, a lavoura arrozeira possibilitou uma distinção dentro da hierarquia social local e sua reiteração ao longo do tempo guarda pouca relação com a função produtora.

Da civilização do arroz, o Vale do Ribeira guardou as águas, os casarões, a pobreza e um padrão sociocultural peculiar, herança dos proprietários de engenho, dos comerciantes, dos açorianos e franceses, dos brigues e dos vapores, mas também dos anônimos Lourenços, Franciscos, Venâncios, Galdinas e Catarinas. Qualquer proposta que procure minimizar os deletérios efeitos da atual desigualdade regional precisa, necessariamente, incorporar este dote como elemento fundamental para a compreensão das relações econômicas e sociais daquele povo. 


\section{APÊNDICE}

\section{A população no Vale do Ribeira}

A composição das populações livre e escrava das duas localidades investigadas guarda peculiaridades que apresentamos nas páginas seguintes. Utilizamos as listas nominativas dos anos de 1789, 1801, 1815, 1828 e 1836, além dos censos populacionais de 1854 e 1874. Inicialmente apresentamos os habitantes de Iguape segundo condição social, como mostra o Gráfico A.1.

\section{Gráfico A.1}

População segundo condição social

(Iguape, anos selecionados)

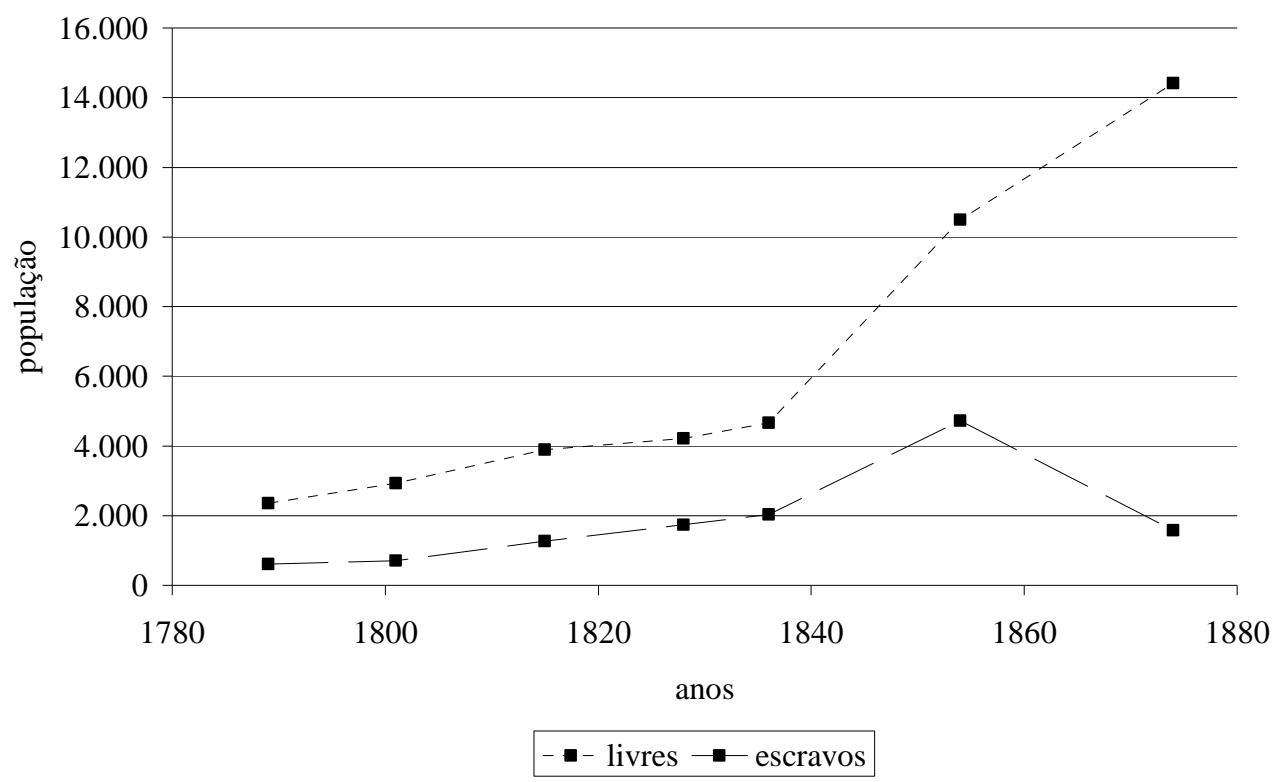

Entre 1789 e 1836, a população livre em Iguape praticamente dobrou e a cativa aumentou 232\%, a taxas geométricas anuais iguais a 1,5\% e 2,6\%, respectivamente. Este período corresponde à fase mais dinâmica da rizicultura na região e particularmente, o mais propício para a aquisição de escravos. Incremento mais intenso, porém, ocorreu entre 1836 e 1854, quando o segmento livre cresceu $148 \%$ e os escravos, $132 \%$, a elevadas taxas anuais de 4,6\% e 4,8\%. Daí até 1872, a população livre manteve-se em crescimento, porém em menor ritmo (1,6\% ao ano), enquanto os cativos apresentaram uma redução absoluta, equivalendo a uma taxa anual de $-4,8 \%$ ao ano. 


\section{Gráfico A.2}

Distribuição etária da população livre

(Iguape, anos selecionados)
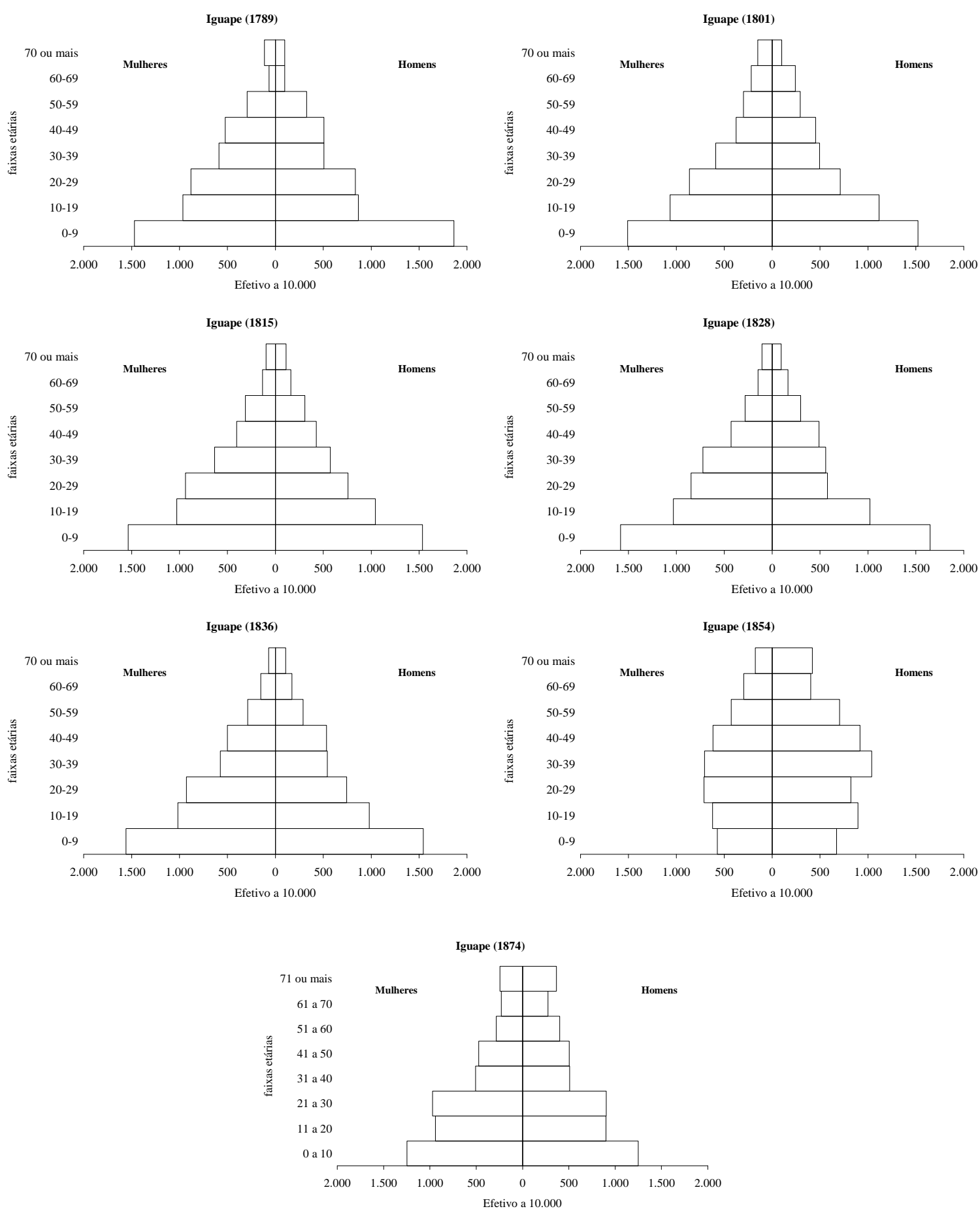

O gráfico A.2 apresenta as distribuições etárias da população livre em cada um dos anos selecionados. Exceto em 1854, predomina o formato acentuadamente triangular, com mais de três décimos da população na primeira das faixas etárias e com reduzida participação das pessoas com 50 anos ou mais em ambos os sexos. Até 1836, verificamos um ligeiro predomínio feminino entre os jovens adultos, especialmente na faixa entre 20 a 39 anos. Esta 
persistência parece sugerir que, não obstante a fase de relativa prosperidade econômica, alguns dos homens iguapenses buscavam novas perspectivas em outras paragens. Esta tendência aparece totalmente invertida em 1854, ano em que as pessoas do sexo masculino respondiam pela maior parte dos casos em todas as faixas etárias.

Aparentemente os dados relativos ao recenseamento de 1854 não guardam uma associação com o perfil demográfico pretérito da localidade. Em que pese a inequívoca subestimação de mulheres e crianças, não foi o único ano a apresentar problemas.

O censo de 1836, pelo menos na forma como se encontra atualmente preservado no Arquivo do Estado de São Paulo, talvez forneça números subestimados. Confrontando os dados aqui coletados com os valores expostos por Daniel Pedro Müller, notamos a ausência de três quarteirões. O próprio Müller apresenta dois valores distintos para Iguape e sua freguesia: 6.699 pessoas livres e 2.726 escravos ou 6.481 livres e 2.917 escravos. $^{366}$ Neste trabalho, utilizamos os seguintes valores: 6.147 livres e 2.558 escravos que, se comparados com o primeiro conjunto, representam reduções equivalentes a $8 \%$ e $6 \%$ ou $5 \%$ e $12 \%$, se considerado o segundo total fornecido por Müller.

Além das implicações próprias ao estudo da estrutura de posse, estas diferenças eventualmente traduziriam taxas de crescimento menores do que as indicadas entre os anos de 1836 e 1854. Pelos dados obtidos no Arquivo do Estado, a população livre e a escrava de Iguape e Xiririca teriam crescido a uma taxa anual de 4,4\% ao ano. Utilizando os maiores valores fornecidos por Müller, as taxas atingiriam, respectivamente, 3,9\% e 3,6\%. Mesmo assim, correspondem a valores ainda relativamente altos, não verificados na fase mais dinâmica da atividade rizicultura.

Especificamente sobre o censo de 1854, ainda que a população esteja corretamente totalizada, a distribuição etária evidencia diferenças que dificilmente poderiam ser atribuídas a algum fenômeno demográfico. Dentre as localidades paulistas recenseadas, apenas Campinas (17\%), Capivari (17\%) e Sorocaba (18\%) apresentavam menos de dois décimos de crianças ( 0 a 9 anos) no total da população livre, porém nenhuma atingiu os $13 \%$ verificados em Iguape. Poder-se-ia supor que as distorções estivessem associadas aos 1.264 estrangeiros contabilizados em Iguape, respondendo por praticamente 19\% do total assinalado para a província e $12 \%$ dos iguapenses presentes no censo. Nesse conjunto predominavam pessoas do sexo masculino (1.180 homens e 84 mulheres), porém nem a exclusão deste segmento

\footnotetext{
${ }^{366}$ Cf. MÜLLER, 1978, p. 145 e p. 166.
} 
promoveu alterações significativas na estrutura etária, como pode ser observado no gráfico seguinte, que compara as duas pirâmides populacionais.

Gráfico A.3

Pirâmides etárias da população livre

(Iguape, 1854)
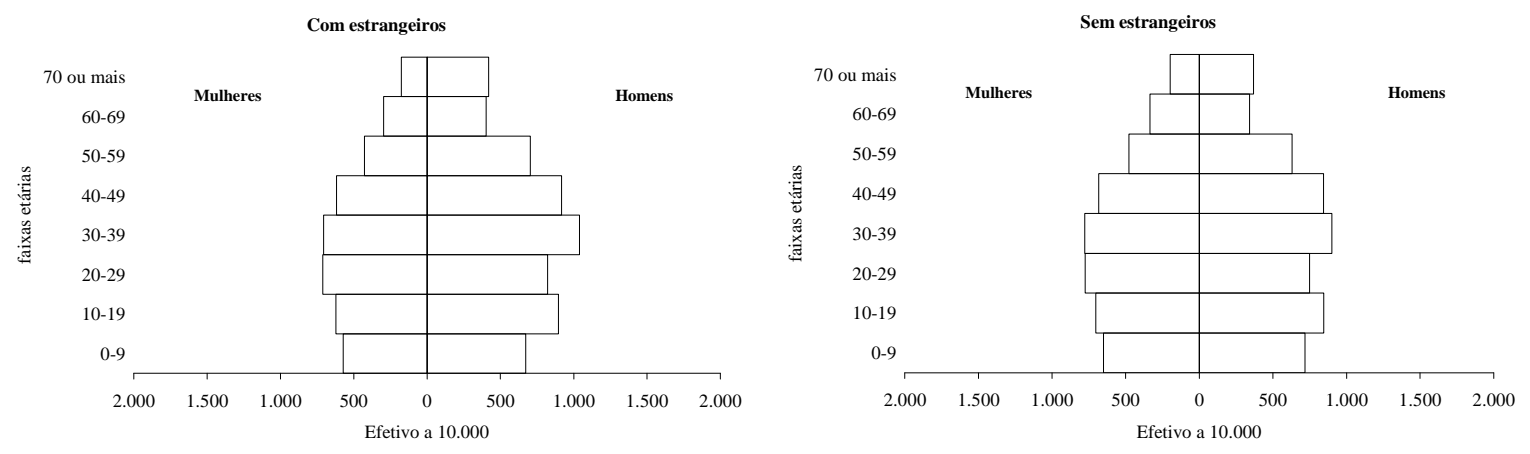

Ademais, na documentação investigada para a confecção desta pesquisa não há menção alguma sobre a presença de um grupo tão significativo de estrangeiros. Em 1836, europeus somavam 78 pessoas no Vale do Ribeira, a maioria oriunda de Portugal e das Ilhas Atlânticas. Conforme destaca Roberto Braga, as primeiras experiências colonizadoras com estrangeiros ocorreram na região a partir de 1861, com a instalação do núcleo colonial de Pariquera-Açu:

O núcleo Colonial de Cananéia foi ocupado por grupos de ingleses, irlandeses e alemães, sendo em pouco tempo abandonado, devido seu isolamento e precariedade de infra-estrutura. A colônia de Pariquera-Açu (que veio a originar posteriormente o município de mesmo nome), com condições um pouco melhores, recebeu pequenos grupos de ingleses, alemães, poloneses e russos, que ficaram por algum tempo; o maior contingente recebido por esse núcleo foi o de italianos, cuja maioria se instalou entre 1886 e 1890, logo desertando para as zonas cafeicultoras do planalto (BRAGA, 1999, p. 15).

Destaca ainda o autor a experiência norte-americana, entre 1865 e 1869, conduzida por iniciativa particular, também fracassada. ${ }^{367}$ Dessa forma, neste momento não há nenhuma explicação satisfatória que justifique a presença de tantos estrangeiros em Iguape, ainda que a eles não possam ser atribuídos os resultados verificados no referido censo. Em 1874, a proporção de estrangeiros entre as pessoas livres em Iguape atingia pouco mais de 7\%. Se até em 1836 os brancos correspondiam a 70\%, em 1874 este segmento respondia por 55\%, com um aumento efetivo das pessoas pretas, cuja participação relativa saltou de $2 \%$ para $10 \%$.

\footnotetext{
${ }^{367}$ Para Roberto Braga “A maior dificuldade para a fixação de colonos na região foi, realmente, a dificuldade de implantação de uma lavoura comercial, que, na época, só poderia ser o café, que traria consigo todos os benefícios levados ao planalto" e que teria fracassado por dois motivos: “(...) a dificuldade de circulação e acesso aos mercados e a restrita aptidão ecológica da região para a cafeicultura, o que restringiu, também, os investimentos em transportes na região (construção de ferrovias), que vinha sendo feito no rastro das novas áreas cafeeiras no oeste paulista" (BRAGA, 1999, p. 19 e 20).
} 
O gráfico seguinte apresenta as pirâmides etárias para a população escrava presente em Iguape. Nos anos de 1789 e 1801, a distribuição de homens e mulheres cativos pouco diferia da observada para a população livre, isto é, uma ampla base conformada na menor das faixas etárias e um rápido estrangulamento nos últimos grupos etários, sugerindo. Este perfil sugere a importância da reprodução natural como uma das formas para a manutenção do contingente cativo em fins do século XVIII e começo do XIX. A partir de 1815, ganha relevância o afluxo de escravos do sexo masculino em idade ativa, principalmente na faixa etária de 20 a 29 anos. Nos anos posteriores, ainda se verifica o desequilíbrio neste grupo etário, porém o maior efeito decorre da propagação do impacto registrado em 1815: entre os cativos mais velhos, em 1836, observa-se a preponderância masculina até entre os cativos com idade entre 60 a 69 anos.

Em 1854 há, novamente, uma ruptura, com sensível perda entre as crianças. Após 1801, esta participação manteve-se ao redor de 20\%, porém em 1854 esta parcela atingia apenas $13 \%$, valor comparável a outras localidades que se destacavam pela maciça presença de escravos, como Campinas (12\%), Bananal (13\%) e Taubaté (13\%), porém em condições econômicas bem distintas das observadas no Vale do Ribeira.

Ainda neste caminho, a faixa etária com maior participação, de 30 a 39 anos, contaria com 21\% dos cativos e em nenhuma delas há preponderância de homens ou mulheres. À guisa de comparação, nas regiões cafeicultoras do Vale do Paraíba predominavam os cativos na faixa etária anterior e com acentuada presença de pessoas do sexo masculino. ${ }^{368}$

Em se considerando corretos os valores coletados pelo recenseamento de 1854, provavelmente parte do contingente teria ingressado na região ao longo da década de 1840 . Conforme descrevemos no Capitulo 2, nesta quadra ocorreu um novo surto de ocupação das terras nas regiões dos rios São Lourenço e Juquiá, com o estabelecimento de unidades agrícolas que cultivavam a cana de açúcar e o café. Lá destacamos a presença de alguns franceses e outros escravistas originários de outras regiões paulistas, como Manoel Tavares Coimbra Cambiva, cujo inventário dava conta da posse de 44 cativos. É possível que outros escravistas tenham se instalado na região, porém o pouco sucesso da cafeicultura na região não serviria de estímulo para a manutenção de grandes plantéis, de tal sorte a não deixar registro algum na documentação compulsada para a elaboração desta tese.

\footnotetext{
${ }^{368}$ Em Pindamonhanga, 35\% dos escravos possuíam idade entre 20 a 29 anos e com razão de sexo igual a 129; em Bananal, a participação atingia 34\% dos cativos na proporção de 158 homens para cada grupo de 100 mulheres.
} 


\section{Gráfico A.4}

Pirâmides etárias da população escrava

(Iguape, anos selecionados)
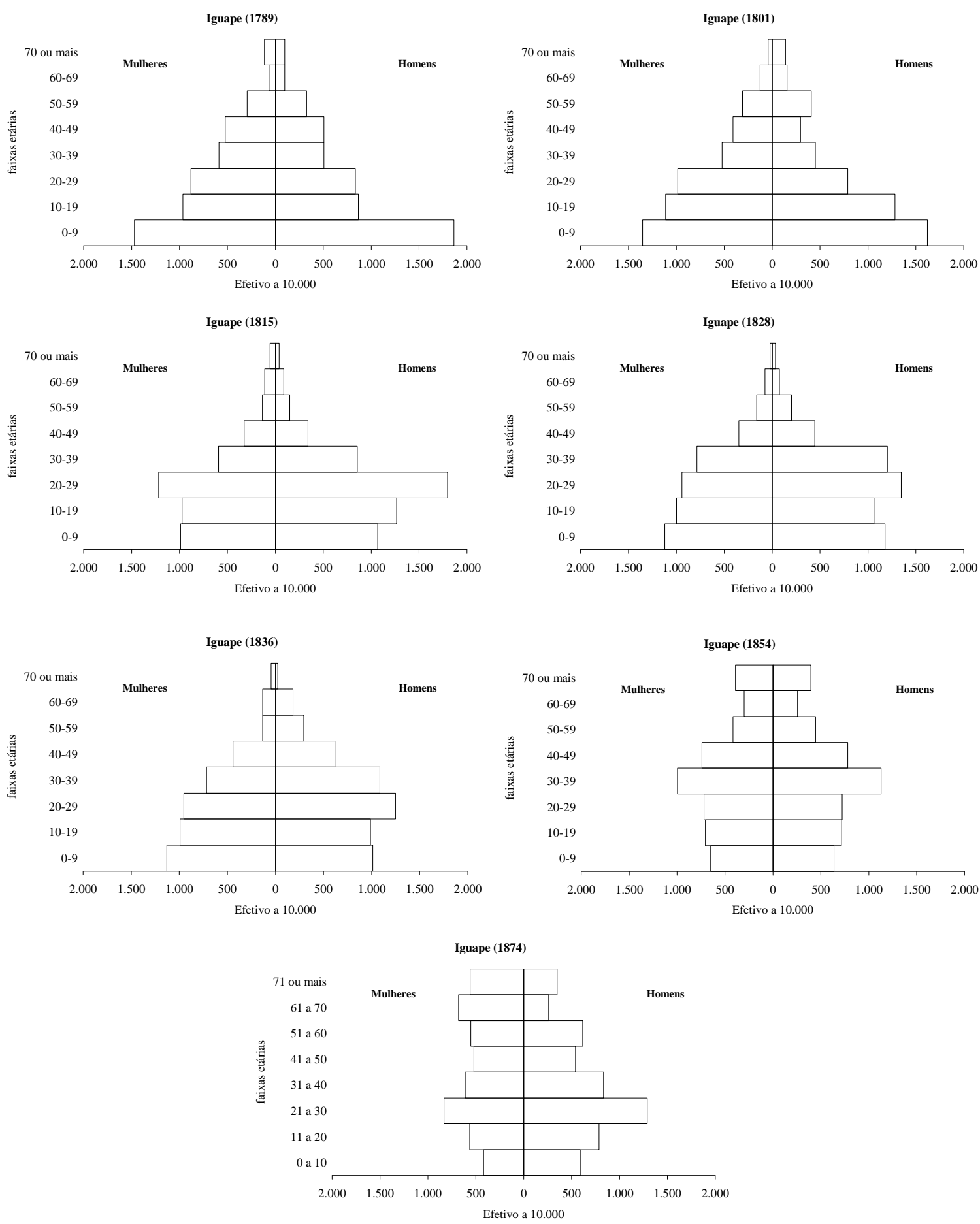

Por fim, a pirâmide etária de 1874 já reflete os efeitos da Lei do Ventre Livre, uma vez que no recenseamento não foram contabilizadas as crianças, filhos de cativas, com menos de dois anos. O perfil da distribuição da população segundo sexo evidencia a concentração de cativos do sexo masculino na faixa etária dos 11 a 40 anos, fato observável tanto para o conjunto da Província paulista como para várias de suas cidades. Entre 1854 e 1874, a 
população cativa na Província passou de 116.991 para 156.612 pessoas. A segunda metade do século XIX foi marcada pela drenagem desta mão-de-obra das regiões menos dinâmicas para as áreas onde o café se desenvolvia com maior intensidade. Possivelmente o Vale do Ribeira se encaixa na primeira categoria, ou pelo menos não fazia frente às localidades cafeiculturas paulistas que mantinham a população cativa através do tráfico interno.

A dinâmica populacional de Xiririca, freguesia que se emancipou de Iguape em 1842 e logo em seguida anexou a freguesia de Iporanga, outrora pertencente à vila de Apiaí, mostrou-se bem mais estável, como revela o Gráfico A.5.

Gráfico A.5

População segundo condição social

(Xiririca, anos selecionados)

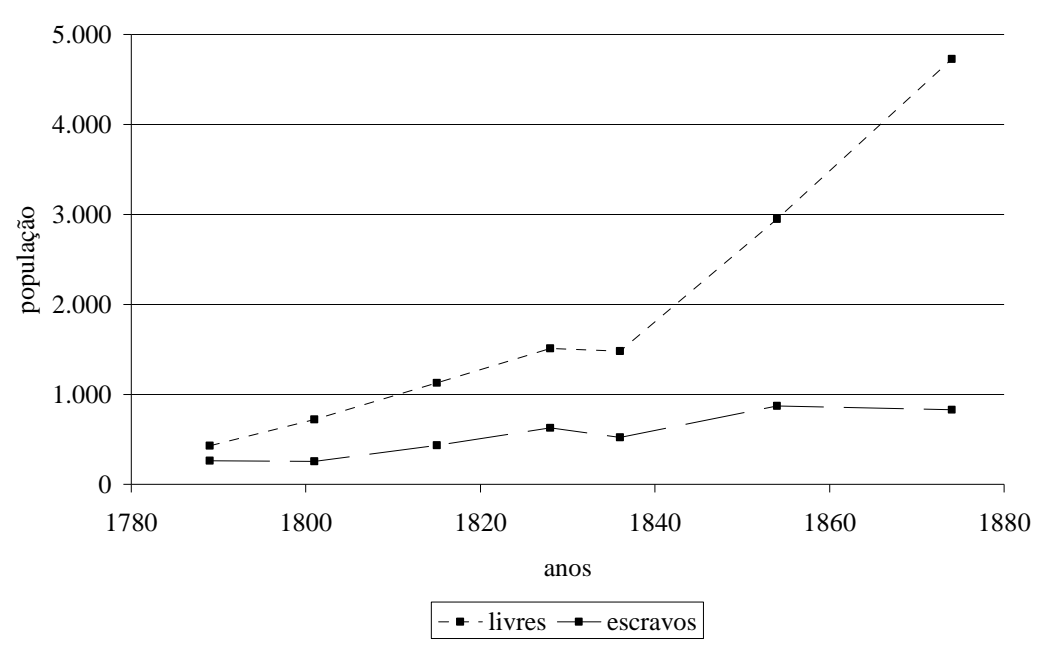

Entre 1789 e 1836, a população livre cresceu a uma taxa de 2,7\% ao ano e a cativa, a 1,5\%. Entre 1828 e 1836 há um ligeiro recuo tanto na quantidade de livres como de cativos. O ritmo de crescimento entre 1836 e 1874, 3,1\% ao ano entre os livres e 1,2\% ao ano para os cativos, possivelmente resulta da soma de fatores demográficos com a referida anexação da nova freguesia. De fato, entre 1854 e 1874, o contingente livre aumentou a taxas de 2,4\% ao ano e o cativo decresceu a $-2,5 \%$ ao ano.

As pirâmides etárias da população livre mostram-se homogêneas em todos os anos selecionados, mantendo o formato triangular com base bastante acentuada e pequena participação de pessoas com 50 anos ou mais, como se observou em Iguape nos primeiros anos. Mesmo em 1854, não há alterações importantes na estrutura etária ou na distribuição entre os sexos. 


\section{Gráfico A.6}

Pirâmides etárias da população livre

(Xiririca, anos selecionados)
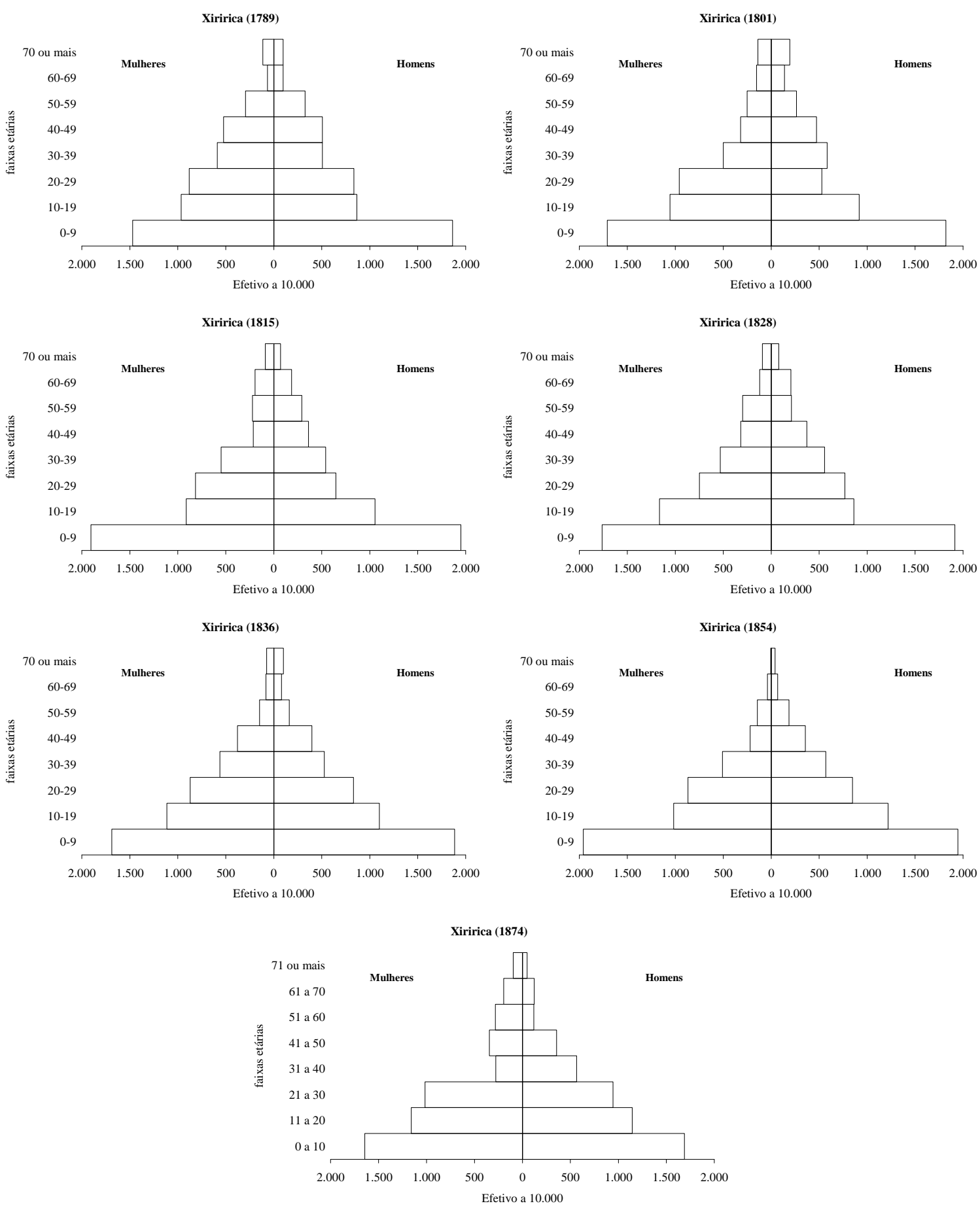

O Gráfico A.7 trata da população escrava, distribuindo-a em faixas etárias. Evidenciamos também os efeitos da entrada de escravos no início do século XIX, visíveis nos anos de 1815 e 1828, anos em que a parcela de escravos do sexo masculino mais jovens respondiam por maiores parcelas do contingente. 


\section{Gráfico A.7}

Pirâmides etárias da população escrava

(Xiririca, anos selecionados)
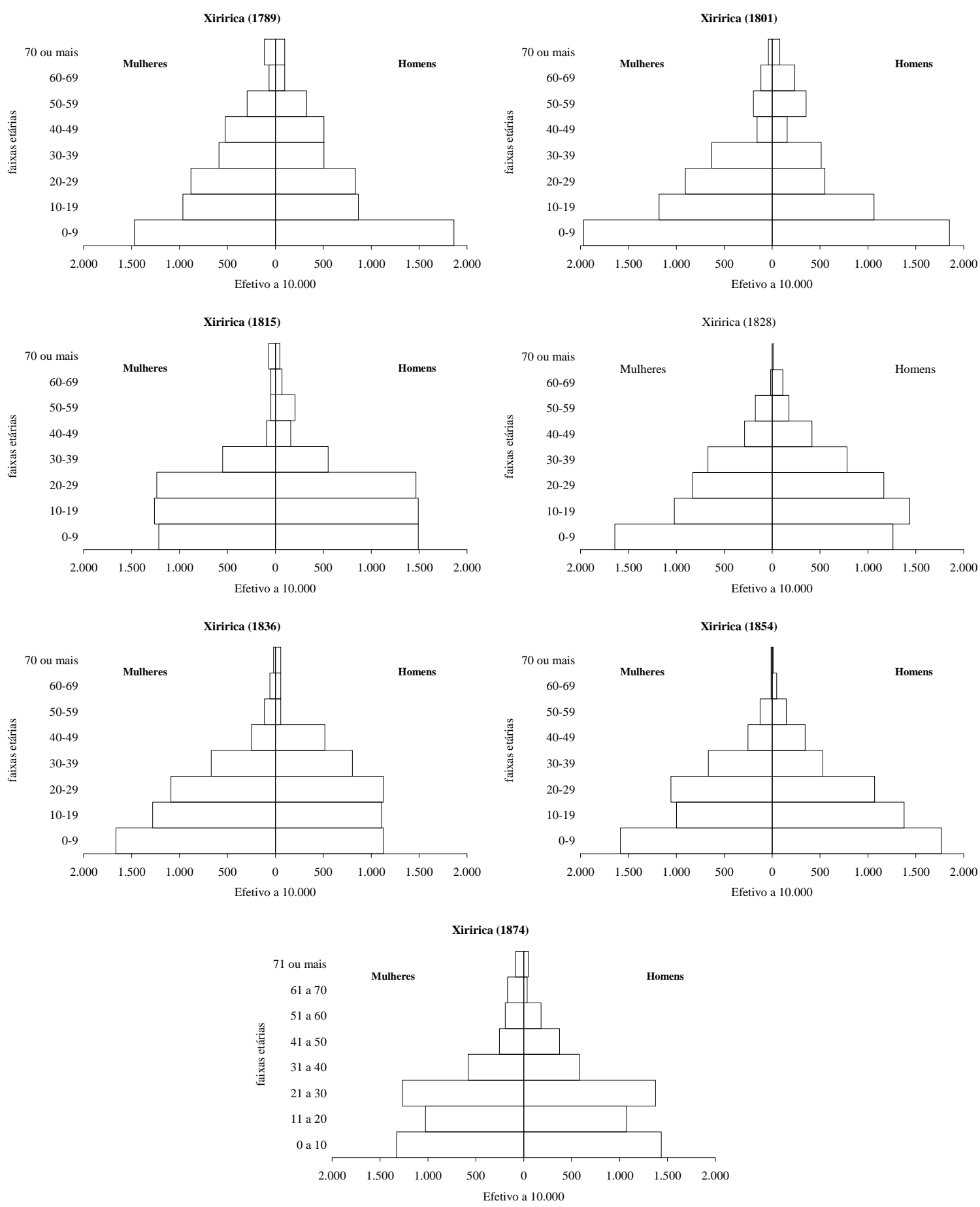

No entanto, os efeitos se mostram minimizados. Isto se deve não apenas à menor magnitude do crescimento da população escrava, mas também pela persistente manutenção da participação de crianças cativas, sempre superando a marca de $25 \%$ dos casos, inclusive em 1874. 


\section{Os ingênuos nos inventários}

O número total de escravos encontrados nos inventários totalizou 2.997 pessoas. Porém, se consideradas as crianças mencionadas e não avaliadas no conjunto dos bens, o total passaria a 3.047 cativos, isto é, um aumento de 1,7\%. Importa destacar que estas crianças não pertenciam somente aos processos abertos após 1871, ano da promulgação da Lei do Ventre Livre. Segundo os resultados apresentados na Tabela A.1, crianças aparecem com alguma freqüência desde o primeiro subperíodo.

Tabela A.1 - Indicadores de posse com e sem crianças cativas não avaliadas

(Iguape e Xiririca, 1800-1880)

\begin{tabular}{l|rrrrr|rrrrr}
\hline \multirow{2}{*}{ Subperíodos } & \multicolumn{4}{|c|}{ sem crianças } & \multicolumn{5}{c}{ com crianças } \\
\cline { 2 - 10 } & \multicolumn{1}{|c}{ inventários escravos } & média desvio-padrão mediana & inventários escravos & média desvio-padrão mediana \\
\hline $1800-1840$ & 90 & 699 & 7,1 & 10,5 & 5 & 90 & 704 & 7,2 & 10,5 & 5 \\
$1841-1860$ & 172 & 1.216 & 5,6 & 8,5 & 4 & 172 & 1.244 & 6,1 & 8,6 & 4 \\
$1861-1880$ & 192 & 1.082 & 6,6 & 8,0 & 4 & 192 & 1.179 & 6,9 & 8,1 & 4 \\
\multicolumn{1}{c}{$1872-1880$} & 74 & 409 & 5,5 & 5,0 & 4 & 74 & 473 & 6,4 & 5,8 & 4 \\
total & 454 & 2.997 & 6,6 & 8,0 & 4 & 454 & 3.127 & 6,9 & 8,1 & 4 \\
\hline
\end{tabular}

Neste intervalo, as 5 crianças encontradas em 4 diferentes inventários resultam em alteração praticamente desprezível tanto nas medidas de tendência central como na dispersão em torno da média. Já os 28 casos ocorridos em 24 inventários do subperíodo seguinte produziram numa ligeira diminuição tanto no valor médio como no desvio-padrão. É certo que a maioria destas crianças deveriam ter menos de um ano, pois em geral eram citadas juntamente com a mãe e, em alguns casos, qualificado com expressões do tipo "com cria de colo" ou "com cria de leite".

Foi no terceiro subperíodo a maior ocorrência de casos, somando 97 crianças sem avaliação em 58 inventários. Destas, cerca de dois terços apareceram após 1871, isto é, representavam ingênuos libertos pela Lei do Ventre Livre. O impacto sobre o valor médio no subperíodo teve magnitude assemelhada ao observado no intervalo anterior, porém se restrito aos oito anos finais da década de 1880, a variação mostrou-se mais intensa: a ausência das 64 crianças promoveu uma redução de 6,4 para 5,5 escravos por inventário. Ainda que estes valores possam representar acréscimos importantes, principalmente considerando o baixo valor médio dos plantéis, optou-se pela exclusão destas crianças, pois além das descrições realizadas nos inventários não fornecerem informações específicas sobre elas (sexo e idade), o diferencial na distribuição entre as faixas de plantéis reduzir-se-ia a apenas 6 dos 15 inventários afetados: 2 deles passariam da faixa de 1 a 4 cativos para a de 5 a 9 escravos e outros 4 sairiam desta para o intervalo de 10 a 19 cativos. 


\section{FONTES E BIBLIOGRAFIA}

\section{Fontes primárias manuscritas, impressas e em meio eletrônico}

Arquivo do Estado de São Paulo

Mss. - Maços de população: Iguape e Xiririca, 1765, 1778, 1789, 1801, 1815, 1828 e 1836.

Mss. - Maços de população: Apiaí, 1798, 1809, 1817, 1824, 1835.

Mss. - Ofícios diversos de Iguape, 1818 a 1882, ordens 1.038 a 1.048.

Mss. - Ofícios diversos de Xiririca, 1843 a 1856, ordem 1.339.

Mss. - Fundo de classificação de escravos, 1874 a 1876, e. 607 a 609.

Mss. - Correspondência com alfândega e mesas de rendas, 1855 a 1863, e. 133 a 135.

Mss. - Estradas e obras públicas, 1823 a 1891, ordens 5.138 a 5.211.

Mss. - Juizes de direito de Iguape, 1833 a 1891, ordens 4.779 e 4.780.

Mss. - Câmara Municipal de Iguape, 1721 a 1822, ordem 237.

Mss. - Ordenanças, 1721-1822, ordem 287.

Mss. - Mesas de rendas, 1865-1885, ordens 2.136 e 2.137.

Mss. - Sisa Iguape, 1810-1877, ordens 8.414 a 8.415.

Mss. - Sisa Xiririca, 1847 a 1889 , ordens 8.600 a 8.605.

SÃO PAULO (Estado). Documentos Interessantes para a História e Costumes de São Paulo. (Publicação Official de Documentos Interessantes até v. 54) Vários volumes. São Paulo: Arquivo do Estado, 1895-p.

SÃO PAULO (Estado). Repertório de Sesmarias: concedidas pelos Capitães Generais da Capitania de São Paulo desde 1721 até 1821. Ed. facsimilada. São Paulo: Divisão de Arquivo do Estado, 1994.

Museu Histórico e Arqueológico de Iguape

Mss. - Inventários post-mortem, 1770 a 1880.

Mss. - Processos diversos, 1800 a 1880. 
Mss. - Rendimentos da taxa do canal de comunicação, 1860 a 1874.

Fórum de Eldorado Paulista

Mss. - Inventários post-mortem, 1823-1880

\section{Biblioteca Nacional}

MEMÓRIA estatística do município de Iguape, escrita por José Inocencio Alves Alvim por incumbência de Manoel da Fonseca Lima e Silva, então presidente da Província de São Paulo. Iguape, 21 fev. 1845. Ms, original, 45p., 26 x 21 cm. loc.: I-31,18,41.

Outras

BRASIL. INSTITUTO BRASILEIRO DE GEOGRAFIA E ESTATÍSTICA. O Brasil, suas riquezas naturais, suas indústrias / Centro Industrial do Brasil: Tomo I. Introdução, Indústria Extrativa. [editado originalmente em 1907]. Rio de Janeiro: IBGE-CNI, edição fac-similar, vol. 2, tomo 1, 1986, (Séries estatísticas retrospectivas, vol. 2, tomo 1).

BRASIL. MINISTÉRIO DA FAZENDA. Balanço da Receita e Despesa do Império. Exercício 1856-1857. Rio de Janeiro: Tipografia Nacional, 1857.

COMISSÃO CENTRAL DE ESTATÍSTICA. Relatório apresentado ao Exmo. Sr. Presidente da Província de São Paulo. São Paulo: Typographia King, 1888.

LAEMMERT, E. Almanak administrativo, mercantil e industrial da corte e província do Rio de Janeiro para 0 ano de 1889. Versão eletrônica disponível em http://brazil.crl.edu/bsd/almanak/. Acessado em 07/12/2004.

MÜLlER, Daniel Pedro. Ensaio d’um quadro estatístico da província de São Paulo: ordenado pelas leis municipais de 11 de abril de 1836 e 10 de março de 1837. Introdução de Honório de Sylos. $3^{a}$ ed. facsimilada. São Paulo: Governo do Estado, 1978. (Coleção Paulística, 11).

ORGANIZAÇÃO DAS NAÇÕES UNIDAS. Ranking do IDH-M dos municípios do Brasil. Disponível em http://www.pnud.org.br/atlas/tabelas/index.php (acesso em 10 de outubro de 2006). 
SÃO PAULO DO PASSADO: DADOS DEMOGRÁFICOS (1854 E 1872). Organização de Maria Sílvia C. Beozzo Bassanezi. Núcleo de Estudos de População (NEPO) Universidade Estadual de Campinas (UNICAMP). 1998, 1 CR-ROM.

YOUNG, Ernesto G. Almach Iguapense para o anno de 1899 consagrado à propaganda agrícola do município de Iguape. Iguape: Typographia Castro, 1899.

\section{Bibliografia citada}

ALDEN, Dauril. Manoel Luis Vieira: an entrepreneur in Rio de Janeiro during Brazil’s Eighteenth century agricultural renaissance. The Hispanic American Historical Review, v. 39, n. ${ }^{\circ}$ 4, p. 521-537, nov. 1959.

ALMEIDA, Antonio Paulino de. Memória histórica de Xiririca. Boletim. São Paulo: Departamento do Arquivo do Estado de São Paulo, v. 14, p. 7-168, 1955.

ALMEIDA, Antonio Paulino de. Memórias memoráveis. Revista do Arquivo Municipal. São Paulo, Departamento de Cultura da Prefeitura Municipal, v. CXX, p. 3-28, 1948.

ALMEIDA, Antonio Paulino. Da decadência do litoral paulista. Revista do Arquivo Municipal. São Paulo, Departamento de Cultura da Prefeitura Municipal, v. CVII, p. 3757, 1946.

ALMEIDA, Antonio Paulino. O Ribeira de Iguape. Revista do Arquivo Municipal. São Paulo, Departamento de Cultura da Prefeitura Municipal, v. CII, p. 27-105, 1945.

ANDRADE, Tânia; PEREIRA, Carlos Alberto Claro; ANDRADE, Marcia Regina de Oliveira (ed.). Negros do Ribeira: reconhecimento étnico e conquista do território. São Paulo: ITESP, 2000. (Cadernos ITESP; 3)

ARRUDA, José Jobson de Andrade. As barreiras de Cubatão, Caraguatatuba, Ubatuba e Cunha: limites e possibilidades da documentação. In IX SIMPÓSIO NACIONAL DOS PROFESSORES UNIVERSITÁRIOS DE HISTÓRIA, Florianópolis, v. 3, 1977, Anais... São Paulo: FFLCH-USP, 1979, p. 1033-1060.

ARRUDA, José Jobson de Andrade. O Brasil no comércio colonial. São Paulo: Ed. Ática, 1980 (Ensaios, 64).

ARRUDA, José Jobson de Andrade. Linguagens historiográficas contemporâneas: por uma nova síntese histórica. Economia e Sociedade. Campinas, IE/UNICAMP, v. 10, p. 175191, jun./1998. 
BACELLAR, Carlos de Almeida Prado. Família e sociedade em uma economia de abastecimento interno (Sorocaba, séculos XVIII e XIX). Tese (Doutorado em História) - FFLCH-USP, 1994.

BACELLAR, Carlos de Almeida Prado. Os senhores da terra: família e sistema sucessório entre os senhores de engenho do Oeste Paulista, 1765-1855. Campinas: CMU/Unicamp, 1997. (Coleção Campiniana, 13)

BERGAD, Laird W. Escravidão e história econômica: demografia de Minas Gerais, 17201880. Bauru: EDUSC, 2004.

BRAGA, Roberto. Raízes da questão regional no Estado de São Paulo: considerações sobre o Vale do Ribeira. Geografia, Rio Claro, v. 24, n. 3, p. 43-68, 1999. Disponível em http://www.rc.unesp.br/igce/planejamento/publicacoes/TextosPDF/Rbraga03.pdf. Acesso em 09/09/2002.

BROWN, Larissa Virginia. Internal commerce in a colonial economy: Rio de Janeiro and it’s hinterland, 1790-1822. Tese (Phd em História) - University of Virginia, 1986.

BUESCU, Mircea. 300 anos de inflação. Rio de Janeiro: APEC Editora, 1973.

CALI, Plácido. O processo de povoamento do litoral sul de São Paulo: Juréia-Itatins. Dissertação (Mestrado em Arqueologia), MAE-USP, 1999.

CALIXTO, Benedito. Capitania de Itanhaen (memória histórica). Revista do Instituto Histórico e Geográfico de São Paulo. São Paulo, v. XX, p. 401-742, 1915.

CANABRAVA, Alice Piffer. A repartição das terras na Capitania de São Paulo, 1818. Estudos Econômicos, São Paulo, IPE/USP, v. 2, n. 6, p. 77-129, 1972.

CANABRAVA, Alice Piffer. Terras e escravos. In História econômica: estudos e pesquisas. São Paulo: Hucitec; UNESP; ABPHE, p. 203-225, 2005.

CARNEIRO, Henrique S. Comida e sociedade: significados sociais na história da alimentação. História: Questões \& Debates. Curitiba, n. ${ }^{\circ}$ 42, p. 71-80, 2005.

CASTELUCCI JÚNIOR, Wellington. Pescadores e roceiros: escravos e forros em Itaparica na segunda metade do século XIX (1860-1888). Tese (Doutorado em História) - FFLCHUSP, 2005.

CASTRO, Hebe Maria M. de. Ao sul da história: lavradores e pobres na crise do trabalho escravo. São Paulo: Brasiliense, 1987. 
CASTRO, Hebe Maria M. de. História Social. In CARDOSO, Ciro Flamarion; VAINFAS, Ronaldo (Org.). Domínios da História: ensaios de teoria e metodologia. Rio de Janeiro: Campus, 1997.

CHEN, Chau-Nan; TSAUR, Tien-Wang \& RHAI, Tong-Shieng. The Gini coefficiente and negative income. Oxford Economic Papers, New Series, v. 34, n. ${ }^{\text {3 }}$ 3, p. 474-478, nov.1982.

COSTA, Hernani Maia. As barreiras de São Paulo: estudo histórico das barreiras paulistas no século XIX. Dissertação (Mestrado em História) - FFLCH-USP, 1984.

COSTA, Hernani Maia. O triângulo das Barreiras: as barreiras no Vale do Paraíba paulista (1835-1860). Tese (Doutorado em História) - FFLCH-USP, 2001.

COSTA, Iraci Del Nero da \& NOZOE, Nelson Hideiki. Economia colonial brasileira: classificação das ocupações segundo ramos e setores. Estudos Econômicos. São Paulo, IPE-USP, v.17, n. 1, p. 69-87, jan./abr. 1987.

COSTA, Iraci del Nero da \& NOZOE, Nelson Hideiki. Elementos da estrutura de posse de escravos em Lorena no alvorecer do século XIX. Estudos Econômicos. São Paulo, IPEUSP, v. 19, n. 2, p. 319-345, mai./ago., 1989.

COSTA, Iraci del Nero da, SLENES, Robert W. \& SCHWARTZ, Stuart B. A família escrava em Lorena (1801). Estudos Econômicos. São Paulo, IPE-USP, v. 17, n. 2, p. 245-295, mai./agos. 1987.

COSTA, Iraci del Nero da. Arraia-miúda: um estudo sobre os não-proprietários no Brasil. São Paulo: MGSP Editores Ltda., 1992.

COSTA, Iraci del Nero da. Ciclo de vida e posse de escravos: algumas relações entre cortes transversais e estudos longitudinais. São Paulo: NEDH-FEA-USP, mimeo., 1997.

DAUMARD, Adeline. Hierarquia e riqueza na sociedade burguesia. São Paulo: Perspectiva, 1985.

DEAN, Warren. Rio Claro: um sistema brasileiro de grande lavoura, 1820-1920. Rio de Janeiro: Paz e Terra, 1977. (Estudos brasileiros v. 21)

EISENBERG, Peter. Homens esquecidos: escravos e trabalhadores livres no Brasil, séculos XVIII e XIX. São Paulo: EDUNICAMP, 1987. 
FARIA, Sheila de Castro. A Colônia em movimento: fortuna e família no cotidiano colonial. Rio de Janeiro: Nova Fronteira, 1998.

FERNÁNDEZ, Ramón Vicente Garcia. A consistência das listas nominativas de habitantes da Capitania de São Paulo: um estudo de caso. Estudos Econômicos. São Paulo, IPE/USP, v. 19, n. 3, p. 477-496, set./dez. 1989.

FERNÁNDEZ, Ramón Vicente Garcia. Transformações econômicas no litoral norte paulista (1778-1836). Tese (Doutorado em Economia) - FEA-USP, 1992.

FERREIRA, Roberto Guedes. Pardos: família, aliança e mobilidade social. Porto Feliz, São Paulo, c. 1798 - c. 1850. Tese (Doutorado em História) - IFCS-UFRJ, 2005.

FLORENTINO, Manolo. Em costas negras: uma história do tráfico de escravos entre a África e o Rio de Janeiro, séculos XVIII e XIX. São Paulo: Companhia das Letras, 1997.

FORTES, Roberto. Iguape... Nossa história. 2 v., Iguape: ed. do autor, 2000.

FORTES, Roberto. Vultos Iguapenses. Ed. preliminar em suporte eletrônico, cortesia do autor, s/d.

FRAGOSO, João Luís Ribeiro \& FLORENTINO, Manolo. História Econômica. In CARDOSO, Ciro Flamarion; VAINFAS, Ronaldo (Org.). Domínios da História: ensaios de teoria e metodologia. Rio de Janeiro: Campus, 1997.

FRAGOSO, João Luis Ribeiro. Homens de grossa aventura: acumulação e hierarquia na praça mercantil do Rio de Janeiro (1790-1830). 2 ${ }^{\text {a }}$ ed. revisada, Rio de Janeiro: Civilização Brasileira, 1998.

FRANCHI, Cleide. Arqueologia histórica do baixo Vale do Ribeira: inventário dos sítios entre Iguape e Icapara. Dissertação (Mestrado em Arqueologia) - MAE-USP, 1999.

FRANCO, Maria Sylvia de Carvalho. Homens livres na ordem escravocata. $4^{\mathrm{a}}$ ed. São Paulo: EDUNESP, 1997.

FURTADO, Celso. Formação econômica do Brasil. 23 ${ }^{\mathrm{a}}$ ed., São Paulo: Editora Nacional, 1989 (Biblioteca Universitária, série 2, Ciências Sociais, v. 23).

GARAVAZO, Juliana. Riqueza e escravidão no nordeste paulista: Batatais, 1851-1887. Dissertação (Mestrado em História) - FFLCH-USP, 2006.

GORENDER, Jacob. O escravismo colonial. São Paulo: Ed. Ática, 1978. 
GRAÇA FILHO, Afonso de Alencastro. A Princesa do Oeste e o mito da decadência de Minas Gerais: São João del Rei (1831-1888). São Paulo: Annablume, 2002.

GUTIÉRREZ, Horacio. A harmonia dos sexos: elementos da estrutura demográfica da população escrava no Paraná, 1800-1830. ANAIS DO V ENCONTRO NACIONAL DE ESTUDOS POPULACIONAIS. São Paulo: ABEP, v. 1, p. 35-52, 1986.

HOLANDA, Sérgio Buarque. O arroz em São Paulo na era colonial. Digesto Econômico. Ano III, n. ${ }^{\circ}$ 31, p. 56-58, jan. 1947.

HOLANDA, Sérgio Buarque de. A mineração: antecedentes luso-brasileiros. In HOLANDA, S. B. \& CAMPOS, P. M. (Orgs.) História Geral da Civilização Brasileira. Tomo I, $2^{\circ}$ volume. São Paulo: Difusão Européia do Livro, 1960.

HOLANDA, Sérgio Buarque de. Caminhos e Fronteiras, $3^{\text {a }}$ ed., São Paulo: Companhia das Letras, 1994.

JOHNSON JR., Harold B. A preliminary inquery into money, prices, and wages in Rio de Janeiro, 1763-1823. In ALDEN, Dauril (Ed.) Colonial roots of modern Brasil: papers of the Newberry Conference. London: University of California Press, p. 231-283, 1973.

KRUG, Edmundo. A ribeira de Iguape. Boletim de Agricultura. Secretária da Agricultura e Comércio do Estado de São Paulo, 1938, v. 39, p. 536-596.

LARAGNOIT, Paulo de Castro. A vila de Prainha. $2^{\text {a }}$ ed. ampliada. São Carlos: Ed. Jaburu, 1984.

LEMOS, A. C. Carlos. Organização urbana e arquitetura em São Paulo dos tempos coloniais. In PORTA, Paula (Org.) História da cidade de São Paulo, v. 1: a cidade colonial. São Paulo: Paz e Terra, p. 145-178, 2004.

LENHARO, Alcir. As tropas da moderação: o abastecimento da Corte na formação política do Brasil 1808 - 1842. $2^{\text {a }}$ ed. Rio de Janeiro: Secretaria Municipal de Cultura, Turismo e Esportes, 1992. (Coleção Biblioteca Carioca, v. 25).

LEVI, Giovanni, A herança imaterial: trajetória de um exorcista no Piemonte do século XVII. Rio de Janeiro: Civilização Brasileira, 2000.

LINHARES, Maria Yedda Leite, História do abastecimento: uma problemática em questão (1530-1918). Brasília: Binagri, 1979, 
LOBO, Eulalia Maria L. História do Rio de Janeiro: do capital comercial ao capital industrial financeiro. 2 vol., Rio de Janeiro: IBMEC, 1978.

LOPES, Luciana Suarez. Sob os olhos de São Sebastião: a cafeicultura e as mutações da riqueza em Ribeirão Preto, 1849-1900. Tese (Doutorado em História) - FFLCH-USP, 2005.

LUCCOCK, John. Notas sobre o Rio de Janeiro e partes meridionais do Brasil tomadas durante uma estada de dez anos nesse país, de 1808 a 1818. 2 a ed., São Paulo: Livraria Martins Editora, 1951 (Biblioteca Histórica Brasileira, v. X).

LUNA, Francisco Vidal. Características demográficas dos escravos em São Paulo (17771829). Estudos Econômicos. São Paulo, IPE-USP, v. 22, n. 1, p. 443-483, set./dez. 1992.

LUNA, Francisco Vidal. Minas Gerais: escravos e senhores - análise da estrutura populacional e econômica de alguns centros mineratórios (1718-1804). São Paulo: IPEUSP, 1981.

LUNA, Francisco Vidal. São Paulo: atividades e posse de escravos em vinte e cinco localidades (1777-1829). Estudos Econômicos. São Paulo, IPE-USP, v. 28, n. 1, p. 99169, jan./mar. 1998.

MAFFEI, Lucy de Abreu \& NOGUEIRA, Arlinda Rocha. O ouro na Capitania de São Vicente nos séculos XVI e XVII. Anais do Museu Paulista. São Paulo, Museu Paulista (USP), XX, p.7-135, 1966.

MANDELL, Paul I. A expansão da moderna rizicultura brasileira - crescimento da oferta numa economia dinâmica. Revista Brasileira de Economia. Rio de Janeiro, v. 26, n. ${ }^{\circ}$, p. 169-236, jul./set. 1972.

MARCÍLIO, Luiza Maria. Bretões em Ubatuba. In MASSA, J. M. (Org.) La Bretagne, le Portugal et le Brésil. Échanges et rapports. Acts du Cinquentenaire de la création en Bregtane de l'enseignement du Portugais. Paris: Université de Haute Bregtane, Université de Bretagne Occidentale et Université de Nantes, 1973, p. 211-215.

MARCÍLIO, Maria Luiza. Caiçara: terra e população; estudo de demografia histórica e da história social de Ubatuba. São Paulo: Edições Paulinas/CEDHAL, 1986.

MARCÍLIO, Maria Luiza. Crescimento demográfico e evolução agrária paulista, 17001836. São Paulo: Edusp/Hucitec, 2000. 
MARCONDES, Renato Leite. A arte de acumular na economia cafeeira: Vale do Paraíba, século XIX. Lorena: Stiliano, 1998.

MARCONDES, Renato Leite. O financiamento hipotecário da cafeicultura no Vale do Paraíba paulista (1865-87). Revista Brasileira de Economia, Rio de Janeiro, v. 56, n. ${ }^{0}$, p. 147-170, jan./mar. 2002.

MARIUTTI, Eduardo Barros; NOGUERÓL, Luiz Paulo Ferreira; NETO, Mário Danieli. Mercado interno colonial e grau de autonomia: críticas às propostas de João Luís Fragoso e Manolo Florentino. Estudos Econômicos. São Paulo, IPE-USP, v. 31, n. ${ }^{0}$ 2, p. 369393, abr./jun. 2001.

MARQUES, Cláudia Eliane Parreiras. Riqueza e escravidão: dimensões materiais da sociedade no segundo reinado (Bonfim/MG). Dissertação (Mestrado em História) FFLCH-USP, 2000.

MELLO, Zélia Maria Cardoso de. Metamorfose da riqueza: São Paulo, 1845/1895. São Paulo: Hucitec, 1985.

MESQUITA, Eni Samara. Papel de agregado na região de Itu de 1780 a 1830. Dissertação (Mestrado em História) FFLCH/USP, 1973.

MOTTA José F., NOZOE, Nelson H. \& COSTA Iraci N. Às vésperas da abolição - um estudo sobre a estrutura de posse de escravos em São Cristóvão (RJ), 1870. Estudos Econômicos. São Paulo, IPE-USP, v. 34, n. 1, p. 157-213, jan./mar. 2004.

MOTTA, José Flávio. Corpos escravos, vontades livres: posse de cativos e família escrava em Bananal (1801-1829). São Paulo: FAPESP-Annablume, 1999.

MOTTA, Márcia Maria Menendes. Nas fronteiras do Poder: conflito e direito à terra no Brasil do século XIX. Rio de Janeiro: Arquivo Público do Estado/Vício de Leitura, 1998.

MOURA, Denise A. Soares de. Saindo das sombras: homens livres no declínio do escravimo. São Paulo: EDUNICAMP, 1998.

MÜLLER, Nice Lecocq. Tipos de sitiantes em algumas regiões do estado de São Paulo. Tese (doutorado em Geografia). FFCL-USP, 1946.

NADALIN, Sergio Odilon. A demografia numa perspectiva histórica. São Paulo: ABEP, 1994 (Textos didáticos, 2). 
NOGUERÓL, Luiz Paulo Ferreira. Sabará e Porto Alegre na formação do mercado nacional no século XIX. Tese (Doutorado em Economia). IE-UNICAMP, 2003.

NOZOE, Nelson Hideiki \& COSTA, Iraci del Nero da. Achegas para a qualificação das listas nominativas. Estudos Econômicos. São Paulo, IPE/USP, v. 21, n. 2, p. 271-284, mai./ago. 1991.

NOZOE, Nelson Hideiki \& COSTA, Iraci del Nero da. Sobre a questão das idades em alguns documentos dos séculos XVIII e XIX. Revista do Instituto de Estudos Brasileiros. São Paulo, v. 34, p. 175-182, 1992.

NOZOE, Nelson \& MOTTA, José Flávio. Os produtores eventuais de café: nota sobre os primórdios da cafeicultura paulista (Bananal, 1799-1829). LOCUS: revista de história. Juiz de Fora, v. 5, n. 1, p. 51-84, 1999.

NOZOE, Nelson Hideiki et alii. Brasil: breves comentários sobre algumas séries referentes à taxa de câmbio. Boletim de História Demográfica. São Paulo: NEHD-FEA-USP, ano XI, n. ${ }^{\circ}$ 32, maio de 2004.

OLIVEIRA, Lélio Luiz de. Economia e história em Franca: século XIX. Franca: UNESPFHDSS: Amazonas Prod. Calçados S/A, 1997.

OSÓRIO, Helen. Estancieiros, lavradores e comerciantes na constituição da estremadura portuguesa na América: Rio Grande de São Pedro, 1737-1822. Tese (Doutorado em História) - ICHF-UFF, 1999.

PETRONE, Maria Thereza Schorer. A lavoura canavieira em São Paulo. São Paulo: Difel, 1968.

PETRONE, Pasquale. Notas sobre os sistemas de cultura na Baixada do Ribeira, SP. Boletim Paulista de Geografia. São Paulo, Assoc. Geógrafos Brasileiros, n. 39, p. 47-63, out./1961.

PETRONE, Pasquale. A Baixada do Ribeira: estudo de geografia humana. São Paulo: FFCL-USP, Boletim n. ${ }^{\circ} 283$ (Cadeira de Geografia n. ${ }^{\circ}$ 14), 1966.

PRADO JÚNIOR, Caio. Formação do Brasil Contemporâneo. 21 ${ }^{\mathrm{a}}$ ed., São Paulo: Ed. Brasiliense, 1989.

PUNTSCHART, William. Negócios e negociantes paulistas: 1808-1822. Tese (Doutorado em História) - FFLCH-USP, 1998. 
RANGEL, Armênio de Souza. Escravismo e riqueza: formação da economia cafeeira no município de Taubaté, 1765-1835. Tese (Doutorado em Economia) - FEA-USP, 1990.

REIS, Déborah Oliveira Martins dos. Teres e deveres, o evolver da riqueza em Araxá: a economia de uma localidade mineira em inventários post-mortem, 1776-1888. Dissertação (Mestrado em História) - FFLCH-USP, 2005.

SAMPAIO, Antonio Carlos Jucá de. Magé na crise do escravismo: sistema agrário e evolução numa economia escravista (Mage, 1850-1888). Dissertação (Mestrado em História) - ICHF-UFF, 1994.

SANTOS, Corsino Medeiros dos. Cultura, indústria e comércio de arroz no Brasil meridional.

Lavoura arrozeira. Porto Alegre, Instituto Rio Grandense de Arroz, n. ${ }^{0}$ 315, p. 6-20, set./out. 1979.

SCHWARTZ, Stuart B. Segredos internos: engenhos e escravos na socidade colonial, 15501835. São Paulo: Companhia das Letras, 1999.

SILVA, Francisco Alves da. Abastecimento em São Paulo (1835-1877): estudo histórico do aprovisionamento da Província via Barreira de Cubatão. Dissertação (Mestrado em História) - FFLCH-USP, 1985.

SIMONSEN, Roberto C. História Econômica do Brasil (1500/1820). $4^{\text {a }}$ ed., São Paulo: Companhia Editora Nacional, 1962 (Coleção Brasiliana, v. 10).

SLENES, Robert W. The demography and economics of Brazilian slavery: 1850-1888. Tese (Doutorado em Economia), Stanford University, 1976.

SMITH, Julia Floyd. Slavery and rice culture in low country Georgia, 1750-1860. Knoxville: The University of Tennessee Press, 1985.

SOARES, Leonel de Oliveira. No caminho dos goiases: formação e desenvolvimento da economia escravista na Mogi Mirim do século XIX. Dissertação (Mestrado em História) - FFLCH-USP, 2003.

SOARES, Sebastião Ferreira. Notas estatísticas sobre a produção agrícola e carestia dos gêneros alimentícios no Império do Brasil. Rio de Janeiro: IPEA-INPES, 1977 (Série Pensamento Econômico, 2).

TEIXEIRA, Heloisa Maria. Reprodução e famílias escravas de Mariana (1850-1888). Dissertação (Mestrado em História Econômica) - FFLCH-USP, 2001. 
TORRES, Haroldo da Gama; FERREIRA, Maria Paula \& DINI, Nádia Pinheiro. Indicadores sociais: por que construir novos indicadores como o IPRS. São Paulo em Perspectiva. Fundação SEADE, v. 17, n. 3-4, p. 80-90, 2003.

VAINFAS, Ronaldo. Os protagonistas anônimos da história: micro-história. Rio de Janeiro: Campus, 2002.

VALENTIN, Agnaldo. Nem Minas, nem São Paulo: economia e demografia na localidade paulista de Apiaí (1732-1835). Dissertação (Mestrado em História) - FFLCH-USP, 2001.

VERSIANI, Flávio Rabelo \& VERGOLINO, José Raimundo de Oliveira. Preços de escravos em Pernambuco no século XIX. Brasília: UNB, 2002 (Texto para discussão n. ${ }^{\circ}$ 252).

VIANNA, Lauro de Brito. O porto do Rio Grande no século XIX através da imprensa (1847-1857): história dos preços e das flutuações. Tese (Doutorado em História) FFLCH-USP, 2000.

YOUNG, Ernesto G. Esboço histórico da fundação da cidade de Iguape. Revista do Instituto Histórico e Geográfico de São Paulo, v. II, p. 49-153, 1898.

YOUNG, Ernesto G. História de Iguape. Revista do Instituto Histórico e Geográfico de São Paulo, v. VIII, p. 222-325, 1903.

ZEMELLA, Mafalda P. O abastecimento da Capitania das Minas Gerais no século XVIII. 2ª ed., São Paulo: HUCITEC: EDUSP, 1990. (Estudos Históricos; v. 19). 
ANEXOS 
Proprietários e escravos do Vale do Ribeira 
Lista Nominativa - 1801

\begin{tabular}{|c|c|c|c|c|c|c|c|c|c|c|c|c|}
\hline \multirow{3}{*}{ Plantéis } & \multicolumn{6}{|c|}{ Iguape } & \multicolumn{6}{|c|}{ Xiririca } \\
\hline & \multicolumn{3}{|c|}{ Proprietários } & \multicolumn{3}{|c|}{ Escravos } & \multicolumn{3}{|c|}{ Proprietários } & \multicolumn{3}{|c|}{ Escravos } \\
\hline & $\mathrm{H}$ & $\mathrm{M}$ & $\mathrm{H}+\mathrm{M}$ & $\mathrm{H}$ & $\mathrm{M}$ & $\mathrm{H}+\mathrm{M}$ & $\mathrm{H}$ & $\mathrm{M}$ & $\mathrm{H}+\mathrm{M}$ & $\mathrm{H}$ & $\mathrm{M}$ & $\mathrm{H}+\mathrm{M}$ \\
\hline 1 & 40 & 11 & 51 & 27 & 24 & 51 & 15 & 1 & 16 & 7 & 9 & 16 \\
\hline 2 & 25 & 3 & 28 & 24 & 32 & 56 & 5 & 3 & 8 & 8 & 8 & 16 \\
\hline 3 & 15 & 4 & 19 & 27 & 30 & 57 & 5 & 2 & 7 & 11 & 10 & 21 \\
\hline 4 & 7 & 1 & 8 & 15 & 17 & 32 & 1 & 1 & 2 & 2 & 6 & 8 \\
\hline 5 & 7 & 5 & 12 & 32 & 28 & 60 & 1 & - & 1 & 3 & 2 & 5 \\
\hline 6 & 8 & - & 8 & 24 & 24 & 48 & 4 & 1 & 5 & 16 & 14 & 30 \\
\hline 7 & 10 & - & 10 & 31 & 39 & 70 & 3 & 1 & 4 & 10 & 18 & 28 \\
\hline 8 & 5 & - & 5 & 18 & 22 & 40 & . & - & - & - & - & - \\
\hline 9 & 3 & 3 & 6 & 31 & 23 & 54 & 2 & - & 2 & 6 & 12 & 18 \\
\hline 10 & 4 & 1 & 5 & 30 & 20 & 50 & 2 & - & 2 & 12 & 8 & 20 \\
\hline 11 & - & 1 & 1 & 7 & 4 & 11 & 2 & - & 2 & 11 & 11 & 22 \\
\hline 12 & 3 & 1 & 4 & 25 & 23 & 48 & 1 & - & 1 & 6 & 6 & 12 \\
\hline 13 & 3 & - & 3 & 21 & 18 & 39 & 2 & - & 2 & 14 & 12 & 26 \\
\hline 14 & 4 & - & 4 & 29 & 27 & 56 & 1 & - & 1 & 8 & 6 & 14 \\
\hline 18 & 1 & - & 1 & 10 & 8 & 18 & . & - & - & - & - & - \\
\hline 19 & - & - & - & - & - & - & . & 1 & 1 & 9 & 10 & 19 \\
\hline 21 & 1 & - & 1 & 15 & 6 & 21 & - & - & - & - & - & - \\
\hline
\end{tabular}


Lista Nominativa - 1815

\begin{tabular}{|c|c|c|c|c|c|c|c|c|c|c|c|c|}
\hline \multirow{3}{*}{ Plantéis } & \multicolumn{6}{|c|}{ Iguape } & \multicolumn{6}{|c|}{ Xiririca } \\
\hline & \multicolumn{3}{|c|}{ Proprietários } & \multicolumn{3}{|c|}{ Escravos } & \multicolumn{3}{|c|}{ Proprietários } & \multicolumn{3}{|c|}{ Escravos } \\
\hline & $\mathrm{H}$ & $\mathrm{M}$ & $\mathrm{H}+\mathrm{M}$ & $\mathrm{H}$ & M & $\mathrm{H}+\mathrm{M}$ & $\mathrm{H}$ & M & $\mathrm{H}+\mathrm{M}$ & $\mathrm{H}$ & M & $\mathrm{H}+\mathrm{M}$ \\
\hline 1 & 46 & 9 & 55 & 32 & 23 & 55 & 19 & 5 & 24 & 17 & 7 & 24 \\
\hline 2 & 30 & 3 & 33 & 36 & 30 & 66 & 8 & 2 & 10 & 9 & 11 & 20 \\
\hline 3 & 22 & 7 & 29 & 43 & 44 & 87 & 10 & 1 & 11 & 18 & 15 & 33 \\
\hline 4 & 22 & 3 & 25 & 55 & 45 & 100 & 11 & 1 & 12 & 26 & 22 & 48 \\
\hline 5 & 13 & 1 & 14 & 39 & 31 & 70 & 7 & 1 & 8 & 22 & 18 & 40 \\
\hline 6 & 8 & 1 & 9 & 28 & 26 & 54 & 4 & . & 4 & 10 & 14 & 24 \\
\hline 7 & 10 & 1 & 11 & 45 & 32 & 77 & 3 & . & 3 & 13 & 8 & 21 \\
\hline 8 & 5 & - & 5 & 17 & 23 & 40 & 4 & . & 4 & 13 & 19 & 32 \\
\hline 9 & 6 & 2 & 8 & 40 & 32 & 72 & 2 & . & 2 & 11 & 7 & 18 \\
\hline 10 & 5 & - & 5 & 26 & 24 & 50 & 5 & - & 5 & 27 & 23 & 50 \\
\hline 11 & 2 & 2 & 4 & 18 & 26 & 44 & 2 & 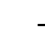 & 2 & 13 & 9 & 22 \\
\hline 12 & 3 & - & 3 & 21 & 15 & 36 & 1 & . & 1 & 8 & 4 & 12 \\
\hline 13 & 4 & - & 4 & 29 & 23 & 52 & . & . & - & - & 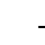 & - \\
\hline 14 & 2 & - & 2 & 16 & 12 & 28 & . & . & - & - & . & - \\
\hline 15 & 2 & 2 & 4 & 35 & 25 & 60 & 1 & . & 1 & 8 & 7 & 15 \\
\hline 16 & 2 & - & 2 & 18 & 14 & 32 & - & - & - & - & - & - \\
\hline 17 & 2 & - & 2 & 23 & 11 & 34 & - & - & - & - & - & - \\
\hline 18 & 2 & - & 2 & 20 & 16 & 36 & - & - & - & - & . & - \\
\hline 19 & 1 & - & 1 & 10 & 9 & 19 & - & . & - & - & 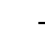 & - \\
\hline 23 & 1 & - & 1 & 10 & 13 & 23 & . & . & - & - & . & - \\
\hline 24 & 1 & - & 1 & 13 & 11 & 24 & - & . & - & - & . & - \\
\hline 25 & - & - & - & - & - & - & 1 & . & 1 & 15 & 10 & 25 \\
\hline 26 & - & - & - & - & . & - & 2 & . & 2 & 29 & 23 & 52 \\
\hline 31 & 1 & - & 1 & 17 & 14 & 31 & - & . & - & - & 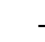 & - \\
\hline 49 & 1 & - & 1 & 35 & 14 & 49 & . & . & - & - & . & - \\
\hline 62 & 1 & - & 1 & 42 & 20 & 62 & . & . & - & - & - & - \\
\hline 63 & 1 & - & 1 & 40 & 23 & 63 & . & . & - & - & - & - \\
\hline
\end{tabular}


Lista nominativa $\mathbf{- 1 8 2 8}$

\begin{tabular}{|c|c|c|c|c|c|c|c|c|c|c|c|c|}
\hline \multirow{3}{*}{ Plantéis } & \multicolumn{6}{|c|}{ Iguape } & \multicolumn{6}{|c|}{ Xiririca } \\
\hline & \multicolumn{3}{|c|}{ Proprietários } & \multicolumn{3}{|c|}{ Escravos } & \multicolumn{3}{|c|}{ Proprietários } & \multicolumn{3}{|c|}{ Escravos } \\
\hline & $\mathrm{H}$ & $\mathrm{M}$ & $\mathrm{H}+\mathrm{M}$ & $\mathrm{H}$ & $\mathrm{M}$ & $\mathrm{H}+\mathrm{M}$ & $\mathrm{H}$ & M & $\mathrm{H}+\mathrm{M}$ & $\mathrm{H}$ & $\mathrm{M}$ & $\mathrm{H}+\mathrm{M}$ \\
\hline 1 & 50 & 6 & 56 & 30 & 26 & 56 & 31 & 5 & 36 & 21 & 15 & 36 \\
\hline 2 & 27 & 4 & 31 & 24 & 38 & 62 & 15 & 3 & 18 & 14 & 21 & 35 \\
\hline 3 & 17 & 10 & 27 & 44 & 37 & 81 & 9 & 3 & 12 & 12 & 24 & 36 \\
\hline 4 & 19 & 6 & 25 & 47 & 53 & 100 & 8 & 2 & 10 & 25 & 15 & 40 \\
\hline 5 & 16 & 4 & 20 & 54 & 46 & 100 & 5 & 1 & 6 & 16 & 14 & 30 \\
\hline 6 & 13 & 3 & 16 & 47 & 49 & 96 & 11 & - & 11 & 37 & 29 & 66 \\
\hline 7 & 13 & 1 & 14 & 55 & 43 & 98 & 5 & 1 & 6 & 29 & 13 & 42 \\
\hline 8 & 8 & 3 & 11 & 51 & 37 & 88 & 1 & 1 & 2 & 6 & 10 & 16 \\
\hline 9 & 2 & - & 2 & 10 & 8 & 18 & 3 & - & 3 & 13 & 14 & 27 \\
\hline 10 & 4 & - & 4 & 25 & 15 & 40 & 2 & - & 2 & 7 & 13 & 20 \\
\hline 11 & 3 & - & 3 & 20 & 13 & 33 & 7 & - & 7 & 51 & 26 & 77 \\
\hline 12 & 2 & 1 & 3 & 19 & 17 & 36 & 1 & 1 & 2 & 16 & 8 & 24 \\
\hline 13 & 3 & - & 3 & 19 & 20 & 39 & 3 & - & 3 & 24 & 15 & 39 \\
\hline 14 & 3 & - & 3 & 29 & 13 & 42 & 1 & - & 1 & 7 & 7 & 14 \\
\hline 15 & 3 & 1 & 4 & 34 & 26 & 60 & - & - & - & - & - & - \\
\hline 16 & - & 1 & 1 & 11 & 5 & 16 & 2 & - & 2 & 16 & 16 & 32 \\
\hline 17 & 1 & 1 & 2 & 19 & 15 & 34 & - & - & - & - & - & - \\
\hline 18 & 1 & 1 & 2 & 22 & 14 & 36 & - & - & - & - & - & - \\
\hline 19 & 3 & - & 3 & 28 & 29 & 57 & - & - & - & - & - & - \\
\hline 20 & 2 & - & 2 & 21 & 19 & 40 & - & - & - & - & - & - \\
\hline 21 & 3 & - & 3 & 38 & 25 & 63 & 1 & - & 1 & 7 & 14 & 21 \\
\hline 22 & 1 & - & 1 & 14 & 8 & 22 & - & - & - & - & - & - \\
\hline 24 & 1 & - & 1 & 11 & 13 & 24 & - & - & - & - & - & - \\
\hline 27 & 1 & - & 1 & 16 & 11 & 27 & - & - & - & - & - & - \\
\hline 29 & 1 & - & 1 & 17 & 12 & 29 & - & - & - & - & - & - \\
\hline 33 & 2 & - & 2 & 36 & 30 & 66 & 1 & - & 1 & 16 & 17 & 33 \\
\hline 34 & 1 & - & 1 & 19 & 15 & 34 & - & - & - & - & - & - \\
\hline 35 & 2 & - & 2 & 37 & 33 & 70 & - & - & - & - & - & - \\
\hline 38 & - & - & - & - & - & - & 1 & - & 1 & 18 & 20 & 38 \\
\hline 39 & - & 1 & 1 & 22 & 17 & 39 & - & - & - & - & - & - \\
\hline 48 & 1 & - & 1 & 25 & 23 & 48 & - & - & - & - & - & - \\
\hline 51 & 1 & - & 1 & 26 & 25 & 51 & - & - & - & - & - & - \\
\hline 62 & 1 & - & 1 & 41 & 21 & 62 & - & - & - & - & - & - \\
\hline 64 & 1 & - & 1 & 49 & 15 & 64 & - & - & - & - & - & - \\
\hline
\end{tabular}


Lista nominativa 1836

\begin{tabular}{|c|c|c|c|c|c|c|c|c|c|c|c|c|}
\hline \multirow{3}{*}{ Plantéis } & \multicolumn{6}{|c|}{ Iguape } & \multicolumn{6}{|c|}{ Xiririca } \\
\hline & \multicolumn{3}{|c|}{ Proprietários } & \multicolumn{3}{|c|}{ Escravos } & \multicolumn{3}{|c|}{ Proprietários } & \multicolumn{3}{|c|}{ Escravos } \\
\hline & $\mathrm{H}$ & $\mathrm{M}$ & $\mathrm{H}+\mathrm{M}$ & $\mathrm{H}$ & $\mathrm{M}$ & $\mathrm{H}+\mathrm{M}$ & $\mathrm{H}$ & M & $\mathrm{H}+\mathrm{M}$ & $\mathrm{H}$ & $\mathrm{M}$ & $\mathrm{H}+\mathrm{M}$ \\
\hline 1 & 60 & 10 & 70 & 31 & 39 & 70 & 21 & 2 & 23 & 7 & 16 & 23 \\
\hline 2 & 33 & 8 & 41 & 43 & 39 & 82 & 22 & - & 22 & 21 & 23 & 44 \\
\hline 3 & 26 & 10 & 36 & 48 & 60 & 108 & 8 & 1 & 9 & 14 & 13 & 27 \\
\hline 4 & 20 & 7 & 27 & 57 & 51 & 108 & 10 & - & 10 & 19 & 21 & 40 \\
\hline 5 & 17 & 2 & 19 & 51 & 44 & 95 & 4 & 2 & 6 & 14 & 16 & 30 \\
\hline 6 & 13 & 2 & 15 & 51 & 39 & 90 & 3 & - & 3 & 9 & 9 & 18 \\
\hline 7 & 10 & - & 10 & 34 & 36 & 70 & 7 & 1 & 8 & 19 & 37 & 56 \\
\hline 8 & 10 & 4 & 14 & 56 & 56 & 112 & 3 & - & 3 & 13 & 11 & 24 \\
\hline 9 & 5 & 3 & 8 & 32 & 40 & 72 & 5 & - & 5 & 23 & 22 & 45 \\
\hline 10 & 9 & 2 & 11 & 60 & 50 & 110 & - & 1 & 1 & 5 & 5 & 10 \\
\hline 11 & 4 & 3 & 7 & 36 & 41 & 77 & - & - & - & - & - & - \\
\hline 12 & 5 & 1 & 6 & 38 & 34 & 72 & 2 & 1 & 3 & 21 & 15 & 36 \\
\hline 13 & 2 & - & 2 & 11 & 15 & 26 & 1 & - & 1 & 8 & 5 & 13 \\
\hline 14 & 3 & 1 & 4 & 28 & 28 & 56 & 1 & - & 1 & 7 & 7 & 14 \\
\hline 15 & 3 & 1 & 4 & 38 & 22 & 60 & 2 & - & 2 & 17 & 13 & 30 \\
\hline 16 & 1 & 2 & 3 & 28 & 20 & 48 & 1 & - & 1 & 7 & 9 & 16 \\
\hline 17 & 1 & 1 & 2 & 18 & 16 & 34 & 1 & - & 1 & 8 & 9 & 17 \\
\hline 18 & 1 & 2 & 3 & 29 & 25 & 54 & - & - & - & - & - & - \\
\hline 19 & 1 & - & 1 & 13 & 6 & 19 & - & - & - & - & - & - \\
\hline 20 & 2 & - & 2 & 21 & 19 & 40 & - & - & - & - & - & - \\
\hline 21 & - & - & - & - & - & - & 2 & - & 2 & 23 & 19 & 42 \\
\hline 22 & 2 & - & 2 & 24 & 20 & 44 & - & - & - & - & - & - \\
\hline 23 & 1 & 1 & 2 & 32 & 14 & 46 & - & - & - & - & - & - \\
\hline 25 & 2 & - & 2 & 30 & 20 & 50 & - & - & - & - & - & - \\
\hline 28 & 1 & - & 1 & 34 & 22 & 56 & . & - & - & - & - & - \\
\hline 29 & 1 & - & 1 & 16 & 13 & 29 & . & - & - & - & - & - \\
\hline 31 & 2 & - & 2 & 37 & 25 & 62 & . & - & - & - & - & - \\
\hline 33 & 2 & - & 2 & 36 & 30 & 66 & - & - & - & - & - & - \\
\hline 38 & - & - & - & - & - & - & - & 1 & 1 & 19 & 19 & 38 \\
\hline 40 & 1 & - & 1 & 25 & 15 & 40 & - & - & - & - & - & - \\
\hline 52 & - & 1 & 1 & 42 & 10 & 52 & - & - & - & - & - & - \\
\hline 57 & 1 & - & 1 & 27 & 30 & 57 & - & - & - & - & - & - \\
\hline 61 & 1 & - & 1 & 35 & 26 & 61 & - & - & - & - & - & - \\
\hline 69 & - & 1 & 1 & 49 & 20 & 69 & - & - & - & - & - & - \\
\hline
\end{tabular}


Inventários - 1800-1840

\begin{tabular}{|c|rrrrrr|}
\hline \multirow{3}{*}{ Plantéis } & \multicolumn{6}{|c|}{ Iguape } \\
\cline { 2 - 7 } & \multicolumn{3}{|c}{ Proprietários } & \multicolumn{4}{c|}{ Escravos } \\
\cline { 2 - 7 } & H & M & H+M & \multicolumn{1}{c|}{ M } & H+M \\
\hline 1 & 10 & 7 & 17 & 10 & 7 & 17 \\
2 & 6 & 5 & 11 & 10 & 12 & 22 \\
3 & 5 & 4 & 9 & 13 & 14 & 27 \\
4 & 2 & 5 & 7 & 13 & 15 & 28 \\
5 & 5 & 4 & 9 & 19 & 26 & 45 \\
6 & 5 & 4 & 9 & 32 & 22 & 54 \\
7 & - & 1 & 1 & 4 & 3 & 7 \\
8 & 3 & - & 3 & 11 & 13 & 24 \\
9 & 3 & - & 3 & 20 & 7 & 27 \\
10 & 3 & 2 & 5 & 29 & 21 & 50 \\
11 & - & 1 & 1 & 7 & 4 & 11 \\
13 & 2 & - & 2 & 16 & 10 & 26 \\
15 & 2 & - & 2 & 16 & 14 & 30 \\
16 & - & 1 & 1 & 10 & 6 & 16 \\
18 & 1 & - & 1 & 8 & 10 & 18 \\
19 & 1 & 1 & 2 & 24 & 14 & 38 \\
24 & 1 & - & 1 & 12 & 12 & 24 \\
25 & - & 1 & 1 & 12 & 13 & 25 \\
27 & 2 & - & 2 & 29 & 25 & 54 \\
43 & - & 1 & 1 & 26 & 17 & 43 \\
44 & 1 & - & 1 & 20 & 24 & 44 \\
69 & 1 & - & 1 & 52 & 17 & 69 \\
\hline
\end{tabular}


Inventários - 1841 -1860

\begin{tabular}{|c|c|c|c|c|c|c|c|c|c|c|c|c|}
\hline \multirow{3}{*}{ Plantéis } & \multicolumn{6}{|c|}{ Iguape } & \multicolumn{6}{|c|}{ Xiririca } \\
\hline & \multicolumn{3}{|c|}{ Proprietários } & \multicolumn{3}{|c|}{ Escravos } & \multicolumn{3}{|c|}{ Proprietários } & \multicolumn{3}{|c|}{ Escravos } \\
\hline & $\mathrm{H}$ & $\mathrm{M}$ & $\mathrm{H}+\mathrm{M}$ & $\mathrm{H}$ & $\mathrm{M}$ & $\mathrm{H}+\mathrm{M}$ & $\mathrm{H}$ & $\mathrm{M}$ & $\mathrm{H}+\mathrm{M}$ & $\mathrm{H}$ & $\mathrm{M}$ & $\mathrm{H}+\mathrm{M}$ \\
\hline 1 & 16 & 10 & 26 & 13 & 13 & 26 & 1 & 2 & 3 & 2 & 1 & 3 \\
\hline 2 & 16 & 7 & 23 & 18 & 28 & 46 & 1 & 2 & 3 & 4 & 2 & 6 \\
\hline 3 & 10 & 10 & 20 & 31 & 29 & 60 & 2 & 2 & 4 & 8 & 4 & 12 \\
\hline 4 & 6 & 3 & 9 & 19 & 17 & 36 & 2 & 2 & 4 & 8 & 8 & 16 \\
\hline 5 & 3 & 5 & 8 & 19 & 21 & 40 & 1 & - & 1 & 3 & 2 & 5 \\
\hline 6 & 4 & 5 & 9 & 26 & 28 & 54 & 1 & 2 & 3 & 9 & 9 & 18 \\
\hline 7 & 2 & 5 & 7 & 21 & 28 & 49 & - & - & - & - & - & - \\
\hline 8 & 3 & 4 & 7 & 34 & 22 & 56 & - & - & - & - & - & - \\
\hline 9 & 1 & 3 & 4 & 14 & 22 & 36 & - & - & - & - & - & - \\
\hline 10 & 6 & 2 & 8 & 38 & 42 & 80 & - & 1 & 1 & 5 & 5 & 10 \\
\hline 11 & - & 1 & 1 & 5 & 6 & 11 & - & - & - & - & - & - \\
\hline 12 & - & - & - & - & - & - & 2 & 1 & 3 & 21 & 15 & 36 \\
\hline 13 & 4 & 1 & 5 & 37 & 28 & 65 & - & - & - & - & - & - \\
\hline 14 & - & 1 & 1 & 6 & 8 & 14 & - & - & - & - & - & - \\
\hline 16 & 2 & - & 2 & 17 & 15 & 32 & 1 & - & 1 & 9 & 7 & 16 \\
\hline 17 & 1 & 1 & 2 & 19 & 15 & 34 & - & 1 & 1 & 10 & 7 & 17 \\
\hline 18 & - & - & - & - & - & - & 1 & - & 1 & 9 & 9 & 18 \\
\hline 19 & 1 & - & 1 & 9 & 10 & 19 & - & - & - & - & - & - \\
\hline 20 & 1 & 2 & 3 & 33 & 27 & 60 & - & - & - & - & - & - \\
\hline 21 & 2 & 1 & 3 & 30 & 33 & 63 & - & - & - & - & - & - \\
\hline 23 & 1 & - & 1 & 13 & 10 & 23 & - & - & - & - & - & - \\
\hline 25 & 1 & - & 1 & 14 & 11 & 25 & - & - & - & - & - & - \\
\hline 26 & 1 & - & 1 & 18 & 8 & 26 & - & - & - & - & - & - \\
\hline 28 & - & 1 & 1 & 9 & 19 & 28 & - & - & - & - & - & - \\
\hline 31 & 1 & - & 1 & 19 & 12 & 31 & - & - & - & - & - & - \\
\hline 34 & - & - & - & - & - & - & 1 & - & 1 & 22 & 12 & 34 \\
\hline 44 & 1 & - & 1 & 27 & 17 & 44 & - & - & - & - & - & - \\
\hline 67 & 1 & - & 1 & 36 & 31 & 67 & - & - & - & - & - & - \\
\hline
\end{tabular}


Inventários - 1861-1880

\begin{tabular}{|c|c|c|c|c|c|c|c|c|c|c|c|c|}
\hline \multirow{3}{*}{ Plantéis } & \multicolumn{6}{|c|}{ Iguape } & \multicolumn{6}{|c|}{ Xiririca } \\
\hline & \multicolumn{3}{|c|}{ Proprietários } & \multicolumn{3}{|c|}{ Escravos } & \multicolumn{3}{|c|}{ Proprietários } & \multicolumn{3}{|c|}{ Escravos } \\
\hline & $\mathrm{H}$ & $\mathrm{M}$ & $\mathrm{H}+\mathrm{M}$ & $\mathrm{H}$ & M & $\mathrm{H}+\mathrm{M}$ & $\mathrm{H}$ & M & $\mathrm{H}+\mathrm{M}$ & $\mathrm{H}$ & M & $\mathrm{H}+\mathrm{M}$ \\
\hline 1 & 13 & 13 & 26 & 13 & 13 & 26 & 10 & $\overline{4}$ & 14 & 7 & 7 & 14 \\
\hline 2 & 9 & 9 & 18 & 17 & 19 & 36 & 5 & 6 & 11 & 13 & 9 & 22 \\
\hline 3 & 7 & 8 & 15 & 23 & 22 & 45 & 4 & 7 & 11 & 11 & 22 & 33 \\
\hline 4 & 4 & 6 & 10 & 24 & 16 & 40 & 3 & 1 & 4 & 6 & 10 & 16 \\
\hline 5 & 4 & 4 & 8 & 24 & 16 & 40 & 4 & 1 & 5 & 12 & 13 & 25 \\
\hline 6 & 4 & 2 & 6 & 16 & 20 & 36 & . & 3 & 3 & 12 & 6 & 18 \\
\hline 7 & 2 & 4 & 6 & 25 & 17 & 42 & 3 & 2 & 5 & 14 & 21 & 35 \\
\hline 8 & 3 & 3 & 6 & 23 & 25 & 48 & 2 & 2 & 4 & 16 & 16 & 32 \\
\hline 9 & 4 & 1 & 5 & 21 & 24 & 45 & 2 & 2 & 4 & 17 & 19 & 36 \\
\hline 10 & 2 & 1 & 3 & 13 & 17 & 30 & 1 & - & 1 & 6 & 4 & 10 \\
\hline 11 & 1 & 1 & 2 & 11 & 11 & 22 & 1 & - & 1 & 5 & 6 & 11 \\
\hline 12 & 1 & 1 & 2 & 13 & 11 & 24 & 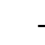 & 1 & 1 & 6 & 6 & 12 \\
\hline 13 & 1 & - & 1 & 8 & 5 & 13 & 1 & 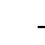 & 1 & 5 & 8 & 13 \\
\hline 14 & 3 & 1 & 4 & 33 & 23 & 56 & 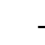 & 1 & 1 & 9 & 5 & 14 \\
\hline 15 & 2 & 2 & 4 & 31 & 29 & 60 & 3 & - & 3 & 23 & 22 & 45 \\
\hline 16 & - & - & - & - & - & - & 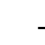 & 1 & 1 & 4 & 12 & 16 \\
\hline 17 & - & - & - & - & - & - & 1 & - & 1 & 10 & 7 & 17 \\
\hline 21 & - & - & - & - & - & - & 1 & - & 1 & 12 & 9 & 21 \\
\hline 28 & 1 & - & 1 & 13 & 15 & 28 & . & - & - & - & . & - \\
\hline 30 & - & - & - & - & - & - & - & 1 & 1 & 17 & 13 & 30 \\
\hline 31 & 1 & - & 1 & 15 & 16 & 31 & . & . & - & - & . & - \\
\hline 40 & - & - & - & - & - & - & 1 & 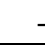 & 1 & 29 & 11 & 40 \\
\hline
\end{tabular}


Distribuição dos proprietários segundo sexo e condição conjugal

(Iguape e Xiririca, anos selecionados)

\begin{tabular}{|c|c|c|c|c|c|c|c|c|c|c|c|c|c|}
\hline & \multirow{2}{*}{ Condição conjugal } & \multicolumn{3}{|c|}{1801} & \multicolumn{3}{|c|}{1815} & \multicolumn{3}{|c|}{1828} & \multicolumn{3}{|c|}{1836} \\
\hline & & $\mathbf{H}$ & $\mathbf{M}$ & $\mathbf{H}+\mathbf{M}$ & $\mathbf{H}$ & $\mathbf{M}$ & $\mathbf{H}+\mathbf{M}$ & $\mathbf{H}$ & M & $\mathbf{H}+\mathbf{M}$ & $\mathbf{H}$ & M & $\mathbf{H}+\mathbf{M}$ \\
\hline \multirow{15}{*}{ 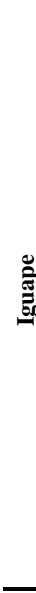 } & Números absolutos & & & & & & & & & & & & \\
\hline & solteiros & 14 & 7 & 21 & 32 & 7 & 39 & 31 & 8 & 39 & 41 & 11 & 52 \\
\hline & casados & 108 & 0 & 108 & 150 & 0 & 150 & 159 & 3 & 162 & 174 & 1 & 175 \\
\hline & viúvos & 14 & 23 & 37 & 11 & 24 & 35 & 16 & 32 & 48 & 25 & 50 & 75 \\
\hline & total & 136 & 30 & 166 & 193 & 31 & 224 & 206 & 43 & 249 & 240 & 62 & 302 \\
\hline & Porcentuais segundo sexo ${ }^{a}$ & & & & & & & & & & & & \\
\hline & solteiros & 66,7 & 33,3 & 100,0 & 82,1 & 17,9 & 100,0 & 79,5 & 20,5 & 100,0 & 78,8 & 21,2 & 100,0 \\
\hline & casados & 100,0 & 0,0 & 100,0 & 100,0 & 0,0 & 100,0 & 98,1 & 1,9 & 100,0 & 99,4 & 0,6 & 100,0 \\
\hline & viúvos & 37,8 & 62,2 & 100,0 & 31,4 & 68,6 & 100,0 & 33,3 & 66,7 & 100,0 & 33,3 & 66,7 & 100,0 \\
\hline & total & 81,9 & 18,1 & 100,0 & 86,2 & 13,8 & 100,0 & 82,7 & 17,3 & 100,0 & 79,5 & 20,5 & 100,0 \\
\hline & Porcentuais segundo condição & & & & & & & & & & & & \\
\hline & solteiros & 10,3 & 23,3 & 12,7 & 16,6 & 22,6 & 17,4 & 15,0 & 18,6 & 15,7 & 17,1 & 17,7 & 17,2 \\
\hline & casados & 79,4 & 0,0 & 65,1 & 77,7 & 0,0 & 67,0 & 77,2 & 7,0 & 65,1 & 72,5 & 1,6 & 57,9 \\
\hline & viúvos & 10,3 & 76,7 & 22,3 & 5,7 & 77,4 & 15,6 & 7,8 & 74,4 & 19,3 & 10,4 & 80,6 & 24,8 \\
\hline & total & 100,0 & 100,0 & 100,0 & 100,0 & 100,0 & 100,0 & 100,0 & 100,0 & 100,0 & 100,0 & 100,0 & 100,0 \\
\hline \multirow{14}{*}{ لֶّ } & Números absolutos & & & & & & & & & & & & \\
\hline & solteiros & 2 & 0 & 2 & 5 & 0 & 5 & 8 & 1 & 9 & 9 & 1 & 10 \\
\hline & casados & 37 & 0 & 37 & 69 & 0 & 69 & 96 & 1 & 97 & 83 & 0 & 83 \\
\hline & viúvos & 5 & 10 & 15 & 6 & 10 & 16 & 3 & 15 & 18 & 1 & 8 & 9 \\
\hline & total & 44 & 10 & 54 & 80 & 10 & 90 & 107 & 17 & 124 & 93 & 9 & 102 \\
\hline & Porcentuais segundo sexo ${ }^{a}$ & & & & & & & & & & & & \\
\hline & solteiros & 100,0 & 0,0 & 100,0 & 100,0 & 0,0 & 100,0 & 88,9 & 11,1 & 100,0 & 90,0 & 10,0 & 100,0 \\
\hline & casados & 100,0 & 0,0 & 100,0 & 100,0 & 0,0 & 100,0 & 99,0 & 1,0 & 100,0 & 100,0 & 0,0 & 100,0 \\
\hline & viúvos & 33,3 & 66,7 & 100,0 & 37,5 & 62,5 & 100,0 & 16,7 & 83,3 & 100,0 & 11,1 & 88,9 & 100,0 \\
\hline & total & 81,5 & 18,5 & 100,0 & 88,9 & 11,1 & 100,0 & 86,3 & 13,7 & 100,0 & 91,2 & 8,8 & 100,0 \\
\hline & $\begin{array}{l}\text { Porcentuais segundo condição } \\
\text { solteiros }\end{array}$ & 4,5 & 0,0 & 3,7 & 6,3 & 0,0 & 5,6 & 7,5 & 5,9 & 7,3 & 9,7 & 11,1 & 9,8 \\
\hline & casados & 84,1 & 0,0 & 68,5 & 86,3 & 0,0 & 76,7 & 89,7 & 5,9 & 78,2 & 89,2 & 0,0 & 81,4 \\
\hline & viúvos & 11,4 & 100,0 & 27,8 & 7,5 & 100,0 & 17,8 & 2,8 & 88,2 & 14,5 & 1,1 & 88,9 & 8,8 \\
\hline & total & 100,0 & 100,0 & 100,0 & 100,0 & 100,0 & 100,0 & 100,0 & 100,0 & 100,0 & 100,0 & 100,0 & 100,0 \\
\hline
\end{tabular}


Distribuição dos proprietários segundo sexo e cor

(Iguape e Xiririca, anos selecionados)

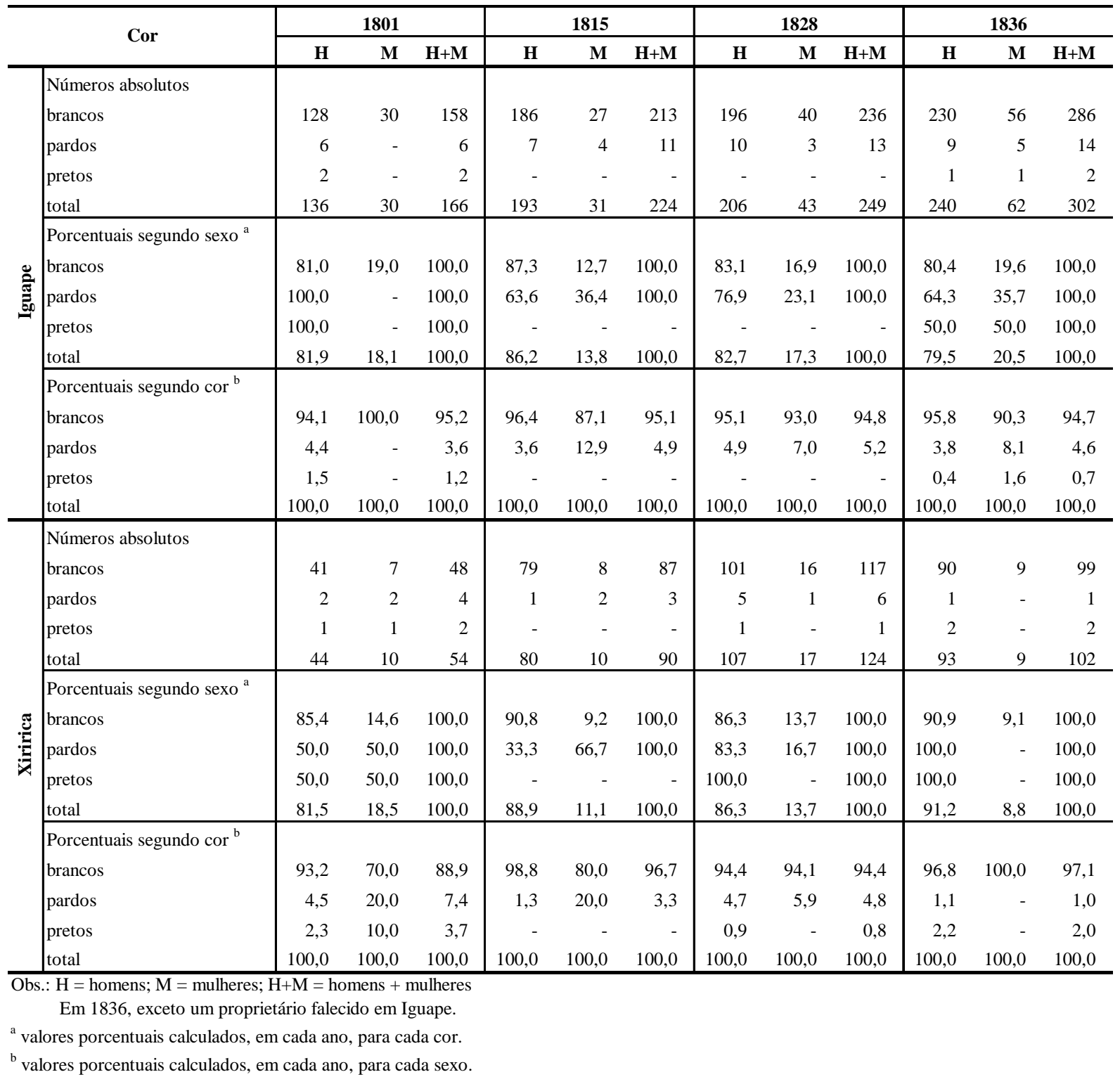


Distribuição dos proprietários segundo sexo e origem

(Iguape e Xiririca, anos selecionados)

\begin{tabular}{|c|c|c|c|c|c|c|c|c|c|c|c|c|c|}
\hline & \multirow{2}{*}{ Origem } & \multicolumn{3}{|c|}{1801} & \multicolumn{3}{|c|}{1815} & \multicolumn{3}{|c|}{1828} & \multicolumn{3}{|c|}{1836} \\
\hline & & $\mathbf{H}$ & $\mathbf{M}$ & $\mathbf{H}+\mathbf{M}$ & $\mathbf{H}$ & $\mathbf{M}$ & $\mathbf{H}+\mathbf{M}$ & $\mathbf{H}$ & M & $\mathbf{H}+\mathbf{M}$ & $\mathbf{H}$ & M & $\mathbf{H}+\mathbf{M}$ \\
\hline \multirow{18}{*}{ 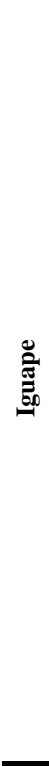 } & Números absolutos & & & & & & & & & & & & \\
\hline & Vale do Ribeira & 92 & 28 & 120 & 123 & 31 & 154 & 139 & 39 & 178 & 185 & 58 & 243 \\
\hline & paulistas & 18 & 1 & 19 & 18 & - & 18 & 20 & 2 & 22 & 16 & 2 & 18 \\
\hline & europeus & 21 & - & 21 & 40 & - & 40 & 40 & - & 40 & 30 & 1 & 31 \\
\hline & outros $^{c}$ & 5 & 1 & 6 & 12 & - & 12 & 7 & 2 & 9 & 9 & 1 & 10 \\
\hline & total & 136 & 30 & 166 & 193 & 31 & 224 & 206 & 43 & 249 & 240 & 62 & 302 \\
\hline & Porcentuais segund & & & & & & & & & & & & \\
\hline & Vale do Ribeira & 76,7 & 23,3 & 100,0 & 79,9 & 20,1 & 100,0 & 78,1 & 21,9 & 100,0 & 76,1 & 23,9 & 100,0 \\
\hline & paulistas & 94,7 & 5,3 & 100,0 & 100,0 & - & 100,0 & 90,9 & 9,1 & 100,0 & 88,9 & 11,1 & 100,0 \\
\hline & europeus & 100,0 & - & 100,0 & 100,0 & - & 100,0 & 100,0 & - & 100,0 & 96,8 & 3,2 & 100,0 \\
\hline & outros & 83,3 & 16,7 & 100,0 & 100,0 & - & 100,0 & 77,8 & 22,2 & 100,0 & 90,0 & 10,0 & 100,0 \\
\hline & total & 81,9 & 18,1 & 100,0 & 86,2 & 13,8 & 100,0 & 82,7 & 17,3 & 100,0 & 79,5 & 20,5 & 100,0 \\
\hline & Porcentuais segund & & & & & & & & & & & & \\
\hline & Vale do Ribeira & 67,7 & 93,4 & 72,3 & 63,8 & 100,0 & 68,8 & 67,5 & 90,6 & 71,5 & 77,0 & 93,6 & 80,4 \\
\hline & paulistas & 13,2 & 3,3 & 11,4 & 9,3 & - & 8,0 & 9,7 & 4,7 & 8,8 & 6,7 & 3,2 & 6,0 \\
\hline & europeus & 15,5 & - & 12,7 & 20,7 & - & 17,9 & 19,4 & - & 16,1 & 12,5 & 1,6 & 10,3 \\
\hline & outros ${ }^{c}$ & 3,6 & 3,3 & 3,6 & 6,2 & - & 5,3 & 3,4 & 4,7 & 3,6 & 3,8 & 1,6 & 3,3 \\
\hline & total & 100,0 & 100,0 & 100,0 & 100,0 & 100,0 & 100,0 & 100,0 & 100,0 & 100,0 & 100,0 & 100,0 & 100,0 \\
\hline \multirow{18}{*}{ : } & Números absolutos & & & & & & & & & & & & \\
\hline & Vale do Ribeira & 36 & 6 & 42 & 69 & 7 & 76 & 91 & 17 & 108 & 89 & 9 & 98 \\
\hline & paulistas & 5 & 2 & 7 & 6 & 3 & 9 & 8 & - & 8 & - & - & - \\
\hline & europeus & 1 & 2 & 3 & 5 & - & 5 & 7 & - & 7 & 2 & - & 2 \\
\hline & outros ${ }^{c}$ & 2 & - & 2 & - & - & - & 1 & - & 1 & 2 & - & 2 \\
\hline & total & 44 & 10 & 54 & 80 & 10 & 90 & 107 & 17 & 124 & 93 & 9 & 102 \\
\hline & Porcentuais segund & & & & & & & & & & & & \\
\hline & Vale do Ribeira & 85,7 & 14,3 & 100,0 & 90,8 & 9,2 & 100,0 & 84,3 & 15,7 & 100,0 & 90,8 & 9,2 & 100,0 \\
\hline & paulistas & 71,4 & 28,6 & 100,0 & 66,7 & 33,3 & 100,0 & 100,0 & - & 100,0 & - & - & \\
\hline & europeus & 33,3 & 66,7 & 100,0 & 100,0 & - & 100,0 & 100,0 & - & 100,0 & 100,0 & - & 100,0 \\
\hline & outros ${ }^{c}$ & 100,0 & - & 100,0 & - & - & - & 100,0 & - & 100,0 & 100,0 & - & 100,0 \\
\hline & total & 81,5 & 18,5 & 100,0 & 88,9 & 11,1 & 100,0 & 86,3 & 13,7 & 100,0 & 91,2 & 8,8 & 100,0 \\
\hline & Porcentuais segund & & & & & & & & & & & & \\
\hline & Vale do Ribeira & 81,8 & 60,0 & 77,7 & 86,2 & 70,0 & 84,4 & 85,0 & 100,0 & 87,1 & 95,7 & 100,0 & 96,0 \\
\hline & paulistas & 11,4 & 20,0 & 13,0 & 7,5 & 30,0 & 10,0 & 7,6 & - & 6,5 & - & - & - \\
\hline & europeus & 2,3 & 20,0 & 5,6 & 6,3 & - & 5,6 & 6,5 & - & 5,6 & 2,2 & - & 2,0 \\
\hline & outros $^{c}$ & 4,5 & - & 3,7 & - & - & - & 0,9 & - & 0,8 & 2,2 & - & 2,0 \\
\hline & total & 100,0 & 100,0 & 100,0 & 100,0 & 100,0 & 100,0 & 100,0 & 100,0 & 100,0 & 100,0 & 100,0 & 100,0 \\
\hline
\end{tabular}

Obs.: $\mathrm{H}=$ homens; $\mathrm{M}=$ mulheres; $\mathrm{H}+\mathrm{M}$ = homens + mulheres

Em 1836, exceto um proprietário falecido em Iguape.

${ }^{a}$ valores porcentuais calculados, em cada ano, para cada cor.

b valores porcentuais calculados, em cada ano, para cada sexo.

${ }^{c}$ outros nacionais e africanos 
Distribuição dos proprietários segundo sexo e faixas etárias

(Iguape e Xiririca, anos selecionados)

\begin{tabular}{|c|c|c|c|c|c|c|c|c|c|c|c|c|c|}
\hline & \multirow{2}{*}{ Faixas etárias } & \multicolumn{3}{|c|}{1801} & \multicolumn{3}{|c|}{1815} & \multicolumn{3}{|c|}{1828} & \multicolumn{3}{|c|}{1836} \\
\hline & & $\mathbf{H}$ & $\mathbf{M}$ & $\mathbf{H}+\mathbf{M}$ & $\mathbf{H}$ & $\mathbf{M}$ & $\mathbf{H}+\mathbf{M}$ & H & $\mathbf{M}$ & $\mathbf{H}+\mathbf{M}$ & H & $\mathbf{M}$ & $\mathbf{H}+\mathbf{M}$ \\
\hline \multirow{22}{*}{ 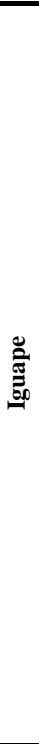 } & $\begin{array}{l}\text { Números absolutos } \\
20-29\end{array}$ & 14 & - & 14 & 12 & 2 & 14 & 16 & 2 & 18 & 21 & 4 & 25 \\
\hline & $30-39$ & 36 & - & 36 & 54 & 3 & 57 & 60 & 7 & 67 & 50 & 9 & 59 \\
\hline & $40-49$ & 32 & 6 & 38 & 56 & 5 & 61 & 48 & 7 & 55 & 73 & 13 & 86 \\
\hline & 50-59 & 20 & 11 & 31 & 38 & 8 & 46 & 45 & 9 & 54 & 48 & 12 & 60 \\
\hline & 60-69 & 25 & 6 & 31 & 17 & 6 & 23 & 25 & 11 & 36 & 36 & 19 & 55 \\
\hline & 70 e mais & 9 & 7 & 16 & 16 & 7 & 23 & 12 & 7 & 19 & 12 & 5 & 17 \\
\hline & total & 136 & 30 & 166 & 193 & 31 & 224 & 206 & 43 & 249 & 240 & 62 & 302 \\
\hline & Porcentuais segundo sexo ${ }^{a}$ & & & & & & & & & & & & \\
\hline & $20-29$ & 100,0 & - & 100,0 & 85,7 & 14,3 & 100,0 & 88,9 & 11,1 & 100,0 & 84,0 & 16,0 & 100,0 \\
\hline & $30-39$ & 100,0 & - & 100,0 & 94,7 & 5,3 & 100,0 & 89,6 & 10,4 & 100,0 & 84,7 & 15,3 & 100,0 \\
\hline & $40-49$ & 84,2 & 15,8 & 100,0 & 91,8 & 8,2 & 100,0 & 87,3 & 12,7 & 100,0 & 84,9 & 15,1 & 100,0 \\
\hline & $50-59$ & 64,5 & 35,5 & 100,0 & 82,6 & 17,4 & 100,0 & 83,3 & 16,7 & 100,0 & 80,0 & 20,0 & 100,0 \\
\hline & 60-69 & 80,6 & 19,4 & 100,0 & 73,9 & 26,1 & 100,0 & 69,4 & 30,6 & 100,0 & 65,5 & 34,5 & 100,0 \\
\hline & 70 e mais & 56,3 & 43,8 & 100,0 & 69,6 & 30,4 & 100,0 & 63,2 & 36,8 & 100,0 & 70,6 & 29,4 & 100,0 \\
\hline & total & 81,9 & 18,1 & 100,0 & 86,2 & 13,8 & 100,0 & 82,7 & 17,3 & 100,0 & 79,5 & 20,5 & 100,0 \\
\hline & $\begin{array}{l}\text { Porcentuais segundo faixas etárias }{ }^{5} \\
20-29\end{array}$ & 10,3 & - & 8,4 & 6,2 & 6,5 & 6,3 & 7,8 & 4,7 & 7,2 & 8,8 & 6,5 & 8,3 \\
\hline & $30-39$ & 26,5 & - & 21,7 & 28,0 & 9,7 & 25,4 & 29,1 & 16,3 & 26,9 & 20,8 & 14,5 & 19,5 \\
\hline & $40-49$ & 23,5 & 20,0 & 22,9 & 29,0 & 16,1 & 27,2 & 23,3 & 16,3 & 22,1 & 30,4 & 21,0 & 28,5 \\
\hline & $50-59$ & 14,7 & 36,7 & 18,7 & 19,7 & 25,8 & 20,5 & 21,8 & 20,9 & 21,7 & 20,0 & 19,4 & 19,9 \\
\hline & $60-69$ & 18,4 & 20,0 & 18,7 & 8,8 & 19,4 & 10,3 & 12,1 & 25,6 & 14,5 & 15,0 & 30,6 & 18,2 \\
\hline & 70 e mais & 6,6 & 23,3 & 9,6 & 8,3 & 22,6 & 10,3 & 5,8 & 16,3 & 7,6 & 5,0 & 8,1 & 5,6 \\
\hline & total & 100,0 & 100,0 & 100,0 & 100,0 & 100,0 & 100,0 & 100,0 & 100,0 & 100,0 & 100,0 & 100,0 & 100,0 \\
\hline \multirow{22}{*}{ 胥 } & $\begin{array}{l}\text { Números absolutos } \\
20-29\end{array}$ & 5 & - & 5 & 14 & - & 14 & 19 & - & 19 & 22 & - & 22 \\
\hline & 30-39 & 11 & - & 11 & 25 & 1 & 26 & 28 & - & 28 & 32 & 1 & 33 \\
\hline & $40-49$ & 11 & 3 & 14 & 14 & 2 & 16 & 24 & 3 & 27 & 13 & 4 & 17 \\
\hline & $50-59$ & 6 & 2 & 8 & 16 & 2 & 18 & 13 & 5 & 18 & 15 & 3 & 18 \\
\hline & $60-69$ & 6 & 3 & 9 & 7 & 4 & 11 & 17 & 4 & 21 & 5 & - & 5 \\
\hline & 70 e mais & 5 & 2 & 7 & 4 & 1 & 5 & 6 & 5 & 11 & 6 & 1 & 7 \\
\hline & total & 44 & 10 & 54 & 80 & 10 & 90 & 107 & 17 & 124 & 93 & 9 & 102 \\
\hline & Porcentuais segundo sexo ${ }^{a}$ & & & & & & & & & & & & \\
\hline & $20-29$ & 100,0 & - & 100,0 & 100,0 & - & 100,0 & 100,0 & - & 100,0 & 100,0 & - & 100,0 \\
\hline & $30-39$ & 100,0 & - & 100,0 & 96,2 & 3,8 & 100,0 & 100,0 & - & 100,0 & 97,0 & 3,0 & 100,0 \\
\hline & $40-49$ & 78,6 & 21,4 & 100,0 & 87,5 & 12,5 & 100,0 & 88,9 & 11,1 & 100,0 & 76,5 & 23,5 & 100,0 \\
\hline & $50-59$ & 75,0 & 25,0 & 100,0 & 88,9 & 11,1 & 100,0 & 72,2 & 27,8 & 100,0 & 83,3 & 16,7 & 100,0 \\
\hline & $60-69$ & 66,7 & 33,3 & 100,0 & 63,6 & 36,4 & 100,0 & 81,0 & 19,0 & 100,0 & 100,0 & - & 100,0 \\
\hline & 70 e mais & 71,4 & 28,6 & 100,0 & 80,0 & 20,0 & 100,0 & 54,5 & 45,5 & 100,0 & 85,7 & 14,3 & 100,0 \\
\hline & total & 81,5 & 18,5 & 100,0 & 88,9 & 11,1 & 100,0 & 86,3 & 13,7 & 100,0 & 91,2 & 8,8 & 100,0 \\
\hline & $\begin{array}{l}\text { Porcentuais segundo faixas etárias }{ }^{D} \\
20-29\end{array}$ & 11,4 & - & 9,3 & 17,5 & - & 15,6 & 17,8 & - & 15,3 & 23,7 & - & 21,6 \\
\hline & 30-39 & 25,0 & - & 20,4 & 31,3 & 10,0 & 28,9 & 26,2 & - & 22,6 & 34,4 & 11,1 & 32,4 \\
\hline & $40-49$ & 25,0 & 30,0 & 25,9 & 17,5 & 20,0 & 17,8 & 22,4 & 17,6 & 21,8 & 14,0 & 44,4 & 16,7 \\
\hline & $50-59$ & 13,6 & 20,0 & 14,8 & 20,0 & 20,0 & 20,0 & 12,1 & 29,4 & 14,5 & 16,1 & 33,3 & 17,6 \\
\hline & $60-69$ & 13,6 & 30,0 & 16,7 & 8,8 & 40,0 & 12,2 & 15,9 & 23,5 & 16,9 & 5,4 & - & 4,9 \\
\hline & 70 e mais & 11,4 & 20,0 & 13,0 & 5,0 & 10,0 & 5,6 & 5,6 & 29,4 & 8,9 & 6,5 & 11,1 & 6,9 \\
\hline & total & 100,0 & 100,0 & 100,0 & 100,0 & 100,0 & 100,0 & 100,0 & 100,0 & 100,0 & 100,0 & 100,0 & 100,0 \\
\hline
\end{tabular}

Em 1836, exceto um proprietário falecido em Iguape.

${ }^{a}$ valores porcentuais calculados, em cada ano, para cada faixa etária.

${ }^{\mathrm{b}}$ valores porcentuais calculados, em cada ano, para cada sexo. 
Distribuição dos escravos segundo sexo e condição conjugal

(Iguape e Xiririca, anos selecionados)

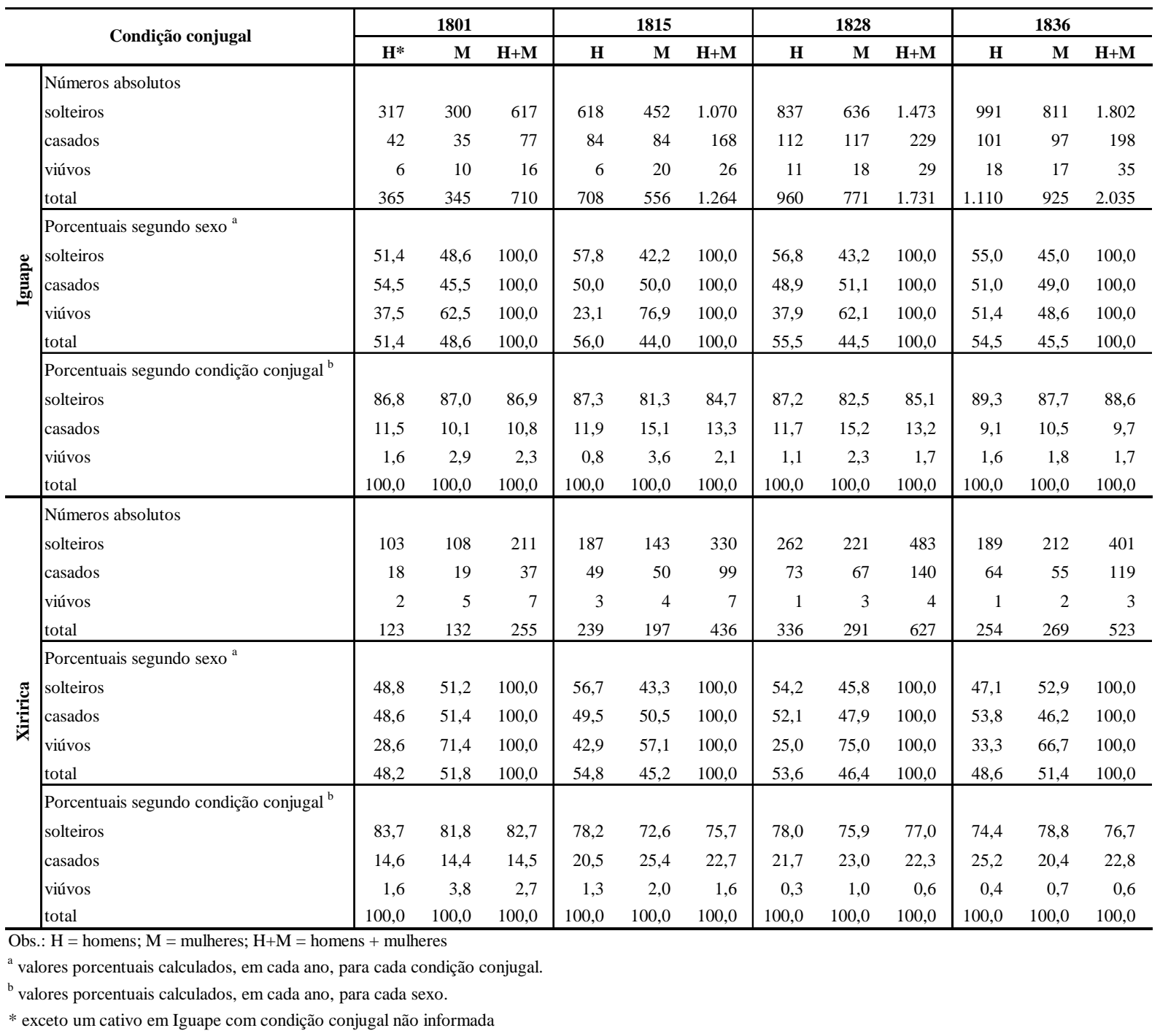


Distribuição dos escravos com 15 anos ou mais segundo sexo e condição conjugal

(Iguape e Xiririca, anos selecionados)

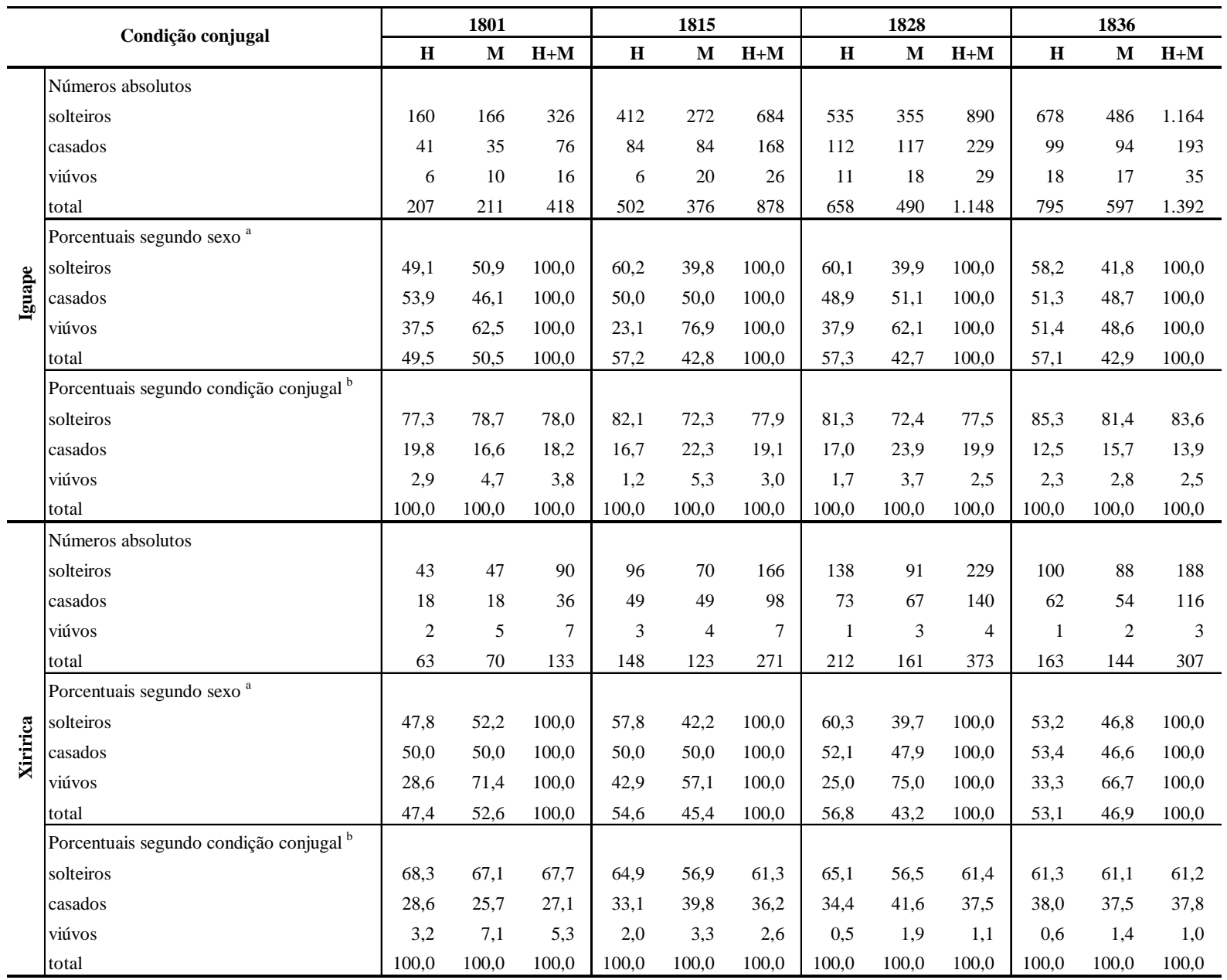

Obs.: $\mathrm{H}$ = homens; $\mathrm{M}$ = mulheres; $\mathrm{H}+\mathrm{M}$ = homens + mulheres

${ }^{\text {a }}$ valores porcentuais calculados, em cada ano, para cada condição conjugal.

${ }^{\mathrm{b}}$ valores porcentuais calculados, em cada ano, para cada sexo. 


\section{Distribuição dos escravos segundo sexo e cor}

(Iguape e Xiririca, anos selecionados)

\begin{tabular}{|c|c|c|c|c|c|c|c|c|c|c|c|c|c|}
\hline & \multirow{2}{*}{ Cor } & \multicolumn{3}{|c|}{1801} & \multicolumn{3}{|c|}{1815} & \multicolumn{3}{|c|}{1828} & \multicolumn{3}{|c|}{1836} \\
\hline & & $\mathbf{H}$ & $\mathbf{M}$ & $\mathbf{H}+\mathbf{M}$ & $\mathbf{H}$ & $\mathbf{M}$ & $\mathbf{H}+\mathbf{M}$ & $\mathbf{H}$ & $\mathbf{M}$ & $\mathbf{H}+\mathbf{M}$ & $\mathbf{H}$ & $\mathbf{M}$ & $\mathbf{H}+\mathbf{M}$ \\
\hline \multirow{12}{*}{$\begin{array}{l}\text { 芯 } \\
\text { 苟 }\end{array}$} & Números absolutos & & & & & & & & & & & & \\
\hline & pardos & 175 & 152 & 327 & 208 & 226 & 434 & 249 & 273 & 522 & 233 & 254 & 487 \\
\hline & pretos & 191 & 193 & 384 & 500 & 330 & 830 & 711 & 498 & 1.209 & 877 & 671 & 1.548 \\
\hline & total & 366 & 345 & 711 & 708 & 556 & 1.264 & 960 & 771 & 1.731 & 1.110 & 925 & 2.035 \\
\hline & Porcentuais segundo sexo ${ }^{a}$ & & & & & & & & & & & & \\
\hline & pardos & 53,5 & 46,5 & 100,0 & 47,9 & 52,1 & 100,0 & 47,7 & 52,3 & 100,0 & 47,8 & 52,2 & 100,0 \\
\hline & pretos & 49,7 & 50,3 & 100,0 & 60,2 & 39,8 & 100,0 & 58,8 & 41,2 & 100,0 & 56,7 & 43,3 & 100,0 \\
\hline & total & 51,5 & 48,5 & 100,0 & 56,0 & 44,0 & 100,0 & 55,5 & 44,5 & 100,0 & 54,5 & 45,5 & 100,0 \\
\hline & Porcentuais segundo cor ${ }^{b}$ & & & & & & & & & & & & \\
\hline & pardos & 47,8 & 44,1 & 46,0 & 29,4 & 40,6 & 34,3 & 25,9 & 35,4 & 30,2 & 21,0 & 27,5 & 23,9 \\
\hline & pretos & 52,2 & 55,9 & 54,0 & 70,6 & 59,4 & 65,7 & 74,1 & 64,6 & 69,8 & 79,0 & 72,5 & 76,1 \\
\hline & total & 100,0 & 100,0 & 100,0 & 100,0 & 100,0 & 100,0 & 100,0 & 100,0 & 100,0 & 100,0 & 100,0 & 100,0 \\
\hline \multirow{12}{*}{ 冚 } & Números absolutos & & & & & & & & & & & & \\
\hline & pardos & 54 & 66 & 120 & 81 & 68 & 149 & 46 & 68 & 114 & 26 & 44 & 70 \\
\hline & pretos & 69 & 66 & 135 & 158 & 129 & 287 & 290 & 223 & 513 & 228 & 225 & 453 \\
\hline & total & 123 & 132 & 255 & 239 & 197 & 436 & 336 & 291 & 627 & 254 & 269 & 523 \\
\hline & Porcentuais segundo sexo ${ }^{a}$ & & & & & & & & & & & & \\
\hline & pardos & 45,0 & 55,0 & 100,0 & 54,4 & 45,6 & 100,0 & 40,4 & 59,6 & 100,0 & 37,1 & 62,9 & 100,0 \\
\hline & pretos & 51,1 & 48,9 & 100,0 & 55,1 & 44,9 & 100,0 & 56,5 & 43,5 & 100,0 & 50,3 & 49,7 & 100,0 \\
\hline & total & 48,2 & 51,8 & 100,0 & 54,8 & 45,2 & 100,0 & 53,6 & 46,4 & 100,0 & 48,6 & 51,4 & 100,0 \\
\hline & Porcentuais segundo cor ${ }^{b}$ & & & & & & & & & & & & \\
\hline & pardos & 43,9 & 50,0 & 47,1 & 33,9 & 34,5 & 34,2 & 13,7 & 23,4 & 18,2 & 10,2 & 16,4 & 13,4 \\
\hline & pretos & 56,1 & 50,0 & 52,9 & 66,1 & 65,5 & 65,8 & 86,3 & 76,6 & 81,8 & 89,8 & 83,6 & 86,6 \\
\hline & total & 100,0 & 100,0 & 100,0 & 100,0 & 100,0 & 100,0 & 100,0 & 100,0 & 100,0 & 100,0 & 100,0 & 100,0 \\
\hline
\end{tabular}

Obs.: $\mathrm{H}$ = homens; $\mathrm{M}=$ mulheres; $\mathrm{H}+\mathrm{M}$ = homens + mulheres

${ }^{a}$ valores porcentuais calculados, em cada ano, para cada cor.

b valores porcentuais calculados, em cada ano, para cada sexo. 
Distribuição dos escravos segundo sexo e origem

(Iguape e Xiririca, anos selecionados)

\begin{tabular}{|c|c|c|c|c|c|c|c|c|c|c|c|c|c|}
\hline & \multirow{2}{*}{ Origem } & \multicolumn{3}{|c|}{1801} & \multicolumn{3}{|c|}{1815} & \multicolumn{3}{|c|}{1828} & \multicolumn{3}{|c|}{1836} \\
\hline & & $\mathbf{H}$ & $\mathbf{M}$ & $\mathbf{H}+\mathbf{M}$ & $\mathbf{H}$ & $\mathbf{M}$ & $\mathbf{H}+\mathbf{M}$ & $\mathbf{H}$ & $\mathbf{M}$ & $\mathbf{H}+\mathbf{M}$ & $\mathbf{H}$ & M & $\mathbf{H}+\mathbf{M}$ \\
\hline \multirow{18}{*}{ 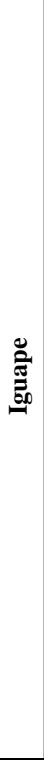 } & Números absolutos & & & & & & & & & & & & \\
\hline & Vale do Ribeira & 322 & 305 & 627 & 416 & 435 & 851 & 647 & 614 & 1.261 & 647 & 690 & 1.337 \\
\hline & paulistas & 6 & 12 & 18 & 17 & 11 & 28 & 16 & 13 & 29 & 13 & 12 & 25 \\
\hline & africanos & 34 & 26 & 60 & 271 & 107 & 378 & 286 & 131 & 417 & 428 & 207 & 635 \\
\hline & outros $^{c}$ & 4 & 2 & 6 & 4 & 3 & 7 & 11 & 13 & 24 & 22 & 16 & 38 \\
\hline & total & 366 & 345 & 711 & 708 & 556 & 1.264 & 960 & 771 & 1.731 & 1.110 & 925 & 2.035 \\
\hline & Porcentuais segunc & & & & & & & & & & & & \\
\hline & Vale do Ribeira & 51,4 & 48,6 & 100,0 & 48,9 & 51,1 & 100,0 & 51,3 & 48,7 & 100,0 & 48,4 & 51,6 & 100,0 \\
\hline & paulistas & 33,3 & 66,7 & 100,0 & 60,7 & 39,3 & 100,0 & 55,2 & 44,8 & 100,0 & 52,0 & 48,0 & 100,0 \\
\hline & aficanos & 56,7 & 43,3 & 100,0 & 71,7 & 28,3 & 100,0 & 68,6 & 31,4 & 100,0 & 67,4 & 32,6 & 100,0 \\
\hline & outros & 66,7 & 33,3 & 100,0 & 57,1 & 42,9 & 100,0 & 45,8 & 54,2 & 100,0 & 57,9 & 42,1 & 100,0 \\
\hline & total & 51,5 & 48,5 & 100,0 & 56,0 & 44,0 & 100,0 & 55,5 & 44,5 & 100,0 & 54,5 & 45,5 & 100,0 \\
\hline & Porcentuais segunc & & & & & & & & & & & & \\
\hline & Vale do Ribeira & 88,0 & 88,4 & 88,2 & 58,8 & 78,2 & 67,3 & 67,4 & 79,6 & 72,8 & 58,3 & 74,6 & 65,7 \\
\hline & paulistas & 1,6 & 3,5 & 2,5 & 2,4 & 2,0 & 2,2 & 1,7 & 1,7 & 1,7 & 1,2 & 1,3 & 1,2 \\
\hline & africanos & 9,3 & 7,5 & 8,4 & 38,3 & 19,2 & 29,9 & 29,8 & 17,0 & 24,1 & 38,6 & 22,4 & 31,2 \\
\hline & outros $^{c}$ & 1,1 & 0,6 & 0,8 & 0,6 & 0,5 & 0,6 & 1,1 & 1,7 & 1,4 & 2,0 & 1,7 & 1,9 \\
\hline & total & 100,0 & 100,0 & 100,0 & 100,0 & 100,0 & 100,0 & 100,0 & 100,0 & 100,0 & 100,0 & 100,0 & 100,0 \\
\hline \multirow{18}{*}{ : } & Números absolutos & & & & & & & & & & & & \\
\hline & Vale do Ribeira & 103 & 118 & 221 & 150 & 139 & 289 & 217 & 235 & 452 & 187 & 227 & 414 \\
\hline & paulistas & 5 & 4 & 9 & 13 & 7 & 20 & 6 & 3 & 9 & 1 & - & 1 \\
\hline & africanos & 13 & 10 & 23 & 76 & 50 & 126 & 113 & 53 & 166 & 66 & 42 & 108 \\
\hline & outros $^{c}$ & 2 & - & 2 & - & 1 & 1 & - & - & - & - & - & - \\
\hline & total & 123 & 132 & 255 & 239 & 197 & 436 & 336 & 291 & 627 & 254 & 259 & 523 \\
\hline & Porcentuais segunc & & & & & & & & & & & & \\
\hline & Vale do Ribeira & 46,6 & 53,4 & 100,0 & 51,9 & 48,1 & 100,0 & 48,0 & 52,0 & 100,0 & 45,2 & 54,8 & 100,0 \\
\hline & paulistas & 55,6 & 44,4 & 100,0 & 65,0 & 35,0 & 100,0 & 66,7 & 33,3 & 100,0 & 100,0 & - & 100,0 \\
\hline & africanos & 56,5 & 43,5 & 100,0 & 60,3 & 39,7 & 100,0 & 68,1 & 31,9 & 100,0 & 61,1 & 38,9 & 100,0 \\
\hline & outros ${ }^{c}$ & 100,0 & - & 100,0 & - & 100,0 & 100,0 & - & - & - & - & - & - \\
\hline & total & 48,2 & 51,8 & 100,0 & 54,8 & 45,2 & 100,0 & 53,6 & 46,4 & 100,0 & 48,6 & 49,5 & 100,0 \\
\hline & Porcentuais segunc & & & & & & & & & & & & \\
\hline & Vale do Ribeira & 83,7 & 89,4 & 86,7 & 62,8 & 70,6 & 66,3 & 64,6 & 80,8 & 72,1 & 73,6 & 87,6 & 79,2 \\
\hline & paulistas & 4,1 & 3,0 & 3,5 & 5,4 & 3,6 & 4,6 & 1,8 & 1,0 & 1,4 & 0,4 & - & 0,2 \\
\hline & africanos & 10,6 & 7,6 & 9,0 & 31,8 & 25,4 & 28,9 & 33,6 & 18,2 & 26,5 & 26,0 & 16,2 & 20,7 \\
\hline & outros $^{c}$ & 1,6 & - & 0,8 & - & 0,5 & 0,2 & - & - & - & - & - & - \\
\hline & total & 100,0 & 100,0 & 100,0 & 100,0 & 100,0 & 100,0 & 100,0 & 100,0 & 100,0 & 100,0 & 100,0 & 100,0 \\
\hline
\end{tabular}

Obs.: $\mathrm{H}=$ homens; $\mathrm{M}=$ mulheres; $\mathrm{H}+\mathrm{M}=$ homens + mulheres

${ }^{a}$ valores porcentuais calculados, em cada ano, para cada cor.

${ }^{\mathrm{b}}$ valores porcentuais calculados, em cada ano, para cada sexo.

c outros nacionais e sem informação 
Distribuição dos escravos segundo sexo e faixas etárias

(Iguape e Xiririca, anos selecionados)

\begin{tabular}{|c|c|c|c|c|c|c|c|c|c|c|c|c|c|}
\hline & \multirow{2}{*}{ Faixas etárias } & \multicolumn{3}{|c|}{1801} & \multicolumn{3}{|c|}{1815} & \multicolumn{3}{|c|}{1828} & \multicolumn{3}{|c|}{1836} \\
\hline & & $\mathbf{H}^{*}$ & $\mathbf{M}$ & $\mathbf{H}+\mathbf{M}$ & $\mathbf{H}$ & $\mathbf{M}$ & $\mathbf{H}+\mathbf{M}$ & $\mathbf{H}$ & $\mathbf{M}$ & $\mathbf{H}+\mathbf{M}$ & $\mathbf{H}$ & $\mathbf{M}$ & $\mathbf{H}+\mathbf{M}$ \\
\hline \multirow{29}{*}{ 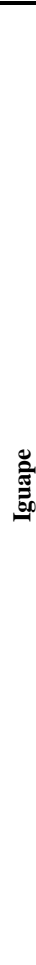 } & Números absolutos & & & & & & & & & & & & \\
\hline & $0-9$ & 115 & 96 & 211 & 135 & 125 & 260 & 204 & 194 & 398 & 206 & 230 & 436 \\
\hline & $10-19$ & 91 & 79 & 170 & 160 & 123 & 283 & 184 & 173 & 357 & 201 & 202 & 403 \\
\hline & $20-29$ & 56 & 70 & 126 & 227 & 154 & 381 & 233 & 163 & 396 & 254 & 194 & 448 \\
\hline & 30-39 & 32 & 37 & 69 & 108 & 75 & 183 & 208 & 136 & 344 & 221 & 146 & 367 \\
\hline & $40-49$ & 21 & 29 & 50 & 43 & 41 & 84 & 77 & 60 & 137 & 126 & 90 & 216 \\
\hline & 50-59 & 29 & 22 & 51 & 19 & 17 & 36 & 35 & 28 & 63 & 60 & 27 & 87 \\
\hline & $60-69$ & 11 & 9 & 20 & 11 & 14 & 25 & 13 & 13 & 26 & 37 & 27 & 64 \\
\hline & 70 e mais & 10 & 3 & 13 & 5 & 7 & 12 & 6 & 4 & 10 & 5 & 9 & 14 \\
\hline & total & 365 & 345 & 710 & 708 & 556 & 1264 & 960 & 771 & 1731 & 1110 & 925 & 2035 \\
\hline & Porcentuais segundo sexo ${ }^{a}$ & & & & & & & & & & & & \\
\hline & $0-9$ & 54,5 & 45,5 & 100,0 & 51,9 & 48,1 & 100,0 & 51,3 & 48,7 & 100,0 & 47,2 & 52,8 & 100,0 \\
\hline & $10-19$ & 53,5 & 46,5 & 100,0 & 56,5 & 43,5 & 100,0 & 51,5 & 48,5 & 100,0 & 49,9 & 50,1 & 100,0 \\
\hline & $20-29$ & 44,4 & 55,6 & 100,0 & 59,6 & 40,4 & 100,0 & 58,8 & 41,2 & 100,0 & 56,7 & 43,3 & 100,0 \\
\hline & $30-39$ & 46,4 & 53,6 & 100,0 & 59,0 & 41,0 & 100,0 & 60,5 & 39,5 & 100,0 & 60,2 & 39,8 & 100,0 \\
\hline & $40-49$ & 42,0 & 58,0 & 100,0 & 51,2 & 48,8 & 100,0 & 56,2 & 43,8 & 100,0 & 58,3 & 41,7 & 100,0 \\
\hline & $50-59$ & 56,9 & 43,1 & 100,0 & 52,8 & 47,2 & 100,0 & 55,6 & 44,4 & 100,0 & 69,0 & 31,0 & 100,0 \\
\hline & $60-69$ & 55,0 & 45,0 & 100,0 & 44,0 & 56,0 & 100,0 & 50,0 & 50,0 & 100,0 & 57,8 & 42,2 & 100,0 \\
\hline & 70 e mais & 76,9 & 23,1 & 100,0 & 41,7 & 58,3 & 100,0 & 60,0 & 40,0 & 100,0 & 35,7 & 64,3 & 100,0 \\
\hline & total & 51,4 & 48,6 & 100,0 & 56,0 & 44,0 & 100,0 & 55,5 & 44,5 & 100,0 & 54,5 & 45,5 & 100,0 \\
\hline & $\begin{array}{l}\text { Porcentuais segundo faixas etárias }{ }^{\mathrm{b}} \\
0-9\end{array}$ & 31,5 & 27,8 & 29,7 & 19,1 & 22,5 & 20,6 & 21,3 & 25,2 & 23,0 & 18,6 & 24,9 & 21,4 \\
\hline & $10-19$ & 24,9 & 22,9 & 23,9 & 22,6 & 22,1 & 22,4 & 19,2 & 22,4 & 20,6 & 18,1 & 21,8 & 19,8 \\
\hline & $20-29$ & 15,3 & 20,3 & 17,7 & 32,1 & 27,7 & 30,1 & 24,3 & 21,1 & 22,9 & 22,9 & 21,0 & 22,0 \\
\hline & 30-39 & 8,8 & 10,7 & 9,7 & 15,3 & 13,5 & 14,5 & 21,7 & 17,6 & 19,9 & 19,9 & 15,8 & 18,0 \\
\hline & $40-49$ & 5,8 & 8,4 & 7,0 & 6,1 & 7,4 & 6,6 & 8,0 & 7,8 & 7,9 & 11,4 & 9,7 & 10,6 \\
\hline & $50-59$ & 7,9 & 6,4 & 7,2 & 2,7 & 3,1 & 2,8 & 3,6 & 3,6 & 3,6 & 5,4 & 2,9 & 4,3 \\
\hline & 60-69 & 3,0 & 2,6 & 2,8 & 1,6 & 2,5 & 2,0 & 1,4 & 1,7 & 1,5 & 3,3 & 2,9 & 3,1 \\
\hline & 70 e mais & 2,7 & 0,9 & 1,8 & 0,7 & 1,3 & 0,9 & 0,6 & 0,5 & 0,6 & 0,5 & 1,0 & 0,7 \\
\hline & total & 100,0 & 100,0 & 100,0 & 100,0 & 100,0 & 100,0 & 100,0 & 100,0 & 100,0 & 100,0 & 100,0 & 100,0 \\
\hline \multirow{29}{*}{ : } & Números absolutos & & & & & & & & & & & & \\
\hline & $0-9$ & 47 & 50 & 97 & 65 & 53 & 118 & 79 & 103 & 182 & 59 & 87 & 146 \\
\hline & $10-19$ & 27 & 30 & 57 & 65 & 55 & 120 & 90 & 64 & 154 & 58 & 67 & 125 \\
\hline & $20-29$ & 14 & 23 & 37 & 64 & 54 & 118 & 73 & 52 & 125 & 59 & 57 & 116 \\
\hline & $30-39$ & 13 & 16 & 29 & 24 & 24 & 48 & 49 & 42 & 91 & 42 & 35 & 77 \\
\hline & $40-49$ & 4 & 4 & 8 & 7 & 4 & 11 & 26 & 18 & 44 & 27 & 13 & 40 \\
\hline & $50-59$ & 9 & 5 & 14 & 9 & 2 & 11 & 11 & 11 & 22 & 3 & 6 & 9 \\
\hline & $60-69$ & 6 & 3 & 9 & 3 & 2 & 5 & 7 & 1 & 8 & 3 & 3 & 6 \\
\hline & 70 e mais & 2 & 1 & 3 & 2 & 3 & 5 & 1 & 0 & 1 & 3 & 1 & 4 \\
\hline & total & 122 & 132 & 254 & 239 & 197 & 436 & 336 & 291 & 627 & 254 & 269 & 523 \\
\hline & Porcentuais segundo sexo ${ }^{a}$ & & & & & & & & & & & & \\
\hline & $0-9$ & 48,5 & 51,5 & 100,0 & 55,1 & 44,9 & 100,0 & 43,4 & 56,6 & 100,0 & 40,4 & 59,6 & 100,0 \\
\hline & $10-19$ & 47,4 & 52,6 & 100,0 & 54,2 & 45,8 & 100,0 & 58,4 & 41,6 & 100,0 & 46,4 & 53,6 & 100,0 \\
\hline & $20-29$ & 37,8 & 62,2 & 100,0 & 54,2 & 45,8 & 100,0 & 58,4 & 41,6 & 100,0 & 50,9 & 49,1 & 100,0 \\
\hline & $30-39$ & 44,8 & 55,2 & 100,0 & 50,0 & 50,0 & 100,0 & 53,8 & 46,2 & 100,0 & 54,5 & 45,5 & 100,0 \\
\hline & $40-49$ & 50,0 & 50,0 & 100,0 & 63,6 & 36,4 & 100,0 & 59,1 & 40,9 & 100,0 & 67,5 & 32,5 & 100,0 \\
\hline & $50-59$ & 64,3 & 35,7 & 100,0 & 81,8 & 18,2 & 100,0 & 50,0 & 50,0 & 100,0 & 33,3 & 66,7 & 100,0 \\
\hline & $60-69$ & 66,7 & 33,3 & 100,0 & 60,0 & 40,0 & 100,0 & 87,5 & 12,5 & 100,0 & 50,0 & 50,0 & 100,0 \\
\hline & 70 e mais & 66,7 & 33,3 & 100,0 & 40,0 & 60,0 & 100,0 & 100,0 & 0,0 & 100,0 & 75,0 & 25,0 & 100,0 \\
\hline & total & 48,0 & 52,0 & 100,0 & 54,8 & 45,2 & 100,0 & 53,6 & 46,4 & 100,0 & 48,6 & 51,4 & 100,0 \\
\hline & $\begin{array}{l}\text { Porcentuais segundo faixas etárias }{ }^{b} \\
0-9\end{array}$ & 38,5 & 37,9 & 38,2 & 27,2 & 26,9 & 27,1 & 23,5 & 35,4 & 29,0 & 23,2 & 32,3 & 27,9 \\
\hline & $10-19$ & 22,1 & 22,7 & 22,4 & 27,2 & 27,9 & 27,5 & 26,8 & 22,0 & 24,6 & 22,8 & 24,9 & 23,9 \\
\hline & $20-29$ & 11,5 & 17,4 & 14,6 & 26,8 & 27,4 & 27,1 & 21,7 & 17,9 & 19,9 & 23,2 & 21,2 & 22,2 \\
\hline & 30-39 & 10,7 & 12,1 & 11,4 & 10,0 & 12,2 & 11,0 & 14,6 & 14,4 & 14,5 & 16,5 & 13,0 & 14,7 \\
\hline & $40-49$ & 3,3 & 3,0 & 3,1 & 2,9 & 2,0 & 2,5 & 7,7 & 6,2 & 7,0 & 10,6 & 4,8 & 7,6 \\
\hline & 50-59 & 7,4 & 3,8 & 5,5 & 3,8 & 1,0 & 2,5 & 3,3 & 3,8 & 3,5 & 1,2 & 2,2 & 1,7 \\
\hline & $60-69$ & 4,9 & 2,3 & 3,5 & 1,3 & 1,0 & 1,1 & 2,1 & 0,3 & 1,3 & 1,2 & 1,1 & 1,1 \\
\hline & 70 e mais & 1,6 & 0,8 & 1,2 & 0,8 & 1,5 & 1,1 & 0,3 & 0,0 & 0,2 & 1,2 & 0,4 & 0,8 \\
\hline & total & 100,0 & 100,0 & 100,0 & 100,0 & 100,0 & 100,0 & 100,0 & 100,0 & 100,0 & 100,0 & 100,0 & 100,0 \\
\hline
\end{tabular}


Relação dos inventários consultados 
LOCAL ANO INVENTARIADO

Iguape 1800 SILVESTRE GOMES BALEIA

Iguape 1800 FRANCISCO DE OLIVEIRA GUIMARÃES

Iguape 1800 SEBASTIÃO GONÇALVES MEXIDO

Iguape 1800 MARIA DA SILVA

Iguape 1802 JOSEFA DOMINGUES RIBEIRA

Iguape 1805 JOSÉ CORREA DE MEIRA

Iguape 1805 JOAQUIM ANTONIO DA SILVA

Iguape 1805 DOMINGAS MARIA

Iguape 1806 LOURENÇO LOPES TRIGO

Iguape 1807 EZEQUIEL GOMES PEREIRA

Iguape 1807 MARIA ANTUNES DE ARAUJO

Iguape 1807 MARIA DE SANTO ANTONIO

Iguape 1807 JOAQUIM MUNIZ

Iguape 1808 JULIA PEREIRA

Iguape 1808 MANOEL RIBEIRO

Iguape 1809 FRANCISCO PEDRO

Iguape 1809 VALERIO ANTONIO DE MELLO

Iguape 1809 INACIO JOSÉ PUPO

Iguape 1810 MARIA DA PAIXÃO

Iguape 1811 FRANCISCA DE PAULA

Iguape 1812 FERNANDO JOSÉ DE MORAES

Iguape 1813 FRANCISCO JOSÉ TAVARES

Iguape 1814 FRANCISCA DE PAULA

Iguape 1814 ESCOLÁSTICA MARIA DE MOURA

Iguape 1815 NICACIO PEREIRA DO VALE

Iguape 1816 ROSA ALVES DE ALEXANDRINA

Iguape 1816 ANTONIO FERNANDES VERAS

Iguape 1816 ANA JOAQUINA

Iguape 1819 MARIA PULICENA

Iguape 1821 MANOEL COELHO DA SILVA

Iguape 1822 MARIA DIAS DE ASSUNÇÃO

Iguape 1822 JOAQUIM PEREIRA DO CANTO

Iguape 1823 JACINTA PEDROSA DE MORAES

Iguape 1823 ESCOLASTICA GONÇALVES DOS REIS

Iguape 1824 ISIDORO NICOLAU DE BRITO

Iguape 1824 NARCISA DIAS BAPTISTA

Iguape 1824 TOME DE SOUZA VILAS BOAS

Iguape 1824 ANA PINTA DE FARIA

Iguape 1826 GREGORIO MARTINS

Iguape 1827 FRANCISCO ANTONIO PENICHE

Iguape 1827 AGOSTINHO ROBERTO COELHO

Iguape 1828 JOÃO PINTO DE FARIA

Iguape 1828 FRANCISCO LUIS PEREIRA

Iguape 1828 DOMINGOS JOSÉ DE SOUZA

Iguape 1828 FRANCISCO DUARTE DE CASTRO

Iguape 1828 LUIZA ANTONIA

Iguape 1828 MARIA ROSA DA TRINDADE

Iguape 1828 VALÉRIO ANTUNES DA SILVA

Iguape 1828 JOÃO GOMES BALEIA

Iguape 1829 ANTONIO JOSÉ ALVES DE CARVALHO

Iguape 1829 MANOEL RODRIGUES CUNHA

Iguape 1830 BENTO JOSÉ DA COSTA

Iguape 1830 BARTOLOMEU DA COSTA ALMEIDA E CRUZ

Iguape 1830 ANA MARIA

Iguape 1831 ANTONIO NUNES

Iguape 1831 ROSA LIA

Iguape 1831 JOÃO VIEIRA DE SÁ

Iguape 1832 GERTRUDES MARIA

Iguape 1832 ANA MARIA RODRIGUES

Iguape 1833 BENTO PUPO DE GOUVEIA

Iguape 1834 DOMINGOS RODRIGUES DE MORAES

Iguape 1834 AMBROSIO JOSÉ DA CONCEIÇÃO

Iguape 1835 JOANA RITA DO ESPIRITO SANTO

Iguape 1835 CLARA FRANCA DE OLIVEIRA

Iguape 1835 MARIA AMALIA

Iguape 1835 JOAQUIM MAXIMIANO DA TRINDADE

Iguape 1835 MANOEL JOÃO DE CARVALHO

Iguape 1835 ANA LUIZA PENICHE

Iguape 1835 ANA JOSEFA MARTINS

Iguape 1835 FLORIDO JOSÉ DE MORAES

Iguape 1836 RAFAEL GOMES MALTA CARNEIRO

Iguape 1836 AGOSTINHO LOURENÇO DA SILVA DORIA

Iguape 1836 DOMINGOS VICENTE PEREIRA

Iguape 1836 JOANA DA SILVA
INVENTARIANTE

MARIA DIAS DOS SANTOS

INÁCIO DE OLIVEIRA GUIMARÃES

MANOEL GONÇALVES MEXIDO

SALVADOR AFONSO DA COSTA

VITORIO DE VERAS

JOSÉ CORREA DE AZEVEDO

ANA RODRIGUES DA CUNHA

INÁCIO JOSÉ LISBOA

ESCOLASTICA GONÇALVES PEREIRA

GRETRUDES MARIA

DOMINGOS RIBEIRO

MIGUEL GONÇALVES DOS REIS

INACIA DE OLIVEIRA

PEDRO NUNES DE SOUZA

ANA FRANÇA

ROSA MARIA FRANÇA

ANTONIA MARIA DE ALMEIDA

BARTOLOMEU DA COSTA ALMEIDA CRUZ

RAIMUNDO PINTO DE ALMEIDA

MANOEL ANTONIO FERREIRA

ESCOLÁSTICA MARIA DE MOURA

PAULA LUIZA DE TOLEDO

JOAQUIM JOSÉ DA LUZ

FRANCISCO GOMES DE MORAES

LEOCADIA PEREIRA VERAS

JOAQUIM PUPO DA ROCHA

INÁCIA MARIA

JOSÉ MIGUEL

JOSÉ DE MATOS

CATARINA RODRIGUES

BENTO DE OLIVEIRA

FRANCISCA DAS CHAGAS ALVIM

BRAS DA CUNHA RAMOS

JOSÉ LOPES TRIGO

FRANCISCO MANOEL DE ALVARENGA

JOAQUIM ANTONIO GOMES

MARIA DE JESUS SOZA

MANOEL PINTO DA CUNHA

ISABEL MARIA DE SOUZA

MARGARIDA DAS GRAÇAS

URSULA MORATA

ANA RODRIGUES

FRANCISCA LUIZA DE PAULA

GERTRUDES MARIA DO ESPIRITO SANTO

FRANCISCO DE CASTRO GUIMARÃES

FRANCISCO MANOEL DE PAULA

ANTONIO PUPO DA ROCHA

JOSÉ DE SOUZA DA ASSUNÇÃO

FRANCISCO GOMES BALEIA

TEODORO GONÇALVES DA SILVA

GERTRUDES MARIA DO ESPIRITO SANTO

INACIA DOMINGUES MUNIZ

FRANCISCA XAVIER DE PAULA ALMEIDA E CRUZ

JOSÉ DE SOUZA ASSUNÇÃO

JOANA DA SILVA

JOSÉ PINTO PEREIRA

JOSÉ BONIFÁCIO DE ANDRADA

CANDIDO JOSÉ GOMES

JOSÉ DE PONTES MACIEL

JOAQUINA MARIA DE JESUS

RITA FAUSTINA DE ALMEIDA

ISABEL MARIA BATISTA

MANOEL JOSÉ DE FARIA

MANOEL FRANCO DE OLIVEIRA

BERNARDO PINTO DE ALMEIDA

JOSÉ BONIFACIO DE ANDRADA

FRANCISCA DOMINGUES

FILADELFO DE SOUZA CASTRO

FRANCISCO DE SOUZA CASTRO

MARIA DAS DORES BRUNA

JOANA AMALIA MALTA CARNEIRO

BERNARDO ANTONIO NEVES

GERTRUDES MARIA LUIZA

MARCELINO JOSÉ
LOCALIZAÇÃO

MHAI, c. 45

MHAI, c. 35

MHAI, c. 149

MHAI, c. 4

MHAI, c. 162

MHAI, c. 73

MHAI, c. 149

MHAI, c. 4

MHAI, c. 50

MHAI, c. 105

MHAI, c. 56

MHAI, c. 149

MHAI, c. 171

MHAI, c. 35

MHAI, c. 149

MHAI, c. 223

MHAI, c. 149

MHAI, c. 4

MHAI, c. 38

MHAI, c. 12

MHAI, c. 195

MHAI, c. 111

MHAI, c. 149

MHAI, c. 196

MHAI, c. 117

MHAI, c. 38

MHAI, c. 38

MHAI, c. 66

MHAI, c. 12

MHAI, c. 172

MHAI, c. 5

MHAI, c. 37

MHAI, c. 33

MHAI, c. 150

MHAI, c. 5

MHAI, c. 99

MHAI, c. 162

MHAI, c. 107

MHAI, c. 12

MHAI, c. 196

MHAI, c. 104

MHAI, c. 177

MHAI, c. 54

MHAI, c. 35

MHAI, c. 35

MHAI, c. 35

MHAI, c. 35

MHAI, c. 35

MHAI, c. 145

MHAI, c. 12

MHAI, c. 66

MHAI, c. 34

MHAI, c. 5

MHAI, c. 218

MHAI, c. 150

MHAI, c. 4

MHAI, c. 141

MHAI, c. 149

MHAI, c. 37

MHAI, c. 34

MHAI, c. 4

MHAI, c. 46

MHAI, c. 62

MHAI, c. 151

MHAI, c. 139

MHAI, c. 141

MHAI, c. 111

MHAI, c. 37

MHAI, c. 110

MHAI, c. 131

MHAI, c. 5

MHAI, c. 117

MHAI, c. 117 
Iguape 1836 JOAQUINA MARIA DE JESUS

Iguape 1836 ANTONIO FERNANDES DE QUEVEDO

Iguape 1836 MARIA DE FREITAS

Iguape 1837 ANTONIO LUIS DE MORAES

Iguape 1837 MARIANO RODRIGUES CUNHA

Iguape 1837 JOÃO ANTONIO DA COSTA MENDONÇA

Iguape 1837 FRANCISCO ANTONIO PENICHE

Iguape 1837 CATARINA RODRIGUES

Iguape 1837 BERNARDINA MARIA DA CONCEIÇÃO

Iguape 1837 JOSÉ ANTONIO PENICHE

Iguape 1837 FRANCISCO XAVIER DA SILVA

Iguape 1837 ISABEL MARIA DE SOUZA

Iguape 1838 ESCOLASTICA LUIZA DA SILVA

Iguape 1838 JOÃO DA SILVA PEREIRA

Iguape 1838 ESCOLÁSTICA MARIA DAS DORES

Iguape 1838 JOAQUIM RODRIGUES DA SILVA

Iguape 1838 MARIA RODRIGUES VIANNA

Iguape 1838 RITA DE SOUZA

Iguape 1838 ROSA MARIA

Iguape 1838 BENTO TOMAS MARTINS

Iguape 1838 EUSEBIO DA CUNHA PAIVA

Iguape 1838 MANOEL ALVES CARNEIRO

Iguape 1838 MARIA JOAQUINA CARNEIRO

Iguape 1839 TOBIAS ANTONIO DA COSTA

Iguape 1839 LUIS FRANCISCO DE PAULA

Iguape 1839 RITA JOAQUINA JUNQUEIRA

Iguape 1840 ANA TEREZA

Iguape 1840 JOSÉ LOPES TRIGO

Iguape 1840 FELICIANO JOSÉ NEVES

Iguape 1840 JOÃO JOSÉ DE CARVALHO SIMÕES

Iguape 1840 INACIO ANTONIO DE SOUZA COUTINHO

Iguape 1840 ANTONIA MARIA DA COSTA

Iguape 1840 ANTONIO RODRIGUES PEREIRA

Iguape 1840 JEREMIAS PEREIRA DA SILVA

Iguape 1840 MANOEL RODRIGUES DO ROSARIO

Iguape 1841 FRANCISCO DE CASTRO GUIMARÃES

Iguape 1841 JOAQUIM JOSÉ COELHO

Iguape 1841 MANOEL JOSÉ GONÇALVES

Iguape 1841 ANTONIO CARLOS DE TOLEDO

Iguape 1841 ANTONIO FRANCISCO XAVIER

Iguape 1841 JOSÉ JACINTO PENICHE

Iguape 1842 ROSA MARIA DE SÁ

Iguape 1842 FLORINDA RIBEIRA

Iguape 1842 ANGELA MARIA DO ESPIRITO SANTO

Iguape 1842 JOAQUIM DE SOUZA CALDEIRA

Iguape 1842 ANTONIO JOAQUIM DA SILVA

Iguape 1842 FRANCISCA PEREIRA

Iguape 1842 INACIA PEREIRA

Iguape 1842 FRANCISCO VAZ DA COSTA

Iguape 1842 GERTRUDES RIBEIRA DE MENDONÇA

Iguape 1842 JOAQUIM LUIS DE MORAES

Iguape 1842 JOSÉ GOMES GARCEZ

Iguape 1842 MANOEL LOPES TRIGO

Iguape 1842 SERAFINA PERPETUA XAVIER

Iguape 1842 GERTRUDES MARIA

Iguape 1843 ANA DE JESUS BANDEIRA

Iguape 1843 ANA LUIZA DA COSTA

Iguape 1843 ANTONIA CORREA DE MEIRA

Iguape 1843 ANTONIO BERNARDINO DA SILVA

Iguape 1843 FRANCISCO JOSÉ DE SOUZA NETO

Iguape 1843 JOÃO JIRAL

Iguape 1843 LUIS NEVES

Iguape 1843 MARIA ALVES CARNEIRO

Iguape 1843 NICOLAS DREYS

Iguape 1843 PEDRO RODRIGUES DE AGUIAR

Iguape 1843 ANTONIO DA COSTA SILVA

Iguape 1843 ANTONIO JOSÉ DE CARVALHO SIMÕES

Iguape 1843 JOSÉ MARIANO DE MOURA E SOUZA

Iguape 1843 MARIA FRANCO DE OLIVEIRA

Iguape 1843 JOSÉ FRANCISCO PUPO DA ROCHA

Iguape 1843 MANOEL RODRIGUES DE AGUIAR

Iguape 1843 MIGUEL DOS PASSOS

Iguape 1843 ANA TEREZA DE MORAES

Iguape 1844 ALEXANDRINA JOAQUINA CARNEIRO

Iguape 1844 JOAQUIM FRANCISCO GARCIA
JOAQUIM PIO PUPO

ANA TOMÁSIA DE AQUINO

FRANCISCO ALVES DE ARAUJO

MARIA ANTONIA DE FRANÇA

INÁCIA MARIA DE JESUS

ANA JUSTINA CARNEIRO DE MENDONÇA

MARIA JOAQUINA DO NASCIMENTO

MANOEL JOSÉ GONÇALVES

ANA MARIA CLEOFA

MARIA MADALENA DE ATAIDE PENICHE

BERNARDO ANTONIO NEVES

INACIO DOS PASSOS GOMES

INACIO RODRIGUES DE FREITAS

TERESA MARIA DE MELO

AGOSTINHO PENICHE

GENEROSA DIAS

INÁCIO ANTUNES DA SILVA

VICTOR RIBEIRO

JOAQUIM FAGUNDES DE MEDEIROS

ISABEL MARIA DE OLIVEIRA

DELFINA MARIA DO ESPIRITO SANTO

JOÃO BERNARDO CARNEIRO

BERNARDO PINTO DE FARIA

ROSA MARIA DA CONCEIÇÃO

GERTRUDES MARIA DE JESUS

ANTONIO FRANCISCO GONÇALVES

JOÃO FAGUNDES DE MEDEIROS

JOSEFA MARIA DO ESPIRITO SANTO

ANA FERREIRA DE MORAES

JOÃO JOSÉ DE CARVALHO SIMÕES SOBRINHO

JOANA MARIA FRANCISCA

ANTONIO DOMINGUES COSTA

JOSÉ FRANCISCO CORREIA

TOMAS PEREIRA DA SILVA

MARIA GERTRUDES GARCEZ

ROSA CANDIDO DE TOLEDO

LUIZ GONZAGA DA SILVA

ANA JESUINA

RITA MARIA DE SOUZA

ANTONIO MANOEL DE MELLO

ANTONIO JOSÉ PENICHE

JOÃO INACIO DE CARVALHO

MANOEL FANCO PEREIRA

DOMINGOS DE SOUZA

JOANA MARIA

MARIA DA ANUNCIAÇÃO

ANTONIO JOSÉ PEREIRA

INACIO DA SILVA MOREIRA

ANTONIO BORGES DINIZ

BRAS DE SOUZA RODRIGUES

TOMASIA DOMINGUES

ISABEL ARCANGELA

JOAQUIM LOPES TRIGO

MHAI, c. 162

MHAI, c. 37

MHAI, c. 37

MHAI, c. 34

MHAI, c. 34

MHAI, c. 99

MHAI, c. 202

MHAI, c. 144

MHAI, c. 150

MHAI, c. 141

MHAI, c. 35

MHAI, c. 37

MHAI, c. 34

MHAI, c. avulsos

MHAI, c. 223

MHAI, c. 223

MHAI, c. 223

MHAI, c. 223

MHAI, c. 223

MHAI, c. 224

MHAI, c. 224

MHAI, c. 224

MHAI, c. 172

MHAI, c. 137

MHAI, c. 224

MHAI, c. 1

MHAI, c. 136

MHAI, c. 142

MHAI, c. 151

MHAI, c. 151

MHAI, c. 195

MHAI, c. 50

MHAI, c. 50

MHAI, c. 50

MHAI, c. 1

MHAI, c. 235

MHAI, c. 235

MHAI, c. 63

MHAI, c. 100

MHAI, c. 50

MHAI, c. 110

MHAI, c. 12

MHAI, с. 97

MHAI, c. 33

MHAI, c. 219

MHAI, c. 224

MHAI, c. 224

MHAI, c. 224

MHAI, c. 54

MHAI, c. 54

MHAI, c. 54

MHAI, c. 163

MHAI, c. 150

FRANCISCO CARNEIRO DA SILVA BRAGA JUNIOR MHAI, c. 1

FRANCISCO FLORENCIO DE SOUZA

ANTONIO FRANCISCO DE ATÍDE PENICHE

MHAI, c. 110

MHAI, c. 12

MHAI, c. 12

MHAI, c. 12

MHAI, c. 12

MHAI, c. 12

MHAI, c. 12

MHAI, c. 12

MHAI, c. 12

MHAI, c. 12

MHAI, c. 12

MHAI, c. 114

MHAI, c. 114

MHAI, c. 114

MHAI, c. 93

MHAI, c. 97

MHAI, c. 189

MHAI, c. 189

MHAI, c. 162

MHAI, c. 235

MHAI, c. 149 
Iguape 1844 JOÃO INÁCIO DE OLIVEIRA GUIMARÃES

Iguape 1844 MARIA DAS DORES LUZ

Iguape 1844 MANOEL CARNEIRO DE SOUZA

Iguape 1844 ANTONIO PUPO DA ROCHA

Iguape 1844 ESCOLASTICA CORREA

Iguape 1844 JOAQUIM JOSÉ PEREIRA

Iguape 1844 MARIA EUFRASIA

Iguape 1844 ANTONIO AUGUSTO SOARES

Iguape 1844 BENTO ANTONIO DO CARMO MOURA

Iguape 1844 FRANCISCO ANTONO DE MOURA

Iguape 1844 JOSÉ GOMES LEITÃO

Iguape 1844 BRAS LOPES PEDROSO

Iguape 1845 ANA PAULA PEDROSA

Iguape 1845 INACIO FERNANDES

Iguape 1845 JOSEFA MARIA RODRIGUES

Iguape 1845 MARIA GERTRUDES

Iguape 1845 MARTINHA MARIA DA SILVA

Iguape 1845 FRANCISCO DE OLIVEIRA DUARTE SILVA

Iguape 1845 ANTONIA MARIA MELO

Iguape 1845 JOSÉ ANTONIO DOS SANTOS PRADO

Iguape 1845 MARIA TEREZA

Iguape 1845 PEDRO MONTEIRO

Iguape 1845 MARIA LODUVINA XAVIER

Iguape 1846 JOAQUIM ALVES DE OLIVEIRA

Iguape 1846 INÁCIA MARIA ROSA

Iguape 1846 FRANCISCO CARNEIRO DA SILVA BRAGA

Iguape 1846 MANOEL ANTONIO DA SILVA

Iguape 1846 TERESA MARIA DE MELO

Iguape 1846 MARIA DE SIQUEIRA DEBORA

Iguape 1846 ROSA MARIA

Iguape 1846 FRANCISCO MANOEL JUNQUEIRA

Iguape 1846 MANOEL BATISTA GOMES

Iguape 1846 JOSÉ ANTONIO PENICHE FILHO

Iguape 1846 MARIA MADALENA DE ATAIDE PENICHE

Iguape 1846 ANTONIO MARTINS RIBEIRO

Iguape 1846 MARIA CAETANA

Iguape 1846 BENEDITO GARCIA

Iguape 1846 MARIA FELIZARDA PEDROSA

Iguape 1846 MANOEL GOMES BALEA

Iguape 1846 MARIA DOMINGUES

Iguape 1846 GERALDO JOSÉ DE FRANÇA

Iguape 1847 ANA MARIA CLEOFA

Iguape 1847 FELISBERTO ALVES DE MELLO

Iguape 1847 JOSÉ DE ALMEIDA

Iguape 1847 MANOEL ANTONIO DURÃES

Iguape 1847 JOSEFA LEONOR DE SIQUEIRA

Iguape 1847 ANTONIO DA COSTA LEITE GUIMARÃES

Iguape 1847 GERTRUDES MARIA DO ESPIRITO SANTO

Iguape 1847 CLARA MARIA DE MORAES

Iguape 1848 URSULA DE OLIVEIRA

Iguape 1848 SALVADOR AFONSO DA COSTA

Iguape 1848 LUIS JOSÉ DE MEDEIROS

Iguape 1848 FRANCISCA MARIA

Iguape 1848 BENTO JOSÉ DE SOUZA

Iguape 1848 MANOEL ANTONIO DE AGUIAR

Iguape 1848 CLEMENTE PEREIRA CARNEIRO

Iguape 1848 DOMINGOS ALVES

Iguape 1848 FRANCISCO CARNEIRO DA SILVA BRAGA FILHO

Iguape 1848 INACIA FLORIPES DA SILVA

Iguape 1848 JOSÉ JACOMO RODRIGUES

Iguape 1849 MANOEL GONÇALVES RIBEIRO

Iguape 1849 NARCISA DIAS BATISTA

Iguape 1849 ISABEL DENICIA DE ALMEIDA

Iguape 1849 ISABEL MARIA DE JESUS

Iguape 1849 ANTONIO JOSÉ PEREIRA

Iguape 1849 ESTEFANIA ROSA DA SILVA

Iguape 1849 MARIA LOURENÇA DE MORAES

Iguape 1849 MARIA MADALENA

Iguape 1850 INACIO DOS PASSOS MARTINS

Iguape 1850 FRANCISCO DE PAULA PENICHE

Iguape 1850 PEDRO RIBEIRO DE OLIVEIRA

Iguape 1850 DELFINA BELMIRA DE TOLEDO

Iguape 1850 JOSÉ BENTO DA SILVA FRANCO

Iguape 1850 VICENTE JOSÉ FERREIRA

Iguape 1850 FRANCISCO DE SIMAS MACHADO
JOAQUINA DE OLIVEIRA

MANOEL ANTONIO DE AGUIAR

FRANCISCA FELIZARDA

MARIA JOAQUINA DA SILVA

JOÃO ANTONIO CARRIÇO

GERTRUDES MARIA DA SILVA

JOÃO FERREIRA DE OLIVEIRA

RITA CANDIDA RODRIGUES

TEREZA MARIA DE JESUS

ANA MARIA DE ANDRADA

MANOEL PINTO DE ALMEIDA

PEDRO ALVES PEDROSO

MATIAS RODRIGUES DE MATOS

MATIAS RODRIGUES DE MATOS

INACIO ANTONIO RODRIGUES

FRANCISCO RIBEIRO

AGOSTINHO BUENO DA VEIGA

ANA JOAQUINA XAVIER

PEDRO GONÇALVES DA ROCHA

BENIGNA MARIA DE JESUS

JOSÉ FELIPE DA SILVA

JOSÉ DOMINGUES BARREIROS

FRANCISCO CARNEIRO DA SILVA BRAGA FILHO

GERMANO ALVES DE OLIVEIRA

JOAQUIM ANTONIO FERNANDES

FRANCISCA DE PAULA DINIZ CARNEIRO

ANA JUSTA DO CARMO

MANOEL EUGENIO DA SILVA

JOANA AMALIA MALTA CARNEIRO

FRANCISCO ANTONIO NUNES

JOÃO MANOEL JUNQUEIRA NETO

JOSEFA LEONOR DE SIQUEIRA

JOSÉ LUIS DE SOUZA FRANÇA

JOSÉ LUIS DE SOUZA FRANÇA

MANOEL MARTINS RIBEIRO

JOAQUIM MARIANO RIBEIRO

JOSEFA MARIA

MATIAS RODRIGUES DE MATOS

MARIA JOAQUINA

ANDRÉ LOPES

ANA RODRIGUES DA SILVA

MANOEL ANTONIO FURTADO

MANOEL HOMEM PAMPLONA

FRANCISCO FRANCO

JOÃO DE SOUZA CASTRO

BENTO FERREIRA DE MORAES

LAUREANO DA SILVA FRANCO

JOSÉ RODRIGUES DA CUNHA

JOAQUIM LOPES TRIGO

JOSÉ DA SILVA

ANTONIO JOSÉ GONÇALVES

FLORENCIA MARIA DAS DORES

JOÃO FERREIRA FANECA

ROSA MARIA MUNIZ

MARIA ALVES DO NASCIMENTO

MANOEL BENTO DE JESUS

MARIA JOSEFA

CANDIDA MARIA XAVIER CARNEIRO

BENTO JOSÉ FERREIRA

JOAQUIM LEMOS

BERNARDO ANTONIO NEVES

MALAQUIAS FRANCISCO TEIXEIRA

JOSÉ JOÃO DA COSTA

TOMÉ MANOEL DE LARA

MARIA LUISA DA TRINDADE

JOSÉ NUNES DA SILVA

FRANCISCO PEREIRA DA SILVA

MANOEL PEREIRA CARNEIRO

ANTONIO MARTINS DE FREITAS

ANA JUSTINA DA SILVEIRA

JOAQUIM PIRES RIBEIRO

JOÃO MANCIO DA SILVA FRANCO

ANA JOAQUINA RODRIGUES FRANCO

JOSÉ RIBEIRO DE CARVALHO

ANTONIO JOSÉ PENICHE
MHAI, c. 194

MHAI, c.194

MHAI, c. 172

MHAI, c. 204

MHAI, c. 96

MHAI, c. 157

MHAI, c. 157

MHAI, c. 158

MHAI, c. 158

MHAI, c. 158

MHAI, c. 158

MHAI, c. 96

MHAI, c. 137

MHAI, c. 137

MHAI, c. 137

MHAI, c. 137

MHAI, c. 200

MHAI, c. 177

MHAI, c. 136

MHAI, c. 202

MHAI, c. 172

MHAI, c. 172

MHAI, c. 239

MHAI, c. 86

MHAI, c. 136

MHAI, c. 2

MHAI, c. 200

MHAI, c. 201

MHAI, c. 141

MHAI, c. 194

MHAI, c. 50

MHAI, c. 50

MHAI, c. 205

MHAI, c. 205

MHAI, c. 1

MHAI, c. 1

MHAI, c. 110

MHAI, c. 110

MHAI, c. 96

MHAI, c. 157

MHAI, c. 104

MHAI, c. 85

MHAI, c. 85

MHAI, c. 235

MHAI, c. 138

MHAI, c. 237

MHAI, c. 194

MHAI, c. 200

MHAI, c. 198

MHAI, c. 114

MHAI, c. 189

MHAI, c. 63

MHAI, c. 151

MHAI, c. 201

MHAI, c. 201

MHAI, c. 215

MHAI, c. 35

MHAI, c. 139

MHAI, c. 4

MHAI, c. 4

MHAI, c. 97

MHAI, c. 97

MHAI, c. 33

MHAI, c. 33

MHAI, c. avulsos

MHAI, c. 130

MHAI, c. 63

MHAI, c. 202

MHAI, c. 130

MHAI, c. 180

MHAI, c. 105

MHAI, c. 85

MHAI, c. 54

MHAI, c. 114

MHAI, c. 66 
Iguape 1850 FRANCISCO XAVIER PEREIRA

Iguape 1850 GREGÓRIO RODRIGUES DE OLIVEIRA

Iguape 1850 JOAQUIM MARTINS RODRIGUES

Iguape 1850 BRIGIDA MARIA

Iguape 1850 MANOEL RIBEIRO DE CARVALHO

Iguape 1850 ROSA MARIA PEREIRA

Iguape 1850 JOSÉ JACINTO RAPOSO

Iguape 1850 JOSEFA MARIA DO ESPIRITO SANTO

Iguape 1850 MANOEL MARTINS RIBEIRO

Iguape 1850 ANDRÉ LOPES

Iguape 1850 MARIA VIEIRA FRANCO

Iguape 1850 DOMINGOS RIBEIRO DE CAMARGO

Iguape 1851 JOSÉ ANTONIO MUNIZ

Iguape 1851 ALEXANDRINA MARIA DA CONCEIÇÃO

Iguape 1851 MANOEL GOMES DA SILVA

Iguape 1851 TOMAS TRUDES DE NORMANDIA

Iguape 1851 ANTONIO ALVES DA SILVA

Iguape 1851 ANTONIO MANOEL RODRIGUES

Iguape 1851 JERONIMO JOSÉ LOPES

Iguape 1851 JOSEFA GERTRUDES ALVES CARNEIRO

Iguape 1852 JACINTA DOMINGUES

Iguape 1852 JOSÉ TIBURCIO

Iguape 1852 JOSEFA TEREZA DO CANTO

Iguape 1852 MANOEL FRANCO DE OLIVEIRA

Iguape 1852 MANOEL DE LARA

Iguape 1852 TORQUATO FRANCISCO RIOS

Iguape 1853 JOSÉ ANTONIO SARDINHA

Iguape 1853 BARBARA INACIA DE AGUIAR

Iguape 1853 MARIA JOAQUINA

Iguape 1853 LUCINDA RODRIGUES TEIXEIRA

Iguape 1853 GREGÓRIO MARTINS

Iguape 1853 MARIA DA GLÓRIA

Iguape 1853 MIQUELINA MARIA DE SÁ

Iguape 1853 VALENTIM TEIXEIRA

Iguape 1853 MAGARIDA GERTRUDES

Iguape 1853 JOAQUIM RAIMUNDO PUPO FERREIRA

Iguape 1854 JOAQUIM TEIXEIRA DE AZEVEDO

Iguape 1854 JUSTINA CARNEIRO DE ARAUJO AGUIAR

Iguape 1854 SABINA PINTO DE QUEIROZ

Iguape 1854 MANOEL ANTONIO CORREA

Iguape 1854 ELIAS PUPO FERREIRA

Iguape 1854 JOSÉ DE SOUZA DE ASSUNÇÃO

Iguape 1854 ELISIA CANDIDA JUNQUEIRA

Iguape 1854 JOSÉ BENTO DE OLIVEIRA MUNIS

Iguape 1854 EMIDIO NUNES DA SILVA

Iguape 1854 MARIA ALVES DO NASCIMENTO

Iguape 1854 JOAQUIM FRANCISCO DE MENDONÇA

Iguape 1854 MARIA MADALENA ALVES

Iguape 1854 MARIA LUIZA DO CARMO

Iguape 1855 ANTONIO FRANCISCO CARNEIRO

Iguape 1855 DOMINGOS POYGARI

Iguape 1855 JOÃO DIAS BATISTA

Iguape 1855 JOSÉ GONÇALVES LOPES

Iguape 1855 MANOEL TAVARES COIMBRA CAMBIVA

Iguape 1855 ANTONIO RODRIGUES DE OLIVEIRA

Iguape 1855 FRANCISCO ALVES DE ARAÚJO

Iguape 1855 FRANCISCA DE PAULA GARCEZ

Iguape 1855 ANTONIO FRANCISCO DE MACHADO

Iguape 1856 INACIO DA COSTA RODRIGUES

Iguape 1856 ANA JUSTINA CARNEIRO DE MENDONÇA

Iguape 1856 MANOEL ANTONIO DA SILVA PRADO

Iguape 1856 BRIGIDA MARIA

Iguape 1856 JOSEFA MARIA

Iguape 1856 CAMILO JOSÉ CORREA

Iguape 1856 INACIO BENEDITO DE SOUZA

Iguape 1856 MARIA CAROLINA HENSLER

Iguape 1856 CANDIDO PUPO DA ROCHA

Iguape 1856 JOAQUIM ALVES SILVA CARNEIRO

Iguape 1856 ANTONIO FRANCISCO DE AGUIAR

Iguape 1856 MARIA DA ANUNCIAÇÃO

Iguape 1857 ESCOLASTICA EUFROSINA DA SILVA

Iguape 1857 MIGUEL RIBEIRO

Iguape 1857 BRAZ CAETANO DA SILVA

Iguape 1857 INÁCIA DO CARMO

Iguape 1857 JOAQUIM PEREIRA DE OLIVEIRA
MARIA RITA VIANA

CAETANA ROSA MARTINS

MARIA BERNARDA ALVES

FRANCISCO AUGUSTO DE OLIVEIRA MUNIZ

ANA MARIA DA TRINDADE

JOAQUIM ANTONIO GOMES

JOSÉ ALVES COSTA PACCA

CANDIDO LOPES TRIGO

CLARA MARIA DE JESUS

ANTONIO LOPES

LAUREANO DA SILVA FRANCO

ANA BENEDITA DE RAMOS

JESUINA MARIA DE JESUS

BENTO JOSÉ FURTADO

RITA MARIA DE JESUS

ANA ESCOLASTICA DE MORAIS

BENEDITA MARIA DO NASCIMENTO

FRANCISCA EUFRÁSIA

JOSÉ RIBEIRO DE CARVALHO

JOÃO PINTO DE FARIA

FRANCISCO DOS SANTOS COSTAS

CAROLINA MARIA PENICHE

JOAQUIM ALVES CARNEIRO

MARIA DAS DORES DE OLIVEIRA

FIDENCIO BELCHIOR DE LARA

GUILHERMINA LUIZA CARNEIRO RIOS

TEREZA MARIA DE JESUS

MIGUEL LOPES DE AGUIAR

JOAQUIM ANTONIO GOMES

RICARDO JOAQUIM TEIXIERA

FRANCISCA MARIA

DOMINGOS JOSÉ DE MORAIS

ANTONIO INACIO DE CARVALHO

LUCINDA RODRIGUES TEIXEIRA

JOÃO FRANCO DA SILVA

ANA JUSTINA FERREIRA

MARIA MARTINS RODRIGUES

ANTONIO JOAQUIM DE ARAUJO AGUIAR

JOAQUIM JOSÉ DE QUEIROZ AZEVEDO

JESUINA MARIA

MARIA DO NASCIMENTO PUPO

JOSEFA MARIA VIANA

FRANCISCO NUNES DE SOUZA PEREIRA

TEOBALDINA MARIA MUNIS

JESUINA RITA DE AGUIAR

AGOSTINHO RIBEIRO DE AGUIAR

MARIA SENHORINHA DE ANDRADE

FRANCISCO MANOEL DE PAIVA

ANTONIO DOS ANJOS SILVA

JOAQUINA OLIVA DE MENDONÇA CARNEIRO

RAQUEL DESCIO POYGARI

MARIA LEOCADIA DE MENDONÇA

RITA JERONIMA DO ESPIRITO SANTO

LUCIANA MARIA DE JESUS

ANA LUISA DO CANTO

IZABEL EUFRASIA DE AZEVEDO

MARIA BENEDITA DE JESUS

FRANCISCA DE LIRIA BUENO

MARIA FELICIANA DA SILVA

MARIA EUSEBIA DO PRADO

PEDRO DA COSTA RODRIGUES

PEDRO JOSÉ PAZ

TOMASIA MARIA

JERONIMO RIBEIRO DE AGUIAR

JOAQUIM CARNEIRO DA SILVA BRAGA

MARIA MAFALDA DAS DORES

ROSA FRANCISCA ALVES

MARIA DE AGUIAR

ANTONIO INACIO RIBEIRO

FELIPE RODRIGUES CUNHA

GERTRUDES MARIA

IZABEL JACINTA

JOÃO FERREIRA DE OLIVEIRA

JOSEFA MARIA DA SILVA
MHAI, c. 177

MHAI, c. 127

MHAI, c. 127

MHAI, c. 128

MHAI, c. 128

MHAI, c. 130

MHAI, c. 64

MHAI, c. 150

MHAI, c. 37

MHAI, c. 149

MHAI, c. 50

MHAI, c. 104

MHAI, c. 180

MHAI, c. 109

MHAI, c. 66

MHAI, c. 128

MHAI, c. 127

MHAI, c. 128

MHAI, c. 128

MHAI, c. 172

MHAI, c. 52

MHAI, c. 52

MHAI, c. 52

MHAI, c. 66

MHAI, c. 100

MHAI, c. 100

MHAI, c. 131

MHAI, c. 52

MHAI, c. 52

MHAI, c. 97

MHAI, c. 200

MHAI, c. 236

MHAI, c. 62

MHAI, c. 50

MHAI, c. 204

MHAI, c. 110

MHAI, c. 12

MHAI, c. 131

MHAI, c. 38

MHAI, c. 202

MHAI, c. 176

MHAI, c. 176

MHAI, c. 195

MHAI, c. 236

MHAI, c. 162

MHAI, c. 63

MHAI, c. 64

MHAI, c. 64

MHAI, c. 237

MHAI, c. 96

MHAI, c. 134

MHAI, c. 97

MHAI, c. 33

MHAI, c. cd3

MHAI, c. 202

MHAI, c. 223

MHAI, c. 71

MHAI, c. 64

MHAI, c. 127

MHAI, c. avulsos

MHAI, c. 52

MHAI, c. 86

MHAI, c. 86

MHAI, c. 85

MHAI, c. 134

MHAI, c. 66

MHAI, c. 97

MHAI, c. 224

MHAI, c. 202

MHAI, c. 198

MHAI, c. 86

MHAI, c. 86

MHAI, c. 127

MHAI, c. 201

MHAI, c. 237 
Iguape 1857 ROSA FRANCISCA ALVES

Iguape 1857 ANA JOAQUINA DE JESUS

Iguape 1857 BALDOINA MARIA

Iguape 1857 BEATRIZ CARLOTA DE RAMOS

Iguape 1857 FRANCISCA DOMINGUES

Iguape 1857 BRAS FRANCISCO DA SILVA

Iguape 1857 JACINTA MARIA MONTEIRO

Iguape 1857 JOSÉ MARIANO DE OLIVEIRA

Iguape 1858 INACIO FIDENCIO MARTINS

Iguape 1858 GERTRUDES DOMINGUES DE OLIVEIRA

Iguape 1858 ANA ESCOLÁSTICA DE MORAES

Iguape 1858 JOAQUIM DOMINGUES

Iguape 1858 AGOSTINHO BUENO DA VEIGA

Iguape 1858 FRANCISCO TEIXEIRA DE OLIVEIRA

Iguape 1858 MANOEL JOSÉ PEREIRA MACHADO

Iguape 1858 AGOSTINHO PEREIRA DE BARROS

Iguape 1858 ANA MARIA DO ESPIRITO SANTO

Iguape 1858 JOAQUIM ALVES CARNEIRO

Iguape 1858 JOAQUIM ANTONIO DOS ANJOS

Iguape 1858 JOSÉ MARTINS

Iguape 1858 MARIA DAS DORES PUPO

Iguape 1858 MARIA JOAQUINA DE JESUS

Iguape 1858 BARBARA JACINTA DE ANDRADA

Iguape 1858 ESCOLASTICA EUFROSINA DO ESPIRITO SANTO

Iguape 1858 JOSEFA MARIA DA ANUNCIAÇÃO

Iguape 1859 MARIA MARTINS RODRIGUE

Iguape 1859 MARIA GERTRUDES BALBINA

Iguape 1859 JOAQUIM MARIA DA COSTA AGUIAR

Iguape 1859 LEANDRO JOSÉ DA CRUZ

Iguape 1859 JOAQUIM PEDRO RIBEIRO

Iguape 1859 TOMASIA MARIA DA SILVA

Iguape 1859 JOSÉ PEREIRA GUERRA

Iguape 1859 DOMINGOS RODRIGUES DE PONTES

Iguape 1860 VITORINO JOSÉ FRANCO

Iguape 1860 ADRIÃO TRUDES DE NORMANDIA

Iguape 1860 LUIS BERANGER

Iguape 1860 JOSÉ PINTO PEREIRA

Iguape 1860 DOMINGOS MARTINS RODRIGUES

Iguape 1860 JOAQUIM GONÇALVES MAIA

Iguape 1860 JOÃO ANTONIO DAS NEVES

Iguape 1860 MARIA RITA NEVES

Iguape 1861 FRANCISCA DE ALMEIDA COSTA

Iguape 1861 ZEFERINO JOSÉ DO PRADO

Iguape 1861 MANOEL BENTO DE ANDRADA SILVA

Iguape 1861 ANTONIO JOSÉ PENICHE

Iguape 1861 FRANCISCA LIRA BUENO DO PRADO

Iguape 1861 ANA MARIA DO ESPIRITO SANTO

Iguape 1861 GUILHERMINA LUIZA CARNEIRO RIOS

Iguape 1861 FRANCISCO AUGUSTO DE OLVEIRA MUNIS

Iguape 1861 MARIA DO ROSARIO SILVA

Iguape 1862 MARIA MAFALDA DAS DORES

Iguape 1862 GERTRUDES MARIA DE SOUZA

Iguape 1862 MARIA ALVES DA COSTA

Iguape 1862 INÁCIO RODRIGUES

Iguape 1862 TOMASIA MARIA DE ASSUNÇÃO

Iguape 1862 JOÃO PINTO DE FARIA

Iguape 1862 ANTONIO BERNARDO PINTO DE ALMEIDA

Iguape 1862 GERTRUDES MARIA DE JESUS

Iguape 1863 FRANCISCO EUSEBIO GONÇALVES

Iguape 1863 BENTO FERREIRA DE MORAES

Iguape 1863 TORQUATO PUPO DA ROCHA

Iguape 1863 FRANCISCA LIMA DE PAULA

Iguape 1863 JOÃO ANTONIO CORREA

Iguape 1863 RITA FERREIRA DA SILVA

Iguape 1864 JOÃO DOMINGUES RIBEIRO

Iguape 1864 GERTRUDES MARIA DA CONCEIÇÃO

Iguape 1864 JOAQUIM ANDRÉ GONÇALVES LARA

Iguape 1864 RAFAEL DIAS DO REIS

Iguape 1864 MARIA DAS DORES

Iguape 1864 JOAQUIM JOSÉ DE QUEIROZ AZEVEDO

Iguape 1864 INACIO MARIANO RODRIGUES

Iguape 1864 JOÃO RODRIGUES FRAGATEIRO

Iguape 1864 CUSTUDIA MARIA MADALENA

Iguape 1864 FELISBINO JOSÉ DE FARIA

Iguape 1864 JOÃO ANTONIO LOPES
JOÃO BATISTA ALVES CARNEIRO

MARIA JOAQUINA DE JESUS

MANOEL MAXIMIANO

MARIA DAS DORES PEREIRA

JOÃO INÁCIO GONÇALVES

INACIA EUFRASIA

FELICIANO PINTO DE ALMEIDA

FELICIA MARIA DAS CHAGAS

MAXIMIANA LAURA DE JESUS

JOÃO FRANCO DA SILVA

ADRIÃO TRUDES DE NORMANDIA

MARIA EUFRASIA

ROSA BUENO DA VEIGA

BENEDITA MARIA CORREA

JOAQUIM JOSÉ BERNARDO

ESCOLASTICA MARIA ANTUNES DA SILVA

JOAQUIM MARIANO RIBEIRO

FRANCISCO ALVES CARNEIRO

MARIA FRANCISCA

SEBASTIÃO FABIÃO DA SILVA

ANTONIO FELICIANO PUPO

JOÃO ANTONIO GOMES

MANOEL MARTINS SILVEIRA

JOÃO ANTONIO DE MORAES FREITAS

MANOEL ANTONIO DA SILVEIRA

FRANCISCO XAVIER DE AZEVEDO

LEANDRO JOSÉ DA CRUZ

MIQUELINA HENRIQUETA DE AGUIAR

JOSÉ RODRIGUES CUNHA

MARIA MADALENA FRANÇA

MANOEL CANDIDO DA SILVA

CLARIANA ANDRESA DA CONCEIÇÃO

ANTONIO VAZ FERREIRA

LAUREANO DA SILVA FRANCO

JOÃO MANCIO DA SILVA FRANCO

EMILIA MARIA

FRANCISCO ANTONIO PEREIRA

JOSEFA NUNES MARTINS

MARIA ANGELICA MAIA

SERAFINA MARIA DAS DORES

AGOSTINHO LOPES TRIGO

PACIFICO JOSÉ RODRIGUES

INACIA RODRIGUES DO PRADO

MARTINHA MARIA CESAR

MANOEL DA ROSA

INÁCIO QUERINO DA VEIGA

JOÃO FRANCISCO MENDES

CANDIDO NUNES DE CARVALHO

FLORENTINA AUGUSTA DE OLIVEIRA PINTO

ANTONIO FRANCISCO DE ATAIDE PENICHE

SEVERINO GOMES DE AGUIAR

BERNARDO LOURENÇO DE SOUZA

JOAQUIM DIAS DA SILVA MARTINS

LIBÓRIO JOSÉ DE ASSUNÇÃO

ANA RITA FORTES

RAIMUNDO PINTO DE ALMEIDA

ANTONIO GOMES

TEREZA MARIA GONÇALVES

JOSEFA LEONOR DE SIQUEIRA

FRANCISCA ROSA DE PAULA

MIGUEL LUIS PEREIRA

MARIA MADALENA

JOSÉ FERREIRA DA SILVA

ANTONIO LOURENÇO RODRIGUES

ANTONIO DOMINGUES MUNIS

RITA JOAQUINA DE OLIVEIRA

LAURIANO DA SILVA FRANCO

MANOEL JOAQUIM BARBOSA

ANTONIO JOSÉ BRANDÃO

JOÃO INACIO GONÇALVES

ANA MANCIA

JOÃO ANTONIO PEREIRA

INACIA MARTINS DE FARIA

JACINTA MARIA DE JESUS
MHAI, c. 237

MHAI, c. 194

MHAI, c. 195

MHAI, c. 195

MHAI, c. 196

MHAI, c. 103

MHAI, c. 104

MHAI, c. 3

MHAI, c. 52

MHAI, c. 66

MHAI, c. 202

MHAI, c. 38

MHAI, c. 38

MHAI, c. 38

MHAI, c. 38

MHAI, c. 1

MHAI, c. 1

MHAI, c. 1

MHAI, c. 1

MHAI, c. 1

MHAI, c. 1

MHAI, c. 1

MHAI, c. 110

MHAI, c. 110

MHAI, c.1

MHAI, c. 62

MHAI, c. 99

MHAI, c. 175

MHAI, c. 160

MHAI, c. 118

MHAI, c. 54

MHAI, c. 151

MHAI, c. 214

MHAI, c. 94

MHAI, c. 101

MHAI, c. 114

MHAI, c. 176

MHAI, c. 127

MHAI, c. 162

MHAI, c. 163

MHAI, c. 107

MHAI, c. 12

MHAI, c. 12

MHAI, c. 224

MHAI, c. 162

MHAI, c. 35

MHAI, c. 195

MHAI, c. 195

MHAI, c. 198

MHAI, c. 96

MHAI, c. 97

MHAI, c. 214

MHAI, c. 214

MHAI, c. 215

MHAI, c. 215

MHAI, c. 152

MHAI, c. 96

MHAI, c. 57

MHAI, c. 131

MHAI, c. 5

MHAI, c. 237

MHAI, c. 4

MHAI, c. 4

MHAI, c. 4

MHAI, c. 105

MHAI, c. 85

MHAI, c. 38

MHAI, c. 236

MHAI, c. 99

MHAI, c. 163

MHAI, c. 164

MHAI, c. 37

MHAI, c. 4

MHAI, c. 4

MHAI, c. 4 
Iguape 1864 TOMASIA MARIA DE SOUZA

Iguape 1864 MARIA JACINTA DE ANDRADE

Iguape 1864 MARIA FELICIANA DE BRITO

Iguape 1865 JOSÉ BONIFACIO DE ANDRADA

Iguape 1865 MARIA BERNARDA ALVES

Iguape 1865 JOAQUINA DE RAMOS

Iguape 1865 ANA CANDIDA DA ROCHA

Iguape 1865 CLARA MARIA FRANCA

Iguape 1865 MAXIMIANA XAVIER DE OLIVEIRA

Iguape 1865 FRANCISCA DUARTE

Iguape 1865 LUIS FRANCISCO ALVES

Iguape 1865 FRANCISCO MORATO DO CANTO

Iguape 1865 ROSA MARIA DE MELO

Iguape 1866 JESUINA MARIA JUSTINA

Iguape 1866 ANTONIO RIBEIRO NUNES

Iguape 1866 CAETANA LOURENÇA

Iguape 1866 FRANCISCA DIONISIA DA SILVA

Iguape 1866 INACIO QUIRINO DA VEIGA

Iguape 1866 JOSÉ FRANCISCO MACIEL

Iguape 1866 JOSÉ PEDRO DE FRANÇA

Iguape 1866 JOSEFA LEONOR DE SIQUEIRA

Iguape 1866 MANOEL VITORIANO DE SOUZA

Iguape 1866 MIQUELINA ANTONIA

Iguape 1866 UMBELINA MARIA DE CAMARGO

Iguape 1866 BRAS FRANCISCO MACIEL

Iguape 1866 MANOEL JOAQUIM DA SILVA GUIMARÃES

Iguape 1866 MARIA TEREZA DE JESUS

Iguape 1866 FRANCISCA MARIA DOMINGUES

Iguape 1866 ANTONIO RODRIGUES DE SOUZA

Iguape 1866 FRANCISCA LUIZA DE MENDONÇA

Iguape 1866 MANOEL JOAQUIM RODRIGUES

Iguape 1866 ESCOLASTICA MARIA

Iguape 1866 TEREZA LEDOBINA XAVIER CARNEIRO

Iguape 1867 JOSÉ FERREIRA DE AGUIAR SILVA

Iguape 1867 DOMINGOS PEREIRA DOS PASSOS

Iguape 1867 CIPRIANO JOSÉ DE LIMA

Iguape 1867 ANA DE SANTA ISABEL

Iguape 1867 JOSÉ TIBURCIO PELICAS RIBEIRO

Iguape 1867 ANTONIO PEREIRA SOARES DE CASTRO

Iguape 1867 BENTO MANOEL DE LIMA

Iguape 1867 CUSTODIA MARIA

Iguape 1867 FILADELFO DE SOUZA CASTRO

Iguape 1867 MARIA JOAQUINA DE JESUS

Iguape 1868 MARIA MAGNA LEMES

Iguape 1868 ISABEL MARIA

Iguape 1868 CAROLINA MARIA DO CARMO

Iguape 1868 CAROLINA DA SILVA MOTTA

Iguape 1868 ANTONIO JOAQUIM GOMES DE OLIVEIRA

Iguape 1868 JOAQUIM MANCIO DE PAULA COSTA

Iguape 1868 JOAQUIM GUILHERME CHAVES

Iguape 1868 JOSÉ JOAQUIM PEREIRA

Iguape 1868 TOMÉ DE SOUZA E SILVA

Iguape 1868 GRACIANA MARIA DE LARA

Iguape 1869 GUIOMAR MARIA DAS DORES

Iguape 1869 ANA GERTRUDES ALVES VIEIRA

Iguape 1869 GREGORIO RIBEIRO DE AGUIAR

Iguape 1869 BENTO LUIZ DE OLIVEIRA

Iguape 1869 JOSEFINA XAVIER PAMPLONA

Iguape 1869 MARCELINO ANTONIO PEREIRA

Iguape 1869 JOÃO INACIO GONÇALVES

Iguape 1869 ANTONIO DIAS TEIXEIRA

Iguape 1869 RICARDO PINTO DE SOUZA

Iguape 1869 FELISBINO PEREIRA DOS PASSOS

Iguape 1869 JOAQUIM FELIPE DUARTE

Iguape 1869 JOSÉ MARTINS DA COSTA

Iguape 1869 RITA MARIA DAS DORES PEREIRA

Iguape 1870 JOVINA CONSTANCIA CHAVES

Iguape 1870 ANA AUGUSTA DA COSTA

Iguape 1870 CLARA MARIA DE JESUS

Iguape 1870 JOÃO JOSÉ PEREIRA MACHADO

Iguape 1870 PEDRO LOPES DE OLIVEIRA

Iguape 1870 MATIAS RODRIGUES DE MATOS

Iguape 1871 LAUREANO DA SILVA FRANCO

Iguape 1871 SERAFINA DE MEDEIROS

Iguape 1871 INÁCIO PEREIRA
ANTONIO DOS ANJOS SILVA

MANOEL CARDOSO PIRES

LUIS ALVARES DA SILVA

JOSÉ BONIFÁCIO DE ANDRADA

GREGORIO RIBEIRO DE AGUIAR

ANTONIO CORREA DE AZEVEDO

ANTONIO PEDRO DE AGUIAR

ANTONIO JOAQUIM GOMES DE OLIVEIRA

MANOEL HOMEM PAMPLONA

MARIA RITA DE AGUIAR

MANOEL FRANCO DE OLIVEIRA CANTO

JOÃO FELICIANO CARNEIRO

ANTONIO VAZ FERREIRA

FRANCISCA RODRIGUES CARNEIRO

ANTONIO LOUREIRO

ANTONIO MARIANO DA SILVA

BELCHIOR DE PONTES VEIGA

CAROLINA MARIA DO ESPIRITO SANTO

GERTRUDES MARIA DO ESPIRITO SANTO

JOAQUIM FERREIRA DE MORAES

ANA MARIA DAS NEVES

ANTONIO FAGUNDES DE MEDEIROS

SABINO RIBEIRO COUTINHO

JOSEFA MARIA DO ESPIRITO SANTO

PORCINA MARIA GUIMARÃES

JOÃO ANTONIO BAPTISTA

BENEDITO TEIXEIRA

MARCIANA MARIA LUSTOSA

ANTONIO MARTINS RODRIGUES

ANA FLORENCIA DE LARA

JOSÉ RIBEIRO DE SOUZA

AUGUSTO FRANCISCO RIOS CARNEIRO

UMBELINA FERREIRA DE AGUIAR

SEBASTIANA DOS PASSOS

ISABEL OLIMPIA DA SILVA

MATEUS BATISTA RODRIGUES

FRANCISCO DE SOUZA DA SILVEIRA

ALEXANDRINA DE ALMEIDA PINTO

ANA MARIA DE ANDRADE

ANTONIO JOSÉ GOMES

LUIZA PENICHE DE CASTRO

JOÃO PEREIRA DE OLIVEIRA

JANUARIO JOSÉ DA SILVA

PEDRO LOPES

ILDEBRANDO JOSÉ DE MACEDO

JOSÉ FRANCISCO PUPO DA ROCHA

FRANCISCO GOMES DE OLIVEIRA

LEOPOLDINA MARIA DAS DORES

HENRIQUETA TERESA DO NASCIMENTO

MARIA ANTONIA DA SILVA

MARIA CANDIDA DA GLORIA

JEREMIAS DE LARA MACIEL

LAUREANO DA SILVA FRANCO

MANOEL ALVES DA COSTA

ANTONIO PEDRO DE AGUIAR

INÁCIO JOSÉ LUIZ

MANOEL HOMEM PAMPLONA

MARIA LUISA DO ESPIRITO SANTO

JOSÉ INACIO MARIANO

LUIS ALVARES DA SILVA

MARIA ANTONIA PINTO

AGOSTINHO LUIS RODRIGUES

ANA PINTO DUARTE

ESCOLÁSTICA LOPES DE MORAES

FRANCISO ANTONIO PEREIRA

HENRIQUETA TEREZA DO NASCIMENTO

ANTONIO AUGUSTO DE OLIVEIRA MUNIZ

MANOEL FRANCISCO MARTINS DE CASTRO

BONIFÁCIO PEREIRA MACHADO

ROSA DE OLIVEIRA

FRANCISCA DE SOUZA MATOS

LOURENÇA JOAQUINA CARNEIRO

JOÃO JOAQUIM DE LARA

EMERENCIANA LOPES
MHAI, c. 118

MHAI, c. 122

MHAI, c. 113

MHAI, c. 170

MHAI, c. 170

MHAI, c. 12

MHAI, c. 97

MHAI, c. 99

MHAI, c. 99

MHAI, c. 162

MHAI, c. 162

MHAI, c. 37

MHAI, c. 95

MHAI, c. 12

MHAI, c. 142

MHAI, c. 142

MHAI, c. 142

MHAI, c. 142

MHAI, c. 142

MHAI, c. 142

MHAI, c. 142

MHAI, c. 142

MHAI, c. 142

MHAI, c. 142

MHAI, c. 143

MHAI, c. 144

MHAI, c. 99

MHAI, c. 162

MHAI, c. 64

MHAI, c. 110

MHAI, c. 75

MHAI, c. 95

MHAI, c. 226

MHAI, c. 205

MHAI, c. 86

MHAI, c. 98

MHAI, c. avulsos

MHAI, c. 202

MHAI, c. 176

MHAI, c. 100

MHAI, c. 201

MHAI, c. 193

MHAI, c. 193

MHAI, c. 102

MHAI, c. avulsos

MHAI, c. 101

MHAI, c. 101

MHAI, c. avulsos

MHAI, c. 202

MHAI, c. 204

MHAI, c. 103

MHAI, c. 104

MHAI, c. 3

MHAI, c. 101

MHAI, c. 101

MHAI, c. 38

MHAI, c. avulsos

MHAI, c. avulsos

MHAI, c. avulsos

MHAI, c. 164

MHAI, c. 71

MHAI, c. 215

MHAI, c. 204

MHAI, c. 96

MHAI, c. 205

MHAI, c. 206

MHAI, c. 33

MHAI, c. avulsos

MHAI, c. avulsos

MHAI, c. avulsos

MHAI, c. 71

MHAI, c. 35

MHAI, c. 235

MHAI, c. 51

MHAI, c. 205 
Iguape 1871 FRANCISCO LOPES DA SILVA

Iguape 1871 INACIO RIBEIRO DE MENDONÇA

Iguape 1871 JOSÉ ANTONIO CABRAL

Iguape 1871 FRANCISCA DOMINGUES

Iguape 1871 JOSÉ ANTONIO DOS SANTOS

Iguape 1871 JOSÉ NOBREGA

Iguape 1871 MARIA SABINA DE LARA

Iguape 1871 MECIA MARIA DO ESPIRITO SANTO

Iguape 1872 JOAQUIM FRANCISCO PUPO DAS DORES

Iguape 1872 LUIS PEDRO DE SIQUEIRA

Iguape 1872 MAXIMIANO PINTO DE FARIA

Iguape 1872 ANTONIO MARIANO DA SILVA

Iguape 1872 MATEUS BATISTA RODRIGUES

Iguape 1872 LAURINDO RIBEIRO MUNIS

Iguape 1872 MARIA ANGELICA DE CARVALHO MAIA

Iguape 1872 TERESA RIBEIRO

Iguape 1873 PEDRO JOSÉ PAZ

Iguape 1873 FRANCISCO MANOEL DIAS

Iguape 1873 MANOEL FERREIRA DE CARVALHO

Iguape 1873 MARIA DA RESSUREIÇÃO

Iguape 1873 ANTONIO DA SILVA REGO

Iguape 1873 MANOEL JOAQUIM MARTINS

Iguape 1873 HENRIQUE PINTO DA COSTA

Iguape 1873 FRANCISCA DE SOUZA MATTOS

Iguape 1873 JOAQUIM RODRIGUES DE OLIVEIRA

Iguape 1873 ANA CLARA DA PAIXÃO

Iguape 1873 HENRIQUE DA SILVA FRANCO

Iguape 1873 MARIA CLEMENCIA

Iguape 1874 AGOSTINHO DOMINGUES RIBEIRO

Iguape 1874 ANTONIO DOMINGUES DA COSTA

Iguape 1874 GERTRUDES MARIA DO ESPIRITO SANTO

Iguape 1874 JOÃO MARTINS DA COSTA

Iguape 1874 MARIA MADALENA DE GOUVEIA

Iguape 1874 RITA JERONIMA DO NASCIMENTO

Iguape 1874 SEBASTIANA PEREIRA

Iguape 1874 ANTONIO JOSÉ GONÇALVES

Iguape 1874 JOSEFINA MONTEIRO DA CUNHA

Iguape 1874 MARIA JOAQUINA DA SILVA

Iguape 1875 FRANCISCO FERREIRA DE PAULA

Iguape 1875 FERMINO RIBEIRO DE MENDONÇA

Iguape 1875 JOANA MARIA DE JESUS

Iguape 1875 ANA LUIZA DO ROSARIO

Iguape 1875 JOAQUIM FERNANDES

Iguape 1875 ANA JANUARIA DAS DORES

Iguape 1875 GERTRUDES MARIA FRANCISCA

Iguape 1875 JOSÉ DE OLIVEIRA XAVIER

Iguape 1875 TRISTÃO RIBEIRO MONTEIRO

Iguape 1875 ANTONIA MARTINS CHAVES

Iguape 1875 MARIA FRANCISCA DE JESUS

Iguape 1875 JOANA MARIA DO ESPIRITO SANTO

Iguape 1875 MARIA PEDROSO DE LIMA

Iguape 1875 JOÃO BATISTA DAS NEVES

Iguape 1875 CONSTANTINA MARIA

Iguape 1876 CESARINA ROSA DO CANTO

Iguape 1876 TEREZA ANGELICA DE JESUS

Iguape 1876 LEOPOLDINA MARIA DO ESPIRITO SANTO

Iguape 1876 INACIO FELIZARDO VERAS

Iguape 1876 JESUINA MARIA RIBEIRO

Iguape 1876 VENANCIO PEREIRA DE OLIVEIRA

Iguape 1876 BERNARDO ANTONIO RAMOS

Iguape 1876 JOÃO ALVES PEREIRA GOMES

Iguape 1876 ANTONIO FRANCISCO DE MENDONÇA

Iguape 1876 MARIA ROSA DA CUNHA

Iguape 1876 ANTONIO DE MAGALHÃES MESQUITA

Iguape 1876 LUDOVINA JOAQUINA CARNEIRO

Iguape 1877 MARIA ROSA CARNEIRO FORTES

Iguape 1877 INES DE OLIVEIRA XAVIER

Iguape 1877 FELICIANO FAGUNDES DE MEDEIROS

Iguape 1877 PEDRO LARAGNOIT JUNIOR

Iguape 1877 ANTONIO FELICIANO PUPO

Iguape 1878 JOANA MARIA RODRIGUES

Iguape 1878 MIGUEL LOPES DE AGUIAR

Iguape 1878 SALVADOR FRANCO DE OLIVEIRA

Iguape 1878 INÁCIO FRANCO DE OLIVEIRA

Iguape 1878 MANOEL FRANCISCO PEREIRA
MARIA PEREIRA DE AGUIAR

JOAQUIM RIBEIRO DE MENDNÇA

JOAQUIM ANTONIO CABRAL

SIMIÃO DA SILVA

MARIA DE OLIVEIRA

ANTONIO RAIMUNDO

BELISARIO FAGUNDES DE MEDEIROS

JOÃO FAGUNDES DE MEDEIROS

FRANCISCO PUPO DE MENDONÇA

DELFINA MARIA PEREIRA

CLEMENCIA MARIA PINTO

CARLOS DOS SANTOS

BELISARIO FAGUNDES DE MEDEIROS

MARIA RODRIGUES

JOÃO JOSÉ DE CARVALHO

JOAQUIM DIAS TEIXEIRA

PEDRO LARAGNOIT JUNIOR

ANA UMBELINA ALVES

JOSÉ LUIS DE SOUZA FRANÇA

ANTONIO JOSÉ DE LIMA

FRANCISCA MARIA PINTO

JOAQUIM DIAS DA SILVA MARTINS

ANTONIA MARIA RIBEIRO DA COSTA

BALDOINO JOSÉ DE SOUZA

MARIA ANTONIA MUNIZ

FRANCISCO MANOEL DOS PASSOS

JOÃO E AUGUSTO

JOÃO ANTONIO PEREIRA RODRIGUES

GERTRUDES MARIA DE JESUS

ANA GERTRUDES MUNIZ

MOISES ALVES PEREIRA GOMES

MARIA JOAQUINA COELHO DUARTE

ROFINO JORGE

FRANCISCO PACHECO DE OLIVEIRA

JOAQUIM ALVES DE SOUZA

FLORIDA MARIA DO ESPIRITO SANTO

JOÃO CRISOSTEMO DA CUNHA

FRANCISCO PUPO DE MENDONÇA

ISABEL UMBELINA DA SILVA

MODESTO RIBEIRO DE MENDONÇA

LUIS DE BARROS CARNEIRO

BENEDITO MOREIRA LOPES

JOÃO FERNANDES

JULIO LEITE DE ATAIDE BARROS

BENTO ANTONIO REGINALDO

ANTONIO DE OLIVEIRA XAVIER

JESUINO MARTINS RIBEIRO

JOÃO MAURICIO CHAVES

JOSÉ DE SOUZA DA SILVEIRA GATTO

FRANCISCO CARNEIRO DA SILVA BRAGA

VENANCIO PEDROSO DE LIMA

JOÃO BATISTA DAS NEVES

JOAQUIM ANTONIO PEDROSO

MAXIMIANO RODRIGUES PEREIRA

JOSÉ EVANGELISTA FRANCO

JACINTO GONÇALVES LOPES

VITORINO JOSÉ LUSTOSA

ANTONIO CORREA

BRIGIDA MARIA DO NASCIMENTO

VITORINO SOARES COSTA

TOMASIA MARIA DA SILVEIRA

ANA JOAQUINA RODRIGUES

JOÃO LINO CALDEIRA

JOSÉ JOAQUIM EGAS

GREGÓRIO URCEZINO PEREIRA

JOSÉ RODOLFO GONÇALVES FORTES

JOAQUIM GOMES DE OLIVEIRA

JOAQUINA FAGUNDES DE MEDEIROS

RITA MARIA DO PRADO LARAGNOIT

LUCIANO FELICIANO PUPO

ANTONIO JOSÉ ALVES

JOSÉ JOAQUIM GOMES PEREIRA

JOAQUINA MARIA DOS PRAZERES

ANA LOURENÇA DO ESPIRITO SANTO

ROSA MARIA PEREIRA
MHAI, c. 103

MHAI, c. 103

MHAI, c. 103

MHAI, c. 104

MHAI, c. 104

MHAI, c. 104

MHAI, c. 104

MHAI, c. 104

MHAI, c. 3

MHAI, c. 66

MHAI, c. 176

MHAI, c. 127

MHAI, c. 127

MHAI, c. 223

MHAI, c. 104

MHAI, c. 3

MHAI, c. 33

MHAI, c. 12

MHAI, c. 33

MHAI, c. 33

MHAI, c. avulsos

MHAI, c. 236

MHAI, c. 54

MHAI, c. 35

MHAI, c. 111

MHAI, c. 9

MHAI, c. 9

MHAI, c. 9

MHAI, c. 38

MHAI, c. 38

MHAI, c. 38

MHAI, c. 38

MHAI, c. 38

MHAI, c. 38

MHAI, c. 38

MHAI, c. 79

MHAI, c. 79

MHAI, c. 79

MHAI, c. 237

MHAI, c. 137

MHAI, c. 114

MHAI, c. 118

MHAI, c. 118

MHAI, c. 130

MHAI, c. 130

MHAI, c. 130

MHAI, c.129

MHAI, c. 62

MHAI, c. 62

MHAI, c. 215

MHAI, c. 240

MHAI, c. 170

MHAI, c. 104

MHAI, c. 92

MHAI, c. 189

MHAI, c. 150

MHAI, c. 188

MHAI, c. 188

MHAI, c. 188

MHAI, c. 229

MHAI, c. 229

MHAI, c. 230

MHAI, c. 230

MHAI, c. 224

MHAI, c. 231

MHAI, c. 97

MHAI, c. 202

MHAI, c. 52

MHAI, c. 172

MHAI, c. 4

MHAI, c. 117

MHAI, c. 235

MHAI, c. 235

MHAI, c. 236

MHAI, c. 201 
Iguape 1878 MAXIMIANO LOPES TRIGO

Iguape 1878 JOAQUIM GOMES DE OLIVEIRA

Iguape 1878 FRANCISCO PUPO DE MENDONÇA

Iguape 1879 ESCOLASTICA MARIA DO ESPIRITO SANTO

Iguape 1879 ANTONIO PEDRO DE AGUIAR

Iguape 1880 ANDRÉ TEIXEIRA

Iguape 1880 EDUARDO DOMINGUES RIBEIRO

Iguape 1880 FRANCISCO XAVIER PEREIRA

Iguape 1880 JOSÉ FERREIRA DA SILVA

Iguape 1880 JOSÉ RODRIGUES CUNHA

Iguape 1880 MARIA DE JESUS SILVA

Iguape 1880 INÁCIO PEREIRA DOS PASSOS

Iguape 1880 CAETANA MARIA DA CONCEIÇÃO

Iguape 1880 MANOEL JOSÉ NOVAES

Xiririca 1842 GORDIANO DE PAULA FRANÇA

Xiririca 1842 JOANA DA SILVA

Xiririca 1843 GREGORIO NUNES DE GUSMÃO

Xiririca 1844 FRANCISCO TRUDES DE MORAES

Xiririca 1847 INACIO GOMES DA SILVA

Xiririca 1848 ANTONIO FELIX DA COSTA

Xiririca 1850 JOAQUIM JOSÉ DA SILVA

Xiririca 1850 JOAQUIM JOSÉ MONTEIRO

Xiririca 1850 JOSÉ GONÇALVES DA COSTA

Xiririca 1850 MARIA EUGENIA CARDOSO

Xiririca 1852 JOANA RODRIGUES

Xiririca 1852 JOAQUINA MARIA DE JESUS

Xiririca 1853 CLAUDIANA MARIA DE JESUS

Xiririca 1853 FLORENTINA MARIA

Xiririca 1853 JACINTA MARIA DE JESUS

Xiririca 1854 JOSÉ MACEDO CUNHA

Xiririca 1854 MARIA GERTRUDES

Xiririca 1855 RITA SENHORINHA DO ESPIRITO SANTO

Xiririca 1857 ANTONIO MANOEL DIAS

Xiririca 1857 MARIA JOAQUINA DO ESPIRITO SANTO

Xiririca 1858 INACIA MARIA DO ESPIRITO SANTO

Xiririca 1858 URSULA MARIA DA TRINDADE

Xiririca 1858 CUSTODIO FRANCISCO DE MORAES

Xiririca 1858 JOÃO EUSEBIO DA COSTA PAIVA

Xiririca 1858 JOAQUIM DE MOURA ROLIM

Xiririca 1858 MARIA ROSA DE ALMEIDA

Xiririca 1859 DELFINA PEDROSA DE MORAES

Xiririca 1859 MARTINHA PEDROSO DE MORAES

Xiririca 1860 MANOEL PEDROSO DE MORAES

Xiririca 1860 MARIA DE FREITAS

Xiririca 1860 JOSÉ DA SILVA GOMES

Xiririca 1861 JOÃO BATISTA PUPO

Xiririca 1861 JOSÉ MIGUEL DE VERAS

Xiririca 1861 LODOVINA MONTEIRO DE FREITAS

Xiririca 1861 PEDRO ANTONIO DOMINGUES

Xiririca 1862 FRANCISCO NICACIO LOPES

Xiririca 1862 JOÃO GONÇALVES DA COSTA

Xiririca 1862 MANOEL ANTONIO DE OLIVEIRA

Xiririca 1863 ANA MARIA DO ESPÍRITO SANTO

Xiririca 1863 ANTONIO FELIZARDO RODRIGUES

Xiririca 1863 ANTONIO PEDROSO DE MORAES

Xiririca 1863 ANTONIO VICENTE DE ANDRADE

Xiririca 1863 CLAUDIANA DE FREITAS RAMOS

Xiririca 1863 DAMIANA ALVARES DE FREITAS

Xiririca 1863 FRANCISCO DE MOURA

Xiririca 1863 GERTRUDES MARIA DA SILVA

Xiririca 1863 INACIO DE OLIVEIRA CARDOSO

Xiririca 1863 JOSÉ GONÇALVES PONTES

Xiririca 1863 PAULA MARIA DA COSTA

Xiririca 1864 INÁCIO FRANCO DE LIMA

Xiririca 1864 JOSEFA GONÇALVES MOREIRA

Xiririca 1864 MARIA GERTRUDES DO ESPIRITO SANTO

Xiririca 1865 BENTO PEREIRA DE OLIVEIRA

Xiririca 1865 ESCOLASTICA MARIA DA TRINDADE

Xiririca 1865 ISABEL EUFRASIA DE RAMOS

Xiririca 1865 RAFAEL DESCIO

Xiririca 1865 MANOEL FRANCISCO DA SILVA

Xiririca 1866 RAFAEL GONÇALVES DE OLIVEIRA

Xiririca 1866 ANA MARIA DAS NEVES

Xiririca 1866 ANTONIO GOMES DA SILVA

Xiririca 1866 BENTO ROMÃO DA SILVA
MARIA ISABEL DAS NEVES TRIGO

ADELINA MATILDES PUPO DE OLIVEIRA

MARIA TEREZA DE JESUS

JOSÉ DE MORAES FREITAS

JOÃO BATISTA DE AGUIAR

JOSÉ TEIXEIRA DE OLIVEIRA

EUFROSINA FERNANDES PONTES

LAUREANA CANDIDA XAVIER

JOÃO FERREIRA DA SILVA

BELISARIO RODRIGUES CUNHA

CANDIDO PUPO DA ROCHA

ADELINDES PEREIRA DE MORAES

MANOEL GONÇALVES PUPO FERREIRA

CLAUDINO PEREIRA DA SILVA

RITA MARIA DO NASCIMENTO

INACIO DA SILVA

MARIA DAS DORES DE MORAES

ANA MARIA DA GLORIA

EZEQUIEL DA CUNHA RAMOS

ANA MARIA RIBEIRO

GERTRUDES MARIA DO ESPIRITO SANTO

ANA PONCIANA MONTEIRO

JOSEFA MARIA DE ALMEIDA

JOÃO DANIEL DA SILVA CARDOSO

JOAQUIM ANTONIO DE ALMEIDA

INACIO BERNARDO DE FREITAS

ANDRE CURSINO DE OLIVEIRA

ANTONIO VICENTE DE ANDRADA

MANOEL PEDROSO DE MORAES

SENHORINHA FERREIRA FRANÇA

RAFAEL JOAQUIM DE PONTES

ANTONIO JUSTINIANO DA COSTA

CATARINA DIAS BAPTISTA

DOMINGOS RODRIGUES CUNHA

RAFAEL GONÇALVES VIEIRA

JOSÉ MENDES DE OLIVEIRA

MARIA DAS DORES

DELFINA MARIA DOS ANJOS

GERTRUDES MARIA DO REGO

DIOGO MARIANO DE ALMEIDA

PEDRO ANTONIO DOMINGUES

BELCHIOR ALVES DE OLIVEIRA

MARIA VICENCIA DO PRADO

RODRIGO BETIM

ESCOLASTICA DIAS BAPTISTA

RITA MARIA DE JESUS

JOSÉ LEMES DE BRITO

GREGÓRIO INCENCIO DE FREITAS

FELIPE ANTONIO DOMINGUES

INACIA MARIA DAS NEVES

URSULA FRANCISCA DE ALMEIDA

MARIA ALVES DAS NEVES

INÁCIO FERNANDES DE OLIVEIRA

JOANA MARIA DO ESPIRITO SANTO

MARIA MUNIZ DAS NEVES

JOAQUINA MARIA DO PRADO

ANTONIO PEREIRA DE OLIVEIRA

FRANCISCO ALVARES DA SILVA

MARIA PEREIRA DE SOUZA

BENTO RODRIGUES CUNHA

APOLONIA MARIA DO ESPIRITO SANTO

JOSEFA GONÇALVES DE MORAES

BEBIANO PEREIRA FRANÇA

JOSÉ RODRIGUES DE LIMA

MATHIAS JOÃO DA COSTA

ANTONIO ALVES DE FRANÇA

FRANCISCA PERIRA DA GUIA

JOÃO FRANCISCO DE FRANÇA

EZEQUIEL DA CUNHA RAMOS

MARIA DESCIO NEVES

MARIA ROSA DE MORAES SILVA

JOAQUIM POLICARPO DE ALMEIDA

JOAQUIM ANTONIO GOMES DA SILVA

JOÃO DIAS DA SILVA MARTINS
MHAI, c. 201

MHAI, c. 132

MHAI, c. 133

MHAI, c. 194

MHAI, c. 200

MHAI, c. 132

MHAI, c. 132

MHAI, c. 132

MHAI, c. 132

MHAI, c. 132

MHAI, c. 132

MHAI, c. 51

MHAI, c. 205

MHAI, c. 240

FEP, c. 34

FEP, c. 34

FEP, c. 34

FEP, c. 34

FEP, с. 39

FEP, c. 33

FEP, c. 33

FEP, c. 35

FEP, c. 35

FEP, c. 35

FEP, c. 33

FEP, c. 35

FEP, c. 35

FEP, c. 35

FEP, c. 35

FEP, c. 36

FEP, c. 36

FEP, c. 37

FEP, c. 36

FEP, c. 36

FEP, c. 36

FEP, c. 36

FEP, c. 37

FEP, c. 37

FEP, c. 37

FEP, c. 37

FEP, c. 37

FEP, c. 37

FEP, c. 37

FEP, c. 37

FEP, c. 38

FEP, c. 38

FEP, c. 38

FEP, c. 38

FEP, c. 38

FEP, c. 38

FEP, c. 38

FEP, c. 38

FEP, c. 38

FEP, c. 38

FEP, c. 38

FEP, c. 38

FEP, c. 38

FEP, c. 38

FEP, c. 38

FEP, c. 38

FEP, c. 38

FEP, c. 38

FEP, c. 38

FEP, c. 39

FEP, c. 39

FEP, c. 39

FEP, c. 39

FEP, c. 39

FEP, c. 39

FEP, c. 39

FEP, c. 40

FEP, c. 37

FEP, c. 40

FEP, c. 40

FEP, c. 40 
Xiririca 1866 FERNANDO GOMES VIEIRA

Xiririca 1866 FRANCISCO DE PAULA FRANÇA

Xiririca 1866 GREGÓRIO JOSÉ RODRIGUES

Xiririca 1866 JEREMIAS DE OLIVEIRA SOUZA

Xiririca 1866 JOAQUIM MANOEL GONÇALVES

Xiririca 1866 JOSÉ JOÃO DA COSTA

Xiririca 1866 MARIA MUNIZ DAS NEVES

Xiririca 1866 MARIA ROSA DE MORAES GUERRA

Xiririca 1867 ANTONIO CARLOS MUNIZ

Xiririca 1867 BENEDITA MARIA DE PONTES

Xiririca 1867 JOÃO BATISTA GUIMARÃES

Xiririca 1868 ANTONIO DA MOTA

Xiririca 1868 ANTONIO JOSÉ DA SILVA FRANÇA

Xiririca 1868 APOLONIA MARIA DO ESPÍRITO SANTO

Xiririca 1868 CIRINO PEREIRA VERAS

Xiririca 1868 DIOGO MARIANO DE ALMEIDA

Xiririca 1868 JOSEFA MARIA E ALMEIDA

Xiririca 1869 CARLOS OLIVA DE ANDRADE

Xiririca 1869 FRANCISCO DE PAULA RIBEIRO DE ALMEIDA

Xiririca 1869 FRANCISCO JOSÉ MACHADO

Xiririca 1869 JOÃO RAFAEL DE LARA

Xiririca 1869 JOAQUIM DIAS DA SILVA

Xiririca 1870 ANTONIO DA SILVA GOMES

Xiririca 1870 BENEDITO ANTONIO DE PONTES

Xiririca 1870 DANIEL PEDROSO DE MORAES

Xiririca 1870 GREGÓRIO JUSTINO DE OLIVEIRA

Xiririca 1870 MARTINHA DE AZEVEDO

Xiririca 1870 TOBIAS GONÇALVES DA SILVA

Xiririca 1871 ANTONIO ALVES FRANÇA

Xiririca 1871 INÁCIO PUPO FERREIRA

Xiririca 1871 JOAQUIM EUSEBIO RODRIGUES

Xiririca 1871 JOSÉ RODRIGUES DE MORAES

Xiririca 1871 MANOEL ROBERTO DE ALMEIDA

Xiririca 1872 GERTRUDES MARIA DO ESPIRITO SANTO

Xiririca 1872 JOÃO FRANCISCO DE FRANÇA

Xiririca 1872 JOAQUIM FIRMINO DE MORAES

Xiririca 1872 JOSÉ DA SILVA CARDIM

Xiririca 1872 MANOEL DE ANDRADA SOBRINHO

Xiririca 1873 ANDRÉ FRANCISCO DE OLIVEIRA E SOUZA

Xiririca 1873 CATARINA ANGELICA MORAES

Xiririca 1873 CATARINA ANTONIA GONÇALVES

Xiririca 1873 ESCOLASTICA MARIA DE JESUS

Xiririca 1873 GERMANA MARIA ITALIA FERNANDES

Xiririca 1873 INÁCIO PUPO FERREIRA JUNIOR

Xiririca 1873 JOÃO PAULO DIAS

Xiririca 1873 JOAQUIM DE OLIVEIRA PRADO

Xiririca 1873 RITA AMÉLIA DO CANTO

Xiririca 1873 SENHORINHA DUARTE DO VALE

Xiririca 1875 FRANCISCA MARIA DE ALMEIDA

Xiririca 1875 MARIA PEREIRA DOS PASSOS

Xiririca 1875 RAFAEL GOMES DA SILVA

Xiririca 1876 ANA LOURENÇA PEREIRA DE OLIVEIRA

Xiririca 1876 ESCOLASTICA JOANA DE RAMOS

Xiririca 1876 ESCOLASTICA RODRIGUES DE FREITAS

Xiririca 1876 GERTRUDES DIONISIA

Xiririca 1876 TERTULIANO DIAS BAPTISTA

Xiririca 1877 EFIGENIA DOMINGUES PEREIRA

Xiririca 1877 FRANCISCO ALVARES DA SILVA

Xiririca 1877 JOAQUIM PEREIRA DOS PASSOS

Xiririca 1877 MIGUEL ANTONIO DE AQUINO

Xiririca 1877 PEDRO INACIO CARDOSO

Xiririca 1878 ANA BRIGIDA DE ALMEIDA

Xiririca 1878 BERNARDO JOSÉ DE LIMA

Xiririca 1878 BERNARDO LOPES TEIXEIRA

Xiririca 1878 RAFAEL DE MOURA ROLIM

Xiririca 1878 RICARDO BENEDITO DA COSTA

Xiririca 1879 EMERENCIANA MARIA DA SILVA

Xiririca 1879 ESCOLÁSTICA MARIA DE RAMOS

Xiririca 1879 JOÃO RAFAEL DE ALMEIDA

Xiririca 1879 JOAQUIM OTAVIANO DE FRANÇA

Xiririca 1879 JOAQUINA ROSA DE SOUZA

Xiririca 1879 JOSÉ JOAQUIM DE OLIVEIRA SOUZA

Xiririca 1880 ANA PEREIRA DE JESUS

Xiririca 1880 CATARINA RIBEIRO

Xiririca 1880 CLARA RODRIGUES DE FREITAS
MARIA DE RAMOS VIEIRA

JOÃO ANTONIO DE FRANÇA

LUZIA ROZO DE FRANÇA

ANA PEREIRA DE JESUS

RITA MARIA DO NASCIMENTO

CATARINA ANTONIA GONÇALVES

JOSÉ DE SANTANA SILVA

SEBASTIÃO FERNANDES GUERRA

MARIA DA GLORIA MARTINS

ANTONIO LEMOS DE PONTES

EUSEBIO COUTINHO DA CUNHA

PRUDENCIA MARIA RODRIGUES

TERTULIANO DA SILVA FRANÇA

PEDRO NÁCIO CARDOSO

FRANCISCA MARIA DE ALMEIDA

DAMIANA MARIA ROSA DE ALMEIDA

DOMINGOS FRANCISCO GOMES

MARIA DE OLIVEIRA LIMA

ANGELICA COELHO DUARTE

BENTO MANOEL DE RAMOS

FRANCISCA MARIA DO ESPIRITO SANTO

INACIA MARIANA DE ALMEIDA

MARIA ANTONIA DA SILVA

ANTONIO TEIXEIRA GUIMARÃES

ISABEL TEREZA DE MORAES

GERTRUDES ISABEL DA SILVA

MANOEL DE ANDRADE REZENDA

CRISTINA MARIA DE JESUS

GERTRUDES MARIA DO ESPIRITO SANTO

ANA AMÉRICA FERREIRA

RITA MARIA DE JESUS

ESCOLÁSTICA JOANA DE RAMOS

CONSTANTINA ALMEIDA DA CUNHA

JOAQUIM APOLINÁRIO DE ALMEIDA

JOAQUIM ALVES DE FRANÇA

MARIA DAS DORES DE MORAES

FELICIDADE MARIA CARDIM

TIMOTEA DE ANDRADA REZENDE

MIQUELINA MARIA DE OLIVEIRA

GREGORIO JOAQUIM OLIVEIRA SOUZA

XISTO ALVES DA SILVA

MANOEL FRANCO DE OLIVEIRA

BENTO PAULO FERNANDES

ROSA MARIA PEDROSA

FELIPA DIAS BATISTA

ANA VITORIA DE OLIVEIRA

JOAQUIM PEDRO DO CANTO

GREGORIO MARIANO DE AZEVEDO

JOAQUIM FERNANDES DE OLIVEIRA

ISABEL MARIA DA GUIA

JOSÉ JOÃO DA COSTA MUNIZ

DOMINGOS RODRIGUES CUNHA

ANACLETO DA SILVA PEREIRA

ANTONIO RODRIGUES DE ALMEIDA

MARIA DE MOURA ROLIM

BENTO LUCIANO DA COSTA

DELFICA JANUARIA DA SILVA

VICENCIA RODRIGUES

ESCOLASTICA RODRIGUES RAMOS

JESUINA MARIA CARDOSO

JOSÉ NUNES DE ALMEIDA

ANA MARIA DE FREITAS

ANA MARIA DA CRUZ

DIOGO DE MOURA ROLIM

ARCANGELA MARIA DA CONCEIÇÃAO

TOMAS GONÇALVES DE MORAES

JOSÉ PASSOS MUNIS

RAFAEL AURÉLIO DE ALMEIDA

JOANA RODRIGUES DE FRANÇA

PAULO ANTONIO DE FRANÇA

ANTONIO MILITÃO DE SOUZA

BALDOINO DE OLIVEIRA SOUZA

DAVID ALVES PEREIRA

FLORIDO JOSÉ DE RAMOS
FEP, c. 40

FEP, c. 40

FEP, c. 40

FEP, c. 40

FEP, c. 40

FEP, c. 40

FEP, c. 40

FEP, c. 40

FEP, c. 40

FEP, c. 40

FEP, c. 40

FEP, c. 41

FEP, c. 41

FEP, c. 41

FEP, c. 41

FEP, c. 41

FEP, c. 41

FEP, c. 41

FEP, c. 41

FEP, c. 41

FEP, c. 41

FEP, c. 41

FEP, c. 41

FEP, c. 41

FEP, c. 41

FEP, c. 41

FEP, c. 41

FEP, c. 41

FEP, c. 41

FEP, c. 41

FEP, c. 41

FEP, c. 41

FEP, c. 41

FEP, c. 42

FEP, c. 42

FEP, c. 42

FEP, c. 42

FEP, c. 42

FEP, c. 42

FEP, c. 42

FEP, c. 42

FEP, c. 42

FEP, c. 42

FEP, c. 42

FEP, c. 42

FEP, c. 42

FEP, c. 42

FEP, c. 42

FEP, c. 44

FEP, c. 44

FEP, c. 44

FEP, c. 44

FEP, c. 44

FEP, c. 44

FEP, c. 44

FEP, c. 44

FEP, c. 44

FEP, c. 44

FEP, c. 44

FEP, c. 44

FEP, c. 44

FEP, c. 44

FEP, c. 44

FEP, c. 44

FEP, c. 44

FEP, c. 44

FEP, c. 45

FEP, c. 45

FEP, c. 45

FEP, c. 45

FEP, c. 45

FEP, c. 45

FEP, c. 45

FEP, c. 45

FEP, c. 45 
Xiririca 1880 ISABEL MARIA DA GUIA

Xiririca 1880 ISABEL MARIANA DA TRINDADE

Xiririca 1880 LEONOR DE FREITAS FRANÇA

Xiririca 1880 MARIA JOAQUINA DOS ANJOS
JOSÉ JOÃO DA COSTA MUNIZ

LUIS ANTONIO DA SILVA

BENTO ANTONIO DE FRANÇA

JOSÉ JOÃO DA COSTA MUNIZ
FEP, c. 45

FEP, c. 45

FEP, c. 45

FEP, c. 45 